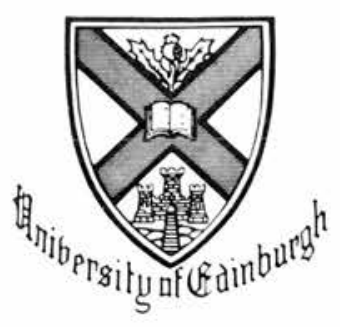

\title{
THE INTERNATIONAL LEGAL RÉGIME FOR THE PROTECTION OF THE STRATOSPHERIC OZONE LAYER
}

\author{
O. YOSHIDA
}

The Ph.D. (Public International Law)

The University of Edinburgh

1998

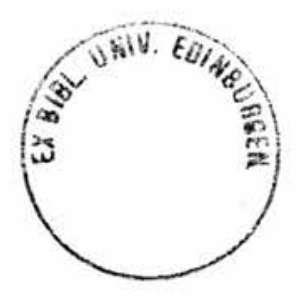


A DISSERTATION SUBMITTED TO THE DEPARTMENT OF PUBLIC INTERNATIONAL LAW IN CANDIDACY FOR THE DEGREE OF DOCTOR OF PHILOSOPHY 


\section{TABLE OF CONTENTS}

Acknowledgements

Abbreviations

vii

Table of Cases

ix

Lists of Diagrams and Tables

xii

INTRODUCTION

xiv

$\mathrm{XV}$

\section{PART I \\ INTERNATIONAL LEGAL RÉGIMES}

\section{Chapter I: International Environmental Régimes}

I A Preliminary Examination of 'International Régimes' 2

II International Régimes in International Environmental Relations 8

III International Environmental Régimes and International Law 12

A. The Law-Making of International Co-operation Régimes of 12

Environmental Regulation

B. The Institutionalisation of International Environmental Co-operation 18

C. 'Soft Enforcement' of Treaty: Implementation of and Compliance with 22

Legal Obligations of International Environmental Régimes

D. Non-Governmental Organisations (N.G.Os.) as International Régime 26

Actors

IV The Emergence of the 'Self-Contained Régime' for International 29

Obligations Erga Omnes : Ensuring Universal Compliance

V Conclusions

\section{PART II \\ THE INTERNATIONAL TREATIES FOR THE PROTECTION OF THE OZONE LAYER}

Chapter II: The 1985 Vienna Convention for the Protection of the Ozone Layer and Principles of Modern International Environmental Law

I Introduction

II The Negotiation of the 1985 Vienna Ozone Layer Convention 42

A. National/Regional Regulation of Major Chlorofluorocarons 43

B. The Vienna Convention Negotiation within the U.N.E.P. 46

(1) The International Régime-Building from 1977 to 1980

(2) The Discussions at the Ad Hoc Working Group (1982-1985) 48

(3) Negotiating an Ozone Protocol for Controlling C.F.Cs. 52

(4) 'The Vienna Convention is Adopted' 53

III The 1985 Vienna Convention for the Protection of the Ozone Layer 54

A. The Definition of 'Adverse Effects' Caused by Ozone Depletion 55

(1) The Limited Scope of the Term 'Air Pollution' in Regional Treaties 55

(2) Adverse Effects Caused by Ozone Depletion 55

B. The Legal Status of the Ozone Layer in Public International Law 56

(1) National Jurisdiction Over the Ozone Layer 57

(2) The Ozone Layer as the Common Concern of Mankind (or Humankind) 59

C. The Vienna Ozone Layer Convention and the 'Principle' of 62

Precautionary Approach in International Environmental Law 
(1) The Vienna Ozone Convention and Principle 21 of the 1972

Stockholm Declaration

(2) The Vienna Ozone Layer Convention and the Precautionary

Environmental 'Principle': The Emergence of a New Approach

(a) International Environmental Co-operation: Developments Subsequent

to the Adoption of Principle 21

(b) The Precautionary Environmental 'Principle'/Approach

D. The Provisions of the 1985 Vienna Ozone Layer Convention

(1) The 'General Obligations': Legal Basis of the Montreal Protocol

(2) The Conference of the Parties to the Vienna Ozone Layer Convention

(3) The U.N.E.P. Ozone Secretariat for the Vienna Convention and the Montreal Protocol

(4) The Dispute Settlement Procedures Under the Vienna Ozone Layer

Convention

IV The Assessment of the Vienna Convention Régime

Chapter III: The Historical Evolution of the International Cooperative and Regulatory Régime for the Protection of the Ozone Layer: The Internationalisation of O.D.S. Regulatory Measures and National Implementation and Enforcement of the Ozone Treaties

PART A: THE DEVELOPMENT OF THE INTERNATIONAL REGULATIONS TO CONTROL O.D.SS. IN THE MONTREAL OZONE PROTOCOL RÉGIME

I Introduction

II The Montreal Protocol Negotiation: Preparation on the Protocol on the

Protection of the Ozone Layer Within the U.N.E.P.

A. The First Session of the Working Group

B. The Second session of the Working Group

C. Toward a Final Decision in Montreal in September 1987

III International Legal Regulation of Specified O.D.Ss. Under the Montreal 97 Protocol

A. The Final Agreement: Provisions of the Montreal Protocol 97

B. International Control Measures for O.D.Ss.: Articles 2 \& $3 \quad 100$

(1) The Substances Covered by the Montreal Ozone Layer Protocol 100

(2) The Percentage Reduction Approach: 'Consumption' and Production 100

(3) The Ozone-Depleting Potentials (O.D.Ps.) 102

(4) The Special Situation of the Former U.S.S.R. 103

(5) Non-Compliance With the Control Measures: Compliance Control 103

C. The Internal Mechanisms for Amendments and Adjustments: 104

Strengthening the System of the International Control Measures

D. The European Community as the 'Regional Economic Integration

106

Organisation': The Joint Implementation of the Control Measures

E. Special Situation of Developing Countries: The 'Grace Period' for 108

Article 5 Countries

(1) The Justification for the Grace Period

(2) The Grace and Phase-Out Period for Article 5 Countries

108

109

110

(3) The 'Principle' of Common-But-Differentiated Responsibility

112

(4) The Consequences of the Grace Period

113

Regulatory Ozone Régime: The Evolution of International Control

Measures and Other O.D.Ss.-Related Issues

A. The Need for Revisions of the 1987 version of the Protocol: New

Scientific Knowledge on the State of the Stratospheric Ozone Layer

B. The 1989 Helsinki Ozone Meeting and Its International 'Soft Law' 
C. The 1990 London Ozone Meeting: Strengthening the Control

Measures and the Establishment of the Montreal Protocol Multilateral

Fund

D. The 1992 Copenhagen Ozone Meeting: Strengthening the Control

Measures of the H.C.F.Cs. and the Establishment of the Montreal N.C.P.

E. The 1995 Vienna Ozone Meeting: The Control Measures for H.C.F.Cs.

and Methyl Bromide, and the Extension of the 'Grace Period'

F. The 1997 Montreal Ozone Meeting: The Control Measures of Methyl

Bromide and Illegal Trade in C.F.Cs./O.D.Ss.

PART B: THE NATIONAL IMPLEMENTATION OF THE INTERNATIONAL 129

TREATIES FOR THE PROTECTION OF THE OZONE LAYER

I Introduction

129

II National Implementation and Enforcement of the International Ozone

Treaties

A. Non-Article 5 Countries

130

(1) The United States

(2) The European Community

(3) Germany

(4) Japan

B. Article 5 Countries

(1) Brazil

(2) Malaysia

(3) Thailand

Conclusions: Looking Ahead

PART III

THE OZONE LAYER RÉGIME AND THE G.A.T.T./W.T.O. LAW RÉGIME

\section{Chapter IV: The Montreal Ozone Protocol Régime and the International Trade Law Régime of the G.A.T.T./W.T.O.}

I Introduction: Multilateral Environmental Agreements and the

International Trade Law Régime of the G.A.T.T./W.T.O.

A. Multilateral Environmental Agreements and the G.A.T.T./W.T.O. Law

B. Multilateral Environmental Agreements - M.E.As.

II The International Trade Régime for the Restrictions of O.D.Ss.

A. The Background of Article IV of the Montreal Ozone Layer Protocol: 149

Resolving the Problem of Non-Participation in the Ozone Régime

B. The Montreal Protocol's Article 4 and P.P.M. Related Arguments 151

III The G.A.T.T./W.T.O. Trade Law

A. The G.A.T.T./W.T.O. Trade Law

156

B. The Governing Economic Principles of the G.A.T.T. Law 1994

C. The G.A.T.T. Case-Law

160

IV The Legal Conflicts Between M.E.As. and the G.A.T.T./W.T.O. Trade Law

162

A. The Legal Conflicts Between M.E.As. and the G.A.T.T./W.T.O. Trade 162 Law

B. The Relationship Between M.E.A. Dispute Settlement Procedures and the W.T.O. Dispute Settlement System: The Montreal N.C.P. or the W.T.O. Dispute Settlement Procedures?

(1) General Discussions

(2) The Formal N.C.P. or the W.T.O. Dispute Settlement Procedures?

G.A.T.T. Article XX and the Global Protection of the Ozone Layer Under the Montreal Protocol Régime

A. The Exceptions Under G.A.T.T. Article XI(1) and XX

B. G.A.T.T. Article XI(2) Exceptions and the Montreal Ozone Layer 
C. The Preamble Conditions for G.A.T.T. Article XX Exceptions and

Article 4 of the Montreal Protocol Régime

D. G.A.T.T. Article XX(b) and the Global Protection of the Ozone Layer

(1) The Montreal Protocol's Article 4 is 'Necessary' to Protect Human

Health and the Environment: G.A.T.T. Article XX(b) and Modern

International Law of the Environment

(2) Environmental Objectives of the International Legal Ozone Régime are Widely Recognised by the International Community

E. G.A.T.T. Article XX(g) and the Protection of the (Stratospheric)

Ozone Layer

VI Conclusions

\section{PART IV \\ THE MONTREAL PROTOCOL'S COMPLIANCE SYSTEM}

\section{Chapter V: The Montreal Non-Compliance Procedure and the Functions of the Internal International Institutions}

I The Montreal Non-Compliance Procedure (N.C.P.)

A. The Judicial Settlement of International Environmental Disputes 186

B. The Avoidance/(Quasi-Judicial) Settlement of 'Multilateral' 187

Environmental Disputes: The Non-Compliance Procedure

II The Negotiation of the Montreal N.C.P. Régime

III The Meaning of 'Non-Compliance' in the Ozone Layer Protocol: A Grey 194 Area of the International Legal Ozone Régime

A. The Meaning of 'Non-Compliance' in the Ozone Régime

B. 'Depoliticising' Multilateral Ozone Disputes?: The Relationship

Between the 'Self-Contained' N.C.P. and the Dispute Settlement

Mechanisms in the 1985 Vienna Ozone Layer Convention

IV The Mechanics of the Operation of the Montreal N.C.P.: The Functions of the Specialised Internal Treaty Institutions

A. The Structure of the Montreal N.C.P. Régime

(1) The Actors of the N.C.P. Régime

(2) The Principle of Good Faith bona fides

B. The Functions of the Internal International Institutions in the Montreal Non-Compliance Procedure

(1) The U.N.E.P. Ozone Secretariat

(a) The N.C.P. Régime Initiators \& the Functions of the Ozone secretariat

(b) The Secretariat of Other Environmental Treaties

(2) The Implementation Committee of the N.C.P.

(a) The Structure of the Implementation Committee

(b) The Functions of the Committee in the Montreal N.C.P.

(3) The Meeting of the Parties to the Montreal Protocol

(a) The Functions of the Meeting of the Parties in the N.C.P.

(b) The Legal Nature of the Decisions by the Meeting of the Parties

The Principal Features of the Montreal Non-Compliance Procedure: The

Montreal N.C.P., International Conciliation and Other Dispute

Settlement Procedures in International Law

A. The Montreal N.C.P. as a Multilateral Conciliation Mechanism

(1) International Conciliation and the N.C.P. Régime

(2) From Conciliation to the Political Organ of the M.E.A. Régime

B. The Dispute Settlement Mechanisms Used by Other International Institutions

(1) The G.A.T.T./W.T.O. Non-Violation Procedure in International

Economic Law

(2) The I.L.O. Complaints Procedure in International Social Law 
VI The Montreal N.C.P. Régime Theory: The Precautionary

'Principle'/Approach as Basic Philosophy of the Montreal N.C.P. - 'Soft

Enforcement' of International Environmental Treaty

VII The Montreal N.C.P. in Practice

A. Ensuring Compliance With Reporting Requirements, Control 236

Measures and Trade Restrictions

(1) The Reporting Requirements

(2) The Control Measures of C.F.Cs./O.D.Ss.

(3) Trade With Non-Parties

B. Case Studies: Non-Compliance by the Russian Federation and the $\quad 244$

Reactions of the N.C.P. Régime Institutions

(1) The Russian Federation and the C.E.I.Ts.

(2) Russia's Non-Compliance Case

Chapter VI: The Financial Mechanism of the Montreal Protocol and the International Transfer of Ozone-Friendly Technology: Capacity Building in the Ozone Régime

I The Concept of 'Capacity Building' in International Law of the

Environment

A. The Question of Defining 'Capacity Building' in International

Environmental Law

B. Capacity Building in M.E.As.

The Negotiation Process of the Montreal Multilateral Fund and the

Technology Transfer-Related Issues

A. 'Capacity Building' Under the 1985 Vienna Ozone Convention and

the 1987 version of the Montreal Protocol

B. The Negotiation of the Montreal Multilateral Fund and the

Technology Transfer

III The Structure of the Financial Mechanism of the Montreal Ozone

Protocol Régime

A. General Legal Aspects

B. The Role of the International Institutions in the Financial

Mechanism of the Montreal Ozone Layer Protocol

(1) The Executive Committee

(2) The Multilateral Fund Secretariat

(3) The Implementing Agencies

(a) The World Bank

(b) The United Nations Development Programme (U.N.D.P.)

(c) The United Nations Environment Programme (U.N.E.P.)

(d) The United Nations Industrial Development Organisation

(U.N.I.D.O.)

C. The Global Environmental Facility (G.E.F.)

D. Strategies: Work Programmes, Country Programmes and Institutional

Strengthening

(1) Work Programmes

(2) Country Programmes

(3) Institutional Strengthening for Project Implementation

(4) The Conditionally Between the M.L.F. Funding and Compliance With the Protocol

IV Special Considerations for the International Transfer of Ozone-Friendly Technology

A. International Technology Transfer

B. The International Technology Transfer of O.D.S. Reduction 
(1) The Phase-Out of Controlled O.D.Ss. 292

(2) The Transfer of Technology of O.D.Ss. 293

(3) Case Study: The People's Republic of China 294

(4) The Montreal Protocol's Multilateral Fund and N.G.Os. 297

VI Conclusions

\section{PART $\mathrm{V}$ \\ CONCLUSIONS}

\section{Chapter VII: The International Legal Régime for the Protection of the Ozone Layer}

The International Legal Régime for the Protection of the Ozone Layer 302

\section{APPENDIX}

I The 1985 Vienna Convention for the Protection of the Ozone Layer

II The 1987 Montreal Protocol on Substances That Deplete the Ozone Layer as adjusted/amended by the Second Meeting of the Parties (London, 2729 June 1990) and by the Fourth Meeting of the Parties (Copenhagen, 23-25 November 1992) and adjusted by the Seventh Meeting of the Parties (Vienna, 5-7 December 1995) and further adjusted/amended by the Ninth Meeting of the Parties (Montreal, 15-17 September 1997)

III Status of Ratification/Accession/Acceptance/Approval of the Agreements on the Protection of the Ozone Layer

IV The List of Parties Categorised as Operating under Article 5 Paragraph 1 of the Montreal Protocol

V N.G.Os. Participating the Meeting of the Parties to the Montreal Protocol 349 as Observers 


\section{ACKNOWLEDGEMENTS}

I am greatly indebted to my supervisor, Professor Alan E. Boyle, Professor of Public International Law in the University of Edinburgh, for his constructive comments and critical advice. He provided consistent guidance and support, well beyond the call of an academic supervisor. I thank him, indeed. It must be noted here, moreover, that I learned a lot from Ph.D. forums organised by Professor Boyle where I enjoyed, in February 1997, an excellent opportunity to give an oral presentation of my doctoral thesis. ${ }^{1}$

I would like to thank Professor Dr. Yuji Iwasawa, Professor of International Law at Tokyo University Graduate School of International Relations, for his encouragement and useful advice. I also would like to express my special gratitude to my first teacher of international law, Professor Sol Picciotto, Professor of International Law at Lancaster University Law School. Warmly encouraged by him, I decided to undertake doctoral studies in international law at Edinburgh.

This Ph.D. thesis also benefited from valuable comments by many international law scholars among whom I am especially grateful to: Professor David Freestone, Legal Adviser at the World Bank; Mr. A. Amkhan Lecture of International Law at Edinburgh University; Professor Dr. Akio Morita, Professor of International Law at Tokyo Metropolitan University; Professor Akira Sakota, Professor of International Law at Otaru University of Commerce (currently, a research fellow at the I.T.L.O.S.) and, Professor Yukari Takamura, Professor of International Law at Shizuoka University. I am also grateful to Mrs. Ximena Fuentes, D.Phil. Candidate at the University of Oxford for her perceptive comments.

This work was supported in part by grants for encouragement of research from Edinburgh University Law School and the University of Edinburgh Development Trust that generously enabled me to carry on doctoral studies. Without the financial support of the former in particular, this Ph.D. thesis could not have been completed.

My thanks are also due to the staff of various libraries which I had occasions to use: Among them are Edinburgh University Law Library, the Institute of Advance Legal Studies (I.A.L.S.), the British Library of Political

\footnotetext{
1 Ph.D. Forum at The University of Edinburgh, Department of Public International Law, (25th February 1997, The Lorimer Room).
} 
and Economic Science (L.S.E.), the Research Centre for International Law (R.C.I.L.), the U.S.E.P.A. Library and the Law Library of Waseda University, Tokyo.

Finally, I wish to express my gratitude to the following governmental, inter-governmental and non-governmental institutions for providing me necessary materials and information on the legal studies in the international régime for ozone: the United Nations Environment Programme (the U.N.E.P. Ozone Secretariat), the U.N.E.P./I.E.-France, the Montreal Protocol's M.L.F. Secretariat, the World Bank, the United Nations Centre for Regional Development in Nagoya, the U.S. Environment Protection Agency, the Japan Environment Agency, the Japan Ministry of International Trade and Industry, Environment Canada, the Foundation of International Environmental Law and Development (F.I.E.L.D.) and the Ozone Action in Washington D.C.

O.Y.

Edinburgh

June 1998 


\section{THE ABBREVIATIONS FOR TECHNICAL TERMS ETC.}

A.F.D.I.

A.J.I.L.

A.S.E.A.N.

A.U.J.I.L.P.

B.I.S.D.

Boston C.E.A.L.R.

Boston C.I.C.L.R.

B.Y.bk.I.L.

C.A.A.A.

C.E.I.T.

$\mathrm{CC} 14$

C.C.O.L.

C.F.Cs.

$\mathrm{CH} 3 \mathrm{Br}$

$\mathrm{C}_{2} \mathrm{H}_{3} \mathrm{C} 13$

C.C.A.M.L.R.

C.C.M.

C.H.M.

C.I.S.

C.I.T.E.S.

C.M.L.R.

C.M.S.

C.T.E.

$\mathrm{CO} 2$

C.Y.bk.I.L.

D.S.B.

D.S.U.

E.C./E.U.

E.C.J.

E.E.C.

E.E.Z.

E.I.A.

E.P.L.

E.P.A.

F.A.O.

G.A.T.S.

G.A.T.T.

G.E.C.

G.E.M.S.

G.E.F.

G.Y.bk.I.L.

H.B.F.Cs.

H.C.F.Cs.

I.B.R.D.

I.C.L.Q.

I.C.J.

I.C.O.L.P.

I.G.Os.

I.J.E.C.L.

I.L.A.
Annuaire Français de Droit International

American Journal of International Law

Association of South East Asian Nations

American University Journal of International Law \& Politics

Basic Instruments and Selected Documents of the G.A.T.T.

Boston College Environmental Affairs Law Review

Boston College International and Comparative Law Review

British Yearbook of International Law

U.S. Clean Air Act Amendment

Countries with Economies in Transition

carbon tetrachloride

U.N.E.P. Co-ordinating Committee on the Ozone Layer

chlorofluorocarbons

methyl bromide

methyl chloroform

Convention on the Conservation of Antarctic Living

Resources

Common Concern of (Hu)Mankind

Common Heritage of Mankind

Commonwealth of Independent States

Convention on International Trade in Endangered Species of Wild Fauna and Flora

Common Market Law Review

Common Market Studies

W.T.O. Committee on Trade and Environment

carbon dioxide

Canadian Yearbook of International Law

Dispute Settlement Body

Dispute Settlement Understanding (Annex 2 of the W.T.O. Agreement

European Community/European Union

European Court of Justice

European Economic Community

Exclusive Economic Zone

Environment Impact Assessment

Environmental Law \& Policy

Environment Protection Agency

Food and Agriculture Organisation

General Agreement on Trade in Services

General Agreement on Tariffs and Trade

Global Environmental Change

Global Environment Monitoring System

Global Environment Facility

German Yearbook of International Law

hydrobromofluoro carbons

hydrochlorofluorocarbons

International Bank for Reconstruction and Development

International and Comparative Law Quarterly

International Court of Justice

Industry Co-operative for Ozone Layer Protection

Intergovernmental Organisations

International Journal of Estuarine \& Coastal Law

International Law Association 


\section{Abbreviations}

I.L.C.

I.L.J.

I.L.M.

I.L.O.

I.L.R.

I.U.C.N.

I.M.O.

I.S.B.A.

I.S.O.

J.E.L.

J.I.L.

J.T.L.

J.W.T.

J.W.T.L.

L.A.T.A.P.

L.J.

L.N.T.S.

L.V.Cs.

M.A.R.P.O.L.

M.E.As.

M.F.N.

M.I.T.I.

M.L.F.

M.P.

N.A.F.T.A.

N.C.P.

N.G.Os.

N.I.K.

N.I.L.R.

N.R.J.

N.V.P.

N.Y.bk.I.L.

$\mathrm{O} 3$

O.A.S.

O.A.U.

O.D.A.

O.D.Ss.

O.J.

P.C.I.J.

P.P.M.

Proc. A.S.I.L.

Q.Rs.

R.G.D.I.P.

SOX

$\mathrm{SO} 2$

T.B.T.

T.E.A.P.

T.I.A.S.

T.R.E.Ms.

T.R.I.Ps.

U.K.

U.N.

U.N.C.L.O.S.

U.N.C.T.A.D.

U.N.D.P.

U.N.C.E.D.
International Law Commission

International Law Journal

International Legal Materials

International Labour Organisation

International Law Reports

International Union for Conservation of Nature \& Natural Resources

International Maritime Organisation

International Seabed Authority

International Organisation for Standardisation

Journal of Environmental Law

Journal of International Law

Journal of Transnational Law

Journal of World Trade

Journal of World Trade Law

Convention on Long-Range Transboundary Air Pollution

Law Journal

League of Nations Treaty Series

Low-Volume-O.D.S.-Consuming Countries

International Convention for the Prevention of Pollution from Ships

Multilateral Environmental Agreements

most-favoured-nation treatment

Japan Ministry of International Trade \& Industry

Montreal Protocol's Multilateral Fund

Montreal Ozone Layer Protocol 1987

North American Free Trade Agreement

Non-Compliance Procedure

Non-Governmental Organisations

not-in-kind (technologies)

Netherlands International Law Review

Natural Resources Journal

Non-Violation Procedure

Netherlands Yearbook of International Law

ozone

Organisation of American States

Organisation of African Unity

Overseas Development Aid

Ozone Depleting Substances

Official Journal of the E.C.

Permanent Court of International Justice

Process \& Production Method

Proceedings of the American Society of International Law

Quantitative Restrictions

Revue Generale de Droit International Public

oxides of sulphur

sulphur dioxides

Technical Barriers to Trade

Technology and Economic Assessment Panel

U.S. Treaties and Other International Acts

Trade Related Environmental Measures

Trade Related Intellectual Property Rights

United Kingdom

United Nations

U.N. Convention on the Law of the Sea

U.N. Conference on Trade \& Environment

U.N. Development Programme

U.N. Conference on Environment \& Development 
U.N.E.C.E.

U.N.E.P.

U.N.I.D.O.

U.N.T.S.

U.S.

U.S.S.R.

V.C.

W.C.E.D.

W.H.O.

W.M.O.

W.T.O.

Y.bk.E.L.

Y.bk.I.E.L.

Z.A.O.R.V.

\begin{abstract}
Abbreviations
U.N. Economic Commission for Europe

U.N. Environment Programme

U.N. Industrial Development Organisation

United Nations Treaty Series

United States

Union of Soviet Socialist Republic

Vienna Ozone Layer Convention 1985

World Commission on Environment \& Development

World Health Organisation

World Meteorological Organisation

World Trade Organisation

Yearbook of European Law

Yearbook of International Environmental Law

Zeitschrift für Ausländisches und Öffentliches Recht und Völkerrecht
\end{abstract}




\section{TABLE OF CASES}

\section{PERMANENT COURT OF INTERNATIONAL JUSTICE}

Phosphates in Morocco Case (1938) ...... 11

\section{INTERNATIONAL COURT OF JUSTICE}

Barcelona Traction Power \& Light Co. Case (1970) . . . . . 33-34, 61

Case Concerning the Gabcíkovo-Nagymaros Case . . . . . 6 6-7, 19, 248, 309

Certain Expenses of the U.N. Case (1962) ...... 23

Corfu Channel Case (1949) ...... 10, 66

East Timore Case (1995) ....... 33

Fisheries Jurisdiction Case (1973) . . . . 11, 248

Libya-Malta Continental Shelf Case (1985) . . . . . 14

Nicaragua Case (1984) ....... 15

North Sea Continental Shelf Case (1969) . . . . . . 14

Nuclear Tests Cases (1974) ......6, 33

Nuclear Weapons Advisory Opinion (1996) ..... 32, 63, 72

Reparation for Injuries Suffered in the Service of the U.N. Case (1949) . . 23 213

South West Africa, International Status of, Case (1950) . . . . . 212

South West Africa Cases (1966) . . . . . 32

Temple Case (1961) ....... 11

U.S. Diplomatic \& Consular Staff in Tehran Case (1980) . . . . 29, 66

W.H.O. and Egypt Case (1980) ......6 6

\section{International Arbitral Tribunals}

Alabama Claims Arbitration Case (1872) ..... 11, 66

Lac Lanoux Arbitration Case (1957) ....... 11

Trail Smelter Arbitration Case $(1938,1941) \ldots \ldots$. $9,65,67$

\section{European Court of Justice}

Case $232 / 78$ Commission v. France (1979) ...... 30

Cases 90-91/63 Commission v. Luxembourg and Belgium (1964) . . . . . 30

\section{G.A.T.T./W.T.O. Decisions}

Belgium-Family Allowances .... . 158

Canada-Measures Affecting Exports of Unprocessed Herring and Salmon . . $160,172,182$

E.E.C.-Production Aids Granted on Canned Fruits and Dried Grapes . . . . . 226

E.E.C.-Tariff Treatment on Imports of Citrus Products from Certain Countries in Mediterranean Region .......226

Italy-Discrimination Against Imported Agricultural Machinery . . . . . . 154 Japan-Customs Duties, Taxes and Labelling Practices on Imported Wines and Alcoholic Beverages ....... 154

Japan-Restrictions on Imports of Certain Agricultural Products . . . . . . 172 Japan-Taxes on Alcoholic Beverages . . . . . . 161,224 
Thailand-Restrictions on Importation of and Internal Taxes on Cigarettes . . 160, 169, 172

United States-Prohibition of Imports of Tuna and Tuna Products from

Canada.......160, 172

United States-Restrictions on Imports of Tuna (Tuna Case I) . . . 155, 160, 171, $180,181,182,183$

United States-Restrictions on Imports of Tuna (Tuna Case II) . . . 155, 160,171 $172,180,183$

United States-Section 337 of the Tariff Act of $1930 \ldots \ldots 154,172$

United States-Standards for Reformulated and Conventional Gasoline . . . $156,160,162,165,171,172,181-82,224$

United States-Taxes on Petroleum and Certain Imported Substances . . . 158 


\section{LIST OF DIAGRAMS AND TABLES}

Diagram no. I: The Framework Convention-Protocol Approach 15

Table no. I: The Development of International Control Measures for 126

O.D.Ss. under the Montreal Ozone Layer Protocol

Table no. II: International Control Measures for Article 5 Countries $\quad 128$ under the Montreal Ozone Layer Protocol

Table no. III: The Relationship between M.E.As. and the G.A.T.T./W.T.O. 164 Trade Law

Diagram no. II: The N.C.P. in the 'Self-Contained' Ozone Layer Régime 235

Table no. IV: The Implementing Agencies' Share in 1996 


\section{INTRODUCTION}

A growing phenomenon of this shrinking world is that the clear-cut distinction between 'national', 'transnational' and 'global' environmental problems is fast disappearing in the international legal community. ${ }^{2}$ The depletion of the ozone layer is in this respect a typical example: no single state's activity will be responsible for potential adverse effects caused by ozone decreases, and most states have only a minimal role in both the production and the consumption of ozone-depleting chemicals (= 'ozone depleters'). ${ }^{3}$ The actions of those states that do produce or consume on a large scale potentially affect all states in the international community.

Ozone is an allotrope of oxygen, made up of three atoms of oxygen $\left(\mathrm{O}_{3}\right)$. It is formed when the molecule of the stable form of oxygen $\left(\mathrm{O}_{2}\right)$ is split by ultraviolet radiation or electrical discharge. ${ }^{4}$ Ozone is mainly found in two regions of the atmosphere, the stratosphere (approximately from ten to fifty kilometres above the Earth's surface, with a peak concentration at twenty kilometres) and the troposphere ${ }^{5}$ (which extends from the Earth's surface up to about ten kilometres). About ninety per cent of protective ozone - the blue, pungent-smelling gas - is concentrated in the stratospheric area (= the 'ozone layer' or 'ozone shield'). The strong consensus of the international community is that certain man-made chemicals are destroying the stratospheric ozone layer, which protects the Earth from harmful UV-B. from the Sun (= 'ozone depletion'), ${ }^{6}$ though there still exists uncertainty on some issues. ${ }^{7}$

2 On 'international environmental law' see among others P. Birnie and A. Boyle, International Law and the Environment, (1992); P. Sands, Principles of International Environmental Law, (1995); A. Kiss, Droit international de l'environment, (1989) or English edition, A. Kiss and D. Shelton, International Environmental Law, (1991); G. Handl, 'Environmental Security and Global Change: The Challenge to International Law', 1 Y.bk.I.E.L. (1990) pp. 3-33; P. H. Sand, 'UNCED and the Development of International Environmental Law', 3 Y.bk.I.E.L. (1992) pp. 3-17. As to policy (and legal) issues see A. Hurrell and B. Kingsbury, The International Politics of the Environment, (1992); L. K. Caldwell, International Environmental Policy: Emergence and Dimensions, 2nd edn. (1990).

3 On the definitions of production/'consumption' of O.D.Ss. see Chapter III(III.B.1-2).

${ }^{4}$ See Dictionary of the Environment, (1994) pp. 155-56.

5 At the ground level, ozone is simply 'bad': it can cause serious adverse effects including eye, nose and respiratory problems in humans and animals, damage plants, field crops, and forests and cause detrimental effects to many materials.

6 In 1974 Drs. F. Sherwood Rowland and Molina from California University published a scientific paper demonstrating how C.F.Cs. destroy ozone in the stratosphere ('Stratospheric Sink for Chlorofluoromethanes: chlorine atom-catalysed destruction of 
According to many experimental studies of plants and animals, and clinical studies of humans, health and environmental effects resulting from decreases in ozone include increased rates of skin cancer and eye cataracts; changes in the immune system in a dose and wavelength dependent fashion; damage to crops such as soya beans; and decreases in phytoplankton in the marine food chain. ${ }^{8}$ Further, it is well known that, as a result of damage to the stratospheric ozone layer, a continent-sized 'ozone hole' has formed over the Southern hemisphere (the 'Antarctic Ozone Hole'). ${ }^{9}$

The leading cause of ozone depletion has proven to be chlorofluorocarbons ('C.F.Cs.'), which were commonly used in air conditioners, refrigerators, foams, solvents and other C.F.Cs. related products. C.F.Cs. were first invented in 1928 by E. I. du Pont de Nemours and Company ('DuPont') and General Motors chemists who were looking for a non toxic heat transfer fluid for refrigeration. Other ozone-depleting substances that are believed to be destroying the stratospheric ozone layer include halons, hydrochlorofluorocarbons ('H.C.F.Cs.'), carbon tetrachloride ('CC14'), methyl chloroform or 1,1,1-trichloroethane ('C2 $\mathrm{H}_{3} \mathrm{Cl}_{3}$ '), hydrobromofluorocarbons ('H.B.F.Cs') and methyl bromide (' $\left.\mathrm{CH} 3 \mathrm{Br}^{\prime}\right)$. Chemicals such as C.F.Cs., halons and H.C.F.Cs. can contribute to global warming. 10

As its title already indicates, this doctoral thesis is about international law for the protection of the ozone layer. It will analyse the international legal ozone régime established by the 1985 Vienna Convention on the Protection of the Ozone Layer and the 1987 Montreal Protocol on Substances That Deplete the Ozone Layer as amended/adjusted (see Appendixes I-II). The treaty régime - regulating the above-mentioned chemicals - is the first international institutional mechanism designed to address a global environmental problem.

ozone' in 249 Nature, 28 June 1974, pp. 810-12). Their hypothesis first received a great deal of skepticism.

7 See Chapter III(III.C.2.b) below.

8 See U.N.E.P. 'Environmental Effects of Ozone Depletion: 1991 Update, Panel Report Pursuant to Article 6 of the Montreal Protocol on Substances that Deplete the Ozone Layer Under the Auspices of UNEP', (November 1991); U.N.E.P. 'Environmental Effects of Ozone Depletion: 1994 Assessment, Pursuant to Article 6 of the Montreal Protocol; R. D. Bojkov, The Changing Ozone Layer, (U.N.E.P./W.M.O. 1995) p. 19.

9 See e.g. R. D. Bojkov, The Changing Ozone Layer, (U.N.E.P./W.M.O. 1995) pp. 11 et seq.

10 See e.g. the U.N.E.P. Action on O3zone, (1989) p. 5. 
In comparison to other M.E.A. régimes such as the 1989 Basel Convention, 11 there is a relatively large amount of material including $\operatorname{articles}^{12}$ and several books ${ }^{13}$ devoted to studies of the ozone layer régime, particularly on the earlier versions of the Montreal Ozone Layer Protocol. My Ph.D. dissertation is indebted partly to these attempts made by the international legal and/or political scholars. However, to my knowledge, a comprehensive and detailed analysis of the international legal ozone layer régime still remains to be seen. Moreover, some parts of the treaty régime has been strangely neglected. For example, (i) the 1985 Vienna Ozone Layer Convention - as a fundamental legal basis of the Protocol régime has not been fully examined; 14 (ii) the literature upon the 'dynamic' Montreal Protocol adjusted four times is already outdated;15 (iii) little is known about the national implementation and enforcement of the ozone

1128 I.L.M. (1989) p. 657, reprinted in P. Birnie and A. Boyle, Basic Documents on International Law and the Environment, (1995) p. 322. The Convention entered into force on 5 May 1992. For a comprehensive review see K. Kummer, International Management of Hazardous Wastes, (1995).

12 There is a voluminous literature on the ozone negotiation. On the legal literature see footnotes below. In the context of international political science see among others P. Haas, 'Banning Chlorofluorocarbons: Epistemic Community Efforts to Protect Stratospheric Ozone', 46 International Organisations (1992) p. 187.

13 Among others see in particular R. Benedick, Ozone Diplomacy: New Directions in Safeguarding the Planet, (enlarged edition, 1998): the author was formerly the chief U.S. negotiator for the ozone treaties. From the perspectives from international political science see e.g. K. T. Litfin, Ozone Discourses: Science and Politics in Global Environmental Cooperation (1994); I. H. Rowlands, The Politics of Global Atmospheric Change, (1995).

14 See e.g. P. H. Sand, 'The Vienna Convention is Adopted', 27 Environment (June 1985) pp. 19-23; I. Rummel-Bulska, 'The Protection of the Ozone Layer under the Global Framework Convention' in J. G. Lammers (eds.), Transboundary Air Pollution, (1986) pp. 281-97; idem, 'Recent Developments relating to the Vienna Convention for the Protection of the Ozone Layer' Yearbook of the Association of Attenders and Alumni of the Hague Academy of International Law (1984/85/86) pp. 115-25; S. M. Williams, 'A Historical Background of the Chlorofluorocarbon Ozone Depletion Theory and its Legal Implications' in Lammers (eds.) Transboundary Air Pollution, (1986) pp. 267-80.

15 See J. Brunnée, Acid Rain and Ozone Layer Depletion: International Law \& Regulation, (1988); P. M. Lawrence, 'International Legal Regulation of the Ozone Layer: Some Problems of Implementation', 2 J.E.L. (1990) pp. 17-52; J. W. Kindt and S. P. Menefee, 'The Vexing Problem of Ozone Depletion in International Environmental Law and Policy', 24 Texas I.L.J. (1989) pp. 261-93; A. M. Capretta, 'The Future's So Bright, I Gotta Wear Shades: Future Impacts of the Montreal Protocol on Substances That Deplete the Ozone Layer', 29 Virginia J.I.L. (1988) pp. 211-48; D. Caron, 'La Protection de la Couche d'Ozone Stratosphérique et la Structure de l'Activité Normative Internationale en Matière d'Environment', A.F.D.I. (1990); D. Bryk, 'The Montreal Protocol and Recent Developments to Protect the Ozone Layer', 15 Harvard E.L.R. (1991) pp. 275-98; J. Tripp, 'The UNEP Montreal Protocol: Industrial and Developing Countries Sharing the Responsibility for Protecting the Stratospheric Ozone Layer', 20 N.Y.U.J.I.L.P. (1988) pp. 733-52. 
layer treaties; (iv) surprisingly, few studies have so far made of the Montreal Protocol's Non-Compliance Procedure; ${ }^{16}$ and (v) the Montreal Protocol's Multilateral Fund has not been fully researched by international lawyers, ${ }^{17}$ although this financial institution is deeply associated with compliance by a growing number of developing countries. Finally and more fundamentally, (vi) the concept of 'international legal régimes' 'international legal régimes for the environment' in particular- has not been clarified, despite the fact that the term is so frequently used in the literature of international law (e.g. 'the ozone régime'/'the L.R.T.A.P. régime').

Ideally, international environmental régimes - such as the technical ozone layer treaties 18 - must be analysed in their entireties as highly specialised legal systems in the sphere of international law. ${ }^{19}$ Partial legal studies of international treaty régimes are often misleading, indeed. 20

The contents of the doctoral thesis are as follows.

Part I (i.e. Chapter I), which will prove helpful as an introduction to the ozone layer régime, analyses international legal régimes for the environment, focusing on their relationship with law-making/developing, international environmental co-operation, 'soft enforcement' of treaty by internal international institutions, and finally, non-governmental organisations. In this part, the international régime for ozone will be conceptually characterised as the 'self-contained' environmental régime, having erga omnes character in the field of general international law.

16 See M. Koskenniemi, 'Breach of Treaty or Non-Compliance? Reflections on the Enforcement of the Montreal Protocol', 3 Y.bk.I.E.L. (1992) pp. 123-62. See also D. Victor's The Early Operation and Effectiveness of the Montreal Protocol's NonCompliance Procedure (1996), focusing on practical - but not on 'legal' - aspects of the procedure.

17 See e.g. R. Bowser, 'History of the Montreal Protocol's Ozone Fund', 20 I.E.R. (November 1991); E. R. DeSombre and J. Kauffman, 'The Montreal Protocol Multilateral Fund: Partial Success Story' in R. Keohane and M. Levy (eds.) Institutions for Environmental Aid (1996) pp. 89-126.

18 For instance, the U.N.E.P. emphasised in its general report that the drafters of the ozone convention 'must include technical and scientific experts including modellers and persons with extensive knowledge of the socio-economic impacts of different strategies for reducing CFC production and use' (UNEP/WG.69/3 ('Toward a Ozone Convention: A Look at Some Issue', para. 55).

19 However, being autonomous legal régimes does not necessarily mean that they deviate from established principles/rules of general public international law (for a discussion see Chapter I below).

20 See R. Benedick, Ozone Diplomacy, (1998) p. xvi. 
Part II (composed of Chapters II \& III) is devoted to the detailed legal analysis of the international treaties for the protection of the ozone layer. Chapter II examines the 1985 Vienna Ozone Layer Convention in the context of modern international law of the environment: it addressed, for example, the precautionary environmental 'principle'/approach and the common concern of (hu)mankind. Chapter III deals with (i) the gradual development or internationalisation of O.D.S. regulatory measures under the 1987 Montreal Protocol and (ii) national implementation and enforcement of the ozone treaties. To understand the real operation of the ozone layer régime, a great number of conference documents or reports prepared by the U.N.E.P. Secretariat will be used here. ${ }^{21}$

Part III (i.e. Chapter IV) discusses extensively the relationship between Article 4 of the Montreal Protocol and the G.A.T.T./W.T.O. trade law régime. It will be established that - viewed in its entirety - the Montreal Protocol's Article 4 trade restrictions seem to be compatible with the stringent trade rules of the G.A.T.T./W.T.O. economic law. Some issues in Part III are, of course, closely analysed by international trade lawyers. 22 This Chapter, however, includes detailed studies of Article 4 provisions as amended (Section II) and the relationship between M.E.As.' dispute settlement mechanisms (Montreal N.C.P. in particular) and the G.A.T.T./W.T.O. dispute settlement system (Section IV(B)).

Part IV (composed of Chapters V \& VI) examines the compliance system of the international ozone layer régime, which can be considered as, to borrow A. Chayes and A. H. Chayes's phrase, 'a managerial model of compliance' relying on a co-operative approach, rather than as a traditional enforcement model'.23 In Chapter $V$, the dispute avoidance/settlement system of the Ozone Layer Protocol, i.e. the NonCompliance Procedure and the functions of the internal treaty organs are

21 The full study of scientific/technical aspects of the Protocol's control measures lies outside the scope of this legal thesis, however. See in detail R. Benedick, Ozone Diplomacy, (1998).

22 See among others E. U. Petersmann, 'International Trade Law and International Environmental Law - Prevention, and Settlement of International Disputes in GATT', 27 J.W.T. (1993) pp. 43-81; W. Lang, 'Les mesures commercials au service de la protection de l'environment', R.G.D.I.P. (1995) pp. 555-56 esp.; J. Cameron and J. Robinson, 'The Use of Trade Provisions in International Environmental Agreements and Their Compatibility with GATT', 2 Y.bk.I.E.L. (1991) pp. 3-30; R. Twum-Barima and L. B. Campbell, Protecting the Ozone Layer through Trade Measures: Reconciling the Trade Provisions of the Montreal Protocol and the Rules of the GATT, (U.N.E.P./1994); T. Schoenbaum, 'Agora: Trade and Environment', 86 A.J.I.L. (1992) p. 700.

23 See A. Chayes and A. H. Chayes, The New Sovereignty: Compliance with International Regulatory Agreements, (1995). 


\section{Introduction}

closely examined. Chapter VI then investigates the Financial Mechanism of the Montreal Protocol, including the Multilateral Fund that was newly established in June 1990.

Part V, Conclusions,(i.e. Chapter VII) is intended as an (provisional) evaluation of the 'dynamic' international legal régime for the protection of the ozone layer. It may serve, at the same time, as a summary of the doctoral thesis. 


\section{PART I}

\section{INTERNATIONAL LEGAL RÉGIMES}




\section{CHAPTER I}

\section{INTERNATIONAL ENVIRONMENTAL RÉGIMES}

\section{A PRELIMINARY EXAMINATION OF 'INTERNATIONAL RÉGIMES'}

In 1990, one international political/legal scholar, Thomas Gehring, concluded that:

'international environmental régimes go far beyond treaty law as such. For a defined issue-area, they are international institutions comprising both an accepted body of normative prescriptions and an organised process for the making and application of these prescriptions. Given the successful integration of these two elements, international régimes turn out to be comparatively autonomous sectoral legal systems. ${ }^{1}$

Perhaps the highly specialised environmental regime that has framed the legally-binding regulation of ozone-depleting chemicals will also be characterised as such a 'sectoral legal system' in international environmental relations. Yet, an often-voiced concern by international lawyers is that such a sectoral legal system in a given issue-area - founded on a multilateral treaty - may still coexist with the system of modern international law, even though its régime institutions have successfully 'internalised' the making and application of law. ${ }^{2}$ I have much to say about the 'comparatively autonomous sectoral ozone régime' in the existing international legal system.

The principal purpose of the present doctoral thesis is to contribute to a better understanding of the international ozone treaties through the study of the so-called 'régimes' within the discipline of public international law. More specifically, we are concerned with a close analysis of the treatybased co-operative/regulatory ozone régime and its 'self-contained' implementation mechanisms at the international level.

1 T. Gehring, 'International Environmental Régimes: Dynamic Sectoral Legal Systems', 1 Y.bk.I.E.L. (1990) p. 56 (emphasis added).

2 See M. Koskenniemi, 'Breach of Treaty or Non-Compliance? Reflections on the Enforcement of the Montreal Protocol', 3 Y.bk.I.E.L. (1992) pp. 123-62. 
At present the term 'international régimes' is frequently used in the literature of both modern international law and international relations. 3 For many of régime theorists, international régimes - as legal normcreating institutions - may normally be established not only by formal multilateral treaties but also by other non-binding legal instruments including 'soft law'. ${ }^{4}$ From this perspective, Professor Eckart Klein's traditional régime-definition that strictly requires first of all a formal treaty seems to be too narrow. ${ }^{5}$ My intention here is not necessarily to stick to the so-called 'legal formalism' or 'legalism'. 6

In the political context of international relations studies, international régimes are generally defined as 'a set of implicit or explicit principles, norms, rules and decision-making procedures around which actors' expectations converge in a given area of international relations'. ${ }^{7}$

3 As regards differences between international law and international relations, see $M$. Sørensen (ed.), Manual of Public International Law, (1968) pp. 1-8 esp.; A. Hurrell, 'International Society and the Study of Regimes: A Reflective Approach' in V. Rittberger (ed.), Regime Theory and International Relations, (1992) pp. 54-57.

4 In the latter case, it is particularly difficult to identify the precise moment when régime-formation occurs in international relations. See footnote no. 7 below.

5 Defined as (i) a treaty between States or States and international organisations regulating the status of an area such as high seas or outer space, (ii) a general interest underlying the regulation, and (iii) the régime which endows the area with the general status erga omnes. See E. Klein, 'International Régimes' in 9 E.P.I.L. (1986) pp. 202 et seq. Cf. L. F. E. Goldie, 'Special Régimes and Pre-emptive Activities in International Law', 11 I.C.L.Q. (1962) pp. 698-99 esp., noting that régimes provide the 'ideal conditions for the early growth of the law'.

6 For a discussion of legalism, see e.g. J. N. Shklar, Legalism, (1964).

7 S. Krasner, 'Structural Causes and Regime Consequences: Regimes as Intervening Variables' in idem (ed.), International Regimes, (1983) pp. 1-22. For a critical argument of international relations theories see A. Hurrell, 'International Society and the Study of Regimes: A Reflective Approach' in V. Rittberger (ed.), Regime Theory and International Relations, (1992) pp. 57-71. Cf. S. Murase, 'Perspectives from International Economic Law on Transnational Environmental Issues', 253 Hague Recueil (1995) pp. 299-300. See also T. Gehring 'International Environmental Régimes', 1 Y.bk.I.E.L. (1990) p. 37 (footnote 16), arguing that régime theorists does not fully deal with the impact of decision-making procedure and the relationship between normative and decision-making elements. In an attempt to improve the most frequently cited international régime definition provided by S. Krasner, some authors further argue, for instance, that régimes could be 'the organising concepts for softer, nonbinding agreements that embody cross-national intentions on particular issues', and they are also 'created and operated primarily through mechanisms of negotiation'. See B. I. Spector, G. Sjostedt, and I. W. Zartman (eds.), Negotiating International Regimes: Lessons Learned from the United Nations Conference on Environment and Development (UNCED), (1994) pp. 3-4 (emphasis added). In addition, Osherenko and Young define international regimes as 'social institutions composed of agreed-upon principles, norms, and decision-making procedures that govern the interactions of actors in specific issue areas'. See G. Osherenko and O. Young, Polar Politics: Creating International Environmental Regimes, (1993) pp. 1 et seq. 
In brief, they are 'international institutions for the governance of limited issue-areas'. 8

Although examples of such régimes in international political/economic relations may be multiplied indefinitely, the General Agreement on Tariffs and Trade ('G.A.T.T.') ${ }^{9}$ - serviced by an ad hoc G.A.T.T. Secretariat in Geneva having uncertain treaty status 10 - can be regarded as the prototype. 11 The G.A.T.T., which is widely regarded as an international institution governing international trade relations, was originally intended to be only a provisional free-trade agreement until the establishment of the International Trade Organisation (i.e. 'I.T.O.'). ${ }^{12}$ In other words, the "G.A.T.T." was applied through the Protocol of Provisional Application (i.e. 'P.P.A.'), 13 from 1 January 1948, essentially as a treaty obligation under public international law. ${ }^{14}$ Although the W.T.O. trade régime has taken over the old G.A.T.T. régime, technically speaking, the

8 T. Gehring, Dynamic International Regimes, (1994) p. 15. But see also Y. Yamamoto, 'International Regimes: Search for Governance without Government', 95 Japanese Journal of International Law \& Policy, (1996) pp. 6-9 esp. On the concept of 'governance' see O. R. Young, 'Global Governance: Toward a Theory of Decentralised World Order' in idem (ed.), Global Governance: Drawing Insights from the Environmental Experience, (1997) pp. 273-99; V. Rittberger (ed.), Regime Theory and International Relations, (1992) pp. 392-94.

9 See Chapter IV(III) below.

10 See W. J. Davey, 'The WTO/GATT Trading System: An Overview' in Handbook of GATT, pp. 14-15. See also J. H. Jackson, The World Trading System: Law \& Policy of International Economic Relations, 2nd edn. (1997) p. 42, noting 'technically as a kind of a "leased group, whereby the GATT reimbursed" the ICITO for the costs of the secretariat'. Y. Iwasawa, WTO Dispute Settlement, (1995) pp. 5-6 (Japanese).

11 See T. Gehring, Dynamic International Regime, (1992) pp. 29 et seq. \& many other school-text books on international politics. The G.A.T.T. contained no explicit provisions for setting up any institutions. On the legal status of the G.A.T.T. see A. Kotera, 'The International Legal Status of the G.A.T.T.', Trade Journal, no. 2 (1990) pp. 39-45 (Japanese).

12 The I.T.O. Charter never entered into force.

13 The Protocol of Provisional Application to the General Agreement on Tariffs and Trade, October 30 1947, T.I.A.S. no. 1700. See J. H. Jackson, The World Trading System: Law \& Policy of International Economic Relations, 2nd edn. (1997) pp. 39-41. The 23 members of the Preparatory Committee of the U.N.E.S.C. signed the General Agreement as an interim measure, and the G.A.T.T. then entered into force in January 1948 with 23 founding contracting members, including China, France, the United Kingdom and the United States. The G.A.T.T. 1994 does not include this Protocol (see further Chapter IV(III) below).

14 For further details see Y. Iwasawa, WTO Dispute Settlement, (1995) Chapter 1(2) \& its footnote no. 25 (Japanese); R. E. Hudec, The GATT Legal System and World Trade Diplomacy, (1975). See also D. W. Bowett, The Law of International Institutions, 4th edn. (1982) p. 117, noting that 'This [i.e. G.A.T.T.] is . . more an international treaty than an international organisation'. On the W.T.O. institutional structure see e.g. W. J. Davey, 'The WTO/GATT World Trading System: An Overview' in Handbook of GATT, pp. 12-16 esp. 
original version of the G.A.T.T. treaty still continues to exist as an international agreement (see Chapter IV(III.A) below). 15

In the international legal system that still lacks a centralised authority, the basic administrative function of régimes will be to organise partly 'unorganised international society', 16 consisting of sovereign states as territorially organised units. The building of such legal/political régimes has been taking place not only in the territorial dimension but also in non-territorial and functional areas, e.g. global environmental protection such as ozone, human rights protection, arms control and the globalization of multilateral trade. In so far as environmental régimes are concerned, their crucial role would be to strictly regulate previously 'unregulated areas' of international environmental relations. In many case studies of environmental régimes, ${ }^{17}$ actors involved in the establishment and operation of environmental régimes are sovereign states or nations, international organisations in general, political organs of treaty régimes, non-governmental organisations, potentially affected industries, individuals and so forth.

In order to understand the legal significance of the ozone régime, for the present purposes, we shall focus on international régimes formally based on multilateral treaties. Unlike a mere political régime (i.e. nonbinding instruments), the creation of a treaty régime can introduce more reliable rules and norms to legally regulate the activities or behaviour of state and non-state actors in need of internationally agreed regulations or standards in a given issue-area of international relations.

International legal or treaty régimes are founded on the principle of good faith (bona fides), 18 which is the natural law concept of international

\footnotetext{
15 In this respect see E. U. Petersmann, The GATT/WTO Dispute Settlement System, (1997) pp. 50-51.

16 On the concept of 'international society' see G. Schwarzenberger, A Manual of International Law, 5th edn. (1967) pp. 8-15 esp. Cf. A. Hurrell, 'International Society and the Study of Regimes: A Reflective Approach' in V. Rittberger (ed.), Regime Theory and International Relations, (1992) pp. 62 et seq.

17 See e.g. O. R. Young and G. Osherenko 'Testing Theories of Regime Formation: Finding from a Large Collaborative Research Project' in V. Rittberger (ed.), Regime Theory and International Relations, (1992) pp. 223-51. See also the political/legal literature mentioned in a footnote no. 7 .

18 See S. Murase, 'Perspectives from International Economic Law on Transnational Environmental Issues', 253 Hague Recueil (1995) pp. 417-18; idem, 'Kokusai Funsou ni okeru "Singiseizitsu no Kinou', ('The Principle of Good Faith in the Implementation of International Obligations: The Function of Complaint Procedures in the Framework of International Regimes'), 38 Sophia University Law Review, (1995) pp. 189-221 (Japanese). See J. F. O'Connor, Good Faith in International Law, (1991) p. 124, defining the principle of good faith as a 'fundamental principle from which the rule
} 
law regarded as an 'implicit provision' of all treaty régimes. ${ }^{19}$ The legal principle is politically important in securing international co-operation between states in the existing international system. In the Nuclear Tests case, the International Court of Justice ('I.C.J.') held that:

One of the basic principles governing the creation and performance of legal obligations, whatever their sources, is the principle of good faith. Trust and confidence are inherent in international co-operation, in particular in an age when this co-operation in many fields becoming increasingly essential. 20

Further, in the W.H.O. and Egypt case, the International Court of Justice stated, in the advisory opinion relating to the transfer of the W.H.O. Regional Office from the territory of Egypt, that:

'the paramount consideration both for the Organisation and the host State in every case must be their clear obligation to co-operate in good faith to promote the objectives and purposes of the Organisation as expressed in its Constitution'.21

More recently, in Case concerning the Gabcikovo-Nagymaros Project (Hungary/Slovakia), the International Court of Justice noted that:

'Article 26 [of the 1969 Vienna Convention on the Law of Treaties] combines two elements, which are of equal importance. It provides that "Every Treaty in force is binding upon the parties to it and must be performed by them in good faith". This latter element, in the Court's view, implies that, in this case, it is the purpose of the

pacta sunt servanda and other legal rules distinctively and directly related to honesty, fairness and reasonableness are derived, and the application of these rules is determined at any particular time by the compelling standards of honesty, fairness and reasonableness prevailing in the international community at that time'. See also the 1969 Vienna Convention on the Law of Treaties (Article 26); the 1986 Convention on the Law of Treaties between States and International Organisations or between International Organisations (Article 26).

19 A. D'Amato, 'Good Faith', 9 E.P.I.L. (1986) pp. 107-09.

20 The Nuclear Tests cases (Australia v France and New Zealand v France), I.C.J. Reports, 1974, p. 268, para. 46 (emphasis added). For a discussion of the binding character of unilateral declaration, see, in particular, D. Kennedy, 'The Sources of International Law', 2 A.U.J.I.L.P. (1987) pp. 48 et seq.; H. E. Chodosh, 'Neither Treaty nor Custom: The Emergence of Declarative International Law', 26 Texas I.L.J. (1991) pp. $122-24$.

21 Interpretation of the Agreement of 25 March 1951 between the WHO and Egypt. I.L.R. 1982, p. 480 , para. 49 (emphasis added), cited in S. Murase, 'Perspectives from International Economic Law on Transnational Environmental Issues', 253 Hague Recueil (1995) p. 418. 
Treaty, and the intentions of the parties in concluding it, which should prevail over its literal application. The principle of good faith obliges the Parties to apply it in a reasonable way and in such a manner that its purpose can be realised'. 22

Good faith is something more than a mere ethical or political principle. These statements by the International Court of Justice are indicative of the philosophical view that the legal principle of good faith within international legal régimes will help maintain not 'blind' but mutual trust between régimes' state actors. 23 Under international treaty régimes states are thus expected to behave rationally at least. Non-compliance in 'bad faith' with obligations of treaty régimes would lead to the collapse of their legal systems. ${ }^{24}$

Section II of this Chapter is devoted to the in-depth analysis of international environmental régimes in the field of international law: it first considers international legal régimes for the environment in general, and then discusses the link between these régimes and (i) the law-making and developing of international co-operation or regulatory régimes of environmental regulation, (ii) the institutionalisation of international environmental co-operation, (iii) 'soft enforcement' of international environmental obligations and (iv) non-governmental organisations or institutions. Section III then examines the legal character of sectoral legal systems or 'self-contained régimes' in international law.

22 See Case Concerning the Gabcikovo-Nagymaros Project (Hungary/Slovakia), para. 142; A. E. Boyle, 'The Gabcikovo-Nagymaros Case', 8 Y.bk.I.E.L. (1997, forthcoming).

23 On the functions of the legal principle good faith in the W.T.O. régime see in particular T. Cottier and K. N. Schefer, 'Non-Violation Complaints in WTO/GATT Dispute Settlement: Past, Present and Future' in E. U. Petersmann (ed.), International Trade Law and the GATT/WTO Dispute Settlement, (1997) pp. 167-70 \& Section V.

24 See M. Virally, 'Review Essay: Good Faith in Public International Law', 77 A.J.I.L. (1983) pp. 130-34; A. Cassese, International Law in a Divided World, (1986) p. 157. Cf. B. O. Iluyomade, 'The Scope and Content of a Complaint of Abuse of Right in International Law', 16 Harvard I.L.J. (1975) pp. 50-51.

It is important to note that the principal source of non-compliance is not wilful disobedience but the lack of capability or clarity or priority. See A. Chayes and A. H. Chayes, The New Sovereignty: Compliance with International Regulatory Agreements, (1995). 


\section{INTERNATIONAL RÉGIMES IN INTERNATIONAL ENVIRONMENTAL RELATIONS}

In the context of environmental protection, Thomas Gehring defines international régimes as certain 'regulations' developed in a supreme organ of a treaty régime, governing a defined areas of international environmental relations. 25 In a similar vein, Dr. L. Jurgielewicz identifies international environmental régimes as the development of legal regulations ('normative expectations') by both state and non-state actors through collective decision-making, governing a specific issue area and creating a legal obligation among the actors. 26 Gehring lays special emphasis on the legislative function played by a Conference of the Parties or an equitable internal organ within a special treaty régime: such a political organ often enjoys considerable independence and it is (only) within the framework of international régimes that authoritative decisions are formally adopted (see Chapter II(III.D.2)). 27 On the other hand, Jurgielewicz's régime definition appears to come close to those of régime theorists of international relations studies. 28

The reason I first referred to these régime-definitions by two international lawyers is to show that international environmental régimes in many instances consist of legal regulations or standards. The standards or regulations established by regulatory régimes fall in the category of 'legal norms' having a relatively high degree of formality. ${ }^{29}$ As Professor

25 See T. Gehring, 'International Environmental Regimes: Dynamic Sectral Legal Systems', 1 Y.bk.I.E.L. (1990) p. 36.

26 L. Jurgielewicz, 'Global Environmental Change and International Law', (Ph.D. thesis, London University, 1994) pp. 157-58.

27 It is noticable in this context that the Consultative Meeting of the Parties to the Antarctic Treaty régime and its 'special' Meetings have steadily developed later international treaties to regulate the conservation of marine living resources, mineral resources, and so forth. See the 1959 Antarctic Treaty (Article 9); the 1972 Antarctic Seals Convention; the 1980 Antarctic Marine Living Resources Convention ('C.C.A.M.L.R.'); the 1988 Antarctic Mineral Resources Convention ('C.R.A.M.R.A.'); the 1991 Antarctic Environment Protocol. See e.g. P. Sands, Principles of International Environmental Law, (1995) pp. 522-34.

28 See régime-definitions in footnote no. 7 above.

29 A. Chayes and A. N. Chayes, The New Sovereignty, (1995) pp. 115-18. Cf. R. Higgins, 'The Role of Resolutions of International Organisations in the Process of Creating Norms in the International System' in W. E. Butler (ed.), International Law and the International System, (1987) p. 21, defining a norm as 'an authoritative provision of law that continues to command significant community expectations as to its contemporary validity and which may be appropriately invoked and applied in the particular factual context'. 
P. Birnie suggests, international regulations are meant to be a 'legal process since it implies an attempt to govern behaviour by the setting of rules and standards and the promulgation of principles'. 30 As far as very detailed legally-binding standards are concerned, however, it may be true that an environmental régime as a body of 'international environmental law' seems alien to general public international law or customary international law. ${ }^{31}$ Such environmental regulations will include the socalled 'ecostandards', emission standards of N.Ox., 'consumption'/production of C.F.Cs. and O.D.Ss. and other related instruments. They are generally annexed to the treaty texts and further adjusted by the highest treaty organ in accordance with developments in related scientific and technical knowledge. Usually, these treaty-based international standards themselves are not capable of being customary international law for environmental protection. 32 For a number of reasons, they must therefore be supervised by internally specialised international agencies or institutions, rather than by formal judicial institutions for legal settlement (see Section III(C) below \& Chapters III and V in particular).

In this particular respect, these treaty régimes are correctly understood as international regulatory régimes for the environment (i.e. international 'standard-setting treaties'). International regulatory régimes are designed to facilitate and consolidate the legal protection of international community interests as well as those of individual states. It is natural that such global regulatory régimes are based on international cooperation among developed and developing nations, international institutions, non-governmental and scientific institutions, industry and other non-state actors. In this way, they are defined as international cooperation régimes established specifically for the purposes of safeguarding the common interests of the international community as a whole. ${ }^{33}$ The

30 P. Birnie, 'International Environmental Law: Its Adequacy for Present and Future Needs', in A. Hurrell and B. Kingsbury, The International Politics of the Environment, (1992) p. 51 (emphasis added).

31 I. Brownlie, 'A Survey of International Customary Rules of Environmental Protection, 13 N.R.J. (1979) pp. 179-89. Under the international case-law, the Trail Smelter arbitration still remains the only international adjudication in the field of air pollution. Trail Smelter Arbitration (United States v. Canada), 33 A.J.I.L. (1939) p. 33; 35 A.J.I.L. (1941) p. 648; J. E. Reid, 'The Trail Smelter Dispute', C.Y.bk.I.L. (1963) pp. 213-29.

32 p. Birnie and A. Boyle, International Law and the Environment, (1992) pp. 12-13 esp. See M. Koskenniemi, 'Breach of Treaty or Non-Compliance', 3 Y.bk.I.E.L. (1992), arguing that detailed international standards have less than formal legal status.

33 In this respect some international co-operation régimes would fall into the category of the régimes that 'endow the areas the general status erga omnes (see Klein's 
terminology is used here to accentuate the growing importance of high levels of international co-operation between Northern industrialised and Southern industrialising countries in modern international environmental relations (see Section III(B) below).

International environmental regulations and legal rules can be defined as, in W. Lang's phrase, 'primary elements' or substantive 'régimes'34 of multilateral environment treaties. For example, Articles 2 and 3 of the Montreal Ozone Protocol and Articles 3, 4 and Articles 7 and 8 of the 1989 Basel Convention 35 can be regarded as such substantive provisions of international environmental régimes. As we shall see later, international diplomatic negotiations on 'primary elements' of environmental treaties are usually protracted and difficult. 36 In addition, the legal dynamics of regulatory régimes will be characterised by further elaboration of precise binding international regulations and detailed rules or practices by 'internal' treaty organs such as the Conference/Meeting of the Parties. ${ }^{37}$ Yet, this is only after the adoption of respective treaty régimes. 38

The international regulatory/co-operative régimes would also in many instances need procedural provisions relating to (i) obligations of prior notification and consultation in the context of environmental hazard, 39 (ii) obligations to notify 40 and consult ${ }^{41}$ in the case of accidents

régime-definitions in footnote no. 5 above). It would be possible to argue that the ozone layer presently enjoys such a general status in general international law (see Chapter II(III.B) above).

34 See W. Lang, 'Diplomacy and International Environmental Law-Making: Some Observations', 3 Y.bk.I.E.L. (1992) pp. 114-15.

3528 I.L.M. (1989) p. 657, reprinted in P. Birnie and A. Boyle, Basic Documents on International Law and the Environment, (1995) p. 322. The Convention entered into force on 5 May 1992.

36 In the context of the ozone régime see Chapter II(II) and Chapter III(II \& IV) below.

37 On the functions of the Conference of the Parties to M.E.As. see J. Werksman, 'The Conference of the Parties to Environmental Treaties' in idem (ed.), Greening International Institutions, (1996) pp. 55-68.

38 See J. Werksman, 'The Conference of the Parties to Environmental Treaties' in idem (ed.), Greening International Institutions, (1996) pp. 56-57. In the context of the ozone régime see Chapter III(IV)) esp.

39 See the 1986 Early Notification Convention; the 1986 I.A.E.A. Assistance Convention; the 1983 Exchange of Notes between the United Kingdom and France Concerning Exchange of Information in the Event of Emergencies Occurring in One of the Two States which could have Radiological Consequences for the Other State.

40 For example, the 1982 U.N.C.L.O.S. (Article 198); the 1972 M.A.R.P.O.L. Convention (Article 8(4)); the 1976 Barcelona Convention (Article 9(2)). See also the Corfu Channel Case (United Kingdom v. Albania), I.C.J. Reports, 1969, p. 4.

41 See e.g. the 1972 London Dumping Convention (Article V(2)); the 1974 Nordic Environmental Protection Convention (Article 11); the 1979 Geneva Convention 
or emergencies capable of causing transfrontier harm in general, (iii) environmental impact assessment ('E.I.A.') 42 and (iv) global environmental monitoring of treaty compliance 43 in general. They can be defined as 'secondary elements' of environment protection agreements. In logic and practice, such procedural 'régimes'44 themselves are not necessarily 'dynamic' in character, but they are absolutely indispensable for the development of substantive provisions of international legal régimes. In other words, procedural régimes are therefore contributory to the above-mentioned 'dynamics' and maintenance of international cooperative/regulatory régimes in international law.

In the light of their environment-related purposes, the dynamic of a regulatory aspect of international environmental régimes (i.e. the developments of substantive provisions) is noteworthy. As T. Gehring argues, 45 it is now undeniably one of the distinctive and unique characteristics of evolving régimes in international environmental relations. However, we as international lawyers must not forget that they nevertheless do co-exist with the system of general public international

(Articles 5 \& 8); the 1978 U.N.E.P. Draft Principles (Principle 7); the 1986 W.C.E.D. Legal Principles (Article 17); and the 1992 Rio Declaration (Principle 19). See also the Lac Lanoux Arbitration (France v. Spain), 24 I.L.R. 1957, p. 101; the Fisheries Jurisdiction cases (United Kingdom v. Iceland), I.C.J. Reports, 1974, p. 3. As to the continental shelf see e.g. the 1989 Kuwait Protocol concerning Marine Pollution Resulting from Exploitation and Exploration and Exploitation of the Continental Shelf; the 1981 U.N.E.P. Principles Concerning the Environment Related to Offshore Drilling and Mining within the Limits of National Jurisdiction. In addition, the principle of 'prior informed consent' ('P.I.C.') would be included in this category.

42 Early examples include the 1978 U.N.E.P. Draft Principles of Conduct; the 1985 A.S.E.A.N. Agreement (Article 14); the 1982 World Charter for Nature; the 1985 E.C. Environmental Assessment Directive; the 1982 U.N.E.P. Conclusions of the Study on the Legal Aspects Concerning the Environment related to Offshore Mining and Drilling within the Limits of National Jurisdiction; the 1982 U.N.C.L.O.S. (Article 206). On E.I.A. see in particular P. Sands and J. Werksman, 'Procedural Aspects of International Law in the Field of Sustainable Development: Citizen;s Rights' in K. Ginther (eds.), Sustainable Development and Good Governance, (1995) pp. 187-96; G. Wandesforde-Smith, 'Environmental Impact Assessment' in M. Bothe (ed.), Trends in Environmental Policy and Law, (1980) pp. 101-29; N. A. Robinson, 'International Trends in Environmental Impact Assessment', 19 Boston College Environmental Affairs Law Review (1992) pp. 591-610; S. Minami, 'The Development of International Environmental Law and E.I.A.', 115 Hitotsubashi Law Review (1996) pp. 190-208 (Japanese).

43 See Section III(C) below.

44 Yet it must be noted that, as with the doctrine of 'estoppel' (by 'representation') as a general principle of international law (see e.g. the Temple case) or of local remedies (see e.g. the Phosphates in Morocco case), the distinction between such 'procedural régimes' and 'substantive régimes' in international law is not necessarily clear-cut. See C. F. Amerasinghe, Local Remedies in International Law, (1990) pp. 347-50.

45 See Section I above. 
law and other specialised treaty régimes for various political and/or economic purposes (e.g. the G.A.T.T./W.T.O. régime), ${ }^{46}$ even though such international environmental régimes often do have a comparatively autonomous 'self-contained' character in international law.

Further, we also need to take account of national implementation of environmental agreements, simply because it is crucial for the successful implementation of régimes. 47 In this respect, it is noteworthy that many environmental agreements, including the 1985 Vienna Ozone Convention, 48 required their parties to adopt domestic measures and national implementation strategies. 49

\section{INTERNATIONAL ENVIRONMENTAL RÉGIMES AND INTERNATIONAL LAW}

\section{A. The Law-Making of International Co-operation Régimes of Environmental Regulation}

As stated earlier, international environmental régimes coming within the scope of the present legal study are created/maintained by formal multilateral treaties between states (i.e. conventions, treaties, accords, agreements and supplementing protocols).

International law can be developed from the following sources, i.e. the above-mentioned international conventions, whether general or particular; international custom; general principles of law, and as secondary sources, judicial decisions and the teaching of the most highly qualified publicists. 50 In the sphere of global environmental protection, as L. Gündling contends, international treaty law is of special importance

46 On the compatibility of the G.A.T.T./W.T.O. trade law régime and environmental treaty régimes see in detail Chapter IV below.

47 On this point see A. Hurrell, 'International Society and the Study of Regimes: A Reflective Approach' in V. Rittberger (ed.), Regime Theory and International Relations, (1992) pp. 69-71: Chapter III, Part B on the national implementation and enforcement of the international ozone treaties.

48 Article 2(2).

49 Notable examples are the 1992 Climate Change Convention (Article 4(2.a)): the 1992 Biodiversity Convention (Article 6): the 1989 Basel Convention (Article 9(5)): the 1985 A.S.E.A.N. Agreement on the Conservation of Nature and Natural Resources (Articles 1 and 2): the 1973 C.I.T.E.S. (Articles VIII.1-2 and 7 esp.).

50 See in particular P. Birnie and A. Boyle, International Law and the Environment, (1992), Chapter 1; I. Brownlie, Principles of Public International Law, 4th edn. (1990), Chapter I; A. Kiss, Droit international de l'environment, (1989) Chapitre II; S. Oda (eds.), Modern International Law, (1986) Chapter 4 (Japanese); Y. Onuma (ed.), InterCivilisation Law: Cases \& Materials, (1996) Chapter 2 (Japanese); S. Yamamoto, International Law, (1994) Chapter 3 (Japanese); D. Kennedy, 'The Sources of International Law', 2 A.U.J.I.L.P. (1987) pp. 1-96. 
because it is by multilateral treaties that the necessary environmental obligations can be formulated in a sufficiently clear and systematic manner. 51 However, it is very likely that, in view of the level of economic and political integration of the present international community, states would hesitate to adopt a comprehensive single agreement that will deal with 'all aspects' of a given issue-area of international environmental relations. 52

A growing number of environmental régimes are based upon multilateral umbrella/framework conventions and/or subsequent implementing protocols. They include: the 1985 Vienna Ozone Layer Convention and its Montreal Protocol; the 1979 L.R.T.A.P. Convention adopted under the auspices of the U.N. Economic Commission for Europe ('U.N.E.C.E.') and its five Protocols; 53 the 1992 Climate Change Convention 54 and the 1997 Kyoto Protocol; U.N.E.P. Regional Sea Conventions and their supplementing protocols; 55 and, arguably, the international waste régime

51 L. Gündling, 'Environment, International Protection', 5 E.P.I.L. (1986) pp. 122 et seq. See also P. C. Szasz, 'International Norm-Making' in E. B. Weiss, Environmental Change and International Law: New Challenges and Dimensions, (1992) pp. 41-62 esp.

52 It is probably true that the existing environment treaty law is therefore fragmentary and unsystematic: unlike the global 'Constitution for the Oceans' (i.e. the 1982 U.N.C.L.O.S.), there does not exist a 'Convention on the Law of Global Air', as was suggested in the 1989 Ottawa Meeting of Legal and Policy Experts on the Protection of the Atmosphere. See P. H. Sands, 'UNCED and the Development of International Environmental Law', 3 Y.bk.I.E.L. (1992) p. 7.

53 The 1979 Convention on Long-range Transboundary Air Pollution, 18 I.L.M. (1979) p. 1442; the 1984 Protocol on Long-term Financing of a Co-operative Programme for Monitoring and Evaluation of the Long-range Transmission of Air Pollutants in Europe ('E.M.E.P.'), 27 I.L.M. (1988) p. 701; the 1985 Protocol on the Reduction of Sulphur Emissions or Their Transboundary Fluxes, 27 I.L.M. (1988) p. 707; the 1988 Protocol Concerning the Control of Emissions of Nitrogen Oxides or Their Transboundary Fluxes, 28 I.L.M. (1989) p. 212; the 1991 Protocol Concerning the Control of Emissions of Volatile Organic Compounds or Their Transboundary Fluxes, 31 I.L.M. (1992) p. 573; the 1994 Protocol on Further Reduction of Sulphur Emissions, 33 I.L.M. (1994) p. 1542. On the effectiveness of the L.R.T.A.P. régime see J. Wettestad, 'Acid Lessons? LRTAP Implementation and Effectiveness', 7 G.E.C. (1997) pp. 235-49.

54 Text in P. Birnie and A. Boyle, Basic Documents on International Law and the Environment, (1995) p. 252.

55 The U.N.E.P. Regional Sea Conventions include the 1976 Barcelona Convention for the Mediterranean and Protocols (15 I.L.M. (1976) p. 290) supplemented by the 1980 Athens Protocol and the 1982 Geneva Protocol; the 1978 Kuwait Convention and Protocol (17 I.L.M. (1978) p. 511) and the 1989/90 Protocols; the 1981 Abidjan Convention and Protocol (20 I.L.M. (1981) p. 746) supplemented by the 1981 Protocol; the 1981 Lima Convention and Agreement supplemented by 1981/83/89 Protocols; the 1982 Jeddah Convention and the 1992 Protocol; the 1983 Cartagena Convention and Protocol (22 I.L.M. (1983) p. 221) and the 1983/90 Protocols; the 1985 Nairobi Convention and Protocols; the 1986 Noumea Convention and Protocols (26 I.L.M. (1987) p. 38). Many of these treaty texts can be found in P. H. Sand, Marine Environment Law in the UNEP, (1988). 
of the 1989 Basel Convention. On many occasions, they incorporated certain elements of non-binding 'soft law' instruments produced beforehand by negotiating state actors. 56 After the adoption of a treaty, the highest treaty institution within the respective régime would also generate not only 'hard law' but also internal 'soft law' such as decisions or resolutions or recommendations that lack formal binding force. 57

One of the major reasons to rely on framework conventionsimplementing protocols - and international 'soft law' - is that their lawcreating/developing techniques generally correspond to economic, political and social realities of the decentralised international legal community of nearly two hundred states. In addition, even in a situation of scientific uncertainty, certain positive action must be taken by states to prevent serious or virtually irreversible environmental damage (e.g. ozone depletion). In short, these legal instruments can provide a flexible lawcreating/developing process in international environmental relations. More concretely, by using these techniques, state actors can tackle controversial or complicated global environmental issues collectively at a time when they are in reality still hesitant in restricting their freedom of action.

In this respect, it cannot be denied that traditional customary international law rules and their law-making methods do not necessarily recognise the urgency of the need for efficient international co-operation and regulatory régimes for the environment: customary law requires state practice in the international community combined with an opinio juris, and usually evolves over a relatively long period. 58 In a somewhat

56 Especially worthy of reference would be the 1972 Stockholm Declaration on Human Environment (see Chapter II(III.C.1) below); the 1982 World Charter for Nature; the 1975 Mediterranean Action Plan ('M.A.P.'); the 1985/87 Cairo Guidelines and Principles for the Environmentally Sound Management of Hazardous Wastes; and the 1989 Helsinki Declaration which preceded the 1990 Revision of the Montreal Ozone Protocol (see Part A of Chapter III(IV.B)) below).

57 As will be described in chapters below, internal 'soft law' adopted by the Ozone Meeting of the Parties (i.e. 'Ozone Decisions') has formed an important part of the international regulatory régime. Under the 1973 C.I.T.E.S. régime, a total of 190 nonbinding recommendations made by the Conference of the Parties - interpreting and elaborating its legal text - have shaped the international régime in a manner barely foreseeable at the time of its adoption. See P. H. Sand, 'Whither CITES? The Evolution of a Treaty Regime in the Borderland of Trade and Environment', 8 E.J.I.L. (1997) p. 35.

58 But see e.g. the North Sea Continental Shelf cases (Federal Republic of Germany v. Denmark; Federal Republic of Germany v. the Netherlands), I.C.J. Reports, 1969, para. 73 , noting that 'it might be that, even without the passage of any considerable period of time, a very widespread and representative participation in the convention might suffice of itself . . .'; the Libya v. Malta case, I.C.J. Reports, 1985, pp. 29-30; the 
different context, a comprehensive set of rules/principles contained in the 1969 Vienna Convention on the Law of Treaties ${ }^{59}$ by itself cannot provide flexible guidelines to quickly 'reach' international treaty régimes relating to global environmental protection. A 'new law-making technique' is needed here. 60

DIAGRAM no. I: THE FRAMEWORK CONVENTIONS-PROTOCOL APPROACH

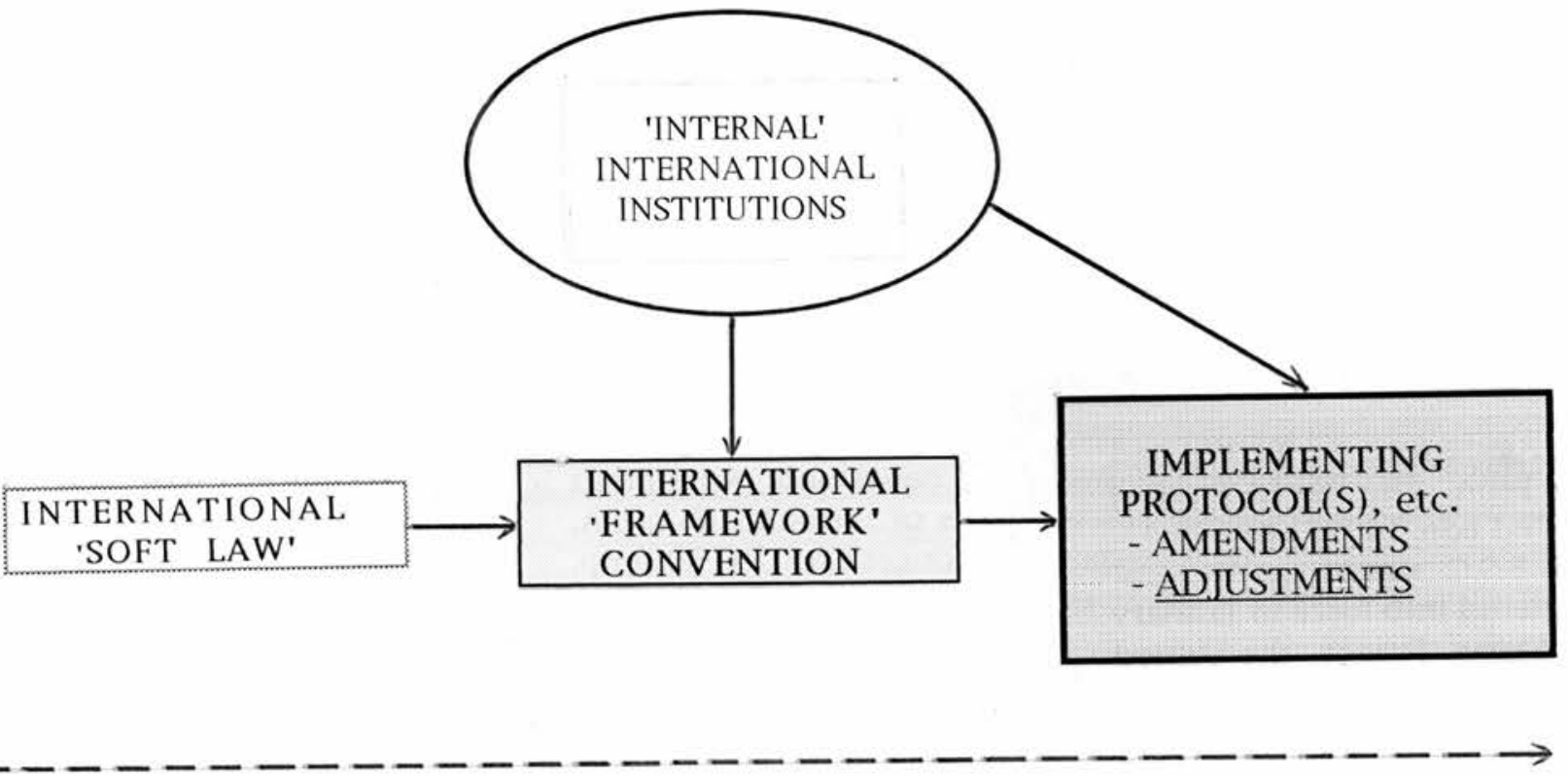

CHANGING SCIENTIFIC EVIDENCE

Nicaragua case (Merits: Nicaragua v. United States), I.C.J. Reports, 1986, p. 98. See also B. Cheng, 'United Nations Resolutions on Outer Space: "Instant" International Customary Law?', Indian J.I.L. pp. 23 et seq.; P. C. Szasz, 'International Norm-Making' in E. B. Weiss, Environmental Change and International Law: New Challenges and Dimensions, (1992) pp. 66-69.

59 8 I.L.M. (1969) p. 679; 63 A.J.I.L. (1969) p. 875, entered into force in 1980. See in particular I. Sinclair, The Vienna Convention on the Law of Treaties, 2nd edn. (1984). Y. Ogawa, The Law of Treaties, (1989, Japanese).

60 See J. I. Charney, 'Universal International Law', A.J.I.L. 87(1993) p. 543, noting that 'Rather than state practice and opinio juris, multilateral forums often play a central role in the creation and shaping of contemporary international law'. On the role of such 'multilateral forums' in the development of the ozone protection régime, see Chapters II(II), III(II), V(II) \& VI(II) esp. 
As sketched here (Diagram no. I), in the first phase, framework conventions 61 lay down international substantive obligations only in general and broad terms for hesitant states to take appropriate measures or enact 'all practicable measures': this is in effect the confirmation of the rule of international 'due diligence' (see Chapter II(III.C.1)). ${ }^{62}$ However, as with the 1985 Vienna Ozone Layer Convention (Articles 2-5) and the 1979 Geneva L.R.T.A.P. Convention (Articles 3-9), framework convention régimes commonly furnish the institutional basis for future international environmental co-operation in scientific research, systematic observation, information exchange and so on.63 For this purpose, Secretariats for environmental conventions typically have important functions as groups of technical experts (see Chapter II(III.D.3)). In the second phase, based on improved or changing scientific knowledge and technical data, protocols or subsequent treaties and/or annexes then set detailed legally-binding international standards or regulations (e.g. emission standards) that will give practical content to the vague rule of customary law, 'due diligence'. In the light of any newly emerging scientific evidence, if the need arises, Conferences/Meetings of the Contracting Parties established by convention/protocol régimes are to take further necessary measures on a regular basis (see Chapter II(III.D.2)). As regards this point, a revolutionary simplified majority voting procedure established by the Montreal Protocol is particularly noteworthy (see Chapter III(III.C).

It should also be pointed out that, since the framework convention sets the fundamental basis on which supplementary protocols are built, no one may become a party to protocols unless they become a contracting party to the original convention régime. 64 In addition, any party which

61 In a report entitled 'Towards an Ozone Convention', the U.N.E.P. Working Group defined a framework convention as 'an agreement by the signatories to a common objective; an agreement to co-operate in research, monitoring and exchange of information; and an expression of intent to effect future agreements for specific actions toward controls and other measures' (UNEP/WG.69/3, 31 December 1981, p. 10)

62 But the 1992 Climate Change Convention introduces certain emission reduction targets (Article 4(2.a-b)).

63 On this point see A. E. Boyle, 'The Principle of Co-operation: the Environment', in A. V. Lowe and Warbrick (eds.), The United Nations and the Principles of International Law, (1994) p. 131, suggesting that 'the inability to agree co-operative solutions, unless evidence of bad faith, is not itself a breach of international law.

64 See the Vienna Ozone Convention (Article 16(1)). The close connection between a convention and expected protocols was emphasised throughout the Vienna Convention negotiation. See also the 1987 Montreal Protocol (Article 14); the Biodiversity Convention (Article 32(1)); the 1992 Framework Convention on Climate Change (Article 17(4)); the 1976 Barcelona Convention (Article 23). Cf. Article 32(2) of the 
withdraws from the convention is therefore considered as also having withdrawn from any protocol to which it is a contracting party. 65 This cooperative and solid relationship between the convention and implementing protocols/annexes forms a united and 'complete' international regulatory régime, which will impose uniform international obligations of protocols on contracting parties. Additionally, this would also exclude different legal interpretations of its environmental treaty provisions. 66

In the final place, it must be added that the eventual results of the framework convention approach are not necessarily always symbolic or 'lowest-common-denominator international agreements', as is often argued by some critical commentators. 67 Rather, a framework convention should be correctly understood as a necessary 'framework' of a solid legal régime for further international environmental co-operation. In many cases, subsequent scientific investigation prosecuted by 'internal' and/or 'external' régime institutions verifies further international co-operation in a given issue area, and new scientific discovery would help adopt future implementing protocols and/or annexes and other legal instruments. 68

Turning to 'soft law',69 the legal terminology is somewhat controversial since the rules of law are considered in general only to be

Biodiversity Convention stating that parties have the right to participate in the meetings of the parties to that protocol. Certainly, whether a party to an original convention ratify the implementing agreements or not depends upon herself.

65 See e.g. the 1985 Vienna Ozone Convention (Article 19(4)); the 1997 Kyoto Protocol (Article 27(3)).

66 The 1969 Vienna Convention on the Law of Treaties provides that the 'context' for the purpose of the interpretation of a treaty includes 'any agreements relating to the treaty which was made between all the parties in connection with the conclusion of the treaty, added to its preamble and annexes' (Article 31(a) para. 2).

67 See e.g. L. Susskind, Environmental Diplomacy: Negotiating More Effective International Agreements, (1992) p.32.

68 In the context of the ozone régime see Chapter III(IV) below.

69 For the analysis of international 'soft law', see in particular P. Birnie and A. Boyle, International Law and the Environment, (1992) pp. 26-30 esp.; P.-M. Dupuy, 'Soft law and International Law of the Environment', in 12 Michigan J.I.L. (1990) pp. 420-435; G. Wesierski, 'A Framework for Understanding Soft Law', 30 McGill L.J. (1984) pp. 37 88; M. Koskenniemi, 'Comment on the Paper by Antonia Handler Chayes, Aram Cheyes and Ronald B. Michell' in W. Lang, Sustainable Development and International Law, (1995) pp. 94-96; C. M. Chinkin, 'The Challenge of Soft Law: Development and Change in International Law', 38 I.C.L.Q. (1989) pp. 850-66; O. Schachter, 'Recent Trends in International Law Making', 12 A.Y.bk.I.L. (1988-89) pp. 11 et seq.; P. W. Birnie, 'Legal Techniques of Settling Disputes: The "Soft Settlement" Approach', in Butler, Perestroika and International Law, (1990) pp. 183 et seq.; M. Fitzmaurice, 'International Environmental Law as a Special Field', in 25 N.Y.bk.I.L. (1994) pp. 199201; 'A Hard Look at Soft Law', in Pro.A.S.I.L. 82nd Annual Meeting,(1988) pp. 37195. See also S. Murase, 'The Changing Views on the Sources of International Law', 25 Rikkyo Review of Law and Politics, (1985) pp. 81-111. 
compulsory or legally binding: that is to say, such legal rules must always be 'hard law' as such. Strictly speaking, the term international 'soft law' may therefore be misleading. 'Soft law' instruments can be considered at best as 'para-droit', 'per-droit' or 'pré-droit'. 70 In the present doctoral thesis, I will use the legal term 'soft law' to refer to legally non-binding instruments which thus do not fall into the categories of sources referred to in Article 38(1)(c) of the I.C.J. Statute, namely, 'Resolutions' or 'Decisions' and 'Declarations' by international organisations and conferences, nonbinding international standards, code of conduct, standard of conduct, gentlemen's agreement, and other non-binding agreements including political principles and goals.

International 'soft law' creates an expectation of future international environmental co-operation. ${ }^{71}$ In political terms, international 'soft law' instruments - less than formal legal status - could contribute to reinforcing certain 'expectations' shared by state actors and/or the international community. ${ }^{72}$ 'Soft law' can produce certain 'legal' effects or norms without formal national ratification. In this sense, an international 'soft law' approach possesses indirect but immediate practical value to the multilateral and global law-creating/developing process.

\section{B. The Institutionalisation of International Environmental Co-operation}

The effectiveness of and compliance with international régimes for the environment depend upon the corresponding degree of environmental cooperation among states, international organisations ('I.G.Os.'), nongovernmental and scientific organisations ('N.G.Os.'), industry and individual citizens. The meaning of the term 'international co-operation' that has never been defined by international treaties 73 - can be defined here as the internationally co-ordinated (collective) actions taken by governmental/non-governmental régime actors in a given issue-area of international environmental relations. ${ }^{74}$ Thus, the concept of

70 See O. Schacther, 'Recent Trends in International Law Making', 12 Australian Y.bk.I.L. (1988-89) p. 12.

71 In the context of the ozone régime see Chapter II(II.B.1) below.

72 As suggested earlier, 'soft law' instruments could produce régimes (see a footnote no. 7 above).

73 See R. Wolfrum, 'International Law of Co-operation', 9 E.P.I.L. (1986) p. 193.

74 Cf. P. T. Stoll, 'The International Environmental Law of Cooperation' in R. Wolfrum, Enforcing Environmental Standards, (1996) pp. 41-43, distinguishing 'a law on 
'international co-operation' introduced here in the context of a régime analysis is much broader than the procedural obligations of notification, consultation and E.I.A. in international law (see Section II above). All of the governmental or non-governmental actors are involved in the creation/development of international environmental régimes: a substantial number of environment-related treaties are adopted within the framework of international institutions as 'catalysts' (e.g. the U.N.E.P. and the International Maritime Organisation ('I.M.O.')); scientific evidence readily piled up by individual scientists and their scientific institutions helps facilitate the further developments of highly technical régimes; in order to restrict economic activities that affect the environment, many governments have formed certain forms of partnership with their industries (e.g. voluntary agreements and various economic instruments). ${ }^{75}$ This means at the same time that the realisation of the socalled 'sustainable development'76 will thus depend upon their environmental efforts. The principle has gained wide recognition in general public international law of the environment. ${ }^{77}$ For the present purpose, however, we are concerned here with international co-operation among governmental actors.

In order to achieve their environmental objectives and purposes, depending upon a specific issue area, international régimes must accommodate universal or wider participation from both developed and developing countries. ${ }^{78}$ The growing role of developing state actors in

cooperation' and 'law of cooperation'. See also H. Milner, 'International Theories of Cooperation Among Nations: Strengths \& Weaknesses', 44 World Politics (1995) pp. 46696.

75 In the context of the ozone régime see Part B of Chapter III below.

76 The Brundtland Report defined the term as 'development that meets the needs of the present without compromising the ability of future generations to meet their own needs' (The W.C.E.D., Our Common Future, (1987) p. 43. See Rio Principle 27, stating that 'State and people shall cooperate in good faith and in a spirit of partnership. . . in the future development of international law in the field of sustainable development'. For an extensive discussion see e.g. W. Lang (ed.), Sustainable Development and International Law, (1995); K. Ginther (eds.), Sustainable Development and Good Governance, (1995). Y. Takamura, 'The Concept of Sustainable Development and Environmental Interests' in Y. Otani, The Concept of Common Interests and International Law, (1993) pp. 361-90.

77 See separate opinion of Vice-President Weeramantry attached to the I.C.J.'s Gabcíkovo-Nagymaros Case, (Hungary/Slovakia), reproduced in U.N.E.P. (eds.), Compendium of Summaries of Judicial Decisions in Environment Related Cases, (1997) pp. 199-243.

78 For instance, due largely to its low number of ratifications and a shortage of funds, the 1979 Bonn Convention with later 'AGREEMENTs' could not provide an effective international co-operative régime for protection of endangered migratory species. See P. Birnie and A. Boyle, International Law and the Environment, (1992) pp. 470-75; S. 
establishing and maintaining régime institutions reflects the present importance of global environmental co-operation. ${ }^{79}$ The following paragraphs will show that modern international treaty law for the environment has introduced relatively new legal and economic instruments to foster global environmental co-operation in securing both participation and compliance. 80

In the first place, as incentives for states' participation, international environmental régimes often contain economic sanctions within their legal instruments. ${ }^{81}$ They include restrictions of foreign trade with non-parties to a treaty and/or non-complying non-party states (the Montreal Protocol (Article 4); the 1973 C.I.T.E.S. (Article 5); 82 the 1989 Basel Convention (Article 4(5)). For instance, as will be discussed in Chapter IV below, Article 4 of the Montreal Ozone Layer Protocol requires parties to strictly restrict international trade in ozone-depleting chemicals with non-complying non-parties to the Protocol.

It cannot be denied that these international trade mechanisms are virtually certain legal tools for promoting 'compulsory' international cooperation in protecting the environment. Perhaps this is indicative of the political aspect of international (environmental) régimes that tends to reflect the economic/political interests of the powerful states, even though their environmental objectives would be adequately justified. 83 In another

Lyster, 'The Convention on the Conservation of Migratory Species of Wild Animals (The 'Bonn Convention'), 29 N.R.J. (1989) pp. 979-1000.

79 However, for a variety of reasons, the interest of environmental protection collides with other societal interests - an economic one in particular - and the necessary decisions often involve 'value judgements' as such. See L. Gündling, 'Environment, International Protection', 9 E.P.I.L. (1986) p. 122.

80 Subjects selected in this section are limited largely to legal instruments concerned directly with 'international environmental co-operation' (see Section II above): for a comprehensive review see in particular P. H. Sand, 'International Economic Instruments for Sustainable Development: Sticks, Carrots and Games', 26 Indian J.I.L. (1996) pp. 1-16.

81 See generally R. Wolfrum (ed.), Enforcing Environmental Standards: Economic Mechanisms as Viable Means?, (1996); K. Kummer, 'Providing Incentives to Comply with Multilateral Environmental Agreements: An Alternative to Sanctions?', European Environmental Law Review, (October 1994) pp. 256-63.

8212 I.L.M. (1973) p. 1055, entered into force in July 1975. For the text amended in 1979 see P. Birnie and A. Boyle, Basic Documents on International Law and the Environment, (1995) p. 415.

83 See PRESS/TEO19 ('WTO Symposium on Trade, Environment and Sustainable Development', July 1997), noting that some participants (presumably including delegations from developing states) felt that 'trade measures in MEAs were inappropriate, reflecting the power of industrialised countries over developing countries'. See also E. A. Nadelmann, 'Global Prohibition Regimes: The Evolution of Norms in International Society', 44 International Organisations (1990) pp. 480, 511 - 
case, it is said that the creation of the post-war regime for human rights depended fundamentally on the particular values and interests of the Western states including the United States. 84

International community pressure exercised by non-governmental institutions upon a particular government may in certain situations encourage its universal participation in international co-operation régimes. 85 However, in most cases, these global sanctions are not sufficient to entice developing states into joining international regulatory régimes for the global environment. 86

In the second place, international environmental régimes therefore commonly provide (general or detailed) provisions for capacity-building for developing countries. 87 The objective of capacity-building is to build up the long-term capacity of aid receiving countries to comply with legal obligations of particular environmental régimes. As will be described in Chapter VI below, these provisions are designed especially for (i) bilateral, regional and/or international financial assistance such as 'internal' treaty-based fund (e.g. the Montreal Multilateral Fund, i.e. 'M.L.F.'), (ii) international technology transfer, (iii) institutional strengthening, and (iv) further development of aid-receiving states' environmental awareness. In this connection, the Global Environmental Facility

24 , arguing that the international drug control régime has reflected the predominance of the United States and European States in creating norms of selecting uses of psychoactive substances. In other words, criminal laws of these dominant States have currently served as models of the drug control régime.

84 A. Hurrell, 'International Society and the Study of Regimes: A Reflective Approach' in V. Rittberger (ed.), Regime Theory and International Relations, (1992) p. 66.

85 It is reported that, in the case of the C.I.T.E.S., 'A major factor influencing the decision of many countries to become Party to CITES is the pressure that stems from adverse publicity about illegal or harmful wildlife trade and about the morality of animals in the large-scale pet trade' (cited in P. H. Sand [ed.] The Effectiveness of International Environmental Agreements: A Survey of Existing Legal Instruments, (1992) p. 81).

86 Concerning this point, it is worth noting that, before the adoption of the 1987 version of the Montreal Ozone Protocol, only a few developing countries decided to become contracting parties to the 1985 Vienna Ozone Convention régime. See Chapter VI(II.A) below. See also P. H. Sand (ed.), The Effectiveness of International Environmental Agreements: A Survey of Existing Legal Instruments, (1992) pp. 1011.

87 See A. E. Boyle, 'Comment on the Paper by Diana Ponce-Nava', in W. Lang, Sustainable Development and International Law, (1995) p. 138, suggesting that the present time these special treaty provisions for developing countries have been regarded as prerequisites or the 'price of participation'. See also P. H. Sand, 'Trust for the Earth: New International Financial Mechanisms for Sustainable Development', in W. Lang, ibid. pp. 167-83. 
('G.E.F.'), 88 which is jointly administered by the World Bank, the U.N.D.P. and the U.N.E.P., will also strengthen the operation of environmental régimes in the fields of ozone protection, global warming, biodiversity and pollution of international waters. 89

In the third place, just like the Montreal Ozone Layer Protocol, international environmental régimes often contain special provisions for the sake of international equity. They will include 'grace periods' delaying implementation of treaty law, 90 the above-mentioned provisions for capacity-building and other compliance-related provisions peculiar to individual environmental régimes. 91 Their underlying philosophy will be the 'principle' of common-but-differentiated responsibility that claims the common responsibility of developed/developing nations for the protection of the environment, whilst such responsibility should be equitably differentiated in accordance with each state's contribution to the environmental damage and its level of economic development (see Chapter III(III.E.3) below). The 1992 U.N. Climate Change Convention (Article 3(1)) and the 1997 Kyoto Protocol (Article 10) explicitly refer to this new 'principle' or approach. Furthermore, in some exceptional cases, régime institutions' decision-making mechanisms are also designed for international equity considerations: under the ozone régime, decisions on adjustments are to be taken by a two thirds majority vote of the contracting parties representing a majority of both developed and developing countries (Article 2(9)(c) of the Montreal Protocol).92 The composition of the Executive Committee of the M.L.F. also reflects the important role of international equity (see Chapter VI(III.B.1)).

C. 'Soft Enforcement' of Treaty: Implementation of and Compliance with Legal Obligations of International Environmental Régimes

International law of the environment is not a matter of either preventive rules or reparative rules: in many respects, both international legal

88 For the text of the G.E.F. restructured in 1994, see 33 I.L.M. (1994) p. 1273, reproduced in P. Birnie and A. Boyle, Basic Documents on International Law and the Environment, (1995) p. 666. On the G.E.F. see Chapter VI(III.C) below.

89 See Chapter VI(III.C) below.

90 See Chapter III(III.E) below.

91 This third category of provisions are not necessarily concerned with the special situation of developing countries, however. In the context of the ozone régime see Chapter III(III).

92 See Chapter III(III.C) below. 
instruments are needed as a united living organism. Yet, in the present study, I would like to lay special emphasis on the point that a growing number of international environmental régimes are founded to a lesser or greater extent on the principle of preventive action - represented by Stockholm Principle 21 (Rio Principle 2)93 - and the precautionary 'principle' of international environmental law.

The precautionary environmental 'principle' - that is, in my view, still closely related to the principle of preventive action - means, in short, that certain preventive measures to protect the environment should be taken even before a causal link has been established by absolutely clear scientific evidence (see further Chapter II(III.C) below). The compelling reasons to rely on legal regulations of preventive character will be as follows: (i) some environmental damage (typically ozone depletion) might be irreversible; (ii) it would be less costly to prevent an environmental degradation than to restore the environment afterwards; (iii) it is difficult - though not impossible - to link environmental harm to a particular economic activity or a particular industrial installation. By relying mainly on the comprehensive package of internationally co-ordinated preventive rules, régime members thus aim to protect the environment, and at the same time they could successfully avoid anticipated environmental disputes in a given issue-area of international environmental relations.

International supervision of treaty-based regulatory measures by internally specialised institutions 94 will be characterised as 'soft enforcement' of environmental treaties. 95 Unlike judicial tribunals that are essentially confrontational and bilateral (e.g. the I.C.J.), mechanisms for dispute avoidance/settlement within environmental régimes are multilateral in character: instead of international adjudication based on

\footnotetext{
93 For a discussion see Chapter II(III.C.1) below.

94 For the present purpose, treaty organs or agencies such as the Meetings of the Parties, treaty Secretariat and technical Committees will be properly called 'internal international institutions'. In a strict sense they are different from 'international organisations of universal character' such as the United Nations and its various specialised agencies. See the 1975 Vienna Convention on the Relationship of States in Their Relations with International Organisations of a Universal Character (Article I(1.2)). Unlike these internal treaty organs in general, it is established that the United Nations and its subsidiary agencies have certain international legal personality. See the Reparation for Injuries Suffered in the Service of the United Nations case, (Advisory Opinion), I.C.J. Reports, 1949, p. 174; the Certain Expenses of the United Nations Case, I.C.J. Reports, 1962, p. 151.

95 See O. Yoshida, '"Soft Enforcement" of Treaty: The Montreal Non-Compliance Procedure and the Functions of the Internal International Institutions', 9 Colorado J.I.E.L.P. (1998, forthcoming).
} 
existing rules/principles of international law, international supervision or control - such as environmental reporting/monitoring, fact-finding and research, data or information collection and inspection - is increasingly used for compliance control of treaty régime rules. 96 In this particular context, it should be emphasised, as Professor Alan E. Boyle says, that:

'The absence of any provision for institutional supervision or regulation is. . . often a sign that the treaty in question is ineffective and leads to obsolescence'. 97

Because of strict limitations of state sovereignty, international environmental régimes rely mainly on intergovernmental compliance monitoring 98 through some forms of data collection including statistics indicating the extent of government/private activity in a given issue-area of international environmental relations, notification of adoption of relevant domestic legislation, and detailed regulations and national specific programmes. 99 Yet self-reporting or its data-analysis is the only first step toward successful international supervision, simply because it is a kind of 'early warning system'100 for non-compliance problems. Under the 1973 C.I.T.E.S. régime, the Standing Committee has frequently recommended all parties to collectively apply sanctions against non-complying states and in a point of fact, that procedure was used regarding several non-compliance cases. ${ }^{101}$ In the sense that such dispute avoidance/settlement systems are operated by 'internal' treaty organs consisting of government representatives, 'soft enforcement' of régime rules is rather political in

96 See e.g. P. Birnie and A. Boyle, International Law and the Environment, (1992) pp. 166 et seq.

97 A. E. Boyle, 'Saving the World? Implementation and Enforcement of International Environmental Law Through International Institutions', 3 J.E.L. (1991) p. 232. But see also idem, 'Remedying Harm to International Common Spaces and Resources: Compensation and Other Approaches', in Harm to the Environment, (1997) pp. 84-100. 98 A. Chayes and A. H. Chayes, The New Sovereignty: Compliance with International Regulatory Agreements, (1995) Chapter 7. See also G. Handl, 'Controlling Implementation of and Compliance with International Environmental Commitments: The Rocky Road from Rio', 5 Colorado J.I.E.L.P. (1994) pp. 305-31; K. Schariew, 'Promoting Compliance with International Environmental Legal Standards: Reflections on Monitoring and Reporting Mechanisms', 2 Y.bk.I.E.L. (1991) pp. 31-52.

99 M. J. Peterson, 'International Organisations and the Implementation of Environmental Régimes' in O. Young (ed.), Global Governance, (1997) pp. 125-26. See also Chapter V(VII.A.1) below.

100 A. Chayes and A. H. Chayes, The New Sovereignty: Compliance with International Regulatory Agreements, (1995) p. 155.

101 See Article XIV(1); P. H. Sand, 'Whither CITES? The Evolution of a Treaty Regime in the Borderland of Trade and Environment', 8 E.J.I.L. (1997) pp. 38-40. 
nature. However, it should not be forgotten that impartial technical experts of internal régime organs (e.g. the U.N.E.P. Secretariat) are also involved in the multilateral 'enforcement' process.

A conspicuous example of highly institutionalised negotiation for an environmental dispute avoidance/settlement system is a formal noncompliance procedure ('N.C.P.') of the Montreal Protocol, which comes close to international conciliation. ${ }^{102}$ In earlier stages, the breach of binding but detailed legal regulations (e.g. Article 2 control measures for C.F.Cs./O.D.Ss.) and other disputes arising under the treaty régime are to be dealt with by 'internal' technical organs of the N.C.P. Ultimately, hardened non-compliance cases would then be addressed by the highest treaty organ, the Meeting of the Parties to the Protocol. The Montreal Protocol type of the N.C.P. is revolutionary in the sense that many international régimes for the environment have no provisions that explicitly promote further compliance and also penalise 'intentional' non-compliance arising from 'bad faith'. However, it must be added that non-compliance should be best addressed on a case-by-case basis, depending upon its reasons and length: in a case that a party still remains non-compliant with treaty obligations after the N.C.P. had been used, there is a slight possibility that traditional mechanisms for dispute settlement would be invoked by the parties to a treaty régime. 103 This opens up the possibility of making the 'comparatively autonomous' ozone régime less 'self-contained' legal system in general public international law. 104

It was decided that the Conference of the Parties to the 1997 Kyoto Protocol to the U.N. Climate Change Convention shall approve, at its First Session, 'appropriate and effective procedures and mechanisms to determine and to address cases of non-compliance. . . . including through the development of an indicative list of consequences, taking into account the cause, type, degree and frequency of non-compliance' (Article 18). Any non-compliance procedures/mechanisms under this article entailing binding consequences must be adopted by means of an amendment to the

102 See Chapter V(VI) below. Cf. the N.C.P. of the 1994 Oslo Sulphur Protocol in EB.Air/WG.5/CPR.13.

103 In most cases, dispute settlement procedures within international co-operative régimes of the environment are only optional for contracting parties, and are therefore not implemented on a compulsory basis. For instance, the 1985 Vienna Ozone Convention provides for optional use of the I.C.J. or arbitration over a dispute regarding treaty interpretation and application; in a case where the parties have accepted no procedure (or a different one), they are then obliged to submit the dispute to international conciliation (see Chapter II(III.D.4) below).

104 See Section IV below. 
Kyoto Protocol - in other words, ordinary 'decisions' by the regular Conference of the Parties to the Protocol - adopted through its internal Rules of Procedure - are not sufficient in this context. ${ }^{105}$

Just like the Montreal N.C.P. régime, how this dispute avoidance/settlement system will develop is a matter of great interest.

\section{Non-Governmental Organizations (N.G.Os.) as International Legal Régime Actors}

There is a general recognition that international co-operation between government actors would not be sufficient to protect the global environment. Not only U.N.-based international organs but also 'internal' treaty institutions within régimes are mostly political meeting places in which traditional state actors still play dominant roles. As a marked trend, however, non-governmental organisations ('N.G.Os.') - that are not endowed with 'international' legal personality 106 - are now involved in the process of international environmental régime-building and maintenance. 107 In general, environmental N.G.Os. aim to advance their particular purposes in a defined issue-area of international environmental relations through means available to them. Of course, it is not necessary for N.G.O. entities that are in principle free from governmental control to look after and to safeguard narrowly defined 'national interests' as such, whether political, economic or social. Their influence over régimes' state actors will depends upon the available financial/human resources and technical skills required (e.g. bargaining, legal or scientific) on the particular occasion.

N.G.Os. generally include public interest and private voluntary organisations, professional associations, academic institutions, industry or

105 In this respect, the binding force of ozone decisions is unclear (but presumably 'non-binding' in most cases). For an extensive discussion see Chapter V(IV.B.3.b).

106 Defined as capacity to bear rights/duties under international law. Yet N.G.Os. often do have legal personality in national legal systems (e.g. the United States of America), regional legal systems of the European Union and the Nordic Community. See P. Sands, 'The Environment, Community and International Law', 30 Harvard I.L.J. (1989) pp. 412-15.

107 See in general H. H.-K. Rechenberg, 'Non-Governmental Organisations', 9 E.P.I.L. (1986) pp. 276-82; P. Birnie and A. Boyle, International Law and the Environment, (1992) pp. 76 et seq.; P. Sands, Principles of International Environmental Law, (1995) pp. 94 et seq.; idem, 'The Role of Non-Governmental Organisations in Enforcing International Environmental Law' in W. E. Butler (ed.), Perestroika and International Law, (1990) pp. 61-81; S. Bilderbeek, Biodiversity and International Law, (1992) pp. 162 et seq. 
trade associations and private companies and so forth. ${ }^{108}$ According to D. Tolbert, 'environmental N.G.Os.' in particular can be divided into three categories, namely, (i) public interests N.G.Os. (e.g. Greenpeace International, World Wide Fund for Nature), (ii) scientific N.G.Os. (e.g. the International Union for Conservation of Nature and Natural Resources ('I.U.C.N.')), and (iii) the so-called 'think tanks' (e.g. the International Law Association ('I.L.A.'), the World Committee on Environment and Development ('W.C.E.D.')). 109 With regard to the principal functions of environmental N.G.Os., they:

(i) identify and choose environmental problems which they are going to support;

(ii) mobilise and organise international public opinions by formulating and disseminating information on the environment to the public and governments;

(iii) monitor compliance with international obligation at national and/or international level;

(iv) participate in international environmental negotiations; in many cases N.G.Os. as official 'observers'110 or 'advisory experts' or equivalent status enjoy access to meetings of supreme organs or committees (and subsidiary agencies) of treaty régimes in international law; ${ }^{111}$ and finally,

(v) often engage in the drafting of international environmental treaties and in setting international standards or 'norms'.112

It is worth mentioning that there are many cases where N.G.Os. are allowed to participate as observers in institutions within environmental

108 See L. A. Kimball, 'The Role of NGOs in the Implementation of the 1982 LOS Convention', in A. Soon (ed.), Implementation of the Law of the Sea Convention Through International Institutions, (1990) p. 141.

${ }^{109} \mathrm{D}$. Tolbert, 'Global Climate Change and the Role of International Non-Governmental Organisations', in R. Churchill and D. Freestone (eds.), International Law and Global Climate Change, (1991) pp. 96-97. He also suggests that a crucial criterion for judging whether an organisation is an 'N.G.O.' or not may depend on the organisation's independence from specific governmental control.

110 As to the definition of 'observers', see H. G. Schermers, 'International Organisations, Observer Status' 5 E.P.I.L. (1983) pp. 151-52.

111 See e.g. M. Bothe, 'Compliance Control beyond Diplomacy: The Role of NonGovernmental Actors, 27/4 E.P.L. (1997) pp. 293-97.

112 See D. Tolbert, 'Global Climate Change and the Role of International Environmental Organisations', in R. Churchill and D. Freestone, International Law and Global Climate Change, (1991) p. 98. Worthy of special mention will be that the International Union for the Conservation of Nature ('I.U.C.N.') framed early draft articles of the 1971 Ramsar Convention, the 1973 C.I.T.E.S. and the 1992 Biodiversity Convention. 
treaty régimes: the 1971 Ramsar Convention (Article 7(1)), 113 the 1972 World Heritage Convention (Article 8(3)), 114 the 1973 C.I.T.E.S. (Article 11(7)), and the 1979 Bonn Convention (Article 7(9)). 115 Added to these, the 1992 Convention for the Protection of the Marine Environment of the North-East Atlantic ${ }^{116}$ inserted provisions that do not discriminate against N.G.Os. and other I.G.Os. (Article 11(1-3)). Yet most M.E.A.s. and their rules of procedure usually do not provide for a specific role of N.G.Os. 117 Provided they have a really expert knowledge and could represent community interests, in my view, they should be allowed to participate in decision-making processes through treaty régimes' specialised internal institutions. 118

In addition, brief mention should be made of N.G.Os.' role in securing compliance with international environmental régimes. Under the C.I.T.E.S. régime, environmental N.G.Os. such as the Wildlife Trade Monitoring Unit in Cambridge ('W.T.M.U.') and the Trade Records Analysis of Flora and Fauna in Commerce ('T.R.A.F.F.I.C.') considerably help the C.I.T.E.S. Secretariat in monitoring compliance with the treaty. 119 In the case of the international waste régime of the 1989 Basel Convention, N.G.Os. such as Greenpeace International have assumed important roles as 'watchdogs' in tracking hazardous wastes exports and in alerting possible importing countries. ${ }^{120}$ Further, under the 1992 Biodiversity Convention régime, supplementary information by environmental N.G.Os. would be important

11311 I.L.M. (1972) p. 963, entered into force on 21 December 1975. The amended text is reproduced in P. Birnie and A. Boyle, Basic Documents on International Law and the Environment, (1995) p. 447.

11411 I.L.M. (1972) p. 1358, reproduced in P. Birnie and A. Boyle, International Law and the Environment, (1995) p. 375.

11519 I.L.M. (1980) p. 15, entered into force on 1 November 1983. The text is reproduced in P. Birnie and A. Boyle, Basic Documents on International Law of the Environment, (1995) p. 433.

11632 I.L.M. (1993) p. 1068.

117 See K. Schariew, 'Promoting Compliance with International Environmental Legal Standards: Reflections on Monitoring and Reporting Mechanisms', 2 Y.bk.I.E.L. (1991) p. 49.

118 On the role of industry in the process of negotiating treaty régimes see M. Bothe, 'The Evaluation of Enforcement Mechanisms in International Environmental Law' in R. Wolfrum (ed.), Enforcing Environmental Standards, (1996) p. 18.

119 See P. Birnie and A. Boyle, International Law and the Environment, (1992) p. 477; K. Ishibashi, 'Tasukokukan Kankyou Zyouyaku no Zissi ni okeru "Kantoku" mataha "Zyunshukantoku" Mekanizumu no Zikkousei" (The Effectiveness of 'Supervision' or 'Compliance Control' in the Implementation of Multilateral Environmental Treaties), 15/2 Kagawa Hogaku (1995) p. 100.

120 G. Handl, 'Environmental Security and Global Change: The Challenge to International Law', 1 Y.bk.I.E.L. (1990) p. 18. 
since the legal régime still does not have any treaty provision for independent monitoring and inspection. 121

In the present case of the Montreal Ozone Layer Protocol, N.G.Os. are allowed to participate in the regular Meeting of the Parties (see Appendix V), ${ }^{122}$ meetings of the Executive Committee of the Multilateral Fund ${ }^{123}$ and meetings of the Open-Ended Working Group established by Decision I/5 of the Meeting of the Parties. ${ }^{124}$ Though N.G.Os. are not currently allowed to participate in meetings of the Implementation Committee of the N.C.P. régime, under the Montreal N.C.P., N.G.Os. could potentially play active roles as international/domestic pressure groups to help enforce international legal rules. 125

\section{THE EMERGENCE OF THE 'SELF-CONTAINED' RÉGIME FOR INTERNATIONAL OBLIGATIONS ERGA OMNES: ENSURING UNIVERSAL COMPLIANCE}

Any international régime established by multilateral treaty law is directly or indirectly based to a greater or lesser extent on the existing system of general public international law. In this restricted sense, the term 'selfcontained régimes' in international law incurs a certain contradiction in terms. ${ }^{126}$ Nonetheless, the reason I dare to discuss 'self-contained régimes' is that they seem to indicate the distinctive character of the international legal régime for the protection of the ozone layer.

Historically, the term 'self-contained régime' was first used by the International Court of Justice in the Teheran Hostages case. ${ }^{127}$ Then,

121 See A. E. Boyle, 'The Convention on Biodiversity', in L. Campiglio (eds.), Environment after Rio, (1994) p. 125.

122 Article 11(5). At the Ninth Meeting of the Parties, Greenpeace International and the Alliance for Responsible C.F.C. Policy were granted the 1997 Ozone Awards among other 21 individuals and organisations. See UNEP.OzL.Pro.9/12, para. 24.

123 Rules 6 and 7 of the Rules of Procedure of the Executive Committee. For a discussion see Chapter VI(V.D) below.

124 See relevant Articles 6 and 11 of the Montreal Protocol.

125 See Chapter V(IV.B.2.b) below. For an extensive discussion see O. Yoshida and A. Sakota, 'The Role of N.G.Os. in the International Legal Régime for the Protection of the Ozone Layer' in The Japanese Society for Human-Environment Related Problems (ed.), N.G.Os. and Global Environmental Problems, (October 1998, Japan E.P.A., Japanese).

126 In a dictionary 'self-contained' is defined as 'something complete and separate and does not need help or resources from outside' (Collins Cobuild English Dictionary, 1987).

127 The United States Diplomatic and Consular Staff in Tehran case, I.C.J. Reports, 1980 , p. 40, para. 86 esp. See also R. Yamamoto, 'An Observation on the Self-Contained Régimes in International Law', 93 Japanese Journal of International Law \& Policy (1994) pp. 36-38 (Japanese). 
Special Rapporteur Professor W. Riphagen later developed the concept in the I.L.C. Draft Article on State Responsibility, but he did not intend the term to have a different meaning from that given by the International Court of Justice. 128 'Self-contained' international régimes are discussed so far specifically in the context of the law of state responsibility: special treaty régimes of 'self-contained' character often preclude legal recourse to normal countermeasures in general international law, and in principle, these treaty régimes as 'self-contained' legal systems practically apply their own legal remedies.

In the final section of his article 'Self-Contained Régimes', Professor B. Simma concludes that 'the adoption of "self-contained régimes" is to be welcomed if these leges speciales increase the effectiveness of the primary rules concerned and introduce procedures and collective decisions'.129 This is an important point to note because there are many international law instruments that are well drafted, but in reality are never put into operation (= 'sleeping treaties'). Simma provides three major examples of such 'self-contained' régimes, ${ }^{130}$ that is to say, (i) diplomatic law, (ii) the law of the European Community 131 and (iii) human rights treaties.

P. J. Kuyper argues that the G.A.T.T./W.T.O. trade law régime also has certain aspects of such a 'self-contained legal system', which could be observed in, for example, treaty interpretation, the exhaustion of local remedies, state responsibility and the law of remedies. ${ }^{132}$ Under the G.A.T.T./W.T.O. system, as Professor Yuji Iwasawa suggests, it is generally agreed that the parties must first use the G.A.T.T./W.T.O. dispute settlement system as a 'special' settlement régime in international law; only if the legal mechanism proves ineffective, G.A.T.T./W.T.O. members then may take 'appropriate' countermeasures in accordance with general international

128 L. A. N. M. Barnhoorn, 'Diplomatic Law and Unilateral Remedies', 25 N.Y.bk.I.L. (1994) p 69.

129 B. Simma, 'Self-Contained Régimes', 16 N.Y.bk.I.L. (1985) p. 135.

130 B. Simma, 'Self-Contained Regimes', 16 N.Y.bk.I.L. (1985) pp. 111-36. This would also means that 'self-contained' régimes is to be 'welcomed' if they can ensure highcompliance by participating parties.

131 See Cases 90-91/63 Commission v. Grand Duchy of Luxembourg and Kingdom of Belgium, E.C.R. (1964) p. 631; Case 232/78 Commission v. French Republic ('Mutton and Lamb'), E.C.R. (1979-8) p. 2379.

132 Article XXIII of the G.A.T.T. law and new Article XXIII of the 1994 Understanding on Rules and Procedures Governing the Dispute Settlement of the Uruguay Round. See also e.g. P. J. Kuyper, 'The Law of GATT as a Special Field of International Law', 25 N.Y.bk.I.L. (1994) pp. 227-57. For supporting evidence see also Y. Iwasawa, WTO Dispute Settlement (1995) Chapter III pp. 54-55, its footnote no. $89-90$ esp. \& pp. 158 et seq. (Japanese). 
law - which must be properly authorised by the G.A.T.T./W.T.O. members, however. 133

The Montreal Protocol régime - which contains an internal quasijudicial system of the non-compliance procedure ('N.C.P.') - is the first multilateral environmental treaty that is labelled as a 'self-contained' legal system in the primary sense that the dispute settlement régime noticeably deviates from established principles and rules of general law. ${ }^{134}$ As was already mentioned in Section I above, in a different context, T. Gehring called the ozone régime a 'comparatively autonomous sectoral legal system'.

If 'self-contained' treaty régimes mean special régimes which maintains their legal rules totally separate from established principles/rules of general public international law or the law of state responsibility, in a strict sense, the international régime for the ozone layer is by no means 'self-contained' as such. The point to observe is that the international ozone layer régime has certain 'substantive' and/or 'procedural' rules that are relatively independent of - or deviate to some extent from - such principles/rules of general international law or traditional customary law. There is no categorical answer to such a debatable question whether the international ozone layer régime is 'selfcontained' or not. Rather, this should be decided on a case-by-case basis, depending upon a specific situation. As the subsequent chapters will show, such legal deviation of the ozone layer régime must be correctly measured not only by general international law but by evolving principles of international environmental law including the precautionary environmental 'principle'/approach (see Chapter V(VII) in particular).

It is tentatively suggested that the 'self-contained' legal character of the international legal régime for the protection of the ozone layer can be characterised by the following four points.

In the first place, the law of state responsibility or international liability in the context of ozone depletion seems to be only of doubtful utility. Since no single state's activities are responsible for 'adverse effects' caused by ozone loss, and most of the states have only a minimal role in both the production and the consumption of C.F.Cs./O.D.Ss., it is therefore impossible to establish a sufficient link of causation or causality between stratospheric ozone-depleting activities of particular states or

\footnotetext{
133 See e.g. Y. Iwasawa, WTO Dispute Settlement, (1995) pp. 159 et seq. (Japanese). 134 See M. Koskenniemi, 'Breach of Treaty or Non-Compliance?', 3 Y.bk.I.E.L. (1992) pp. 123-62.
} 
private individuals and companies (i.e. a culpable act) and potential direct injury to individual states (e.g. deteriorating human health or economic loss) that might have been caused potentially by ozone loss or depletion. 135 This clearly means that since such 'injured states' - if any - cannot acquire standing to bring international claims, accordingly, individual states cannot have recourse to such inter-state claims even against one of the largest producers and consumers of C.F.Cs./O.D.Ss. In this respect, the legal character of the international regulatory régime for the ozone layer is essentially different from that of other environmental régimes, e.g. the international waste régime of the 1989 Basel Convention - because breaches of legal rules regarding the international control of transboundary movements of hazardous wastes normally affect only two or three states, not only the compensation for the victims, but also the application of the 'polluter pays principle'136 developed by the O.E.C.D. would be presumably possible. ${ }^{137}$

A potentially alternative approach, the notion of actio popularis (or actio communis ) - which is often controversial even in national legal systems - has not however been recognised by general public international law. 138 Since third parties (such as environmental N.G.Os.) do not have such standing before international tribunals, they cannot seek 'preventive relief', even if it is scientifically considered that actual damage or harm to the global environment has been taking place.

\footnotetext{
135 See e.g. A. Kiss, Droit international de l'environment, (1991) pp. 106 et seq.; H. Thierry (eds.), Droit international public, (1986) pp. 637-38.

136 On the polluter pays principle see in particular A. E. Boyle, 'Economic Growth and Protection of the Environment: The Impact of International Law and Policy', in idem (ed.), Environmental Regulation and Economic Growth, (1994) pp. 179 et seq.; idem, 'Making the Polluter Pay? Alternative to State Responsibility in the Allocation of Transboundary Environmental Costs' in F. Francioni and T. Scovazzi (ed.) International responsibility for Environmental Harm, (1991) pp. 363-79.; S. E. Gaines, 'The Polluter-pays Principle: From Economic Equity to Environmental Ethos', 26 Texas I.L.J. (1991) pp. 436-96.

137 See K. Kummer International Management of Hazardous Wastes, (1995) p. 36.

138 In the South West Africa cases (Second Phase), the I.C.J. decided that 'although a right of this kind may be known to certain municipal systems of law, it is not known to international law as it stands at present: nor is the Court able to regard it as imposed by "general principles of law" referred to in Article 38, paragraph 1(c), of its Statute'. See I.C.J. Reports, 1966, p. 47; C. Gray, Judicial Remedies in International Law, (1987), pp. 212-14; B. Bollecker-Stern, Le préjudice dans la theorie de la responsabilité internationale, (1973) pp. 21-22. But Cf. Legality of the Threat or Use of Nuclear Weapons (Advisory Opinion of 8 July, 1996), 35 I.L.M. pp. $809 \& 1343$ (1996); Matheson, M., 'The Opinions of the International Court of Justice on the Threat or Use of Nuclear Weapons', 91 A.J.I.L. (1997) pp. 417-35. It is said that the request by the General Assembly originated early in political ideas pushed by N.G.Os. (see dissenting opinion of Judge Oda, Part I).
} 
Of course, it is also important to consider that under Article 19(3.d) of the I.L.C. Draft Articles on State Responsibility, ${ }^{139}$ massive pollution of the atmosphere or sea is categorised as a 'international crime': in this context all states will be 'injured states' with standing. The depletion of the ozone layer as the 'common concern of mankind' 140 will be a strong candidate in this context. However, as a practical matter, it is still difficult to see what kind of legal value such a designation would have in the present international legal community: obviously, normal judicial remedies such as compensation are largely unthinkable. ${ }^{141}$

Arguably, as Oscar Schachter suggests, 142 the global protection of the ozone layer would be included in the general category of international obligations erga omnes - 'opposable to, valid against, "all the world", i.e. all other legal persons, irrespective of consent on the part of those thus affected'. ${ }^{143}$ If this is so, the international ozone layer régime will fall into Professor Klein's classic régime-definition: he argues that 'In any case international régimes always purport to have effect on third States'.144

In its judgement on the Barcelona Traction case delivered in February 1970, the I.C.J. stated that: ${ }^{145}$

\footnotetext{
139 Draft Articles on State Responsibility, 37 I.L.M. (1998) p. 440.

140 See Chapter II(II.B).
}

141 A. E. Boyle, 'Remedying Harm to International Common Spaces and Resources: Compensation and Other Approaches; in Harm to the Environment, (1997) pp. 93-94: P. Birnie 'International Environmental Law: Its Adequacy for Present and Future Needs', in A. Hurrell and B. Kingsbury (eds.) The International Politics of the Environment, (1992) pp. 81-82.

142 See International Law in Theory and Practice, (1991) p. 381,

143 I. Brownlie, Principles of Public International Law, 4th edn. (1990) p. xlvii. See in general J. Frowein, 'Obligations Erga Omnes', 3 E.P.I.L. (1995) pp. 757-59. For a comprehensive review see M. Ragazzi, The Concept of International Obligations Erga Omnes, (1997). Dr. Ragazzi offers five common elements helpful in evaluating candidates of obligations erga omnes (see ibid. pp. 215-16)

144 See footnote no. 5 above.

145 Barcelona Traction, Light and Power Company Limited Case (Belgium v Spain: Second Phase) I.C.J. Reports, 1970, p. 3. Cf. I.C.J.'s controversial South West Africa decision of 1966, I.C.J. Reports, 1966, p. 6.

See also the East Timore case, 34 I.L.M. (1995) para. 29, saying that 'In the Court's [I.C.J.'s] view, Portugal's view that the right of peoples to self-determination, as it evolved from the Charter and from United Nations practice, has an erga omnes character is irreproachable.... it is one of the essential principles of contemporary international law'. On a unilateral undertaking erga omnes see Nuclear Tests cases, I.C.J. Rep. (1974) pp. 265-67 \& pp. 469-71; M. Ragazzi, The Concept of International Obligations Erga Omnes, (1997) pp. 174-75. 
'[33] . . . an essential distinction should be drawn between the obligations of a State towards the international community as a whole, and those arising vis-à-vis another State in the field of diplomatic protection. By their nature the former are the concern of all States. In view of the importance of the rights involved, all States can be held to have a legal interest in their protection; they are obligations erga omnes'. [34] Such obligations derive, for example, in contemporary international law, from the outlawing of acts of aggression, and of genocide, as also from the principles and rules concerning the basic rights of the human person, including protection from slavery and racial discrimination. Some of the corresponding rights of protection have entered into the body of general international law. . . .; others are conferred by international instruments of a universal or quasi-universal character'.

As we shall see, the international ozone layer régime has gradually assumed the erga omnes character in general public international law. For example, more than 160 states (of which nearly 110 are developing countries) are now parties to the Montreal Protocol and the Vienna Ozone Layer Convention (see Appendixes III-IV); ${ }^{146}$ though the Montreal Protocol's Article 4 trade restrictions seem to run against the traditional maxim pacta tertiis nec nocent nec prosunt, ${ }^{147}$ these trade provisions are never formally challenged by any states including parties to the G.A.T.T./W.T.O. law; moreover, even non-parties to the Protocol régime regularly submit required technical data on C.F.Cs./O.D.Ss. to the U.N.E.P. Ozone Secretariat ${ }^{148}$ and; the ozone layer is now given the evolving legal status of 'common concern of mankind ('C.C.M.'). ${ }^{149}$ It may safely be assumed that both parties and non-parties - i.e. virtually all states - are acting in the interests of the (hu)mankind, the international protection of

146 To date only twenty-five U.N. members are non-parties to the Protocol.

147 'Third states cannot be bound by treaty obligations without their consent' (the 1969 Vienna Convention on the Law of Treaties (Articles 34-38)). Cf. R. Wolfrum, 'Purposes and Principles of International Environmental Law', 33 G.Y.bk.I.L. (1990) p. 329.

148 See Chapter V(VII.1) below. See e.g. Decision IV/17C; Decisions III/16 \& IV/17(1) regarding data reports on the Montreal Protocol's Article 4. It is suggested that, because of the fear that Article 4 trade measures may conflict with the GATT law, data-reporting requirements on that Article was not included in the 1987 original text. See further Chapter V(VII.A.3) below.

149 One possible interpretation of the C.C.M. is that it creates international obligations erga omnes. See A. E. Boyle, 'International Law and the Protection of the Global Atmosphere: Concepts, Categories and Principles' in R. Churchill and D. Freestone (eds.), International Law and Global Climate Change, (1991) p. 12. See further Chapter III(III.B). 
the stratospheric ozone layer. ${ }^{150}$ As Jonathan I. Charney says, it will be true that 'If the community responds strongly in favour of universal application, no obstacle to such a choice can be found in the constitutional foundation of the international legal system'. ${ }^{151}$ However, even if the ozone treaty régime has created intended general legal effects of an erga omnes nature as regards ozone-depleting activities, the remedies available in case of their breach would be, again, severely limited. ${ }^{152}$

In the second place, with regard to dispute avoidance/settlement procedure of the Montreal N.C.P., as M. Koskenniemi argued, 'noncompliance' - thus implying that the violated international obligation is not necessarily legally binding 153 - can ultimately result in (collective) suspension of rights and privileges under the Ozone Layer Protocol 'in accordance with the applicable rules of international law concerning the suspension of the operation of a Treaty'. This cannot be taken for granted, because the new procedure eliminates the determination of breach of treaty or 'wrongful act' from the beginning. 154

It is important to note, however, that the commencement of the N.C.P. operation is not founded on the traditional system of state responsibility for environmental damage or the establishment of standing to bring inter-state claims. In this respect, the Montreal N.C.P. - as an internally instituted dispute settlement system consistent with the 'consensus building of communication within an international régime'155 - can be characterised as an unprecedented procedural mechanism that is designed to effectively 'operate' or 'enforce' erga omnes (i.e. the global protection of the ozone layer). 156 Paradoxically speaking, the ozone layer

150 In this respect see R. J. Dupuy, 'Humanity and the Environment', 2 Colorado J.I.E.L.P. (1991) p. 2, arguing that international obligations erga omnes are especially concerned with respect for the rights of man and the environment.

151 'Universal International Law', 87 A.J.I.L. (1993) p. 550. It is also important to notice that the Montreal Protocol introduced a revolutionary simplified majority voting procedure under Article 2(9): adjustments are binding all the parties (see in detail Chapter III(III.C) below).

152 P. Birnie and A. Boyle, International Law and the Environment, (1992) p. 157.

153 See footnote no. 32 above.

154 The meaning of 'non-compliance' may be seen as a grey area of the ozone régime (see Chapter V(III) below).

155 See T. Gehring, 'International Environmental Regimes', 1 Y.bk.I.E.L. (1990), p. 37; Chapter $\mathrm{V}$ below.

156 Cf. T. Usuki, 'The Development of Dispute Settlement Procedures in Global Environmental Conventions' in International Law for Dispute Settlement: Essays in Celebration of Judge S. Oda's Seventieth Birthday, (1997) pp. 182-83 (Japanese). 
régime needed a 'self-contained' dispute avoidance/settlement system to implement international obligations erga omnes.

Under the Montreal N.C.P., the legal rules of binding control measures in Article 2 (and Article 5) are supervised by special and 'internal' implementation mechanisms (see further Part IV composed of Chapters V and VI below). As for ozone treaty disputes over highly technical issues, traditional settlement mechanisms thus in effect seem out of place. 157 On most occasions, it will be only after the N.C.P. régime is 'exhausted' that traditional dispute settlement mechanisms provided for in Article 11 of the Vienna Ozone Convention (i.e. the use of the international tribunals such as the I.C.J. and arbitration: see Chapter III(III.D.4)) would be invoked by the contracting parties to the Protocol. Yet such 'soft enforcement' of treaty obligations 158 should be correctly understood as 'supplementary' to these traditional legal settlement procedures. In other words, international supervision or control by political treaty organs is not meant to readily 'supplant' or 'replace' the final resort still available to the parties to the Montreal Protocol régime. 159

In the third place, after the adoption of the 1987 Montreal Protocol, 'internal' political institutions established by the regulatory treaty régime (i.e. the Meeting of the Parties to the Montreal Protocol in particular) 160 has successfully 'internalised' the making and application of the ozone treaty rules: at present the international legal ozone régime whose highest treaty organs have adopted more than 200 hundred Decisions ${ }^{161}$ appears to have its own international jurisprudence. In relation to treaty interpretation, the 1991 Third Ozone Meeting of the Parties decided that it could make/interpret its legal ozone rules as it prefers: 'the responsibility for legal interpretation of the Protocol ultimately rests with the Parties themselves' (Decision IV/5(5)). 162 Further, it must be noted that the legal character of ozone-oriented 'Decisions' adopted by the Meeting of the Parties has often caused legal conflicts with established principles and

157 See Chapter V(VII) on 'the Montreal N.C.P. in practice' below.

158 See Section III(C) above and Chapter V(VII) below.

159 On the relationship between Article 11 dispute settlement mechanisms and the Montreal N.C.P. see Chapter V(III.B) below.

160 As with its Protocol, the 1985 Vienna Ozone Layer Convention régime has its own supreme institution, i.e the Conference of the Parties (see Chapter III(III.D.2)).

161 See U.N.E.P. Handbook for the International Treaties for the Protection of the Ozone Layer, 4th edn. (1996) Section 2.3 and other later decisions contained in reports of the 1996/1997 Meeting of the Parties to the Montreal Protocol.

162 See further Chapter V(IV.B.3.b) below. 
rules of public/private international law and other generally accepted treaty régime rules such as those contained in G.A.T.T./W.T.O. trade law (see further Chapter IV below).

It must be added however that, if the need arises, the ozone régime reaffirms established principles of international law: to take a simple example, in its Thirteenth Meeting, the Implementation Committee of the Montreal N.C.P. requested the U.N.E.P. Ozone Secretariat to seek clarification from the Legal Council of the United Nations on the status of new states emerging out of the former Soviet Union and their succession to international treaties like the Montreal Protocol. 163

In the fourth place, the Montreal Ozone Protocol régime has somewhat controversial trade-related provisions within its Article 4 that have caused legal conflicts with another 'self-contained legal system' of the G.A.T.T./W.T.O. trade law. This view is supported in academic discussion (see further Part III composed of Chapter IV below). However, it is interesting that dispute settlement systems of both the international regulatory ozone régime and the G.A.T.T./W.T.O. have not been invoked by contracting parties to these multilateral agreements. ${ }^{164}$

In the following chapters below, these 'self-contained' aspects of the international régime for the ozone layer - having erga omnes character will be extensively discussed in the broad context of the system of rules or principles of international environmental law and general public international law.

\section{CONCLUSIONS}

A supra-national law-making/developing institution for the global environment (i.e. supranational government) is unlikely to emerge from the existing international system. International environmental regimes (i.e. not global environmental régimes) within specific issue-areas of environmental relations are practical alternatives to the 'highest human institution' for the environment, political, legal and social.

163 UNEP/OzL.Pro/ImpCom/13/3, para. 8(b). In the Seventh Ozone Layer Meeting held in 1995, the Russian Federation in non-compliance with the Montreal Protocol argued that the collapse of the former Soviet Union constituted an event of a fundamental change in circumstances. For a discussion see further Chapter V(VII.B.1) below.

164 In this respect see reports of meetings of the W.T.O. Committee on Trade and Environment ('C.T.E.'), e.g. PRESS/TE021 (19 December 1997). See also Chapter IV(IV.B). 
An individual international régime for the environment acquires, depending upon the issue-area and subject matter, its own characteristics. As discussed in the previous section, the international legal régime for ozone has several 'self-contained' aspects or autonomous character in the system of international law. In any case, the creation of international legal régimes by itself is not an ultimate goal, and it is a means employed by I.G.Os. (and N.G.Os.) to achieve their environmental, economic, social and/or political objectives. This might mean that, in certain exceptional cases, the stated purposes and objectives of international environmental régimes might be achieved at the sacrifice of 'strict consistency'165 in general public international law.

Yet it is important to bear in mind that any international legal régime is commonly founded on generally accepted guiding principles of international law, including the legal principle of good faith (bona fides). Many modern treaty régimes for the environment - some of which are established by the framework-implementing protocol approach - now specifically endorse not only customary rules of the environment but also the evolving precautionary 'principle' of international environmental law. In addition, international regulatory régimes also have 'internal' institutions for internationally co-ordinated environmental actions. As a strategy for ensuring close co-operation and greater compliance, these régimes contain within their legal frameworks collective economic sanctions, capacity-building instruments, international equity considerations, and so forth.

The effective combination of the fragmented sectoral régimes consisting of these legal 'sticks' and 'carrots' would ultimately help establish a mass of environmental régimes for the promotion of 'sustainable development', although this will depend upon efforts made by state and non-state régime actors in the international community.

165 Certainly it will be legal régimes' law-makers (e.g. states, highest treaty organs) who must ensure such consistency. 
International Legal Régimes for the Environment

Needless to say, international legal régimes are only limited guarantees of environmental protection: the same thing could be true of the present ozone régime. However, it is still necessary to ask to what extent international régimes in a given issue-area of environmental relations can legally guarantee protection of the environment such as ozone. 


\section{PART II}

\section{THE INTERNATIONAL TREATIES FOR THE}

PROTECTION OF THE OZONE LAYER 


\section{CHAPTER II}

\section{THE 1985 VIENNA CONVENTION FOR THE PROTECTION OF THE OZONE LAYER AND PRINCIPLES OF MODERN INTERNATIONAL ENVIRONMENTAL LAW}

\section{INTRODUCTION}

The 1985 Vienna Convention for the Protection of the Ozone Layer (hereafter, the 'Vienna Ozone Layer Convention') ${ }^{1}$ is a 'framework' lawmaking treaty (see Chapter I(III.A) above), which itself contains no specific legal standards or regulations for C.F.Cs. at the international level. Since the adoption of the 1987 Montreal Ozone Layer Protocol that contains not only control provisions for C.F.Cs./O.D.Ss. but also strong supervisory and implementation mechanisms, the 'umbrella' Convention régime has been given only a secondary role. ${ }^{2}$ Despite its evident weaknesses, however, it is still important to remember that the 1985 Vienna Ozone Convention has been one of the first international environmental agreements to give an indication of the precautionary environmental 'principle'/approach, and at the same time the treaty laid the legal basis for the Montreal Protocol régime. In a period of grave scientific uncertainty about ozone depletion, the Vienna Convention was a politically acceptable international co-operation régime for participating states in the context of C.F.C. regulation and further scientific research.

In Chapter II, we are concerned with the framework Ozone Layer Convention. Section II first describes briefly national regulatory measures prior to the adoption of the 1985 Convention, focusing on the United States of America that belonged to the so-called 'Toronto Group' (i.e. the United States, Canada, Sweden, Norway, Finland, Denmark, New Zealand, Australia and Switzerland) ${ }^{3}$ and the European Community ('E.C.'). Then, by using

\footnotetext{
1 Convention for the Protection of the Ozone Layer, Vienna, 22 March, 1985. 26 I.L.M. (1987) p. 1529, reprinted in P. Birnie and A. Boyle, Basic Documents on International law of the Environment, (1995) p. 211; U.N.E.P. Handbook for the International Treaties for the Protection of the Ozone Layer, 4th edn. (1996) p. 3.

2 But see Decision I/3 of the Conference of the Parties saying that 'the Convention is the most appropriate instrument for harmonizing the policies and strategies on research'.

3 Named after the group's first meeting in Toronto (see R. Benedick, Ozone Diplomacy, (1998) p. 42). However, the Group called themselves the 'Friends of the Protocol'. See
} 
The 1985 Vienna Ozone Convention and International Environmental Law

conference documents, it analyses the protracted Convention negotiation, i.e. the first stage of the international régime building. ${ }^{4}$ Section $I I I$, which is devoted to the detailed analysis of the Vienna Ozone Convention, considers the meaning of 'adverse effects' (section A); the legal status of the ozone layer (section B); the relationship between the evolving precautionary 'principle'/approach and the international ozone régime (section C) and: basic provisions of the Convention (section D) - including 'General Obligations' (Article 2), the role of the Conference of the Parties (Article 6) and the dispute settlement procedures (Article 11).

\section{THE NEGOTIATION OF THE 1985 VIENNA OZONE LAYER CONVENTION}

The negotiation of the Vienna Convention régime formally started in January 1982 within the framework of the United Nations Environmental Programme (the 'U.N.E.P.'). Under the meetings of the Ad Hoc Working Group of Legal and Technical Experts for the Elaboration of a Global Framework Convention for the Protection of the Ozone Layer established by the U.N.E.P. Governing Council in May 1981, 5 participating states considered proposals not only on a global framework ozone convention but also a supplementary (separate) protocol of a highly technical nature containing specific control measures for specified C.F.Cs. ${ }^{6}$ The 1985 Convention negotiation process was rather tedious and laborious because of a divisive confrontation between the Toronto Group and the European Community. Moreover, a number of scientific uncertainties about ozone depletion (i.e. its cause/effects) continued throughout the Vienna Convention negotiation. The drafting of the Convention and its annexes/protocols was therefore very difficult. However, the U.N. Environmental Programme and its former Executive Director, Dr. Mostafa Tolba, did what could be done to cope with such a challenging situation and participating governmental/non-governmental actors succeeded in agreeing on international environmental efforts for the protection of the ozone layer.

\footnotetext{
E. A. Parson, 'Protecting the Ozone Layer' in P. M. Haas (eds.) Institutions for the Earth, (1993) footnote no. 31.

4 The second and third phases are (ii) from Vienna to Montreal (1986-1987) and (iii) the post-Montreal period (1988-1997). For a discussion see Part A of Chapter III(II) below.

5 Decision 9/13B adopted on May 261981.

6 However, from its Third Session, the Working Group decided to focus on discussions on an expected framework ozone convention.
} 
The 1985 Vienna Ozone Convention and International Environmental Law

The 1985 Vienna Convention for the Protection of the Ozone Layer was signed on 22 March 1985 by twenty states plus the E.C. Commission. It entered into force on 22 September 1988. ${ }^{7}$ By May 1998, 166 countries had ratified the Vienna Ozone Convention, including most of the major C.F.C./O.D.S. producers and consumers in the international community (see Appendix III).

\section{A. National/Regional Regulation of Major chlorofluorocarbons (C.F.Cs.)}

Before discussing the Vienna Convention negotiation, it may be helpful to describe briefly earlier ozone regulations at the national/regional levels. In negotiating specific contents of expected ozone treaties including annexes and protocols, participating states naturally supported regulatory measures that would reflect their own domestic or regional ozone legislation.

The United States, which was the largest producer/consumer of C.F.Cs., held about forty per cent of the international market share of C.F.Cs. in 1976. Thus it was only natural that such a manufacturing country took an initiative in legally restricting the use of C.F.Cs. at the domestic level. In January 1975, the Council on Environmental Quality and the Federal Council for Science and Technology jointly established the Federal Interagency Task Force on Inadvertent Modification of the Stratosphere ('I.M.O.S.'). In addition, a special Federal Action was undertaken in order to restrict uses of C.F.C.-11 and C.F.C.-12.8 Further, in August 1977 the U.S. Clean Air Act Amendment ('C.A.A.A.') relating to the protection of the stratospheric ozone layer was passed by Congress. ${ }^{9}$ In 1978 it also unilaterally banned C.F.C. use as a propellant in non-essential aerosols (e.g. deodorants, polishes, hair lacquer and paint). By that time, adequate substitutes for most propellant uses of C.F.Cs. were already securable. The domestic market for spray cans containing C.F.Cs. had dramatically fallen by almost two-thirds owing to American citizens' consideration of the potential environmental impact of these ozone-depleting substances. ${ }^{10}$ At the time of the adoption of the global ozone framework convention, the

\footnotetext{
7 Seven states and governmental and non-governmental Organizations participated in the meeting as observers. See 'Final Act of the Conference', paras 4-5.

8 See UNEP/WG.69/8, para. 14 and its footnote no. 14 .

9 See also Part B of Chapter III(II.A.1).

10 R. Benedick, Ozone Diplomacy, (1998) pp. 27-28.
} 
United States backed by its industries aimed to internationalise such domestic regulations that limited the aerosol use of C.F.Cs. only .

Mention should also be made of the fact that the U.S. Environment Protection Agency ('E.P.A.') was sued in 1984 by an environmental N.G.O., the Natural Resources Defence Council ('N.R.D.C.'). ${ }^{11}$ What the plaintiff organisation insisted in the suit was that the U.S.E.P.A. had not fully implemented its legal obligations based on Section 157 (b) of the C.A.A.A. The N.R.D.C. further demanded that a schedule be established for a decision on the control of C.F.Cs. ${ }^{12}$ Perhaps it may be possible to argue that the prominent leadership of the United States during the formation of the ozone régime was strengthened by such environmental movement at the domestic level.

Following the example of the United States, Sweden (in 1979) and Norway (in 1980) formed similar domestic ozone policies in order to implement C.F.C. can bans. ${ }^{13}$ In 1980 Canada also banned three main C.F.C. products, namely, hair spray, deodorant and antiperspirant. In addition, the Netherlands imposed labelling requirements for C.F.C. aerosol containers upon its industry.

The attitude of the European Community - which was in 1976 responsible for thirty-four per cent of the international sales of C.F.Cs. contrasted remarkably with that of the United States and other abovementioned countries belonging to the Toronto Group.

The position of the Community was substantially influenced by the European chemical industry that relied heavily on C.F.C. technologies (e.g. the U.K.-based Imperial Chemical Industries). 14 For instance, the European industry had insisted that C.F.C. substitutes were unthinkable and the regulation of the use of C.F.Cs. - as seen in the United States - might create unemployment among its workers. 15 Though Holland proposed in 1977 a measure requiring the labelling of spray cans containing C.F.Cs., the European Community emphatically rejected this proposal. ${ }^{16}$ Likewise, a

\footnotetext{
11 The N.R.D.C. participated in the First/Second/Fourth Ozone Meeting of the Parties (see Appendix VI).

12 See R. M. Seaver, 'Stratospheric Ozone Protection: IR Theory and the Montreal Protocol on Substances that Deplete the Ozone Layer', 6 Environmental Politics (1997) p. 55 .

13 These two countries are non-producing and importing countries of C.F.Cs.

14 N. Heigh, 'The European Community and International Environmental Policy,' 3 International Environmental Affairs, (1991) pp. 160-178.

15 R. Benedick, Ozone Diplomacy, (1998) p. 25.

16 R. Benedick, Ozone Diplomacy, (1998) p. 25.
} 
The 1985 Vienna Ozone Convention and International Environmental Law Community-wide C.F.C. aerosol ban led by West Germany was rejected in 1979 by other member states. 17

With regard to its regional C.F.C. regulation, the European Community adopted in 1978 a Council Resolution on the use of C.F.Cs. 18 The regulation required the member states 'to present the research which they had carried out into the effects of C.F.Cs. on man and the environment, and to co-operate on a Community basis so that the research could be planned and the results made available'. In 1980 the Council of the E.C. further adopted Decision 80/372, 19 which set an immediate freeze on production 'capacity' - i.e. not to enlarge but maintain C.F.C.-11 and C.F.C.-12 production facilities, without restricting the actual production of C.F.Cs., and a provision for a 30 per cent reduction compared to the 1976 level of the use of C.F.Cs. in aerosols by the end of 1981.20 The Decision also required the E.C. to develop 'the best practicable technologies' in order to limit emissions in refrigeration, solvent and foam plastics sectors. Furthermore, in 1982 the Council adopted the Decision in order to consolidate the previous measures already taken in 1980 . The decision required the member states to apply precautionary measures to the other sectors using C.F.Cs., such as synthetic foam, refrigeration and solvents as well as aerosol use of C.F.Cs. ${ }^{21}$

Finally, in 1980, Japan - whose negotiating position was largely similar to that of the European Community - publicly declared in the O.E.C.D. its readiness to control C.F.C. production (C.F.C.-11 and C.F.C.-12 in particular) and aerosol uses. 22 Since then, the Japanese Ministry of International Trade and Industry ('M.I.T.I.') has provided its industry with related administrative guidance. ${ }^{23}$

17 See further ibid. p. 24.

18 Council Regulation of 30 May 1978 on Chlorofluorocarbons in the Environment, O.J. No. C133 (7 June) p. 1.

19 Decision $80 / 372$ of 26 March 1980 Concerning Chlorofluorocarbons in the Environment, O.J. No. 90 (3 April) p. 45.

20 But this reduction level had already been achieved by the beginning of 1980 .

21 Decision $82 / 795$ of 15 November 1982 on the Consolidation of Precautionary Measures Concerning Chlorofluocarbons in the Environment, in O.J. No. 329 (25 November) p. 29.

22 H. Goto, 'The Protection of the Stratospheric Ozone Layer', 69 Environmental Studies (1988) pp. 25-26 (Japanese).

23 On national ozone laws and regulations in Japan see Part B of Chapter III(II.A.4). 
B. The Vienna Convention Negotiation within the U.N.E.P.

(1) The International Régime-Building from 1977 to 1980

The creation of the 1985 Vienna Convention régime (and the 1987 Montreal Protocol régime) was a major test of U.N.E.P.'s effectiveness in its catalytic role in the progressive development of international environmental law. As we shall see, we may say that the U.N.E.P. succeeded in passing this painstaking test. 24

At the international level, the U.N.E.P. first convened in 1977 an international meeting of scientists, with representatives from thirty-three states and the European Community to draft 'the World Plan of Action on the Ozone Layer'. 25 The Ozone Layer Action Plan was to be implemented by international institutions such as the World Meteorological Organisation ('W.M.O.') 26 and the World Health Organisation ('W.H.O.'), ${ }^{27}$ along with the U.N.E.P. as a catalyst, national governments and non-governmental organisations. At the same time, the U.N.E.P. Co-ordinating Committee on the Ozone Layer (U.N.E.P. 'C.C.O.L.') was established to make periodic scientific assessments relating to the state of potential ozone depletion. 28 This newly established scientific institute undertook most of the research on ozone depletion. 29 The U.N.E.P. C.C.O.L. was independent of governments, and mainly funded by the U.N.E.P. and environmental N.G.Os. 30 Yet the Committee was not given any power to provide policy recommendations.

24 See also R. Benedick, Ozone Diplomacy, (1998) p. 6, noting that 'UNEP went far beyond a traditional secretariat function: it was a model for effective multilateral action'.

25 See Decision 65/IV of the U.N.E.P. Governing Council. See also proceedings, UNEP/WG.7/25 in Biswas (ed.), The Ozone Layer: Proceedings of the Meeting of Experts Designated by Governments, International Nongovernmental Organizations on the Ozone Layer Organised by the United Nations Environmental Programme in Washington DC, 1-9 March 1977.

26 Established in 1878 , U.N. specialised agency since 1950. See in general D. W. Bowett, The Law of International Institutions, 4th edn. (1982) pp. 115-16.

27 Established in 1948, U.N. specialised agency. See generally ibid. p. 114.

28 See U.N.E.P. Governing Council Decision 84/C(V) of 25 May 1977 (A/32/25); M. K. Tolba (eds.) The World Environment 1972-1992: Two Decades of Challenge, (1992) p. 51.

29 On the C.C.O.L. see UNEP/WG. 7/25/Rev. 1; UNEP/WG.69/5, paras. 6-7. The C.C.O.L. was annually convened until 1985 .

30 On the other hand, the Intergovernmental Negotiating Committee for the Framework Convention on the Climate Change ('I.N.C.') - which is the main body carrying out research on climate change - consists chiefly of government representatives. In the end the U.N.E.P. and the W.M.O. were forced to give up their control over the Climate 
In April 1980, at its Eighth Session, the U.N.E.P. Governing Council adopted the W.M.O./U.N.E.P. Principles that called for reductions in the production of two major C.F.Cs. (i.e. C.F.C.-11 and C.F.C.-12) plus a production capacity cap. 31 The Principles also asked for the development of scientific research and techniques in order to avoid further ozone depletion. 32 Subsequently, the U.N.E.P. Governing Council adopted Decision 9/13B of 26 May 1981 that argued for 'the desirability of initiating work aimed at the elaboration of a global framework convention which would cover monitoring, scientific research and the development of best available and economically feasible technologies'.33 Under this decision the U.N.E.P. Governing Council therefore decided to establish an Ad Hoc Working Group of Legal and Technical Experts for the Elaboration of a Framework Convention. The decision also requested the U.N.E.P. Executive Director 'to ensure that in the work so initiated, all relevant information and related work under way in other forums, as well as the results of any discussions on this subject at the Ad Hoc Meeting of Senior Government Officials Experts in Environmental Law are taken into account' and to 'invite the Coordinating Committee on the Ozone Layer, as part of its activities under its mandate'. 34

The 'Montevideo Meeting' held in Uruguay in November 1981 endorsed Decision $9 / 13 \mathrm{~B}$ and selected the protection of the ozone layer as a 'major subject area' for which guidelines, principles or agreements should be developed. 35 The meeting also adopted an objective, a strategy and

Change Convention negotiation (see the U.N. General Assembly Resolution 45/212, 21 December 1990). On the I.N.C. see e.g. S. Nilsson and D. Pitt, Protecting the Atmosphere: The Climate Change Convention and its Context, (1994) pp. 15-17. See also I. Rowlands, The Politics of Global Atmospheric Change, (1995) p. 91, saying that 'the decision of "where" to conduct the science was political, and it had implications for the subsequent international political'.

31 Decision 8/7B of 29 April 1980 (A/35/25). The Nordic countries took initiative in adopting the decision. See P. H. Sand, 'The Vienna Convention is Adopted', 27 Environment, (1985) p. 40.

32 See 6 E.P.L. (1980) p. 101. Principle VI of Weather Modification Provisions embodies Principle 21 of the 1972 Stockholm Declaration.

33 Decision 9/13B(a) and (b) in UNEP/WG.69/10, para. 1.

34 Additionally, the Executive Director was also requested to (i) contribute to the work of the ad hoc working group and to (ii) compile all relevant information, including statistical and technical data, on implementation of the recommendations contained in decision $8 / 7 \mathrm{~B}$ of 29 th April 1980, in particular that relating to the reduction in the use of chlorofluorocarbons 11 and 12 , as well as to production capacity on the basis of an agreed definition.

35 For further details of the Montevideo Programme see Timoshenko, 'Development and Periodic Review of Environmental Law in the 1990s: UNEP Programmatic Approach' in A. Kiss (ed.) A Law for the Environment, (1994) pp. 17-20. 
The 1985 Vienna Ozone Convention and International Environmental Law

elements of strategy and specific recommendation for initial action concerning this subject matter. The recommendations suggested highlighting the need for the catalytic role of the U.N.E.P. - that the environmental institution 'should continue to strengthen its co-ordinating role as regards research, monitoring and assessment of the ozone layer, in particular through the C.C.O.L. mechanism, and expand the dissemination of information on the problems of the stratospheric ozone layer'.

In this meeting, the delegations of Finland, Sweden and Switzerland tabled 'Draft Recommendations' on an expected framework convention for the protection of the ozone layer. 36 The Draft Recommendation stated that the legal framework should 'be sufficiently flexible to be easily adaptable to changing circumstances as new scientific evidence becomes available'.37 The Recommendations also suggested that (i) the framework should be provided by an original convention and (ii) the specific measures - which are internationally agreed and shall be nationally enforced - are to be laid out in the annex(es) that may be amended whenever need be without disturbing the functioning of the basic structure. 38 This early proposal text therefore gave an important indication of a flexible approach adopted later in the 1985 Vienna Ozone Layer Convention. 39 Yet, the 1981 Montevideo Meeting did not adopt the Nordic Recommendation. 40

(2) The Discussions at the Ad Hoc Working Group (1982-1985)

From 1982 to 1985 , the Ad Hoc Working Group held a total of four sessions consisting of seven meetings among the fifty participants and eleven intergovernmental and non-governmental organisations. 41 It was quite

\footnotetext{
36 'Draft Recommendations on Legal Aspects and Elements of a Global Framework Convention for the Protection of the Stratospheric Ozone Layer' in Report of the Ad Hoc Meeting of Senior Government Officials Expert in Environmental Law, UNEP/GC.10/3, Appendix II.

37 UNEP/GC.10/5/Add.2/Annex/Appendix II, para. 2, cited in T. Gehring, Dynamic International Regimes, (1994) p. 202.

38 These are based on the Nordic proposal and statements made at the First Session of the Working Group held in Stockholm in January 1982 (UNEP/WG.69/CPR.2).

39 In this respect see T. Gehring, Dynamic International Regimes, (1994) p. 202.

40 UNEP/GC.10/5/Add.2, para. 38, cited in T. Gehring, Dynamic International Regimes, (1994) p. 202.

41 UNEP/IG. 53/4. First Session (20-28 January 1982, Stockholm); Second Session (first part: 10-17 December 1982, Geneva), (second part: 11-15 April 1983, Geneva); Third Session, (first part: 17-21 October 1983, Geneva), (second part: 16-20 January 1984, Vienna) and; Fourth Session, (first part: 22-26 October 1984, Geneva), (second
} 
difficult to agree on the specific contents of the framework ozone convention, detailed annexes and implementing technical protocols. 42 During the negotiations leading up to the adoption of the 1985 Vienna Convention, the Toronto Group insisted on the need for C.F.C. emission reductions focused on non-essential uses of these chemicals in spray cans with a possible capacity cap (i.e. the 'multi-option approach'). On the other hand, the European Community preferred C.F.C. production capacity limitation (i.e. the 'single-option approach'). Because of the different strategic positions, participating states finally decided to adopt a framework ozone convention only.

In January 1982, the U.N.E.P. convened the First Session of the Working Group in Stockholm at the invitation of the Swedish government. 43 All members of the United Nations were invited to the meeting of this Session: this represents the fact that ozone depletion was truly regarded as global in nature.

For the First Session, the delegations of Finland, Norway and Sweden 44 and the U.N.E.P. Secretariat ${ }^{45}$ prepared draft texts of a global ozone convention. The Nordic countries' ambitious proposal - whose contents are largely similar to the previous text submitted at the 1981 Montevideo Meeting - addressed several important aspects including Fundamental Obligations' (article 1); 46 'co-operation' (article 2); information exchange (article 3); national report (article 4); technology transfer (article 5); institutional structures (articles 7-9); dispute settlement (article 10) and a simplified amendment procedure (articles 12 and 13). In short, the Nordic proposal already reflected the fundamental structure of the 1985 Vienna Ozone Layer Convention. Its flexible approach combining a framework convention with annexes and/or protocols was

\footnotetext{
part: 21-25 January 1985, Geneva). See UNEP/IG.53/4 para. 10, noting that the following governments provided financial support and/or meeting facilities for the sessions: Austria, Canada, Finland, Netherlands, Norway, Sweden, Switzerland and the United States.

42 See among others R. Benedick, Ozone Diplomacy, (1998) Chapters 4-8.

43 See UNEP/WG.69/10.

44 'Draft International Convention for the Protection of the Stratospheric Ozone Layer: Text submitted by the delegations of Finland, Norway and Sweden', (UNEP/WG.69/3). 45 See 'Draft International Convention for the Protection of the Stratospheric Ozone Layer', (UNEP/WG.69/3/Add.1), containing a preamble only.

46 It reads that 'The parties shall limit, reduce and prevent activities under their jurisdiction or control which have or are likely to have adverse effects upon the stratospheric ozone layer'. See also comments by participating experts in UNEP/WG.69/10, para. 20.
} 
generally supported by the Toronto Group and the European Community. 47 However, the debatable issues on the relationship between the convention and annexes and/or protocols was not settled yet (note: in the Nordic proposal, annexes containing C.F.C. controls are to form integral parts of the ozone convention). In addition, at this session, there was agreement that there should be internal régime institutions such as the conference of the parties as a major decision-maker and a treaty secretariat (by the U.N.E.P.) having administrative functions, 48 and some provisions on ozone dispute settlement. ${ }^{49}$.

The Working Group considered such a flexible approach would be necessary 'in order to allow the accommodation of changing scientific knowledge and policy alternatives as they became available'.50 The Working Group agreed to draw up a framework convention to be supplemented by annexes and/or protocols that would contain provisions aimed at controlling specific types of actions or substances. It also recommended that the U.N.E.P. Secretariat should prepare a new draft text for its Second Session. 51 This preparation proceeded on the basis of the analysis of the following international treaties: the U.N. Charter; the 1969 Vienna Convention on the Law of Treaties; the 1972 Stockholm Declaration; the 1982 U.N.C.L.O.S.; framework conventions/protocols of U.N.E.P. Regional Seas Programmes; 52 the 1973 M.A.R.P.O.L.; the 1979 Geneva L.R.T.A.P. Convention; the 1973 C.I.T.E.S.; Principles on Shared Natural Resources (UNEP/IG.12/2), the draft convention submitted by Finland, Norway and Sweden (UNEP/WG.69/3) and other relevant treaties. 53

Subsequently, in the first part of the Second Session held in January 1983, a number of delegations - influenced by scientific uncertainties cautioned against 'moving too rapidly' since that would eventually lead to

\footnotetext{
47 See T. Gehring, Dynamic International Regimes, (1994) p. 206. .

48 UNEP/WG.69/10, paras 21, 24 and 25.

49 For a discussion see UNEP/WG.69/10, para. 25. The 1979 Geneva Convention (Article 13), the draft Convention on the Law of the Sea (Article 279), the U.N. Charter (Article 33), the 1972 London Dumping Convention (Article 10) were mentioned as possible models in the context of ozone layer protection.

50 UNEP/WG.69/10, para. 10. See also ibid., para. 26.

51 See the draft convention in UNEP/WG.78/2.

52 The most successful example is seen in the Mediterranean. The 1976 Barcelona Convention and its two Protocols were signed and ratified by many countries in this region. The 1980 Athen Protocol addresses land-based and airborne sources pollution, but most of the agreements related marine environment avoid these problems. See P. H. Sand, Marine Environment Law in the UNEP, (1988) ix-xxvi, eps. 53 See UNEP/WG.78/2, para. 8.
} 
The 1985 Vienna Ozone Convention and International Environmental Law an 'ill-conceived convention'.54 There was also disagreement as to whether technical annexes or protocols should be developed simultaneously with the convention. 55

In the second part of the Second Session held in April 1983, Sweden, on behalf of the Nordic countries, introduced a revised new text, namely, a proposal annex concerning measures to control/limit/reduce C.F.C. emission and use (the 'Nordic Annex'). 56 In response to this ambiguous proposal, a number of delegations including the European Community, Japan and the former Soviet Union suggested that such a proposal could only be regarded as one of the options for an expected protocol, since its contents were of a regulatory nature. ${ }^{57}$ In this respect, the United Kingdom expert made a general reservation regarding the need for annexes and/or protocols. 58

In the subsequent first part of the Third Session of the Working Group, Sweden noted that the proposed draft annex may be discussed as a proposal for a future ozone protocol.59 In this context the United States, which was initially critical of this Nordic proposal text, indicated support for an integral protocol to the convention concerning non-essential aerosol uses of C.F.Cs. 60 In addition, though the number itself was very small, several developing countries participated in this meeting. They insisted on the need for transfer of environmentally sound technology in order to ease anticipated serious economic burdens. 61 It was stressed at the first part of the Third Session that more extensive participation from developing countries was desirable to ensure that the ozone convention was universal in scope. 62

In the heated confrontation between the United States, Canada, and the Scandinavian countries and the European Community, the second

54 UNEP/WG.78/8, para. 9.

55 Ibid., para. 10.

56 UNEP/WG.78/11. See also relevant statements in UNEP/WG.78/13, paras. 17-22.

57 See UNEP/WG.94/4/Add.1. But see also comments developing countries that are generally supportive of this Nordic proposal (the Central African Republic, Djibouti, Kenya and Sri Lanka) in UNEP/WG.94/4/Add.2.

58 UNEP/WG.78/13, para. 16. The UK later withdrew this reservation (UNEP/WG.94/5), para. 8.

59 See the draft text in UNEP/WG.94/4 or in UNEP/WG.78/13, Annex III.

60 UNEP/WG.94/5, para 9.

6110 E.P.L. (1983) p. 35.

6211 E.P.L. (1983) p. 58. 
The 1985 Vienna Ozone Convention and International Environmental Law

revised draft convention 63 and protocols ${ }^{64}$ were discussed in 1983 , the third draft convention in January 1984,65 the revised second draft protocol in January 1984,66 the fourth revised convention containing draft technical annexes ${ }^{67}$ and the fourth revised draft protocol in March 1985.68 By the beginning of the first part of the Fourth Session of the Working Group held in January 1984, the draft ozone convention had been virtually finalised. 69

(3) Negotiating an Ozone Protocol for Controlling C.F.Cs.

In respect of the much disputed protocol(s) to the convention, at the second meeting of the Fourth Session of the Working Group held in January 1985, the Toronto Group introduced a flexible 'multi-option approach' consisting of four options from which each party to the convention may choose preferable one. ${ }^{70}$ It was argued, for example, that the approach would 'enable countries in widely differing circumstances to accept the protocol and would also reward past action by governments to reduce C.F.C. use'. ${ }^{71}$ An uncompromising response from the European Community was, however, that the 'so-called multi-option approach would still amount to a ban on use of C.F.Cs. in aerosols and did not imply any effort on the part of those countries to limit C.F.C. production': the Community thus concluded that 'his proposal constituted a truly global approach to the problem of protecting the ozone layer, since it proved not only for limitations on

\footnotetext{
63 UNEP/WG.94/3.

64 UNEP/WG.94/9.

65 UNEP/WG.94/8.

66 UNEP.WG.94/12.

67 UNEP/WG.94/11.

68 See UNEP/IG.53/4, Annex III.

69 Most articles in the fourth draft convention (UNEP/WG.94/11) remained unchanged.

70 See UNEP/IG.53/4, Annex II, paras. 17 et seq. Options (1) \& (2) commonly concerned only with a staged reduction of the total annual use/exports of C.F.Cs. in aerosols. The Option (3) addressed total production capacity for C.F.Cs. regardless of their use did not exceed the total production capacity at the entry into force of the protocol. The Option IV addressed a reduction of the total annual use of C.F.Cs. of only $20 \%$. See in detail J. G. Lammers, 'Efforts to Develop a Protocol on Chlorofluorocarbons to the Vienna Convention for the Protection of the Ozone Layer', 1 Hague Y.bk.I.L. (1988) pp. 227-30.

71 UNEP/IG.53/4, Annex II, para. 17.
} 
production but also for reductions in the use of C.F.Cs. in the aerosol sector and for measures in the non-aerosol sector'. ${ }^{72}$

As one expert pointed out in this meeting held at the last stage, both of the major approaches had some shortcomings and future elaboration was required: 'All CFC emissions, and not only those originating from aerosols, should be reduced'. ${ }^{73}$ The underlying problem of this expected article 2 on control measures is expressed best by Johan G. Lammers: 'neither proposal embodied a set of interrelated rules covering all elements which are vital for effective CFCs control mechanism, i.e. production, use, import, export and emission of all CFCs'. ${ }^{74}$

\section{(4) 'The Vienna Ozone Layer Convention is Adopted'}

After the Fourth Session of the Working Group, the draft convention was finally adopted and signed on 22 March 1985 by twenty states and the E.E.C. In the end, the fifth draft protocol on C.F.Cs. prepared by the Working Group 75 was not adopted in spite of diplomatic missions and an informal meeting at the absolute edge of the 1985 Vienna Conference.

Under Article 1(6) of the Vienna Ozone Layer Convention, for the first time, the European Community was allowed to become party to a 'mixed international agreement' (i.e. both the Community and its member states are party to it) as a 'regional economic integration organisation' without any of its member states being required to do so. ${ }^{76}$ It is pointed out that this was the E.C. Commission's legal/political strategy to gain greater competence within the European Community; such an international treaty clause potentially allows the E.C. Commission to propose Community

72 UNEP/IG.53/4, Annex II, para. 31. See also discussions in the first part of the Fourth Session in UNEP/WG.110/4, Section V.

73 UNEP/IG.53/4, Annex II, para. 25.

74 J. G. Lammers, 'Efforts to Develop a Protocol on Chlorofluorocarbons to the Vienna Convention of the Ozone Layer, 1 Hague Y.bk.I.L. (1988) p. 231 (emphasis added).

75 'Fifth Revised Draft Protocol on Chlorofluorocarbons' (UNEP/IG.53/3).

76 Defined as 'an organization constituted by sovereign States of a given region which has competence in respect of matters governed by the Convention or its protocols and has been duly authorised, in accordance with its internal procedures, to sign, ratify, accept, approve or accede to the instruments concerned'. On the conditions see Article 13(2). This definition is based on earlier relevant provisions regarding signature, ratification, acceptance or approval and accession by such an organization, including Article 1 of Annex IX of the U.N.C.L.O.S. See 'Texts Relating to Final Clause' in UNEP/WG.94/5/Add.1. See also Article 2(8) of the Montreal Ozone Protocol and Part A of Chapter III(III.D). 
legislation to regionally implement the framework ozone convention and expected protocols. ${ }^{77}$

The Vienna Conference for the Protection of the Ozone Layer adopted a Resolution that urged 'all States and regional integration organisations, pending entry into force of a protocol, to control their emissions of CFCs, inter alia in aerosols, by any means at their disposal, including controls on production or use, to the maximum extent possible'. ${ }^{78}$ The Resolution also required the Working Group to continue work on a protocol that would address 'both short and long term strategies to control equitably global production, emissions and use of CFCs', taking into account the special situation of developing countries and new scientific evidence. ${ }^{79}$

A series of negotiations of the protocol to the Vienna Ozone Convention formally started in December 1986, again within the framework of the U.N. Environment Programme (see Chapter III(II) below).

\section{THE 1985 VIENNA CONVENTION FOR THE PROTECTION OF THE OZONE LAYER}

We can now turn to the basic provisions of the 1985 Vienna Ozone Layer Convention. As is the case with the 1979 Geneva L.R.T.A.P., the operational parts of the 'framework' Convention are specifically designed for facilitating international environmental co-operation in scientific research and the exchange of information. However, the Convention also contains several important evolving rules and principles of international law for environmental protection.

As with its Montreal Ozone Layer Protocol (Article 18), the Vienna Convention totally excludes reservations with a view to maintaining the universality of the international ozone régime (Article 18). 80

\footnotetext{
77 See M. Jachtenfuchs, 'The European Community and the Protection of the Ozone Layer', 28 C.M.S. (1990) p. 263.

78 Resolution 2(6).

79 Resolution 2(1).

80 However, it should be noted that even if reservations are completely excluded from treaties, states can still enter 'political statements' or 'interpretative declarations'. For the definition of interpretative declarations see I.L.C. Yearbook, (1966-II) pp. 189-90; A. D. McRae, 'The Legal Effect of Interpretative Declarations', 49 B.Y.bk.I.L. (1978) p. 155.
} 
A. The Definition of 'Adverse Effects' Caused by Ozone Depletion

(1) The Limited Scope of the Term 'Air Pollution' in Regional Treaties

According to the textbooks of environmental science, ozone depletion is generally included in the category of air pollution such as global warming caused by C.O.2 emissions. ${ }^{81}$ Yet, as seemingly a minor difference in wording, the term 'pollution' 82 - contained in the 1979 Geneva L.R.T.A.P. Convention (Article 1) or the 1991 Canada/United States Air Quality Agreement (Article 1(1-2)) 83 - cannot fully explain the global nature of potential 'adverse effects' posed by ozone depletion. To take an example of acid rain, the most obvious pollutants of the atmosphere (e.g. sulphur dioxide and oxides of nitrogen) are being transported over long distances and, as a result, these substances cause transboundary adverse effects on the environment. In this general context, the term 'transboundary pollution' illustrates short range, regional or bilateral environmental harm or damage. On the other hand, ozone depletion shows the emergence of a different kind of 'pollution' within the ecosystem: the 'adverse effects' in the context of ozone depletion cannot be clearly divided according to national territorial boundaries (see Introduction \& Chapter I(IV) above). Just as the concept of 'pollution' cannot address environmental disasters happening within an individual state, it cannot deal adequately with 'pollution' within the global environment.

But the definitions of both 'pollution' and 'adverse effects' contained in environmental agreements are helpful in determining the 'threshold' beyond which environmental damage might entail state liability. 84

(2) Adverse Effects Caused by Ozone Depletion

The technical term 'adverse effects' is defined in the Convention text as, inter alia, 'changes in the physical environment or biota, including

81 See e.g. D. M. Elsom, Atmospheric Pollution, (1992) Chapter 1.

82 The concepts of 'pollution' are controversial: its meaning will depend largely on each treaty's context. The full study of the definition of 'pollution' lies outside the scope of this thesis. For a discussion see P. Birnie and A. Boyle, International Law and the Environment, (1992) pp. 101-02. See also A. L. Springer, The International Law of Pollution, (1983) Chapter 3, pp. 63-88, defining 'pollution' mainly as 'a particular level of environmental change that is legally significant because of the nature and degree of injury that does or can result to important human interests'.

8330 I.L.M. (1991) p. 676 . Cf. the 1982 U.N.C.L.O.S. (Article 1(4)).

84 p. Sands, Principles of International Environmental Law (1995) p. 634. 
changes in climate, which have significant deleterious effects on human health or on the composition, resilience and productivity of natural and managed ecosystems, or on materials useful to mankind' 85 This definition which is based on a text prepared by technical experts -86 is used here to accurately define negative impacts of ozone depletion that must be mitigated by international environmental co-operation. 87 As indicated in the Introduction above, ozone loss could lead to increases in solar ultraviolet radiation (U.V.-B.) with detrimental biological effects such as additional cases of skin cancer and eye cataracts, reduced growth of crop plants sensitive to U.V.-B. and other commercially important materials. Moreover, although its environmental adverse effects are long-distance and only cumulatively harmful (i.e. not immediate or apparent), the depletion of the ozone layer is virtually irreparable. The definition further recognises that some C.F.Cs./O.D.Ss. could probably contribute to global atmospheric warming. It is also important to notice that it contains a broad meaning capable of covering human rights protection (i.e. the right to life and a healthy environment). 88

\section{B. The Legal Status of the Ozone Layer in General International Law}

'The ozone layer is located in the atmosphere at an attitude ranging between 1- and 50 $\mathrm{km}$. The question arises of what its legal status is'. ${ }^{89}$

\footnotetext{
85 Article 1. The relevant draft provision, as proposed by the U.N.E.P. Secretariat, read as follows; "'Adverse effects" means changes in the physical environment or biota, including changes in climate, which are, taken over-all, deleterious to human health or to the composition, resilience and productivity of natural and managed ecosystems' (UNEP/WG.78/2), p. 8. Cf. the 1979 L.R.T.A.P. defining the environment as 'agriculture, forestry, materials, aquatic and other natural ecosystems and visibility' (Article 7(d)); the 1992 Climate Change Convention (Article 1(1)), placing effects on 'the operation of socio-economic systems or on human health' after deleterious effects on the environment, and inserting the term 'human (health and) welfare'.

86 UNEP/78/2, p. 8.

87 See UNEP/WG.69/10, para. 20, noting that the need to precisely define the term was stressed during the First Session .

88 On the role of human rights law in environmental protection see A. E. Boyle and M. Anderson (eds.), Human Rights Approaches to Environmental Protection, (1996).

89 Statements by the U.N.E.P. Secretariat in its report 'Some Observations on the Preparation of a Global Framework Convention for the Protection of the Stratospheric Ozone Layer' (UNEP/WG.69/8), para. 29. The U.N.E.P. Secretariat did not define the legal status of the ozone layer. By referring to the 1979 L.R.T.A.P., the Secretariat simply emphasised the importance of scientific and technological co-operation (ibid., para. 35).
} 
At the outset it must be noticed that in the present case of ozone depletion unlike the utilisation of the living resources of the High Seas or the deep seabed - what matters in the international community has been not 'equal access' or 'freedom' of the stratospheric ozone layer as an internationalised public territory, but potential 'adverse effects' (see Introduction \& section A above) that would be produced by gradual ozone loss. Indeed, it is true that human history has been a long story about man's allocation and exploitation or 'regulation' of (renewable/non-renewable) natural resources, and not a 'moralised story' of environmental conservation or protection. It can easily be assumed that there will be few customary international law rules based on state practice concerning the possible 'utilisation' of the ozone layer as 'physical' res communis omnium for any specific commercial purposes.

However, it will be very strange to think that the stratospheric ozone layer - which states formally decided to protect by international legal instruments - does not have any specific legal status in international law.

(1) National Jurisdiction over the Ozone Layer

As a matter of a academic legal argument, it is possible to geographically divide state jurisdiction over the ozone layer. 90

In theory, national jurisdiction extends only to the portion of the ozone layer that lies directly above the territory and territorial sea of any particular state. 91 In this respect, the 1944 Chicago Convention on International Civil Aviation illustrates the established legal principle of exclusive state sovereignty over (i) the airspace above its territory and (ii) the territorial sea. 92 Yet air space above (i) the high sea, 93 (ii) the continental shelf, 94 (iii) the Exclusive Economic Zone ('E.E.Z.') 95 and (iv)

90 P. M. Lawrence, "International Legal Regulation for Protection of the Ozone Layer', 2 J.E.L. (1990) pp. 21-22;

91 See the 1944 Chicago Convention on International Civic Aviation (Articles 1 \& 15), 15 U.N.T.S. p. 295; the 1958 Convention on Territorial Sea and the Contiguous Zone (Article 2); the 1982 U.N.C.L.O.S. (Article 2).

92 Articles 1 and 2; the 1982 U.N.C.L.O.S. (Article 2(2)). See also the 1919 Convention on the Regulation of Aerial Navigation, (Paris 13 October 1919), 11 L.N.T.S. p. 173.

93 See the 1982 U.N.C.L.O.S. (Article 87).

94 See the 1982 U.N.C.L.O.S. (Article 78(2)).

95 See the 1982 U.N.C.L.O.S. (Articles 55 and 58) 
Antarctica 96 must be considered as outside of the sovereignty of any individual state - that is to say, must be considered as 'common property' in international law.

However, even if state jurisdiction concerned is clarified to some extent, as a practical matter, such an academic argument appears to be utterly fruitless. First, in a strict sense, the ozone layer is by no means 'exploitable shared natural resources' 97 as such (e.g. an international river, fish, and other aquatic life), and not subject to the obligation of equitable utilisation that is seen as a customary international law rule. 98 Second, ozone depletion simply ignores the traditional notion of artificial geographic boundaries between sovereign states. 99 Hence, it cannot be denied that the legal concept of 'shared natural resources'100_ which is embodied in bilateral or regional environmental treaty agreements such as the 1979 L.R.T.A.P. Convention, U.N.E.P. Regional Sea Agreements and international 'soft law' instruments 101 - would not particularly apply in the present international regulatory régime for the ozone layer.

In a somewhat different context the same can be said of the more ambitious but controversial legal concept of the 'common heritage of mankind' ('C.H.M.') 102 employed in the 1979 Moon Treaty and in the 1982 U.N.C.L.O.S. The concept of the C.H.M. is concerned with the international 'management' of certain (shared) natural resources or areas, including (i) the deep sea-bed and ocean floor beyond the limits of the present national

96 See the 1959 Antarctic Treaty.

97 See N. Schrijver, Sovereignty Over Natural Resources: Balancing Rights and Duties, (1997) defining the term 'natural resources' as 'supplies drawn from natural wealth which may be either renewable or non-renewable and which can be used to satisfy the needs of human beings and other living species'.

98 But see P. Birnie and Alan Boyle, International Law and the Environment, (1992) p. 398, pointing out that under the regional treaty of the 1979 Geneva L.R.T.A.P. the Parties seem to treat the European air mass as a shared resources.

99 See Section A and Introduction above.

100 On this concept see e.g. A. E. Boyle, 'International Law and the Protection of the Global Atmosphere: Concepts, Categories and Principles' in R. Churchill and D. Freestone (eds.) International Law and Global Climate Change, (1991) p. 8 esp.

101 See e.g. the 1988 Toronto Conference 'The Changing Atmosphere', Conference Statement (reprinted in 5 A.U.J.I.L.P. (1990) pp. 515 et seq.; the 1989 Ottawa Conference of Legal and Policy Experts, Statement of the Meeting of Legal and Policy Experts (reprinted in 5 A.U.J.I.L.P. (1990) p. 528).

102 On this concept see e.g. P. Birnie and A. Boyle, International Law and the Environment, (1992) pp. 120-22. 
The 1985 Vienna Ozone Convention and International Environmental Law

jurisdiction, 103 (ii) outer space ${ }^{104}$ and arguably (iii) Antarctica. 105 For instance, the International Sea Bed Authority ('I.S.B.A.') - as a means of achieving 'distributive justice' - is a certain form of international marine co-operation in the exploration, conservation and use of the area concerned.106

Ozone cannot be described as the C.H.M. because of the following reasons: (i) areas to which the notion of the C.H.M. can be applied seem rather limited; (ii) the C.H.M. is associated with 'conservation', 107 but in the context of resources; 108 (iii) the idea of the C.H.M. is originally intended to internationalise ownership of natural resources (i.e. 'international management') 109 and;(iv) the C.H.M. was employed neither in the Ozone Layer Convention nor modern environmental treaties including the 1992 Climate Change Convention and the 1992 Biodiversity Convention. 110

\section{(2) The Ozone Layer as 'Common Concern of Mankind (or Humankind)'}

Under the legal text of the 1985 Vienna Ozone Layer Convention, the 'ozone layer' is defined as the 'layer of atmospheric ozone above the planetary boundary layer' (i.e. ozone in the upper troposphere and the stratosphere

103 The U.N.C.L.O.S. (Articles 133, 136 \& 137).

104 See U.N. General Assembly Resolution 1962 (XVIII) of 13 December 1963; the 1967 Outer Space Treaty (Article 1); the 1979 Moon Treaty (Article 1(1), Article 3(1), Article 4(1) \& Article 11).

105 See the Preamble of the 1991 Protocol to the Antarctic Treaty, stating that 'the development of a comprehensive regime for the protection of the Antarctic environment and dependent and associated ecosystems is in the interest of mankind as a whole'. See also P. Birnie and A. Boyle, International Law and the Environment, (1992) p. 121; P. Sands (eds.) The Antarctic Environment and International Law, (1992) Chapters 12-13.

106 On the I.S.B.A. see R. R. Churchill and A. V. Lowe, The Law of the Sea, (1983) pp. 182-88; S. Yamamoto, International Law, (1994) pp. 439-42; P. Birnie and A. Boyle, International Law and the Environment, (1992) pp. 171-75.

107 The 1980 C.C.A.M.L.R. (Article II(3)); the 1958 High Seas Conservation Convention (Article 2). See also 1986 W.C.E.D. Principles (para. (i)) in P. Sands, Principles of International Environmental Law, (1995) p. 203.

108 J. Brunnée, 'A Conceptual Framework for an International Forests Convention' in Canadian Council on International Law Conseil (ed.) Global Forests and International Environmental Law, (1996) p. 56.

109 See A. E. Boyle, 'The Rio Convention on Biological Diversity' in C. Redgwell and M. Bowman (eds.) International Law and the Conservation of Biological Diversity, (1995) p. 40. For instance, Article 4 of the Moon Treaty emphasises co-operation in enterprises concerning the moon and other celestial bodies. See P. Malanczuk, 'Space Law as a Branch of International Law', 25 N.Y.bk.I.L. (1994) p. 172.

110 Ibid.; P. Birnie and A. Boyle, International Law and the Environment, (1992) p. 121. 
that acts to filter out U.V.-B.). 111 This definition is based on a report by an informal technical working group suggesting that it is consistent with the definition by the U.N.E.P. C.C.O.L. and moreover avoids conflicts with the 1979 Geneva L.R.T.A.P. Convention that concerns boundary layer pollution. 112 It indicates that 'ozone' in this environmental treaty régime means the planet's only natural sun screen 'stratospheric ozone layer' or 'ozone shield', and thus not 'ground-level ozone'. 113 We may say therefore that this legal definition of the ozone régime seems to treat the protective ozone layer as a global unity having no national boundaries. ${ }^{114}$ As M. N. Shaw says, the area defined thus constitutes 'a distinctive unit with an identity of its own irrespective of national sovereignty or shared resources claims'.115

In the light of the recent development of international environmental régimes, though the legal texts of neither the 1985 Ozone Layer Convention nor the Montreal Protocol refers to this new legal term, 116 it will be logical to treat the ozone layer as having the international legal status of the 'common concern of (hu)mankind' ('C.C.M.'). The C.C.M. should be rightly observed as something more than a vague political principle or declaration. According to Professor A. E. Boyle, a common concern (of (hu)mankind) implies that 'the international community has both a legitimate interest in resources of global significance and a common responsibility to assist in their protection'. ${ }^{117}$

111 Article 1(1), (emphasis added). Thus, the 'ozone layer' does not necessarily belong to a particular part of the atmosphere. See a discussion at the Second Session of the Working Group in UNEP/WG.78/13, para. 24. An corresponding article 1 in an earlier draft convention reads that "'The ozone layer" means the total ozone above the earth's surface, most of which is found in the stratosphere' (UNEP/WG.78/8, Annex I). 112 See UNEP/WG.78/13, Annex IV, para. 2.

113 See Introduction above.

114 See P. Birnie and A. Boyle, International Law and the Environment (1992) p. 391.

115 M. N. Shaw, International Law, 4th edn. (1997) p. 610.

116 On this point see J. Brunnéé, 'A Conceptual Framework for an International Forests Convention: Customary Law and Emerging Principles', in Canadian Council of International Law, Global Forests and International Environmental Law, (1996) footnote no. 98, saying that 'It may be speculated that, were the convention [the 1985 Vienna Convention] to be adopted today, it would declare the depletion of the ozone layer a "common concern of humankind"'.

117 A. E. Boyle, 'Remedying Harm to International Common Spaces and Resources: Compensation and Other Approaches', in Harm to the Environment: The Right to Compensation and the Assessment of Damages, (1997) p. 86. On this legal concept see also idem, 'International Law and Protection of the Global Atmosphere: Concepts, Categories and Principles', in R. Churchill and D. Freestone (eds.), International Law and Global Climate Change, (1991); J. Werksman, 'Consolidating Governance of the Global Commons: Insights from the Global Environmental Facility', 6 Y.bk.I.E.L. (1995) 
The 1985 Vienna Ozone Convention and International Environmental Law

Similar to the concept of the C.H.M., the C.C.M. is also intended to conserve the environment (e.g. the ozone layer) for the interests of future generations.

The legal concept of the C.C.M. was first used by U.N. General Assembly Resolution 43/53.118 It was then incorporated into two modern multilateral environmental agreements, namely, the 1992 Climate Change Convention régime and the 1992 Biodiversity Convention régime. The Preamble of the Climate Change Convention states that 'change in the Earth's climate and its adverse effects are a common concern of mankind'.119 This seems to favour the idea that all states in the international community - irrespective of whether injured or not - share equally the international common legal interests in preventing potential adverse effects caused by global climate change. In this respect, it seems possible to argue that this comparatively new legal concept, the C.C.M., is to an important extent concerned with the notion of international obligations erga omnes - i.e. 'obligations owed to the international community as a whole' - introduced by the International Court of Justice in its judgement on the Barcelona Traction case (see Chapter I(IV) above). 120 Perhaps the same may be said of a norm of jus cogens in international law. Yet, as was discussed, the legal consequences that would flow from the concept of international obligations erga omnes or jus cogens in the context of ozone protection are undeniably unclear. ${ }^{121}$

In summary, the ozone layer as 'common concern of mankind' therefore belongs to all states and to mankind as a whole. This means that all states presently have a legal duty to adequately protect the ozone layer from ozone-depleting economic activities. Yet it must be said at the same time that this norm-creating legal concept in public international law is still

pp. 40-44; A. Kiss, 'La notion de patrimoine commun de l'humanité' in 175 Hague Recueil (1982II) Chapitre I esp.; idem, 'Common Concern of Mankind', 27/4 E.P.L. (1997) pp. 244-47.

118 Text in P. Birnie and A. Boyle, Basic Documents on International Law and the Environment, (1995) p. 248.

119 Cf. The 1959 Antarctic Treaty (Preamble); The 1946 International Convention for the Regulation of Whaling (Preamble).

120 The Barcelona Traction, Light and Power Company Limited Case (Belgium v Spain: Second Phase) I.C.J. Reports, (1970) p. 3. See F. L. Kirgis, 'Standing to Challenge Human Endeavours That Could Change the Climate', 84 A.J.I.L. (1990) p. 527; P. Birnie and A. Boyle, International Law and the Environment, (1992) p. 156.

121 See Chapter I(IV) above. 
The 1985 Vienna Ozone Convention and International Environmental Law

premature and its future implications for the international community and for individual states have yet to be developed. 122

\section{The Vienna Ozone Layer Convention and the 'Principle' of the Precautionary Approach in Modern International Law of the Environment}

'If and when a global convention for the protection of the ozone layer came into force, it would represent a major break-through in international environmental co-operation, in the sense that the world community would have declared its determination to take action before a serious global environmental threat materialized, i.e. preventive global action instead of the remedial action taken hitherto'.123

The international ozone régime has been based on the precautionary environmental 'principle'/approach 124 that is seen as a gradual and marked development or an effective modification of Principle 21 of the 1972 Stockholm Declaration. As we shall see, the concept of a precautionary approach would not emerge as a 'new legal principle' without the existence or elaboration of this old customary norm in international environmental law.

(1) The Vienna Ozone Convention and Principle 21 of the 1972 Stockholm Declaration

The Vienna Ozone Convention, just like the 1982 U.N.C.L.O.S. (Article 194(2)), 1979 Geneva L.R.T.A.P. (Preamble), the 1992 Biodiversity Convention

122 See J. Werksman, 'Consolidating Governance of the Global Commons: Insights from the Global Environmental Facility', 6 Y.bk.I.E.L. (1995) p. 41, rightly observing that 'Such designation [the common concern of humankind] alone does not change the nature of legal rights and duties associated with the designated area or resource'. The same opinion is expressed by F. Biermann, Saving the Atmosphere: International Law, Developing Countries and Air Pollution (1995) p. 15.

123 Opening statement by the Swedish Minister for Agriculture and the Environment at the First Session of the Working Group in UNEP/WG.69/10, para. 3 (emphasis original).

124 See e.g. UNEP/OzL.Pro.7/12 para. 60, noting that 'A number of representatives said that the precautionary principle, which had been a cornerstone of the ozone regime from the outset, should continue to be applied as Parties addressed ongoing threat to the ozone layer. For a discussion see also Section $C(2 . b)$ below. 
(Article 3) and the 1992 Climate Change Convention (Preamble), contains a specific reference to Principle 21 of the 1972 Stockholm Declaration on the Human Environment: 125

'States have, in accordance with the Charter of the United Nations and principles of international law, the sovereign right to exploit their own resources pursuant to their own environment policies, and the responsibility to ensure that activities within their jurisdiction or control do not cause damage to the environment of other States or areas beyond the limits of national jurisdiction'. 126

Stockholm Principle 21 (= Principle 2 of the Rio Declaration) ${ }^{127}$ is an expression of the 'principle of preventive action' or sic utere tuo ut alienum non laedas : in general, it requires states to take certain positive and preventive action and at the same time, it fixes a 'threshold' 128 of transboundary environmental harm that will be unacceptable. Although Principle 21 is widely regarded as a rule of customary international law, 129 in the view of some authors such as M. Koskenniemi, it is often seen as a 'process-definition' that indicates relevant values but leaves the determination of their normative impact into further process. 130

125 For a discussion of Principle 21 see among others P. Birnie and A. Boyle, International Law and the Environment, (1992) pp. 90 et seq.; N. Schrijver, Sovereignty Over Natural Resources: Balancing Rights and Duties, (1997) pp. 125-28 \& its footnote no. 15.

126 The first draft convention also addresses this principle (UNEP/WG.69/3/Add.1). See also the commentary of a draft convention saying that 'obligation to protect the ozone layer is indirectly embodies in principle 21 of the Stockholm Declaration' (UNEP/WG.78/2, p. 7).

127 But Stockholm Principle 21 was slightly modified by Rio Principle 21 containing the words 'and developmental [policies]'. See P. Sands, 'International Law in the Field of Sustainable Development', 66 B.Y.bk.I.L. (1995) pp. 342-43, suggesting such modification 'does not materially change its meaning and effect'..

128 On its definition see K. Sachariew, 'The Definition of Thresholds of Tolerance for Transboundary Environment Injury under International Law: Development and Present Status', 37 N.I.L.R. (1990) pp. 193-206.

129 P. Birnie and A. Boyle, International Law and the Environment, (1992) pp. 89 et seq.; A. Kiss, Droit international de l'environment, (1989) pp. 80 et seq.; P. Sands, Principles of International Environmental Law, (1995) pp. 190 et seq.; R. J. Dupuy, 'Humanity and the Environment', 2 Colorado J.I.E.L.P. (1991) p. 203. See also I.C.J.'s Nuclear Weapons Advisory Opinion, 35 I.L.M. (1996) paras. 29-30. Cf. O. Schachter, International Law in Theory and Practice, (1991) p. 364, arguing that Principle 21 has not become a customary law.

130 M. Koskenniemi, 'Peaceful Settlement of Environmental Disputes', 60 Nordic J.I.L. (1991) p. 76. 
However, it should be noted that the essential element of this Principle is that states have the 'responsibility'131 to take certain preventive measures in order to protect the 'environment' (i.e. not 'territory'). In this sense, Principle 21 is something more than a mere principle of good neighbourliness or bon voisinage,. 132 and it is concerned to some extent with ozone having a C.C.M. character. At present it is regarded as including the high seas and the airspace above them, the deep seabed, outer space, the Moon and other celestial bodies, and Antarctica. 133

Principle 21 that is now seen in the Preamble of the Convention was originally inserted into both article 1 of the draft ozone convention submitted by the delegations of Finland/Norway/Sweden, 134 and article 2 of the draft conventions prepared by the U.N.E.P. Secretariat. 135 Those earlier proposals lacked adequate support from some states because of the reason that they are likely to entail obligations that might exceed their capacities. ${ }^{136}$ Unlike its operative treaty provisions, the Preamble itself does not establish binding legal obligations and therefore the Principle in question can be seen as an informative guide not only to determining the object and purpose of the Convention but also to interpreting the meaning of these particular provisions. 137 Yet Principle 21 is supported by Article 2(2)(b) of 'General Obligations' of the present text of the Ozone Convention (see section $\mathrm{D}(1)$ below).

This widely supported Principle 21 by itself is unlikely to provide a workable legal approach to address the depletion of the ozone layer. To

131 In the context of Principles 21/22 and the 1982 U.N.C.L.O.S. (Article 235), 'responsibility' means the obligation to protect and conserve the environment, while 'liability' suggests the obligation to compensate for environmental damage. Cf. The I.L.C.'s definition on 'responsibility' and 'liability' in 'International Liability for the Injurious Consequences of Acts Not Prohibited by International law'. See also A. E. Boyle, 'State Responsibility and International Liability for Injurious Consequences of Acts Not Prohibited by International law: A Necessary Distinction?', 39 I.C.L.Q. (1990) pp. 8-10 esp.

132 For further details of this principle, see e.g. M. Gavouneil, Pollution from Offshore Installations, (1995) pp. 82-84.

133 P. Birnie and A. Boyle, International Law and the Environment, (1992) pp. 90 et seq.; R. Pisillo-Mazzeschi, 'Form of International Responsibility for Environmental Harm', in Francioni and Scovazzi, International Responsibility for Environmental Harm, (1991) pp. 28 et seq.; G. Handl, 'State Liability for Accidental Transboundary Environmental Damage by Private Persons', 74 A.J.I.L. (1980) pp. 528-29.

134 'Fundamental Obligation' (Article 1) in Draft International Convention for the Protection of the Stratospheric Ozone Layer, (UNEP/WG.69/3).

135 Alternatives $1 \& 2$ of Article 2 in 'General Obligation' in UNEP/WG.78/2.

136 See UNEP/WG.78/8, para. 8 , reporting that a number of delegations expressed a strong preference for weaker 'alternative 3 '.

137 I. Sinclair, The Vienna Convention for the Law of Treaties, (1984) pp. 127 et seq. 
begin with, it is important to notice that the origin of the rule is derived from or based on the frequently cited international case law, the Trail Smelter Arbitration (1938 \& 1941). The tribunal directly addressed state liability for transboundary air pollution and it supported responsibility for wrongful acts for breach of such obligations, and not for lawful acts. 138 In this context, as Professor G. Handl observed, it may not be denied that 'Principle 21 can only be understood as referring to material damage alone, and that it thus confirms that material damage is the precondition for a state's responsibility arising out of an activity lawful per se'.139 This remark can be borne out by the fact that many delegates, in the preparatory works for Stockholm Principle 21, endorsed the view that responsibility for environmental harm should be solely based on a state's negligence, but not on the forms of liability for lawful acts. 140 Therefore, it may be assumed that states' responsibility in the context of customary international law arises only if the breach of specific primary obligation exists. Principle 22 of the Stockholm Declaration recognised this crucial point ${ }^{141}$ - nevertheless liability schemes for lawful acts have been poorly developed over the past three decades. The same thing may be said of the concept of objective responsibility for wrongful acts. 142

The above review will show that, although many international environmental treaties including the Vienna Ozone Layer Convention

138 In the Trail Smelter case, the tribunal declared that; '. . no State has a right to use or permit the use of its territory in such a manner as to cause injury by fumes in or to the territory of another or the properties or persons therein, when the case is of serious consequences and the injury is established by clear and convincing evidence (emphasis added)'.

139 G. Handl, 'Territorial Sovereignty and the Problem of Transnational Pollution', in 69 A.J.I.L. (1975) p. 67 (emphasis added) and its footnote 103; idem, 'Balancing of Interests and International Liability for the Pollution of International Watercourses: Customary Principles of Law Revisited', 13 C.Y.bk.I.L. (1975) pp. 160 et seq.; idem, 'State Liability for Accidental Transboundary Environmental Damage by Private Persons', 74 A.J.I.L. (1980) pp. 535 et seq.

140 See U.N. Doc. A/CONF.48/PC. 12, Annex II, p. 15. See also R. Pisillo-Mazzeschi, 'The Due Diligence Rule and the Nature of the International Responsibility of States', 35 G.Y.bk.I.L. (1992) p. 38; G. Lang, 'Balancing Interests and International Liability for Pollution of International Watercourses: Customary Principles of Law Revised', 13 C.Y.bk.I.L. (1975) pp. 160 et seq.

141 'States shall co-operate to develop further the international law regarding liability and compensation for the victims of pollution and other environmental damage caused by activities within the jurisdiction or control of such States to areas beyond their jurisdiction'.

142 But see K. Kummer, International Management of Hazardous Wastes, (1995) pp. 215-16 \& its footnotes 14, 16. See also P. Birnie and A. Boyle, International Law and the Environment, (1992) pp. 142 et seq. Cf. L. F. E. Goldie, 'Liability for Damage and the Progressive Development of International Law', 14 I.C.L.Q. (1965) pp. 1189-1264. 
incorporated Principle 21, it ultimately proved that in a sense their primary aim was to establish obligations of prevention limited by the rule of 'due diligence'. 143 The legal terminology of due diligence can be generally defined as 'necessary and practicable measures' i.e. an expression of good environmental conduct. ${ }^{144}$ It is commonly accepted that states are not responsible for environmental damage unless it results from a lack of international due diligence. 145 Perhaps its advantages (= flexibility) are reflected in the following three points:

(i) the effectiveness of different environmental control measures concerning the severity of the threat;

(ii) considerations for the various levels of national economic developments (e.g. resources available to developed/developing countries) ${ }^{146}$ and;

(iii) approaches toward the different nature of the specific activity. 147

Its flexibility means at the same time its serious disadvantages, e.g. the lack of 'clear' and 'reliable' guidance for state actors and its industries in relation to specific environmental legislation and administrative controls. Accordingly, under these conditions it is very likely that states/industries

143 See the Alabama Claims Arbitration, 1872, Moore International Arbitration, vol. 1, pp. 495-682; the Hostages in Iran case, I.C.J. Reports, pp. 29-33; the Corfu Channel case, I.C.J. Reports, 1949, p. 3. R. Pisillo-Mazzeschi, 'The Due Diligence Rule and the Nature of the International Responsibility of States', 35 G.Y.bk.I.L. (1992) pp. 9-51; idem, 'Forms of International Responsibility for Environmental Harm', in F. Francioni and T. Scovazzi, International Responsibility for Environmental Harm, (1991) pp. 1535; A. E. Boyle, 'Nuclear Energy and International Law: An Environmental Perspective', B.Y.bk.I.L, (1989) pp. 272-73 and its footnote no. 109.

144 P. Birnie and A. Boyle, International Law and the Environment, (1992), pp. 92-94 and its footnotes: A. E. Boyle, 'Nuclear Energy and International Law: An Environmental Perspective', in B.Y.bk.I.L. (1989) pp. 272 esp.

145 The rule of 'due diligence' has been applied particularly to (i) the security of aliens and representatives of foreign states, (ii) the security of foreign states and (iii) the conservation of the environment. See R. Pisillo-Mazzeschi, 'The Due Diligence and the Nature of the International Responsibility of States', 35 G.Y.bk.I.L. (1992) pp. 22 et seq.

146 As far as the resources available to the states are concerned, considerable controversy could arise as to the question of the standard of national treatment and an 'international minimum standard' or 'a moral standard for civilised states'. For a discussion see I. Brownlie, Principles of Public International Law, (1990) pp. 523-28; D. J. Harris, Cases and Materials on International Law, 4th edn. (1991) pp. 493-34. Disagreement about this subject partly lead to the failure of the 1930 Hague Codification Conference and García Amador's attempt at the I.L.C. on the subject of state responsibility (1956-1961). I.L.C.'s present draft articles seem to avoid this issue, though it deals with 'due diligence' in Article 23 of its Draft Articles.

147 See U.N.E.P. 'International Due Diligence' (informal note for the Executive Director's Advisory Group on Banking and the Environment, October 1993). 
The 1985 Vienna Ozone Convention and International Environmental Law

should naturally follow 'agreed-upon minimum international environmental standards' (e.g. those contained in the International Standards Organisation ('I.S.O.'), 148 the World Health Organisation ('W.H.O.') and the International Maritime Organisation ('I.M.O.')). ${ }^{149}$ Further, in the field of environmental protection, sometimes scientific uncertainty makes the concept of due diligence more complicated and difficult for states/industries to apply on a particular occasion.

In the context of international ozone protection, the customary law rule of international due diligence cannot form dependable standards for production/'consumption' of ozone-depleting chemicals such as C.F.Cs. This point is illustrated in the Chernobyl disaster: although it may be assumed that Principle 21 could be applicable to this type of transboundary environmental harm, it was in reality difficult to show a failure of due diligence in the absence of binding international standards that regulate national nuclear activities. 150

In summary, the customary rule of due diligence only requires states to take appropriate measures or make every effort in accordance with the means at their disposal and capabilities. In other words, the rule leaves too much discretion and offers no clear guideline or specific standards. ${ }^{151}$

148 On the functions of standards/rules (e.g. the I.S.O. 14000) see N. Roht-Arriaza, 'Private Voluntary Standard-Setting, the International Organisation for Standardisation, and International Environmental Lawmaking', 6 Y.bk.I.E.L. (1995) pp. 107-63.

149 See U.N.E.P. 'International Due Diligence', (information note for the Executive Director's Advisory Group on Banking and the Environment, October 1993). See also A. E. Boyle, 'Nuclear Energy and International Law: An Environmental Perspective', in B.Y.bk.I.L. (1989) pp. 272-73.

150 But this may be done in the above-mentioned Trail Smelter Case.

The former Soviet Union was not a party to both the 1960 Paris Convention and the 1963 Vienna Convention. See ibid., pp. 272-73; idem, 'Chernobyl and the Development of International Environmental Law', in W. E. Butler, Control Over Compliance With International Law, (1991) pp. 203-119; P. Sands, 'The Environment, Community and International Law', 30 Harv.I.L.J. (1989) pp. 401 et seq.

151 Seen in this way, it is quite understandable that Principle 24 of the Stockholm Declaration provides that 'Co-operation through multilateral or bilateral arrangements or other appropriate means is essential to effectively control, prevent, reduce and eliminate adverse environmental effects'. 
The 1985 Vienna Ozone Convention and International Environmental Law

(2) The Vienna Ozone Layer Convention and the Precautionary

Environmental 'Principle': The Emergence of a New Approach

(a) International Environmental Co-operation: Developments Subsequent to the Adoption of Principle 21 of the 1972 Stockholm Declaration 152

As was discussed above, Principle 21 suggests that states have the responsibility to take certain preventive measures to protect the environment, even though the meaning of 'responsibility' is not necessarily clear. In addition, even if this rule is seen only as a 'processdefinition' of environmental treaties (see section (1) above), it is likely that such a general legal norm could have facilitated further international cooperation on various aspects of environmental protection and developments of its application. 153

It should be noted that early references to 'preventive measures' can be seen in many legal instruments: they include several principles of the Final Declaration of the 1972 Stockholm Declaration, 154 the 1975 Final Act of the Conference on Security and Co-operation in Europe, the 1982 Nairobi Declaration adopted by the U.N.E.P. Governing Council (No. 9) and the 1982 World Charter for Nature. 155 Moreover, it can be possible to argue that in certain cases the customary rule has inevitably entailed procedural obligations to co-operate in protecting the human environment: ${ }^{156}$ examples will include (i) obligations of prior notification and consultation in the context of environmental hazard, 157 (ii) obligations to notify ${ }^{158}$ and

152 See generally M. N. Shaw, International Law, 4th edn. (1997) pp. 600-07.

153 See R. Pisillo-Mazzeschi, 'Forms of International Responsibility for Environmental Harm' in F. Francioni and T. Scovazzi, International Responsibility for Environmental Harm, (1991) pp. 28-9.

154 Conservation of Natural Resources for Present and Future Generations (Principle 2); Maintenance of the Capacity of the Earth to Produce Vital Renewable Resources (Principle 3); Non-Exhaustion of Non-Renewable Resources (Principle 5).

155 U.N. General Assembly Resolution 37/7. The Charter provides that 'Activities which are likely to cause irreversible damage to nature shall be avoided' (No. 11(a)), and 'Activities which are likely to pose a significant risk to nature shall be preceded by an exhaustive examination' (No. 11(b)).

156 See e.g. A. E. Boyle, 'Nuclear Energy and International Law: An Environmental Perspective', in B.Y.bk.I.L. (1989) pp. 278-87 esp.; A. Kiss, 'Nouvelles tendances en droit international de l'environnement' 16 G.Y.bk.I.L. p. 246; A. E. Utton, 'International Environmental Law and Consultation Mechanisms', 12 Columbia J.T.L. (1973) pp. 56-72; P. N. Okowa, 'Procedural Obligations in International Environmental Agreements', 67 B.Y.bk.I.L. (1996) pp. 275-336.

157 Examples include the 1986 Early Notification Convention and the 1986 I.A.E.A. Assistance Convention (see further Chapter I footnote no. 39).

158 See Chapter I footnote no. 40. 
The 1985 Vienna Ozone Convention and International Environmental Law

consult ${ }^{159}$ in the case of accidents or emergencies capable of causing transfrontier harm in general, and (iii) environmental impact assessment ('E.I.A.').160 This will mean that the so-called 'Principle 20' of the 1972 Stockholm Declaration prepared by the Working Group - which could not get final approval, however -161 was now widely supported by modern international environment treaties containing these procedural obligations.

In so far as environmental impact assessment shows a foreseeable risk, the problems of the rule of due diligence will be partly mitigated. However, we should note that it is usually difficult to build up consensual scientific knowledge in most environmental problems. This is an important fact to stress: during the formation of scientific consensus in the international community, the environment is increasingly polluted, and sometimes we may be going 'beyond the limits' of the physical environment, although not intending to do so. 162

(b) The Precautionary Environmental 'Principle'/Approach

Under the condition that the customary international law rule of 'due diligence' secures little promise for environmental protection, a radical idea has gradually emerged from the customary rule of Principle 21 - i.e. even when there does exist lack of scientific proof of the cause and effect relationship, certain preventive measures to protect the environment

159 See e.g. the 1972 London Dumping Convention (Article V(2)); the 1974 Nordic Environmental Protection Convention (Article 11); the 1979 Geneva Convention (Article $5 \& 8$ ). See further Chapter I footnote no. 41 .

160 See e.g. the 1978 U.N.E.P. Draft Principles of Conduct; the 1985 A.S.E.A.N. Agreement (Article 14); the 1982 U.N.C.L.O.S. (Article 206). See further Chapter I footnote no. 42.

161 It reads 'Each State has the duty to undertake international consultations before proceeding with activities which may damage to the environment of another State or to the environment of areas beyond the limits of national jurisdiction. A State having reason to believe that the activities of another State may cause damage to its environment or to the environment of area beyond the limits of national jurisdiction, may request international consultations concerning the envisaged activities'. See UN.Doc.A/CONF.48/PC/WG.I (II)/CRP.4(1972), p. 2, cited in L. B. Sohn, 'The Stockholm Declaration on the Human Environment', 14 Harvard I.L.J. (1973), p. 497. For conflicting opinions, see ibid. pp. 496 et seq.

162 See D. H. Meadows, D. L. Meadows and J. Randers, Beyond the Limits: Global Collapse or a Sustainable Future, (1992), dealing with potential 'overshoot' caused by human society. 
The 1985 Vienna Ozone Convention and International Environmental Law

should be taken. This is the so-called precautionary (environmental) 'principle' or approach. 163

It is widely agreed that the 1987 Ministerial Declaration of the Second International Conference on the Protection of the North Sea (London Declaration) is the first agreement that explicitly formulated the precautionary principle. It reads:

'. . in order to protect the North Sea from possibly damaging effects of the most dangerous substances, a precautionary approach is necessary which may require action to control inputs of such substances even before a causal link has been established by absolutely clear scientific evidence' (Paragraph VII). 164

The 1985 Vienna Ozone Layer Convention, for the first time, made reference to the term 'precautionary measures' taken at national and international level for the protection of the ozone layer (Preamble). 165 Although there was already general agreement at the First Session of the Working Group held in 1982 in Stockholm that 'precautionary action is necessary for the sake of man and the environment', ${ }^{166}$ perhaps not surprisingly, the wording 'precautionary' was bracketed in earlier draft framework conventions.

The introduction of 'precautionary measures' mentioned above is a remarkable development in international environmental law. International environmental treaties adopted before the 1985 Ozone Layer Convention - for instance, the 1979 Geneva L.R.T.A.P. - only claimed the recognition of the existence of 'possible adverse effects' of transboundary

163 From among a considerable literature on this 'principle' see D. Freestone and A. Hey, 'Origins and Development of the Precautionary Principle' in D. Freestone and H. Hey (eds.), Precautionary Principle and International Law, (1996) pp. 3-15; J. Cameron, 'The Status of the Precautionary Principle in International Law', in O'Riordan and Cameron (eds.) Interpreting the Precautionary Principle, (1994) pp. 276 et seq.; P. Birnie and A. Boyle, International Law and the Environment, (1992) pp. 97-98; G. Handle, 'Environmental Security and Global Change: The Challenge to International Law', 1 Y.bk.I.E.L. (1990) pp. 20-24. Perhaps it may also be possible to argue that the principle was deprived from the German law, Vorsorgeprinzip. See D. Freestone, 'The Precautionary Principle' in R. Churchill and D. Freestone, International Law and Global Climate Change, (1991) p. 21.

164 See Y. van der Mensbrugghe, 'Legal Status of International North Sea Conference Declarations', 5 I.J.E.C.L. (1990) pp. 15-22.

165 This terminology is first found in the Alternative 1 of 'General Obligations' of the second revised draft convention. (Second Revised Draft Convention for the Protection of the Ozone Layer, (UNEP/WG.94/3).

166 UNEP/WG.69/10, para. 9. 
air pollution in the short/long term (Preamble). 167 As P. Birnie and A. Boyle say, the Ozone Layer Convention is therefore one of the first international treaties that perceived the need for precautionary action without full scientific certainty: 168 in the middle of 1980 serious scientific difficulties about the theory of ozone-depletion remained unsolved, and there was not sufficient scientific consensus; until 1985 no scientific observation of the actual ozone-loss was published, and; the Rowland-Molia hypothesis suggested in $1974^{169}$ was not confirmed until 1988.

As we shall see in later chapters, it was the 1987 Montreal Ozone Layer Protocol that actually achieved the precautionary 'principle'/approach by introducing specific control measures for specified eight C.F.Cs./O.D.Ss. contained Annex A (see Chapter III(III.B.1) below). The Preamble of the Montreal Protocol provides that the parties are 'determined to protect the ozone layer by taking precautionary measures to control total emissions of substances that deplete it' (emphasis added).

At present there is already enough cogent scientific evidence to support Articles 2 and 5 control measures of the Montreal Protocol régime (see Introduction above). In this more restricted sense, this regulatory ozone régime may not be a precautionary treaty régime any more. ${ }^{170}$ However, it should be emphasised that scientific information for the shaping of global environmental policy about ozone depletion will never be perfect or accurate. ${ }^{171}$ Thus it must continue to be strengthened (Note!: skin cancer is still the only expected impact for which sufficient data and information are available to make quantitative predictions). ${ }^{172}$

167 In this respect, it is probable that this pre-1980 position was partly influenced not only by the political will of member states but also by scientific uncertainty on the causes and effects of acid rain. See e.g. L. Gündling, 'Multilateral Co-operation of States under the ECE Convention on Long-Range Transboundary Air Pollution' in C. Flinterman, B. Kwiatkowska and J. Lammers (eds.) Transboundary Air Pollution, (1986) p.20.

168 p. Birnie and A. Boyle, International Law and the Environment, (1992) p. 406.

169 See Introduction above (footnote no. 5).

170 On this point see J. Brunnéé, 'Conceptual Framework for an International Forests Convention: Customary Law and Emerging Principles' in Global Forests and International Environmental Law, (1996) footnote no. 175, noting that 'only after compelling evidence that depletion was in fact occurring emerged, were concrete measures agreed to in the Montreal Protocol'.

171 For a discussion of the relationship between science and policy-making see in particular J. Stonehouse and J. Mumford, Science, Risk Analysis and Environmental Decisions, (U.N.E.P.'s Environment \& Trade no. 5: 1994).

172 See statement by Dr. J. C. Van der Lean (Co-Chair of the Panel on Environmental Effects of Ozone Depletion) at the 1997 Ninth Ozone Meeting of the Parties in 
The precautionary environmental 'principle'/approach is now widely incorporated into a number of environmental law instruments including Principle 15 of the 1992 Rio Declaration; the 1996 Protocol to the London Dumping Convention (Articles 2, 3 and 4), the 1995 Straddling Fish Stocks Convention (Article 6/Annex II), 173 the Maastricht Treaty of the European Union (Article 130(R)(2)), the Convention for the Protection of the Marine Environment of the North-East Atlantic (the O.S.P.A.R. Convention: Preamble \& Article 2(2)(a)), the 1992 Convention on the Protection of the Marine Environment of the Baltic Sea Area (Baltic Sea Convention (Article 3(2)), the 1992 Helsinki Convention on the Protection and Use of Transboundary Watercourses and Lakes (Article 2(5)(a)), the 1992 Bamako Convention (Article 4(3)(f)), the 1992 Climate Change Convention (Preamble), and perhaps arguably, Article 6 of the 1989 Basel Convention (the Prior Informed Consent Procedure ('P.I.C.')). 174

As noted by many commentators, though these multilateral environmental treaties seem to accept the new approach, defining the international legal 'principle' is not a easy task. 175 Although I have space for no more than an indication, the international legal status of this 'principle' in international law still remains undeniably ambiguous. 176 As some authors have suggested, there may be some cogent evidence to show that the precautionary 'principle' has already become part of customary

UNEP/OzL.Pro.9/12, para. 32. See also statement by Co-Chair of the T.E.A.P. in UNEP/OzL.Pro.9/12, para. 29, suggesting the need of financial resources for monitoring and further research of ozone depletion.

As to the emergence of revisionism against ozone science see R. Benedick, Ozone Diplomacy, (1998) pp. 226-28; F. Singer, 'Swedish Academy's Choice of Honourees Signals That Ozone Politics Played a Role', The Scientist, (4 March 1996) p. 9, cited in ibid., p. 228.

173 A/CONF.164/37 (8 September 1995). D. A. Balton, 'Strengthening the Law of the Sea: The New Agreement on Straddling Fish Stocks and Highly Migratory Stocks', 27 O.D.I.L. (1996) pp. 125-51.

174 Other examples include: the 1988 C.R.A.M.R.A. (Article 4); the 1992 Biodiversity Convention (Preamble); the 1992 Baltic Sea Convention (Article 3(2)); the 1992 Transboundary Watercourses Convention (Article 2(5)(a)); the 1992 O.S.P.A.R., Convention (Article 2(2)(a)); the 1992 Maastricht Treaty (Article 130f). 29-30.

See also I.C.J.'s Nuclear Weapons Advisory Opinion, 35 I.L.M. (1996) paras.

175 For an extensive discussion see P. Sands, Principles of International Environmental Law, (1995) pp. 208-13; D. Freestone, 'The Precautionary Principle' in D. Freestone and R. Churchill (eds.), International Law and Global Climate Change, (1992); Freestone and Hey 'Origins and Development of the Precautionary Principle' in D. Freestone and E. Hey, Precautionary Principle and International Law, (1996) pp. 315; L. Gündling, 'The Status in International Law of the Principle of Precautionary Action', 5 I.J.E.C.L. (1990) pp. 25 et seq.

176 For a discussion see e.g. L. Gündling, 'The Status in International Law of the Principle of Precautionary Action', 5 I.J.E.C.J. (1990) pp. 23-30. 
international law of the environment, but it must be said that the authenticity for that argument still remains uncertain. 177

In my view, this is hardly surprising, however. 178 First, it should be noticed that, despite a marked difference between the precautionary 'principle' or approach and the Stockholm Principle 21/Rio Principle 2, as far as the former new approach is inherently based on the latter customary rule, these two principles are still closely inter-related. Secondly, and perhaps more importantly, what the precautionary approach actually means will significantly depend on context, objective and the nature of each environmental issue. For instance, the legal character of the precautionary approach in the ozone régime intrinsically differs from that of oceans and sea, water resources or hazardous activities that are more closely concerned with the 'threshold' of environmental damage (see Chapter I(IV)).

Regardless of its formal legal status in international law, in the present international community of over 190 developed and developing states, this evolving 'principle'/approach within modern environmental treaty régimes would not be maintained by participating states unless supported, to a greater or less extent, by legal instruments for international environmental co-operation and global capacity-building (see Chapter I(III.B)).

D. The Provisions of the 1985 Vienna Ozone Layer Convention

(1) The 'General Obligations': Legal Basis of the Montreal Ozone Protocol

'General Obligations', 'Fundamental Principles' or equivalent articles which are thus central to international environmental treaties - contain contracting parties' legitimate expectations for development/maintenance of the international régimes. In general, they are regimes' legal (and political) guiding rules that address the rational behaviour of participating states. Some general provisions in this kind of article may be regarded as

177 See e.g. J. Cameron and J. Abouchar, 'The Precautionary Principle: A Fundamental Principle of Law and Policy for the Protection of the Global Environment', 14 B.C.I.C.L.R. (1991) pp. 34-52.

178 For similar arguments see D. Freestone and Z. Makuch, 'The New International Environmental Law of Fishries: The 1995 United Nations Straddling Stocks Agreement', 7 Y.bk.I.E.L. (1996) p. 13, saying that "the precautionary principle may not be such a radical departure from existing international principle'. 
confirmation of the legal rule of international due diligence ${ }^{179}$ to take appropriate measures at least (see Section III(C.1) above). 180 This means that on most occasions these provisions may not gain clear or objective meaning unless supported by other substantial treaty provisions and specific environmental regulations for successful implementation of the respective regimes.

Although the contents of such provisions depend largely on the character of each environmental régime, they generally cover (i) the control over activities within (and outside) national jurisdiction, (ii) exchange of information relating to scientific/technical information and data, (iii) financial/technical assistance and international transfer of technology, and (iv) the general obligations to internationally cooperate. 181 Good examples that include some or most of the abovementioned obligations are the 1979 Geneva L.R.T.A.P. Convention (Article 2); the 1989 Basel Convention (Article 4); the 1991 Bamako Convention on the Transboundary Movement and Management of Hazardous Wastes within Africa (Article 4); 182 the 1992 Biodiversity Convention (Article 3) ${ }^{183}$; the 1992 Climate Change Convention (Article 3); the 1985 A.S.E.A.N. Agreement (Article 1); the 1994 U.N. Convention to Combat Desertification in Those Countries Experiencing Serious Drought and/or Desertification, Particularly in Africa (Article 4).

The following content of 'General Obligations' of the Vienna Ozone Convention (Article 2) is a product of constructive discussions, selected from many 'Alternatives' in its draft texts revised several times (see Section II(B.1-2) above).

Responding to 'preventive measures' in the Preamble, Article 2 provides that the parties are to take appropriate measures to protect human health and the environment against adverse effects resulting from related

179 Cf. S. Kuwabara, The Legal Regime of the Protection of the Mediterranean against Pollution from Land-Based Sources, (1984) p. 71.

180 See e.g. Article 192 of the 1982 U.N.C.L.O.S. ('General Obligation'), providing that 'States have the obligation to protect and preserve the marine environment' and Article 194 requiring them to use the 'best practicable means at their disposal and in accordance with their capabilities'.

181 For a discussion of environmental co-operation see A. E. Boyle, 'The Principle of Co-operation: the Environment' in V. Lowe and C. Warbrick (eds.), The United Nations and the Principles of International Law: Essays in Memory of Michael Akehurst, (1994) pp. 129-32.

18230 I.L.M. (1991) p. 775.

183 But note that most of important principles seen in draft article 3 were moved up to its 'Preamble' at the final stage of the negotiation. 
human activities (Article 2(1)). The phrase 'appropriate measures' accurately reflects the nature of this framework environmental treaty. 184 Such measures must be based on relevant scientific and technical considerations (Article 2(4)).185 In accordance with the means at their disposal and capabilities (Article 2(2)), the parties are to 'adopt appropriate legislative or administrative measures'186 and to 'co-operate in harmonising appropriate policies to control, limit, reduce or prevent human activities under their jurisdiction or control' if these activities have or are likely to have adverse environmental effects concerned with ozone depletion (Article 2(2.b)). The parties may adopt domestic measures 'additional' to measures mentioned above in accordance with international law (Article 2(3)).187 Yet 'General Obligations' of the Ozone Convention do not specifically deal with the special treatment of developing countries, although Article 4(2) addresses such matters in the context of transfer of environmentally sound technology. In this respect, unlike the 1985 Vienna Convention, the Montreal Protocol as amended/adjusted contains strong provisions for the so-called 'Article 5 developing country' and moreover it established the Multilateral Fund within the ozone régime (see Chapter III(III.E) and Chapter VI below).

Article 2(2.a) requires the parties to co-operate through systematic observations, research and information exchange to understand and assess the relationship between human activities and ozone depletion. Such obligations to globally co-operate are absolutely indispensable for environmental framework conventions facing scientific uncertainty since it would help to achieve relevant scientific breakthroughs (see Chapter I(III.A) above). 188 This provision 2(2.a) is read together with Article 3

184 See H. Hohmann, Basic Documents of International Environmental Law, vol. II (1992) p. 668, saying that Article $2(2)$ is a loophole for all - especially for economically weaker states. The corresponding article of the 1974 Paris Convention provides that the parties 'pledge themselves to take all possible steps to prevent pollution of the sea' (Article 1) - this wording is comparatively stronger than that of the Vienna Ozone Convention.

185 During the Session of the Working Group, one expert argued that it was possible to interpret the phrase 'in accordance with the means at their disposal and their capabilities' (Article 2(2)) as suggesting that the member states would not necessarily enact any legislation in implementation of the Convention. UNEP/WG.94/10, p. 10.

186 On national ozone laws/regulations see Part B of Chapter III below.

187 In the third revised draft convention, the term 'stricter' was used instead of 'additional'. See UNEP/WG.94/8, p. 2.

188 The 1979 Geneva L.R.T.A.P. also laid a basis for further co-operation in scientific research, and it established a 'Co-operative Programme for the Monitoring and Evaluation of the Long-Range Transmission of Air Pollutants in Europe (Article 9). 
('Research and Systematic Observation') and Article 4 ('Co-operation in the Legal, Scientific and Technical Field'). Article 4(1) provides that the parties are to facilitate and encourage the exchange of scientific, technical, socio-economic, commercial and legal information relevant to the Convention as elaborated in Annex II. 189

In order to adopt supplementing protocols/annexes, the parties are required to co-operate in the formulation of agreed measures, procedures and standards for the implementation of the Convention (Article 2(2.c)). 190

(2) The Conference of the Parties to the Vienna Ozone Layer Convention Régime

In many cases, just like other treaty régimes, modern international environmental agreements establish independent intergovernmental organs to ensure effective implementations of and compliance with their legal commitments. ${ }^{191}$ These highest treaty organs - which provide forums for continuous multilateral environmental negotiations - are called by a variety of names such as the 'Conference of the Parties', the 'Meetings of the Parties', the 'Executive Body', and so forth. 192 They are usually empowered to adopt amendments to conventions, implementing protocols and/or related technical annexes, and additional international treaties, technical annexes and legally non-binding recommendations or resolutions (see Chapter III(III.C) below). These treaty bodies as main

189 See Annex 2(2), providing that 'The Parties to the Convention, in deciding what information is to be collected and exchanged, should take account the usefulness of the information and the costs of obtaining it. The Parties further recognise that cooperation under this annex has to be consistent with national laws, regulations practice regarding patents, trade secrets, and protection of confidential and proprietary information'. This expresses the developed countries' view that patents and intellectual property concerned with the protection of the ozone layer should be guarded.

190 See Article 9. At the Third Session of the Working Group, it was agreed that the adoption of any protocols should be by the Conference of the Parties rather than diplomatic conference. See also UNEP/WG.94/3, commentary on article 9, saying protocols should be adopted at an 'extraordinary' meeting.

191 See J. Werksman, 'The Conference of Parties to Environmental Treaties' in idem (ed.), Greening International Institutions, (1996) pp. 55-68; A. E. Boyle, 'Saving the World? Implementation and Enforcement of International Environmental Law through International Institutions', 3 J.E.L. (1991) pp. 229-45.

192 Examples include the 'Conference of Parties' (the 1985 Vienna Ozone Convention, the 1992 Climate Change Convention), the 'Executive Body' (the 1979 transboundary Air Pollution Convention), and so on. Yet, supreme organs of international organisations are called; 'Assembly' (I.C.A.O., I.M.O., W.H.O., O.A.U.); 'General Conference' (I.A.E.A., I.L.O., U.N.E.S.C.O.); 'Conference' (F.A.O., O.A.S.), or; 'Congress' (W.M.O., U.P.U.). 
sources of régime-dynamics thus often enjoy considerable legislative autonomy. ${ }^{193}$ Further, they also provide forums for dispute avoidance/settlement by discussion and negotiation or consultation. 194 As was mentioned in Chapter I(III.D), N.G.Os. are widely allowed to participate in the institutions' regular meetings.

The Conference of the Parties to the Vienna Ozone Layer Convention as a legislative body is empowered to adopt (i) amendments to the Convention, protocols and their annexes, (ii) protocols to the Convention, and (iii) additional annexes to the Convention (Article 6(e-h)). 195 With regard to amendments of the Convention, only if all efforts at consensus proved unsuccessful, adoption by a two-thirds majority vote is then allowed as a last resort (Article 9(3)). This procedure applies to amendments to any protocol, although in this case a two-thirds majority of the parties to the protocol present and voting at the meeting is required (Article 9(4)). 196 This procedure is also applicable to the adoption and amendment of annexes to the Convention and protocols (Article 10(2)). Amendments adopted in accordance with Article 9(3/4) mentioned above shall enter into force between parties having accepted them (Article 9(5)). 197 As for the Rules of Procedure for the Conference of the Parties, they are substantially the same as those for the Meeting of the Parties to the Montreal Protocol except for Rules 1 and 2.198

193 See T. Gehring's régime-definition in Chapter I(II) above. See also J. Werksman, op. cit. n. 187 , p. 60 , suggesting that these organs' decision-making procedures are shaped by Stockholm Principle 21.

194 See A. E. Boyle, 'Saving the World? Implementation and Enforcement of International Environmental Law Through International Institutions', 3 J.E.L. (1991) pp. 232-33. In the context of the N.C.P. see Chapter V(IV.B.3 \& VII.B.2) below.

195 Annexes to the Convention or to any protocols are strictly restricted to scientific, technical and administrative matters, but form an integral part of the Convention or of such protocols. The amendment procedure mentioned above was a compromise reached by mutual concession - many experts supported a two-third majority vote in both cases, but others insisted on the necessity of a large majority vote or consensus. UNEP/WG.94/10, para 24. See also 12 E.P.L. 'Draft Convention Not Finalised', (1984) p. 10.

196 See the Montreal Protocol (Article 2(9)(c-d)). Under the Montreal Ozone Layer Protocol, both developed and developing countries have a 'veto power', and further amendments can be easier to achieve than the Convention (see Chapter III below). Cf. the 1992 Framework Convention on Climate Change (Articles 15 \& 17) and its Protocol (Articles 20(3) \& 21(4)).

197 In contrast, the Conference of the Parties of the 1992 Biodiversity Convention does not have such power to adopt binding amendments to annexes by majority decisionmaking (Article 29(4)). See A. E. Boyle, 'The Convention on Biodiversity', in L. Campiglio, (1994) p. 126.

198 See Article 6(3)). Rules of Procedure in U.N.E.P., Handbook, 4th edn. (1996) Section 1.5 . 
The Conference of the Parties is also designed to fulfil many other institutional functions: it reviews the scientific information concerned with the destruction of the ozone layer (Article 6(4.b)); ${ }^{199}$ promotes the harmonisation of policies, strategies and measures to minimise the omissions of ozone-depleting substances and make recommendations on any other measures relating to the Convention (Article 6(4.c)) and adopts programmes for research, systematic observations, scientific and technological co-operation, the exchange of information and transfer of technology and knowledge (Article 6(4.d)).200

In relation to co-operation with other international organisations, the Conference of the Parties may ask for the services of the W.M.O., the World Health Organisation ('W.H.O.'), and the U.N.E.P. C.C.O.L. relating to scientific and systematic observation, etc. (Article 6(4.j)). Lastly, in accordance with paragraph 4(i) of Article 6, the Conference of the Parties has established internal treaty institutions such as the Trust Fund of the Vienna Convention 201 and the Bureau of the Conference of the Parties. 202

(3) The U.N.E.P. Ozone Secretariat for the Vienna Convention and the Montreal Protocol

The basic function of Secretariats for environment treaties is to help implement multilateral agreements by co-ordinating and facilitating data collection and information exchange and by giving certain technical assistance for state parties (developing countries in particular). Secretariats are usually required to compile information submitted by the parties and prepare and distribute periodic summary reports. ${ }^{203}$ Generally speaking, their authority is strictly limited, and they are not expected to verify the information received by the parties. 204

Initially the U.N.E.P. Ozone Secretariat had carried out this function on an interim basis (Article $7(2)$ ), but it currently serves as a permanent

\footnotetext{
199 See also Article 5 and Decision I/2 of the Conference of the Parties.

200 The basis of these provisions can be found in Institutional Arrangements for a Convention for the Protection of the Ozone Layer, (UNEP/WG.78/4).

201 See Decision I/9 of the Conference of the Parties and Terms of Reference for the Trust Fund (Annex III).

202 See Decision I/ 6 of the Conference of the Parties.

203 U.S. General Accounting Office ('G.A.O.'), International Environmental Agreements are not Well Monitored, (January 1992), p. 29.

204 Ibid., pp. 29-30. But see also Chapter V(IV.B.1) below.
} 
basis. 205 The U.N.E.P. disseminates a great deal of information concerning the international ozone treaties, the science and technologies, government policies, industry news, meetings and workshops, and training programmes. 206 The reason the U.N.E.P. in Nairobi (Kenya) is designated to this post is that it possesses assessment programmes such as the Global Environmental Monitoring System ('G.E.M.S.')207 for monitoring the effectiveness of the provisions of the global convention and co-ordinating international mechanisms such as the U.N.E.P.'s Co-ordinating Committee on the Ozone Layer, and an Environmental Law Unit. 208 Of course, another advantage of the treaty secretariat co-located with this U.N. organ will be that the creation of a new organ will not be necessary (i.e. those of economy of staff and so forth). 209

The U.N.E.P. Ozone Secretariat exercises some influence over the compliance of the Ozone Layer Convention and the Montreal Protocol. In general the Ozone Secretariat arranges for or services the Conference of the Parties, the Meeting of the Parties, their committees, Bureaux, working groups and assessment panels. It will also arrange for implementing the decisions taken by these meetings. The Secretariat is to prepare reports based on information received in accordance with treaty provisions (see Chapter V(VII.A)), and ensure the necessary co-ordination with other relevant international agencies (Article $7(1)$ ). In this respect, the Ozone Secretariat often represents the Convention/Protocol in the relevant international bodies (e.g. the W.T.O. Committee on Trade \& Environment). 210 As a subsidiary institution, the Secretariat also performs other functions determined by the Conference of the Parties (Article 7 (f)). As we shall see, under the Montreal Protocol, the Ozone Secretariat havs expanded its functions (Article 12) and it is now empowered to trigger the Non-Compliance Procedure (see Chapter V(IV.B.1)).

Lastly, it should be noted that the Ozone Secretariat is to communicate proposed amendments not only to the contracting parties but also to the 'signatories' to the Convention for information (Article 9(2)).

205 See Decision $1 / 8$ of the Conference of the Parties.

206 R. Benedick, Ozone Diplomacy, (1998) p. 253; '"Ozone-Friendly" Computer Programme Updated', Envirolink Environment News Service (24 April 1997).

207 The G.E.M.S. is one of the first programmes established by the U.N.E.P. in 1970s. See in detail e.g. M. K. Tolba (eds.) The World Environment 1972-1992: Two Decades of Challenge, (1992) pp. 614-15.

208 UNEP/WG.78/4, para. 11-13.

209 UNEP/WG.78/4, para. 11-12.

210 See Chapter IV(I.B) below. 
The 1985 Vienna Ozone Convention and International Environmental Law Although this procedure was - as discussed in the Third Session of the Working Group - contrary to common treaty practice as embodied e.g. in the 1982 U.N.C.L.O.S., 211 recent environmental treaties widely follow such a trend. 212 Due to this formality by the U.N.E.P. Ozone Secretariat, some signatories - which are pending ratification - might decide to become new contracting parties to the ozone layer régime.

(4) The Dispute Settlement Procedures under the Vienna Ozone Layer Convention 213

Dispute settlement mechanisms of international treaty régimes usually include (i) diplomatic means of dispute settlement - namely, negotiation or consultation, mediation, and international conciliation, and/or (ii) legally binding methods - namely, recourse to arbitration and tribunals at the international level.214 The formal non-compliance procedure of the Montreal Protocol can be regarded as a form of international conciliation (see Chapter V(V.A)). Dispute settlement procedures within environmental régimes are important for a variety of reasons, including the interpretation or application of the treaty and preservation of the integrity of the treaty. 215 In most cases, dispute settlement procedures within international environmental régimes are, however, only optional for contracting parties and are not implemented on a compulsory basis.

The Vienna Ozone Convention follows the classical model of providing a wide range of techniques to settle environmental disputes arising between the parties. It provides for optional use of the International Court of Justice or arbitration over a dispute regarding treaty interpretation/application; in a case where the parties have accepted no procedure (or a different one), they are then obliged to submit the dispute to international conciliation. 216 Perhaps it may be possible to argue that

211 UNEP/WG.94/10, para. 25. See also 12 E.P.L. 'Draft Convention Not Finalised', (1984), p. 10.

212 The 1989 Basel Convention, (Article 17(2)), The 1992 Framework Convention on Climate Change (Article 15 (2)), The 1992 Biodiversity Convention (Article 29(2)).

213 For a discussion of dispute settlement in environmental context, see Chapter $\mathrm{V}$ below.

214 For a detailed analysis of dispute settlement procedures see e.g. United Nations, Handbook on the Peaceful Settlement of Disputes Between States, (1992) Chapter II esp.

215 See A. E. Boyle 'Settlement of Disputes Relating to the Law of the Sea and the Environment' (unpublished, 1996).

216 See Article 11; Chapter II below. 
the mere existence of such mechanisms is important.217 Yet, not surprisingly, the procedures under the Ozone Convention have never so far been invoked or used.

Article 11 of the Convention ('Settlement of Disputes') firstly states that the parties concerned are to seek a solution through diplomatic channels, i.e. negotiation (Article 11(1)). This is consistent with the view that negotiation in general should be considered as the preferred way as this is listed in Article 33 of the United Nations Charter. Needless to say, its primary objective is, first of all, to identify an existing problem and moreover to define the issues. 218 It is also widely recognised that the essence of negotiation is to demonstrate considerable flexibility toward political and economic problems. However, it must be added that such an outcome often reflects power-relations between the states concerned. 219

If negotiation proves ineffective, the parties concerned can seek mediation through the intervention of a third party (Article 11(2)). If a party has not accepted such compulsory dispute settlement procedures as arbitration $^{220}$ or/and the International Court of Justice (as a rule, most of the parties reject such a compulsory jurisdiction), the Convention is formally to endorse conciliation, which contains elements of both inquiry and mediation (Article 11(4)). Based on the request of one of the parties concerned, a conciliation commission will be established, and the commission decides a final and recommendatory award (Article 11(5)). Just like mediation, this is not legally binding and thus will be considered only in good faith. 221

These dispute settlement procedures in general apply to the Protocol(s) concluded under the Convention (Article 11(6)). In this respect, there exist some legal questions on the relationship between the dispute settlement procedure of the Vienna Ozone Convention and the N.C.P.

217 I. Sinclair, The Vienna Convention on the Law of Treaties, 2nd. edn. (1984) p. 235. It is still necessary to appreciate the deterrence effects of third party judicial mechanisms. See further Chapter V below.

218 See O. Schachter, International Law in Theory and Practice, (1991) pp. 214-17.

219 See e.g. J. G. Merrils, International Dispute Settlement, (1991) p. 24. In the context of the G.A.T.T. see in particular Y. Iwasawa, WTO Dispute Settlement, (1994) pp. 36-38 (Japanese).

220 In its First Meeting, the Conference of the Parties adopted the Arbitration Procedure. See Decision I/7: Annex II of the Report of the First Meeting, reprinted in U.N.E.P. Handbook for the International Treaties for the Protection of the Ozone Layer, 4th edn. (1996) pp. 75-77.

221 A. E. Boyle, 'Settlement of Disputes Relating to the Law of the Sea and the Environment', 26 Thesaurus Acroasium (1996). 
of the Montreal Protocol.222 Theoretically speaking, the institutional mechanisms of both ozone layer regimes might clash over how to respond to 'ozone disputes' among the parties (see Chapter V(III.B) below).

Though there is no need to go into details about this political issue, in spite of the fact that during the convention negotiation many Western countries advocated procedures for the compulsory jurisdiction of the International Court of Justice, the United States firmly rejected this idea because of the I.C.J.'s judgement in 1984 against the United States (the Nicaragua Case). In the Final Act, the sixteen countries officially stated that it was a truly regrettable decision. 223

\section{Assessment of the Vienna Convention Régime}

Weaknesses of the key provisions of the 1985 Vienna Ozone Layer Convention will be the reflection of customary international law relating to preventive actions, unsolved scientific uncertainty about ozone depletion, and contracting parties' political will influenced by economic considerations. Consequently, it is not surprising that the Convention did not mention anything specific about reducing the use of C.F.Cs. or O.D.Ss., but merely listed in its Annex I(4) specific substances only 'thought' to have the potential to modify the ozone layer. The analysis above therefore verifies the inevitable conclusion that the Vienna Ozone Convention provided in effect a far from perfect solution to the depletion of the ozone layer.

However, the framework ozone treaty, which presently includes major C.F.C. producing/consuming nations, proved to be an initial step toward creating a much stronger Montreal Ozone Layer Protocol containing in its Article 2 (and Article 5) strong control measures for O.D.Ss. It has therefore formed the legal basis for the 'dynamic' international régime for the protection of the ozone layer. 224

The following four points were given explicit emphasis in this Chapter.

222 M. Koskenniemi, 'Breach of Treaty or Non-Compliance?', 3 Y.bk.I.E.L. (1992) Section IX.

223 See the Final Act to the Vienna Convention for the Protection of the Ozone Layer, in 14/2/3 E.P.L. (1985) p. 71. See also P. H. Sand, 'The Vienna Convention is Adopted', 27 Environment, (1985) p.42.

224 See U.N.E.P., 'Vienna plus Ten - The Vienna Convention: 10 years of Achievement', OzonAction, (special supplement, no. 3, November 1995). 
The 1985 Vienna Ozone Convention and International Environmental Law

First, under the Convention régime, the ozone layer - 'above the planetary boundary layer', i.e. not belonging to any particular part of the global atmosphere - can be regarded as the 'common concern of mankind' ('C.C.M.') having erga omnes character. In this context, all states in the international community have a legal duty to adequately protect the 'ozone shield'.

Second, the Ozone Layer Convention claimed to implement Principle 21 of the 1972 Stockholm Declaration and it, for the first time, made reference to the term 'precautionary measures' in international environmental law. As we have seen, a number of scientific uncertainties regarding ozone depletion remained unresolved throughout the Convention negotiations. Viewed against this background, we may say that the Vienna Ozone Convention illustrated the precautionary approach/'principle' and may have influenced to some extent subsequent treaty making in the sphere of environmental protection.

Third, the Ozone Layer Convention established a relatively strong institutional machinery for international supervision and control, i.e. the Conference of the Parties. The Conference of the Parties to the Convention is designed to ensure sound implementation of the international environmental régime. Under Article 6, the highest internal organ within the ozone régime enjoys considerable legislative autonomy. The Convention also created the U.N.E.P. Ozone Secretariat as a group of technical experts in the field of ozone protection.

Finally, as with the 1979 Geneva L.R.T.A.P. Convention, the Vienna Convention has provided a framework for strengthening international environmental co-operation in scientific research on ozone depletion and related problems. The Ozone Layer Convention's stated purpose has been to promote the exchange of information, research, and data on monitoring to protect human health and the environment against activities that have an adverse effect on the ozone later (Preamble). In this respect, the contracting parties are specifically required to internationally co-operate through systematic observations, research and information exchange to understand and assess the link between human activities and ozone depletion. As I emphasised, such legal obligations to internationally cooperate are absolutely indispensable for evolving environmental régimes faced with scientific uncertainty (see Chapter I(III.A)). 
The 1985 Vienna Ozone Convention and International Environmental Law

Having observed the 1985 Vienna Ozone Convention, we are now ready to consider how the Montreal Ozone Layer Protocol has remedied the deficiencies of the framework/umbrella Convention.

The following Chapters III-VI will examine the Montreal Ozone Layer Protocol. 


\title{
CHAPTER III
}

\author{
THE HISTORICAL EVOLUTION OF THE INTERNATIONAL CO- \\ OPERATIVE AND REGULATORY RÉGIME FOR THE PROTECTION \\ OF THE STRATOSPHERIC OZONE LAYER
}

THE INTERNATIONALISATION OF O.D.S. REGULATORY MEASURES AND NATIONAL IMPLEMENTATION AND ENFORCEMENT OF THE OZONE TREATIES

\section{PART A}

THE DEVELOPMENT OF THE INTERNATIONAL REGULATION TO CONTROL O.D.SS. IN THE MONTREAL OZONE PROTOCOL RÉGIME

\section{INTRODUCTION}

Absolutely indispensable for the precautionary ozone régime have been, as addressed in Chapter II above, internationally accepted legal standards or regulations to control chemicals which potentially deplete ozone in the stratosphere. In relation to this point, we have already observed that customary law rules of the environment cannot provide such satisfactory international legal instruments for the preservation of the ozone layer, even though this does not necessarily mean, however, that they have no part to play.

A series of meetings and negotiations of the Protocol to the 1985 Vienna Ozone Convention - conducted in an Ad Hoc forum within the framework of the U.N.E.P. ${ }^{-}$- formally started in December 1986, and concluded, in a remarkably brief period of time, in September 1987. Perhaps not surprisingly, it was thus prior to the entry into force of the Vienna Ozone Convention. ${ }^{2}$

It is often said that the global ozone régime (the subsequent implementing Protocol) supplies a working model for multilateral negotiations of future environmental régimes: as Richard E. Benedick (the chief U.S. negotiator for the ozone treaties) observed very truly, the Montreal Ozone Protocol has been regarded as a prototype for an 'evolving new form of international co-operation', particularly in its treatment of (i)

\footnotetext{
1 For the role of the U.N.E.P. in the development of environment treaties including regional sea agreements, see Chapter I(III.A) above.

2 As stated earlier, the 1985 Vienna Ozone Convention entered into force on 22 September 1988.
} 
The Historial Evolution of the International Ozone Layer Régime scientific uncertainty, (ii) commercial rivalries, (iii) economic incentives to non-parties and (iv) North-South relations. ${ }^{3}$ In addition, to borrow Gehring's phrase, the Protocol could have been characterised as a 'comparatively autonomous sectoral legal system'. ${ }^{4}$

At present, in Non-Article 5 developed countries, the most dangerous specified O.D.Ss. (namely, C.F.Cs., halons, carbon tetrachloride and methyl chloroform) have been phased out, and O.D.Ss.-related industry and governments have established certain forms of co-operation or partnership - such as binding or non-binding 'voluntary agreements' - for mitigating ozone depletion. Added to this, some Article 5 developing countries that have been given a ten year grace period are phasing out major O.D.Ss. faster than legally required under the Montreal Protocol, 5 whilst in some Article 5 nations 'consumption' of O.D.Ss. is, in fact, still increasing. In the light of strong control provisions and actual state practice, we may safely say that the Montreal Protocol régime has clearly established the precautionary environmental 'principle', 6 which was only illustrated in the framework Convention régime.

In Chapter III, we shall be largely concerned with the discussions on the substantive provisions for international control measures for specified O.D.Ss. under the Montreal Protocol (i.e. Articles 2, 2A to $2 \mathrm{H}$ and 3 in particular). Part $A$ of the present chapter provides a legal (and political) analysis of the historical evolution of the co-operative/regulatory ozone treaty, focusing on the development of its control measures based on a 'percentage reduction approach'. However, since numerous attempts have already been made by many commentators to explain the negotiation

\footnotetext{
3 R. Benedick, Ozone Diplomacy, (1991) pp. 3 et seq. (emphasis added).

4 See T. Gehring, 'International Environmental Régimes', 1 Y.bk.I.E.L. (1990) pp. 3556. For a discussion see also Chapter I(IV) esp. It has been pointed out that the basis of such a régime is the so-called ecological epistemic community' defined as 'a knowledge-based network of specialists who shared beliefs in cause-and-effect relations, validity tests, and underlying principles values and pursued common policy goals'. See P. M. Haas, 'Banning Chlorofluorocarbons: Epistemic Community Efforts to Protect Stratospheric Ozone', 46 International Organisations, (1992) pp. 187-224.

5 At the Ninth Meeting of the Parties the U.N.E.P. Executive Director granted the following 12 parties awards for 'exceptional efforts' to implement the Protocol: Burkina Faso, Egypt, Ghana, Islamic Republic of Iran, Malaysia, Peru, Philippines, Singapore, Tunisia, Turkey, Uruguay and Venezuela. See UNEP/OzL.Pro.9/12, para. 7. 6 On this point see Chapter II(III.C.b) above, dealing with the relationship between the Montreal Protocol and the precautionary 'principle'/approach..
} 
process of the Montreal Protocol, ${ }^{7}$ for the present purposes, only basic points in the history of the ozone protection régime are underlined.

Part $B$ then deals with national implementation and enforcement of the ozone treaties; obviously, national implementation of the treaties is crucial for the successful implementation of the regulatory ozone régime. 8

More concretely, Part A looks into the second and third phases of ozone régime building, that is, (i) from Vienna to Montreal (1986-1987) and (ii) the post-Montreal period (1988-1997). ${ }^{9}$ Phase II considers law-making within the framework of the U.N.E.P., i.e. key Sessions of the Ad Hoc Working Group of Legal and Technical Experts ('Vienna Group'), i.e. the First Session of the Working Group (December 1986), the Second Session (February 1987) and the Third Session (April 1987). Then, the final international agreement in Montreal regarding control measures for O.D.Ss. will be analysed.

Phase III briefly examines law-making within the institutional structure of the international ozone régime. As will be argued below, the Montreal Protocol is a constructively flexible legal instrument - owing to a revolutionary decision-making procedure for adjustments, the regulatory measures of the environmental régime could be periodically updated by the Meeting of the Parties to the Protocol, as the scientific evidence concerned strengthens without having to be completely re-negotiated. The Section thus deals with subsequent 'Decisions' or Revisions taken by the Ozone Meeting, including the 1989 Helsinki Declaration, the 1990 London Amendments and Adjustments, the 1992 Copenhagen Amendments and Adjustments, the 1995 Vienna Adjustments and the 1997 Montreal Amendments and Adjustments.

Naturally, the present chapter will also frequently refer to other substantive legal issues concerning the Montreal Protocol, including trade

\footnotetext{
7 For a more detailed account of the ozone negotiations, see among others R. Benedick, Ozone Diplomacy: New Directions in Safeguarding the Planet, (1998); T. Gehring, Dynamic International Regimes: Institutions for International Environmental Governance, (1994) Part III (Chapters 5-7); K. T. Litfin, Ozone Discourses: Science and Politics in Global Environmental Cooperation, (1994); P. Széll, 'Negotiations on the Ozone Layer' in G. Sjostedt (ed.), International Environmental Negotiation, (1993) pp. 31-47; E. A. Parson, 'Protecting the Ozone Layer' in P. M. Pass (eds.), Institutions for the Earth: Sources of Effective Environmental Protection, (1993) pp. 27-73. For a discussion of the Sessions of the Working Group, see J. Lammers, 'Efforts to Develop a Protocol on Chlorofluorocarbons to the Vienna Convention for the Protection of the Ozone Layer', 1 Hague Y.bk.I.L. (1988) pp. 225-69.

8 See Introduction for Part B below

9 The first stage of the ozone layer régime-building is the Vienna Convention negotiation (see Chapter II(II.B) above).
} 
The Historial Evolution of the International Ozone Layer Régime with non-parties (Article 4), the Non-Compliance Procedure (Article 8/Decisions) and the Montreal Protocol's Financial Mechanism, including the Multilateral Fund and related technology transfer of O.D.Ss. (Articles 10 $\& 10 \mathrm{~A})$. However, their concrete details are to be properly analysed in the subsequent chapters.

\section{THE MONTREAL PROTOCOL NEGOTIATION: PREPARATION OF THE PROTOCOL ON THE PROTECTION OF THE OZONE LAYER WITHIN THE U.N.E.P.}

As with the case of the Vienna Convention (see Chapter II above), the main actors of the negotiations of the Montreal Protocol were, again, the two blocs of industrialised states - namely, the Toronto Group (i.e. the United States, Canada, Sweden, Norway, Finland, New Zealand, Australia and Switzerland), and the European Community, whose negotiating position was generally supported by some other states including Japan and the former Soviet Union. 10 The Toronto Group supported a regulatory approach based on a reduction of C.F.C. 'consumption' (strictly speaking, 'adjusted production') while the European Community preferred to control their C.F.C. production only.

\section{A. The First Session of the Working Group}

Six months after the conclusion of the 1985 Vienna Conference, the U.N.E.P. decided to convene two informal workshops, in Rome in May 1986, ${ }^{11}$ and in Leesburg, Virginia in September 1986.12

At the Leesburg workshop, for the first time, the representatives of Japan and the former Soviet Union acknowledged that they would accept the need for international ozone regulation. 13 Also for the first time, environmental N.G.Os. participated in an international ozone negotiation as observers. ${ }^{14}$

10 See P. Széll, 'Negotiations on the Ozone Layer', in G. Sjostedt (ed.), International Environmental Negotiation, (1993) p. 45, saying that 'In general, countries that operated individually did not make a significant impact on the texts of the ozone agreements' with an exception of the former Soviet Union.

11 UNEP/WG.148/2; E.P.L. (1986) pp. 139-40. It is said that the meeting was a grave disappointment and dominated by European industries. See R. Benedick, Ozone Diplomacy, (1998) pp. 47-48.

12 UNEP/WG.148/2 Corr. 4 and UNEP/WG.148/3.

13 R. Benedick, Ozone Diplomacy, (1998) p. 49.

14 N.G.Os. include the World Resources Institute, the Sierra Club, Environmental Defence Fund, the N.R.D.C. and the U.S.E.P.A. See 'Report of the Second Part of the 
The Historial Evolution of the International Ozone Layer Régime

Yet, 'conclusive scientific evidence' of ozone modification - this is an unimpeachable source of legitimacy in any environmental régime - was not readily provided. The existence of scientific uncertainty continued after the adoption of the 1987 Montreal Protocol (see Section IV(A) below). Thus, the European Community, Japan and their industry decided to emphasise this crucial point.

Nevertheless, R. Benedick recollects that there was already 'a growing general belief that some kind of international regime was required, that past national positions would have to be modified, and that every country would have to make concessions'. 15 In fact, as will be discussed below, the final text of the Protocol included certain kinds of special environment treaty provisions for the European Community, 16 Japan, ${ }^{17}$ the former U.S.S.R. ${ }^{18}$ and Article 5 developing countries. ${ }^{19}$

In December 1986, the First Session of the AdHoc Working Group of Legal and Technical Experts for the Preparation of the Protocol on Chlorofluorocarbons to the Vienna Convention for the Protection of the Ozone Layer (the 'Vienna Group') was held in Geneva (Switzerland) in accordance with U.N.E.P. Governing Council's Decision 13/18.20

At this session, the United States, Canada, the European Community and the Nordic countries put forward the following different proposals.

The United States - which initially focused on aerosol restrictions 21 proposed a near complete ban of O.D.Ss., including major C.F.Cs. and halons. The U.S. proposal envisaged that emissions of these chemicals calculated on the basis of 1986 levels were to be reduced in three steps, i.e. by 20 per cent, 50 per cent and 95 per cent in accordance with each target year. ${ }^{22}$ Because such aggregate annual emissions or consumption of a country would be in

Workshop on the Control of CFCs', 08-12 September 1986, UNEP/WG.151/Background 2, Annex III.

15 Ibid. p. 49.

16 See Section III(D) below.

17 See Section III(B.3) below.

18 See Section III(B.4) below.

19 See Section III(E.2) below.

20 See UNEP/WG.151/L.4. (1-5 December, 1986). The Ad Hoc Working Group was divided into two groups, that is, (i) an ad hoc scientific working group that determines which ozone depleting substances should be included in the protocol for regulation, and (ii) an ad hoc working group on legal and institutional matters that considers the legal, institutional and financial aspects of the protocol. The second ad hoc working group was to discuss on the Fifth Revised Draft Protocol on Chlorofluorocarbons which had been prepared by the Ad Hoc Working Group.

21 See Chapter II above.

22 UNEP/WG.151/L.4, para. 8. 
The Historial Evolution of the International Ozone Layer Régime

reality difficult to estimate, this proposal depended on the so-called 'adjusted production' approach (i.e. production, plus bulk imports, minus bulk exports to parties, minus amount destroyed). 23 In other words, the United States proposal addressed annual national emissions or 'consumption' levels of parties whose data would be readily obtainable. Of course, it was clear that this U.S. proposal focused on the world's biggest O.D.S. exporter, the European Community. 24 The United States argued that this legal formulation would (i) allow for free trade among the parties, 25 (ii) provide a more equitable allocation (than control measures based strictly on production) 26 and (iii) address the issues of shared responsibility. 27

The United States proposal also contained provisions for an economic incentive, i.e. international trade with non-parties that is designed to ensure maximum participation in the expected protocol. 28 Similarly to the existing provisions of Article 4, the U.S. proposal called for trade restrictions on imports of controlled substances from non-parties, unless they do not comply with the control measures and periodically offer information about their compliance with the ozone treaty. ${ }^{29}$ However, these proposals calling for trade restrictions were, as expected, bitterly denounced by the United Kingdom and the European Commission through the ozone negotiations. ${ }^{30}$ The United States proposal also had a provision for the regular assessment and adjustments of O.D.S. control measures, which later developed into a revolutionary procedure for future adjustments. $^{31}$ Prior to this meeting, the United States had already started

23 See U.S. proposal, UNEP/WG.151/L2, Article 3; UNEP/WG.167/2:11. For example, if a country imported 6 kilograms of C.F.C.-11, produced 100 kilograms of C.F.C.-11, and exported 20 kilograms of C.F.C.-11, its 'adjusted production' would be 86 kilograms (UNEP/WG.167/CPR.4).

24 See T. Gehring, Dynamic International Regimes, (1994) p. 237.

25 The United States argued that, by not penalising producer nations for exports to other parties, it facilitated free trade and access to these chemicals consistent with the responsibilities identified under the Protocol. See UNEP/WG.167/CPR.4, p. 3.

26 UNEP/WG.167/CPR.1, p. 2. 'It [adjusted production] allocates an annual quota to both producer and consumer nations, thus substantially broadening the number of nations with access to CFCs and Halons'. See UNEP/WG.167/CPR.4, p. 3.

27 'By increasing the number of nations to include both producers and users, this definition encourages more nations to be part of a unified effort to reduce the risks of global pollution'. UNEP/WG.167/CPR.4, p. 3.

28 See UNEP/WG.151/L.2, Article V. See also UNEP/WG.167/CPR.1.

29 See e.g. UNEP/WG.167/CPR.7.

30 It was at Montreal in 1987 that compromises were finally reached. See R. Benedick, Ozone Diplomacy, (1998) p. 92.

31 See Section II(C) below. 
The Historial Evolution of the International Ozone Layer Régime

its political strategies to mobilise support for this U.S. proposal by other states. 32

Canada, which also favoured a strong regulatory régime, 33 took an entirely different approach, however. In short, Canada advocated a proposal that each state should be equally granted an entitlement to emit within the 'global emission limit' ('G.E.L.') 34 in accordance with the socalled 'national emission limits' ('N.E.Ls.'). 35 This proposal was based on the ground that there would be a safe margin for the distribution of emissions without causing irreversible harm to the ozone layer. As Gehring pointed out, it thus structured a 'pollution rights approach' based on 'maximum sustainable pollution', 36 rather than placing the burden directly on producers and emitters of O.D.Ss. Although this proposal could not find favour with the United States and the European Community, it addressed all potential 'ozone-modifying substances' ('O.M.Ss.'). In this limited sense, the Canadian proposal went beyond the control measures devised by the United States.

On the other hand, the European Community - strongly influenced by its industry 37 - countered these two elaborate proposals with its own control measures based on a limitation of C.F.C. production. However, since the European Community was one of the biggest net exporters of O.D.Ss., it was virtually essential to put certain restrictions on the consumption of C.F.Cs. and foreign trade in C.F.Cs.

\footnotetext{
32 See R. Benedick, Ozone Diplomacy, (1998) p. 55.

33 See Chapter II(II.B) above.
}

34 Defined as the total quantity of ozone modifying substances ('O.M.Ss.') weighed in accordance with their ozone depleting potential whose release did not cause irreversible harm to the ozone layer. See Article I, Draft Protocol on Chlorofluorocarbons or Other Ozone-Depleting Substances, (Proposal Submitted by Canada), (UNEP/WG.151/L.1, 29 October 1986). See also UNEP/WG.167/CPR.3.

35 This means the emission limit calculated using the G.E.L. and in accordance with certain procedural mechanism. See ibid.

36 See T. Gehring, Dynamic International Regimes, (1994) p. 238. Canada once stated 'It [its approach] recognises the uncertainties which continues to exist regarding the ozone depletion issue, for example smaller, less stringent, steps than are now contemplated might be appropriate if the science does not continue to offer convincing evidence of harm' (UNEP/WG.167/CRP.3, cited in ibid. p. 243).

37 Such a position of the European Community represented opinions of France, Italy and the United Kingdom under considerable influence of their industries, namely, Atochem, a subsidiary of Elf-Aquitaine (France), I.C.I., Europe's largest producer (the United Kingdom), and Hoechst (Denmark). See e.g. N. Heigh, 'The European Community and International Environmental Policy', 3 International Environmental Affairs, (1991) p. 177. See also Chapter II(II.B) above.

Within the Community, however, West Germany, the Netherlands, Denmark and Belgium supported a strong regulatory régime and therefore a respective position of governments was not necessarily similar (see also Chapter II(II.A) above). 
The Historial Evolution of the International Ozone Layer Régime

Having rejected the control measures based on both emissions of and use of C.F.Cs, the European Community offered a proposal based on a 'staged approach' under which the future protocol would initially control C.F.Cs. 11 and 12 - and possibly C.F.Cs. 113 and 114 - and then a definite timetable should be set down for a comprehensive review of the control measures. 38 This meant that, theoretically, the European Community would reduce exports in order to maintain consumption of O.D.Ss. in its domestic market, and a number of developing countries would then encourage their own manufacture of C.F.Cs., without joining an expected regulatory régime. 39 As to foreign trade issues, the European Community merely suggested that parties should study the feasibility of restrictions on importation of the regulated substances from non-parties to the protocol. 40

As illustrated above, it was clear that, in comparison to those proposals by the United States and Canada, the proposal(s) made by the European Community were in reality severely weaker in (i) the contents of chemicals to be controlled, (ii) the gradual reduction schedule, (iii) the procedure for adjustments and (iv) an economic incentive.

It was natural that the Nordic countries - which were net C.F.C. importing countries - supported a regulatory approach based on a reduction of C.F.C. emissions. ${ }^{41}$ It can be easily assumed that, if a reduction scheme based on the production approach were finally adopted, those C.F.C. importing countries might potentially be discriminated against by major C.F.C. producers. Consequently, the Nordic countries followed the U.S. proposal, and they even offered stronger control measures for C.F.Cs. 42

Finally, the former Soviet Union, for the first time, presented its draft. ${ }^{43}$ The U.S.S.R. generally supported the above-mentioned Canadian proposals that were based on the 'global emission limit'. 44 Some other participating countries, such as Australia, and developing countries represented by Argentina, Brazil, Egypt, Kenya and Venezuela - were

\footnotetext{
38 UNEP/WG.151/L.4, para. 16.

39 For fuller details, see R. Benedick, Ozone Diplomacy, (1998) pp. 79-82.

40 UNEP/151/CRP.5 cited in T. Gehring, Dynamic International Regimes, (1994) p. 240. Without restrictions on trade with non-parties, it can be analysed that, in the light of European scheme based on production, European C.F.C. industries could externalise their production capacity in the territory of non-parties to the protocol.

41 See UNEP/WG.151/L.4, paras. 9 \& 11.

42 See UNEP/WG.151/CPR.2.

43 Other Eastern European countries did not regularly join the ozone negotiations.

44 See UNEP/WG.151/CRP.10.
} 
The Historial Evolution of the International Ozone Layer Régime initially neutral, but they later moved closer to the strong U.S. position. 45 At the time of the adoption of the Protocol, less enthusiastic developing countries did not dispute the validity of the scientific evidence. 46

\section{B. The Second Session of the Working Group}

The Second Session of the Working Group was held in Vienna in February 1987. At this session four informal ad hoc working groups were established; 47 those $\mathrm{AdHoc}$ working groups addressed, respectively;

(i) the periodic review process and hierarchy of ozone-depleting substances;

(ii) the special needs of developing countries in respect of regulatory measures;

(iii) control measures of Article II of the future protocol, and;

(iv) trade issues.

However, the core subject of this session was still regulatory measures of O.D.Ss. Nevertheless, no agreement was reached on whether the 'adjusted production' formula or the production approach should be regulated, nor on the drawing up of a specific time schedule for gradual reductions of O.D.Ss. As to the question of the hierarchy of ozone-depleting substances, the scientific working group listed C.F.C.-11, C.F.C.-12, C.F.C.-22, C.F.C.-113, C.F.C.-114, C.F.C.-115, halon-1211, halon-1301, methyl chloroform $\left(\mathrm{CH}_{2} \mathrm{H}_{3} \mathrm{Cl}_{3}\right)$ and carbon tetrachloride $\left(\mathrm{CC} 1_{4}\right)$. Although it was generally agreed that C.F.C.-11 and C.F.C.-12 should be subject to future international regulation, opinions divided on the question of other ozone-depleting chemicals.

By this stage in the negotiations, the United States proposal based on its 'adjusted production' approach had attracted considerable support from the majority of participating states. Accordingly, Canada and the Nordic countries finally decided to withdraw their own regulatory proposals mentioned above. 48

The European Community - just as in the First Session - sought to control O.D.S. production only on the grounds of simplification of

\footnotetext{
45 R. Benedick, Ozone Diplomacy, (1998) p. 69.

46 See K. T. Litfin, Ozone Discourses, (1994) p. 118.

47 See UNEP/WG.167/2, paras 9-10.

48 Yet negotiating positions of Japan and the U.S.S.R. were still 'enigmatic'. See R. Benedick, Ozone Diplomacy, (1998) p. 70.
} 
The Historial Evolution of the International Ozone Layer Régime

procedures. 49 In its discussion paper, the Community said that the concept of 'adjusted production' is 'too complicated to be implemented effectively and adds nothing to the protection of the environment'. 50 It further argued that some C.F.C. reduction could be a precautionary measure, provided that industry has a suitable time in which to adjust. 51 However, this opposing argument was in practice unsound, simply because, as the United States suggested, all three fundamental components of the 'adjusted production' approach (i.e. (i) production, (ii) imports and (iii) exports) were not necessarily difficult to analyse.

The United States and its allies brushed off the E.C.'s negative suggestion. These countries insisted that controlling production of O.D.Ss. only would invalidate the effectiveness of the future regulatory ozone protocol, because, as stated above, production control alone would fail to cover a number of countries that do not produce C.F.Cs. but consume these chemicals. What is more, as the Toronto Group pointed out, it was also obvious that the European Community was likely to make unreasonable profits and hold advantages over C.F.C.-importing countries (developing states in particular). 52

Though the Second Session of the Working Group could not settle much controversy between the big two camps, it seemed apparent that considerable pressure was eventually brought to bear on the European Community to change its isolated position in the protocol negotiation process. 53 Nevertheless, it was still true that ozone disputes as to scientific knowledge were not yet resolved.

As regards preferential treatment of developing countries whose contribution toward the potential threat to the ozone was only slight, the Working Group on developing countries noted that the 'element of equity" in the context of regulatory measures would encourage more such countries to adhere to the Protocol régime, and it would also facilitate implementation of the ozone treaty obligations. ${ }^{54}$ However, since the

49 See ibid. p. 11. A representative of the Commission of European Communities suggested that Article 9 of the Vienna Ozone Convention could justify its regulatory approach (ibid.). See also discussion paper by the Commission (UNEP/WG.167/CPR.6). 50 UNEP/WG.167/CPR.6, para. 4.

51 Ibid. para. 7. In addition, it may be worth mentioning that the Community suggested that 'We do not believe that scientific information available today justifies the total phasing out of C.F.Cs. (ibid.).

52 R. Benedick, Ozone Diplomacy, (1998) p. 81.

53 See T. Gehring, Dynamic International Regimes, (1994) p. 246 and its footnote no. 162; R. Benedick, Ozone Diplomacy, (1998).

54 UNEP/WG.167/2, p. 25. 
The Historial Evolution of the International Ozone Layer Régime special needs of these countries in themselves could not be clearly identified, at this phase, the Working Group could only provide rather broad possible options on this issue to be subsequently analysed. 55

In relation to economic sanctions to be applied to non-co-operating nations, most experts emphasised the need to restrict imports from nonparties and to discourage movement of capital and facilities outside the regulatory protocol area. 56

\section{Toward a Final Decision in Montreal in September 1987}

In early April 1987, the U.N.E.P. Secretariat led by Dr. M. Tolba - an Egyptian scientist - convened a scientific meeting of five modelling teams in Würzburg, former West Germany (i.e. Ad Hoc Meeting to Compare Model Assessment of the Ozone Layer). 57

The results and findings of the Würzburg meeting had a 'decisive impact' on the subsequent negotiations of the regulatory régime. ${ }^{58}$ In spite of the fact that participating scientists used different computer models to compare the predictable results of C.F.C. control strategies or measures, those computer models clearly showed striking similarities: this meant that serious ozone loss would continue to happen under the regulatory measures proposed by the ozone negotiators. In addition, participating scientists envisaged the need for controlling the main O.D.Ss., namely, C.F.C.-11, C.F.C.-12, C.F.C.-113, C.F.C.-114 and C.F.C.-115, and halon1301 and halon-1211.59 The conclusions of the U.N.E.P. report on the Würzburgh meeting were endorsed by an informal scientific group at the Third Session of the Working Group. 60

By the Third Session, scientific certainty about ozone decreases was thus finally confirmed. 61 It was thus revealed, as the Executive Director

\footnotetext{
55 See UNEP/WG.167/2, p. 29.

56 UNEP/WG.167/2, p. 14. See also a report of the Working Group on Trade Issues, ibid. p. 22.

57 See UNEP/WG.167/INF.1; UNEP/WG.167/INF.1/Add.1; UNEP/WG.172/2, pp. 2-3.

58 R. Benedick, Ozone Diplomacy, (1998) p. 71.

59 UNEP/WG.167/INF.1. See also R. Benedick, Ozone Diplomacy, (1998) p. 78 et seq.

$60 \mathrm{UNEP} /$ WG.172/2, para. 10. However, the representative of Japan publicly stated that 'it was regrettable that Japan had not been invited to the Ad Hoc scientific meeting at Würzburg', and thus still emphasised scientific uncertainty. See UNEP/WG.172/2, para. 13.

61 However, this did not mean that such ozone decreases were concerned with manmade C.F.C. emissions or human activities. See Section IV(A) below.
} 
The Historial Evolution of the International Ozone Layer Régime said, that 'it was no longer possible to oppose action to regulate CFC releases on the grounds of scientific dissent'.62

The Third Session of the Working Group was held in April 1987 in Geneva.63 During this session Dr. M. Tolba, for the first time, convened informal meetings of chief delegations 64 to address control measures for O.D.Ss. 65 As a result, the Executive Director produced the so-called 'Chairman's Personal Text',66 which subsequently came to serve as the basis for subsequent ozone negotiations. The proposed text dealt with major O.D.Ss. (C.F.C.-11, -12, $-113,-114,-115$ and possibly halons) and it was fairly similar to the proposal made by the United States.

The European Community decided to re-examine its strategic position: 67 although the Community still favoured the above-mentioned production approach as the appropriate basis for simple calculation, it tentatively accepted a freeze on imports, provided that European Community members were treated as a 'single unit'.68 This was an important fact to stress, because such a trade restriction on imports implies that the European Community was ready to accept compromise with the United States supported by many other countries.

In this meeting, as to the special treatment of developing countries, Canada suggested that industrialising states be exempt from the provisions of any agreement for a period of five years, or until their annual use of C.F.Cs. reached $0.1 \mathrm{~kg}$ per capita. 69

In the Revised Proposal for Reduction Formula, which was produced as a result of the Third Meeting, the U.S. 'adjusted production' approach was labelled as 'consumption', which is to be measured therefore as 'production,

62 See UNEP/WG.172/2, p. 2 (emphasis added).

63 See UNEP/WG.172/2. Out of thirty three participating governments, eleven were developing countries.

64 The chief delegation heads who participated in the meetings were from Canada, Japan, New Zealand, Norway, the former Soviet Union, the United States, the European Commission, and Belgium, Denmark and the United Kingdom. The Executive Director served as a representative of developing countries. See R. Benedick, Ozone Diplomacy, (1998) p. 72.

65 R. Benedick, Ozone Diplomacy, (1998) p. 72.

66 See 'Text Prepared by the Executive Director After Consultation With A Small SubWorking Group of Heads of Delegations', (UNEP/WG.172/2: Article II, Control Measures in Annex).

67 UNEP/WG.172/2, p. 5; See also a proposal of the European Community in UNEP/WG.172/CRP.2.

68 See UNEP/WG.172/2, para. 11. See also R. Benedick, Ozone Diplomacy, (1998) pp. 94-97. The E.C. was allowed to jointly implement Article 2 control measures (see further Section III(D) below).

69 UNEP/WG.172/2, p. 20 and its Annex. See also section B(2) below. 
The Historial Evolution of the International Ozone Layer Régime plus imports, minus exports and minus quantities of the substances destroyed by techniques approved by the Parties'. As we shall see, this definition of 'consumption' has been incorporated in the Montreal Ozone Protocol régime. 70

In June 1987, the Informal Consultations toward the Elaboration of a Protocol on the Control of C.F.Cs. to the Vienna Convention was held in Brussels, and the European Environmental Bureau invited to the meetings N.G.Os. from Europe and the United States. As a result of those meetings, some progress was made on the reduction schedule for C.F.Cs. In addition, immediately after those meetings, the Environmental Committee of the European Parliament announced an 85 per cent reduction of C.F.C. production and 'consumption' by 1997.71

In the light of the arguments developed in the Informal Consultations, the Working Group drew up the Seventh Revised Draft Protocol. ${ }^{72}$ Though the draft text still had to evade some questions that should have been thrashed out long ago, at this final stage, it envisaged the following regulatory measures;

(i) C.F.C.-11, C.F.C.-12, C.F.C.-113, C.F.C.-114, C.F.C.-115, halon-1211, halon-1301 should be regulated;

(ii) a freeze at 1986 levels of production and 'consumption' within one year after the protocol entered into force;

(iii) $80 \%$ reduction of production and 'consumption' at 1986 levels within four years, and;

(iii) 50\% reduction of production and 'consumption' at 1986 levels within eight or ten years.

\section{INTERNATIONAL LEGAL REGULATION OF SPECIFIED O.D.Ss. UNDER THE MONTREAL PROTOCOL}

\section{A. The Final Agreement: Provisions of the Montreal Protocol}

The diplomatic 'Conference of Plenipotentiaries on the Protocol on Chlorofluorocarbons to the Vienna Convention for the Protection of the Ozone Layer' was convened at the invitation of the Canadian government

\footnotetext{
70 Article 1(6).

71 See M. Jachtenfuchs, 'The European Community and Protection of the Ozone Layer', 28 C.M.S. (1990) p. 266.

72 See UNEP/IG.79/3/Rev.1.
} 
The Historial Evolution of the International Ozone Layer Régime

from 14 to 16 September 1987 in Montreal. Fifty-eight states, the European Community and five states in an observer status participated in the conference, and the Montreal Protocol on Substances That Deplete the Ozone Layer was finally adopted on 16 September 1987.73 The Protocol was signed by twenty-six parties ${ }^{74}$ and then entered into force on 1 January 1989.

The 1987 version of the Protocol was adjusted/amended by the 1990 Second Meeting of the Parties, adjusted/amended by the 1992 Fourth Meeting of the Parties, adjusted by the 1995 Seventh Meeting of the Parties and further adjusted/amended by the 1997 Ninth Meeting of the Parties. ${ }^{75}$ At present the Protocol includes virtually all major developed countries and most developing countries, including China and India.

Unlike the 1985 Vienna Convention that demonstrated only certain general principles, the 1987 Montreal Protocol (and its subsequent Amendments/Adjustments) contains specific targets in its substantive provisions of Article 2. On the basis of a 'percentage reduction approach', the Protocol sets specific quantitative limits both on the production and on 'consumption' of the so-called specified 'controlled ozone-depleting substances'.76

With regard to other main treaty provisions, Article 7 of the Protocol requires contracting parties to supply statistical data on each of the controlled O.D.Ss. in technical Annexes to the Protocol. ${ }^{7}$ Article 4, which is essentially based on U.S. proposals, is instituted in order to legally control foreign trade in O.D.Ss. with non-parties to the Protocol. ${ }^{78}$ Article 5 is dedicated to the special situation of developing countries. ${ }^{79}$ In addition, Article 9 of the Montreal Ozone Protocol calls for international cooperation in further promoting scientific research, development issues,

7326 I.L.M. (1987) p. 1550; 17 E.P.L. (1987) p. 256.

74 Out of the 24 signatories, only 7 were developing countries, however.

75 See Section IV below. The London/Copenhagen Amendments have entered into force with the ratification of twenty parties (see Section III(C) below).

76 'Controlled substances' means a substance in Annexes A-E to the Protocol, whether existing alone or in a mixture. It includes the isomers of any such substances, but excludes any controlled substances or mixture which is in a manufactured product other than container used for the transportation or storage of that substance. On the definition of the 'controlled substances', see further Decisions I/12A; IV/12.

77 See also Decision I/11. Non-compliance with reporting requirements is a serious problem (see Chapter V below). For instance, by the 19997 Ninth Ozone Meeting, only 43 parties out of 152 reported data for 1996 (Decision IX/11(2)).

78 See in detail Chapter IV(II.B) below.

79 See section E and Chapter VI(III-IV) below. 
The Historial Evolution of the International Ozone Layer Régime

public awareness and exchange of scientific/technical information. 80 Article 10 of the 1987 Protocol required participating parties to promote technical assistance to the developing countries with a view to facilitating their participation in and implementation of the control measures of O.D.Ss. In this regard, as will be described, the 1990 Ozone Meeting decided to establish the Financial Mechanism that includes the Multilateral Fund. 81 Though the question of the Non-Compliance Procedure was not fully addressed during the Montreal negotiations, 82 the 1992 Copenhagen Ozone Meeting formally adopted the new dispute avoidance/settlement procedure as Annexes to the Protocol (see further Chapter V below).

In line with the Ozone Convention, parties to the Protocol may not make any reservations to the Protocol's legal requirements (Article 18). Yet, it is also important to notice that any party can withdraw at any time after four years after a party's obligation to comply becomes operative. 83

As for specialised treaty institutions, the Montreal Protocol currently has (i) the Meeting of the Parties to the Protocol as the highest treaty organ, (ii) the Implementation Committee of the N.C.P., (iii) the Executive Committee of the Multilateral Fund, (iv) the U.N.E.P. Ozone Secretariat in Nairobi/the Multilateral Fund Secretariat in Montreal and (v) technical sub-committees such as the Technology and Environment Assessment Panel ('T.E.A.P.'). ${ }^{84}$ International institutions such as the International Civil Aviation (I.C.A.O.) 85 and the World Meteorological Organisation (W.M.O.) 86 are also working with the U.N.E.P.

80 In this respect, parties must also submit reports on summaries of such activities to the Ozone Secretariat every two years (Article 9(3)). See Chapter V(VII.A.1) below.

81 In accordance with the London Amendments, Article 10 of the original Protocol was then replaced by new Articles 10 and 10A. See further Chapter VI.

82 In this respect see R. Benedick, Ozone Diplomacy, (1998) p. 270, noting that 'As the negotiator who introduced article 8 , I can attest that it was consciously intended as a laconic but important maker, not as a tactic'. See further Chapter V(II) below.

83 See Article 19 and Decision II/6.

84 See Figure 15.1 in R. Benedick, Ozone Diplomacy, (1998) p. 221; Figure 2.1 in D. Brack, International Trade and the Montreal Protocol, (1996) p. 24 . On the T.E.A.P. see Chapter V(IV.B.2.a) below. On the role of M.E.As.' subsidiary bodies see J. Werksman, 'The Conference of Parties to Environmental Treaties' in idem, Greening International Institutions, (1996) pp. 58-59.

85 See generally D. W. Bowett, The Law of International Institutions, 4th edn. (1982) pp. 130-31. On the impact of aircraft engine emissions on ozone see U.N.E.P./W.M.O., Scientific Assessment of Ozone Depletion 1994, (W.M.O. Global Ozone Research and Monitoring Project - Report no. 37) p. 15.

86 See Chapter II(II.B.1) above. 
The Historial Evolution of the International Ozone Layer Régime B. International Control Measures for O.D.Ss.: Articles $2 \& 3$

The Montreal Protocol's Article 2 specifies precisely what level of reduction in time is required for each O.D.S. (see Table I below). In addition, the Protocol does not prevent parties from taking stronger regulatory action if they wish to do so (Article 2(11)).

(1) The Substances Covered by the Montreal Ozone Layer Protocol

In Montreal, it was decided to control five principal C.F.Cs. (i.e. C.F.C.-11, C.F.C.-12, C.F.C.-113, C.F.C.-114 and C.F.C.-115: Group I of Annex A) and three halons (i.e. halon-1211, halon-1301 and halon-2402: Group II of Annex A). These chemicals are widely considered to have high ozone-depleting potential and the largest commercial significance. Perhaps it cannot be denied that the now out-dated Protocol addresses only limited numbers of O.D.Ss., though it paved the way for the negotiations of further amendments and adjustments. 87

As a result of subsequent treaty amendments by the regular Meeting of the Parties, 88 other fully halogenated C.F.Cs. (Article 2C/Group I of Annex B), carbon tetrachloride (CC14: Article 2D/Group II of Annex B), methyl chloroform or 1,1,1-trichloroethane $\left(\mathrm{C}_{2} \mathrm{H}_{3} \mathrm{Cl}_{3}\right.$ : Article 2E/Group III of Annex B), H.C.F.Cs. (Article 2F/Group I of Annex C), hydrobromofluoro carbons (H.B.F.Cs.: Article 2G/Group II of Annex C) and methyl bromide $\left(\mathrm{CH}_{3} \mathrm{Br}\right.$ : Article $\left.2 \mathrm{H} / \mathrm{Annex} \mathrm{E}\right)$ were added to the original text. ${ }^{89}$

Reduction schedules for these newly added substances are also adjusted periodically by the Meeting of the Parties, as we shall see. 90

(2) The Percentage Reduction Approach: 'Consumption' and Production

The Montreal Protocol has adopted a percentage reduction approach (a calculated level of production/'consumption' of controlled O.D.Ss.: see Tables I and II below). At the international (regional) level, this reduction approach was first formally included in the out-dated 1985 Sulphur

\footnotetext{
87 See in detail Section IV(A) below.

88 See Section IV(C, D and F) below.

89 See Section IV and Tables I and II below.

90 See in detail Section IV(C, D, E and F) below.
} 
Protocol to the 1979 Geneva Convention (i.e. the Helsinki Protocol). ${ }^{91}$ Yet, unlike the Montreal Protocol, the reduction rates of the Sulphur Protocols related exclusively to 'emissions' of possible pollutants. 92

As regards 'consumption', 93 Article 2 of the 1987 Protocol as adopted in Montreal required the parties to reduce the 1986 C.F.C. 'consumption' level by 50 per cent by 1999, and to freeze the 'consumption' of halons at the 1986 level by 1992 . The production 94 of C.F.Cs. also follows the same reduction scheme, except for the allowance of a 10 or 15 per cent increase for the purpose of 'industrial rationalisation' 95 between parties and/or for satisfying the 'basic domestic needs'96 of developing countries.

By enabling such 'industrial rationalisation', under paragraph (5) of Article 2, Non-Article 5 developed countries still may exceed their decided production quotas - even after domestic phaseout - as long as such excess goes to Article 5 low-volume-consuming countries. This is the transfer of O.D.S. production, which may be seen as a limited form of joint implementation. 97 This treaty provision - proposed by the Canadian government in Montreal - is also designed partly to prevent these Article 5

91 The Protocol on the Reduction of Sulphur Emissions or Their Transboundary Fluxes by at least Thirty Per Cent, 27 I.L.M. (1988) p. 707. See J. Ebbesson, Compatibility of International and National Environmental Law, (1996) p. 138. However, the Montreal Protocol sets up uniform percentage reduction targets for the two categories of the parties, i.e. Article 5 and Non-Article 5 countries.

92 In addition, the 1994 Sulphur Protocol - which is regional in scope - fixes specific reduction rates for each contracting party.

93 For the purposes of the Montreal Protocol, Consumption = Production + Imports Exports ( of controlled substances): Production = Production (of controlled substances) - the amount destroyed by technologies - the amount used as feedback in the manufacture of other chemicals. The amount recycled and reused is not be considered (Article 1(5)). The definitions of both 'production' and 'consumption' are to be discussed further in subsequent ozone meetings. On the definition of 'production', see e.g. Decisions I/12B; VI/10; VII/10; VII/30. As to calculation of control levels see section 3 below.

94 Defined as 'the amount of controlled substances produced minus the amount destroyed by technologies to be approved by the Parties and minus the amount entirely used as feedstock in the manufacture of other chemicals. The amount recycled and reused is not to be considered as "production"'.

95 Under Article 1(8), 'industrial rationalisation' is defined as 'the transfer of all or a portion of the calculated level of production of one party to another, for the purpose of achieving economic efficiencies or responding to anticipated shortfalls in supply as a result of plant closures'.

96 See in detail Section III(E) below.

97 See F. Yamin, 'The Use of Joint Implementation to Increase Compliance with the Climate Change Convention' in J. Werksman (eds.), Improving Compliance with International Environmental Law, (1996) p. 229, endnote no. 1. In the context of the E.C. see also section D below. 
The Historial Evolution of the International Ozone Layer Régime industrialising nations from putting up new manufacturing facilities of ODSs in these regions. 98

The international base level (in this case, '1986') for calculating the level of the freeze/subsequent O.D.S. reductions is important in order to facilitate detailed comparison of the technical/scientific data in question (see Table I below). 99 The 1985/1994 Sulphur Protocols to the 1979 Geneva Convention also refers to the year of reference (in the case of the 1994 Sulphur Protocol, the base year is 1980).

Although Article 2 of the Executive Directors' text prescribed an 'ultimate objective of . . elimination' of O.D.Ss., at the request of the E.C. Commission, this ambitious clause was then transferred to the 'less authoritative' Preamble of the Protocol text. ${ }^{100}$ Further, the three-year delayed freeze on the halons mentioned above was also the E.C.'s partial success in the ozone diplomacy. 101

(3) The Ozone-Depleting Potentials ('O.D.Ps.')

The chemicals in Annexes A-C and $\mathrm{E}$ of the Protocol are weighted in accordance with their ozone-depleting potentials (O.D.Ps.) to calculate the international base levels of both production and 'consumption'. In common with the control measures, the O.D.Ps. are official estimates based on existing knowledge, and therefore, they must be reviewed and revised periodically.

Article 3 provides the detailed methods for calculating production and consumption levels (e.g. production = multiplying annual production of each O.D.S. by O.D.P., and adding together, for each such group, the resulting figures). It is important to notice that, by calculating in this way, parties can organise a highly flexible reduction schedule within each of the classes of substances, e.g. C.F.Cs., halons and H.C.F.Cs. As far as they do not exceed an O.D.P. limit, parties could use whatever combinations of C.F.Cs. or O.D.Ss.

98 A. C. Aman, Jr., 'The Montreal Protocol on Substances that Deplete the Ozone Layer' in F. Francioni and T. Scovazzi (eds.), International Responsibility for Environmental Harm, (1991) pp. 203-04.

99 See Article 3. As for the negotiation on the base year, see ibid., pp. 82-83.

100 R. Benedick, Ozone Diplomacy, (1998) p. 87.

101 Ibid. p. 79. 
The Historial Evolution of the International Ozone Layer Régime

These provisions were inserted partly to accommodate Japan's concern about controlling C.F.C.-113, that is much used for cleaning electronic components. 102

(4) The Special Situation of the Former U.S.S.R.

Regarding the special situation of the former U.S.S.R., it was also decided that paragraph (6) of Article 2 - which allows parties that had facilities under construction prior to signing of the Protocol (i.e. September 16, 1987 ) to add the production of such facilities to its 1986 production level should be inserted to accommodate the concerns of the former Soviet Union that had a five-year plan for new C.F.Cs.-related plants.

It is argued that this concession created a potential loophole for the former U.S.S.R.103

(5) Non-Compliance with the O.D.S. Control Measures: Compliance Control 104

International ozone disputes, having a 'group aspect', are essentially global in character and therefore they would affect all states, rather than a limited number of states. 105 In early stages, anticipated non-compliance with these detailed legal standards or regulations to control O.D.Ss. should be dealt with by the specialised internal treaty institutions, i.e. the U.N.E.P. Ozone Secretariat and the standing Implementation Committee of the N.C.P. - and ultimately, the Ozone Meeting of the Parties as the highest treaty organ within the régime. ${ }^{106}$ By using various compliance-management techniques, 107 they can organise community pressure on non-complying countries. In this respect, the decision-making process of Decision VII/18

102 See R. Benedick, Ozone Diplomacy, (1998) pp. 78-79. See also B. M. Seaver, 'Stratospheric Ozone Protection: IR Theory and the Montreal Protocol on Substances that Deplete the Ozone Layer', 6 Environmental Politics (1997) p. 39.

103 See C. B. Davidson, 'The Montreal Protocol: The First Step toward Protecting the Global Ozone Layer', 20 N.Y.J.I.L. and Pol. (1988) pp. 814-15; R. Benedick, Ozone Diplomacy, (1998) p. 83. The 1989 Ozone Meeting decided that this clause does not allow an increase in production to be exported to non-parties. See Decision $12 \mathrm{G}(\mathrm{b})$ in UNEP/OzL.Pro.1/5, p. 19.

104 On 'compliance monitoring' see Chapter I(III.C) above.

105 See Chapters I(IV) and V(I) esp.

106 Unlike judicial tribunals, their dispute settling/avoiding functions are of conciliatory rather than adjudicative in character (see further Chapter V(V.A) below). 107 See Chapter I(III.C); A. Chayes and A. N. Chayes, The New Sovereignty: Compliance with International Regulatory Agreements, (1995). 
The Historial Evolution of the International Ozone Layer Régime as to Russia's non-compliance may illustrate the 'group aspect' of the N.C.P. régime. 108

However, it is also right to say that, depending upon the nature of issues involved and reasons for such treaty non-compliance, noncompliance with the Protocol should be best addressed on a case-by-case basis. 109

C. The Internal Mechanisms for Amendments and Adjustments:

Strengthening the System of the International Control Measures

Just like the control measures for C.F.Cs., the adoption of a procedure for the expected adjustments of O.D.Ss. was also subject to disagreement during the negotiations of the international ozone régime. 110 As a result of the negotiations, however, the following agreement about the procedure which is unprecedented in international environmental treaty law - was finally reached between the two giants, i.e. the Toronto Group states and the European Community supported by the former Soviet Union.

As an initial step, paragraph 9(c) of Article 2 encourages parties to make every effort to reach agreement by consensus. Yet, if all efforts at consensus have been exhausted, decisions in question are then to be adopted by a two-thirds majority vote of the parties present and voting representing a majority of both industrialised non-Article 5 and industrialising Article 5 countries. ${ }^{111}$ It is important that such decisions on adjustments are binding on all state parties to the Protocol, even though their contents may in reality be unacceptable to up to one-third of the régime members (Article 2(9)(d)). ${ }^{112}$ This provision may thus indicate one

108 As we shall see in Chapter V(VII.B) below, the Montreal N.C.P. was first invoked in 1995 by the several countries of C.E.I.Ts., which are currently in non-compliance with O.D.S. control measures of the Montreal Protocol.

109 Reasons for non-compliance would be, for example, lack of economic capability to comply, careless mistakes, ambiguity of texts and even wilful treaty violations. See further Chapter V below.

110 See T. Gehring, Dynamic International Regimes, (1994) p. 225.

111 According to the 1990 London Amendment. the words 'representing at least fifty per cent of the total consumption of the controlled substances of the Parties' were thus deleted from paragraph 9(c) of Article 2 of the 1987 original version. On double majority see P. Széll, 'Decision Making under Multilateral Environmental Agreements', 26/5 E.P.L. (1996) p. 213.

Under the 1994 Sulphur Protocol, 'adjustments' must be adopted by consensus and thus, unlike the Ozone Protocol, not by majority voting (Article 11(6)).

112 An international committee of legal experts hailed this procedure as a 'great novelty in international environmental law', cited in R. Benedick Ozone Diplomacy, (1991) p. 90. Cf. the 1994 Sulphur Protocol (Article 11), calling for consensus only; 
The Historial Evolution of the International Ozone Layer Régime

of the essential features of the ozone layer régime having erga omnes character, i.e. a changing direction from individual sovereignty to multilateralism. 113 O.D.Ss., which are newly incorporated into the regulatory Protocol text, are then subject to this simplified voting procedure under Article 2(9).

As to assessment and review of control measures, Article 6 of the Protocol requires parties to assess, at least every four years, the substantive regulatory measures for O.D.Ss. on the basis of 'available scientific, environmental, technical and economic information'.114 In the light of such subsequent assessments, parties are to consider proposals for future adjustments.

In practice, however, the 1990 London Adjustments, the 1992 Copenhagen Adjustments, the 1995 Vienna Adjustments and 1997 Montreal Adjustments to the Protocol have all been adopted by consensus among the parties and thus without resort to the above-mentioned revolutionary simplified majority voting process. Yet this does not necessarily mean that this procedure has no impact on the development of the ozone layer régime. As Dr. J. Werksman says, it may be possible to argue that, 'the majority voting provisions help to set the parameters of the Parties expectations'.115 Such shared 'expectations' can be included in a general category of 'régime-rules' we have considered in Chapter $\mathrm{I}(\mathrm{I})$ above. ${ }^{116}$

Finally, it must be noted that, unlike 'adjustments' of control measures, further 'amendments' to the Montreal Protocol text must be adopted in accordance with Articles 9 and 10 of the 1985 framework Ozone Convention: amendments are thus subject to domestic treaty-acceptance

the 1989 Basel Convention (Article 17(3)), calling for consensus and a three-fourth majority vote; the 1992 Climate Change Convention (Article 15(3)), calling for consensus and a three-fourth majority vote..

113 See J. Werksman, 'The Conference of the Parties to Environmental Treaties' in idem, Greening International Institutions, (1996) pp. 60-61. But see also P. Széll, 'Decision Making under Multilateral Environmental Agreements', 26/5 E.P.L. (1996) p. 213, noting that 'the circumstances of the Montreal Protocol were unusual': at the adoption of the 1987 Protocol, ozone negotiators anticipated eventual total elimination of all O.D.Ss.

114 See U.N.E.P./W.M.O., Scientific Assessment of Ozone Depletion 1994, (W.M.O. Global Ozone Research and Monitoring Project, Report no. 37); U.N.E.P., Environmental Effects of Ozone Depletion: 1994 Assessment, (November 1994). On the importance of periodic assessments see Environment Canada, '10th Anniversary Colloquium: 'Lessons from the Montreal Protocol', (13 September 1997).

115 The Conference of Parties to Environmental Treaties' in J. Werksman, Greening International Institutions, (1996) p. 61.

116 'A set of implicit or explicit principles, norms, rules and decision-making procedures around which actors' expectations converge in a given area of international relations'. 
The Historial Evolution of the International Ozone Layer Régime

procedures (see in detail Chapter II(III.D.2) above). ${ }^{117}$ The pace of ratification of the London/Copenhagen/Montreal Amendments have been slow and the number of parties to these instruments is still unsatisfactory 118 (see Appendix III below). It is important to note in this respect that G.E.F. funding 119 is directly linked to the ratification of the 1990 London Amendment, and the C.E.I.T. parties are required to do so.

It is worth noting in this respect that the London and Copenhagen Amendments entered into force with the ratification of only twenty parties to the Protocol, whilst Article 9(5) of the Vienna Convention requires a two-third majority vote. ${ }^{120}$ The 1997 Montreal Amendments will also enter into force in the exactly same way (Article 3(1)). 121 Just like the Protocol's dynamic control measures, these decisions may also contribute to the dynamics of the international ozone régime as a whole.

D. The European Community as the 'Regional Economic Integration

Organisation': The 'Joint Implementation' of the O.D.S. Control Measures

With regard to the much-disputed question of a 'regional economic integration organisation', 122 the parties could also reach the following agreement at a very late stage in the ozone régime negotiations.

The European Community - as a 'single unit'123 - was allowed to jointly fulfil its reduction obligations, provided that (i) the combined levels of 'consumption' of the individual states did not exceed the determined levels and (ii) all states of the European Community became

117 See also J. Werksman, 'The Conference of Parties to Environmental Treaties' in idem, Greening International Institutions, (1996) p. 61.

118 'To urge all States that have not yet done so, to ratify, approve or accede to the Vienna Convention, the Montreal Protocol and its Amendments, taking into account that universal participation is necessary to ensure the protection of the ozone layer' (Decision IX/10(3) adopted in September 1997).

119 On the G.E.F. see Chapter VI(III.C) below.

120 ibid., p. 61. See Article 2(1) of the 1990 Amendments and Article 3(1) of the 1992 Amendments.

121 See also Article 2 of the Montreal Amendments (Relationship to the 1992 Amendments), providing that no state may ratify the Amendment unless previously or simultaneously ratified the 1992 Amendment.

122 As was suggested, the definition provided for in Article 1(6) of the Ozone Convention was taken from the 1982 U.N.C.L.O.S. (see in detail Chapter II(II.B.4) above).

123 See Section II(C) above. 
The Historial Evolution of the International Ozone Layer Régime

parties (Article 2(8.a)). 124 This 'joint implementation' mechanism ${ }^{125}$ is not applicable to production obligations, however. ${ }^{126}$

To date, the European Community is the only regional economic integration organisation under the international ozone régime. This legally 'differentiated' treatment under the Protocol régime will also be regarded as the partial success of the European Community's ozone diplomacy. 127 The European Community is also treated as an organisation having a special status, e.g. in the 1992 Climate Change Convention ${ }^{128}$ and the 1992 Biodiversity Convention, 129 and the 1989 Basel Convention. 130 Similarly, the 1994 Sulphur Protocol provides that the Executive Body may decide to allow two or more parties jointly to implement treaty obligations to reduce emissions. 131

Such special treatment may be potentially beneficial for the régime members of the Community and their industry. In the case of the Montreal Protocol, the special status of the organisation enables members of the Community to exchange consumption quotas, thus allowing European industry to re-distribute production among C.F.C. manufacturers in different countries to secure the 'maximum efficiency'. ${ }^{132}$ Corresponding

\footnotetext{
124 Since the European Community can exchange consumption quota, it is possible that some member states could evade a treaty obligation of reductions on CFC production/'consumption'. See R. Benedick, Ozone Diplomacy, (1998) pp. 94-97.

125 Farhana Yamin says that a limited form of joint implementation has been adopted in the Montreal Protocol (i.e. Articles 2(5) \& 2(8.a)). See 'The Use of Joint Implementation to Increase Compliance with the Climate Change Convention' in J. Werksman (eds.), Improving Compliance with International Environmental Law, (1996) p. 229, endnote no. 1; P. Okowa, 'The European Community and International Environmental Agreements', 15 Y.bk.E.L. (1995) p. 180; O. Kuik, P. Peters and N. Schrijver (eds.), Joint Implementation to Curb Climate Change: Legal \& Economic Aspects, (1994) pp. 9-11. As to Article 2(5) see Section III(B.2) above.

126 See P. Széll, 'Ozone Layer and Climate Change' in W. Lang (eds.), Environmental Protection and International Law, (1992) p. 171 \& its footnote no. 12, noting that the E.C. tried to achieve such a concession for the Organisation.

127 'The Community is prepared to support the idea that there should be a freeze on production together with a limitation of imports of C.F.Cs. by non-producing countries, provided that for this purpose the Community itself is treated as a single producing unit' (emphasis added). UNEP/WG.167/CPR.6, para. 3.

128 See Article 1(6). See F. Yamin, 'The Use of Joint Implementation to Increase Compliance with the Climate Change Convention' in J. Werksman (eds.), Improving Compliance with International Environmental Law, (1996) pp. 229-42; S. Nilsson and D. Pitt, Protecting the Atmosphere: The Climate Change Convention and Its Context, (1994) pp. 48-49 \& 141-43.

129 See Article 2.

130 The European Community is considered as a 'political and/or economic integration organisation'. See Article 2(20).

131 Article 2(7).

132 See K. T. Litfin, Ozone Discourses, (1994) p. 114.
} 
The Historial Evolution of the International Ozone Layer Régime Article 3(11) of E.C. Regulation 94/3093 therefore allows trading in production rights between E.C. members. ${ }^{133}$ However, as the United States argued during the Montreal negotiation process, this would imply that over-fulfilment of environmental obligations by some ambitious members (e.g. Germany) might be potentially exploited by others (e.g. the United Kingdom and France). 134

Finally, it must be added that the members of the Community still have to report technical data to the U.N.E.P. Ozone Secretariat individually. ${ }^{135}$

\section{E. Special Situation of Developing Countries: The 'Grace Period' for Article 5 Countries}

Participation by developing countries - as large potential sources of O.D.S. emissions - has been essential to both establishing and sustaining the regulatory Protocol régime. As will be addressed in Chapter IV(II.A) below, a substantial number of industrialising nations decided to participate in the ozone layer régime due partly to possible economic sanctions provided for in Article 4 of the Montreal Protocol. ${ }^{136}$

However, is the universal and immediate application of Article 2 control measures acceptable for newly industrialising nations?

(1) The Justification for the Grace Period

In the first place, it should not be forgotten that the contribution to ozone modification by developing nations has been relatively modest. 137 On the other hand, industrialised nations as major polluters have substantively benefited from almost unrestrained use of ozone-depleting C.F.Cs./O.D.Ss. for the past forty years or more. For this historical reason, differentiated environmental standards should apply to these countries defined as 'lowvolume-consuming countries'.

133 See Section IV(B.2) below.

134 See T. Gehring, Dynamic International Regimes, (1994) p. 254.

135 Non-compliance with data reporting has been observed in some member states (see Chapter V(VII.A.1) below.

136 To date, only twenty-five members of the United Nations are non-parties to the Montreal Protocol. See also Conclusion below.

137 While in 1986 developing countries accounted for 15 per cent of the total usage of O.D.Ss., by 1991 the figure had risen 21 per cent. 
The Historial Evolution of the International Ozone Layer Régime

In the second place, most of developing countries do not currently have the capability to comply fully with the control measures for C.F.Cs. and O.D.Ss. ${ }^{138}$ In other words, they still suffer financial, structural and administrative difficulties in meeting their legal obligations under the Protocol. Technically speaking, their treaty compliance depends on the availability of financial resources or C.F.C.-free replacements including H.F.Cs. and not-in-kind technologies ('N.I.K.'), the extent of O.D.S. recycling and its technological feasibility, and environmental acceptability. ${ }^{139}$

Therefore, it would seem apparent that, under the evolving cooperative ozone régime, Non-Article 5 industrialised nations should take on greater international responsibility regarding a decrease of stratospheric ozone.

(2) The Grace and Phase-Out Period for Article 5 Countries

The Montreal Protocol shows international equity considerations for industrialising countries (or 'low-volume-consuming' countries: 'L.V.Cs.').

A special treaty provision under Article 5 allows 'developing countries' to delay their compliance with the international regulations under Article 2 for ten years, provided that their annual 'consumption' of Annex A substances is less than 0.3 kilograms per capita and 0.2 kilograms per capita for Annex B controlled substances. As a result, they are allowed to produce and consume specified C.F.Cs. and halons until 2010,140 though they must put an immediate freeze on their consumption by 1 July 1999 (see Table II below). In other words, these Article 5 developing countries are not allowed to consume more than 0.3 or 0.2 kilograms per capita on the date of entry into force of the Protocol and ten years thereafter. Parties in non-compliance with these requirements (and potentially reporting requirements under Article 7 of the Protocol) would not be

\footnotetext{
138 See Principle 23 of the 1972 Stockholm Declaration, stating that 'the extent of the applicability of standards which are valid for the most advanced countries but which may be inappropriate and of unwarranted social cost for the developing countries' (emphasis added).

139 See further Chapter VI(IV.B) below.

140 See Article 5(1) \& 8 bis in UNEP/OzL.Pro.7/12, Annexes I-II; Section IV(F) below. Yet, as Bales says, it must be noted that developing countries are not necessarily allowed unlimited pollution of the environment through O.D.S. use. His argument may be further developed in the context of the concept of international obligations erga omnes. See J. S. Bales, 'Transnational Responsibility and Recourse for Ozone Depletion', 19 Boston C.I.C.L.J.(1996) pp. 285-86 esp.
} 
The Historial Evolution of the International Ozone Layer Régime

classified as 'developing countries' under the Montreal Protocol. ${ }^{141}$ Such a situation whereby Article 5 countries exceed that limit should be first dealt with by - just like non-compliance with Article 2 control measures ${ }^{142}$ - the Ozone Secretariat and the Implementation Committee on a case-by-case basis. 143

An average of each Article 5 country's 'consumption' between 1995 and 1997 will be used as the reference base level for the staged reductions, which will take effect in 1999 (i.e. freeze of C.F.C. consumption: see Table II below).

At the final stage of the negotiations, Canada's proposal advocating a five year delay in compliance was rejected by developing countries as 'too restrictive'. ${ }^{144}$ The grace period of ten years, as part of a package deal, is a product of political compromise, and thus not necessarily based on detailed scientific or economic considerations or reliable technical data. ${ }^{145}$ It appears that the ozone negotiators were not necessarily clear about the long-term consequences of this unprecedented environmental provision. 146 What was certain was that, during this specified period of 'capacity-building', ${ }^{147}$ they would have to develop capabilities to fully comply with the detailed binding controls under the Protocol with the help of Non-Article 5 industrialised nations.

\section{(3) The 'Principle' of Common-But-Differentiated Responsibility}

This 'differentiated' legal obligation, the grace period, could be labelled as a so-called mutual but differentiated duty or common-but-differentiated responsibility in the field of international law for sustainable development. ${ }^{148}$

141 As at August 1997, there are 98 developing countries operating under Article 5 paragraph 1 of the Protocol. On non-compliance with date reporting by developing countries see Chapter V(VII.A.1) below.

142 See III(B.5) above.

143 See Decision IV/15 and discussion at the Open-Ended Working Group, UNEP/OzL.Pro/WG.I/7/4, para. 135.

144 See Section II(C) above \& R. Benedick, Ozone Diplomacy (1998) p. 93.

145 In the case of the 1985 Sulphur Protocol, the figure 30 per cent was chosen as an 'achievable first step'; thus, similarly, this reduction rate was also not founded on reliable technical data. See R. R. Churchill, G. Kütting and L. M. Warren, 'The 1994 UN ECE Sulphur Protocol', 9 J.E.L. (1995) p. 179.

146 See ibid. pp. 92-94.

147 See Chapter I(III) above and Chapter VI below.

148 For an extensive discussion see P. Sands, Principles of International Environmental Law (1995) pp. 217-20; J. Werksman, 'The Conference of Parties to 
The Historial Evolution of the International Ozone Layer Régime

The 'principle' of common-but-differentiated responsibility claims the common responsibility of developed/developing nations for the protection of the environment, whilst such responsibility should be equitably differentiated in accordance with (i) each state's contribution to environmental damage and (ii) its level of economic development. In short, this therefore means that industrialised nations may be required to shoulder immediate heavier burdens of environmental protection in a given issue-area of international environmental relations. International environmental régimes, containing this newly developing legal principle, may be called 'concentric régimes' for the environment. ${ }^{149}$

Not surprisingly, this 'principle' has recently gained significant recognition in environmental legal instruments. ${ }^{150}$ The Preambles of the 1985 Vienna Convention and its Protocol seem to endorse the evolving new 'principle'. In addition, Principle 7 of the Rio Declaration provides that 'states shall co-operate in a spirit of global partnership to conserve, protect and restore the health and integrity of the Earth's ecosystem. In view of the different contributions to global environmental degradation, states have common but differentiated responsibilities'. Under the 1994 Sulphur Protocol régime, differentiated target years 2005/2010 were introduced in order to accommodate participation from Central/Eastern European states.

Yet, it is right to say that the terminology in the sphere of international law presently has no definite meaning, and therefore it may be regarded as a policy-oriented concept in the international legal system. ${ }^{151}$ Perhaps we can only say that, as in the present case of the international ozone layer régime, its potential flexibility as a concept can be of some practical use in the law-making process of environmental treaties (see Chapter I(III.B)). It is easily assumed that, without this grace

Environmental Treaties' in idem, Greening International Institutions, (1996) pp. 6468; P. H. Sand, Lessons Learned in Global Environmental Governance, (1990) pp. 6-14. In the context of the ozone régime see R. Benedick, Ozone Diplomacy, (1998) Chapter 16.

149 See J. Werksman, 'The Conference of Parties to Environmental Treaties' in idem, Greening International Institutions, (1996) pp. 65-67.

150 Legal instruments advocating this 'principle' include the 1992 Climate Change Convention and its 1997 Protocol (Preamble, Articles 3(1), 4) and the 1992 Biodiversity Convention (Preamble).

151 The term is loosely and generally used in many meetings of the parties. See e.g. UNEP/OzL.Pro9/12, para. 48. See also R. Benedick, Ozone Diplomacy, (1998) p. 241, saying that 'the principle was never precisely defined and was subject to differentiated interpretations (emphasis added). The 'polluter pays principle' is also used in the same way (see e.g. UNEP/OzL.Pro.8/12, para. 4). 
The Historial Evolution of the International Ozone Layer Régime

period, the regulatory ozone layer régime would remain merely a rich club of industrialised nations located in the northern hemisphere. 152

Essential ingredients of the 'principle' of common-but-differentiated responsibility would be (i) time required for compliance (e.g. a grace period of a limited time span), (ii) money (financial/technical assistance), and (iii) other compliance-related factors peculiar to each environmental agreement. In the present case of the ozone régime, major contents of the 'principle' will be (i) the ten years' grace period, (ii) the creation of the Multilateral Fund and technology transfer ${ }^{153}$ and (iii) the provisions for 'basic domestic needs' in Article 5.154

\section{(4) The Consequences of the Grace Period}

Apart from its expected utility to secure universal participation from developing nations, the real value of the compliance-delay clause in maintaining (i.e. not 'establishing') the global ozone régime still remains uncertain, however. At present, the Article 5 grace period has created the serious danger of weakening the precautionary environmental 'principle' that has formed the core of the international regulatory régime.

First, rapid increase in C.F.C. consumption in Article 5 nations is likely to eventually undermine non-Article 5 countries' earlier phaseout efforts: undeniably, it will retard - rather than expedite - the possible recovery of the stratospheric ozone layer. 155 Second, unfortunately, this first introduction of the grace period in environmental treaties has become a source of illegal international trade in controlled C.F.Cs (see Section IV(F) \& Chapter V(VII.A.2) below). Perhaps the same may be true of the term 'basic domestic needs' that was deliberately left undefined by the original ozone negotiators. 156

152 In spite of such special treatment under Article 5(1), developing countries including India and China - remained reluctant to participate in the international regulatory ozone régime. In reality, it was since the creation of the Montreal Protocol Multilateral Fund that most industrialising nations decided to participate in the legal régime.

153 Article 5(5) provides that the ability of Article 5 countries to comply with the Protocol 'will depend upon the effective implementation of the financial co-operation . $\ldots$ and the transfer of technology' clauses. See further Chapter VI below.

154 See Section IV(E) below.

155 It is said that if they keep on increasing their consumption of O.D.Ss. at current growth rate, their use will double every seven years. See U.N.E.P. 'Press Release' under <http://www.unep.ch/iuc/submenu/press/ozone/pr9-97a.htm>.

156 See Section IV(E). 
The Historial Evolution of the International Ozone Layer Régime

It could be tentatively suggested that having only one category of 'developing countries' with a uniform grace period of ten years seems to be too broad. Ideally, parties to the Protocol should introduce two or three categories of 'developing countries' whose grace or phase-out period should also be differentiated depending on the amount of their O.D.S. consumption and/or their state of economic growth (e.g. Gross Domestic Product ['G.D.P.'], and so on). 157

Having said this, attention should be drawn to the fact that during the phaseout period, Article 5 industrialising countries have already received financial and technical assistance from the Montreal Protocol's Multilateral Fund established in 1990. Indeed, faster phase-out of the major O.D.Ss. earlier than 2010 depends on the political will of Article 5 developing nations as well as strong commitments by Non-Article 5 countries, including available financial resources and technological alternatives as provided by Articles 10 and 10A of the Protocol (see Chapter VI(V) below). In this respect, some Article 5 countries such as Thailand and Cameroon have developed and implemented programmes to phase out C.F.Cs. in advance of the treaty reduction schedules. ${ }^{158}$

\section{THE MAINTENANCE/DEVELOPMENT OF THE INTERNATIONAL CO- OPERATIVE AND REGULATORY OZONE RÉGIME : THE EVOLUTION OF INTERNATIONAL CONTROL MEASURES AND OTHER O.D.Ss.-RELATED ISSUES}

The following is a brief overview of régime-developments subsequent to the adoption of the 1987 Montreal Ozone Protocol.

A. The Need for Revisions of the 1987 version of the Protocol:

New Scientific Knowledge on the State of the Ozone Layer

Shortly after the signing of the 1987 Montreal Protocol, the Protocol régime was accused of not going far enough to protect the global ozone layer.159 Dramatic scientific advances on ozone modification suggested that even full global compliance with the existing regulatory measures

157 Under the Climate Change Convention, countries 'undergoing the process of transition to a market economy' are to enjoy 'a certain degree of flexibility' in the implementation of their commitments, only if it is so allowed by the Conference of the Parties (Article 4(6)).

158 See also Part B below.

159 See e.g. the Royal Institute of International Affairs, The Environment in International Relations (1992) p. 226. 
The Historial Evolution of the International Ozone Layer Régime

under the 1987 Protocol would be insufficient to protect the severely damaged ozone layer. 160

Only two weeks after signing the Protocol, scientists of the second international expedition in Antarctica announced that the Antarctic 'ozone hole' in the stratosphere could be attributed to anthropogenic chemicals containing chlorine and bromide. It must be noted therefore that, until this 'post-Montreal period', the existence of the Antarctic ozone hole could not be decisively linked to man-made C.F.C. emissions. 161

This means at the same time that, because of this localised 'hole', countries such as Argentina and Australia are at a high risk due to increased solar U.V.-B. radiation, although the major parts of O.D.Ss. are released by developed nations located in the northern hemisphere. Furthermore, it is also revealed that measurements over the Arctic indicated that real reductions of ozone were occurring over the Arctic as well.162 The 1989 U.N.E.P. Scientific Meeting, therefore, reported that; '[O]ne ramification of our conclusion is that even if the Montreal Protocol with its present control measures, was ratified by all nations the Antarctic ozone hole would remain forever'.163

One of the early criticisms of the Protocol was that the C.F.C. and halon reduction targets were not substantial enough to protect the damaged ozone layer. In addition to this point, the Protocol was severely accused of not covering all C.F.Cs. and other important O.D.Ss. H.C.F.Cs. - which became

160 See UNEP/OzL.Pro.Asmt.1/2.

161 Though the ozone hole had already been discovered before the adoption of the Montreal Protocol, the cause for the hole was not been established during the treaty negotiations. See e.g. R. Benedick, 'Protecting the Ozone Layer: New Directions in Diplomacy' in J. T. Mathews, Preserving the Global Environment: The Challenge of Shared Leadership, (1991) p. 133; B. M. Seaver, 'Stratospheric Ozone Protection: IR Theory and the Montreal Protocol on Substances that Deplete the Ozone Layer', 6 Environmental Politics (1997) pp. 33-34; L. B. Talbot, 'Recent Development in the Montreal Protocol on Substances that Deplete the Ozone Layer: The June 1990 Meeting and Beyond', 26 The International Lawyer, (1992) p. 14.

162 UNEP/OzL.1/5, para. 17; Scientific Assessment of Ozone Depletion 1994: Executive Summary, World Meteorological Organisation Global Ozone Research and Monitoring Project - Report No. 37, W.M.O. \& U.N.E.P. In April 1997 the W.M.O. reported that the ozone layer was 15-25 per cent thinner over the Arctic in March 1997 than in March 1996 and that the worst-affected area was over the North pole region and north-central Siberia.

163 UNEP/OzL.Sc.1/14, p. 2. It is worth noting that a 1989 scientific report to the parties of the Protocol reviewed new scientific findings: the dilution effect on ozone over southern populated latitudes caused by the recurring Antarctic ozone hole; unexpectedly large ozone losses over northern latitudes; the potential for serious ozone loss over Arctic; a hypothesis that a large volcano eruption could propel minute sulfate particles into the stratosphere, which could intensify chlorine's ozonedestroying effect over heavily populated regions 
The Historial Evolution of the International Ozone Layer Régime popular among the C.F.C.-producing companies in the late 1980s, as a substitute - turned out to have an ozone depleting potential of from two to ten per cent of the C.F.Cs. regulated under the Protocol régime. Moreover, it was emphasised that not only C.F.Cs. but the next best substitutes, H.C.F.Cs., have global warming potential. Methyl chloroform $\left(\mathrm{CH}_{3} \mathrm{OCl}_{3}\right)$, which is the fifth biggest destroyer of the stratospheric ozone layer, contributes more to chlorine loading in the atmosphere than C.F.C.-113, but the chemical was not covered under the 1987 version of the Montreal Protocol. Similarly, carbon tetrachloride (CC14) was also not covered until the 1990 amended Protocol.

Apart from these international ozone regulations, the special treatment of Article 5 developing countries and the establishment and operation of the Financial Mechanism for the implementation of the Protocol - which were not pressing central concerns until 1987 - has also become one of the substantive issues in the international co-operation régime. ${ }^{164}$ Thus, after the Montreal-period, developing countries (i.e. Article 5 countries) have also become key ozone régime actors in international environmental relations.

B. The 1989 Helsinki Ozone Meeting and its International 'Soft Law'

Following an international Conference on Saving the Ozone Layer organised by the British government and the U.N.E.P., 165 the First Meeting of the Conference of the Parties to the Vienna Convention and the First Meeting of the Parties to the Protocol took place in Helsinki from 26 to 28 April 1989 and from 2 to 5 May 1989, respectively. 166 The Vienna Ozone Convention had already entered into force on 22 September 1988, and the 1987 Montreal Protocol on 1 January 1989.

We may say that, at this development stage, the international ozone layer régime had largely been based on the Montreal Protocol and therefore, the 1985 Vienna Ozone Layer Convention and its treaty institution (i.e. the Conference of the Parties) were given only a secondary role in ozone diplomacy. 167 Yet it was decided that (i) the Convention is the most appropriate instrument for harmonising the policies and strategies

\footnotetext{
164 See further Chapter VI below.

165 The Conference was attended by 123 countries. See UNEP/OzL.Pro.1/5, p. 5; 19/2 E.P.L. (1989) pp. 45-46; R. Benedick, Ozone Diplomacy, (1998) pp. 123-24.

166 See UNEP/OzL.Conv.1/5 and UNEP/OzL.Pro.1/5.

167 T. Gehring, Dynamic International Regimes, (1994) pp. 268-69.
} 
The Historial Evolution of the International Ozone Layer Régime on research, and (ii) the Protocol is the appropriate instrument for achieving the harmonisation of policies, strategies and measures for minimising the release of O.D.Ss (Decision I/3 made by the Conference of the Parties to the Convention).

Although the Protocol in itself was not legally revised due mainly to notice requirements, 168 the First Meeting of the Parties produced an important international 'soft law' instrument that influenced strong decisions in London in 1990 - the Helsinki Declaration on the Protection of the Ozone Layer. 169

Concretely, under the Helsinki Declaration it was declared that a phase-out of C.F.Cs. would be necessary no later than the year 2000, 170 and halons should eventually be phased out completely. ${ }^{171}$ In addition, it was further agreed that controls should be introduced for H.C.F.Cs., methyl chloroform $\left(\mathrm{CH}_{3} \mathrm{OC}_{13}\right)$ and carbon tetrachloride $(\mathrm{CC} 14)$ as soon as feasible.

Added to this, the Helsinki Declaration also addressed developingcountry issues, including the disputable interpretation of 'basic domestic needs', 172 and the creation of an international fund for financial and technical assistance for such states.

It is worth mentioning that the First Meeting decided to create four 'assessment panels' consisting of internationally recognised experts in the respective field, that is to say, (i) the Panel for Ozone Scientific Assessment, (ii) the Panel for Environment Assessment, (iii) the Panel for Economic Assessment and (iv) the Panel for Technical Assessment. ${ }^{173}$ Yet the Panels for Economic and Technical Assessment have been merged into the Technology and Economic Assessment Panel ('T.E.A.P.').

Lastly, the First Ozone Meeting decided to establish an Open-ended Working Group - a comparatively less formal régime group open to all parties - inter alia to prepare draft proposals for any amendments to the Montreal Protocol. 174

\footnotetext{
168 The Vienna Ozone Convention and its Protocol provide that any proposed amendments and adjustments of the Protocol must be submitted to the U.N.E.P. for communication to all parties at least six months before the meeting of the parties which would consider them.

169 UNEP/OzL.Pro.1/5: Appendix 1; 19/3/4 E.P.L. (1989) p. 137.

170 However, this was subject to the special situation of developing countries.

171 Helsinki Declaration on the Protection of the Ozone Layer, May 2, 28 I.L.M. (1989) p. 1335.

172 See Section E below.

173 See UNEP/OzL.Pro.1/5, Annex VI. On Terms of Reference of the T.E.A.P., see Annex V of UNEP/OzL.Pro.8/14.

174 Decision I/5.
} 
The Historial Evolution of the International Ozone Layer Régime

C. The 1990 London Ozone Meeting: Strengthening the Control Measures and the Establishment of the Montreal Protocol Multilateral Fund

The Second Meeting of the Parties to the Montreal Protocol, which was hosted by the British government, was held in London from 27 to 29 June 1990.175 The primary goals of the London Ozone Meeting of the Parties were (i) to further expedite the total phaseout of C.F.Cs. and O.D.Ss. and (ii) to establish a Funding Mechanism for assistance to developing countries, with a view to securing wide participation by major O.D.Ss.producing/consuming states (i.e. India and China, together accounting for 40 per cent of the world's population). 176 The 1990 London Amendments entered into force on 10 August 1992 in accordance with Article 2(1) of the Amendment. 177

With regard to the control measures for O.D.Ss., by updating the 1987 text, the London Ozone Meeting could adopt a comprehensive regulatory régime. Besides the political will of the parties, this was due partly to the astonishing speed of technological advances (e.g. the availability of C.F.C. substitutes and alternatives in virtually all sectors) and growing domestic and international pressures for ozone protection, which are generated by the alarming scientific evidence described above.

In respect of contents of O.D.Ss., unlike the original 1987 regulatory régime, the 1990 London Amendments addressed five Groups of controlled O.D.Ss. under the Protocol: (i) the original five C.F.Cs. and (ii) three important halons in Annex A, (iii) ten C.F.Cs. (iv) carbon tetrachloride $\left(\mathrm{CC} 1_{4}\right)$ and $(\mathrm{v})$ methyl chloroform $\left(\mathrm{CH}_{3} \mathrm{OCl}_{3}\right)$ in Annex B.178 In addition, the Meeting of the Parties also adopted a non-binding resolution that addressed other halons and 'transitional substances', namely, hydrochlorofluorocarbons (H.C.F.Cs.). 179

As regards the reduction schedules, the 1990 London Adjustments introduced the gradual phaseout of both 'consumption' and production of

175 The Conference was attended by 54 parties to the Protocol and 42 non-parties. See UNEP/OzL.Pro.2/3; 20/4-5 E.P.L. (1990) pp. 134-35.

176 By the time of the Meeting, fifty-eight countries plus the European Community representing ninety-nine per cent of estimated C.F.Cs. in the world production and ninety per cent of the consumption had ratified or acceded to the Protocol.

177 It had ninety-three parties on 1 October 1994. The Adjustments entered into force on 1 March 1991. See also Section III(C) above.

178 See T. Gehring, Dynamic Environmental Regimes, (1994) p. 285, pointing out that the reduction schedule for methyl chloroform was the only major surprise, however.

179 See UNEP/OzL.Pro.2/3. para. 51 and its Annex VII. 
The Historial Evolution of the International Ozone Layer Régime

the five original C.F.Cs. and three halons by the year 2000, 180 which is subject to the ten-year period of grace for Article 5 developing countries and an allowance of 15 per cent on production, based on 1986 levels. Other newly added controlled substances were scheduled for various interim reductions and/or phase out in ten to fifteen years (see Table I below). For the most part, however, industrialising countries were not actively involved in the discussion on the control measures for O.D.Ss.

Apart from these control measures, the parties could also agree to establish the Financial Mechanism that includes the Multilateral Fund of $\$ 160$ million for assisting Article 5 developing countries in meeting their legal obligations under the Protocol. ${ }^{181}$ It is particularly important to notice here that Article 5(5) states that the capacity of Article 5 developing countries to fulfil their obligations will depend on the effective implementation of the international financial co-operation relating to technology transfer. ${ }^{182}$ In addition, the procedure for voting on adjustments has also changed based on the principle of international 'equity'.183

Furthermore, at this stage, the 'interim' Montreal N.C.P. was adopted, and its Implementation Committee as a standing governmental institution thus began its early operations. 184

D. The 1992 Copenhagen Ozone Meeting: Strengthening the Control Measures of H.C.F.Cs. and the Establishment of the Montreal N.C.P. Régime

The Forth Meeting of Parties was convened in Copenhagen from 23 to 25 November 1992. The Copenhagen Amendments entered into force on 1 June 1994 in accordance with Article 3(1) of the Amendments. 185 According to Decision III/12, the Panels established by the First Ozone Meeting had

180 Though many of the Parties favoured a total phaseout of C.F.Cs. by 1997, as a matter of fact, U.N.E.P.'s technology assessment panel had not concluded that a complete phaseout before 2000 was technically feasible. See R. Benedick, Ozone Diplomacy, (1998) pp. 171-72.

181 See further Chapter VI(III.A) below.

182 But there exists conditionality between the M.L.F. funding and compliance with the Protocol (see Chapter VI(III.D.4) below).

183 See Section III(C) above.

184 See further Chapter VI(VII.A) below.

185 It had thirty-four parties on 1 October 1994. The Adjustments entered into force on 22 September 1993. See also Section III(C) above. 
The Historial Evolution of the International Ozone Layer Régime produced a 'synthesis document'. ${ }^{186}$ Scientific/technical finding in the paper influenced the sequences of the negotiations led to Copenhagen.

In general, the new package of O.D.S. control provisions under Article 2 may be considered as an amicable agreement based on political/economic considerations; the reduction schedules of O.D.Ss. were, again, re-negotiated by régime members and then significantly accelerated. 187 Because the 1995/1997 Ozone Meetings of the Parties did not radically change the legal regulatory measures for O.D.Ss. that have already been taken, most of the measures described here represent current strategies for global stratospheric ozone protection.

In relation to the reduction schedules, the Meeting agreed on a 75 per cent reduction of 'consumption' and production of five major C.F.Cs. by 1994 with a total phaseout by 1996 . The Meeting also decided on the total elimination of an additional ten C.F.Cs. to January 1996, with the possible exception of certain necessary 'essential uses', which have to be agreed by the parties. 188 Though the most serious exception in the 1990 London Amendments was the treatment of H.C.F.Cs. as 'transitional substances' (i.e. not subject to a reduction schedule), the 'consumption' of H.C.F.Cs. in Group I of Annex C was to be capped at 1989 levels with a total elimination by 2030. 189 H.C.F.Cs. are to be selected for use in a manner that minimises ozone depletion and that also meets other environmental, safety and economic considerations. 190 Moreover, the 1992 Copenhagen Adjustments introduced the total phase-out of halons to take effect from January 1994. The 'essential use' exception is still valid, and definitions of 'essential use' were adopted by Decision IV/25 of the Adjustment. 191

186 UNEP/OzL.Pro/WG.1/6/3.

187 For details see R. Benedick, Ozone Diplomacy, (1998) pp. 202-09; K. T. Litfin, Ozone Discourses, (1994) p. 174; T. Gehring, 'The Copenhagen Meeting', 23/1 E.P.L. (1993) pp 6-12.

1881992 Adjustment, Article 2A, Article 2C(1), (2) and (3).

189 The Article also requires parties to endeavour to ensure that the use of H.C.F.Cs. is limited to applications where alternatives are not available, that such use is not outside the areas of application currently met by substances in Annex A, B and C, except in rare cases for the protection of human life or human health.

1901992 Amendments, Article 2F(7) (a), (b) and (c).

191 Use will only be 'essential' if it is necessary for health and safety or critical for the functioning of society and there are no technically and economically feasible alternatives or substitutes which are acceptable from a health and environment standpoint. Furthermore, 'essential use' will only be permitted if all economically feasible steps have been taken to minimise the essential use and associated emissions, and the controlled substance is not available in sufficient quantity and quality from existing stocks or banked or recycled controlled substances. See also Decisions V/14; $\mathrm{V} / 18$; VI/8; VI/9; VII/28; VII/11. Environmental N.G.Os. consider 'essential uses' as 
The Historial Evolution of the International Ozone Layer Régime

The Meeting also agreed on a prohibition on the 'consumption' of 'new' O.D.Ss. not covered by the $1987 / 1990$ text, i.e. hydrobromofluorocarbons (H.B.F.Cs.) in Group II of Annex C after January 1996, except for 'essential uses'. Similarly, under Article 2H, annual 'consumption' of methyl bromide ( $\left.\mathrm{CH}_{3} \mathrm{BR}\right)$ in Group I of Annex $\mathrm{E}^{192}$ is to be limited to 1991 levels for 1995 and hereafter. In addition, the 1992 Copenhagen Adjustments brought forward the total phase-out of carbon tetrachloride (CC14) in Group II of Annex B and methyl chloroform $\left(\mathrm{CH} 3 \mathrm{CC}_{3}\right)$ in Annex E to January 1996 (see Table I below). 193

It is true that previous Ozone Meetings did not pay much attention to the problems of recycling or reclamation of O.D.Ss. to prevent their release into the atmosphere. In this context the Copenhagen Ozone Meeting adopted Decision IV/24 that is followed by Decision VI/19. The parties agreed, for instance, that the import/export of recycled and used O.D.Ss. should not be taken into account in calculating 'consumption', provided that parties report relevant data to the Ozone Secretariat. 194

However, Decision VI/24(2) has now become a source of the illegal 'gray' market in C.F.Cs. that are disguised (or mislabelled) as 'recycled substances'. It is reported that the availability of recycled materials for maintaining O.D.Ss.-using equipment, and the potential to trade in these chemicals for non-Article 5 nations phasing out such equipment, will be an important factor in minimising the so-called 'adaptation costs'.195

Finally, the 1992 Copenhagen Ozone Meeting further strengthened the Financial Mechanism including the Multilateral Fund. The 1992 Meeting could also adopt the formal Montreal N.C.P. régime as 'Annexes' to the Protocol text - the Montreal N.C.P. is to be given a first case in the 1995 Seventh Meeting of the Parties.

potential loopholes. For a discussion see R. Benedick, Ozone Diplomacy, (1998) pp. 236-40.

192 Methyl bromide is a economically important chemical that is used for fumigating commodities and soils for crops. Some 70,000 tonnes are produced every year and developing countries account for nearly eighty per cent of its use. On the negotiations on methyl bromide see R. Benedick, Ozone Diplomacy, (1998) pp. 207-09.

1931992 Adjustments, Article 2D(1) and (2); Article 2E(1), (2) and (3).

194 See also Decision VI/19 saying that 'only used controlled substances may be excluded from the calculated level of consumption of countries importing or exporting such substances'. See also discussions at the Open-Ended Working Group, UNEP/OzL.Pro/WG.I/7/4, para. 79.

195 See UNEP/OzL.Pro/WG.12/2/Add.1, cited in D. Brack, International Trade and the Montreal Protocol (1996) p. 42. 
The Historial Evolution of the International Ozone Layer Régime

E. The 1995 Vienna Ozone Meeting: The Control Measures for H.C.F.Cs. and Methyl Bromide, and the Extension of the 'Grace Period'

In 1995 the Seventh Meeting of the Parties was held in Vienna, immediately after an unofficial ceremonial event - the tenth anniversary of the 1985 Vienna Ozone Convention. 196 The Vienna Adjustments entered into force on 7 August 1996.

In the meantime, the 1993 Fifth Ozone Meeting decided not to allow any production of halons for 'essential uses' (Decision V/14) and further extended the funding of the Financial Mechanism. ${ }^{197}$ The 1994 Sixth Ozone Meeting then decided to allow production of certain O.D.Ss. to continue at a low level after January 1996 for certain defined 'essential uses' (Decision VI/9). 198 At this stage, Non-Article 5 nations had already concentrated their efforts on control measures for H.C.F.Cs. and methyl bromide in Annexes C and E, rather than on C.F.Cs. in Annexes A and B.

In the Vienna Meeting, only after arduous negotiations, the parties could have agreed on new - but rather tentative - reduction schedules for some O.D.Ss.

In accordance with E.C. Regulation 3093/94, the European Community had already agreed in 1994 to completely phase out H.C.F.Cs. by the year 2015, i.e. fifteen years earlier than the Copenhagen decision of 2030. However, the United States - whose industries had already heavily invested in H.C.F.Cs. - were resolutely opposed to the restrictions of these chemicals. 199 As a result, the Ozone Meeting could not adopt a new reduction schedule for H.C.F.Cs. 200 However, a number of parties delivered harsh criticisms of control measures for H.C.F.Cs. and methyl bromide: twenty-four parties thus officially signed the 'Vienna Declaration on

196 See UNEP/OzL.Pro.7/12; 'The Vienna Meeting', 26/2/3 E.P.L. (1996) pp. 66-71; R. Benedick, Ozone Diplomacy, (1998) pp. 287 et seq.; W. Lang, 'Ozone Layer', Y.bk.I.E.L. (1995) pp. 220-23 See also U.N.E.P., 'Vienna Plus Ten: The Vienna Convention: 10 Years of Achievement' (OzonAction Special Supplement, November 1995).

197 See UNEP/OzL.Pro.5/12; 24/2/3 E.P.L. (1994) pp. 67-68.

198 See UNEP/OzL.Pro.6/7; 25/1/2 E.P.L. (1995) pp. 21-23; W. Lang, 'Ozone Layer', 5 Y.bk.I.E.L. (1994) pp. 162-63.

199 See also R. Benedick, Ozone Diplomacy, (1998) pp. 292-93. Under the U.S.E.P.A. Regulations the United States is to phase out all H.C.F.Cs. as Class II substances by the year 1 January 2030 (sec. 82.4 q). See also Part B, II(A.1).

200 Yet it was decided that the calculated baseline level of consumption had been changed and consumption of H.C.F.Cs. before its phaseout was to be restricted to the servicing of refrigeration and air conditioning equipment (Article $2 \mathrm{~F}(1)(\mathrm{a})$ and (5)). See Annex III of UNEP/OzL.Pro.7/12. 
The Historial Evolution of the International Ozone Layer Régime HCFCs'201 and the 'Declaration on Methyl Bromide' 202 respectively. One representative of the N.G.O. even professed concern that 'many of those positions [on the control measures for HCFCs and methyl bromide] represented a retreat from commitments at London and Copenhagen'.203

In addition, the Vienna Ozone Meeting clarified requirements of the regulatory Protocol régime on Article 5 developing countries. According to the 1992 Copenhagen Adjustments, developing countries - who are given a ten year grace period 204 - are eventually to phase out C.F.Cs. by the year 2006 and halons by 2004. However, at the Meeting, these Article 5 nations insisted that the Copenhagen Adjustments should not apply to these nations. 205 As a result, it was finally agreed that, in order to meet their 'domestic needs', Article 5 countries are thus entitled to delay for ten years compliance with the control measures for C.F.Cs. and halons, adopted by the 1990 London Meeting, thus not by the 1992 Copenhagen Meeting (Article $5(8$ bis $\mathrm{a}))$. This means that they are entitled to consume and produce the specified C.F.Cs. and halons by the year 2010 (in case of methyl chloroform by 2015$)$.

The meaning of the term 'basic domestic needs' was not defined in the 1987 Protocol due partly to a lack of time. 206 Thus subsequent Meetings of the Parties had to clarify the ambiguity of the text.207 In this respect, the 1989 First Ozone Meeting had decided only that 'basic domestic needs' should be understood as not to allow production of products containing O.D.Ss. to expand for the purpose of export. 208

201 UNEP/OzL.Pro.7/12, p. 80.

202 Ibid. p. 81.

203 Ibid. p. 22.

204 See Section III(E) above.

205 See Article 5(1) \& 8 bis in UNEP/OzL.Pro.7/12, Annexes I-II; R. Benedick, Ozone Diplomacy, (1998) pp. 212-13. The developing countries even made abortive effort to weaken the 1990 London Agreement: they demanded a 'service tail' after the year 2010. See 26/2/3 E.P.L. (1996) p. 67. On this point see Article 40 of the 1969 Vienna Convention on the Law of Treaties.

206 See P. Széll, 'Negotiations on the Ozone Layer' in G. Sjostedt (ed.) International Environmental Negotiation, (1993) p. 46, noting that the key term was deliberately left undefined.

207 For an extensive discussion of 'basic domestic needs' see D. Brack, International Trade and the Montreal Protocol, (1996) pp. 90-94. It is important to bear in mind that the ambiguity of treaty texts - which could often provide certain flexibility would become a potential source of environmental disputes (in this context, this is 'treaty disputes').

208 Decision I/12C. Other Decisions relating to the term are Decision IV/29, Decision V/16, Decision V/25 and Decision VI/14A. 
The Historial Evolution of the International Ozone Layer Régime

The 1995 Vienna Ozone Meeting adopted Decision VII/9, which recognises the 'need of Article 5 countries for adequate and quality supplies of ozone-depleting substances at fair and equitable price' and the need to avoid monopolies of supply. It was thus decided that until July 1999 Article 5 countries may supply controlled O.D.Ss. to meet the 'basic domestic needs' of other Article 5 industrialising nations. 209 At the same time Decision VII/9(7) prohibit new production capacity for O.D.Ss. in Annexes A and B after December 1995. They have to monitor and regulate such O.D.S.related trade by means of a new licensing system, which was instituted by the 1997 Montreal Ozone Meeting ( see section F below).

Lastly, the Non-Compliance Procedure ('N.C.P.') of the Montreal Protocol régime was, for the first time, invoked regarding the implementation of treaty obligations in the Russian Federation, Belarus, Bulgaria, Poland and Ukraine. 210

\section{F. The 1997 Montreal Ozone Meeting, the Control Measures of Methyl}

Bromide and Illegal Trade in C.F.Cs. and O.D.Ss.

The Ninth Meeting of the Ozone Parties, which reached the tenth anniversary of the Montreal Ozone Protocol, took place in Montreal from 15th to 17 th September 1997. In the previous year, the 1996 Meeting of the Parties discussed issues concerning the replenishment of the Multilateral Fund and illegal trade in C.F.Cs. and adopted Decisions about these issues. 211

In respect of O.D.Ss., the Montreal Ozone Meeting of the Parties decided to take more strict measures on methyl bromide in Annex E of the Protocol. Article $2 \mathrm{H}$ decided, with regard to non-Article 5 countries, on the interim reductions of 25 per cent by 1999, 50 per cent by 2001, 70 per cent by 2003 and a total phaseout by 2005 with exemptions for emergency and critical uses, and quarantine and pre-shipment. 212

Regarding Article 5 countries that were committed only to a freeze by 2002, the Meeting decided on a 20 per cent reduction by 2005 and a phaseout by 2015.213 A four-year average from 1995 to 1998 will be used as the reference year (period) for calculating the O.D.S. phaseout. ${ }^{214}$ Yet the

\footnotetext{
209 Decision $\mathrm{V} / 12 \mathrm{C}(2)$.

210 See further Chapter V(VII.B) below.

211 See UNEP/OzL.Pro.8/12; E.P.L. 27/2(1997) pp. 86-88.

212 See Decisions IX/3, IX/6 \& IX/7; Article 2H, Annex III in UNEP/OzL.Pro.9/12.

213 See Article 5(8)(ter (d)(ii)-(iii)). See also Decision IX/5.

214 Article 5(8)(ter (d)(ii)).
} 
The Historial Evolution of the International Ozone Layer Régime

interim reduction schedule must be reviewed in 2003.215 The Multilateral Fund will make available \$25 million per year for activities in both 1998 and 1999 to phase out methyl bromide in Article 5 developing nations. 216

The proposals by the European Community and Switzerland to strengthen the consumption controls for H.C.F.Cs. and to add controls on its production 217 were eventually withdrawn due to widespread rejections mainly by the Group of 77 and China.218 Yet the European Community, supported by other parties, adopted a declaration that at the Eleventh Meeting in Egypt the parties should decide further steps to control H.C.F.Cs. 219

As indicated above, it must also be noted that, as the date of the 1996 phaseout of O.D.S. production and its use by Non-Article 5 industrialised countries came around, a black market for O.D.Ss. had newly emerged in the international community. Consequently, it now impairs the ozone régime's developmental process and effectiveness (see also Part B, Section II(A.1) \& Chapter V(VII.A.2 \& VII.B) below). 220

In relation to this point, it should be remembered that, due to their delayed compliance, Article 5 developing countries may continue to produce large amounts of O.D.Ss. at relatively cheap prices. Consequently, these chemicals are illegally imported from Article 5 industrialising countries to Non-Article 5 industrialised countries such as the rich O.E.C.D. nations. 221 As in the case of India, by using the international financial aid, the country had built new industrial plants capable of producing or using C.F.Cs. that are in fact unnecessary for meeting its 'basic domestic needs'.222 This non-compliance matter is thus not necessarily concerned with Article 4 trade restriction provisions imposed on non-parties, which are designed to plug possible loopholes in the global ozone régime.

215 Decision IX/5(e).

216 See Decision IX/5(b).

217 See the proposal by the E.C. in UNEP/OzL.Pro/WG.1/15/2/Add.3. Cf. proposals by the United States (UNEP/OzL.Pro/WG.1/15/2/Add.2; Canada (UNEP/OzL.Pro/ WG.1/15/2/Add.5); Switzerland (UNEP/OzL.Pro/WG.1/15/2/Add.6.

218 See UNEP/OzL.Pro.9/12, para. 87.

219 Annex XI in UNEP/OzL.Pro.9/12.

220 See Decision IX/23 on continuing availability of C.F.Cs. See also e.g. F. P. Landers, Jr., 'The Black Market Trade in Chlorofluorocarbons: The Montreal Protocol Makes Banned Refrigerants a Hot Commodity', 26 Georgia J.I.C.L. (1997), pp. 457-85; D. Brack, International Trade and the Montreal Protocol (1996) Chapter 6; R. Benedick, Ozone Diplomacy, (1998) pp. 273-76 esp.

221 This means that the demand for C.F.Cs. or O.D.Ss. from industrised countries is still likely to continue in the international community.

222 On Basic Domestic Needs see Section E above. 
The Historial Evolution of the International Ozone Layer Régime

In an attempt to remedy the situation, the Meeting of the Parties adopted Decision VII/33 that requests the U.N.E.P. Secretariat additional reports on dumping, illegal imports/exports, was adopted in 1995.223 In 1996, Decision VIII/20 that is based on a U.S. proposal ${ }^{224}$ was adopted by the Eight Meeting of the Parties. It urged Non-Article 5 countries to establish a system for validation and approval of imports of any used, recycled or reclaimed O.D.Ss. before they are imported. The 1997 Montreal Ozone Meeting then agreed to institute a new licensing system to help national governments track international trade in O.D.Ss. and discourage unlicensed black/grey market trade (Article $4 \mathrm{~B}$ and Decision IX/8). Article $4 \mathrm{~B}(1)$ requires the parties to establish and implement a system for licensing the import/export of new/recycled/reclaimed O.D.Ss. in Annexes A, B, C and E (by January 2000 or within three months of the entry into force of this new Article).

The illegal O.D.S. trafficking will be examined further by the Tenth Meeting of the Parties to the Protocol, which will be held in Egypt in November 1998.

223 This decision is based on a U.S. proposal. See R. Benedick, Ozone Diplomacy, (1998) p. 276.

224 See R. Benedick, Ozone Diplomacy, (1998) p. 276. 
The Historial Evolution of the International Ozone Layer Régime

Table no. I: THE DEVELOPMENT OF INTERNATIONAL CONTROL

MEASURES FOR O.D.SS. UNDER THE MONTREAL OZONE LAYER PROTOCOL

\begin{tabular}{|c|c|c|c|c|c|}
\hline $\begin{array}{l}\text { Substances } \\
\text { [Base level] }\end{array}$ & $\begin{array}{l}1987 \text { Montreal } \\
\text { Protocol } \\
\end{array}$ & $\begin{array}{l}1990 \text { London } \\
\text { Adjustments }\end{array}$ & $\begin{array}{l}\text { 1992Copenhage } \\
\text { n Adjustments }\end{array}$ & $\begin{array}{l}1995 \text { Vienna } \\
\text { Adjustments }\end{array}$ & $\begin{array}{l}1887 \text { Montreal } \\
\text { Adjustments }\end{array}$ \\
\hline $\begin{array}{c}\text { CFCs } 11,12, \\
113,114,115 \\
\text { Annex } \\
\text { Group I } \\
\text { [1986] }\end{array}$ & $\begin{array}{l}\text { Freeze at } 1986 \\
\text { levels in mid- } \\
1989 \\
50 \% \text { reduction } \\
\text { in mid- } 1998\end{array}$ & $\begin{array}{l}\text { No Change } \\
85 \% \text { reduction } \\
\text { in } 1995 \\
\text { Phaseout in } \\
2000\end{array}$ & $\begin{array}{l}\text { No Change } \\
25 \% \text { reduction } \\
\text { in } 1994 \\
\text { Phaseout in } \\
1996\end{array}$ & No Change & No Change \\
\hline $\begin{array}{l}\text { Halons } 1211, \\
1301,2402 \\
\text { Annex A Group } \\
\text { B }[1986]\end{array}$ & $\begin{array}{l}\text { Freeze at } 1986 \\
\text { levels in } 1992\end{array}$ & $\begin{array}{l}\text { No Change } \\
50 \% \text { reduction } \\
\text { in } 1995\end{array}$ & $\begin{array}{l}\text { Phaseout in } \\
1994\end{array}$ & No Change & No Change \\
\hline $\begin{array}{l}\text { Other fully } \\
\text { halogenated } \\
\text { CFCs } \\
\text { Annex B } \\
\text { Group I [1989] }\end{array}$ & Not covered & $\begin{array}{l}85 \% \text { reduction } \\
\text { in } 1997 \\
\text { Phaseout in } \\
2000\end{array}$ & $\begin{array}{l}25 \% \text { reduction } \\
\text { from } 1989 \\
\text { levels in } 1994 \\
\text { Phaseout in } \\
1996\end{array}$ & No Change & No Change \\
\hline $\begin{array}{l}\text { Carbon } \\
\text { tetrachloride } \\
\text { (Annex B: Group } \\
\text { II) [1989] }\end{array}$ & Not covered & $\begin{array}{l}85 \% \text { reduction } \\
\text { from } 1989 \\
\text { levels in } 1995 \\
\text { Phaseout in } \\
2000\end{array}$ & $\begin{array}{l}\text { No Change } \\
50 \% \text { reduction } \\
\text { in } 1994 \\
\text { Phaseout in } \\
1996\end{array}$ & No Change & No Change \\
\hline $\begin{array}{l}\text { Methyl } \\
\text { chloroform } \\
\text { Annex B } \\
\text { Group III } \\
\text { [1989] }\end{array}$ & Not covered & $\begin{array}{l}\text { Freeze at } 1989 \\
\text { levels in } 1993 \\
70 \% \text { reduction } \\
\text { in } 2000 \\
\text { Phaseout in } \\
2005 \\
\end{array}$ & $\begin{array}{l}\text { No change } \\
50 \% \text { reduction } \\
\text { in } 1994 \\
\text { Phaseout in } \\
1996\end{array}$ & No Change & No Change \\
\hline $\begin{array}{l}\text { HCFCs } \\
\text { Annex C Group I } \\
\text { [1989 HCFC } \\
\text { consumption + } \\
2.8 \% \text { of } 1989 \\
\text { CFC } \\
\text { consumption] }\end{array}$ & Not covered & $\begin{array}{l}\text { Nonbinding } \\
\text { resolution calls } \\
\text { for phaseout no } \\
\text { later than } 2040\end{array}$ & $\begin{array}{l}\text { Phaseout in } \\
2030\end{array}$ & No Change & No Change \\
\hline
\end{tabular}


The Historial Evolution of the International Ozone Layer Régime

\begin{tabular}{|c|c|c|c|c|c|}
\hline $\begin{array}{l}\text { hydrobromo- } \\
\text { fluoro-carbons } \\
\text { (Annex C: Group } \\
\text { II) }\end{array}$ & Not covered & Not covered & $\begin{array}{l}\text { Prohibition on } \\
\text { the } \\
\text { consumption } \\
\text { after } 1996\end{array}$ & No Change & No Change \\
\hline $\begin{array}{l}\text { Methyl Bromide } \\
\text { (Annex E) } \\
{[1991]}\end{array}$ & Not covered & Not covered & $\begin{array}{l}\text { Freeze at } 1991 \\
\text { levels in } 1995\end{array}$ & $\begin{array}{l}\text { No Change } \\
\text { Phaseout in } \\
2010\end{array}$ & $\begin{array}{l}\text { No Change } \\
\text { Phaseout in } \\
2005\end{array}$ \\
\hline
\end{tabular}

Source: Figures from the Montreal Protocol as Ajusted/Amended 
The Historial Evolution of the International Ozone Layer Régime

Table no. II: INTERNATIONAL CONTROL MEASURES FOR ARTICLE 5 COUNTRIES UNDER THE MONTREAL OZONE LAYER PROTOCOL

\begin{tabular}{|c|c|c|c|c|}
\hline $\begin{array}{l}\text { Substances } \\
\text { [Base Level] }\end{array}$ & Stage I & Stage II & Stage III & Stage IV \\
\hline $\begin{array}{l}\text { CFCs 11, 12, 113, } \\
\text { 114, 115/Annex A: } \\
\text { Group ] [Average of } \\
\text { 1995-1997 }\end{array}$ & $\begin{array}{l}\text { Freeze at 1995-97 } \\
\text { levels in (July ) } 1999\end{array}$ & $\begin{array}{l}50 \% \text { reduction in } \\
2005\end{array}$ & $\begin{array}{l}85 \% \text { reduction in } \\
2007\end{array}$ & $\begin{array}{l}100 \% \text { reduction in } \\
2010\end{array}$ \\
\hline $\begin{array}{l}\text { Halons 1211, 1301, } \\
\text { 2402/Annex A: } \\
\text { Group II [Average } \\
\text { of 1995-1997 }\end{array}$ & $\begin{array}{l}\text { Freeze at 1995-97 } \\
\text { levels in } 2002\end{array}$ & $\begin{array}{l}50 \% \text { reduction in } \\
2005\end{array}$ & $\begin{array}{l}100 \% \text { reduction in } \\
2010\end{array}$ & - \\
\hline $\begin{array}{l}\text { Other fully } \\
\text { halogenated CFCs/ } \\
\text { Annex B: Group I } \\
\text { [Average of } 1998 \text { - } \\
\text { 2000] }\end{array}$ & $\begin{array}{l}\text { Freeze at 1998-2000 } \\
\text { levels in } 2003\end{array}$ & $\begin{array}{l}85 \% \text { reduction in } \\
2007\end{array}$ & Phaseout in 2010 & - \\
\hline $\begin{array}{l}\text { Carbon } \\
\text { tetrachloride/ } \\
\text { Annex B: Group II } \\
\text { [Average of 1998- } \\
2000\end{array}$ & $\begin{array}{l}85 \% \text { reduction in } \\
2005 \text { from } 1998- \\
2000 \text { levels }\end{array}$ & $\begin{array}{l}100 \% \text { reduction in } \\
2010\end{array}$ & - & - \\
\hline $\begin{array}{l}\text { Methyl chloroform/ } \\
\text { Annex B: Group III } \\
\text { [Average of } 1998 \text { - } \\
\text { 2000] }\end{array}$ & $\begin{array}{l}\text { Freeze at } 1998-2000 \\
\text { levels in } 2003\end{array}$ & $\begin{array}{l}30 \% \text { reduction in } \\
2005\end{array}$ & $\begin{array}{l}70 \% \text { reduction in } \\
2010\end{array}$ & $\begin{array}{l}100 \% \text { reduction in } \\
2015\end{array}$ \\
\hline $\begin{array}{l}\text { HCFCs*/ Annex C: } \\
\text { Group I [ } 2015 \\
\text { consumption] }\end{array}$ & $\begin{array}{l}\text { Freeze at } 2015 \\
\text { consumption levels } \\
\text { in } 2016\end{array}$ & $\begin{array}{l}100 \% \text { reduction in } \\
2040\end{array}$ & - & - \\
\hline $\begin{array}{l}\text { hydrobromo- } \\
\text { fluoro-carbons/ } \\
\text { Annex C: Group II }\end{array}$ & $\begin{array}{l}100 \% \text { reduction in } \\
1996\end{array}$ & - & - & - \\
\hline $\begin{array}{l}\text { Methyl Bromide/ } \\
\text { Annex E [Average } \\
\text { of } 1995-1998\end{array}$ & $\begin{array}{l}20 \% \text { reduction in } \\
2005\end{array}$ & Phaseout in 2015 & - & - \\
\hline
\end{tabular}

Source: Figures from the Montreal Protocol as Adjusted/Amended 
PART B

\section{THE NATIONAL IMPLEMENTATION OF THE INTERNATIONAL TREATIES FOR THE PROTECTION OF THE OZONE LAYER}

\section{INTRODUCTION}

In Part A of the present chapter, the historical evolution of the Montreal Protocol régimes was examined through the dynamic development of its regulatory measures taken by the Meeting of the Parties to the Protocol.

Yet, measures for implementing the international ozone treaties are to be undertaken by domestic means of the parties that formally decided to accept the international commitments to global ozone protection. 225 In this regard, it must be recalled here that the Vienna Ozone Convention specifically requires parties to adopt 'appropriate legislative or administrative measures and co-operate in harmonising appropriate policies'.226 Although the regulatory Protocol certainly does not require states to adopt any definite form of ozone laws at the national level, the obvious lack of such legislative, administrative and/or executive measures would therefore imply a possible violation of the treaty.

As we shall see, the parties to the Protocol régime have taken creative approaches, including domestic percentage reductions, taxes on O.D.Ss., voluntary agreements between government and industry, labelling requirements, economic incentives/disincentives, and so forth.

In Part $B$, we are thus concerned with national implementation and enforcement of the international ozone treaties. Part B provides an overview of national laws and regulations regarding ozone protection in specific countries, namely, (i) non-Article 5 countries including the United States, the European Community, Germany and Japan, and (ii) Article 5 countries, including Brazil, Malaysia and Thailand. These parties to the Protocol that I have selected here are all important in sustaining the international co-operation ozone régime. 227 Section $B$ on ozone legal

225 For an extensive discussion of the relationship between international and national law, see in particular J. Ebbesson, Compatibility of International and National Environmental Law, (1996).

226 Article 2(2). Cf. The 1973 C.I.T.E.S. (Article VIII.1-2 and 7) and the 1989 Basel Convention (Article 9(5)).

227 Part B does not deal with national laws and regulations in China and India, although both Article 5 countries are undeniably crucial to the management of the ozone layer régime. One of the main reasons for this is that relevant information was not readily provided by these two governments and international organisations involved in ozone activities (to date, no reply to my many letters). But see countries 
The Historial Evolution of the International Ozone Layer Régime

instruments in Article 5 countries also briefly describes various country programmes under the Montreal Protocol's Multilateral Fund.

Lastly, it must be said that, for reasons of space, this part cannot deal with an analysis of each country's national legal system. ${ }^{228}$

\section{NATIONAL IMPLEMENTATION AND ENFORCEMENT OF THE INTERNATIONAL OZONE TREATIES}

\section{A. Non-Article 5 Countries}

\section{(1) The United States 229}

In the United States, the following statute and regulations are used to control O.D.Ss.: (i) 1990 Clean Air Act Amendments ('C.A.A.A.'), 230 (ii) U.S.E.P.A. Regulations 231 - Phaseout Regulations, ${ }^{232}$ Refrigerant Recycling Regulation, 233 Motor Vehicle A/C Regulation, ${ }^{234}$ Ban on Nonessential Uses, 235 Labelling Regulation, 236 Significant New Alternatives Regulation, 237 Federal Procurement Regulations, 238 and (iii) Internal

programmes in China in Chapter VI(D) below. As for Russia's national ozone laws and its country programmes see Chapter V(VII.B) below.

228 For a comprehensive review see e.g. J. A. Schlickman (eds.) International Environmental Law and regulation, (1991).

229 The United States, which is non-Article 5 country, ratified the Protocol 21 April 1988, the London Amendment 18 December 1991 and the Copenhagen Amendment 2 March 1944. U.S. controls measures of O.D.Ss. are primarily governed by federal regulations, though several states have also promulgated ozone regulations. Parts of this section are indebted to information provided by the U.S. Government and the U.N.E.P. 'Regulations to Control Ozone-Depleting Substances: A Guidebook' (1996).

230 Title VI: Stratospheric Ozone Protection, Sections 601-18, signed into Law by the President 15 November 1990.

231 Cited here as 40 C.F.R. Part 82. The E.P.A. Regulations are founded on directives and mandates in the 1990 Clean Air Act Amendment.

23240 C.F.R. Part 82, Subpart A implementing Sec. 603-606 and 616 of 1990 C.A.A.A. See the daily Federal Register, vol. 60, p. 24970.

23340 C.F.R. Part 42, Subpart F implementing Sec. 608 of 1990 C.A.A.A. See The Federal Register, vol. 58, p. 28660.

23440 C.F.R. Part 82, Subpart B implementing Sec. 609 of 1990 C.A.A.A. See The Federal Register, vol. 57,

23540 C.F.R. Part 82, Subpart C implementing Sec. 610 of 1990 C.A.A.A. See The Federal Register, vol. 58, p. 69672.

23640 C.F.R. Part 82, Subpart E implementing Sec. 611 of 1990 C.A.A.A. See The Federal Register, vol. 60, p. 4010.

23740 C.F.R. Part 9 \& 82, Subpart G implementing Sec. 612 of 1990 C.A.A.A. See The Federal Register, vol. 59, p. 13044; ibid., vol. 60, p. 31092.

23840 C.F.R. Part 82, Subpart D implementing Sec. 613 of 1990 C.A.A.A. See The Federal Register, vol. 58, p. 54892. 
The Historial Evolution of the International Ozone Layer Régime

Revenue Service ('I.R.S.') Code. 239 The 1990 C.A.A.A. is the most comprehensive legislation for ozone protection in the United States.

The U.S. Environment Protection Agency ('U.S.E.P.A.') has the main responsibility for implementing O.D.S. phaseout strategies and it also issues rules or decisions to implement the C.A.A.A. on a regular basis. The U.S.E.P.A. has adopted a Significant New Alternatives Policy (S.N.A.P.) and it published a list of acceptable substitutes for O.D.Ss. 240

Sanctions against violations of the 1990 C.A.A.A. and its regulations include inter alia fines, jail and withdrawal of permits to operate, such as withdrawal of certificates for refrigerant technicians. Criminal enforcement actions have been taken under 1990 C.A.A.A. Sec. 606 (phaseout) and Sec. 608 (refrigerant recycling). Monitoring of O.D.S. imports is based on mandatory reporting by all importers 241 and customs statics. It is reported that in 1997 a Miami-based company and three employees - who were found of guilty of conspiring to smuggle 4,000 tons of C.F.C.-12 - agreed to forfeit more than $\$ 10$ million in assets. 242

The United States has not entered into any formal voluntary agreements with the industry on actions to phase out O.D.Ss.

Under the I.R.S. Code the United States has imposed an excise tax on C.F.Cs., halons, carbon tetrachloride and 1,1,1 - trichlorroethane in proportion to their O.D.Ps. ${ }^{243}$ The tax is applicable to these chemicals when sold or used by a producer, manufacture or importer. The tax is also applicable to imported products which are made with these chemicals. Yet the United States has not introduced any economic incentives to encourage use of O.D.S. alternatives.

23926 C.F.R. Part 52 Sec. 4681-82, as amended in 1990 by Pub.L. 101-508, in 1992 by Pub.L. 102-486 and in 1995 .

240 E. E. Shea, Introduction to U.S. Environmental Laws, (1995) p. 17.

24140 C.F.R. Part, Subpart A, sec. 82.13.

242 U.S. v. Refrigeration USA, DC SFla, No. 96-0276-CR-Moreno, 5/28/97, cited in 20/12 International Environment Reporter, (11 June 1997) p. 558. A German citizen living Florida was also found guilty of smuggling an ozone depleting refrigerant into the United States. See 20/11 International Environment Reporter, (28 May 1997) p. 519.

243 Secs. 4681-82. In 1993 the tax revenue amounted only to approximately 0.06 per cent of total U.S. government receipt. P. Dubois-Felsmann, 'US Revenue from ODS Excise Tax', under <ozone-webweaver@acd.ucar.edu>. 
The Historial Evolution of the International Ozone Layer Régime

In this connection, Denmark has special levies on C.F.Cs. and halons. 244 The Seychelles has also introduced differentiated taxes and duties for aerosols. 245

\section{(2) The European Community 246}

The European Community legally controls C.F.Cs. and O.D.Ss. by using three kinds of E.C. legislation, that is, (i) a regulation ('directly applicable'), (ii) a recommendation (non-binding) and (iii) a Council decision to ratify the ozone treaties on behalf of the Community. In general, although these E.C. legal instruments regarding the ozone are endorsements of international ozone treaties, the European Community has adopted comprehensive control measures for O.D.Ss.

It was in early 1980 that the European Community adopted its first binding measures, Council Decision 80/372/E.E.C. concerning C.F.Cs. in the environment of 26 March 1980.247 Under the decision, the member states were required to take all appropriate measures to ensure that industry situated in their territories did not increase its production capacity of C.F.Cs. 248 Subsequent Recommendation 89/349 limits the use of C.F.Cs. in aerosols with some exceptions. 249 Further, the Directive 67/548/E.E.C. requires labelling of ODSs with the name of substances, and so forth. 250

Since then, the European Community has adopted Regulation 94/3093 of 15 December 1994 on substances that deplete the ozone layer 251

244 Act from the Ministry of Taxes on taxes on certain C.F.Cs. and halons, 30 June 1994.

245 U.N.E.P. Regulations to Control Ozone-Depleting Substances: A Guidebook, (1996) p. 132.

246 The European Community - that is the regional economic integration organisation - approved the Protocol 16 December 1988, the London Amendments 20 December 1991 and the Copenhagen Amendments 20 November 1995. For a critical analysis of the relationship between the Community law and multilateral treaties, see among others P. Okowa, 'The European Community and International Environmental Agreements; 15 Y.bk.E.L. (1995) pp. 169-92.

247 O.J. No. L 90/45. Previously, the European Community adopted a non-binding Council Resolution of 30 May 1978 on fluorocarbons in the environment. See O.J. No. C 133/1. See also Chapter II above.

248 Article 1(1).

249 See also Directive $92 / 72$ on a harmonised procedure for monitoring, information exchange, etc.

250 67/548/E.E.C.; 93/21/E.E.C., Articles 5.2.2.1 and 7.1. On H.C.F.Cs. see Article 5.2.2.2.

251 O.J. No. L 333/1. 
amending Regulation 91/594, 252 to speed up the phasing out of O.D.Ss. under the Montreal Protocol. Its Articles 3, 4 and 5 are dedicated to detailed O.D.S. control measures. 253 For the purpose of 'industrial rationalisation' within the members states, Article 3(11) allows trading in production rights between member states. 254 O.D.S. import from and export to nonparties to the Protocol is prohibited. 255

Articles 14 and 15 address the recovery of used controlled O.D.Ss. and leakages of these chemicals. As to monitoring of O.D.S. import, producers, exporters and importers of O.D.Ss. are required to submit annual reports to the E.C. Commission and the competent authority of the member state concerned. 256 In this respect, the Commission shall take 'appropriate steps to protect the confidentiality of the information submitted'. 257

One of the most valuable provisions of the implementing regulation will be Article 18 concerning inspection. Under Article 18(3) the competent authorities must carry out the investigations which the E.C. Commission considers necessary under this regulation. 258 This seems to suggest that the member states have little or no discretion regarding this matter. 259

252 O.J. No. L 67/1. The Regulation was amended by Council Regulation/E.E.C. 92/3952, O.J. No. L 405/41.

253 A producer may not produce, sell or use for his account virgin O.D.Ss. after the following date: C.F.Cs. (1 January 1995); halons (1 January 1994); carbon tetrachloride (1 January 1995); 1,1,1-trichloroethane (1 January 1996); H.B.F.Cs. (1 January 1996).

254 On E.C.'s status as a regional economic integration organisation, see Section III.D above.

255 Articles 8 and 11. The same rules apply to any territory which is not covered by the Protocol (Article 13). But see also Article 12.

256 Article 17.

257 Article 17(4). See also Article 18(5).

258 When the Commission requests information from an undertaking, it must at the same time forward a copy of the request to the competent authority of the member states within whose territory the undertaking's seat is situated, together with the reasons why that information is required (Article 18(2)).

259 See J. H. Jans, European Environmental Law, (1995) p. 318. 
The Historial Evolution of the International Ozone Layer Régime

(3) Germany 260

As stated above, E.C. regulations are automatically binding on all member states including Germany.

In addition to the above mentioned regulations, Germany introduced the following national regulations for O.D.Ss., that is, (i) an Ordinance on the Prohibition of Certain Ozone-depleting Halogenated hydrocarbons (C.F.C./Halon Prohibition Ordinance), 261 (ii) an Ordinance on the Limitation of Emissions of Highly Volatile Halogenated Hydrocarbons, 262 and (iii) a Notification on Alternatives for Appliances Containing C.F.C.12.263

Sanctions against non-compliance include fines and jail. 264 The national German regulations prohibit manufacture and sale of O.D.Ss. including C.F.Cs. and H.C.F.C.-22 as refrigerants, cleansing agents and solvents, fire extinguishants, and for production of foams. 265 In accordance with E.C. Regulation $3093 / 94266$ monitoring of O.D.S. import is based on information acquired in connection with the import permit process and subsequent mandatory reporting by all importers. Germany does not have specific regulations banning import of products containing O.D.Ss. from non-parties. In this respect, Article 9 of E.C. Regulation 3093/94 prohibits import of certain products containing, for example, C.F.Cs., halons and H.B.F.Cs. from non-parties. 267

The Federal Ministry for Environment, Nature Conservation and Nuclear Safety ('B.M.U.') 268 entered into (binding) voluntary agreements with industries and trade associations.

260 Germany - which is non-Article 5 country - ratified the Protocol 16 December 1988, the London Amendment 27 December 1991 and the Copenhagen Amendment 28 December 1993. Parts of this section are indebted to information furnished by the U.N.E.P. 'Regulations to Control Ozone-Depleting Substances', (1996) and the German Government.

2616 May 1991.

26210 December 1990, amended 5 June 1991.

263 Issued 21 December 1995 by the Federal Environment Agency. In this respect, the U.K. Environment Protection (Controls on Substances that Deplete the Ozone Layer) Regulations of 1996 set out detailed offences and penalties in relation to noncompliance with the Council Regulation or Regulations (Regulations 11-13). Statutory Instruments, (1996, Part I), 1996/506, p. 1393.

264 See Article 9 of the C.F.C./Halon Prohibition Ordinance.

265 The 1991 Ordinance (Articles 3, 4, 5, 6, $10 \& 11$ ).

266 Article 17.

267 See Annex V of E.C. Regulation 3093/94.

268 The B.M.U. may authorise exemptions to meet the needs of users licensed by the EC Commission to use O.D.Ss. for approved 'essential use'. 
The Historial Evolution of the International Ozone Layer Régime

Regarding recycling of C.F.Cs., it is important that under Article 8(2) of the C.F.C./Halon Prohibition Ordinance distributors of C.F.Cs. must accept the return of these chemicals and preparations after use or ensure return is accepted by a third party designated by them.

\section{(4) Japan269}

Japan enacted the Law Concerning the Protection of the Ozone Layer through Regulation of Specified Substances and Other Measures (the 'Ozone Protection Law') in May 1988, and other administrative ordinances on ozone protection. 270 The Ozone Protection Law has been amended two times, in 1991 and in 1994. On the basis of the Ozone Law of Japan, regulations on the production and importation of specified C.F.Cs. and O.D.Ss. have been enforced by the Ministry of International Trade and Industry ('M.I.T.I.') since 1989.

The controls in Japan on production and import of O.D.Ss. in particular are governed by Chapter II of the Law and Article 52 of the Japanese Foreign Exchange and Foreign Trade Control Law. ${ }^{271}$ In accordance with the Foreign Exchange/Trade Control Law, trade with nonparties in O.D.Ss. and products containing or made with these specified chemicals has been strictly prohibited.

Sanctions against violation of these legal regulations include fines and jail. 272

As to financial and other assistance, it is provided that Japan should make efforts to take necessary measures with a view to facilitating the development/use of substitutes for O.D.Ss. and of equipment for controlling

269 Japan - non-Article 5 country - ratified the Protocol 30 September 1988, the London Amendment 4 September 1991, the Copenhagen Amendment 20 December 1994. For a discussion of environmental law in Japan in general, see e.g. A. Morishima, 'Environmental Law of Japan', in J. A. Schlickman (eds.), International Environmental Law and Regulation, (1991). A. Yasutaka and T. Awagi (eds.), Environmental Law, (1995), (Japanese).

270 See The Ministry of Trade and Industry (ed.) The Ozone Protection Law (Japanese). To date, no English translation is available.

See also an Ordinance on the Protection of the Ozone Layer Through Regulation of Specified Substances and Other Measures of 26 September 1994 as amended; An Enforcement Regulation of the Ozone Protection Law of 1988 as amended; A Guideline for Control on the Emissions and Use Rationalisation of Specified Substances of 1989 as amended. To date, no English translation is available.

271 Promulgated in 1 December 1949, amended in 1979 and in 1987. See further, The Ministry of Trade and Industry, The Ozone Protection Law, pp. 95-156 (Japanese).

272 See further Chapter 6, Articles 30-34 and Article 70 of the Japanese Foreign Exchange and Foreign Trade Control Law. 
The Historial Evolution of the International Ozone Layer Régime

emissions of specialised substances. 273 In this regard, for the year 1991-96, Japan has agreed to contribute U.S.\$ 98 million to the Montreal Protocol Multilateral Fund, 274 and has also engaged in practical bilateral assistance for Article 5 countries, including Asian countries such as China and Thailand. 275

Local governments of Japan - which are delegated administrative functions by the national government 276 - have also introduced various regulations regarding ozone protection, including criminal sanctions. 277

Recently, the M.I.T.I. introduced strategic plans that require manufacturers to recycle their products-consumers will bear some of the estimated U.S.\$ $30-90$ cost per machine. 278

\section{B. Article 5 Countries}

\section{(1) Brazil $^{279}$}

At present Brazil's share of ozone depletion is five per cent - though it was one per cent in 1986 - and this Article 5 country is the third largest consumer of O.D.Ss. to be eligible for the Montreal Multilateral Fund. It is reported that a significant increase in the manufacture of O.D.S.-related equipment (e.g. refrigerators and air conditioner) to meet the rising internal demand led to industrialising nations exporting C.F.Cs. to Brazil at marginal cost. Yet Brazil decided to phase out C.F.Cs. by 2001, and since 1997 manufacturers, aiming to build up external markets, have been using substitutes for O.D.Ss. in some equipment.

273 Article 21 of the Ozone Protection Law. See also Preamble and Article 3.

274 See UNEP/OzL.Pro/ExCom/21/36, Annex I.

275 See Section $\mathrm{B}(2)$ below.

276 In this respect, the Japanese Constitution provides that local authorities may enact local regulations (Article 94). See also Article 2 of the Local Autonomy Law. Yet the relationship between the general law and local regulations is controversial.

277 See The Environment Agency, The Measures for the Protection of the Ozone Layer, (1996) pp. 343-50 (Japanese).

278 of the 3.2 million refrigerators collected by local governments in 1995, less than one-fourth were virtually recycled. See 24 OzonAction, (October 1997).

279 Brazil - which is Article 5 country - ratified the Protocol 19 March 1990, the London Amendment 1 October 1992 and the Copenhagen Amendment 30 may 1996. Parts of this section are indebted to information provided by the U.N.E.P. 'Regulations to Control Ozone-Depleting Substances: A Guidebook' (1996) and the Brazilian government, under: <http:www.mma.gov.br/ingles/SMA/decop/conv4.html>. 
The Historial Evolution of the International Ozone Layer Régime

Brazil has adopted the following ozone regulations: (i) a decree authorising the manufacturers of aerosols to use labels or stamps, 280 (ii) a decree prohibiting the use of C.F.Cs. as a propellant in the manufacturing and trade of aerosols, 281 (iii) a decree specifying the substances referred to in Portaria M.S. N.R. 534 as substances in Annex A of the Protocol, 282 (iv) a decree requesting the producers, importers, exporters, traders and users of O.D.Ss. to register their enterprise at I.B.A.M.A. 283 In addition, a resolution implementing the Brazilian Country Programme ('C.O.N.A.M.A.') prohibits the use of O.D.Ss. in Annexes of the Protocol and bans the use of O.D.Ss. in new, locally produced or imported equipment, products and systems and even recycled O.D.Ss. 284

Recently, Brazil has implemented legislation that prohibits all governments and companies from purchasing products and equipment containing O.D.Ss. ${ }^{285}$ Trade with non-parties in products containing O.D.Ss. has been prohibited since January 1995. Further, Brazil intends to start restricting the use of methyl bromide in 2000.286 A Communiqué No. 7 , dated 13 December 1995, creates procedures for importing and exporting controlled O.D.Ss.

The monitoring of O.D.S. import is based on mandatory reporting by all importers and customs statistics. By reducing/increasing tax, Brazil also intends to introduce economic incentives to encourage use of O.D.S. alternatives, and economic disincentives to discourage use of O.D.Ss.

Brazil adopted the Brazilian Programme to Eliminate the Production and Consumption of Ozone Depleting Substances ('P.B.C.O.'), which is designed to meet the objectives of the Protocol. The P.B.C.O. was approved by the Executive Committee of the Protocol in July 1994, and project financing is implemented through the U.N.D.P., the U.N.E.P. and the World Bank.

The Programme has been implemented in a decentralised manner with participation from various entities of Federal and State Governments and the private sector. In order to implement the P.B.C.O., Brazil established the Inter-ministerial Executive Committee ('P.R.O.Z.O.N.'), consisting of

\footnotetext{
280 MS-NR 01/88.

281 MS-NR 534/88.

282 MS-NR 647/89.

283 I.B.A.M.A. NR 29/95.

284 C.O.N.A.M.A. NR/13/95, published on 29 December 1995.

285 See 24 OzonAction (October 1997).

286 See also 23 OzonAction (July 1997).
} 
The Historial Evolution of the International Ozone Layer Régime representatives from Ministries and private sectors. At present the P.R.O.Z.O.N. has an established co-operation with thirteen trade associations $^{287}$ to promote reduction of O.D.Ss.

Until now, the Montreal Protocol Multilateral Fund has financed fifty-two projects in Brazil, amounting to U.S.\$ 25.4 million, corresponding to an elimination of 3,491.85 tonnes O.D.P. Recently, at its Twenty-Second Meeting in June 1997, the Executive Committee approved nine projects and it requested the Implementing Agencies and the Secretariat to provide additional information on the project implementation in Brazil. 288

(2) Malaysia289

Malaysia has adopted eleven orders and guidelines to discourage any use of O.D.Ss. that would be contradictory to the phaseout targets stated in Malaysia's Country Programme. They include, for example, (i) a 1989 Custom Duties Order,290 (ii) a 1993 Environmental Quality Order, prohibiting the use of C.F.Cs. and other gases as propellants and blowing agents, 291 (iii) Custom Duties on prohibition of import, 292 (iv) 1994 Guidelines on Control Measures for the Protection of the Ozone Layer and (v) 1995 Guidelines for Prequalifying and Selection Criteria for Acceptable Alternatives of O.D.Ss. in Malaysia.

Administrative orders and guidelines - which are based on mandates in the 1974 Environmental Quality Act, the 1967 Custom Act and the 1988 Fire Act - are not binding, however. All acts must be passed and endorsed by the Cabinet or the Parliament.

Sanctions against non-compliance include fines, jail, withdrawal of permits to operate and withdrawal of privileges. 293 Monitoring of O.D.S.

287 They are all members of Enterprises Council to Implement the Montreal Protocol in Brazil (CCSEE).

288 Decision 22/39 of the Executive Committee in UNEP/OzL.Pro/ExCom/22/79/Rev.1.

289 Malaysia - which is Article 5 country - ratified the Montreal Protocol 29 August 1989, the London Amendment 16 June 1993 and the Copenhagen Amendment 5 August 1993. Parts of this section are indebted to information provided by the U.N.E.P. 'Regulations to Control Ozone-Depleting Substances: A Guidebook' (1996) and the Malaysia Government. For a discussion of environmental law of Malaysia, see e.g. M. Kimura, 'Malaysia's Environmental Law and Administrative System' in Y. Nomura and N. Sakumoto, Environmental Law of Developing Countries, (1996) pp. 81-118.

290 Entered into force 14 December 1989, revised 17 November 1994 by a 1994 Customs Duty Order.

29131 December 1993.

292 Entered into force 7 April 1994.

293 See the 1974 Environmental Quality Act and the 1967 Custom Duty. 
The Historial Evolution of the International Ozone Layer Régime import is based on information obtained in connection with the approval of import permits, as well as information from customs and the Statics Department and voluntary information from trade associations and importing companies. In addition, under the Approved Permit system ('A.P.') no import from non-parties will be approved. Yet there are no regulations banning import or sale of any products containing, made with or requiring O.D.Ss. for its use.

Although Malaysia has no formal voluntary agreements with industry on ozone actions, it formed a sector specific Working Group under an O.D.S. Working Groups Committee to formulate strategies to eliminate the use of O.D.Ss. The Country Programme and its strategies are developed in co-operation with the participating industrial associations in the Working Group.

Furthermore, Malaysia has introduced duty exemptions for recovery and recycling machines and import of H.C.F.Cs. (134a), and tax reductions for manufacture and imports of environmental protective equipment to encourage the use of O.D.S. alternatives. 294

The strategy applied in the Multilateral Fund is the adoption of regulatory and control measures to discourage future investments in production and use of O.D.Ss., direct investment in ozone-friendly technologies, and incentive schemes to encourage industries to use substitutes. 295 Under the Protocol's Fund, implementation of the M.A.C. recycling project was completed in 1995.296 The project by the World Bank is expected to result in an annual phaseout of 370 tons of C.F.C.-12, which is the largest O.D.S. consuming sector in Malaysia. Yet it is reported that implementation of the O.D.S. Project I was delayed due partly to the fact that an Ozone Unit was not yet established within the Department of the Environment in Malaysia. 297

As to the refrigeration sector, the World Bank is now engaged in, for instance, the Phaseout Project of C.F.C.-12 M.A.C. (Mobile Air Conditioners)

294 Enacted under the 1967 Customs Act.

295 See Country Programme (1992).

296 See The World Bank, 1996 Work Programme: Bank-Implemented Montreal Protocol Operations as Proposed to the 18th Meeting of the Fund EC, (October 1995), p. 14. With regard to O.D.S. Investment Project II, grant became effective in January 1996.

297 See The World Bank, Implementation Performance Review of Bank-Implemented Montreal Protocol Investment Operations, (December 1994), p. 2. 
The Historial Evolution of the International Ozone Layer Régime manufacturing equipment and conversion to H.F.C.-134a system, which is to be completed in November 1999.298

(3) Thailand299

Thailand has established the following two national regulations, that is, (i) the Hazardous Substance Act, 300 and (ii) the 1995 Notification by the Ministry of Industry, 301 which designated controlled substances in Annexes of the Protocol. 302 The 1995 Notification incorporated an earlier Declaration by the Ministry of Public Health on consumer aerosols containing C.F.Cs. In addition, the Department of Industrial Works ('D.I.W.') under the Ministry of Industry, that undertakes the major responsibility for implementation, has passed two guidelines, i.e. (i) the Instructions by the D.I.W. to control the use of O.D.Ss. in industrial plants ${ }^{303}$ and (ii) the Ministerial Declarations and other D.I.W. Orders and Guidelines. 304

Monitoring imports is based on information by the D.I.W. concerning clearance of import shipments and mandatory reporting from the importers. Sanctions against non-compliance include fines and jail. 305 Foreign trade with non-parties is controlled as part of the general permit approval procedures for O.D.Ss. As to voluntary agreements, Thailand has a trilateral agreement with U.S.E.P.A. and the Japanese Ministry of International Trade and Industry ('M.I.T.I.'). 306 Further, duty exemptions

298 See Multilateral Fund for the Implementation of the Montreal Protocol: Inventory of Approved Projects, (as at November 1995), p. 210.

299 Thailand - which is Article 5 country - ratified the Montreal Protocol 7 July 1989, the London Amendments 25 June 1992 and Copenhagen Amendments 1 December 1995. Parts of this section are indebted to information furnished by the U.N.E.P. 'Regulations to Control Ozone-Depleting Substances: A Guidebook', (1996) and the Thai Government. For a discussion of environmental law in Thailand, see e.g. S. Ogano, 'Thailand's Environmental Law and Administrative System', in Y. Nomura and N. Sakumoto, Environmental Law of Developing Countries, (1996) pp. 119-64.

300 B.E. 2535, 29 March 1992.

30117 February 1995.

302 These chemicals are also regulated by the 'Toxic Substance Act'.

3031 April 1992.

304 English translation is not available.

305 See the Hazardous Substance Act.

306 At the Japan-U.S.-Thailand Joint Technical Seminars on Ozone Layer Protection held in Bangkok in March 1992, seven Japanese companies pledged the complete elimination of C.F.Cs. from household refrigerations by the end of 1996 . This phaseout goal - the earliest in the world in developing countries - was achieved with support from Japan, the United States and Thai governments through the efforts of the member companies of the Japan Electrical Manufactures' Association (J.E.M.A.). Information provided by Ms. Fukuhara of the Japan M.I.T.I. (2 February 1998). 
The Historial Evolution of the International Ozone Layer Régime

are introduced for import of recovery and recycling equipment. Thai industries seeking support from the Government are encouraged not to use O.D.Ss.

As at November 1995, about thirty projects in various sectors are prepared and carried out under the Financial Mechanism of the Protocol.307 In relation to capacity-building, the U.N.D.P. and the World Bank in particular have been implementing institutional strengthening projects for the D.I.W. More recently, at its Twenty-Second Meeting, the Executive Committee approved additional two projects on incremental operating costs for compressors. 308

\section{CONCLUSIONS: LOOKING AHEAD}

As discussed in Part A, the overall success of the Montreal Protocol régime will be characterised by international co-operation in protecting ozone among régime actors, e.g. Non-Article 5 and Article 5 nations, international institutions such as the U.N.E.P., scientists, industry, and environmental N.G.Os. Attention should also be directed at the régime's specialised internal institutions - e.g. the Executive Committee of the Multilateral Fund, the Implementation Committee of the N.C.P. and their subsidiary bodies - that have been playing important roles in long sustaining the co-operative and regulatory régime. 309

As described in Part B, the Protocol's concept of international cooperation or global partnership has been well translated into partnership at the national level. Parties, both Non-Article 5 and Article 5 countries (with the exception of India), have dedicated considerable efforts to meet the legal requirements of the Montreal Protocol. Many of those parties are ahead of the Protocol reduction schedules for O.D.Ss., and only a few countries - such as the Russian Federation of the C.E.I.Ts. - are currently not complying with the strict control measures of the regulatory Protocol.

However, it should be noted that, even with full compliance with the amended Protocol régime, the ultimate objective of the international régime, i.e. complete recovery of the ozone layer, would not occur until the middle of the next century: peak ozone decreases are expected to occur

307 See the U.N.E.P. 'Multilateral Fund for the Implementation of the Montreal Protocol: Inventory of Approved Projects (as at November 1995)'.

308 Decision 22/48 of the Executive Committee in UNEP/OzL.Pro/ExCom/22/79/Rev.1.

309 See Chapters V-VI below. 
The Historial Evolution of the International Ozone Layer Régime during the next several years. In this sense, the international environmental régime is a precautionary environmental régime for future generations.

The Montreal Protocol and its Amendments and Adjustments must continue to be strengthened to further protect the stratospheric ozone layer; there is still much progress to be made. Only eight points - some of which might be debatable - are stressed here.

With regard to the binding controls of O.D.Ss., (i) the control measures for H.C.F.Cs. 310 and methyl bromide in particular should be strengthened: with regard to methyl bromide, as seen in the case of the Netherlands, alternatives, substitutes and related technologies are already widely available. ${ }^{311}$

As a newly emerging problem of the ozone régime operation, (ii) illegal trade in C.F.Cs., which has become a lucrative activity, must be resolved as soon as possible through e.g. the new import/export licensing system adopted at the 1997 Ninth Ozone Meeting (Article 4B). How the system will develop is a matter of great interest.

In relation to the previous point (iii) the grace period for production of C.F.Cs. in Article 5 nations should, arguably, be shortened considerably. Undeniably, the grace period has become a source of illegal trade.

For purposes of assessing/judging the effectiveness of the regulatory measures for O.D.Ss., (iv) data reporting under Articles 7 and 9 of the Protocol must be improved substantially. It has been pointed out that Non-Article and Article 5 country parties are submitting incomplete data. 312

Though this was not discussed in the present chapter, (v) greater financial resources for monitoring, research and analysis of the state of the ozone layer should be allocated to internal/external scientific régime institutions such as the T.E.A.P. and its sub-Committees and the W.M.O.; 313 as in the past, it will be new scientific findings and technological/economic assessments that can encourage further developments of the international control measures for O.D.Ss.

310 It should be noted that production/use of H.C.F.Cs. have risen in developed and developing countries (from 13.000 tons in 1989 to 35,000 tons in 1995). See 20/18 International Environment Reporter, (3 September 1997) p. 820.

311 But see R. Benedick, Ozone Diplomacy, (1998) p. 207, noting that there is no universal substitute for all the uses and pests.

312 See 20/18 International Environment Reporter, (3 September 1997) p. 820. See further Chapter V(VII.A.1) below.

313 See statements by Co-Chair of the T.E.A.P. in UNEP/OzL.Pro.9/12, para. 29. 
The Historial Evolution of the International Ozone Layer Régime

Perhaps one of the most important points is that (vi) the number of ratifications of the Amendments to the Protocol is still unsatisfactory. In this respect, the regular Meeting of the Parties has continuously adopted Decisions. If not widely and quickly ratified by the majority of the parties, the international régime may not maintain or strengthen its wellrecognised dynamic character.

Further, (vii) it is expected that a large number of developing countries - probably two-thirds of them - will have difficulties in achieving in 1999 a freeze of C.F.C. consumption. 314 In this respect, it must be emphasised that the phase-out by Article 5 countries depends on adequate financing and technology transfer being available from the Multilateral Fund, as stated in the Montreal Protocol text.

Finally, (viii) in accordance with Decisions by the Meeting of the Parties, the countries with their economies in transition should be given special and appropriate assistance to enable them to comply with the Protocol (e.g. G.E.F. funding, which is, however, external to the Multilateral Fund of the international ozone régime). ${ }^{315}$ An effective combination of 'sticks' and 'carrots' has to be achieved in this context. 316

The following chapters will examine Article 4 trade restrictions (Chapter IV), the Montreal N.C.P. régime (Chapter V), and the Financial Mechanism of the Protocol including the Multilateral Fund (Chapter VI) - these treaty provisions and institutions all help toward securing full compliance with the above-mentioned substantive provisions of Articles 2, 2A to $2 \mathrm{H}-$ and corresponding control measures contained in Article 5.

314 See UNEP/OzL.Pro.9/12, para 69.

315 As we shall see in Chapter $\mathrm{V}$ below, many of the C.E.I.Ts. are presently in noncompliance with the treaty.

316 See Chapters I(III.B) and V(VII.B) esp. 


\section{PART III}

THE OZONE LAYER RÉGIME AND THE G.A.T.T./W.T.O. LAW RÉGIME 


\section{CHAPTER IV}

THE MONTREAL OZONE PROTOCOL RÉGIME AND

THE INTERNATIONAL TRADE REGIME OF THE G.A.T.T./W.T.O. LAW

\section{INTRODUCTION: MULTILATERAL ENVIRONMENTAL AGREEMENTS AND THE INTERNATIONAL TRADE LAW RÉGIME OF THE G.A.T.T./W.T.O.}

A. Multilateral Environmental Agreements and the G.A.T.T./W.T.O. Law

One of the vexing problems of global environmental protection is the complicated relations between multilateral environmental agreements ('M.E.As.') and trade-oriented rules/principles of the G.A.T.T./W.T.O. law (the General Agreement on Tariffs and Trade/World Trade Organisation). Although the relentless pursuit of economic growth or free capital mobility - which is likely to have adverse environmental impacts - is frequently subject to certain treaty obligations under M.E.As., the G.A.T.T./W.T.O. trade law does not specifically address current issues relating to environmental protection. Consequently, the legal status of trade-related provisions of M.E.As. within the framework of the G.A.T.T./W.T.O. law régime remain, to a greater or lesser extent, controversial. International trade restrictions of O.D.Ss. contained in Article 4 of the Montreal Ozone Layer Protocol provide an archetypal and striking example of M.E.As.-G.A.T.T./W.T.O. conflicts in the context of newly developing modern international environmental law. ${ }^{1}$

To begin with, it will be helpful to describe M.E.As. briefly, before moving to the main exacting task in this Chapter.

\footnotetext{
1 See in general J. Cameron and J. Robinson, 'The Use of Trade Provisions in International Agreements and Their Compatibility with the GATT', 2 Y.bk.I.E.L. (1991) pp. 3-30: E. U. Petersmann, 'International Trade and International Environmental Law: Prevention and Settlement of International Environmental Disputes in GATT'; 27 J.W.T. (1993) pp. 43-81; H. Ward, 'Trade and Environment in The Round - and After', 6 J.E.L. (1994) pp. 263-95: the G.A.T.T. Secretariat, Trade and the Environment, (1992) reprinted in J. H. Jackson (eds.) International Economic Relations, (1995) pp. 561-72.
} 


\section{B. Multilateral Environmental Agreements ('M.E.As.')}

The newly-coined term 'M.E.As.' - which is widely received in international legal literature 2 - implies that the environmental treaties contain some kinds of trade-related provisions or international economic law rules. Currently, there are at least one hundred and eighty M.E.As. Some twenty of those M.E.As. contain trade-related environmental measures ('T.R.E.Ms.') and they lay down quantitative restrictions on foreign trade (at least). ${ }^{3}$ As was described in Chapter III(III-IV) above, the Montreal Ozone Layer Protocol places quantitative limits on production/'consumption' of specified controlled substances in its Article 2 and technical Annexes. 4

M.E.As. are generally classified in three broad categories: (i) agreements to protect wildlife - e.g. the 1973 C.I.T.E.S., 5 (ii) agreements to

2 As to the basic features of M.E.As. see e.g. J. Werksman, 'The Conference of Parties to Environmental Treaties' in idem (ed.), Greening International Institutions, (1996) pp. 55-68; V. Rege, 'GATT Law and Environment-Related Issues Affecting the Trade of Developing Countries', 28 J.W.T. (1994) p. 126.; T. J. Schoenbaum, 'International Trade and Protection of the Environment: The Continuing Search for Reconciliation', 91 A.J.I.L. (1997) pp. 281-84.

3 The 1933 Convention Relative to the Preservation of Fauna/Flora in Their Natural State (Article 9), 172 L.N.T.S. 241; the 1940 Western Hemisphere Convention (Article 9), 161 U.N.T.S. 193; the 1950 Birds Convention (Article 6), 638 U.N.T.S. 185; the 1956 F.A.O. Plant Protection Agreement for South-East Asia and the Pacific Region (Article III), 247 U.N.T.S. 400; the 1957 Interim Convention on Conservation of North Pacific Fur Seals (Article VIII), 314 U.N.T.S. 105; the 1959 Agreement Concerning the Co-operation in the Quarantine of Plants and Their Protection against Pests and Diseases (Article 4), 1 S.M.T.E. 153; the 1967 Phyto-sanitary Convention for Africa; the 1968 African Nature Convention (Article IX); the 1968 European Convention for the Protection of Animals During International Transport (Article I), I.E.L.M.T;; the 1970 Benelux Birds Convention (Articles 6 \& 9), 847 U.N.T.S. 255; the 1973 Polar Bears Agreement, 13 I.L.M. (1974) 13; the 1980 Convention for the Conservation/Management of the Vicuña (Article 4); the 1985 A.S.E.A.N. Agreement; the 1985 F.A.O. Code of Conduct on the Distribution/Use of Pesticides; the 1989 Amended London Guidelines for the Exchange of Information on Chemicals in International Trade; the 1989 Wellington Convention (Article 3(2.c), 29 I.L.M. (1990); the 1992 U.N. Climate Change Convention, 31 I.L.M. (1992) p. 849; the 1992 Biodiversity Convention (Article 16), 31 I.L.M. (1992) p. 822; the 1994 Oslo Sulphur Protocol (Preamble); the 1994 International Tropical Timber Agreement (Article 36). See E. U. Petersmann, International and European Trade and Environmental Law after the Uruguay Round, (1996) Annex VIII.

4 The original version of the 1987 Montreal Protocol intended to adopt restrictions on the methods used in the production or processing of products (see Section II(B) below). The legal strategies of the ozone layer régime are not based on domestic production/consumption taxes, labelling, etc. But see also Part B of Chapter III regarding various national ozone laws/regulations containing economic incentives/disincentives.

5 Articles III, IV \& V. See further S. Lyster, International Wildlife Law, (1985) Chapter 12(5); T. M. Swanson, 'The Evolving Trade Mechanisms in CITES', 1 R.E.C.I.E.L. (1992) pp. 57-63. 
protect the environment of the importing states from harmful organisms and products - e.g. the 1989 Basel Convention, 6 and (iii) agreements to protect the so-called 'global commons'. ${ }^{7}$ It is said that at present the Montreal Ozone Layer Protocol is arguably the only M.E.A. which addresses in considerable detail the third category. 8

It is interesting to note here that the North American Free Trade Agreement ('N.A.F.T.A.') specifically referred to the Montreal Ozone Layer Protocol as amended, the 1973 C.I.T.E.S. and the 1989 Basel Convention. Under Article 104 of the N.A.F.T.A., these M.E.As.' trade-related environmental provisions - such as provided for in the Ozone Protocol's Article 4 - may prevail over the N.A.F.T.A. general exceptions 'to the extent of their consistency [with the N.A.F.T.A.], provided that where a Party chooses among equally effective and reasonably available means of complying with such obligations, the Party chooses the alternative that is the least inconsistent with the other provisions of the Agreement'. ${ }^{9}$

On the other hand, the G.A.T.T./W.T.O. trade law does not contain such a provision designed specifically for clarifying the complicated relationship between any of these major M.E.As. and the international trade law régime: it is only in the Preamble that the W.T.O. addresses the principle of sustainable development. ${ }^{10}$ In this respect, however, the W.T.O. Committee on Trade and Environment ('C.T.E.') - which is newly

\footnotetext{
6 Article 4, arguably, the most controversial M.E.A. in the context of the G.A.T.T. law. Cf. The 1991 Bamako Convention (Article 4); the 1989 Lomé Convention (Article 39). For a comprehensive review see K. Kummer, Transboundary Movements of Hazardous Wastes at the Interface of Environment and Trade, (1994), available from the U.N.E.P.

7 See J. Cameron, Mjolo-Thamage and J. Robimson, 'Relationship between Environmental Agreements and Instruments Related to Trade and Development' in P. H. Sand, (1992) pp. 475 et seq.

8 Ibid., pp. 487 et seq.

9 Article 104 also states that parties may add to an Annex additional agreements to which the consistency provisions of Article 104 apply. See also Article 904 regarding scientific justification for strict environmental regulations; Article 2015 as to the possibility of some environmental expertise in the D.S.Ps.; Article 1106 regarding investment incentives.

10 It reads 'allowing for the optimal use of the world's resources in accordance with the objective of sustainable development, seeking both to protect and preserve the environment and enhance the means of doing so in a manner consistent with their respective needs and concerns at different levels of economic development' (emphasis added). On the meaning of 'sustainable development' in the context of the W.T.O. see W. Benedek, 'Implications of the Principle of Sustainable Development, Human Rights and Good Governance for the GATT/WTO' in K. Ginther (eds.) Sustainable Development and Good Governance, (1995) pp. 274-88.
} 
established in accordance with the Decision of 14 April 1994 - has played an active role within the framework of the G.A.T.T./W.T.O.11

At the Meeting of the C.T.E. held in July 1996, Singapore (on behalf of A.S.E.A.N. countries) put forward an expost or ex ante proposal for creating a 'multi-year' and 'case-by-case' waiver for trade measures of M.E.As., based on non-binding guidelines for measures that might be eligible for such treatment. ${ }^{12}$ A.S.E.A.N. pointed out that trade measures that are specifically to be used in M.E.As. could be recognised on a case-by-case basis as exceptional circumstances qualifying for a W.T.O. Article IX waiver, subject to them meeting conditions and criteria including 'necessity', 'least trade restrictiveness', 'effectiveness', 'proportionality' and the 'degree of scientific evidence'.13

Members of the W.T.O. Committee have continued inconclusive discussions with regard to such a question (see further Sections below). ${ }^{14}$

The purpose of this Chapter is to explore in depth the trade related aspects of the Montreal Protocol régime. Section II analyses Article 4 trade measures against non-parties to the Ozone Layer Protocol. Section III briefly discusses international trade rules governing the G.A.T.T./W.T.O. régime, though limitations of space do not permit a detailed discussion on that issue - we will focus rather on the relationship between the wellknown Article XX exceptions in the G.A.T.T. trade law and Article 4 trade controls of the Ozone Layer Protocol. Section IV then focuses on the legal conflicts between M.E.As. and the G.A.T.T./W.T.O., including the relationship between dispute settlement procedures of M.E.As. - the Montreal N.C.P. in particular - and the W.T.O. dispute settlement system. In deciding which international treaty obligations should be given priority, it will be desirable to consider briefly the principles and rules of the 1969 Vienna

11 See e.g. J. Schult, 'The GATT/WTO Committee on Trade and the Environment Toward Environmental Reform', 89 A.J.I.L. (1995) pp. 423-39. For a discussion see R. G. Tarasofsky, 'Ensuring Compatibility between MEAs and GATT/WTO', 7 Y.bk.I.E.L. (1996) pp. 58-62.

12 PRESS/TE013 (September 1996).

13 PRESS/TEO13 (September 1996). Yet some W.T.O. Members such as the United States, Switzerland and Canada suggested that the waiver approach would be inappropriate to resolve legal conflicts of M.E.As. and the G.A.T.T./W.T.O. On this point Cf. E. U. Petersmann, International and European Trade and Environmental Law after the Uruguay Round, (1996) p. 43.

14 'The breadth and complexity of the issues covered by the Committee's Work Programme shows that future work needs to be undertaken on all items of its agenda, as contained in its report', the Singapore Ministerial Declaration, adopted on 13 December 1996. 
The Ozone Layer Régime and the GATT/WTO Trade Law Régime

Convention on the Law of Treaties (Section IV(A)). Section $V$ is then devoted to the main analysis of the relationship between G.A.T.T. Article XX and the global protection of the ozone layer under the Montreal Protocol.

\section{THE INTERNATIONAL RÉGIME FOR THE TRADE RESTRICTIONS OF C.F.Cs./O.D.Ss.}

A. The Background of the Montreal Ozone Layer Protocol's Article 4: Resolving the Problem of Non-Participation in the M.E.A. Régime

It is no exaggeration to say that most transboundary or global - or even purely domestic - environmental problems assume, to a greater or lesser extent, trade-related aspects. In other words, nowadays the nation state and its contemporary life-style could not eliminate direct or indirect dependence on the growing world trade system (i.e. 'interdependence'). 15

Yet, unlike the above-mentioned cases of species extinction (the 1973 C.I.T.E.S. régime) or illegal hazardous waste disposal (the 1989 Basel Convention régime), the ultimate cause of ozone depletion is not necessarily trade transactions in themselves at the bilateral, regional or international levels. C.F.Cs. or O.D.Ss. in themselves are neither directly harmful to human health nor natural resources shared by any particular countries. More correctly, it may be said that the restrictions of 'consumption' and production of C.F.Cs. or other O.D.Ss. within each state whether 'developed' or 'developing' - could be considered as the central and obvious cause of the stratospheric ozone depletion. 16

Nonetheless, it is only natural that, in order to control or limit the proliferation of ozone-depleting substances, members of the international ozone layer régime needed some kind of trade restrictions on the O.D.Ss. commonly used in the import/export of industrial products (see Introduction above). In other words, they therefore needed legally effective global strategies to surmount knotty problems of the so-called 'free-rider':17 in this respect, R. Snape refers to the undeniable fact that

\footnotetext{
15 'The World has become increasingly interdependent': see J. H. Jackson, The World Trading System: Law \& Policy of International Economic Relations, 2nd. edn. (1996) Chapter 1 esp.; idem (eds.) Legal Problems of International Economic Relations, 4th edn. (1995) Chapter 1 esp.

16 For a discussion see G.A.T.T. 'The 1990-91 GATT Report on International Trade', (1993) and Section V(D.1) below.

17 In general it means 'to try to make individual gains without contributing to the collective control of the resource'. See A. Enders and A. Porges, 'Successful
} 
'Trade measures are not ideal instruments of environmental policy, but they may often be the only policy options available' to environmentally motivated countries. 18

In concrete, it can be said that, without such trade restrictions, nonparties would simply increase their production as ozone parties gradually phase down their O.D.S. production, and it is possible that unrestricted imports from non-parties would impair the further development of C.F.C./O.D.S. substitutes. Furthermore, if industries using O.D.Ss. simply moved to non-parties and then manufacture such products for export to the parties, this would eventually nullify the environmental benefits of the Montreal Protocol régime. ${ }^{19}$ During the negotiation leading up to the 1987 Montreal Protocol, the United States therefore argued that 'Without restrictions on imports of ozone-depleting chemicals from non-parties, there would be a strong incentive for the development of 'pollution heavens'. 20

It cannot be emphasised too strongly that Article 4 T.R.E.Ms. are therefore likely to help accommodate much wider participation by sovereign states: the incorporation of the tough export/import restrictions in the Montreal Protocol is designed to prevent C.F.C.-producing countries and potential producers (developing states in particular staying outside the international régime for ozone) to gain market shares left behind by the parties to the Protocol. 21 Under the Montreal Protocol régime, possible 'free-riding' non-parties are wholly denied access to international markets

Conventions and Conventional Success: Saving the Ozone Layer' in K. Anderson and R. Blackhurst (eds.) The Greening of World Trade Issues, (1992) pp. 135 et seq.; Turner (eds.) Environmental Economics, (1994) pp. 215-16; A. C. Aman, 'The Montreal Protocol on Substances that Deplete the Ozone Layer: Providing Prospective Remedies Relief for potential Damage to the Environmental Commons', in F. Francioni and T. Scovazzi (eds.) International Responsibility for Environmental Harm, (1991) p. 192.

18 R. H. Snape, 'The Environment, International Trade and Competitiveness', in K. Anderson and R. Blackhurst (eds.) The Greening of World Trade Issues, (1992) pp. 7392 (emphasis added). But Cf. G.A.T.T. 'The 1990-91 GATT Report on International Trade'.

19 See R. Twum-Barima and L. Campbell, Protecting the Ozone Layer through Trade Measures, (1994) pp. 51-54; discussion paper submitted by the United States, 'GATT Considerations and the Ozone Protocol', (4 September, 1987).

20 Ibid. p. 1. See in more detail Chapter III(II.A) above.

21 It is pointed out, for instance, that the threat of economic sanctions by ozone régime members (such as the United States and the United Kingdom) against Korean exports seems to have influenced South Korea's 1992 decision to become a party to the Montreal Protocol régime. See D. Brack, International Trade and the Montreal Protocol, (1996) pp. 55-56; B. Kingsbury, 'The Tuna-Dolphin Controversy, The World Trade Organisation, and the Liberal Project to Reconceptualize International Law', 6 Y.bk.I.E.L. (1995) p. 29; R. Benedick, Ozone Diplomacy, (1998) p. 244. 
for C.F.Cs./O.D.Ss., although many of these controlled chemicals are today indispensable for high-technology industries, etc. Moreover, it is also worth noticing that non-parties are denied access to the 'best available, environmentally safe substitutes and related technologies' in the context of the Protocol's Financial Mechanism.22 On one view, Article 4 trade restrictions employed for the purposes of global ozone layer protection can be seen as environmental 'sanctions' against non-parties to the international legal régime for ozone. 23

For the reasons stated above, it seems right to say that Article 4 of the Montreal Protocol does not necessarily conform to the maxim pacta tertiis nec nocent nec prosunt. 24 Nevertheless, it is also true at the same time that because 'a treaty does not create either obligations or rights for a third State [ = a non-party $]$ without its consent', 25 in theory, the Montreal Protocol régime still cannot entirely prevent non-parties from legally producing any ozone-depleting chemicals. 26

\section{B. The Montreal Protocol's Article 4 and 'P.P.M.' related Arguments}

Such trade provisions had been contemplated since the first discussions on an expected protocol to the Vienna Ozone Convention. The fundamental structure of this article can be seen in a proposal by the United States of America. 27 The G.A.T.T. Secretariat - participating in the 1987 Montreal Protocol's negotiation 28 - rather favourably commented upon the expected

\footnotetext{
22 As for the Multilateral Ozone Fund see Chapter VI below.

23 On this point see A. Nadelmann, 'Global Prohibition Regime: The Evolution of Norms in International Society', 44 International Organizations, (1990), suggesting that political aspects of international régimes tend to reflect the economic/political interests of the powerful states e.g. the U.S.A. For a discussion see also Chapters I(III.B) \& V(VI) below.

24 See e.g. I. Sinclair, The Vienna Convention on the Law of the Treaties, (1984) p. 99 et seq.

25 The 1969 Vienna Convention on the Law of Treaties (Article 34). See also, I. Sinclair, The Vienna Convention on the Law of Treaties, (1984), pp. 98 et seq.; I. Brownlie, Principles of Public International Law, (1990), pp. 622-24; H. Fugita, International Law, vol. 1 (1992) pp. 82-89 (Japanese).

26 But, in reality, most newly developing countries (= Article 5 L.V.Cs.) - which do not have necessary technologies to produce C.F.Cs./O.D.S. related industrial products would have to decide to join the international ozone layer régime.

27 See UNEP/WG.167/CPR.7; Discussion paper by the United States 'GATT Considerations and the Ozone Protocol' (4 September 1987).

28 See Part II of Chapter III(II) above.
} 
The Ozone Layer Régime and the GATT/WTO Trade Law Régime

inclusion of Article 4 trade provisions in the ozone layer agreement (see further Section V(D) below). 29

The Montreal Ozone Protocol contains no restrictions on foreign trade between contracting parties, although the Ozone Protocol seems to conflict with the terms of the 1989 Basel Convention, about the shipment of controlled O.D.Ss. such as C.F.Cs. and halons. 30

Article 4 of the Protocol, however, requires contracting parties to prohibit international trade of O.D.Ss. with non-parties and/or non-treatycomplier. The global strategies prescribed by the Ozone Layer Protocol are:

(i) trade in controlled substances by parties with states that are not parties to the Protocol:

(ii) trade in products containing controlled substances:

(iii) trade in products produced with but not containing controlled substances, and;

(iv) the export of relevant technologies.

It is said that Article 4 'constitutes a highly sophisticated and well graduated scheme' (i.e. from O.D.Ss. themselves to products containing O.D.Ss. or products produced with O.D.Ss.). 31 Yet parties are not necessarily required to report on the implementation of this Article (see in detail Chapter V(VII.A.3) below).

The Montreal Ozone Layer Protocol (as amended in London, Copenhagen, Vienna and Montreal) envisages that, after January 1990, the import of major O.D.Ss. in Groups II and II of Annex A (i.e. C.F.Cs. and halons) from non-parties was to be totally banned (Article 4(1)), and import of O.D.Ss. in Annex B was also banned from January 1993 (Article $4(1$ bis $)$ ). Within one year of the date of entry into force of the 1992 Copenhagen Amendment (i.e. June 1994), imports of any controlled substances in Group II of Annex C such as hydrobromofluorocarbons from non-parties must be banned (Article 4(1ter)). Similarly, the import of the

29 See also R. Twum-Barima and L. Campbell, Protecting the Ozone Layer through Trade Measures, (1994) endnote no. 113.

30 See Decision V/24 and Decision VII/31. It is agreed, however, that recycled C.F.Cs. and halons meeting usable purity specifications prescribed by appropriate institutions (such as International Standards Organisation ('I.S.O.')) would not be considered as 'wastes' under the Basel Convention.

31 W. Lang, 'Trade Restrictions as a Means of Enforcing Compliance with International Environmental Law' in R. Wolfrum (ed.), Enforcing Environmental Standards: Economic Mechanisms as Viable Means? (1996) p. 270. In this respect, Prof. Lang argues that drafters of Article 4 were aware of the so-called G.A.T.T. 'necessity' argument. 
O.D.Ss. in Annex E (i.e. methyl bromide) was to be prohibited within one year of the date of the entry into force of the 1997 Montreal Amendment.

Article 4 of the Montreal Protocol also requires parties to ban the export of the O.D.Ss. in Annex A (from January 1993); O.D.Ss. in Annex B (from August 1993); ODSs in Annex C (from June 1995) and; O.D.Ss. in Annex E (one year after the entry into force of the 1997 Montreal Amendment). With regard to restrictions on products containing O.D.Ss. in Annex A, as required by Article 4(3), the 1991 Third Ozone Meeting of the Parties adopted a list as Annex D to the Protocol. 32

Further, it is important to notice that Article 4(4) of the Protocol provides that the parties shall determine the feasibility of banning or restricting the import of products produced with, but not containing, controlled O.D.Ss. from non-parties to the Protocol.33 The 1993 Fifth Meeting of the Parties in Bangkok adopted in this respect a decision which states 'it is not feasible to impose a ban or restriction on the import of such products [i.e., products produced with, but not containing, controlled substances] under the Protocol at this stage'. ${ }^{34}$ This means that the risk of a complaint as to the use of P.P.Ms. as trade barriers has therefore been greatly diminished - or even 'vanished'.35 Yet some developed countries

32 Products contain (i) automobile and truck air conditioning units, (ii) domestic and commercial refrigeration and air conditioning/heat pump equipment, (iii) aerosol products, except medical aerosols, (iv) portable fire extinguisher, ( $v$ ) insulation boards, panels and pipe covers and (vi) pre-polymers. Regarding this issue the 1985 Vienna Ozone Meeting adopted Decision VII/32 ('Control of Export and Import of Products and Equipment Containing Substances Listed in Annexes A and B of the Montreal Protocol' in UNEP/OzL.7/12, p. 43). For a comprehensive analysis see D. Brack, International Trade and the Montreal Protocol, (1996) pp. 46-47.

33 See also Articles (4bis) \& (4ter), amended in London and Copenhagen. Ozonedepleting substances such as C.F.C.-11 and C.F.C.-113 used as solvents for cleaning semiconductor chips are related to such environmental P.P.Ms. During the Montreal Protocol negotiation Japan initially insisted that C.F.C.-113 should be excluded from the list of controlled substances since it is indispensable for the technology of manufacturing computers. However, since it was finally decided through the Montreal negotiations that parties can organise lexible reduction schedule within each of the two classes of controlled substances (i.e. C.F.Cs. and halons), Japan's objection was resolved (see Chapter III(III.B.3) above). Enders and Porges suggest that products produced with but not containing C.F.Cs. amount to sixteen per cent of world trade. See A. Enders and A. Porges, 'Successful Conventions and Conventional Success: Saving the Ozone Layer', in K. Anderson and K. Blackhurst, The Greening the World Trade Issues, (1992) p. 132.

34 See Decision V/17 in UNEP/OzL.Pro.5/12. See also D. Brack, International Trade and the Montreal Protocol, (1996) pp. 48-49; E. U. Petersmann, International and European Trade and Environmental Law after the Uruguay Round, (1996) p. 43..

35 W. Lang, 'Trade Restrictions as a Means of Enforcing Compliance with International Environmental Law' in R. Wolfrum (ed.) Enforcing Environmental Standards, (1996) p. 273. 
such as Finland have banned the import of certain products containing or made with C.F.Cs (Decree no. 891 of 24 September 1992). Finland has given notification of this decision in accordance with G.A.T.T. rules. 36

G.A.T.T. Article XX environmental exceptions are generally applicable to 'like products'37 that directly address characteristics of products, and not the production or processing of products ('P.P.M.') 38 in the exporting countries. This argument is primarily based on G.A.T.T. Article III, which imposes the national treatment obligation on domestic taxes or standards applied to imports. Article III(4) reads:

'The products of the territory of any contracting party imported into the territory of any other contracting party shall be accorded treatment no less favourable than that accorded to like products of national origin in respect of all laws, regulations and requirements affecting their internal sale, offering for sale, purchase, transportation, distribution or use'. 39

In the view of some legal authors, since Article 4(4) of the Montreal Ozone Layer Protocol is closely related not only to the characteristics of products but also to the methods used in P.P.Ms., such measures are therefore in breach of the related G.A.T.T. obligations. 40 Assuming that products which use C.F.Cs. in the production process are not distinguishable from products using other 'ozone safe' P.P.M., we could say that they would fall in the 'like

36 See R. Twum-Barima and L. B. Campbell, Protecting the Ozone Layer through Trade Measures: Reconciling the Trade Provisions of the Montreal Protocol and the Rules of the GATT, (1994) p. 104.

37 In the G.A.T.T. law there is no precise definition of this term. The meaning of the word 'like product' would be clarified only in a concrete context. See J. H. Jackson, World Trade and the Law of GATT, (1969) pp. 259 et seq.; V. Rege, 'GATT Law and Environment-Related Issues Affecting the Trade of Developing Countries', 28 J.W.T. (1994) pp. 159-62: G.A.T.T. Guide to GATT Law and Practice, 6th edn. (1994) p. 35. See also the Panel Report on 'Japan - Custom Duties, Taxes and Labelling Practices on Imported Wine and Alcoholic Beverages', B.I.S.D. 34S/83, para. 5.6.

38 On this theme see in particular, M. Schlagenhof, 'Trade Measures Based on Environmental Processes and Production Methods', 30 J.W.T. (1995) pp. 123-55; T. J. Schoenbaum, 'International Trade and Protection of the Environment', 91 A.J.I.L. (1997) pp. 288-301; S. Murase, Perspectives from International Economic Law on Transnational Environmental Issues, 253 Hague Recueil (1995) pp. 336 et seq.

39 G.A.T.T. Panel frequently offers interpretations of G.A.T.T. Article III: see e.g. the Italy-Discrimination Against Imported Agricultural Machinery', adopted October 23 1958, B.I.S.D. 7S/60; 'United States-Section 337 of the Tariff Act of 1930', adopted November 7 1989, B.I.S.D. 36S/345.

40 See e.g. M. Schlagenhoff, 'Trade Measures Based on Environmental Process and Production Methods', 30 J.W.T. (1995) pp. 147 et seq. 
products' concept of the G.A.T.T. 41 With regard to the G.A.T.T. case law, it is worth noting that the Tuna Panels distinguished between a regulation regarding product characteristics and a regulation related to a production process. Significantly, the Panels held that Article III covered the former, but not the latter. 42 Perhaps supporters of the G.A.T.T. Panel decisions may argue that restrictions on international trade with products produced with (but not containing) controlled substances are by no means 'necessary' trade-related environmental measures.

Under paragraph (5) of Article 4, each party undertakes to the 'fullest practicable extent' to discourage the export to any non-parties to the Protocol of technology for producing and utilising controlled substances in Annexes A, B, C (Group II) and E. Article 4 of the Protocol also requires parties to discourage the export of technology for producing and for utilising controlled substances (Article 4(5)), and to refrain from providing new subsidies, aid, credits, guarantees or insurance for the export to non-parties of products, equipment, plants or technology which would facilitate the production of controlled substances (Article 4(6)). However, it should be noticed that certain exceptions are allowed for products, equipment, plants or technology that could improve the containment, recovery, recycling or destruction of controlled substances, promote the development of alternative substances, or otherwise contribute to the reduction of emissions of these controlled substances (Article 4(7)).

Article $4 \mathrm{~A}$ provides that where a party is unable to cease production of O.D.Ss. for domestic consumption, it shall ban the export of used, recycled and reclaimed quantities of the O.D.Ss., other than for the purpose of destruction: this paragraph applies 'without prejudice to the operation of

41 See Ibid., pp. 148 et seq.; A. Enders and A. Poegers, 'Successful Conventions and Conventional Success: Saving the Ozone Layer' in Anderson and Blackhurst (eds.) Greening World Trade Issues, (1992) pp. 134 et seq. It can be also assumed that such P.P.M. might invite discrimination in certain elements of trade competitiveness, such as low labour costs. See 'Relationship between Environmental Agreements and Trade and Development Instruments', p. 488.

42 'United States-Restrictions on Imports of Tuna' (i.e. 'Tuna case II'), reproduced in 30 I.L.M. (1991) p. 1594, paras. 5.8-5.9; 'United States-Restrictions on Imports of Tuna' (i.e. 'Tuna case I'). B.I.S.D. 39S/155, reproduced in 33 I.L.M. (1994) p. 839, paras. 5.11-15. Provided tuna imports from Mexico were polluted, unsafe, or harmed humans or animals, there is little question that the United States could impose a regulation that is practically equal to that imposed on their own products. However, the United States' prohibition of imports of tuna and its product caught by vessels of Mexico was based on humanitarian considerations, i.e. incidental killing of dolphins that is caused by the use of 'purse sein nets' in fishing for tuna. The panel said that such incidental taking of dolphin could not possibly affect tuna as a product'. 
Article 11 of the Convention and the non-compliance procedure developed under Article 8 of the Protocol' (Article 4A(2)). Finally, it is also decided that, by January 2000 or within three months of the date of entry into force of the 1997 Montreal Amendment, each party shall establish and implement a system for licensing the import/export of new, used, recycled and reclaimed O.D.Ss. in Annexes A, B, C and E (Article 4B).

\section{THE G.A.T.T./W.T.O. TRADE LAW}

The G.A.T.T./W.T.O. trade law, consisting of substantive, procedural and institutional rules, is the specialised branch of international economic law, which is part of public international law. 43 It is often argued in legal literature that the G.A.T.T./W.T.O. has its own flexible 'jurisprudence' and in a certain sense the trade law régime may be seen as a 'self-contained system' in the context of general international law. 44 However, strictly speaking, the question whether the G.A.T.T./W.T.O. (trade law) is selfcontained or not depends largely on the particular context in which the term 'self-contained' is used. 45 It is important to note that recent reports by the panels and the W.T.O. Dispute Settlement Body frequently refer to the customary international law rules codified in the 1969 Vienna Convention on the Law of Treaties (e.g. the U.S. Standards for Gasoline case). 46

\section{A. The G.A.T.T./W.T.O. Trade Law}

To put it plainly, the central aim of the G.A.T.T./W.T.O. law is to encourage the world trading system. In this regard the G.A.T.T./W.T.O. is vitally

\footnotetext{
43 See Y. Iwasawa, WTO Dispute Settlement (1994) Chapter 2 p. 16 (Japanese), noting the so-called 'constitutional functions' of 'International Economic Law' within nation states. See also E. U. Petersmann, Constitutional Functions and Constitutional Problems of International Economic Law, (1991) cited in ibid. footnote no. 12. On the term 'International Economic Law' see in general J. H. Jackson, The World Trading System, 2nd edn. (1997) pp. 25-26; M. Matsushita, International Economic Law, (1988) pp. 1-6 (Japanese).

44 See P. J. Kuyper, 'The Law of GATT as a Special Field of International Law', 25 N.Y.bk.I.L, (1994) pp. 227-57. On the concept of 'self-contained' régimes see Chapter I(IV) above.

45 Y. Iwasawa, WTO Dispute Settlement, (1994) Chapter 6 p. 161 \& its endnote 355 (Japanese). See also the D.S.U. (Article 3(2)), saying that 'The Members recognise that it [i.e. the W.T.O.'s settlement system] serves . . to clarify the existing provisions of those agreements in accordance with customary rules of interpretation of public international law' (emphasis added).

46 See Section IV(A) below.
} 
important in creating a degree of certainty for international traders. The G.A.T.T. 47 is the principal multilateral treaty for trade in goods supported by a series of over two hundred agreements, protocols, process-verbaux and statements. It is often said that 'only ten people in the world understand it [i.e., G.A.T.T.], and they are not telling anybody.' 48

It is certain that environmental protection was not regarded as a serious 'international' issue when the G.A.T.T. trade law was drafted in the post-war periods. Therefore, as with the U.N. Charter, ${ }^{49}$ it contains no explicit reference to (global) environmental issues. Rather, the original negotiators were concerned largely with free trade law instruments that are designed to promote 'better relations among nations', i.e. world peace that is based on economic well-being. 50

\section{B. The Governing Economic Principles of the G.A.T.T. Law}

G.A.T.T. law is designed to regulate multilateral trade mainly by reducing tariffs and other barriers to trade, and by using the principle of the (unconditional) 'most-favoured-nation treatment' ('M.F.N.'). 51 The G.A.T.T.

47 The 1994 Uruguay Round Agreement established the World Trade Organisation (W.T.O.) as a successor to the G.A.T.T.: the W.T.O. thus incorporated the G.A.T.T. 1947 and the 'G.A.T.T. 1994' was thus newly established. The G.A.T.T. 1994 is legally distinct from G.A.T.T. 1947 (General Agreement on Tariffs and Trade, opened for signature 30 October 1947: see Chapter I(I)). To be precise, once all contracting parties to the G.A.T.T. 1947 have become Members of the W.T.O. Agreement, the G.A.T.T. 1947 could be considered to be terminated and states would be governed exclusively by the W.T.O. Agreement (a country joining the W.T.O. is to adhere to all and not just one or some of its agreements). Even if one argues that the G.A.T.T. 1947 would not be terminated, it would remain applicable only to the extent that it is compatible with the W.T.O. Agreement. However, a country which is a signatory of the G.A.T.T. 1947 and which chooses not to join the W.T.O. would remain a contracting party of the G.A.T.T. 1947. See Article II(4) of the Agreement Establishing the W.T.O. See also Y. Iwasawa, WTO Dispute Settlement, (1994) pp. 6-7 (Japanese); G. Marceau, 'Transition from GATT to WTO: A Most Pragmatic Operation', 29 J.W.T. (1995) pp. 150-51.

48 Statement by a American jurist, Gardner cited in A. Cassese, International Law in a Divided World, (1986) p. 340. In this respect see also Y. Iwasawa, WTO Dispute Settlement, (1994) Chapter 1 p. 2 \& its footnotes no. 8-9 (Japanese). As to the complexities of G.A.T.T. Articles see in particular J. H. Jackson, World Trade and the Law of GATT, (1969) Chapter 1 esp.

49 On this issue see P. Birnie 'Environmental Protection and Development', 20 Melbourne U.L.R. (1995) pp. 66-67.

50 W. J. Davey, 'The WTO/GATT World Trading System: An Overview' in Handbook of GATT, pp. 10-11.

51 Article I reads 'any advantage, favour, privilege or immunity granted by any contracting party to any product originating in or destined for any other country shall be accorded immediately and unconditionally to the like product originating in or destined for the territories of all other contracting parties' (Article I(1), emphasis 
The Ozone Layer Régime and the GATT/WTO Trade Law Régime

trade law therefore obliges contracting parties to treat other G.A.T.T. members at least as well as it treats any other country with regard to imports or exports. In other words, G.A.T.T. contracting parties are to accord non-discriminatory treatment to goods coming from the territories of other contracting parties. In addition, the principle of legal 'reciprocity' forms the basis of this M.F.N. treatment. 52

It is interesting to note that the International Law Commission ('I.L.C.') once observed that the legal principle of the M.F.N., which has existed over several centuries, 53 is not an established rule of customary international law: this means that the principle of the M.F.N. must be based specifically on bilateral/multilateral economic treaty law. ${ }^{4}$ In this respect, distinguished international (trade) lawyers, Georg Schwarzenberger and John H. Jackson take a similar view. 55

To take a shortsighted and surface view of the Ozone Layer Protocol, the restrictions on international trade with 'free-riding' non-parties under Article 4 of the legal ozone régime seem to be in breach of the principle of the 'multilateral' M.F.N., simply because it provides that trade with nonparties must be banned or more severely restricted than trade between states parties. 56

The G.A.T.T. trade law further provides that imports shall be treated no worse than domestically produced goods under internal taxation or regulatory measures ( 'National Treatment on Internal Taxation and Regulation': Article III). ${ }^{57}$ Its general purpose is to ensure that

added). See e.g. G. Schwarzenberger, The Frontiers of International Law, (1962) pp. 225-26: idem, 'The Most-Favoured-Nation Standard in British State Practice', 22 B.Y.bk.I.L. (1945) pp. 96-121: J. H. Jackson, The World Trading System, (1989), Chapter 6: 'The Most-Favoured-Nation Clause', 2 J.W.T. (1968) pp. 581-86. See also 'Belgium-Family Allowances', adopted on 7 November 1952, B.I.S.D. 1S/59.

52 There are two types of reciprocity, however: discriminatory and nondiscriminatory. The former is concerned chiefly with bilateral agreements.

53 See G. Schwarzenberger, 'The Most-Favoured-Nation Standard in British Practice', 22 B.Y.bk.I.L. (1945) pp. 96-121.

54 See S. Zamora, 'Is There Customary Economic Law?', 32 G.Y.bk.I.L. (1989) p. 29 \& its footnote no. 97.

55 See e.g. G. Schwarzenberger, 'Equality and Discrimination in International Economic Law', 25 Yearbook of World Affairs, (1971) p. 163: J. H. Jackson, The World Trading System, (1989) p. 23 \& p. 134.

56 See e.g. U.N.E.P. The Use of Trade Measures in Selected Multilateral Environmental Agreements, (1995) p. 79.

57 See 'W. J. Davey, 'The WTO/GATT World Trading System: An Overview' in Handbook of GATT, pp. 28-35; G.A.T.T. Guide to GATT Law and Practice, 6th edn. (1994) pp. 116 et seq. See also 'United States-Taxes on Petroleum and Certain Imported Substances', adopted 17 June 1987, B.I.S.D. 34S/136. However, Part II (Article III-XXIII) of the 
The Ozone Layer Régime and the GATT/WTO Trade Law Régime

taxes/regulations are not imposed to afford protection to the domestic industries of the importing country. The 1973 C.I.T.E.S.'s import/export ban based on a finding of detriment may be regarded as the violation of both the M.F.N. principle and the principle of national treatment, provided that the parties fail to regulate domestic or internal consumption. 58

In the context of environmental protection, what has to be noted is that G.A.T.T. Article XI provides for the general elimination of quantitative restrictions ('Q.Rs.'). ${ }^{59}$ It has been suggested that this provision is the subject of more G.A.T.T. dispute panel reports than any other. 60 Many international trade lawyers have pointed out that M.E.As. with global trade controls that distinguish between parties to the agreements and nonparties, such as the Montreal Ozone Layer Protocol, the 1989 Basel Convention and the 1973 C.I.T.E.S., might violate the general prohibition against quantitative restrictions provided in G.A.T.T. Article XI. This is a point to which we shall return later.

G.A.T.T. Article XVI deals with subsidies which are tolerated if they do not harm the export interests of other countries. 61 Some commentators point out that the Montreal Multilateral Fund, 62 which provides 'environmental subsidies' for developing country parties, may be in violation of a basic G.A.T.T. principle that aims to eliminate subsidies as undesirable barriers to international trade. 63

Generally speaking, the newly established W.T.O. deals with not only tariff barriers but non-tariff barriers to foreign trade, subsidies, trade in services, intellectual property and other trade policies. The W.T.O. trade law includes: (i) the Agreements on Trade in Goods (this includes G.A.T.T. 1994); (ii) the Agreement on Trade in Services (G.A.T.S.); (iii) the Agreement on Trade-related Aspects of Intellectual Property Rights including trade in

agreement is subject to 'grandfather rights'. See e.g. J. H. Jackson, (1995) pp. 300301; idem, World Trade and the Law of GATT, (1969) Chapter 12.

58 See footnote no. 5 above.

59 See Section V(A) below. On this theme see e.g. G.A.T.T. Guide to GATT Law and Practice, 6th edn. (1994) pp. 287 et seq.: J. H. Jackson, World Trade and the Law of GATT, (1969) Chapter 13; T. Murray and I. Walter, 'Quantitative Restrictions, Developing Countries, and GATT', 11 J.W.T. (1977) pp. 391-421.

60 W. J. Davey, 'The WTO/GATT World Trading System: An Overview' in Handbook of GATT, pp. 41-42.

61 See in general W. J. Davey, 'The WTO/GATT World Trading System: An Overview' in Handbook of GATT, pp. 59-62 \& its footnote no. 201.

62 See Chapter VI below.

63 S. N. Carlson, 'The Montreal Protocol's Environmental Subsidies and GATT: A Needed Reconciliation', 29 Texas I.L.J. (1994). Cf. R. Twum-Barima and L. Campbell, Protecting the Ozone Layer through Trade Measures, (1994) pp. 77-79. 
counterfeit goods (T.R.I.Ps.) ${ }^{64}$; (iv) the Understanding on Rules and Procedures Governing the Settlement of Disputes (1994 W.T.O. Understanding 'D.S.U.'); and (v) the Trade Policy Review Mechanism.65

However, these W.T.O. obligations are subject to many exceptions. G.A.T.T./W.T.O. members could justify the breach of the principles of the G.A.T.T./W.T.O. trade law by relying on them. 66 Examples of those exceptions include: (i) the waiver authority of Article XXV para. 5; (ii) the escape clause of Article XIX that specifies conditions of emergency action on imports of particular products; (iii) Article XII-XIV addressing balance of payments problems; (iv) Article XXIV relating to customs unions and free trade areas; and (v) Article XX and Article XXI, mainly dealing with general exceptions for national health and safety regulations and national security.

The point to observe here is that some of these G.A.T.T. exceptions are directly or indirectly related to the protection of the ozone layer. For reasons that we shall go into later, it seems reasonable to suppose that, as far as the Montreal Ozone Layer Protocol is concerned, its T.R.E.Ms. for O.D.Ss. could be justified on grounds of G.A.T.T. Article XX exception(s).

\section{The G.A.T.T. Case-Law67}

With regard to the G.A.T.T. case-law, Professor Shinya Murase has observed that '[I]n studying an instrument such as GATT, we should take "common law approach" rather than "legalist" or "management" approaches, as was

64 The T.R.I.Ps. (Article 27(2)) is concerned with the Biodiversity Convention (Article 16: Access to and Transfer of Technology).

65 See in more detail G.A.T.T., The Results of the Uruguay Round of Multilateral Trade Negotiations: The Legal Texts, (1994); E. U. Petersmann, The GATT/WTO Dispute Settlement System, (1997) Chapter 1(5); J. H. Jackson (eds.) Legal Problems of International Economic Relations, 3rd edn. (1995) Chapter 6(3).

66 See also J. H. Jackson, World Trade and the Law of GATT, (1969) Chapters $21 \& 28$ esp.; B. Kingsbury, 'Environment and Trade: The GATT/WTO Regime in the International Legal System' in A. Boyle (ed.), Environmental Regulation and Economic Growth, (1994) pp. 217-19.

67 The G.A.T.T. case law regarding environmental matters include e.g. 'United StatesRestrictions on Imports of Tuna' (i.e. 'Tuna case I'), not adopted, B.I.S.D. 39S/155 reproduced in 30 I.L.M. (1991) p. 1594; 'United States-Restrictions on Imports of Tuna' (i.e. 'Tuna case II'), not adopted, D.S.29/R reproduced in 33 I.L.M. (1994) p. 839; 'Thailand-Restrictions on Importation of and Internal Taxes on Cigarettes', adopted on 7 November 1990, B.I.S.D. 37S/200; 'United States-Prohibition of Imports of Tuna and Tuna Products from Canada', adopted on 22 February 1982, B.I.S.D. 29S/91; 'CanadaMeasures Affecting Exports of Unprocessed Herring and Salmon', adopted on 22 March 1988, B.I.S.D. 35S/98; 'United States-Standards for Reformulated and Conventional Gasoline', adopted on 20 May 1996, WT/DS2/29. These cases are briefly summarised in E. U. Petersmann, The GATT/WTO Dispute Settlement System, (1997) Chapter 3. 
once mentioned by Dr. Frieder Roessler, then Director of the GATT Legal Office. The reality of the GATT law cannot be well understood by simply reading the statutes. . Rather, the GATT law is largely an accumulation of panel findings that leads to the continuous development of substantive GATT law'.68 In a sense, G.A.T.T./W.T.O. panel decisions that have evolved in its legal system could be regarded as 'subsequent practice in the treaty which establishes the agreement of the parties regarding its interpretation' stated in the 1969 Vienna Convention on the Law of Treaties. 69

In addition, it should be pointed out that the reasoning advanced by reports of the G.A.T.T./W.T.O. dispute settlement panels or the D.S.B. does not necessarily apply to future transnational disputes over the G.A.T.T./W.T.O., simply because, in principle, these precedents do not produce a legally binding effect. Yet, just like other national and international tribunals, G.A.T.T./W.T.O. panels frequently refer to the previous panel decisions with a view to resolving trade disputes. ${ }^{70}$

It is interesting to note that, in the Japan Alcohol Taxes case of 4 October 1996, by rejecting the view of the Panel that adopted panel reports 'constituting subsequent practice in the specific case', the Appellate Body described panel reports as 'an important part of the GATT acquis', creating 'legitimate expectations among WTO members': ${ }^{71}$ this seems to fall short of the 'subsequent practice' principle and thus indicates that the Body may wish to retain some flexibility in G.A.T.T. case law. ${ }^{72}$

Lastly, it should be noted that the 1994 Agreement provides that 'The Ministerial Conference and the General Council shall have the exclusive

68 See S. Murase, Perspectives from International Economic Law on Transnational Environmental Issues, 253 Hague Recueil (1995) p. 329. See also Y. Iwasawa, WTO Dispute settlement, (1994) pp. 3 \&18 (Japanese).

69 See further Y. Iwasawa, WTO Dispute Settlement, (1994) pp. 138 et seq. (Japanese)

70 See J. H. Jackson, The World Trading System, 2nd edn. (1997) p. 122, noting that 'A common-law lawyer would find himself very much at home in GATT legal discussions'. W. Davey notes in this respect that reports by the new Appellate Body will often be relied upon by future panels and effectively constitute 'fairly stable body of precedent'. W. J. Davey, 'The WTO/GATT World Trading System' in Handbook of GATT, pp. 19-20.

71 See the discussion in 'Japan-Taxes on Alcoholic Beverages', adopted on 1 November 1996, WT/DS8, 10 \& 11/AB/R, Section E.

72 Thus its decision disagreed with the above-mentioned view of Prof. Murase. Cf. W. J. Davey, 'The WTO/GATT World Trading System: An Overview' in Handbook of GATT, p. 20. Cf. E. U. Petersmann, The GATT/WTO Dispute Settlement System, (1997) pp. 111-17. 
The Ozone Layer Régime and the GATT/WTO Trade Law Régime

authority to adopt interpretations of this Agreement and of the Multilateral Trade Agreement'.73

\section{THE LEGAL CONFLICTS BETWEEN M.E.As. AND THEG.A.T.T./W.T.O. TRADE LAW}

In Chapter I(IV) above, it is argued that the international régime for ozone is a multilateral treaty of a unique erga omnes character: however, does this mean at the same time that contracting parties to the ozone layer régime - most of the members are also contracting parties to the G.A.T.T./W.T.O. law - can completely ignore G.A.T.T./W.T.O. trade law obligations that are also widely accepted in the international community? In order to effectively 'operate' erga omnes, they would have to minimise (at least) expected legal conflicts in the 'practice' of public international law of the environment (this is the so-called 'bridge-building' between environment and trade law régimes ${ }^{74}$ ).

It is also important to note that, apart from the ozone layer régime, most M.E.As. do not have such legal character erga omnes. ${ }^{75}$

A. The Legal Conflicts Between M.E.As. and the G.A.T.T./W.T.O. Trade Law

In the 1996 panel report on U.S. Standards for Gasoline, the W.T.O. Appellate Body noted that Article 31 of the 1969 Vienna Convention on the Law of Treaties 'forms part of the "customary rules of interpretation of public international law"' and that the G.A.T.T. law 'is not to be read in clinical isolation from public international law'. ${ }^{76}$ The 1969 Treaty for treaties has therefore proved in practice relevant to the international trade law of a highly technical character. ${ }^{77}$

\footnotetext{
73 Article IX(2), (emphasis added).

74 See W. Lang, 'Is the Protection of the Environment a Challenge to the International Trading System?', Georgetown I.E.L.R. 7(1995) pp. 463-83.

75 See W. Lang, 'International Environmental Agreements and the GATT: The Case of the Montreal Protocol', 3-4 Wirtschaftspolitische Blatter (1993) p. 371, noting that 'drafters of environmental treaties should be invited to consider/reconsider the trade impact of certain measures written into the respective instruments'.

76 See the discussion in 'United States-Standards for Reformulated and Conventional Gasoline' (the Venezuela Gas case), adopted on 20 May 1996, WT/DS2/AB/R, Section B. 77 In this respect see also Y. Iwasawa, WTO Dispute Settlement, (1995) p. 117 esp.; E. U. Petersmann, The GATT/WTO Dispute Settlement, (1997) pp. 111 et seq.; J. H. Jackson, The World Trading System, 2nd edn. (1997) p. 127.
} 
The Ozone Layer Régime and the GATT/WTO Trade Law Régime

Legal principles and rules provided for in the 1969 Vienna Convention on the Law of Treaties supply basic guidelines on problems posed by successive treaties or incompatible treaties concerned with the same subject matter. It may be said that the T.R.E.Ms. provided for in the Montreal Ozone Layer Protocol and the G.A.T.T. deal with such 'same subject matter' of international trade restrictions of certain goods (i.e. controlled C.F.Cs. and O.D.Ss.).

Article 30 of the 1969 Vienna Convention lays down (i) the hierarchical principle and the principles of (ii) lex prior and (iii) lex posterior: 78

1. Subject to Article 103 of the Charter of the United Nations, the rights and obligations of States parties to successive treaties relating to the same subject-matter shall be determined in accordance with the following paragraphs.

2. When a treaty specifies that it is subject to, or that it is not to be considered as incompatible with, an earlier or later treaty, the provision of that other treaty prevail.

4. When the parties to the later treaty do not include all the parties to the earlier one; (a) as between States parties to both treaties the same rule applies as in paragraph 3 [that is, the earlier treaty applies only to the extent that its provisions are compatible with those of the later treaty];

(b) as between a State party to both treaties and a State party to only one of the treaties, the treaty to which both States are parties governs their mutual rights and obligations.

The principle of lex specialis - i.e. more specific treaties take priority over earlier ones - is also important in this context (note: it is not provided for in Article 30). ${ }^{79}$ In addition, we should notice here that the decision as to which treaty is the earlier depends on the date of adoption, and not that of its entry into force.

78 See I. Sinclair, The Vienna Convention on the Law of Treaties, (1984) pp. 96-98.

79 Ibid. p. 96. 
Table no. III: THE RELATIONSHIP BETWEEN M.E.As. AND THE G.A.T.T./W.T.O. TRADE LAW 80

COUNTRY 'A' IS A PARTY TO:

\begin{tabular}{|c|c|c|c|c|c|}
\hline \multirow{3}{*}{$\begin{array}{c}\text { COUNTRY } \\
\text { 'B' IS A }\end{array}$} & & MEAs & WTO & MEAs+WTO & [Non-Party] \\
\hline & \multirow{2}{*}{$\begin{array}{l}\text { MEAs } \\
\text { WIO }\end{array}$} & $\mathrm{X} 1$ & $\mathrm{X} 2$ & $\mathrm{X} 3$ & - \\
\hline & & $\mathrm{X} 4$ & $\mathrm{X} 5$ & $\mathrm{X6}$ & - \\
\hline \multirow[t]{2}{*}{ PARTY TO: } & MEAs+WTO & $\mathrm{X} 7$ & $\mathrm{X} 8$ & X9 & - \\
\hline & [Non-Party] & - & - & - & - \\
\hline
\end{tabular}

As the Table III illustrates, types of potential trade-environmental disputes multiply enormously. Furthermore, the number of both M.E.As. and independent sovereign states is likely to grow in the international community. With regard to the Ozone Layer Protocol, since most of the members of the ozone layer régime are also parties to the G.A.T.T./W.T.O., it may safely be assumed that the potential legal conflicts are likely to happen in the case of $X 9$, rather than $\mathrm{X} 2$ or $\mathrm{X} 4.81$ In this connection, Professor E. U. Petersmann submits the following three legal situations: (i) disputes between W.T.O. members over the W.T.O. consistency of M.E.A. trade measures accepted by both parties to the disputes, (ii) disputes between W.T.O. members over the W.T.O. consistency of M.E.A. trade measures accepted by only one party and (iii) disputes between W.T.O. members over trade measures not specifically regulated in M.E.As. 82

Before the establishment of the W.T.O., under Article 30 of the 1969 Vienna Convention on the Law of Treaties, the international ozone treaties were given priority over G.A.T.T. 1947 obligations for those states that are parties to both agreements. Therefore, those treaty provisions that were likely to be violations of the G.A.T.T. principles generally formed exceptions to the rules (see Table III: X2, X7 and X9). It thus meant that only if the G.A.T.T. parties were not parties to the 1985 Vienna Convention and

80 See N. Iwata, 'Environmental Problems and Trade Disputes in the WTO System', 6 Trade Journal, (1996) p. 50 (Japanese).

It assumed that the countries are parties to both G.A.T.T. 1994 and the W.T.O. Agreement. In X1, X3 and X7, parties should refer to M.E.As. In X5, X6 and X8, parties can settle disputes by referring to the G.A.T.T./W.T.O. law. In X2 and X4, it is actually difficult to rely on either M.E.As. or G.A.T.T./W.T.O. law. See the 1969 Vienna Convention on the Law of Treaties (Article 30 (4)).

81 Yet it may be true that, as Canada pointed out in a meeting of the WTO Committee on Trade and Environment, disputes between parties and non-parties had the potential to become a more important issue. PRESS/TEO08.

82 E. U. Petersmann, The GATT/WTO Dispute Settlement System, (1997) pp. 132-34. 
The Ozone Layer Régime and the GATT/WTO Trade Law Régime

the Montreal Ozone Protocol (see Table III: X4, X5, X8 or 'Non-Party'), they were allowed to hold prior rights to the G.A.T.T. incompatible provisions.

However, in 1994 the W.T.O. formally incorporated the G.A.T.T. 1947 (see Section III(A) above). The 'G.A.T.T. 1994' was thus newly established and CONTRACTING PARTIES (not 'Members' as such) effectively withdraw from the original 'G.A.T.T. 1947'. They formally became 'members' of the 'G.A.T.T. law 1994'. In this context it would be possible to argue that the situation has been completely reversed. This means that the 1994 G.A.T.T./W.T.O. law now prevails over all earlier M.E.As. in accordance with the principle of lex posterior (see Table III: X6, X8 and X9).

Nevertheless, it should also be noted - as I strongly emphasised in this thesis - that international environmental treaty régimes have a dynamic character - just like the international ozone layer régime, they are in many cases subject to periodic review, future amendments and adjustments that may be often extensive. 83 It is for this reason that Conferences/Meetings of the Parties have played a central role in the development of international environmental régimes (see Chapter $\mathrm{I}(\mathrm{I})$ and Chapter II(III.D.2)).

In conclusion, it is not to be denied that conflicts between the G.A.T.T./W.T.O. legal régime and M.E.A. régimes cannot be easily solved by traditional legal principles such as lex prosterior or lex specialis, just mentioned above. ${ }^{84}$ A simple example will be that, whilst M.E.A. provisions allowing trade restrictions are certainly more 'specific' and 'technical' than G.A.T.T. Article XX environmental exceptions, it is also certain that these environment-related exceptions must be read in context together with other relevant rules of the G.A.T.T./W.T.O. trade law régime. 85 In addition, as exceptional cases, some treaty rules contained e.g. in the Agreement on Technical Barriers to Trade (i.e. 'T.B.T.') or other G.A.T.T./W.T.O. law instruments can be more specific than the T.E.R.Ms. contained in M.E.A.s. ${ }^{86}$

83 See Chapter I \& Part I of Chapter III(IV.C-F) esp. above.

84 The same opinion is expressed in R. G. Tarasofsky, 'Ensuring Compatibility between MEAs and GATT/WTO', 7 Y.bk.I.E.L. (1996) p. 65.

85 On this point see e.g. 'United States-Standards for Reformulated and Conventional Gasoline', adopted on 20 May 1996, WT/DS/AB/R, Section B ('relating to the conservation of exhaustible natural resources').

86 See ibid., p. 63. 
The Ozone Layer Régime and the GATT/WTO Trade Law Régime

As Professor W. Lang observes, it will be true that:

'[T]rade and environment disputes in general would probably need some special kind of overarching jurisdiction in which the different legal regimes [i.e. ozone and G.A.T.T. régimes] could be considered together and applied in a balanced way'. 87

B. The Relationship Between M.E.A. Dispute Settlement Procedures and the W.T.O. Dispute Settlement System: the Montreal N.C.P. or the W.T.O. Dispute Settlement Procedures?

There are many problems as to a legal hierarchy between M.E.A. dispute settlement procedures and the W.T.O. dispute settlement system. 88

\section{(1) General Discussions}

Some commentators argue, for instance, that potential legal conflicts between M.E.As. and the G.A.T.T./W.T.O. should be decided in their entirety by an authoritative international tribunal, e.g. the International Court of Justice ('I.C.J.'). 89 It has been suggested that seeking an Advisory Opinion from the I.C.J. would be 'attractive especially as regards systematic problems'.90

It is generally agreed in a limited political forum, i.e. the C.T.E., that an environment-related trade dispute between an M.E.A. party and an M.E.A. non-party that is a member of the W.T.O. should be addressed by a W.T.O. dispute settlement panel. 91 It is certain that when parties to a W.T.O. trade dispute are also M.E.A. parties, their right to the W.T.O. dispute

\footnotetext{
87 W. Lang, 'Trade Restrictions as a Means of Enforcing Compliance with International Environmental Law' in R. Wolfrum (ed.) Enforcing Environmental Standards, (1996) p. 282.

88 For a comprehensive discussion of the G.A.T.T./W.T.O. settlement system, see from among a considerable literature, Y. Iwasawa, WTO Dispute Settlement, (1995), Japanese; E. U. Petersmann, The GATT/WTO System: International Law, International Organisations and Dispute Settlement, (1997).

89 As with the cases of M.E.As., however, disputes involving the G.A.T.T./W.T.O. law has so far never been brought to the I.C.J. See J. H. Jackson, The World Trading System, 2nd edn. (1997) p. 124; Y. Iwasawa, WTO Dispute Settlement, (1995) Chapter 3 p. 55 \& its footnotes no. 95-97 (Japanese).

90 See R. G. Tarasofsky, 'Ensuring Compatibility between MEAs and GATT/WTO', 7 Y.bk.I.E.L. (1996) p. 71.

91 See 'WTO Trade and Environment Bulletin', No. 3 (22 May 1995).
} 
settlement system is not to be denied. ${ }^{92}$ However, it is important to note that at the C.T.E., a number of countries have argued that (i) the W.T.O. settlement procedures should not be overburdened, and (ii) the M.E.A. dispute settlement process should be 'exhausted' before a dispute is brought to the W.T.O.'s settlement mechanism. 93

(2) The Formal N.C.P. or the W.T.O. Dispute Settlement Procedures?

To discuss all the questions submitted by the W.T.O. legal adviser Professor E. U. Petersmann is certainly beyond the scope of this doctoral thesis, having as it does the limited purposes stated in the Introduction. 94 However, as many delegations at the C.T.E. meetings suggested, it might be ideal that environment-related disputes (e.g. between W.T.O. members which are M.E.A. parties or non-parties) should first be dealt with by M.E.A. dispute settlement procedures, thus not by the more 'judicial' W.T.O. settlement mechanism, 95 particularly if the M.E.A. contains a flexible dispute settlement procedure, i.e. the non-compliance procedure ('N.C.P.').

Only two points are noted here in the context of the non-compliance régime of the Montreal Protocol type (Article 8/Decisions). ${ }^{96}$ :

In the first place, it can be possible to argue that the settlement of M.E.A./W.T.O. related trade disputes by the formal non-compliance procedure would be 'politically' feasible. 97 In the Montreal N.C.P. model, non-parties to the M.E.A. 98 - particularly non-parties in non-compliance with the T.R.E.Ms. - are likely to be allowed to participate in the meetings of

92 In this context, at the Third Meeting of the W.T.O.'s C.T.E., some delegations - such as Columbia - suggested that W.T.O. Members had to maintain their right of submitting to the W.T.O. dispute settlement mechanism any conflicts which might arise as a result of an environmental measure (PRESS/TEO08). See also E. U. Petersmann, The GATT/WTO Dispute Settlement System, (1997) pp. 132-33.

93 In this connection, the delegations of Norway rightly observe that the issue of nonparties could be problematic, especially if dispute settlement procedures of M.E.As. were insufficient - efficient dispute settlement mechanisms should be developed within M.E.A. régimes. See PRESS/TE008.

94 See E. U. Petersmann, The GATT/WTO Dispute Settlement System, (1997) pp. 132 34.

95 This means that the formal N.C.P. presently has many political aspects, rather than judicial ones (see 'Russia's Non-Compliance Case' in Chapter V(VIII) below).

96 See in detail Chapter $\mathrm{V}$ below.

97 Cf. R. G. Tarasofsky, 'Ensuring Compatibility between MEA and GATT/WTO', 7 Y.bk.I.E.L. (1996) pp. 70-71.

98 That is, even in case of disputes between W.T.O. members over the W.T.O. consistency of a particular M.E.A.'s provisions for trade accepted by only one party. 
the standing Implementation Committee. 99 Constructive discussions within this international conciliation body could potentially contribute to amicably settling/avoiding this kind of T.R.E.M.-related dispute.

As a precondition, in order to supply the internally specialised institutions of the ozone régime with impartial and workable advice, the U.N.E.P. Ozone Secretariat - as a group of technical experts - should mutually co-operate with the W.T.O. Secretariat and other secretariats of international institutions in various fields. Undeniably, the Ozone Secretariat is not necessarily expert in questions of international economic law rules such as the G.A.T.T./W.T.O. trade law. 100 In this connection, Switzerland suggested at the C.T.E. that 'Many conflicts between MEAs and WTO rules could be prevented if co-operation existed between trade and environment officials at the national and international level, and a cooperation mechanism should be concluded between the WTO and competent MEA bodies, based on reciprocity which applied, inter alia, to observer status and information exchange'.101 Several countries including Japan take a similar view. 102

In the second place, although this will be arguable, the law of the G.A.T.T./W.T.O. is still 'ill-equipped' for settling 'amicably' increasing global environmental problems today. In this sense, the legal tools that a W.T.O. dispute settlement panel may employ so as to approach environmental matters are still severely limited. Certainly, the 'basic sources' of G.A.T.T./W.T.O. law will be the General Agreement, the 1994 Uruguay Understandings on the General Agreement and Side Agreements. ${ }^{103}$ In a meeting of the C.T.E., the United States argued the 'necessity'104 of trade measures in M.E.As. was best determined by M.E.A. negotiators, and the W.T.O. did not have the technical competence to determine whether other

99 In case of the Montreal N.C.P., although observers (e.g. environmental N.G.Os.) are currently not allowed to participate in the meetings of the ImCom (see Chapter V(IV.B.2.b), non-parties to the Protocol (e.g. Czech and Slovak Federal Republic) in reality participate in such political forums (see UNEP/OzL.Pro/ImpCom/3/3, para. 4).

100 It is important that the U.N.E.P. Secretariat is invited as an observer to meetings of the W.T.O. Committee on Trade and Environment.

101 PRESS/TEO10 (Item 1). See also WTO Trade and Environment Bulletin, no. 3 (22 May 1995).

102 'The Relationship between Trade Measures Pursuant to MEAs and the WTO Agreement' (WT/CTE/W/31, May 1996), proposal by Japan.

103 W. J. Davey, 'The WTO/GATT World Trading System: An Overview' in Handbook of GATT, pp. 18-21.

104 See Section V(A) below. 
The Ozone Layer Régime and the GATT/WTO Trade Law Régime

measures that are 'reasonably available' to achieve the same objectives of M.E.As. meet the M.E.A. objectives. 105

However, it must be noted at the same time that, provided that a trade-related environmental dispute is to be dealt by the W.T.O. Expert Review Groups, which is provided for in Appendix 4 of the 1994 W.T.O. Understanding (i.e. 'D.S.U.'/Annex 2), would contribute greatly to resolving such a technical question. 106 Moreover, Article 13 of the W.T.O. Understanding states that W.T.O. panels shall have the right to seek useful information and technical advice from any individual or body - which might be environmental experts (e.g. M.E.A. Secretariats) ${ }^{107}$ and they may also seek information from any relevant source (e.g. N.G.Os). In the 1990 case 'Thailand-Restrictions on Importation of and Internal Taxes on Cigarettes', the Panel sought some specialist advise from the W.H.O. on the health risks of smoking on the effectiveness of non-discriminatory tobacco-control strategies. ${ }^{108}$

To summarise, it is my opinion that (i) the N.C.P. régime would be a reasonable starting point. From the above, however, it still cannot be denied that (ii) possible conflicts between M.E.As. and the G.A.T.T./W.T.O. (e.g. trade measures applied against non-parties) should be addressed caseby-case (through dispute settlement of M.E.As., including the N.C.P. and/or the W.T.O.).

Moreover, (iii) in the present case of the international ozone treaties, provided that the new Montreal N.C.P. proved too 'soft' or ineffective, it is still possible that traditional dispute settlement procedures under Article 11 of the 1985 Vienna Ozone Convention (see Chapter II(III.D.4)) could also be applied to Article 4-related environmental ozone disputes (see Chapter V(III.B) \& V(VI) below).

\footnotetext{
105 PRESS/TEOO8.

106 It is provided that '[p]articipation in expert review groups shall be restricted to persons of professional standing and experience in the field in question' (Appendix 4(3): emphasis added).

107 On the role of the M.E.A. Secretariat see Chapter II(III.D.3) above.

108 E. U. Petersmann, International and European Trade and Environmental Law after the Uruguay Round, (1996) p. 39.
} 


\section{G.A.T.T. ARTICLE XX AND THE GLOBAL PROTECTION OF THE OZONE LAYER UNDER THE MONTREAL PROTOCOL RÉGIME}

\section{A. The Exceptions Under G.A.T.T. Articles XI(1) and XX}

G.A.T.T. law exceptions - which were usually provided for in bilateral trade agreements 109 - are largely based on a proposal made by the United States of America. The travaux préparatoris of Article $\mathrm{XX}$ is not necessarily helpful in clarifying the exact meaning of these G.A.T.T. exceptions. 110 Yet, it must be noted at the outset that the treaty drafting history is only a 'supplementary means of interpretation' (Articles 31 \& 32 of the 1969 Vienna Convention on the Law of Treaties). 111

In order to eliminate trade barriers between parties to the international economic régime, G.A.T.T. Article XI(1) in general prohibits the use of quotas or other quantitative limitations on exported or imported products. Article XI(1) provides:

'[N]o prohibitions or restrictions other than duties, taxes or other charges, whether made effective through quotas, import or export licences or other measures shall be instituted or maintained by any contracting party on the importation of any product of the territory of any other contracting party or on the exportation or sale for export of any product destined for the territory of any other contracting party (emphasis added).'

However, exceptions are permitted under G.A.T.T. Article XI(2), inter alia, for temporary prohibitions or restrictions applied to prevent or relieve critical shortages of other products essential to the exporting contracting parties (see section B below). We can find here striking similarities in

109 In this respect see T. J. Schoenbaum 'Free International Trade and Protection of the Environment: Irreconcilable Conflicts?', 86 A.J.I.L. (1992) p. 711, pointing out that 'The text apparently derived from the kinds of exceptions traditionally written into bilateral treaties of friendship, commerce and navigation'.

110 For a discussion of drafting history of G.A.T.T. Article XX, see G.A.T.T. Guide to GATT Law and Practice, 6th edn. (1994), pp. 519 et seq.: S. Charonvitz, 'Exploring the Environmental Exceptions in GATT Article XX', 25 J.W.T. (1991) pp. 38-47; J. H. Jackson, World Trade and the Law of GATT, (1969) Chapter 28.

111 Cf. J. H. Jackson, The World Trading System, 2nd edn. (1997) p. 122. 
Articles 30 and 34 of the E.C. Treaty that generally prohibit quantitative restrictions and all measures having equivalent effects on imports. 112

Article XX contains general exceptions to the G.A.T.T. trade law régime. As we will see, Article XX exceptions are closely related to possible 'adverse effects'113 caused by the depletion of the ozone layer. Article XX states that:

"Subject to the requirement that such measures are not applied in a manner which would constitute a means of arbitrary or unjustifiable discrimination between countries where the same conditions prevail, or a disguised restriction on international trade, nothing in this Agreement shall be construed to prevent the adoption or enforcement by any contracting party of measures: (emphasis added)"

(b) necessary to protect human, animal or plant life or health; ...

(f) imposed for the protection of national treasures of artistic, historic or archaeological value;

(g) relating to the conservation of exhaustible natural resources if such measures are made effective in conjunction with restrictions on domestic production or consumption ....114

Any such restrictions, to be permitted under Article XX, must not be applied in a manner which would constitute (i) a means of arbitrary discrimination (between countries where the same conditions prevail) or (ii) unjustifiable discrimination (with the same qualifier) or (iii) a disguised restriction on international trade. 115 It has been suggested that

112 For a discussion see E. U. Petersmann, International and European Trade and Environmental Law after the Uruguay Round, (1996) pp. 64-71.

113 See Chapter II(III.A) above.

114 See 'United States-Standards for Reformulated and Conventional Gasoline' adopted on 20 May 1996, WT/DS/R, Sections D \& G. The Tuna Panel II ('United StatesRestrictions on Imports of Tuna', D.S.29/R) stated that Article XX (b) and (g) adjudication should follow a three step process:

1. Whether the policy underlying the trade measure at issue fit within the range of policies meant to conserve exhaustible natural resources and whether the policy was made effective in conjunction with domestic restrictions.

2. Whether the trade measure was "related to" the conservation of exhaustible natural resources.

3. Whether the measure conformed to the Article XX headstone.

115 Preamble ("Chapeau"). See 'United States-Standards for Reformulated and Conventional Gasoline', adopted on 20 may 1996, WT/DS2/AB/R, Section IV; G.A.T.T. Guide to GATT Law and Practice, 6th edn. (1994) pp. 519-21; J. H. Jackson, World Trade and the Law of GATT, (1969) p. 743.

Likewise, Principle 12 of the 1992 Rio Declaration states that: 
this introductory paragraph of G.A.T.T. Article XX - 'whose legal meaning had never before been convincingly and precisely clarified in GATT panel practice 116 - was inserted in order to prevent abuse of possible general exceptions of Article XX.

It is generally observed that Article XX(b) focuses on the use of sanitary measures to safeguard life or health of humans, animals or plants within the jurisdiction of the importing states. 117 It is interesting to note here that during the Geneva Session of the Preparatory Committee it was agreed to delete from the New York draft of paragraph (b) the phrase 'if corresponding domestic safeguards under similar conditions exist in the importing country'. 118 The term 'necessary' under G.A.T.T. Article XX(b) has been strictly interpreted, and parties invoking Article XX are therefore faced with a number of hurdles before their claims of exception to the G.A.T.T. obligations will be accepted. 119 For a treaty provision to be 'necessary', there must be 'no alternative measure consistent with the General Agreement, or less inconsistent with it, which [a country] could reasonably be expected to employ to achieve its health policy objectives'.120

'States should cooperate to promote a supportive and open international economic system that would lead to economic growth and sustainable development in all countries, to better address the problems of environmental degradation. Trade policy measures for environmental purposes should not constitute a means of arbitrary or unjustifiable discrimination or a disguised restriction on international trade'.

116 E. U. Petersmann, The GATT/WTO Dispute Settlement System, (1997) pp. 114 et seq.; T. J. Schoenbaum, 'International Trade and Protection of the Environment', 91 A.J.I.L. (1997) p. 274. Cf. 'United States-Standards for Reformulated/Conventional Gasoline', WT/DS2/AB/R, Section IV, noting that '[t]he text of the chapeau is not without ambiguity, including one relating to the field of application of the standards its contains'.

117 See the Tuna Panel II, para. 5.27. See further Section D below.

In this respect, we may recall, again, that Article 36 of the E.C. Treaty allows Member State to adopt measures restricting the free movement of goods for the purpose of protecting a series of non-economic values such as public morality, public policy, public security and protection of human health, animals and plants. See e.g. R. Griffith, 'International Trade Treaties and Environmental Protection Measures', 1 R.E.C.I.E.L. (1992) pp. 26-27; M. Wheeler, S. Weatherill and P. Beaumont, EC Law, (1993) Chapters 16 \& 17; 'Greening the EEC Treaty' in P. Sands, (1993) pp. 89 et seq.

118 See further G.A.T.T. Guide to GATT Law and Practice, 6th edn. (1994) p. 521. Cf. the interpretation of Article XX(d) in 'United States-Section 337 of the Tariff Act of 1930', adopted on 7 November 1989, B.I.S.D. 36S/345, para. 5.26.

119 Recent G.A.T.T. cases have defined this term to mean 'least G.A.T.T.-inconsistent'. See 'Thailand-Restrictions on Importation of and Internal Taxes on Cigarettes', adopted on 7 November 1990, B.I.S.D. 37S/200; 'United States-Prohibition of Imports of Tuna and Tuna Products from Canada', adopted on 22 February 1982, B.I.S.D. 29S/91; 'Canada-Measures Affecting Exports of Unprocessed Herring and Salmon', adopted on 22 March 1988, B.I.S.D. 35S/98.

120 'Thailand-Restrictions on Importation of and Internal Taxes on Cigarettes', (emphasis added). 
The Ozone Layer Régime and the GATT/WTO Trade Law Régime

Article XX thus generally establishes the following legal requirements: ${ }^{121}$

(i) Trade measures must avoid arbitrary or unjustifiable discrimination between countries where the same conditions prevail;

(ii) Trade measures must not be a disguised restriction on international trade;

(iii) The purpose of the import or export bans must be for one of the purposes listed in G.A.T.T. Article XX and;

(iv) The measures invoking an Article XX exception must be necessary for the purpose in question.

Next, we will examine whether the trade restrictions against non-parties under the Montreal Protocol régime comply with these stringent requirements.

B. G.A.T.T. Article XI(2) Exceptions and the Montreal Ozone Layer Protocol

As has been suggested, though certain exceptions are permitted under G.A.T.T. Article XI, they are not particularly applicable to the trade controls of ozone-depleting substances. As in the Japanese Agricultural Restriction case, ${ }^{122}$ the Article XI(2) exceptions - which are designed essentially for agricultural products - have been very strictly construed. ${ }^{123}$

First, trade measures under Article 4 of the Montreal Protocol are by no means 'temporary prohibitions' in the context of Article XI(2.a). Second, O.D.Ss. are not 'foodstuffs'. In addition, controlled substances (e.g. C.F.Cs. and specified halons) would not be 'essential', since there already exist some substitutes available for these chemicals. 124 Third, the (stratospheric) ozone layer as the 'C.C.M.'125 does not come under the

121 See in detail Sections B-E.

122 'Japan-Restrictions on Imports of Certain Agricultural Products', adopted on 22 March 1988, B.I.S.D.35S/163, partly reproduced in J. H. Jackson (eds.), Legal Problems of International Economic Relations, 3rd edn. (1995) pp. 355-56.

123 J. H. Jackson (eds.) Legal Problems of International Economic Relations, 3rd edn. (1995) p. 423; W. J. Davey 'The WTO/GATT World Trading System: An Overview' in Handbook of GATT, pp. 44-45.

124 See e.g. U.N.E.P. 1991 Assessment Report of the Technology and Economic Assessment Panel, (December 1991, Final); Chapter 1 above.

125 See Chapter II(III.B) above. 
category of tradable products. 126 Further, the Montreal Protocol's trade measures are not 'necessary to the application of standards or regulations for the classification, grading or marketing of commodities in international trade' (G.A.T.T. Article XI(2.b)).

C. The Preamble Conditions for G.A.T.T. Article XX Exceptions and Article 4 of the Montreal Protocol Régime: Compliance with the Terms of the "Chapeau"

As to the question whether trade measures discriminate on justifiable and nonarbitrary bases, it can be said that the Montreal Protocol's T.R.E.Ms. are not arbitrary discrimination and at the same time, have not disguised trade restrictions on international trade. The M.E.A. ozone régime commonly set up guiding purposes in their legal texts and the foreign trade restrictions of controlled O.D.Ss. are by no means unpredictable. ${ }^{127}$ In addition, just as the United States suggested during the negotiation of Article 4, terms of the T.R.E.Ms. are clear, open and environmentally-motivated. ${ }^{128}$ If the country applying the import ban was acting with the intention of protecting human health or other related issues as listed in G.A.T.T. Article $\mathrm{XX}(\mathrm{b})$ - thus not seeking to protect its own O.D.S. production - this cannot be seen as disguised restrictions. 129

The same logic could apply in the cases of the 1973 C.I.T.E.S. and the 1989 Basel Convention. 130

Further, we can be fairly certain that cogent scientific evidence contributes to eliminating such arbitrary or unjustifiable discrimination between countries. It is also important to notice that a precautionary environmental 'principle' or approach (see Chapter II(III.C)) approved by many environmental agreements is in many cases subject to careful

126 Baker argues that '[t]he ban is certainly being applied to prevent a critical shortage of an item, ozone, that is essential to the CFC exporting country'. See B. Baker, 26 Vanderbilt J.T.L. (1993) p. 449.

127 U.N.E.P. The Use of Trade Measures in Selected Multilateral Environmental Agreements, (1995) p. 83. As we have seen, such legitimate environmental purposes can be observed in 'General Obligations' or 'Fundamental Principles' of these international treaties (see Chapter II(III.D.1) above).

128 See 'GATT Considerations and the Ozone Protocol' (discussion paper by the United States, 4 Spetember, 1987).

129 See P. M. Lawrence, 'International Legal Regulation for Protection of the Ozone Layer: Some Problems of Implementation', 2 J.E.L. (1990) p. 39.

130 See U.N.E.P., The Use of Trade Measures in Selected Multilateral Environmental Agreements, (1995) Chapters 6 \& 5 . 
periodic reviews of trustworthy data produced by scientists and their scientific institutions.

A question arises, however, as to the application of the environmental measures, T.R.E.Ms.: the Montreal Ozone Layer Protocol once encountered judicious criticism from the G.A.T.T. Secretariat for claiming a clear distinction between parties and non-parties. ${ }^{131}$ However, it is nevertheless possible to argue that under G.A.T.T. Article XX, trade discrimination would be legally permissible provided it does not take place between countries 'where the same conditions prevail'.132 The ozone drafters therefore inserted the following provision to ensure compatibility between Article 4 of the Montreal Protocol and the G.A.T.T. rule:

'Notwithstanding the provisions of this Article, imports referred in [this Article] and exports referred in [this Article] may be permitted from, or to, any State not Party to this Protocol, if that State is determined, by a meeting of the Parties, to be in full compliance with Article 2, Article 2A to $2 \mathrm{E}$ and this Article, and have submitted data to that effect as specified in Article $7 \cdot .133$

It must be noted that this provision allows export to non-parties and thus tactfully suggests that the Montreal Ozone Layer Protocol draws a distinction between treaty compliers - whether they are parties to the Protocol or not - and noncompliers, rather than parties and nonparties. 134 In other words, a state's membership or formal status is not the ozone régime's paramount concern. Of course, non-parties to the Ozone Protocol régime can avoid this discrimination so far as they would apply the Article 2 production/'consumption' restrictions provided by the Montreal Protocol. In the light of the fact that non-parties, which seek

131 For the same reason, the 1973 C.I.T.E.S. and the 1989 Basel Convention were also criticised as discriminatory. See the 1989 Basel Convention(Article 4(5)).

132 See UNEP/WG.167/2, p. 22.

133 The Montreal Protocol (Article 4(8)), emphasis added. Likewise, trade provisions of the 1973 C.I.T.E.S. would be justified unless non-parties to the treaty substantially conform to the C.I.T.E.S. and supply comparable documentation (Article X).

However, it was pointed out during the negotiation of the Montreal Protocol that 'If the Protocol were to provide for such a year-by-year escape . ..., this would be a powerful incentive for states not to join the Protocol. The Protocol would be weakened from an institutional standpoint, and its environmental benefits would be nullified or impaired'. See 'GATT Considerations and the Ozone Protocol' (discussion paper by the United States, Spetember 4, 1987).

134 See also UNEP/Trade/IEA/1/7, para. 13 g, cited in W. Lang, 'Trade Restrictions as a Mean of Enforcing Compliance with International Environmental Law' in R. Wolfrum (ed.) Enforcing Environmental Standards, (1996) p. 281. 
special permission for exportation or importation, are required to submit to the U.N.E.P. Ozone Secretariat scientific and technical data on their O.D.S. production 135 imports and exports of O.D.Ss., it seems reasonable to suppose that they may wisely decide to ratify the Montreal Protocol in order to regain lost markets.

Unlike the Montreal Protocol régime, the 1989 Basel Convention régime has adopted trade measures that clearly distinguish between parties and non-parties, rather than treaty-compliers and non-compliers, such a restriction is not fully compatible with the one Preamble condition of G.A.T.T. Article XX. 136

In addition, it could be pointed out that the differences between production costs in countries accepting and not accepting reductions in production and use of O.D.Ss. could make them countries where the 'same conditions' do not prevail. 137 Moreover, it would be possible to argue that, unlike parties to the Ozone Layer Protocol, non-parties are not subject to the N.C.P. régime of the Montreal Protocol - this would also support the argument that the same conditions do not prevail between parties and nonparties. ${ }^{138}$ Yet, as the U.N.E.P. Ozone Secretariat suggests, if the Meeting of the Parties decides to take a countermeasure as listed in the N.C.P. régime i.e. suspension of Protocol privileges'139 - then the 'same condition' would then prevail. ${ }^{140}$

135 See the discussion on non-parties' compliance in Chapter V(VII) below.

136 Whilst trade restrictions of the Basel Convention raise a number of serious G.A.T.T./W.T.O. issues, in practice parties to the treaty would seem more likely to conclude appropriate bilateral agreements under Article 11 than to initiate a G.A.T.T./W.T.O. challenge.

137 Such differences in production costs soared by the M.E.A. compliance would be a matter of foreign trade competition. However, it is pointed out that 'it is impossible to distinguish between the sort of cost difference. . . and that caused, for example, by differences in the minimum wage'. It is interesting to note that if 'different conditions' under G.A.T.T. Article XX contain environmental law in different countries, the 'internationalisation of environmental costs' would grow. This does not require an amendment of Article XX. See R. Buckley, 'International Trade, Investment and Environmental Regulation: An Environmental Perspective', 27 J.W.T. (1993) p. 132.

138 See U.N.E.P. The Use of Trade Measures in Selected Multilateral Environmental Agreements, (1995) pp. 81-82.

139 See Chapter V(IV.B.3.a) below.

140 In this respect see B. Kingsbury, 'Environment and Trade: The GATT/WTO Regime in the International Legal System' in A. E. Boyle (ed.) Environmental Regulation and Economic Growth, (1994) p. 207, noting that 'Question as to whether the same conditions exist and, if so, what forms of discrimination would be arbitrary or unjustified, are potentially problematic, particularly as in some cases the onus of demonstrating that a measure is justified under Article XX appears to rest on the party relying on it'. 
The Ozone Layer Régime and the GATT/WTO Trade Law Régime

With regard to the 1973 C.I.T.E.S. régime, Wold plausibly argues that restrictions on trade with non-parties under the C.I.T.E.S. would not discriminate between countries where the same conditions prevail as far as parties to the environmental treaty, which comply with substantive provisions of the C.I.T.E.S., operate under a strict régime affecting their economy and trade. 141

D. G.A.T.T. Article XX(b) and the Global Protection of the Ozone Layer

It must be noted at the outset that during the negotiation of the 1987 version of the Montreal Ozone Layer Protocol, the G.A.T.T. Secretariat said that 'such an article on control of trade would be in order in accordance with article XX paragraph (b) of the G.A.T.T. concerning the protection of human, animal or plant life or health'.142

Added to this, there is fairly general agreement that Article 4 T.R.E.Ms. of the Montreal Protocol régime seem to qualify for the exception under Article XX(b) due to growing threats to human, animal and plant life and health from the severe depletion of the stratospheric ozone layer.

(1) The Montreal Protocol's Article 4 is 'Necessary' to Protect Human Health and the Environment: G.A.T.T. Article XX(b) and Modern International Law of the Environment

As we have seen in Chapter II(III.A) \& the Introduction above, degradation of the ozone layer would result in injury not only to the health of human beings but also to the ecosystem as a whole. 143 The global protection of the ozone layer is indispensable for maintenance of human health. In this connection, it is worth noting that, as the 1994 Final Report of the SubCommission (so-called the 'Ksentini Report') asserts '[a]ll persons have the right to freedom from pollution, environmental degradation and activities that adversely affect the environment, threaten life, health, livelihood,

141 See C. Wold, 'The Conservation on International Trade in Endangered Species of Wild Fauna and Flora' in U.N.E.P. The Use of Trade Measures in Selected Multilateral Environmental Agreements, (1995) pp. 178-80 \& pp. 190-92.

142 Yet it should be noted that the G.A.T.T. Secretariat stressed that the final judgement as to whether the action proposed satisfied Article XX lay with the G.A.T.T. contracting parties themselves. See UNEP/WG.172/2, p. 18. See also UNEP/167/2, p. 22; E. U. Petersmann, 'International Trade Law and International Environmental Law: Prevention and Settlement of International Environmental Disputes in GATT', 27 J.W.T. (1993) pp. 74 et seq.

143 See Chapter II(III.A) above. 
well-being or sustainable development within, across or outside national boundaries'. 144

As was described earlier, scientific uncertainty regarding ozone observations was already settled after the adoption of the 1987 Montreal Protocol (see Chapter III(IV.A)). Surely, this will lessen to a great extent the ozone régime members' burden of proof that G.A.T.T. Article XX applies to their environmental legal régime. The 'principle' of sound scientific evidence would not be used as opposed to the ozone régime's precautionary approach. ${ }^{145}$ In addition, it is particularly important to note that - as E. U. Petersmann rightly observes 146 - since all G.A.T.T. contracting parties have recognised the customary law rule of Stockholm Principle 21/Rio Principle 2 (see Chapter II(III.C.1)), the rule of international environmental law must be taken into account in interpreting the G.A.T.T. law rules. Viewed from this perspective, the parties to the Protocol could argue collectively or individually that Article 4 trade restrictions would protect human, animal and plant life at the domestic levels. The global protection of the stratospheric ozone is a matter of no small concern to each country in the international community and therefore the trade control régime is 'necessary' to protect parties' own environments.

Article 4 T.R.E.Ms. of the Montreal Protocol régimes could therefore be justified or exempted under G.A.T.T. Article $\mathrm{XX}(\mathrm{b})$ as 'necessary' environment-related trade measures that are consistent with the G.A.T.T. law. Likewise, it is also possible to argue that trade restrictions of endangered species of wildlife under the 1973 C.I.T.E.S. are also 'necessary' in order to protect the life and health of animals and plants listed in the Appendixes. These measures would fall within the category of G.A.T.T. Article XX(b).

An expected opposing argument will be that - as T. J. Schoenbaum $\operatorname{argued}^{147}$ - the principal purpose of the Montreal Protocol's Article 4

144 U.N. Document, E/CN.4/Sub.2/1994/9 (6 July 1994), reprinted in A. E. Boyle, 'The Role of International Human Rights Law in the Protection of the Environment' in A. E. Boyle (ed.) Human Rights Approaches to Environmental Protection, (1996) pp. 65-69.

145 It is worth noting that in the meeting of the C.T.E., one W.T.O. member suggested that the principle of a sound scientific basis for environmental measures should be used as opposed to the precautionary principle. See PRESS/TEO10 (Item 2). On the precautionary 'principle'/approach see Chapter II(III.C.2.b) above.

146 E. U. Petersmann, 'The Settlement of International Environmental Disputes in GATT and EEC' (F.I.E.L.D. London Conference, 23 April 1993) p. 12 footnote no. 19.

147 See T. Schoenbaum, 'Free International Trade and Protection of the Environment: Irreconcilable Conflicts?', 86 A.J.I.L. (1992) p. 720; M. Schlagenhof, (1995) p. 149. Cf. E. Petersmann, 'International Trade and International Environmental Law: 
T.R.E.Ms. is only to incite non-parties to join the ozone layer regime and therefore this could be done by other available means including financial/technical assistance through the Protocol's Financial Mechanism. While the ozone layer regime's stated purpose has been 'to protect human health and the environment against adverse effects' (see Chapter II(III) above), it seems difficult to deny, however, that Article 4 trade provisions as collective 'sanctions' specifically aim to secure states' participation. ${ }^{148}$ In this similar vein, the 1990-91 G.A.T.T. Report on International Trade suggests that 'the parties to the Montreal Protocol on Chlorofluorocarbons (CFCs) could have structured the Protocol in such a way that it reduced consumption of CFCs in the participating countries by the target amount, without the necessity of including provisions for special restrictions on trade with non-parties'. 149

But, it is still unlikely that these economic measures constitute 'reasonably available alternatives' to the Protocol's Article 4 restrictions, which are, as we have seen, skilfully drafted so as to prevent potential 'free-riders' in the international community of over 190 states. Though seen as less inconsistent with the G.A.T.T., they cannot be arguably 'alternative measures' in the context of ozone protection: after exhausting 'all options reasonably available' to the parties to the Protocol, ozone would be completely depleted and all states in the international community would then be subject to cumulative adverse effects.

(2) Environmental Objectives of the International Legal Ozone Régime are Widely Recognised by the International Community

It is also important to note that more than one hundred and sixty states are now parties to the 1987 version of the Montreal Protocol and the 1985

Prevention and Settlement of International Environmental Disputes in GATT', J.W.T. p. 76.

148 See Section II(A) above. In this respect see also Chapter V, footnote no. 229.

149 The G.A.T.T. Report advocates, for instance, a proposal to impose taxes on the consumption of C.F.Cs.; '[O]ne way would be to impose taxes on the consumption of CFCs, or quota on domestic consumption, implemented by a system of auctioned domestic sales licences which permitted the licence holder to buy from all potential suppliers, regardless of whether they are in a participating country. In either case, the scarcity value of the reduced amount of CFCs would accrue to the government (in the form of tax or auction receipts). Production of CFCs in participating countries could then be regulated by quotas set at the projected level of consumption in those countries' (cited in V. Rege, 'GATT Law and Environment-Related Issues Affecting the Trade of Developing Countries', J.W.T. p. 124); Cf. A. Enders and A. Porges, (1992) pp. 133 et seq. 
Vienna Ozone Layer Convention (see Appendix III). This could mean that the environmental objectives of the international ozone régime are now widely accepted in the international community (see also Chapter I(IV) above). Indeed, as the G.A.T.T. Secretariat says:

'GATT rules could never block the adoption of environmental policies which have broad support in the world community. . . What the rules do constrain is attempts by one or a small number of countries to influence environmental policies in other countries not by persuasion and negotiation, but by unilateral reductions in access to their markets'. 150

Perhaps one may notice here that this point is in line with Principle 12 of the 1992 Rio Declaration on Environment and Development. It states:

'Environmental measures addressing transboundary or global environmental problems should, as far as possible, be based on an international consensus. ${ }^{151}$

Similarly, the 1994 T.B.T. Agreement provides that technical regulations that are prepared, adopted, or applied in accordance with relevant international standards are rebuttably presumed not to create an unnecessary barrier to international trade. 152

In contrast, in the famous Tuna cases, ${ }^{153}$ the United States took a unilateral trade policy (i.e. embargo of tuna against Mexico) based on the Marine Mammal Protection Act ('M.M.P.A.'), which is national act based on P.P.M.154 standards (i.e. harvesting techniques), still lacking in widely obtained international support. Consequently, the G.A.T.T. Panels decided that such a trade embargo could not be justified under the exceptions in G.A.T.T. Article XX(b) or XX(g).

It is assumed that, should the United States apply the trade measure under the authority of a related international environmental agreement,

150 See 'Trade and the Environment' - a report prepared by the G.A.T.T. Secretariat, (1992). The final judgement of a bilateral dispute would depend on the contracting parties to the G.A.T.T./W.T.O., however (see Table III above).

151 U.N. Doc. A/CONF.151/5/Rev.1 (reprinted in 31 I.L.M. (1992) p. 878).

152 Article 2(5).

153 See panel reports on the Tuna cases I \& II reproduced in 30 I.L.M. (1991) p. 1594 \& 33 I.L.M. (1994) p. 839.

154 See Section below. 
the G.A.T.T. Panels might approve the G.A.T.T. Article XX exception(s). ${ }^{155}$ In this regard, at the meetings of the W.T.O.'s C.T.E., many government delegations repeatedly warned against the use of unilateral trade measures for environmental purposes, and indicated a general preference for multilateral approaches over any form of unilateral measures. ${ }^{156}$

E. G.A.T.T. Article XX(g) and the Protection of the (Stratospheric) Ozone Layer

As regards Article XX(g), since G.A.T.T. Article XX does not make reference to the term 'environment' itself - neither does the G.A.T.T./W.T.O. Agreements provide the definition of this term - it is debatable whether the protection of the (stratospheric) ozone layer falls into the category of 'exhaustible natural resources' in the context of the G.A.T.T. trade law. 157

It is said that - in the light of the drafting history of Article XX(g) 'natural resources' in question can be generally considered as 'resources of certain economic value rather than resources not exploitable economically in any shape or form'. ${ }^{158}$ Presumably, they include renewable flow resources (e.g. animals, plants and fisheries) as well as stock resources (e.g. 'like minerals'). 159 Given that, we may say that the protection of life and health of listed animals and plants under the 1973 C.I.T.E.S. is directly concerned with the 'exhaustible natural resources', and trade measures under the environmental treaty might cover the meaning of G.A.T.T. Article XX(g) exceptions. ${ }^{160}$ In the panel report on U.S. Standards for

\footnotetext{
155 See Tuna Panel I, para. 5.28. Cf. W. Shih, 'Multilateralism and the Case of Taiwan in the Trade Environment Nexus', 30 J.W.T. (1996) p. 131.

156 In the Trade and Environment Committee several delegations cautioned that 'only appropriate and effective manner with which to address transboundary environmental problems at the international level was through MEAs' (TEO06, 8 December 1995). On unilateralism in the context of environmental protection see e.g. I. Cheyne, 'Environmental Unilateralism and the WTO/GATT System', 24 Georgia J.I.C.L. (1995) pp. 433-65.

157 See P. M. Lawrence, 'International Legal Regulation for Protection of the Ozone Layer: Some Problems of Implementation', 2 J.E.L. (1990) p. 39.

158 See P. M. Lawrence, 'International Legal Regulation for Protection of the Ozone Layer: Some Problems of Implementation', 2 J.E.L. (1990) p. 39.

159 E-U. Petersmann, 'International Trade Law and International Environmental Law', 27 J.W.T. (1993) p. 70, footnote no. 55. See also S. Charnoviz, 'Exploring the Environmental Exceptions in GATT Article XX', 25 J.W.T. (1991) pp. 45-47. The Tuna case I (para. 5.26) \& the Tuna case II (para. 5.13).

160 U.N.E.P. The Use of Trade Measures in Selected Multilateral Environmental Agreements, (1995) pp. 181-82 esp.
} 
The Ozone Layer Régime and the GATT/WTO Trade Law Régime

Gasoline, the G.A.T.T./W.T.O. panel observed that clean air was an 'exhaustible natural resource' in the context of Article XX(g).161

In the context of ozone, we should take into account that the cumulative effects of stratospheric ozone loss on plants, including crops, animals and global climate could hinder the world's food production (see Introduction above). Theoretically speaking, the 'complete destruction' of the ozone layer - as Dotto and Schiff suggested with some emphasis - would result in 'the end of all life on earth'. 162 In this respect, although the stratospheric ozone in itself is free from any economic value, it may be possible to argue that 'policy' for ozone conservation would fall within the range of laws or policies regarding the conservation of 'exhaustible natural resources'. Article 4 restrictions would thus seem to qualify under Article XX(g). ${ }^{163}$ In this connection, one knowledgeable commentator on the G.A.T.T. law observes that the wording of the Article XX exceptions seem to address most trade-related environmental objectives. 164

Added to the above-mentioned requirement for an Article XX(g) environmental exception is, as stated in a panel report on Canada's Restrictions on Exports of Unprocessed Herring and Salmon, that a trade measure as to the conservation of natural resources must primarily be aimed at rendering effective restrictions on domestic production or consumption (i.e. 'effectiveness requirement'). ${ }^{165}$ Nevertheless, the ninety per cent of the protective ozone layer (i.e. 'stratospheric ozone shield') is located in the upper atmosphere area.

With regard to jurisdictional issues, the Panel in the Tuna I case decided that G.A.T.T. Article XX(b) and (g) had no application to natural resources located outside the jurisdiction of the trade-restricting state. 166 In this context, one commentator has observed that the C.I.T.E.S. régime

161 See WT/DS2/AB/R, para. 6.37, noting that 'a policy to reduce the depletion of clean air was a policy to conserve a natural resource within the meaning of Article $\mathrm{XX}(\mathrm{g})^{\prime}$ (emphasis added). See also WT/DS2/AB/R, Section B.

162 L. Dott and H. Schiff, The Ozone War, (1978) p. 2.

163 The same opinion is expressed in R. Twum-Barima and L. Campbell, Protecting the Ozone Layer through Trade Measures, (1994) p. 71.

164 E. U. Petersmann, 'International Trade Law and International Environmental Law: Prevention and Settlement of International Environmental Disputes in GATT', 27 J.W.T. (1993) p. 72.

165 B.I.S.D. 35S/98(1988) p. 114. See also Tuna Panel I, para. 5.31; 'United StatesStandards for Reformulated and Conventional Gasoline', WT/DS2/R, paras. 6.39-40. Cf. the 1996 U.S. Standards for Gasoline, WT/DS2/AB/R, Section B \& E. U. Petersmann, The GATT/WTO Dispute Settlement System, (1997) p. 116, noting that 'the term "relating to" need no longer be interpreted as "primarily aimed at"..

166 Tuna/ Dolphin Panel I, paras. 5.26 \& 5.31-32. 
The Ozone Layer Régime and the GATT/WTO Trade Law Régime

violates G.A.T.T. Article XI(1) due to trade restrictions applied to natural resources outside the jurisdiction of a party. 167 However, the next Panel in the Tuna case II suggested that the text of environmental exceptions does not explicitly provide any jurisdictional limitation as far as public international law permits governments to exercise jurisdiction over their nationals and vessels outside their territory. ${ }^{168}$ Likewise, David Pearce points out, the legal text of the G.A.T.T. does not strongly indicate the 'location' of the environmental damage done relevant to an exception. 169 In the context of the global protection of ozone, it must be emphasised that, since the depletion of the ozone will not respect territorial boundaries, the above-mentioned argument presented by the Tuna Panel II cannot not be overemphasised.

\section{CONCLUSIONS}

It should be concluded, from what has been observed above, that we can broadly accept the coexistence of the T.R.E.Ms. in the Montreal Protocol régime (Article 4) with the free-market principles/rules governing the G.A.T.T./W.T.O. trade law régime. At the very least, the Montreal Ozone Protocol's Article 4 could be seen as compatible with Article XX(b) of the G.A.T.T. trade rules. Viewed in its entirety, Article 4 of the Montreal Ozone Layer Protocol thus seems to be a 'non-discriminatory' trade measures for the protection of ozone. Hence, the Montreal Protocol régime forms an important environmental exception to the international free trade principles/rules of the G.A.T.T./W.T.O. law.

However, apart from the above-mentioned problems of Article 4 of the Ozone Layer Protocol, there will be further points which need to be clarified as to the relationship between the G.A.T.T./W.T.O. régime and other existing M.E.As., such as the 1989 Basel Convention, the 1973 C.I.T.E.S., the 1992 Climate Change Convention and the 1992 Biodiversity Convention. In addition, there would be, perhaps, other potential tension or conflicts between future international environmental régimes which decide to use trade restrictions and the existing G.A.T.T./W.T.O. trade régime: T.R.E.Ms. provided for in these M.E.As. must be applied and enforced in practice.

167 See T. Schoenbaum, 'Tree International Trade and Protection of the Environment', 86 A.J.I.L. (1992) p. 720.

168 The Tuna/Dolphin case II, paras. 5.15-20 \& 5.31-33.

169 D. Pearce, 'The Greening of the GATT: Some Economic Considerations' in J. Cameron (eds.) Trade and the Environment, vol. 1, (1994) p. 25. 
Although we did not discuss potential amendments to the G.A.T.T. law for environmental protection, it may be desirable or advisable that members should partly amend the G.A.T.T. Article XX and other environment-related provisions so as not to retard the evolving concept of 'sustainable development' in international law. 170 This assumption is now widely accepted in legal writing. ${ }^{171}$ However, it is true that adding amendments to the G.A.T.T. law depends on the political will of the contracting parties of the G.A.T.T. régime and, in practice, this is extremely difficult. 172 It has been suggested that at the C.T.E. circle, developing states are generally opposed to making any modification to the WTO trade rules in favour of M.E.A.s. ${ }^{173}$

It is hoped that the new C.T.E. would contribute to settling the question as to the disputed legal status of trade provisions of M.E.As., such as those in the Montreal Ozone Layer Protocol within the G.A.T.T./W.T.O. trade régime.

170 See R. G. Tarasofsky, 'Ensuring Compatibility between Multilateral Environmental Agreements and GATT/WTO', 7 Y.bk.I.E.L. (1996) p. 54, noting the legal uncertainty and 'the chill effect' on elaborating T.E.R.Ms. in future M.E.As.

171 See e.g. J. Cameron and J. Robinson, (1994) pp. 18 et seq.; S. Murase, 'Perspectives from International Economic Law on Transnational Environmental Issue', 253 Hague Recueil (1995); T. J. Schoenbaum, 'International Trade and Protection of the Environment', 91 A.J.I.L. (1997) pp. 268-313. See however Trade and the Environment: News and Views from the GATT, TEOO4 (26 November 1993) p. 3; E. Petersmann, 'International Trade Law and International Environmental Law', J.W.T. p. 72.

172 Amendment of G.A.T.T. Article XX requires two-thirds majority of the Members (Article X of the WTO Agreement), but forced votes will be rare. See also Y. Iwasawa, WTO Dispute Settlement, (1994) p. 9 (Japanese); S. Murase, 'Perspectives from International Economic Law on Transnational Environmental Issues, 253 Hague Recueil (1995) pp. 346-48. See J. H. Jackson, The World Trading System, 2nd edn. (1997) p. 343 , noting that the difficulty of amending the texts could lead to a host of 'ad hoc or other "end-run" type measures'.

173 See R. G. Tarasofsky, 'Ensuring Compatibility between MEAs and GATT/WTO', 7 Y.bk.I.E.L. (1996) p. 61 \& its footnote no. 49. 


\section{PART IV}

THE MONTREAL PROTOCOL'S

COMPLIANCE SYSTEM 


\title{
CHAPTER V
}

\author{
THE MONTREAL NON-COMPLIANCE PROCEDURE AND \\ THE FUNCTIONS OF THE INTERNAL INTERNATIONAL INSTITUTIONS
}

\section{THE MONTREAL NON-COMPLIANCE PROCEDURE ('N.C.P.')}

\section{A. The Judicial Settlement of International Environmental Disputes}

International environmental disputes do arise on sundry occasions, and corresponding means of settling these disputes often vary widely in accordance with the type of issues involved, the type of natural resources, the parties concerned, geographical scope, the source of pollution or adverse effects, and the nature of the harm done, its potential remedies, and so forth. 1 In order to fully guarantee treaty compliance with their environment-related obligations, the dispute settlement mechanisms of international environmental régimes must be designed properly and flexibly to enable these régimes to settle, or ideally 'avoid', such various kinds of environmental disputes.

In actual practice, however, it is disappointing that a number of environmental agreements contain, if they exist at all, inadequate dispute settlement clauses in their legal instruments. In addition, traditional and legally binding methods of dispute settlement procedures - such as those envisaged in Article 33 of the U.N. Charter - are not necessarily preferred approaches to settling environmental disputes at the international level because of their highly complex procedures, a lack of confidence, timeconsuming legal processes with considerable expense, and long-pending problems as to the principles of state responsibility. ${ }^{2}$ Consequently, states do not usually resort to these strictly judicial procedures, even though several environmental agreements provide the widest possible choice of legal devices for the settlement of disputes (e.g. the dispute 'settlement' procedures under Article 11 of the Ozone Convention: see Chapter

\footnotetext{
${ }^{1}$ For a further discussion of 'international' or 'transnational' environmental disputes, see R. B. Bilder, 'The Settlement of Disputes in the Field of the International Law of the Environment', 144 Hague Recueil, (1973) pp. 153-236.

2 See ibid., p. 225-27; P. Birnie and A. Boyle, International Law and the Environment, (1992) pp. 136 et seq. See also Chapter II(III.C) above.
} 
The Montreal Non-Compliance Procedure and the Internal Institutions

II(III.D.4)). ${ }^{3}$ In most cases, states are more inclined to retain their freedom of action relying on the principle of state sovereignty. 4

Naturally, where an appropriate or reliable dispute avoidance or settlement mechanism or system still does not exist for the purpose of ensuring treaty performance, it would often be much easier for régime member states to ignore their established treaty obligations. Analysing these real-life situations, Professor G. Palmer thus observed in the early 1990s that 'Nearly twenty years after the Stockholm Declaration, we still lack the institutional and legal mechanisms to deal effectively with transboundary and biosphere environmental degradation'. 5

\section{B. The Avoidance/Quasi-Judicial Settlement of 'Multilateral'}

Environmental Disputes: The Non-Compliance Procedure ('N.C.P.')

It is possible to argue that ozone disputes can arise from 'non-compliance' relating to 'compatibility with the objectives of international régimes', 6 for non-performance with ozone treaty obligations would affect the international community as a whole rather than be geographically limited to particular sovereign states or individuals under state jurisdictions. In this sense, potential ozone disputes differ radically from environmental conflicts concerning transboundary air pollution or conservation of living/non-living natural resources (see Chapter III(III.A) above).

Judging from the above we may say therefore that 'there is undoubtedly need for regime-specific legal compliance mechanisms'. ${ }^{7}$

With this background in mind, drafters of the Montreal Protocol's dispute avoidance/settlement régime have become more concerned with

3 In this respect see Y. Iwasawa, WTO Dispute Settlement, (1994) Chapter III p. 55 \& its footnotes 95-97, suggesting that the role of the I.C.J. in 'settling' economic disputes (of highly technical nature) is rather limited and treaty instruments regarding international economy does not usually contain resort to the international tribunal (Japanese).

${ }^{4}$ Indeed, it is true that the most frequently used mechanism for settling international or transnational environmental disputes is, without doubts, direct discussion of a dispute between states - i.e. official and/or unofficial diplomatic negotiation and consultations.

5 G. Palmer, 'New Ways to Make International Environmental Law', 86 A.J.I.L. (1992) p. 259.

6 s. Murase, 'Perspectives From International Economic Law on Transnational Environmental Issues', 253 Hague Recueil, (1995) p. 415. On ozone treaty disputes see also Section $\mathrm{V}(\mathrm{A})$ below.

7 G. Handl, 'Controlling Implementation of and Compliance with International Environmental Commitments: The Rocky Road from Rio', 5 Colorado J.I.E.L.P. (1994) p. 327. 
the crucial question of ensuring greater 'compliance' with the ozone treaties' obligations that generally deal with the application (and interpretation) of complex and detailed environment-related obligations and standards - e.g. O.D.S. emission reductions (Articles 2 \& 5), trade controls of C.F.Cs./O.D.Ss. (Article 4) and national/regional reporting requirements (Articles $7 \& 9$ ) - rather than with purely legalistic and political issues in the branch of customary international law or international human rights law. As a result of their pioneering endeavours, ${ }^{8}$ a flexible arrangement for environmental dispute avoidance/settlement - i.e. a 'non-compliance procedure' ('N.C.P.') régime9 has only recently been added as an integral part to the Montreal Ozone Protocol (Article $8 /$ Decisions). It is said that the creation of the Implementation Committee in particular constituted a 'real breakthrough' in international environmental law. ${ }^{10}$

The N.C.P. of the 1994 Oslo Sulphur Protocol follows with substantial accuracy the existing lines of the Montreal N.C.P. model (Article 7/Decision) ${ }^{11}$ and the parties of the 1992 U.N. Climate Change Convention have also recently started to have discussions on the expected establishment of a 'Multilateral Consultative Process' to deal with questions of non-compliance or non-performance in accordance with Article 13 of the agreement. ${ }^{2}$ In addition, the Conference of the Parties to the 1997

8 On the N.C.P. negotiation see Section II below.

9 The 'Montreal N.C.P. (ozone) régime' to refer to an 'internal' compliance-monitoring or dispute avoidance/settlement mechanism based on Article 8 of the Protocol. P. Széll also describes the N.C.P. as a 'régime'. See e.g. 'Compliance Regimes for Multilateral Environmental Agreements', 27/4 E.P.L. (1997) pp. 304-07.

10 A. Kiss, 'Compliance with International and European Environmental Obligations', Hague Y.bk.I.L. (1996) p. 51. Cf. G. Palmer (eds.), International Environmental Law \& World Order, (1994) p. 1120.

11 See EB.Air/WG.5/CPR.13. See also ECE/EB.AIR/38. para. 9 and ECE/EB.AIR/40 cited in P. Széll, 'Compliance Regimes for Multilateral Environmental Agreements: A Progress Report', 27/4 (1997) pp. 304-07.

12 Article 13 (Resolution of questions regarding implementation) reads 'The Conference of the Parties shall, at the first session, consider the establishment of a multilateral consultative process, available to Parties on their request, for the resolution of questions regarding the implementation of the Convention'. For a discussion of the Climate Change Convention's compliance system, see in particular J. Werksman, 'Designing a Compliance System for the UN Framework Convention on Climate Change', in J. Cameron (eds.), Improving Compliance With International Environmental Law, (1996), pp. 85-121; D. G. Victor, Design Options for Article 13 of the Framework Convention on Climate Change: Lessons from the GATT Dispute Panel System, (1996); P. Széll, 'Compliance Regimes for Multilateral Environmental Agreements: A Progress Report', 27/4 E.P.L. (1997) pp. 304-07.. Similarly, the 1994 U.N. Convention to Combat Desertification in Those Countries Experiencing Serious Drought and/or Desertification provides that 'The Conference of the Parties shall 
The Montreal Non-Compliance Procedure and the Internal Institutions

Kyoto Protocol is to approve a new non-compliance régime (see Chapter I(III.C) above).

In the present case of the international régime for the protection of the ozone layer, as we have already seen, the only legal 'remedy' is collective treaty compliance, but not monetary compensation by sovereign states or transnational corporations ('T.N.Cs.') producing/consuming C.F.Cs./O.D.Ss. (see Chapters I(IV) \& III(III.C) above). In this view, it cannot be emphasised too strongly that, under the Montreal N.C.P. régime, both any member state and the U.N.E.P. Ozone Secretariat can initiate this new procedural mechanism to ensure the implementation of the ozone layer treaties, without any question of its own legal interests being involved. Therefore, needless to say, these international N.C.P. régime initiators do not have to exhaust any domestic legal remedies as a precondition. In this way, the Montreal N.C.P. can be characterised as an unprecedented procedural mechanism that is designed to effectively 'operate' or 'enforce' erga omnes (i.e. the global protection of the ozone layer: for details see Chapter I(IV) above).

In this context, we may say that this new dispute avoidance/settlement régime differs essentially from pre-existing human rights conciliation committees such as those under the First Optional Protocol to the International Covenant on Civil and Political Rights ('I.C.C.P.R.'), and under the European Convention for the Protection of Human Rights and Fundamental Freedoms (European Human Rights Convention) that strictly require the exhaustion of local remedies. 13

Although we still should not make any easy generalisations about the Montreal N.C.P. régime on the basis of its early operation (see Section

consider and adopt procedures and institutional mechanisms for the resolution of questions that may arise with regard to the implementation of this convention' (Article 27). Cf. Contracting Parties to the Convention on the Prevention of Marine Pollution by Dumping of Wastes and Other Matter (London Convention), 1972: Final Act, 1996 Protocol and Resolutions (Article 11), 36 I.L.M. (1997) p. 1.

13 The 1966 I.C.C.P.R. (Article 5.2(b)); Universal Declaration of Human Rights (Article 41); the European Convention (Article 26[Article 35 of the Revised Convention]). The Committee against Torture under the Convention against Torture and Cruel, Inhuman or Degrading Treatment or Punishment has a similar provision. Yet these interstate complaints procedures (i.e. Committee jurisdiction) must be formally accepted by states concerned. As to the burden of proof in relation to human rights protection, see C. F. Amerssinghe, Local Remedies in International Law, (1990) pp. 291-97 esp. Likewise the 1962 U.N.E.S.C.O. Protocol provides that 'The Commission shall deal with a matter referred to. . . only after it has ascertained that all available domestic remedies have been invoked and exhausted in the case, in conformity with the generally recognised principles of international law'. (Article 14). See further J. P. Cot, International Conciliation, (1972) pp. 311 et seq. 
The Montreal Non-Compliance Procedure and the Internal Institutions

VII below), the N.C.P. régime - in which the internal treaty institutions exercise regulatory and supervisory functions - can be regarded as the compliance-monitoring ${ }^{14}$ or quasi-judicial settlement mechanism based on a 'collective reaction' or 'multilateralism', but not on confrontational bilateralism common to formal dispute settlement mechanisms. The 'multilateralism' is concerned with traditional collective non-sanctions such as 'informal persuasion' and the 'mobilisation of shame' applied by global institutions. 15 What is more, compared with formal judicial settlement that usually require time-consuming processes, the N.C.P. régime seems to be much more 'flexible', 'simple' and 'rapid'. We may say at the same time that, in the light of step-by-step negotiation processes of the N.C.P. régime, this mechanism shows, by seeking feasible and amicable solutions, a scrupulous respect for the sovereignty of ozone régime member states.

Apart from these four characteristics - i.e. multilateralism, flexibility, simplicity and rapidity, it is also important to notice that the Montreal N.C.P. régime has gradually established a close link with international financial mechanisms, namely, the Multilateral Fund of the Montreal Protocol and the Global Environment Facility (see further Chapter VI below): this will certainly strengthen 'soft enforcement' of international environmental régime rules.

The organisation of this Chapter is as follows: Section II provides a brief summary of the Montreal N.C.P. negotiation process. Section III then clarifies, to some extent, the meaning of the legal term 'non-compliance' within the Montreal Protocol and the Ozone Convention. It also addresses the relationship between the Montreal N.C.P. and the settlement procedures under Article 11 of the Vienna Convention. Section IV deals with the mechanics of the operation of the Montreal N.C.P. régime, pointing out the important functions played by the specialised N.C.P. régime institutions i.e. the U.N.E.P. Ozone Secretariat, the standing Implementation Committee and the Meeting of the Parties. Section $V$ then attempts a comparison between the Montreal N.C.P. and other dispute settlement procedures, (i) the G.A.T.T./W.T.O. Violation Procedure and (ii) the Complaints Procedure in the I.L.O. Supervisory Machinery. It also characterises the N.C.P. as a

\footnotetext{
14 See Chapter I(III.C).

15 See F. L. Kirgis, International Organisations in their Legal Setting, 2nd edn. (1993) pp. 524 et seq.
} 
The Montreal Non-Compliance Procedure and the Internal Institutions

multilateral conciliation mechanism. Section VI discusses the unique relationship which exists between the Montreal N.C.P. régime and the evolving principle of international environmental law, i.e. the precautionary environmental 'principle'/approach. Section VII is devoted to the Montreal N.C.P. régime in practice: it analyses the effectiveness of the specific treaty requirements - including technical data reporting, control measures of O.D.Ss. and trade controls. This Section also gives a case study of the Russian Federation's non-compliance with Article 2 control measures.

\section{THE NEGOTIATION OF THE MONTREAL N.C.P. RÉGIME}

Whilst the 1987 version of the Montreal Protocol succeeded in introducing specific control measures of O.D.Ss. to prevent steady ozone depletion (see Chapter III(II-III)), negotiators of the ozone régime could not conclusively establish the non-compliance procedure in time for its adoption. 16 As a result, it was provided in Article 8 of the Protocol that:

'The Parties, at their first meeting, shall consider and approve procedures and institutional mechanisms for determining non-compliance with the provisions of this Protocol and for treatment of Parties found to be in non-compliance'.

Yet, it then took several years of gradual preparations to establish the existing Montreal N.C.P. régime.

The 1989 Helsinki Meeting of the Parties 17 established an Ad Hoc Working Group of Legal Experts, ${ }^{18}$ which was to develop three different proposals for a non-compliance procedure submitted by the United

\footnotetext{
16 See D. G. Victor, The Early Operation and Effectiveness of the Montreal Protocol's Non-Compliance Procedure, (1996) p. 4, pointing out that, although the United States offered a detailed non-compliance procedure in the final stages of the negotiation, some negotiators of the E.C. considered it as a 'strategy to clutter the agenda at the last minutes'. See also R. Benedick, Ozone Diplomacy, (1998) p. 270, noting that 'I can attest that it was consciously intended as a laconic but important maker, not as a tactic'. On the U.S. proposal see UNEP/OzL.WG.Data.2/3/Rev.2/Annex VII.

17 See Chapter III(IV.B) above.

18 Decision $\mathrm{I} / 8$.
} 
The Montreal Non-Compliance Procedure and the Internal Institutions

States, 19 the Netherlands, 20 Austria 21 and Finland. 22 At this stage, some developed states - the United States and Nordic countries, in particular strongly supported a 'more stringent and punitive approach' rather than an 'encouragement-based approach' that was recommended by the Working Group of Legal Experts. 23 Industrialising countries and the European Community supported the encouragement-based approach.

The First Meeting of the Ad Hoc Working Group was held in Geneva in 1989.24 The U.S. proposal, unlike its initial proposal, addressed a conciliation procedure with non-compliance under the 1985 Vienna Ozone Layer Convention, which could ultimately lead to recommendations and/or further punitive measures approved by the Meeting of the Parties. Under an Australian proposal, the Secretariat was to be given stronger powers as the 'guardian of the Protocol', which included regular reporting as to both compliance and non-compliance. 25 After an extensive discussion about the non-compliance procedure, it was agreed that:

(i) it was important to avoid drawing up an unnecessarily complex and duplicative system;

(ii) the procedure should not be confrontational;

(iii) action under the non-compliance procedure could be commenced by either one or a number of Parties or the Parties collectively registering concern with the Secretariat;

(iv) the procedure proposed should not alter or weaken in any way article 11 of the Vienna Convention on the Protection of the Ozone Layer;

(v) confidentiality must be respected and specific reference to this should be made in the procedures proposed;

(vi) the Secretariat's role should be that of a servicing, administrative body rather than a judicial one;

(vii) the Secretariat should compile the necessary data and other information;

19 UNEP/OzL.Pro.LG.1/2/Annex II.

20 UNEP/OzL.Pro.LG.1/CRP.1.

21 UNEP/OzL.Pro.LG.1/CRP.4.

22 See UNEP/OzL.Pro.LG.1/3, para. 20, noting that Finland supported the adoption of a conciliation procedure.

23 See UNEP/OzL.Pro.WG.IV/3, para. 4; R. Benedick, Ozone Diplomacy, (1998) pp. 18283.

24 UNEP/OzL.Pro.LG.1/3;EPL, 19/5(1989) pp. 147-48.

25 The proposal also stated that 'the determination of compliance or non-compliance should be as far as possible a time-bound, non-political process, producing a legal and technical decision' (emphasis added), cited in T. Gehring, Dynamic International Regimes, (1994) p. 315. 
The Montreal Non-Compliance Procedure and the Internal Institutions

(viii) early indications of possible non-compliance might be resolved through administrative action by the Secretariat and through diplomatic contacts between Parties;

(ix) decisions on non-compliance should be recommendatory rather than mandatory. 26

In addition to these matters, the Working Group also agreed that there should be a supervisory body that was called the 'Implementation Committee' ('ImpCom'). 27 However, many delegations emphasised that such a standing committee should not have a judicial function, and therefore any decisions as to non-compliance by a Party would have to be taken by the Ozone Meeting of the Parties. 28 The Working Group also approved a 'Draft Non-Compliance Procedure', which specified basic functions of the Ozone Secretariat, the Implementation Committee and the Meeting of the Parties. 29 The 1990 London Meeting of the Parties ${ }^{30}$ adopted this draft N.C.P. as prepared by the Working Group on an 'interim' basis, and it established the standing Implementation Committee. 31

In the Second Meeting of the Working Group held in 1991, the European Community offered the most sweeping proposal. That proposal included in its draft text 'Indicative Lists of Steps to Bring about Full Compliance with the Protocol' that dealt with three types of noncompliance, i.e. (i) reporting requirements, (ii) control measures of O.D.Ss. and (iii) trade restrictions. 32 Under the E.C.'s proposal, the functions of internal international institutions - including the Ozone Secretariat and the Committee - were essentially similar in many respects to the existing Montreal N.C.P. régime. Apart from draft proposals submitted, it is worth noting that many experts in this Meeting communicated the view that dispute settlement procedures under the 1985 Vienna Ozone Convention and the Montreal N.C.P. were 'two distinct and separate procedures which could

26 UNEP/OzL.Pro.LG.1/3, para. 9. The ideas propounded were all shaped into the existing Montreal N.C.P. régime, as we shall see.

27 Ibid., para. 10.

28 Ibid., paras. $11 \& 17$.

29 Ibid., Annex.

30 See Chapter III(IV.C) above.

31 Decision IV/5. This Decision also extended the mandate of the Ad Hoc Working Group to elaborate (i) N.C.P. régime itself and (ii) terms of reference for the Committee. The Decision III/2 adopted by the Third Ozone Meeting also extended the mandate of the Working Group with regard to the development of a Indicative List of Measures.

32 UNEP/OzL.Pro/WG.3/2/3/Annex; T. Gehring, Dynamic International Régimes, (1994) pp. 316-17. 
well exist in parallel'.33 The formal N.C.P., as improved by the Third Meeting of the Ad Hoc Working Group, was finally adopted at the 1992 Copenhagen Ozone Meeting 34 (Decision IV/5). The decision is legally binding because of the enabling provisions of Articles 8 and 11(3.d). 35

Lastly, it must be noted that, in order to review and strengthen the N.C.P., the 1997 Montreal Meeting of the Parties 36 decided to establish an Ad Hoc Working Group of Legal and Technical Experts on the N.C.P., which is composed of fourteen members. 37

\section{THE MEANING OF 'NON-COMPLIANCE' IN THE OZONE LAYER PROTOCOL: A GREY AREA OF THE INTERNATIONAL LEGAL OZONE RÉGIME}

\section{A. The Meaning of 'Non-Compliance' in the Ozone Layer Régime}

In general, 'compliance' means a 'desired state of conformity with the law, a regulation, or a demand'. Its working definition will not be static (= dynamic). Unlike the term 'enforcement', compliance implies that régime member states are induced to comply, rather than being coerced to do so. 38 In this sense, the use of the legal terminology 'non-compliance' in the Montreal Protocol seems to be particularly appropriate for its global regulatory rules on O.D.S. controls (see also Chapter I(III.C) above).

\footnotetext{
33 UNEP/OzL.Pro/WG.3/2/3, para. 18. See Section IV. A(3).

34 See Chapter III(IV.D) above.

35 See M. Bothe, 'The Evaluation of Enforcement Mechanisms in International Environmental Law' in R. Wolfrum (ed.), Enforcing Environmental Standards (1996) p. 31.

36 See Chapter III(IV.F) above.

37 Decision IX/35. See the following recent reports by the Ad Hoc Working Group: UNEP/OzL.Pro/WG/1/1/Add.1 (14 April 1998); UNEP/OzL.Pro/WG.4/1/1/Add.2 (18 May 1998); UNEP/OzL.Pro/WG/1/1/Add.1 (15 April 1998).
}

38 See B. M. Hutter, Compliance: Regulation \& Environment, (1997) Chapters 1-4 esp. Generally speaking, 'compliance', in English, (non-conformité/ Nicht-befolgung) refers to 'obedience' or 'conformance'. See E. B. Weiss and H. K. Jacobson, Strengthening Compliance with International Environmental Accords: Preliminary Observations from a Collaborative Project', 1 Global Governance, (1995) pp. 123 et seq., defining compliance as 'whether countries in fact adhere to the provisions of the accord and to the implementing measures that they have instituted' - 'compliance' should be thus distinguished from 'effectiveness'. The term 'violation' (in English) can be defined as 'breach of right, duty or law' and 'enforcement' as the execution of a law. 'Enforcement' implies rather positive coercion, such as 'countermeasures', 'reprisals' and 'police force and courts'. These terms are often used interchangeably, however. See Black's Law Dictionary, (1990); L. Henkin, 'General Course on Public International Law', 216 Hague Recueil, (1989) pp. 67 et seq.; L. Chazournes, 'Mise en oeuvre du droit international dans le domaine de la protection de l'environment: enjeux et défis', Revue générale de droit international public, (1995) pp. 62 et seq. 
States' 'non-compliance' could be defined as the 'breach' of obligations owed under public international law - i.e. the determination of 'internationally wrongful acts'. However, it should be noted, again, that possible non-compliance with the international ozone treaty provisions is not necessarily concerned with states' responsibility or liability in the context of the payment of compensation for environmental damage (see Chapter I(IV) \& Section I above).

The definition of the term 'non-compliance' is not provided for in the legal text of the Montreal Protocol or in that of the 1985 Vienna Ozone Layer Convention. The reason for this is that the 1992 Copenhagen Ozone Meeting was not ready to adopt an 'Indicative List of Possible Situations of Non-compliance with the Protocol' as prepared by the Ad Hoc Working Group of Legal Experts. 39 In the absence of such a helpful list of potential non-compliance, the risk of non-compliance is likely to increase: as Professor M. Bothe says, 'Compliance is furthered by the possibility of obtaining a clear determination of the content of a norm in relation to a given case'. 40 Yet, in the light of the nature of the N.C.P. régime (i.e. its flexibility), it is also possible to argue in response that formal determination of non-compliance could be merely counterproductive. 41

In taking account of the draft Indicative List, we may safely assume that non-compliance with regard to the following four ozone treaty obligations would first go to the Montreal N.C.P.:

(i) non-compliance with treaty provisions relating to O.D.S. control measures (Articles 2, 2A-2H);

(ii) non-compliance with treaty provisions relating to restrictions on trade with non-parties (Articles 4);

(iii) non-compliance with time schedules reporting of data (Article 7);

(iv) non-compliance with reporting of a summary of national ozone activities (Article 9): 42

39 See UNEP/OzL.Pro/WG.3/3/3/Annex II. paras. 32-43.

40 See M. Bothe, 'International Obligations, Means to Secure Performance', 1 Encyclopaedia of Public International Law, (1982) p. 102.

41 Cf. M. Koskenniemi, "New Institutions and Procedures for Implementation Control and Reaction' in J. Werksman, Improving Compliance with International Environmental Law, (1996) p. 246 and its endnotes.

42 Other candidates include; 'non-provision of the contributions referred to in Article 10, paragraph 1, for the purpose of financing on a grant or concessional basis the incremental costs agreed upon in its paragraph 3 , as well as what is provided for in Article 10 A concerning substitute substances and the transfer of technology'; failure to take 'every practicable step' consistent with the programmes supported by 
It is arguable, however, that non-payment of contributions to the financial mechanism - namely, the Montreal Multilateral Fund, could be also regarded as possible non-compliance with the ozone layer treaty. Whereas most donor countries consider the obligation to contribute to the M.L.F. as legally binding, the United States, for instance, interprets it as merely 'voluntary compliance'. 43 The legal text of the M.L.F. is silent on this contentious matter, and, consequently, the legal status of these monetary contributions is still left intentionally ambiguous. ${ }^{44}$

\section{B. 'Depoliticising' Multilateral Ozone Disputes?: The Relationship between}

the 'Self-Contained' N.C.P. and the Dispute Settlement Mechanisms in the 1985 Vienna Ozone Layer Convention:

The above analysis implies therefore that the ascertainment of 'noncompliance' with ozone layer treaty obligations is likely to depend on the 'practical decisions' of the Meeting of the Parties to the Protocol as a supreme treaty organ and/or the contracting parties themselves.

In relation to this point, Professor M. Koskenniemi rightly observes that 'a dispute about whether some particular type of non-compliance is wrongful act is another dispute about interpretation or application of the treaty [i.e. 'treaty disputes'] and capable of being resolved only within the

the financial mechanism, for transfer of technology; non-compliance with the obligations in decisions of the Parties to the Protocol. The Working Group noted, however, that 'The above list is without prejudice to the generally accepted rules of international law related to the interpretation and application of treaties'. UNEP/OzL.Pro/WG.3/3/3 (Annex II: Indicative Lists).

43 See UNEP/OzL.Pro/WG.3/3/3, paras. $37-38$, noting that developing countries disputed the view that Article 10 ('Financial Mechanism), after entry into force, did not contain an obligation to contribute to the financial mechanism. This disruptive issue among ozone régime members is often raised in the Ozone Meeting of the Parties (see e.g. UNEP/OzL.Pro.5/12, para. 22; UNEP/OzL.Pro.7/12). Whilst the 1992 Climate Change Convention and the 1992 Biodiversity Convention require industrised state parties to provide 'new and additional financial resources to newly industrising state parties, monetary contributions under these two environmental agreements could be regarded as only voluntary. See A. E. Boyle, 'The Rio Convention on Biological Diversity' in C. Redgwell and M. Bowman (eds.), International Law and the Conservation of Biological Diversity, (1995) pp. 46-47.

44 The Implementation Committee has never discussed on this issue. See R. Benedick, Ozone Diplomacy, (1998) p. 262 \& p. 271 , saying that 'the contributions are, from a strictly legal perspective, voluntary' and that 'arranges of payment were never formally deplored by the parties but never labelled as non-compliance with the protocol'. See also D. G. Victor, 'The Montreal Protocol's Non-Compliance Procedure: Lessons for Making Other International Environmental Régimes More Effective' in W. Lang, (ed.), The Ozone Treaties and Their Influence on the Building of Environmental Régimes, (Austrian Ministry of Foreign Affairs, Vienna, Austria) pp. 67 et seq. 
procedures under Article 11 of the Vienna Ozone Convention', and ultimately, 'the question of wrongfulness is one of general international law, and not a question that can be solved, or indeed even approached, from within the special regime of the Vienna Ozone Convention and the Protocol at all'.45 Thus he argues that, to be a strictly judicial organ, the Meeting of the Parties may suspend the rights of an allegedly defaulting party only if there exist 'non-compliance' (breach of treaty) as an internationally wrongful act by that state party. 46

With regard to the relationship between Article 11 of the Convention (see Chapter II(III.D.4) above) and the Montreal N.C.P. régime, the Convention provides that 'the provisions of Article 11 of the Vienna Convention shall apply with respect to any protocol except as provided in the protocol concerned' (Article 11(6)). ${ }^{47}$ This means that the operation of the Montreal N.C.P. is not necessarily stipulated as condition precedent to the settlement mechanisms enumerated in the Vienna Ozone Layer Convention. 48 Moreover, since under the ozone treaty régime (and under general public international law) there does not exist a hierarchy - except for the full use of diplomatic negotiations as a departure point - in settling disputes, no ozone régime member could or would eliminate the possibility of invoking binding procedures under the Ozone Convention. 49 For instance, the allegedly defaulting party (e.g. Article 5 country parties and the 'C.E.I.Ts.': see Section VII(B.1) below) - which considers that it has not committed an internationally wrongful act entailing state responsibility can invoke, as a means of avoiding collective suspension of rights or countermeasures, the traditional settlement mechanisms under the Convention. At this later stage, the Montreal N.C.P. may not be seen as 'selfcontained' régime any more.

45 See M. Koskenniemi, 'Breach of Treaty or Non-Compliance?', 3 Y.bk.I.E.L. (1992) p. 144 (and its footnotes), saying that 'The travaux préparatories of the NCP as well as the composition and functions of the Implementation Committee and, a foriori, the Meeting of the Parties, make it clear that neither can, or is expected to, work as a judicial body, assessing the performance of the parties' obligations with a view of determining whether or not there has been a wrongful act triggering state responsibility'. See also UNEP/OzL.Pro/WG.3/3/3, para. 46; Section II above.

46 M. Koskenniemi, ibid., p. 145.

47 See also Article 14 of the Montreal Protocol.

48 The Implementation Committee once noted that the parallel exercise might even be conductive to the functioning of the N.C.P. See W. Lang, 'Ozone Layer', 2 Y.bk.I.E.L. (1991) p. 109.

49 In cases of disputes involving T.R.E.Ms., parties to the Protocol may first use the G.A.T.T./W.T.O. dispute settlement system, rather than the N.C.P. (see Chapter IV(IV.B) above). 
The Montreal Non-Compliance Procedure and the Internal Institutions

The N.C.P. of the Protocol provides only that:

(i) the special procedural régime (i.e. the N.C.P.) shall apply 'without prejudice to the operation of the settlement of disputes procedure laid down in Article 11 of the Vienna [Ozone] Convention' (Preamble);

(ii) the Meeting of the Parties may issue an interim call and/or recommendations, pending completion of these proceedings (Annex IV(13)) and:

(iii) the contracting parties that decide to use a dispute settlement mechanism described in Article 11 of the Vienna Ozone Convention must inform the Meeting of the Parties through Ozone Secretariat (Annex IV(12)).

These three points will not radically change the above-mentioned controversial relationship between Article 11 traditional settlement mechanisms and the new Montreal N.C.P. régime. 50

It should be noted that the 1991 Nairobi Meeting of the Parties decided, as has already been pointed out, that these two types of processes for dealing with parties' non-compliance were distinct and separate procedures (Decision III/2) 51 Further, at the 1992 Copenhagen Ozone Meeting of the Parties, it was also decided that 'the responsibility for legal interpretation of the Protocol rests ultimately with the Parties themselves' (Decision IV 5(5): see Section IV(B.3.2) below). 52

Perhaps one acceptable explanation for this current situation will be that the internally specialised treaty bodies - as legal advisers to the régime-practitioners - still have to take account of the existing principles and rules of international law as a whole, in deciding what is 'noncompliance' or breach of treaty and which measure should then be taken 53 - even if members of these bodies are, in reality, unwilling to clarify such a nagging question and, in the quest for flexibility, would allow it to remain a grey area of the international legal ozone régime.

Though this view is not necessarily confirmed in practice, ${ }^{54}$ it is probable that the international institutional supervision of compliance

50 For a comprehensive discussion see M. Koskenniemi, 'Breach of Treaty or NonCompliance?', 3 Y.bk.I.E.L. (1992) pp. 157-61.

51 See UNEP/OzL.Pro.3/L.4 .

52 See also Section IV. B(3) below.

53 See also Section $\mathrm{V}$ below.

54 See Section VII below. It has been often pointed out, however, that the N.C.P. of the Montreal type is 'too soft' (e.g. statement made by J. E. Butler at the 91st Annual Meeting of the American Society of International Law, 'The Establishment of a Dispute 
The Montreal Non-Compliance Procedure and the Internal Institutions through the Montreal N.C.P. would be only powerless or too weak to resolve certain ozone disputes. Hence, as a rule, should failure by the new N.C.P. régime to settle ozone disputes occur, an allegedly defaulting party could still be taken to the formal dispute settlement procedure under Article 11 of the Vienna Ozone Layer Convention that includes binding third party settlement (see also Section VI below). 55

IV. THE MECHANICS OF THE OPERATION OF THE MONTREAL N.C.P.: THE FUNCTIONS OF THE SPECIALISED INTERNAL TREATY INSTITUTIONS

\section{A. THE STRUCTURE OF THE MONTREAL NCP RÉGIME}

1. The Actors of the N.C.P. Régime

The main actors of the Montreal N.C.P. régime are, apart from each state party, three specialised internal treaty institutions - namely, (i) the U.N.E.P. Ozone Secretariat, (ii) the Implementation Committee, and (iii) the Meeting of the Parties. They are all both 'functional' and 'sectional' institutions in the field of international ozone layer protection. The N.C.P. régime can be triggered in the three régime actors by (i) one party against another party, (ii) a party itself which is/would be in non-compliance, and (iii) the U.N.E.P. Ozone Secretariat.

The role of régime-supporting actors of international financial mechanisms (i.e. the Executive Committee ('ExCom'), the Multilateral Fund Secretariat, the World Bank and other U.N. institutions such as the U.N.D.P. and the U.N.I.D.O.) will be considered in Chapter VI below. Unlike N.G.Os. in the field of international human rights protection law - such as Amnesty

Resolution/Non-Compliance Mechanism in the Climate Change Convention', 11 April 1997, Washington D.C.).

55 See M. Koskenniemi, 'Breach of Treaty or Non-Compliance?', 3 Y.bk.I.E.L. (1992) p. 160. 
The Montreal Non-Compliance Procedure and the Internal Institutions International 56 - environmental N.G.Os. are given only a minor role in releasing informal information about anticipated non-compliance. ${ }^{57}$

\section{The Principle of Good Faith (bona fides)}

In the light of its characteristic features - notably those demanding voluntary or political co-operation in ensuring implementation of the technical obligations including the self-reporting requirements, it is especially important to note at the outset that the fundamental basis of the N.C.P. régime is the principle of good faith - that which has also formed the foundation of the international ozone régime itself (see Chapter I(I) above). The principle of good faith is based on reciprocity: member states of the ozone régime - i.e. mainly Non-Article 5 developed countries, which already have the capacity to fully comply with ozone treaty obligations entertain the rational expectation that other majority group members namely Article 5 developing states ('L.V.Cs.') - will also try to comply with stringent but differentiated ozone treaty obligations (see Chapter III(III.E.2) above) and other related principles/rules of international law.

In view of the 'enforceability' of multilateral environmental treaty rules, international reputations are also politically important: as Henkin observed, it may be said with some exaggeration that 'States recognise that stability, law and order, reliability (and a warranted reputation for reliability) are in their national interest, and therefore that they have a more-or-less enlightened self-interest in compliance'. 58

56 As regards human rights law régime, under the European Convention for the Protection of Human Rights and Fundamental Freedoms, individuals and N.G.Os. can submit applications against states that have accepted the right of individual petition (Article 25(1)[Article 34 of the Revised Convention]; entered into force in 3 September 1953, amended by Protocol No. 11). The Inter-American Commission, likewise, receives complaints from individuals and other non-state entities (The American Convention on Human Rights, Article 44). See also the Charter of the United Nations (Article 87(b)).

57 For details see O. Yoshida \& A. Sakota, 'The Role of N.G.Os. in the International Legal Régime for the Protection of the Ozone Layer' in The Japanese Society of HumanEnvironment Related Problems (ed.), N.G.Os. and Global Environmental Problems, (October 1998, Japan Environment Agency).

58 See L. Henkin, 'General Course on Public International Law', 216 Hague Recueil (1989) p. 72. 
The Montreal Non-Compliance Procedure and the Internal Institutions

B. THE FUNCTIONS OF THE INTERNAL INTERNATIONAL INSTITUTIONS IN THE MONTREAL NON-COMPLIANCE PROCEDURE

\section{The U.N.E.P. Ozone Secretariat}

The 1985 Vienna Ozone Layer Convention established the U.N.E.P. Ozone Secretariat on an interim basis, and the Secretariat currently serves on a permanent basis (see Chapter II(III.D.3) above). Whereas the Secretariat also carries out similar secondary functions in its routine as provided for in Article 12 of the Montreal Protocol, it expanded its role as a régimesupporter in the N.C.P. The U.N.E.P. Ozone Secretariat acts at a early stage to monitor compliance with detailed technical ozone regulations, and then identify the points at issue. 59

(a) The N.C.P. Régime Initiators \& the Functions of the Ozone Secretariat

As stated earlier, it is in the following three situations that the Montreal N.C.P. régime will be invoked through/by the U.N.E.P. Ozone Secretariat, regardless of the fact that there will exist material damage, or breach of treaty under general international law: the mechanics of the operation of the Montreal N.C.P. Régime are not based on the establishment of standing to bring inter-state claims.

CASE (I): One Party Against Another Party

In this event, the U.N.E.P. Secretariat (i) receives a report presented by any contracting parties that have reservations as to another party's implementation of its treaty obligations under the Protocol, 60 (ii) sends that submission made by party/parties to the party whose implementation is at issue, 61 and (iii) transmits the submission provided by parties, including reply and information, to the standing Implementation Committee. 62 The submission must be supported by 'corroborating

\footnotetext{
59 For details see Section VII(A) below.

60 Annex IV(1).

61 Annex IV(2).

62 Annex IV(2).
} 
The Montreal Non-Compliance Procedure and the Internal Institutions

information', which might include informal information offered by nonstate international actors such as environmental N.G.Os. ${ }^{63}$

\section{CASE (II): Self-Reporting}

The U.N.E.P. Secretariat, in this case, (i) obtains a written explanation given by the party with regard to the particular circumstances of the causes for non-compliance, and 64 (ii) transmits the submission to the Implementation Committee. 65

It is interesting to note that this self-reporting system was instituted into the N.C.P. régime based on the proposal made by the former Soviet Union:66 several of whose successors, i.e. the Countries with Their Economies in Transition, for the first time, initiated the N.C.P. ozone dispute settlement régime (see Section VII(B) below).

\section{CASE (III): The U.N.E.P. Ozone Secretariat}

The U.N.E.P. Secretariat can also invoke the N.C.P. régime by itself, where it becomes aware of possible non-compliance 'during the course of preparing its reports'. The Ozone Secretariat can request any party to provide necessary information in connection with its possible non-compliance, including the reporting requirements, control measures and trade restrictions. 67 This will be the first case in which the Secretariat has been empowered to invoke a formal dispute avoidance/settlement procedure of M.E.As. Compared with the Montreal N.C.P., the Secretariat under the N.C.P. of the 1994 Oslo Sulphur Protocol seems to be given relatively stronger power. 68

63 For details see O. Yoshida \& A. Sakota, 'The Role of N.G.Os. in the International Legal Régime for the Protection of the Ozone Layer' in The Japanese Society of HumanEnvironment Related Problems (ed.), N.G.Os. and Global Environmental Problems, (October 1998, Japan Environment Agency).

64 Annex IV(4).

65 Ibid.

66 See P. Széll, 'The Development of Multilateral Mechanisms for Monitoring Compliance, in W. Lang (ed.), Sustainable Development and International Law, (1995) p. 100.

67 Annex IV(3); Article 7.

68 The N.C.P. of the 1994 Oslo Sulphur Protocol provides that 'Where the secretariat, in particular upon reviewing the reports..., become aware of possible non-compliance by any Party. ..., it may request the Party concerned to furnish necessary information about the matter'(emphasis added). See EB.AIR/WG.5/CPR.13, para. 14. 
The Montreal Non-Compliance Procedure and the Internal Institutions

Here we can see that it is possible that information derived from environmental N.G.Os. might - without any governmental support - reach the Montreal N.C.P. régime. 69 However, until now, the U.N.E.P. Ozone Secretariat is rather reluctant to invoke the N.C.P. régime in this way.

In the case that the party concerned does not respond within fixed periods or that the matter cannot be settled by diplomatic means, the Ozone Secretariat then includes that matter in its report of the Ozone Meeting of the Parties, and it also informs the Implementation Committee. ${ }^{70}$ We may say that this 'sociological sanction' might, to some extent, have immediate effect (see also Section IV(A.2) above).

(b) The Secretariat of Other Environmental Régimes

The Secretariat of the 1994 Oslo Sulphur Protocol takes on almost the same functions in its newly established N.C.P. régime. ${ }^{71}$ Yet, unlike the Montreal N.C.P., the quality of data reported by parties is evaluated by the Evaluation of the Long-Range Transmission of Pollutant Technical Centres ('E.M.E.P.'), and/or by 'independent experts' nominated by the Implementation Committee of the Oslo Sulphur Protocol. 72

To take other examples, the U.N.E.P. Secretariat of the 1973 C.I.T.E.S. may ask for additional data and information as to the implementation of the C.I.T.E.S. Convention where it considers necessary, though, in reality, this function is not well activated yet. ${ }^{73}$ It can also make recommendations for the 'implementation of the aims and provisions of the present Convention, including the exchange of information of a scientific or technical nature'.74

69 See A. E. Boyle, 'Settlement of Disputes Relating to the Law of the Sea and the Environment', 26 Thesaurus Acruasium (1996) p. 259; T. Gehring, Dynamic International Regimes, (1994) p. 318. Same thing can be said of the N.C.P. under the 1994 Protocol on Further Reduction of Sulphur. See D. G. Victor, The Early Operation and Effectiveness of the Montreal Protocol's Non-Compliance Procedure, (1994) p. 7, suggesting that though an N.G.O. appealed for its participation in the meeting of the Committee in 1992, it was denied on the ground that 'confidential, delicate, and sensitive information might be discussed and the presence of an NGO could limit frank discussion'.

70 Ibid.

71 EB.AIR/WG.5/CPR.13, paras. 3-5.

72 EB.AIR/WG.5/CPR.13, para. 6(d).

73 Article XV. 2(d). See D. S. Favre, International Trade in Endangered Species, (1989) p. 286.

74 Article XII. 2(h). 
The Secretariat of the 1991 Bamako Convention is given relatively greater powers, and it may also conduct a 'verification of the substance of the allegation and submit a report thereof to all the Parties to the Convention'. ${ }^{75}$ On the other hand, the U.N.E.P. Secretariat under the 1989 Basel Convention is only required to inform the parties of the alleged violations. ${ }^{76}$

Finally, under the N.A.F.T.A. Side Agreements on Labour, Health and Environmental Regulation, the Secretariat is to consider complaints from environmental N.G.Os. that a party is 'failing to effectively enforce its environmental law', and it can also request a response from the party if it decides that the submission so merits. ${ }^{77}$

2. The Implementation Committee of the Montreal N.C.P.

(a) The Structure of the Implementation Committee

The standing Implementation Committee - as the 'legitimate first stop' in any formal discussion' 78 - has examined and decided most of the debatable non-compliance issues (see Section VII(A) below). However, vexed questions such as non-compliance by the Countries with Their Economies in Transition may have to be ultimately referred to the Meeting of the Parties.

It is widely agreed that the Committee is not an international judicial institution. 79 Rather, the Committee can be regarded as a conciliatory body within the ozone régime (see also Section $\mathrm{V}$ below).

As we noted, the 1990 London Meeting of the Parties established the Implementation Committee under the interim N.C.P. as a standing governmental committee, which originally consisted of five members in

75 Article 19. See K. Kummer, International Management of Hazardous Wastes, (1995) p. 234.

76 Article 19. Cf. The 1957 Interim Convention on Conservation of North Pacific Fur Seals (Article 12). Yet during the negotiations of the 1989 Basel Convention it was proposed that the Secretariat should have the power to investigate alleged contraventions of the Convention. See K. Kummer, International Management of Hazardous Wastes, (1995) p. 76-77.

77 Article 14(1), North American Free Trade Agreements: Treaty Materials, p. 13; J. I. Garvey, 'Trade Law and Quality of Life - Dispute Resolution under the NAFTA Side Accords on Labour and the Environment', 89 A.J.I.L. (1995) pp. 439-53.

78 See D. G. Victor, The Early Operation and Effectiveness of the Montreal Protocol's Non-Compliance Procedure, (1996) p. 36.

79 See UNEP/OzL.Pro/7/12, para. 39, noting that 'the Committee had operated in a cooperative, non-judicial and non-confrontational atmosphere'.. 
accordance with Decision II/5.80 The Implementation Committee meets regularly twice a year at least and its meetings are organised by the U.N.E.P. Ozone Secretariat.

At present, the Implementation Committee consists of ten representatives from governmental parties elected by the Meeting of the Parties to the Protocol for two years. As is often pointed out, sovereign states are usually reluctant to entrust independent experts with decisionmaking powers. On this particular point, A. Kiss, for example, argues that: '[T]he existence of independent elements inside a commission may be considered as fundamental criterion for deciding whether it really may be called an international institution'. 81

Whilst the members of the Committee - unlike the I.L.O. supervisory commissions, the I.C.C.P.R./I.C.E.S.C.R. Committees or other human rights

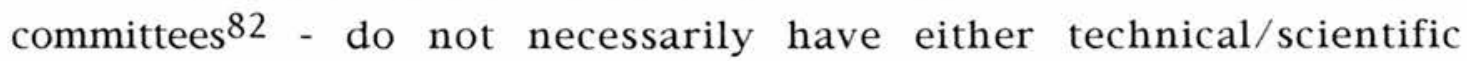
expertise and skills or any special legal competence, they still have to deal with not only political or diplomatic matters, but all matters pertaining to technical or scientific non-compliance issues. 83 In this respect, the importance of the role of the U.N.E.P. Ozone Secretariat as a highly experienced body of technical/scientific experts cannot be overemphasised. In addition, in order to improve the immediate situation, a subsidiary agency of the U.N.E.P., the Technical and Economic Assessment

80 UNEP/OzL.Pro.2/3, para. 47. The first parties elected were Japan, Norway, Trinidad and Tobago, Hungary and Uganda.

81 See A. Kiss, 'Mechanisms of Supervision of International Environmental Rules', in G. Lammers (eds.), Essays on the Development of the International Legal Order, (1980) p. 103 (emphasis added).

82 It is noteworthy that in 1985 an E.C.O.S.O.C. working group composed of governmental representatives was replaced by a committee of eighteen independent experts, i.e. the Committee on Economic, Social and Cultural Rights (the I.C.E.S.C.R. Committee). The composition of the Committee, established in 1987, reflects the principle of an equitable geographic distribution. See E.C.O.S.O.C. Res. 1985/17 (cited in H. G. Schermers and N. M. Blokker, International Institutional Law, (1995) pp. 190 et seq. \& 416. See further P. Alston (eds.), International Human Rights in Context, (1996) Chapter 6. On the I.L.O. Compliance Machinery, see, 4.2. below; Cf. United Nations Rules for Conciliation of Disputes between States (Article $21 \& 25$ ). See also the 1965 Convention on the Settlement of Investment Disputes between States and Nationals of Other States (Article 14). However, in many cases, such individual experts are not entirely independent from their governments. See e.g. H. G. Schermers and N. M. Blokker, International Institutional Law, (1995) pp. 194 et seq.

83 See P. Széll, 'The Development of Multilateral Mechanisms for Monitoring Compliance' in W. Lang (ed.), Sustainable Development and International Law, (1995) p. 108. 
The Montreal Non-Compliance Procedure and the Internal Institutions

Panel ('T.E.A.P.'), has been contributing toward selecting, organising and supplying information as to expected non-compliance of parties. 84

Like many other international conciliation commissions, the composition of the Committee is based on the principle of equitable geographical distribution designed to ensure 'political equilibrium' in which common interests of the international community are to be represented as intended. 85 Unlike the Implementation Committee, however, the Executive Committee of the Montreal Multilateral fund consists of seven representatives from both developed country parties and developing county parties (i.e. " $7+7 "$ formula). 86

(b) The Functions of the Committee in the Montreal N.C.P. Régime

Under the Montreal N.C.P. régime the Implementation Committee assumes the following prominent four roles 'with a view to securing an amicable solution of the matter on the basis of respect for the provisions of the Protocol'. 87 These conciliatory functions do not necessarily cause legal conflicts with the dispute settlement procedures of the 1985 Vienna Ozone Convention, if taken at all. 88

\footnotetext{
84 The T.E.A.P. has reported on anticipated non-compliance by countries with Economic in Transition (C.E.I.Ts.), such as the Russian Federation and Ukraine. Yet it is natural that powers delegated to the agency are no more than these of the Implementation Committee. See Assessment of Basic Problems Confronting Countries With Economies in Transition in Complying With the Montreal Protocol: Report of the TEAP Ad-Hoc Working Group on CEIT Aspects, UNEP, (November 1995). See also Decision VII/34 in UNEP/OzL.Pro.7/12, pp. 43-46.

85 Ongoing Parties of the Montreal N.C.P. may be re-elected for one immediate consecutive terms (Annex IV(5)). The Implementation Committee elects its own President and Vice-President who serve for one year. In the Third Meeting of the Parties it was decided that the number of Parties should be increased by 5 to ten (UNEP/OzL.Pro.3/L.4: Decision III/21). The N.C.P. Committee of the 1994 Oslo Sulphur Protocol consists of eight Parties (EB.AIR/WG.5/CRP, para. 1).

86 See Decision II/20. It is important to note that the United States holds a permanent seat on the Executive Committee.

87 Annex IV(8). The N.C.P. of the 1994 Oslo Sulphur Protocol employs the phrase, 'securing a constructive solutions'. See EB.AIR/WG.5/CPR.13, para. 6(c); P. Széll, 'The Development of Multilateral Mechanisms for Monitoring Compliance' in W. Lang (ed.), Sustainable Development and International Law, (1995) p. 106.

88 Cf. M. Koskenniemi, 'Breach of Treaty or Non-Compliance?', 3 Y.bk.I.E.L. (1992) p. 159.
} 
The Montreal Non-Compliance Procedure and the Internal Institutions

First, the Implementation Committee receives, considers and reports on:

(i) a report from a party/parties in another party's implementation of its treaty obligations under the Protocol; 89

(ii) the submission provided by a party that considers itself unable to comply fully with its obligations; 90

(iii) other relevant submissions, replies and information concerned; 91

(iv) any information or observations with regard to compliance or production, import and export of controlled substances received and forwarded by the U.N.E.P. Secretariat. 92

In analysing those reports/submissions, in order to make appropriate recommendations, the Implementation Committee must ascertain particular underlying reasons for anticipated non-compliance. In the light of national data reporting from parties, the Committee also 'amicably' arranges the classification/re-classification of 'developing countries'93 entitled to receive funding from the established Montreal Multilateral Fund. In addition, the Implementation Committee may request further information where it considers it to be necessary, through the U.N.E.P. Ozone Secretariat. ${ }^{94}$ The Committee's initial four years were occupied with discussions on such reported data, though, since late 1993, it has also examined substantial non-compliance issues such as trade controls (see Section VII(A) below). 95

The Committee considers confidential information as to treaty performance contained in such data reports provided. However, its reports must not include such delicate matters 96 and the members of the Committee

89 Annex IV(7-a).

90 Ibid.

91 Ibid. The U.N.E.P. Ozone Secretariat, as we noted, is assigned the role to transmit such information on possible non-compliance.

92 Annex IV(7-b).

93 The Implementation Committee often put in a necessary correction of data reports from state parties.

94 Annex IV(7-c)

95 See also D. G. Victor, The Early Operation and Effectiveness of the Montreal Protocol's Non-Compliance Procedure, (1996) Chapter 6.

96 Annex IV (15-16). It is important to note that the Third Meeting of the Parties decided that data submitted to the Secretariat on the production of controlled substances would be confidential, while data on the 'consumption' of these substances would not. It follows that environmental N.G.Os. by themselves could not compile exact data as to global trade in O.D.Ss. 
The Montreal Non-Compliance Procedure and the Internal Institutions

and any party involved in its N.C.P. processes must protect the confidentiality of information. 97 Due partly to the fear that such confidential data might be publicly disclosed, 98 environmental N.G.Os. are, at present, totally excluded from the Implementation Committee meetings. Yet it is important that N.G.Os. are free to send any written submissions on any matter they consider important for the attention of the Implementation Committee. 99

By contrast, it is noticeable that a number of committees and commissions in the field of international humanitarian law rely, to an appreciable extent, on unofficial information supplied by human rights N.G.Os. at national and international levels, whereas their 'complaints procedures' are undertaken in closed meetings. 100 The 1989 Basel Convention compliance régime also depends in part on N.G.Os.' active informal monitoring as to trading in illegal hazardous wastes at national/international levels. ${ }^{101}$ It is also interesting to note that under the dispute settlement mechanisms of the North American Free Trade Agreement ('N.A.F.T.A.') environmental N.G.Os. are allowed to file complaints with its Commission. 102

Second, the Implementation Committee submits a report, including any recommendations on individual non-compliance cases, to the Meeting of the Parties. 103 The Implementation Committee may also make recommendations where it considers it appropriate, though the parties

97 The N.C.P. of the 1994 Oslo Sulphur Protocol does not contain a similar provision.

98 P. Széll, 'The Development of Multilateral Mechanisms for Monitoring Compliance' in W. Lang (ed.), Sustainable Development and International Law, (1995) p. 102.

99 Information provided by the Ozone Secretariat, Mr. G. Bankobeza, (11 March 1998). Environmental N.G.Os. are allowed to attend the Meetings of the Parties as observers (see Appendix), and they may circulate certain documents at such formal ozone meetings. They also participate in meetings of the Executive Committee of the Montreal Multilateral Fund.

100 Their legal texts mostly does not prescribe for the role of human rights N.G.Os. See e.g. H. J. Steiner and P. Alston, International Human Rights in Context: Law, Politics, Morals, (1996) Chapter 8.

101 See G. Handl, 'Environmental Security and Global Change: The Challenge to International Law', 1 Y.bk.I.E.L. (1990) p. 18. On the role of N.G.Os. in the 1973 C.I.T.E.S. see K. Sachariew, 'Promoting Compliance with International Environmental Legal Standards', 2 Y.bk.I.E.L. (1991) p. 39.

102 See e.g. N. Aldaraca, 'The North American Agreement on Environmental Cooperation', 2 R.E.C.I.E.L. (1994) pp. 98-104; P. Sands, Principles of International Environmental Law, (1995) pp. 713-14.

103 Annex IV(7-e) and Annex IV(8). Under the early N.C.P. the Committee was not empowered to make such recommendations. 
concerned cannot participate in the decision-making process. 104 In making such recommendations, the Implementation Committee - as a subsidiary body of the Meeting of the Parties - must conform to the Rules of Procedure adopted by the 1989 Ozone Meeting, by applying mutatis mutandis, however. 105

It should be noted that, under international law, the Committee as a conciliation body is not necessarily restricted to basing its recommendations on the ozone treaties, but it can also provide recommendations ex aequo et bono by taking all the relevant circumstances into account. 106 Whilst such recommendations are legally non-binding on ozone régime members, they may carry to some extent political' weight 107 and in many cases they are widely followed. Such voluntary acceptances of the Committee's recommendations has gradually developed the favourable reputation of the Implementation Committee on anticipated treaty non-compliance.

Third, the Implementation Committee undertakes informationgathering in the territory of a party for achieving its functions based on the consent of the party. This is the so-called 'on-the-spot investigations', or a kind of 'verification', in a limited sense. 108

Although during the negotiation of the Montreal N.C.P. régime developing countries regarded as unacceptable consideration by the Implementation Committee of related information from on-site inspections

104 Annex IV(9). This is also provided for in the Oslo Protocol N.C.P. régime (EB.AIR/WG.5/CPR.13, para. 10). See also the statement by the President of the Implementation Committee, Mr. Schally, who stresses the importance of confidentiality (UNEP/OzL.Pro.7/INF.1, paras. $38 \& 41$ ).

105 The Rules of Procedures in UNEP/Ozl.Pro.1/5. See U.N.E.P., Handbook for the International Treaties for the Protection of the Ozone Layer, 6th edn. (1996) pp. 5260 . In principle, they would apply to meetings of any subsidiary committees/panels (UNEP/OzL.Pro.1/5, para. 7). Yet it can be assumed that the Committee usually takes their recommendations by unanimous vote or consensus. The Executive Committee has its own rules of procedure.

106 See R. L. Bindschedler, 'Conciliation and Mediation', 1 Encyclopaedia of Public International Law, (1982) pp. 47 et seq. See also Section V(A) below.

107 See further 5 Encyclopaedia of Public International Law, (1982), p. 133.

108 Annex IV(7-d). This provision is also provided for in the N.C.P. of the 1994 Oslo Sulphur Protocol. Cf. The 1991 Protocol to the Antarctic Treaty on Environmental Protection (Article 14); the 1971 Nuclear Weapons Treaty (Article III(6)). For instance, the I.A.E.A. has its own inspectors who carry out on-site inspections and then report to the institution: for further details of inspection, see A. E. Boyle, 'Saving the World? Implementation and Enforcement in International Environmental Law Through International Institutions', 3 J.E.L. (1991) pp. 236 et seq.; H. G. Schermers and N. M. Blokker, International Institutional Law, (1995) pp. 878 et seq.; W. Fischer, The Verification of International Convention on Protection of the Environment and Common Resources, (1992). 
The Montreal Non-Compliance Procedure and the Internal Institutions

that is based on the Committee's initiative, and from N.G.Os., industries, mass media and individuals, 109 this workable compromise was finally reached by mutual concession.

Fourth, since financial and/or technical assistance are, in practice, closely related to a party's capability to comply with obligations, the Implementation Committee maintains an exchange of information with the Executive Committee of the M.L.F. concerning financial and technical assistance. 110

\section{The Meeting of the Parties to the Montreal Protocol}

(a) The Functions of the Meeting of the Parties in the N.C.P. Régime

As already pointed out, the Meeting of the Parties has served as the final decision-maker under the Montreal N.C.P. régime. ${ }^{111}$ Hence the highest institution of the ozone régime retains, to the very end, direct control over multilateral ozone disputes raised among member states. It would not be denied that this decision-making technique reveals parties' intentions to conserve their various economic/political national interests. The same may be said of other non-compliance mechanisms of the 1994 Oslo Sulphur Protocol and the Climate Change Convention régime.

After receiving the reports from the standing Implementation Committee, the Meeting of the Parties will consider 'the circumstances of the matter, decide upon and call for steps to bring about full compliance with the Protocol, including measures to assist the Parties' compliance with the Protocol, and to further the Protocol's objectives'.112

The 'Indicative List of Measures' in Annex V, which might be taken by the Meeting of the Parties as regards non-compliance with the treaty obligations, include:

(i) Appropriate assistance, including assistance for the collection and reporting of data, technical assistance, technology transfer and financial assistance, information transfer and training.

109 See UNEP/OzL.Pro/WG.3/3/3, para. 23.

110 Annex IV(7-e). It is since 1992 that the Implementation Committee has invited to its meetings representatives from the Secretariat of the Montreal Multilateral Fund and its implementing organisations.

111 See Section IV(B) above. As to the Conference of the Parties to the 1985 Vienna Ozone Convention, see Chapter III(III.5) above.

112 Annex IV(9). 
(ii) Issuing cautions.

(iii) Suspension, in accordance with the applicable rules of international law concerning the suspension of the operation of a treaty, of specific rights and privileges under the Protocol, whether or not to time limits, including those concerned with industrial rationalisation, production, consumption, trade, transfer of technology, financial mechanism and institutional arrangements. ${ }^{113}$

The Meeting of the Parties may also make an interim call and/or recommendations. 114 Moreover, it can request the standing Implementation Committee to make recommendations to assist the Meeting's consideration of matters of treaty non-compliance. 115 Those decisions and recommendations made by the Meeting of the Parties with a view to implementation must be fully effective in accordance with the objectives of the international ozone régime.

It is worth pointing out, in passing, other basic but vital functions of the Meeting of the Parties that will help enhance its efficiency in deciding which measure(s) should be taken for a member state's anticipated noncompliance with treaty obligations:

(i) decide on any adjustments/reductions; 116

(ii) decide on any addition to/insertion in/removal from any annex of substances and on related control measures; 117

(iii) establish guidelines or procedures for reporting of information; ${ }^{118}$

(iv) review requests for technical assistance submitted; 119

(v) review reports prepared by the Secretariat;

113 Cf. The International Monetary Fund (denial of access to funds or credits, Article XXVI: 2(a). Yet, in practice, the I.N.F. usually does not resort to these sanctions and adapts other means of securing compliance. See H. G. Schermers and N. M. Blokker, International Institutional Law, (1995) pp. 913. The G.A.T.T. 1994 (withdrawal and denial of concessions, Articles II:5, XII:4, XVIII:7, XVIII:21, XIX:3, XXIII, XXVII, and XXVIII:4); the N.A.F.T.A. (withdrawal of benefits, Article 40); the United Nations (the loss of voting rights, Article 19; suspension/expulsion from membership, Articles 56, UN Charter); the I.A.E.A. (the suspension of the privileges/rights, Article XIX); the I.L.O. (the loss of voting rights, Article 13(4), the I.L.O. Constitution); the I.C.A.O. (the loss of voting rights, Article 62, the I.C.A.O. Convention); the I.M.O. (the loss of voting rights, the I.M.O. Convention); the W.M.O. (the suspension of rights/privileges, Article 31, the W.M.O. Convention).

114 Annex IV(13); Section VII below.

115 Annex IV(14); Section VII below.

116 See Chapter Part A of Chapter III(IV) above.

117 Ibid.

118 Ibid.

119 Chapter VI below. 
(vi) assess and review control measures; 120

(vii) consider and adopt proposals for amendment of the Protocol or any annex and for any new annex; ${ }^{121}$

(viii) consider and adopt the budget for implementing the Protocol; 122 and

(iv) consider and undertake any additional action that may be required for the achievement of the purposes of the Protocol. 123

(b) The Legal Nature of the Decisions of Meeting of the Parties

Here we shall focus on some of the important features of the binding 'quality' of Decisions adopted by the Meeting of the Parties to the Montreal Ozone Protocol.

By September 1997, the Meeting of the Parties to the Protocol alone adopted more than two hundred Decisions in accordance with the 'Rules of Procedure',124 and many of them are - directly or indirectly - related to non-compliance issues concerning international regulation of O.D.Ss., trade controls of O.D.Ss. and data reporting. These Decisions usually stipulate that régime members shall take further necessary measures for the achievement of the purposes of the dynamic regulatory régime, or they often reiterate obligations already laid down in Articles of the international ozone treaties. 125

However, the legal status of the Decisions of the Meeting remains unsettled (but presumably 'ordinary decisions' are non-binding: see below), and it is not necessarily clear that non-compliance with the obligations in the Decisions of the Parties to the Protocol (and to the Vienna Ozone Convention) can be regarded as 'non-compliance' (= breach of

\footnotetext{
120 See Part A of Chapter III(IV) above.

121 Ibid.

122 See Chapter VI below.

123 See Section IV.B(b) below. It is worth noting that, in order to analyse destruction technologies, the 1990 London Meeting of the Parties established an Ad Hoc Technical Advisory Committee on Destruction Technologies; 'The members shall be experts on destruction technologies and selected with due reference to equitable geographical distribution' (UNEP/OzL.Pro.2/3, pp. 15-16 \& para. 48).

124 The processes to adopt these decisions are rather complicated; see 'Rules of Procedures for the Meeting of the Parties' in UNEP/OzL.Pro.1/5/Annex I; Cf. Article 11.4(j) of the Montreal Protocol. Cf. the Rules of Procedure for Meetings of the Executive Committee in UNEP/OzL.Pro.3/11/Annex VI. On Rules of Procedure in M.E.As. see P. Széll, 'Decision Making under Multilateral Environmental Agreements', 26/5 E.P.L. (1996) p. 211.

125 See U.N.E.P., Handbook for the International Treaties for the Protection of the Ozone Layer, 6th edn. (1996) pp. 63-175.
} 
The Montreal Non-Compliance Procedure and the Internal Institutions

treaty). In addition, they are often vague and open to a variety of interpretations - their vagueness may often be the result of workable political compromise within the environmental régime (see e.g. Decision VII/ 8 as to Russia's non-compliance with Article 2 control measures). ${ }^{126}$

It is interesting to note that during the negotiations of the Montreal N.C.P. régime many representatives from the governments suggested that such Decisions made by the Meeting of the Parties to the Protocol were distinct from Articles of the Montreal Protocol's text, and likewise some states were of the opinion that not all decisions were binding on the state parties. 127 Yet some other representatives stated that such decisions were always legally binding if they related to 'matters of substance'. ${ }^{128}$ In this regard, China made a formal reservation. 129 Consequently, as stated earlier, the 1992 Copenhagen Meeting failed to adopt the 'Indicative List of Possible Situations of Non-Compliance'. Until now, this matter has not been formally discussed in the Meeting of the Parties and in meetings of the Conference of the Parties to the Vienna Ozone Convention.

One may notice that, essentially different from state entities that have established their fully independent legal personality in international law, 130 the functional capacity or 'implied powers' of the Meeting of the Parties - as the product of the multilateral ozone layer treaty - are strictly limited to their 'objectives' and 'functions', and, generally speaking, they are not well defined by customary international law or general international law, but based primarily on the Montreal Ozone Layer Protocol. Whilst the regular Meeting of the Parties has some supranational aspects, it is not a 'super-state' organisation: as Professor P. Birnie and Professor A. Boyle shrewdly pointed out, 'the supervisory body, whether a meeting of the parties or a Commission, is in substance no more than a diplomatic conference of states, and the existence. . . of a separate legal

126 See Section VII(B.2) below.

127 See UNEP/OzL.Pro/WG.3/3/3, para. 41 \& 'Indicative List of Possible Situations of Non-Compliance with the Protocol' (in Annex II). See also comments made at the time of adoption of Decision IV/17 C ('Application of Trade Measures Under Article 4 to Non-Parties to the Protocol) in UNEP/OzL.Pro.4/15, paras. 73-74.

128 Ibid.

129 Ibid.

130 As for legal personality, see Reparation for Injuries Suffered in the Service of the United Nations Case, I.C.J. Reports, (1949) p. 180; The International Status of South West Africa Case, I.C.J. Reports, (1950) pp. 136-38. I. Brownlie, Principles of Public International Law, 4th edn. (1990), Chapter III; D. W. Bowett, The Law of International Institutions, 4th edn. (1982) Chapter 11; N. D. White, The Law of International Organisations, (1996) Chapter 2; R. Higgins, Problems and Process: International Law and How We Use it, (1994) pp. 46 et seq. 
personality does not alter the reality that the membership of these institutions is in no sense independent of the states they represent'. ${ }^{131}$ In this connection, it is also possible to argue that 'any additional action'132 required for the achievement of the purposes of the Montreal Protocol should be defined in terms of its limited functional capacity or 'implied powers' in general international law. 133

In addition, it is important to note that 'internal' international law and procedural rules of the Meeting of the Parties (i.e. Rules of Procedure) are subject to customary international law and rules governing the principles of state sovereignty and equality of states. ${ }^{134}$ Therefore, in theory, the individual Decisions adopted through the internal legal rules of the Ozone Meeting are - in a formal sense, at least - of secondary importance for the legal ozone régime unless declared with an expressed intention to be bound. It should also be pointed out that ozone régime members may dispute the validity of a Decision adopted by the Ozone Meeting on the ground of violation of the Rules of Procedure. 135

In the light of the above considerations, we may say that an ozone Decision cannot impose on régime member states a legal obligation to adopt measures which will conflict with the objectives of the international ozone régime. Needless to say, however, certain specific decisions adopted through 'formal' procedures provided in advance in the ozone treaties (e.g. adjustments/amendments) are legally binding on member states - in this context, they may be properly regarded as 'hard' international law.

Yet it is right to say at the same time that this controversial issue offers one of the absolutely key factors to the understanding of the selfcontained ozone régime that now assumes a dynamic character (see

\footnotetext{
131 P. Birnie and A. Boyle, International Law and the Environment, (1992) p. 165.

132 Article 11(f); see Section IV(B.a) above.

133 It is noteworthy, however, that a key feature of the doctrine of 'implied powers' is its flexibility, and such powers must be defined in the light of specific circumstances. See H. G. Schermers and N. M. Blokker, International Institutional Law, (1995) pp. 232-37; R. Jennings and A. Watts, Oppenheim's International Law, 9th edn. (1992) pp. $16-22$.

134 G. Schwarzenberger, A Manual of International Law, 5th edn. (1967) pp. 32-33 \& pp. 268-69. Article 38 of the Statute of International Court of Justice does not necessarily refer to the legal status of 'internal' international law of institutions.

135 For a discussion of non-compliance with rules of procedure, see for instance B. Conforti, 'The Legal Effect of Non-Compliance With Rules of Procedure in the U.N. General Assembly and Security Council', 63 A.J.I.L., (1969) pp. 479-89,
} 
The Montreal Non-Compliance Procedure and the Internal Institutions

Chapter I(IV) above). 136 Indeed, one of the primary functions of the Meeting of the Parties as a quasi-legislative body is to change 'constantly' the international law of ozone layer protection. Numerous Decisions whether adopted as 'soft' or 'hard' law instruments (see Chapter I(III.A) above) - have created certain legal norms (and expectations) and elements, which are capable of forming part of the international legal system of the developing regulatory régime. As this question is taken up in Chapter VI below, it is worth noting that, as with the N.C.P., the 'Interim' Multilateral Fund of the Montreal Protocol - which is seen as a prototype for financial mechanisms in protecting the global environment - was established on the basis of Decision II/18 of the Ozone Meeting of the Parties, rather than by amendment. ${ }^{137}$ Hence it is mistake to think that they have no legal effects. As decisions of international organisations have contributed to customary international institutional law, arguably, many Decisions of the Meeting of the Parties could show 'immediate' evidence of consensus among régime actors $^{138}$ and at the same time they provide essential indicators for a proper understanding of the developing ozone regulatory régime.

Finally, we should not overlook the fact that the current rapid pace of environmental degradation has produced a situation in which customary international law obviously does not necessarily keep pace with the immediate need to surmount such new environmental problems, including ozone depletion, global climate change and the loss of living/non-living natural resources. 139

There is another important legal issue to be taken account in the present discussion - namely, the intergovernmental Meeting's 'power' to interpret the ozone layer treaties.

In the 1995 Vienna Meeting, the Russian Federation insisted that the Meeting of the Parties should have applied 'appropriate measures' in accordance with the 'Indicative List' in an ascending order of importance, that is, from assistance, caution to sanctions. 140 At present there does not

136 See A. E. Boyle, 'State Responsibility for Breach of Obligations to Protect the Global Environment' in W. E. Butler (ed.), Control over Compliance with International Law, (1991) pp. 75-77; Chapters I, IV \& IX.

137 It is also important to note that, subsequently, the Ozone Meeting adopted Decision VIl/16 regarding judicial personality, privileges and immunities of the Montreal Multilateral Fund. See UNEP/OzL.Pro.6/7, p. 22. See Chapter VI below.

138 See J. I. Charney, 'Universal International Law', 87 A.J.I.L. (1993) pp. 529-51.

139 See Chapter I(III.A) above on the framework-protocol \& 'soft law' approaches. 140 In this context, the 1969 Vienna Convention on the Law of Treaties provides 'A treaty shall be interpreted in good faith in accordance with the ordinary meaning to be given to the terms of treaty in their context and in the light of its object and purpose' 
The Montreal Non-Compliance Procedure and the Internal Institutions

exist, in a legal sense, a clear preference in choosing such 'Measures' as listed. Such an 'appropriate measure' - Decision VII/18 which Russia would not describe in such mild terms - was, as we shall see, adopted through Rules of Procedure of the Meeting of the Parties, but with the help of the U.N.E.P. Ozone Secretariat's own interpretation. In this respect, it is possible to argue that, referring to Article 31 of the Vienna Convention on the Law of Treaties, ${ }^{141}$ the travaux préparatories of the Montreal N.C.P. régime would partly defend Russia's position (see Section II above). Further, this kind of dispute relating to treaty interpretation could potentially be settled by traditional settlement procedures under Article 11 of the Vienna Ozone Layer Convention (see Section IV(A.3) above) as a last resort.

However, as we noted, the Meeting of the Parties to the Protocol decided in its Third Meeting that: 'the responsibility for legal interpretation of the Protocol ultimately rests with the Parties themselves' (i.e. the 'control' of the interpretation of the ozone layer treaty texts).

Given that this debatable statement implies that the quasi-judicial interpretative organ of the ozone régime would not be entirely bound by a body of principles/rules of general public international law, such Decisions (or 'rules of behaviour') ratified by the Meeting of the Parties as a result of the inter-state bargaining process may not conceal their political orientations in existing international environmental relations. Such outcomes might be criticised by some for lack of 'legitimacy'142 or as mere declarations of international environmental politics: So, to what extent must such Decisions take account of general international law? Is the Ozone Meeting's real intention declared, ultimately, to interpret and apply the provisions of the ozone layer treaties in the light of multi-faceted national interests of the ozone régime member states? These are difficult questions.

(Article 31). Yet the subsequent conduct of the Meeting of the Parties (or the Implementation Committee) may determine this controversial issue (see the 1969 Vienna Convention on the Law of Treaties (Article 31(3)).

141 Article 32. See e.g. I. Sinclair, The Vienna Convention on the Law of Treaties, (1984) p. 115-17. Yet it is also important that the régime member's original intentions would be clarified in terms of the purposes of the ozone treaties.

142 In the widest sense, the term 'legitimacy' can be defined as 'quality of a rule which derives from a perception on the part of those whom it is adhered that it has come into being in accordance with right process ' [i.e. 'the notion of valid sources but also encompasses literary, socio-anthropological and philosophical insights']. See T. Frank, 'Legitimacy in the International System', 82 A.J.I.L. (1988) pp. 705-59: O. Schachter, 'United Nations Law', 88 A.J.I.L. (1994) pp. 9-16 esp. 
It can be tentatively suggested that internal international régime institutions within the system of the ozone treaties are more suitable for interpretations and settlement of disputes than judicial organs external to them. For instance, interpretation of I.M.F. rules are always made by the Executive Board, the Board of Governors (or/and a Committee on Interpretation). ${ }^{143}$ Similar examples are abundant. ${ }^{144}$ In addition, it has been argued in the legal literature that governmental representation in one environmental legal régime can be often regarded as a certain 'guarantee' for a consistent diplomatic policy in another international legal régime or international organisation. ${ }^{145}$ This could partially explain why member states of the G.A.T.T./W.T.O. trade law régime have never formally disputed the validity of Article 4 T.R.E.Ms. of the Montreal Protocol, the Multilateral Fund's environmental subsidies ${ }^{146}$ and other M.E.A. trade restrictions.

\section{THE PRINCIPAL FEATURES OF THE MONTREAL NON-COMPLIANCE PROCEDURE: THE MONTREAL N.C.P., INTERNATIONAL CONCILIATION AND OTHER DISPUTE SETTLEMENT PROCEDURES}

What I seek to show in this Section is that dispute settlement under the N.C.P. régime can be viewed as a mixture of diplomatic and quasi-judicial efforts in resolving treaty disputes at the multilateral level. It is a new set of institutionalised global negotiation processes that decrease the possibilities of international confrontation. ${ }^{147}$ Among other settlement

143 H. G. Schermers and N. M. Blokker, International Institutional Law, (3rd edn. 1995) p. 843. See also G. Schwarzenberger, A Manual of International Law, 5th edn. (1967).

144 In the World Bank Administrative Tribunal and in the Administrative Tribunal of the I.N.F., there is no possibility for judicial review by the I.C.J. (see H. G. Schrmers and N. M. Blokker, International Institutional Law, (1995) pp. 437-38). In this connection, secretariats of international legal régimes in many cases play important functions to deal with questions of interpretations. Cf. the I.M.O. Convention (Article 69); F. L. Kirgis, International Organisations in their Legal Setting, (1992) pp. 47981. See, also, constitutions of; the F.A.O. (Article 17); the W.H.O. (Article 75); and the W.M.O. (Article 29). Yet, it is not necessarily clear that the Ozone Meeting of the Parties to the Protocol would make consistent interpretation of the ozone treaties.

145 As to arguments against composing independent technical bodies, see H. G. Schermers and N. M. Blokker, International Institutional Law, (1995), pp. 192-95.

146 For details of the relationship between the Fund's environmental subsidies and the G.A.T.T., see S. N. Carlson, 'The Montreal Protocol's Environmental Subsidies and GATT: A Needed Reconciliation', 29 TEXAS I.L.J. (1994) pp. 211-30.

147 It is also probable that, in certain circumstances, such an 'institutionalised' negotiation procedure would reduce the impact of 'power relations' of the parties to the dispute, which is inherent in negotiation process. 
techniques ${ }^{148}$ international conciliation ${ }^{149}$ is chosen here as a candidate somewhat similar to the Montreal N.C.P. model. In addition, dispute settlement procedures in (i) the European Human Rights Convention (the role of the Committee of Ministers in particular), (ii) the G.A.T.T./W.T.O. and (iii) the I.L.O. will be briefly considered in comparison to the Montreal N.C.P.

\section{A. The Montreal N.C.P. as a Multilateral Conciliation Mechanism}

\section{International Conciliation and the N.C.P. Régime}

In conciliation, a friendly third party or an international institution such as a conciliation commission works out not necessarily an authoritative but an amicable solution, and it reports with recommendations for the parties concerned, based on hearings, findings and evidence. In contrast to an arbitral award, its marked advantages will be that 'the parties retain control over the outcome and remain free to negotiate a politically acceptable settlement of their differences without being bound to adhere to treaty provisions of international law'. 150

\footnotetext{
148 Methods of peacefully settling disputes are generally classified into seven broad categories, i.e. (i) negotiations, (ii) good offices, (iii) enquiry and fact-finding, (iv) mediation, (v) conciliation, (vi) arbitration and (vii) formal judicial settlement. For details see United Nations, Handbook on the Peaceful Settlement of Disputes between States, (1992).

149 See e.g. J. G. Merrills, International Dispute Settlement, (1991) Chapter IV; D. W. Bowett, 'Development in the Settlement of Disputes', 180 Hague Recueil, pp. 185 et seq.; J. P. Cott, International Conciliation, (1972) pp. 8-11; the Unuted Nations, Handbook on the Peaceful Settlement of Disputes between States, (1992) Section II.E. See also Y. Iwasawa, WTO Dispute Settlement, (1994) Chapter 3(2). The 1928 General Act for the Pacific Settlement of International Disputes, revised on April 28 1949, (Article 1-16); the 1957 European Convention for the Peaceful Settlement of Disputes; the 1969 Vienna Convention on the Law of Treaties (Article 66 \& Annex); the 1971 Convention on International Liability for Damage caused by Space Objects (Article XIX); the United Nations Rules of the Conciliation of Disputes between States (Chapter VII regarding rules applicable to conciliation by commission, esp.); the 1992 Decision on Peaceful Settlement of Disputes Including the Convention on Conciliation and Arbitration Within the C.S.C.E. (Annex III).

150 See A. E. Boyle, 'Settlement of Disputes Relating to the Law of the Sea and the Environment', 26 Thesaurus Acroasium, (1996) p. 259. See also the 1969 Law of the treaties (Annex. 6); Brierly, The Law of Nations, (6th edn. 1963) pp. 373-76. But Cf. the 1975 Convention on the Representation of States in their Relations with International Organisations (Article 87(5)).
} 
The Montreal Non-Compliance Procedure and the Internal Institutions

The text of the Montreal N.C.P. does not employ the term 'conciliation', although it refers to an 'amicable solution'. 151 Yet, so far as the functions of the standing Implementation Committee as an international conciliation body 152 (and of the Secretariat as a group of technical experts ${ }^{153}$ ) are concerned, the N.C.P. régime comes close to international conciliation as a formal method of settling 'treaty disputes'. Such treaty disputes are, as was described above, concerned with reporting of data (Articles 7 and 9), O.D.S. control measures (Article 2), ${ }^{154}$ trade matters (Article 4) and the classification of Article 5 country parties. Under the Montreal N.C.P. régime, the Implementation Committee plays a similar role to a conciliator who is given the task of investigating the dispute in its various aspects and of helping parties reach an amicable but non-binding agreement (see Section VII(A) below). The Ozone Secretariat and subsidiary treaty bodies are to provide the N.C.P. Committee with relevant expert information (see Section IV(B.1)).

However, the N.C.P. régime is not a conciliatory dispute settlement procedure in a more restricted sense of the term; ${ }^{155}$ strictly speaking, this means therefore that the N.C.P. may fall into the category of 'other peaceful means' of settling disputes provided for in Article 33 of the U.N. Charter. 156 There are at least two differences between normal conciliation procedures and the N.C.P. of the Montreal Protocol type.

In the first place, international conciliation - and formal judicial proceedings - is more applicable in the case of bilateral, rather than multilateral disputes or agreements. ${ }^{157}$ Strictly speaking, as Bindschedler says, the primary objective of conciliation is not to establish a 'uniform

151 Cf. Article 28 of the European Human Rights Convention reads 'it shall at the same time place itself at the disposal of the parties concerned with a view to securing a friendly settlement of a matter on the basis of respect for Human Rights as defined in this Convention' (emphasis added).

152 See Section IV(B.2) above

153 Chapter II(III.D.3) and Section IV(B.1) above.

154 And freeze of C.F.C. consumption for Article 5 countries, which will take effect in 1999.

155 It should be noticed that the 1985 Vienna Ozone Layer Convention contain a good 'international' conciliation procedure. See in detail Chapter II(III.D.4) above.

156 For 'other peaceful means' see United Nations, Handbook on the Peaceful Settlement of Disputes between States (1992) paras. 288-312.

157 Yet a number of multilateral treaties contain detailed conciliation procedures. See United Nations, Handbook on the Peaceful Settlement of Disputes between States, (1992) para. 143. 
legal order'. 158 As noted above, a non-compliance dispute about the ozone treaties is not a bilateral one between two or more parties but a multilateral one between a party and all other parties. ${ }^{159}$ It is important in this respect that non-compliance complaints will be initiated by both any party and the Secretariat. Those N.C.P. initiators by themselves may determine the 'right timing' to trigger the dispute avoidance/settlement procedure. 160 Unlike normal international conciliation procedures, the N.C.P. régime as a multilateral conciliation mechanism thus inspires a collective reaction taken by the parties in cases of non-compliance. 161

In the second place, the N.C.P. Committee is not an independent third party but is composed of government representatives: 162 this partly reflects one of the noteworthy political aspects of the Montreal N.C.P. régime. It may be assumed that the Committee is likely to decide what measures should be taken on non-compliance cases at its broad discretion. Under the N.C.P. régime the members of the Committee are strictly required to protect the confidentiality of information from the parties and, moreover, N.G.Os. are not allowed to participate in the Committee's meetings (see Section IV(B.2.a) above). In this respect, G. Palmer argues that the Committee could 'ignore certain rules of international law whose application might not be considered desirable and it may draw upon the body of normative expectations developed within the [ozone] regime regardless of the formal legal status of any particular rule'. ${ }^{163}$

Yet under the Montreal N.C.P. - unlike under both an ad hoc conciliation or arbitration commission and the so-called 'panels' in the field of international economic law - the question at issue will be addressed by the permanent Committee that meets several times a year, and not therefore by a temporary ad hoc third party commission; the Committee is a treaty organ created specifically for the settlement of treaty disputes concerning the global protection of the ozone layer. In political terms,

158 See e.g. R. L. Bindschedler, 'Conciliation and Mediation', in Encyclopaedia of Public International Law, 1(1982), p. 49.

159 See also M. Bothe, 'The Evaluation of Enforcement Mechanisms in International Environmental Law' in R. Wolfrum (ed.), Enforcing Environmental Standards, (1996) pp. 32-33.

160 See Section VII(B.2) below. See also R. Benedick, Ozone Diplomacy, (1998) p. 281.

161 See Chazournes, 'Mise en oeuvre du droit international dans le domaine de la protection de l'environment: enjeux et défis', Revue générale de droit international public, 1(1995), p. 63; T. Gehring, Dynamic International Régimes, (1994) pp. 318-19. 162 For details see Section IV(B.2) below.

163 G. Palmer (eds.), International Environmental Law \& World Order, (1994) p. 1120 (emphasis added). 
The Montreal Non-Compliance Procedure and the Internal Institutions this pre-constituted international institution may foster a 'basic set of ideas relating to societal values' 164 shared by the ozone régime members.

\section{From Conciliation to the Political Organ of the M.E.A. Régime}

Although the role and capability of the Implementation Committee are strictly limited to making non-binding recommendations, the Committee thus being conferred with not comprehensive but only conciliatory powers, should the standing Committee not succeed in settling an ozone dispute, the supreme organ of the ozone régime, i.e. the Meeting of the Parties is then to take quasi-judicial decisions as to treaty non-compliance by a régime member in accordance with the Indicative List of Measures in Annex V165 (see Section IV(B.3) above). As in Russia's non-compliance case, this dynamic quasi-legislative activity of the international political institution often far exceeds the conciliatory role of the Implementation Committee. As we shall see below, its decisive power may be comparable to that of the Committee of Ministers under the European Human Rights Convention.

In exceptional circumstances involving cases which have not been referred to the European Court of Human Rights, the Committee of Ministers of the European Convention on Human Rights - which consists of state representatives, usually the foreign ministers of member states - is empowered to make a binding determination whether or not there has been a violation of the Convention. Its deliberations on certain cases is highly confidential and the individual applicant is totally excluded from the Committee's procedure. ${ }^{166}$ In short, as is the case with Decisions of the Meeting of the Parties, 167 it is likely that the Committee of Ministers might also politicise to a not inconsiderable extent legal/political disputes that are unsolved.

\footnotetext{
164 See W. D. Coplin, The Functions of International Law: An Introduction to the Role of International Law in the Contemporary World, (1966) Chapter 5.

165 It should be noted, however, that even if a régime member refuses to accept compliance-related recommendations by the Implementation Committee, the whole procedure for settling ozone disputes does not have to be restarted before the Meeting of the Parties. International ozone negotiations within the Meeting of the Parties will continue based on the evidence and factual, technical data provided by the Committee, the Ozone Secretariat and other technical bodies such as temporary sub-committees.

166 F. G. Jacobs and R. C. A. White, The European Convention on Human Rights, (1996) p. 693 and its footnote 13 .

167 See Decision VIII/26(1) discussed in Section VII(B.2) below.
} 
The Montreal Non-Compliance Procedure and the Internal Institutions

In addition, it is worth noting that there have been many cases in which the Committee of Ministers has failed to achieve the required twothirds majority, and, in fact, the Committee has taken no decision at all: in such cases, in a certain sense, lack of decisions might be viewed as noncompliance of the Committee under Article 32(1) in deciding whether or not there has been a violation of the European Human Rights Convention. 168 This fact clearly shows the inherent limitations of such political bodies when dealing with controversial 'legal' and/or 'political' issues.

Accordingly, whilst the Committee of Ministers thus acts in a quasijudicial capacity, it is probable that the Committee takes account of considerations of political expediency and in certain cases, such decisions made by the diplomatic institution are thus not necessarily consistent with principles of general international law (see also Section III(B) above).

\section{B. The Dispute Settlement Mechanisms Used by Other International Institutions}

Let us, for the moment, consider dispute settlement procedures of the G.A.T.T./W.T.O. legal system and of the International Labour Organisation ('I.L.O.'). There are some similarities between the Montreal N.C.P. régime and the G.A.T.T./W.T.O. non-violation procedure under international economic law or the complaints procedure in the I.L.O. under the branch of international social law.

1. The G.A.T.T./W.T.O. Non-Violation Procedure in International Economic Law 169

168 See D. J. Harris, M. O'Boyle and C. Warbrick, Law of the European Convention on Human Rights, (1995) p. 695.

169 On the G.A.T.T./W.T.O. dispute settlement system see among others Y. Iwasawa, WTO Dispute Settlement, (1994), Japanese; E. U. Petersmann, The GATT/WTO Dispute Settlement System, (1997). With regard to the non-violation complaints in particular see E. U. Petersmann, 'Violation and Non-Violation Complaints in Public International Trade Law', 34 G.Y.bk.I.L. (1991) p. 192; T. Cottier and K. Schefer, 'Non-Violation Complaints in WTO/GATT Dispute Settlement: Past, Present and Future' in E. U. Petersmann (ed.), International Trade Law and the GATT/WTO Dispute Settlement System, (1997) Chapter 3; A. von Bogdandy, 'The Non-Violation Procedure of Article XXIII:2, GATT: Its Operational Rationale', 26 J.W.T. (1992) pp. 95-111; P. J. Kuyper, 'the Law of GATT As a Special Field of International law', 25 Netherlands Y.bk.I.L. (1994) pp. 245-49. 
The G.A.T.T. dispute settlement procedure - though formally based on G.A.T.T. Articles XXII and XXIII (and a few other provisions) - has been built over time through the progressive development of subsequent customary practice. ${ }^{170}$ It is important that the principal purpose of the G.A.T.T./W.T.O. dispute settlement procedure is not to sanction breaches of a treaty rule but to ensure predictability and the maintenance of the balance of advantages in the changing circumstances of international economic relations. ${ }^{171}$

The dispute settlement system of G.A.T.T./W.T.O. trade law is now clearly described in the 1994 W.T.O. Understanding on Rules and Procedures Governing the Settlement of Disputes (i.e. the 1994 'D.S.U.'/Annex II) that prescribes considerable changes. ${ }^{172}$ The early operation of the W.T.O. dispute settlement system (1995-97) appears to have been successful. ${ }^{173}$ Article 3(1) of the D.S.U. provides that the Members affirm their adherence to the principles for the management of disputes heretofore applied under G.A.T.T. Articles XXII and XXIII, and the procedures further elaborated and modified. Further, Article 3(2) of the D.S.U. states that the W.T.O. settlement system is 'a central element in providing security and predictability to the multilateral trading system and it serves to 'clarify the existing provision of [the] agreements in accordance with customary rules of interpretation of public international law'.

One of the distinguishing feature of the G.A.T.T./W.T.O. dispute settlement procedures has been the introduction of the panel system (Articles 6-16 \& 18-19 of the 1994 D.S.U.), 174 having certain elements of

170 See Y. Iwasawa, WTO Dispute Settlement, (1995) Chapter 2; (Japanese); E. U. Petersmann, The GATT/WTO Dispute Settlement System, (1997) Chapter 2; J. H. Jackson, The World Trading System: Law \& Policy of International Economic Relations, 2nd edn. (1997) pp. 112-20 esp.

171 See 'General Provisions' contained in Article 3 of the 1994 D.S.U. in particular (e.g. Articles 3(2-3), 3(7) \& 3(10).

172 W.T.O., The WTO Dispute Settlement Procedures: A Collection of the Legal Texts, (1995). It applies to all the 'multilateral trade agreements' in the Annexes to the 1994 W.T.O. Agreements. For a brief summary of these improvements see J. H. Jackson, The World Trading System: Law \& Policy of International Economic Relations, 2nd edn. (1997) pp. 125-26; Y. Iwasawa, 'WTO Dispute Settlement: The Significance of the 1994 D.S.U.', Jurist, no. 1071 (1995) pp. 53-58 (Japanese).

173 J. H. Jackson, The World Trading System, 2nd edn. (1997) pp. 126-27. For a critical analysis of its operation see in particular E. U. Petersmann, The GATT/WTO Dispute Settlement System, (1997) Chapter 6.

174 The G.A.T.T./W.T.O. dispute settlement procedure commences with bilateral consultations, however (see G.A.T.T. Articles XXII(1) \& XXIII(1): Article 4 of the D.S.U.). The member concerned must reply within ten days to a request for consultations and should enter into consultations within thirty days (from the date of request). If these consultations prove unsuccessful - and if both parties so agree - the case may be brought to the W.T.O. General, acting ex officio, may offer his good office. 
international conciliation with a marked (quasi-)judicial character. ${ }^{175}$ Members of a panel perform their duties in their individual capacities and may not receive instructions from their government (Article 8(9) of the D.S.U.). ${ }^{176}$ The panels examine the dispute, consider the various questions of fact and law involved, record their findings and recommendations, and send their report to the D.S.B. for a decision. In accordance with Article 11 of the D.S.U., such a report must include 'an objective assessment of the matter before it', and present such findings and recommendations as will assist the Dispute Settlement Body ('D.S.B.') in making its recommendations or rulings (Article 7 of the D.S.U.). ${ }^{177}$ The panel report in and of itself has no legal force and is therefore treated as an advisory opinion by the D.S.B. Unlike the procedures under the G.A.T.T. 1947, panel reports are now automatically adopted by the political body of the D.S.B., unless otherwise decided by consensus (Article 16(4) of the D.S.U.). Of course this essentially differs from the Montreal Protocol's N.C.P. In addition, the 1994 D.S.U. newly instituted an appellate review system (Articles 17-19 of the D.S.U.). 178

It is interesting that, in support of its request for a panel, a party does not necessarily have to invoke the actual breach of a rule of the 'covered agreements', including the G.A.T.T., G.A.T.S. and T.R.I.Ps. ${ }^{179}$ A

If the party concerned does not respond to a request for consultations within ten days, or if the consultations fail to arrive at a solution after sixty days, the party concerned may request that a panel be set up by the Dispute Settlement Body ('D.S.B.'). It is interesting to note that, a panel is to be established unless there is a consensus not to do so (almost 'automatic'). The W.T.O. dispute settlement system contains 'mandatory' consultations (Article 4), arbitration procedures (Article 25), and 'optional' procedures for good offices (Articles 5 \& 24), conciliation (Articles 5 \& 24) and mediation (Articles $5 \& 24$ ). There are also several special dispute settlement bodies such as the Textile Monitoring Body ('T.M.B.').

175 For a comprehensive discussion see Y. Iwasawa, WTO Dispute Settlement, (1995) Chapters 3(1.2), $4 \& 7$ esp. (Japanese). See also panel reports on the cases referred to in Chapter IV above.

176 The W.T.O. Secretariat must suggest the names of three possible panellists to the dispute and, if the parties could not agree on the panellists within twenty days, the Director General shall constitute the panel by appointing the panellists he considers most appropriate.

177 See also Y. Iwasawa, WTO Dispute Settlement, (1995) pp. 117-18 (Japanese).

178 For a discussion see e.g. E. U. Petersmann, The GATT/WTO Dispute Settlement System, (1997) pp. 186-91; Y. Iwasawa, WTO Dispute Settlement, (1995) pp. 133-35 (Japanese). See reports on 'United States-Standards for Reformulated and Conventional Gasoline', adopted on 20 May 1996, WT/DS2/AB/R (discussed in Chapter IV above); 'Japan-Taxes on Alcoholic Beverages', adopted on 1 November 1996, WT/DS8, 10 \& 11 $\mathrm{AB} / \mathrm{R}$.

179 Cf. e.g. The 1960 Agreement establishing the E.F.T.A. (Articles 13(2) \& 31(3)); the 1992 North American Free Trade Agreement (Article 2004), 32 I.L.M. (1993) pp. 
The Montreal Non-Compliance Procedure and the Internal Institutions

party need only claim that [1] a benefit accruing to it under the 'covered agreements' is nullified or impaired, 180 or that [2] the attainment of any objective of the covered agreements is impeded, as a result of the following three situations:

(a) the failure of another contracting party to carry out its obligations under this Agreement (i.e. 'violation complaints'), or;

(b) the application by another contracting party of any measure, whether or not it conflicts with the provisions of this Agreement (i.e. 'non-violation complaints'); or,

(c) the existence of any other situation ('situation complaints).

If the breach of a rule is invoked, the adverse effects on the balance of benefits is presumed. Only two of the six different kinds of complaints mentioned above (i.e. [1]/[2] X $(a)(b)(c)=6$ ) have been so far used by the parties, i.e. (1-(a)) 'violation complaints' over 'nullification or impairment' (over ninety per cent) and (1-(b)) 'non-violation complaints' over 'nullification or impairment' (less than ten per cent, however). ${ }^{181}$ Complaints by the G.A.T.T. parties about the case [2] have been extremely rare. ${ }^{182}$ This means, therefore, that parties and G.A.T.T. panels have chosen to lay the greatest emphasis on normal violation complaints [1]. ${ }^{183}$ G.A.T.T. Article XXIII(2) provides for three types of remedies, i.e. (i) 'appropriate' recommendations; (ii) 'appropriate' rulings, and; (iii) suspension of obligations. ${ }^{184}$

It is interesting that, under the non-violation procedure (Article XXIII(1.b)), parties can bring complaints, regardless of the actual breach of the G.A.T.T./W.T.O. trade rules in itself or of the existence of material damage. In this context, it could be possible to argue that the non-violation procedure - in the field of international trade law - is something to do with the concept of 'international liability for injurious consequences arising

$289 \& 605$. On the N.A.F.T.A. dispute settlement system see Y. Iwasawa, WTO Dispute Settlement, (1995) pp. 68-73 (Japanese).

180 '[A]n fortunately ambiguous phrase'. See J. H. Jackson, The World Trading System, 2nd edn. (1997) p. 115.

181 E. U. Petersmann, The GATT/WTO Dispute Settlement System, (1997) p. 136.

182 Yet complaints over this case (2) are indicative of the notion of 'actio popularis'. See Y. Iwasawa, WTO Dispute Settlement, (1995) p. 76 (Japanese).

183 See E. McGovern, 'Dispute Settlement in the GATT - Adjudication or Negotiation?', in E. U. Petersmann (eds.), The European Community and GATT, (1986), p. 77.

184 See also the 1994 D.S.U. (Articles 19, 21 22). For a discussion see e.g. P. J. Kuyper, 'The Law of GATT as a Special Field of International Law', 25 N.Y.bk.I.L. (1994) Section 5. 
out of acts not prohibited by international law'.185 In the past, the nonviolation procedure - as a supplement to G.A.T.T. Article XXVIII - appeared to be useful particularly in protecting tariff concession ${ }^{186}$ (yet, panels reports regarding the non-violation procedure on E.E.C. Production Aid on Canned Fruit 187 and E.E.C. Tariff Treatment 188 have not been adopted). 189

The non-violation provision of the specialised trade régime, W.T.O. may be of potential utility in handling growing international economic transactions, but only if it is to be properly used on the case-by-case basis. 190 Armin von Bogdandy made several important statements on the non-violation procedure:

'it is sensitive to have a procedure in which any trade related concern can be brought up, irrespective of the lawfulness of the measure in question. The non-violation procedure is important as it allows ... the closing-up of a loophole in substantive law. It offers the possibility of maintaining the balance of interests even in cases where the substantive law does not cover the issues at hand'. ${ }^{191}$

Finally, it must be briefly noted that the 1994 D.S.U. brought about significant improvements. It decided that, for example, a complaining party that triggers the non-violation procedure must submit a 'detailed justification in support of any complaint relating to a measure which does not conflict with the relevant covered agreement': this is the introduction

185 E. U. Petersmann, 'Violation-Complaints and Non-Violation Complaints in Public International Trade Law', 34 G.Y.bk.I.L. (1991) pp. 175-77; Y. Iwasawa, WTO Dispute Settlement, (1995) pp. 77-78 (Japanese). Cf. P. J. Kuyper, 'The Law of GATT as a Special Field of International Law', 25 N.Y.bk.I.L. (1994) pp. 246-47.

186 See cases as to non-violation complaints summarised in E. U. Petersmann, 'Violation-Complaints and Non-Violation Complaints in Public International Trade Law', 34 G.Y.bk.I.L. (1991) pp. 200-20; Y. Iwasawa, WTO Dispute Settlement, (1995) pp. 82-84 (Japanese).

187 'EEC-Production Aids Granted on Canned Fruits and Dried Grapes', L/5778 (1985).

188 'EEC Tariff Treatment on Imports of Citrus Products from Certain Countries in Mediterranean Region', L/5776 (1985).

189 On this point see A. von Bodandy, 'The Non-Violation Procedure of Article XXIII:2, GATT: Its Operation and Rationale', 26 J.W.T. (1992) pp. 98-99.

190 See T. Cottier and K. N. Schefer, 'Non-Violation Complaints in WTO/GATT Dispute Settlement: Past, Present and Future' in E. U. Petersmann, International Trade Law and the GATT/WTO Dispute Settlement, (1997) p. 182, noting that 'The political agenda of trade policy must remain separated from the legal debate if the non-violation provision is not to develop into the all-encompassing - and therefore meaningless tool for harassment and ex aequo et bono decisions'. See also ibid. Section V.

191 von Bogdandy, 'The Non-Violation Procedure of Article XXIII:2, GATT: Its Operation and Rationale', 26 J.W.T. (1992) p. 110. 
of a reversal of burden of proof (Article 26(1.a) of the D.S.U.). ${ }^{192}$ This requirement indicates partly the growing trend towards 'legalisation' or 'judicialisation' of the G.A.T.T./W.T.O. dispute settlement rules and procedures - 'from power-oriented diplomatic to rule-oriented legal methods of dispute settlement'. 193 Added to this is that the 1994 D.S.U. only requires a panel/Appellate Body to make rulings or recommendations as to such 'non-violation complaints' (Article 26(1.b) of the D.S.U.). It follows that there is actually no obligation to withdraw the measure discussed, even though they are regarded as inconsistent with objectives and purposes of the G.A.T.T./W.T.O. legal system. Further, the T.R.I.Ps. agreement also limits the use of the non-violation procedure (Article 64). ${ }^{194}$

\section{The I.L.O. Complaints Procedure in International Social Law}

The International Labour Organisation ('I.L.O.'), which is one of the specialised agencies of the United Nations, aims basically to improve conditions of 'labour'. 195 In order to fulfil the particular purpose in mind, the I.L.O. advocates two guiding principles: (i) 'the interdependence of human rights and social policy', and: (ii) 'the interdependence of social policy and policies of an economic character and the primacy of the social objective'.196

\footnotetext{
192 See T. Cottier and K. Schefer, 'Non-Violation Complaints in WTO/GATT Dispute settlement: Past, Present and Future' in E. U. Petersmann (ed.), International Trade Law \& the GATT/WTO Dispute Settlement System, (1997) p. 154 \& its footnote 37-38, suggesting that this is meant to clarify the principle of G.A.T.T. case-law. With regard to subparagraph (c) of 'situation complaints', similarly, a complaining party must present a 'detailed justification in support of any argument made with respect to issues covered under this paragraph' (Article 26(2.a)).

193 See E. U. Petersmann, 'The Dispute Settlement System of the WTO and the Evolution of the GATT Dispute Settlement System Since 1948', 31 C.M.L.R. (1994) p. 1169.

194 See further T. Cottier and K. Schefer, 'Non-Violation Complaints in WTO/GATT Dispute Settlement: Past, Present and Future' in E. U. Petersmann (ed.), International Trade Law \& the GATT/WTO Dispute Settlement System, (1997) p. 156. In relation to the G.A.T.S. see ibid. pp. 157-58.

195 The I.L.O. was established in 1919 as a part of the League of Nations. Since then, the 1946 Montreal Amendments to the I.L.O. Constitution greatly expanded its roles in protecting human rights regarding labour conditions. For detailed arguments for the historical background of the institution, see, for example, V. Y. Ghebali, The International Labour Organisation: A Study on the Evolution of U.N. Specialised Agencies, (1988).

196 See F. Morgenstern, 'Wilferd Jenks in the I.L.O.', 46 B.Y.bk.I.L. (1972-73) pp. xxii-xxiii.
} 
It is interesting to note that - as in the case of the ozone régime - the founders of the I.L.O. recognised that non-compliance behaviour of one member state would undermine the stability of the established legal régime of the I.L.O.; the I.L.O. Constitution declares that 'the failure of any nation to adopt humane conditions of labour is an obstacle in the way of other nations which desire to improve the conditions in their own countries'. 197

The I.L.O. is unique in that it included representation of workers and employers, as well as governments (i.e., the principle of 'tripartism'), and it consists of three permanent treaty institutions - that is, the General Conference of Representatives of the Member States (International Labour Conference), the Governing Body and the International Labour Office. 198 These institutions have played important functions in ensuring the effective application of international labour standards.

The I.L.O. supervision/compliance system could be roughly divided into three categories: (i) examinations of periodic reports from member states by the Committee of Experts on the Application of Conventions and Recommendations ('the Committee of Experts') and the Conference Committee on the Application of Standards ('the Conference Committee): 199 (ii) the I.L.O. Representation Procedure: 200 and (iii) the I.L.O. Complaints Procedure. These I.L.O. supervision procedures are widely seen as instructive and 'sophisticated' precedents for other international institutions and multilateral treaties' régimes. 201

197 Preamble, Constitution of the International Labour Organisation, (adopted October 9 1946),15 U.N.T.S. 35. Wilfred Jenks observed very truly, regarding South Africa's apartheid, that; 'the universality and performance of the world community preclude recourse to expulsion as an effective sanction for violation of its standards; such problems must be solved within its membership by insistence on the obligations of membership, not by measures of expulsion or exclusion the practical effect of which is to release the offender from those obligations'. See Universality and Ideology in the ILO, (Geneva, 1969), p. 7 in F. Morgenstern, 'Wilfred Jenks in the I.L.O.', 46 B.Y.bk.I.L. (1972-73) p. xviii.

198 See Article 2-13.

199 See Article 19, 22 and 23. Article 22 requires a ratifying state to report regularly to the International Labour Office 'on measures which it has taken to give effect to the provisions of the Convention to which it is a party'. Complaints may be raised with regard to the examinations of reports. See, Victor, ibid., p. 4 et seq.

200 Article 24 of the I.L.O. Constitution provides for representations by employers/workers associations alleging failure to secure the observance of ratified Conventions. The Governing Body may establish an Examination Committee in order to examine the representation and publish its findings. See further D. G. Victor, The ILO System of Supervision and Compliance Control: A Review and Lessons for Multilateral Environmental Agreements, (1996) pp. 10-11. As for the 'Freedom of Association Procedures', see, ibid., pp. 16-19.

201 See e.g. D. W. Bowett, The Law of International Institutions, (4th edn. 1982) p. 152; Consideration of the Establishment of a Multilateral Consultative Process for the 
Yet, it is the third category of the I.L.O. supervision techniques that, for the present, we shall concentrate on.

Under Article 26 of the I.L.O. Constitution, any member (including employees/employers), dissatisfied with the adherence of other ratifying members, can invoke ad hoc dispute settlement procedure by filing a complaint with the International Labour Office, and this is the so-called I.L.O. Complaints Procedure. 202 The Governing Body can also trigger this procedure either of its own motion or on receipt of a complaint from a delegate to the Conference. 203 Unlike the Montreal N.C.P. régime, the I.L.O. Secretariat is not, however, given power to invoke this procedure on its own initiative. However, it is interesting to note that - just like the Montreal N.C.P. complaints - formal complaints made by I.L.O. plaintiffs including States and their nationals do not necessarily have to be based on any direct injury to them, provided that they are much concerned with common purposes of I.L.O. régime member states.

After prior communication to the government in question, 204 the Governing Body can appoint ad hoc Commissions of Inquiry to consider and report on the complaint. 205 The Commissions are normally composed of three highly qualified individuals who serve in their personal capacity (e.g. university professors) 206 and may carry out on-the-spot investigations, though this is subject to the consent of the government involved. 207

Resolution of Questions Regarding Implementation, (Conference of the Parties of the 1992 Climate Change Convention, 22 March 1995) in J. Werksman (eds.), Improving Compliance with International Environmental Law, (1996) pp. 138-39; D. C. Victor, (1996) pp. 3-4 esp.

202 Provisions of Constitutions of the International Labour Organisation Relating to Complaints Concerning the Observance of Ratified Conventions' (Article 26(1)). For Useful information on the Commissions of Inquiry is given by N. Valticos, 'Les commissions d'enquéte de l'Organisation internationale du travail', 91 Revue générale de droit international public, (1987) pp. 847-79.

203 Article 26(4). See e.g. E. A. Landy, The Effectiveness of International Supervision: Thirty Years of I.L.O. Experience, (1966) p. 173 et seq.

204 Article 26(2).

205 Article 26(3).

206 See N. Valticos, 'Les commissions d'enquéte de l'Organisation internationale du travail', 91 Revue générale de droit international public, (1987) pp. 855-56. They are appointed by the Governing Body on the recommendation of the Director-General.

207 Recently, Commissions have investigated situations in Chile, the Dominican Republic, the Federal Republic of Germany, Haiti, Nicaragua, Portugal, Romania and South Africa. See N. Valticos, 'Les Commissions d'enquéte de l'Organisation internationale du travail', 91 Revue générale de droit international public, (1987) pp. 873 et seq.; D. C. Victor, The ILO System of Supervision and Compliance Control: A Review and Lessons for Multilateral Environmental Agreements, (1996) p. 12 and its footnote no. 50 . 
The Montreal Non-Compliance Procedure and the Internal Institutions

In the initial stages the Commission of Inquiry investigates the charges in question; it considers not only information offered by the parties concerned, but other governments, international institutions, workers/employers agencies and N.G.Os. 208 Provided they are in breach of an I.L.O. Convention, the Commission then incorporates its findings/recommendations in a published report. The reports of the Commission are legally non-binding, however; in this respect, the I.L.O. Commission of Inquiry could be regarded as, like the Montreal Implementation Committee, a quasi-judicial body, rather than a judicial one. 209

Unlike the Montreal N.C.P., however, a government that declines to accept these recommendations can refer the complaint to the International Court of Justice ('I.C.J.'), 210 which 'may affirm, vary or reserve any of findings/recommendations of the Commission of Inquiry'.211 In the event that a member fails to implement the recommendations made by the Commission (or the decision of the Court), the Governing Body 'may recommend to the Conference such action as it may deem wise and expedient to secure compliance therewith'. 212

In practice, in the majority of cases, the governments concerned have accepted reports presented by the Commission of Inquiry. Consequently, the I.C.J. has never participated in the legal processes of the I.L.O. Complaints Procedure.

Under the I.L.O.'s machinery of supervision, complaints, in themselves, have been infrequent, however.

\footnotetext{
208 See D. G. Victor, The ILO System of Supervision and Compliance control: A Review and Lessons for Multilateral Environmental Agreements, (1996) p. 12.

209 See D. G. Victor, The ILO System of Supervision and Compliance Control: A Review and Lessons for Multilateral Environmental Agreements, (1996) pp. 11 et seq.

210 Article 29(2).

211 Article 32.

212 Article 33. However, it should be noted that the defaulting party may at any time inform the Governing Body that it has taken the steps necessary to comply with the recommendations of the Commission or the decisions of the I.C.J. In addition, the party may require the Governing Body to constitute a Commission of Inquiry to verify its contention (Article 34).
} 
The Montreal Non-Compliance Procedure and the Internal Institutions

VI. THE MONTREAL N.C.P. RÉGIME THEORY: THE PRECAUTIONARY 'PRINCIPLE'/APPROACH AS BASIC PHILOSOPHY OF THE MONTREAL N.C.P. 'SOFT ENFORCEMENT' OF INTERNATIONAL ENVIRONMENTAL LAW

Before turning to an examination of the Montreal N.C.P. régime in practice, we must now draw attention to a 'philosophical foundation' of this new dispute avoidance/settlement procedure in the sphere of international environment protection law. 213

The point to observe is that the distinctive characteristics of the Montreal N.C.P. régime must be viewed against a background of the nature of the technical Protocol's specific obligations - which requires international environmental co-operation in facilitating Article 5 industrialising countries' capabilities to comply with their obligations (see Chapter I(III.B) above), and of the evolving principle/rules of public international law of the environment - i.e. the precautionary environmental 'principle' (see Chapter II(III.C) above).

It is true that certain issues of law 'enforcement' arise whenever states fail to comply with their legally binding obligations under environmental treaties or under customary international law. It is also right to say that most reprisals or countermeasures in a limited sense, including suspension of certain rights/privileges, are presented as direct responses to consequences of such violations of international rules or obligations. In early 1990, Professor M. Koskenniemi therefore brought forward the argument that '[F]rom the perspective of state responsibility, the Montreal NCP appears as a mechanism for collective countermeasures (or reprisals ) in case of non-performance'("Breach of Treaty or NonCompliance?": see Section $\Pi(B)$ above).214 His detailed analysis on the Montreal N.C.P. may be true - though within certain limitations.

It would be nearer the truth to say that, in theory, resorting to the new N.C.P. régime in itself reflects both limitations of existing principles of customary rules of environmental protection or of state responsibility, and growing roles of international supervisory institutions (see Chapters I and

213 On the role of the principle of good faith in the Montreal N.C.P. see Section IV(A.2) above.

214 M. Koskenniemi, 'Breach of Treaty or Non-Compliance', 3 Y.bk.I.E.L. (1992) p. 142, (emphasis added); Section III(B) above. He also criticised, for example, the character of the amicable solution, nature of decisions by the Meeting of the Parties, and the relationship between the N.C.P. and the dispute settlement procedures under the 1985 Vienna Ozone Convention. See also his recent writing, "New Institutions and Procedures for Control and Reaction' in J. Werksman (ed.), Improving Compliance With International Environmental Law, (1996) pp. 236-48. 
The Montreal Non-Compliance Procedure and the Internal Institutions II(III.C) above). In my view, his speculative legal argument, founded on traditional international rules on law 'enforcement', obscures the fact that the N.C.P. - within a self-contained international ozone régime - is or must be based on the precautionary approach to environmental destruction, and that the N.C.P.'s redeeming characteristic feature can be adaptability to changing circumstances, i.e. the greatest possible flexibility, even though it may also have both merits and limitations in complicated international relations. The Montreal N.C.P. is not a consequence of ignorance of the principles and rules of general public international law.

To begin with, the nature and contents of the international ozone layer régime must be recalled here.

In the first place, it is important to notice that many developing countries including Article 5 L.V.Cs. decided 'rather reluctantly' to join in the international regulatory régime due mainly to Article 4 trade restrictions in spite of the fact that they were not quite sure, in reality, how to comply with the substantial and technical treaty obligations (including reporting procedures, control measures of C.F.Cs./O.D.Ss. and trade controls). With a few exceptions, states usually decide to participate in international legal régimes only when they think they would comply with the treaty obligations. 215 Hence, we may say that, in a certain sense, considerable 'collective (economic) countermeasures' - which would make it possible to ensure not only treaty compliance but the necessary universal participation - were therefore employed beforehand in this Article 4 T.R.E.Ms. of the Montreal Protocol (see Chapter IV above).

In the second place, it is also important that - despite the objection of state parties - adjustments of control measures of O.D.Ss. to the Protocol are binding on all the parties on the basis of the revolutionary 'simplified majority decision-making' (Article 2(9)). 216 Assuming that there would be some dissenting minority states that unsuccessfully oppose, on account of their recognised low capacity to comply, time-targeted adjustments adopted in such a simplified procedure, we may say that this departure from the traditional principle of unanimity might become a potential cause of multilateral ozone disputes. 217

215 M. Bothe, 'The Evaluation of Enforcement Mechanisms in International Environmental Law' in R. Wolfrum (ed.), Enforcing Environmental Standards' (1996) p. 14 (and its footnote no. 6).

216 See also Part A of Chapter III(III.B.C) above.

217 However, the 1990 London Adjustments, 1992 Copenhagen Adjustments, the 1995 Vienna Adjustments and the 1997 Montreal Adjustments were adopted on consensus, without resorting to that voting procedure. 
The Montreal Non-Compliance Procedure and the Internal Institutions

In the third place, in order to ensure strict consistency in the international obligations of all the state parties to the ozone régime, no reservation is allowed under the 1985 Vienna Ozone Layer Convention and its Protocol. 218 Nevertheless, in reality, most Non-Article 5 developed state parties have come to duly recognise that a number of Non-Article 5 developing state parties, unlike developed states, do not necessarily have the capacities at present to comply fully with the technical treaty obligations, including the national reporting requirement (see section VII(A.1) and Chapter VI below).

In point of fact, as we shall see, the Implementation Committee under the Montreal N.C.P. régime has been overloaded with routine administrative work - such as missing baseline/annual data, the correction of such data reports from parties, and a detailed classification/reclassification of 'Article 5 developing countries'. Obviously, apart from purely bureaucratic matters, such non-compliance with national/regional reporting requirements has stemmed back to a lack of member states' capacities to do so, and it cannot be denied that, in most cases, non-complying states within the regulatory ozone régime are at present Article 5 developing countries under the Montreal Protocol, and Countries with Economies in Transition ('C.E.I.Ts.') such as the Russian Federation, Baltic states and Eastern European states - this view is entirely confirmed in practice (see Section VII below).

Given that, we can now explain why the basic mechanics of the Montreal N.C.P. régime in dealing with possible non-compliance would be to encourage, by giving 'appropriate' financial/technical assistance, the party that is willing to - but occasionally unlikely to - fulfil its treaty obligations .

Mr. P. Széll, who was the Chairman of the N.C.P. negotiations, noted that 'a régime should be based on the recognition that non-compliance was frequently the consequence, not of malice or greed, but rather of technical, administrative or economic difficulties'. 219 In addition, as was described earlier, the travaux préparatories of the Montreal N.C.P. support the idea that the new procedure should be the encouragement-based

218 Article 18 (1985 Vienna Ozone Convention) \& Article 18 (Montreal Ozone Protocol).

219 See UNEP/OzL.Pro.7/INF.1, para. 28. 
The Montreal Non-Compliance Procedure and the Internal Institutions

approach, or a rather friendly settlement of environmental disputes: 220 'All possible assistance measures encouraging Parties to comply with the Protocol should be exhausted before stronger measures were considered'. 221

We may say, at the same time, that the primary functions of both the standing Committee and the Ozone Meeting of the Parties are to effectively control the fulfilment by member states of their international obligations derived from the international ozone régime (i.e. compliance monitoring: see Chapter I(III.C) above), rather than to decide what sources of international law should be applied in cases of treaty 'non-compliance' or non-performance: 222 there is now some validity to this concept, though it should not be pushed too far. 223

In summary, countermeasures as seen in the paragraph $(C)$ of the Indicative List of the Montreal N.C.P. could or would be merely counterproductive. One of the central aims of the N.C.P. régime is, therefore, not to take controversial countermeasures that would occasionally give rise to questions of state responsibility, but basically to seek 'amicable solutions' to expected non-compliance arising from 'good faith' bona fides. 224 In another case - not surprisingly - the N.C.P. régime of the 1994 Oslo Sulphur Protocol does not even provide any sanctions.

Viewed in this light, we can see now that the Montreal N.C.P. régime - which is (i) multilateral: (ii) flexible: (iii) simple, and: (iv) rapid 225 - is therefore designed carefully for applying the precautionary environmental 'principle'/approach to the urgent global environmental problem, that is, stratospheric ozone layer depletion (see Diagram no. II below).

Furthermore, in the present case of the regulatory ozone régime, the evolving precautionary environmental 'principle' must be provided global financial support for developing low-volume-O.D.S.-consuming countries' ('L.V.Cs.') capacities to fulfil their technical treaty obligations (see in detail Chapter VI below).

220 See UNEP/OzL.Pro.LG.1.3, para. 9; proposal made by the Netherlands in UNEP/OzL.Pro.LG.1/CPR.1.; T. Gehring, Dynamic International Regimes, (1994) pp. 314-17.

221 UNEP/OzL.Pro/WG.3/3/3, para. 44, (emphasis added).

222 Cf. G. Palmer (eds.), International Environmental Law and World Order, (1994) p. 1120.

223 See Section II(B) above.

224 See Section IV(A.2) above.

225 See Introduction \& Sections IV \& V(B) above. 
The Montreal Non-Compliance Procedure and the Internal Institutions

DIAGRAM no. II: THE N.C.P. IN THE 'SELF-CONTAINED' OZONE RÉGIME

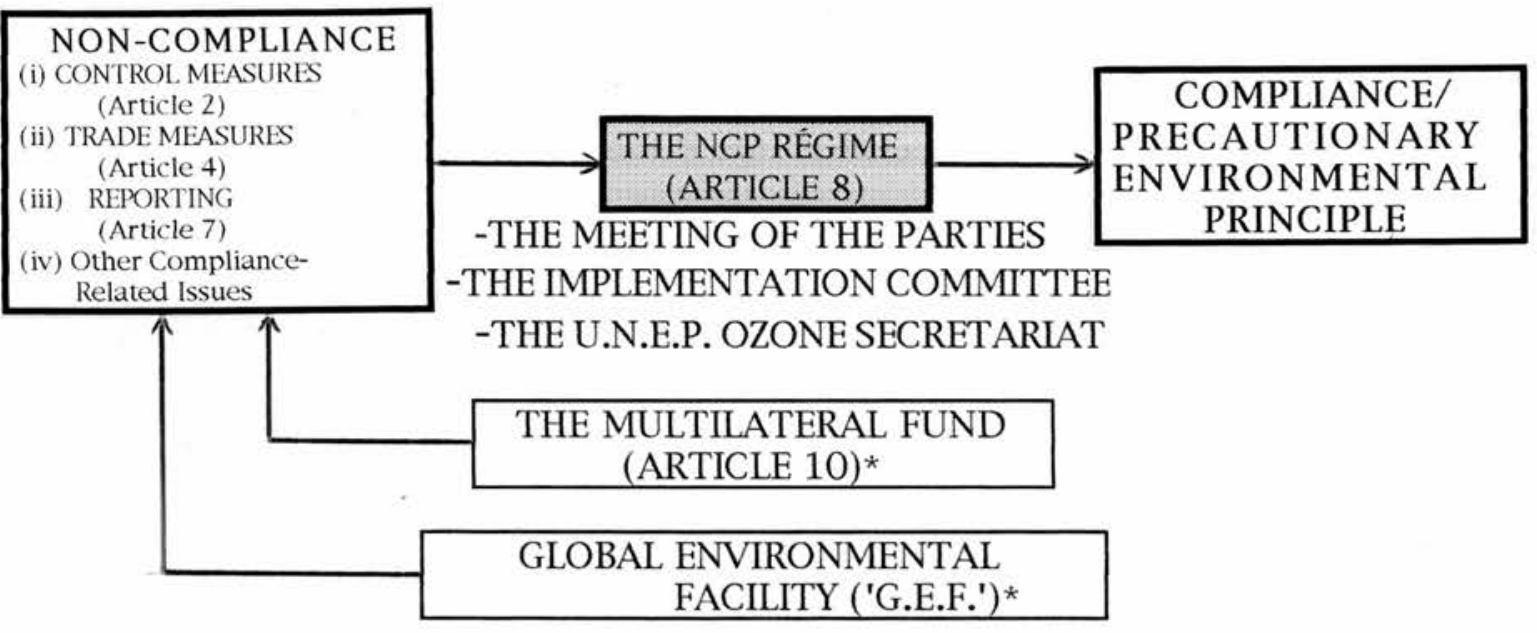

* See Chapter VI below.

It follows naturally that, in such situations, unless non-compliance results from malice or greed and is therefore considered strictly to be 'intentional or systematic non-compliance', the Ozone Meeting of the Parties would not resort to painful international sanctions against the party in question: as was described above, any 'bad faith' or intentional non-compliance would seriously endanger the value of the new Montreal N.C.P.

In addition, we should not overlook the fact that - even if the 'real guarantee' of treaty compliance is the system of collective sanctions - the measures termed 'sanctions' are not necessarily intended to be directly punitive or repressive, but rather 'coercive' in the sense that they would apply 'sufficiently strong pressure' on the defaulting member states. 226

Nevertheless, it does not necessarily follow that various principles and rules of customary international law and state responsibility have nothing to do with the avoidance or settlement of possible ozone disputes.

226 See J. Combacau, 'Sanctions', in 9 Encyclopaedia of Public International Law, (1982) pp. 337-40. See also R. Higgins, Problems and Process: International Law and How We Use It, (1994) pp. 13-16 \& their footnotes; O. Schachter, 'United Nations Law', 88 A.J.I.L. (1994) pp. 14-15. In practice, as Schermers and Blokker has pointed out, international institutions such as U.N. specialised organs, the W.M.O. and the I.N.F. usually do not invoke the power to suspend a state's rights/privileges, and employ other means of securing compliance. See International Institutional Law, (1995) Chapter 10. The same may be true in the G.A.T.T. legal system. See J. H. Jackson, World Trade and the Law of GATT, (1969) pp. 178-87, Chapter 29. 
The Montreal Non-Compliance Procedure and the Internal Institutions

Indeed, response measures required should be commensurate with the importance of the provision itself as well as the nature and degree of compelling reasons behind non-compliance, frequency of non-compliance and length of non-compliance. 227 It cannot be denied, perhaps, that the question of whether the N.C.P. régime is a kind of conciliation, quasijudicial mechanism, or a mere institutionalised negotiation process would depend in part on the nature of the issues the specialised internal régime institutions must handle (see Section VII below).

Whilst the N.C.P.'s flexibility has contributed to the effective implementation of the ozone treaties, it is still probable that the N.C.P. régime would not often counterbalance the ultimate disadvantage of its considerable 'softness'; we should therefore note the following statements by Professor Francesco Francioni:

'[T]his question [whether soft enforcement procedures are exclusive of countermeasures] will arise whenever the soft implementation procedure has failed to satisfy a contracting party which, for instance, objects to an amicable compromise ... ; or when a state reiterate the breach or becomes a systematic defaulting state. In these instances it would have little sense to exclude the operation of ordinary countermeasures under customary international law or under the Vienna Convention on the Law of Treaties. Soft law and soft remedies cannot be understood in such a way as to displace and curtail the operation of hard law. 228

VII. THE MONTREAL N.C.P. RÉGIME IN PRACTICE

A. ENSURING COMPLIANCE WITH REPORTING REQUIREMENTS, CONTROL MEASURES AND TRADE RESTRICTIONS

\section{The Reporting Requirements}

Most international environmental agreements impose periodic reporting requirements as to compliance with their treaty obligations 229 - this treaty

227 See UNEP/OzL.Pro/WG/3/3/3, para. 44, (emphasis added) \& a Discussion Paper from Canada (UNEP/OzL.Pro/WG.1/15/3.

228 F. Francioni, 'International "Soft Law": A Contemporary Assessment' in V. Lowe and M. Fitzmaurice (eds.), Fifty Years of the International Court of Justice: Essays in Honour of Sir Robert Jennings, (1996) p. 178 (emphasis added).

229 M. Bothe, 'The Evaluation of Enforcement Mechanisms in International Environmental Law' in R. Wolfrum (ed.), Enforcing Environmental Standards, (1996) pp. 22-26; A. E. Boyle, 'Saving the World? Implementation and Enforcement in 
obligation is often called 'procedural compliance. 230 Reports can be broadly divided into two categories: (i) reports containing information on the overall implementation of a treaty, and (ii) reports as to the compliance with specific treaty obligations. 231 The national/regional reporting system of international environmental law has great importance for (i) assessing/judging the effectiveness of control measures and for (ii) adjusting the existing international standards set up by implementing treaty bodies. State administrations - including developed ones - usually devote much time to drafting this kind of data reports 232 and noncompliance with reporting requirements does not lead to a breach of a substantive international obligation 233

The Montreal Protocol requires contracting parties to provide the U.N.E.P. Ozone Secretariat with baseline and annual data on their production, imports and exports of each controlled substance that is conveniently divided into a group (see Part A of Chapter III above) or the 'best possible estimates' of such data, provided actual data are not available (Article 7(1)-(2)). Parties also have to report on the ozone activities in research, development, public awareness, and exchange of information

International Environmental Law Through International Institutions', 3 J.E.L. (1991) pp. 236 et seq.; P. Birnie and A. Boyle, International Law and the Environment, (1992) pp. 166-67; A. Kiss 'Compliance with International and European Environmental Obligations', Hague Y.bk.I.L. (1996) pp. 51-52. See e.g. the 1992 Biodiversity Convention (Article 26); the 1992 Climate Change Convention (Article 12(1)); the 1989 Basel Convention (Article 13); the 1991 Protocol to the Antarctic Treaty on Environmental Protection (Article 17); the 1988 N.Ox. Protocol (Article 8(1)); the 1985 S.O.2 Protocol (Article 4); the 1976 Rhine Chloride Pollution Convention (Article 3(5)); the 1974 Paris Convention (Article 11 \& 17); the 1973 C.I.T.E.S. Convention (Article 8(7)); the 1973 M.A.R.P.O.L. Convention (Article 6. 8 \& 11); the 1972 World Heritage Convention (Article 11). Sands divides reporting requirements under environmental treaties into four types; (i) regular reporting requirements provided by international institutions to state parties; (ii) regular reporting by parties to international institutions or other parties; (iii) a party may be required to provide information to another party on certain occasions (e.g. nuclear accidents); (iv) a treaty may allow for a report to be submitted by a N.G.O. to a party. See P. Sands (1995), p. 600 et seq.

230 See 'Compliance with International Standards: Environmental Case Studies', (remarks by Professor Weiss), Proceedings of A.S.I.L. (1995) pp. 210-14; Chapter III above.

231 See K. Sachariew, 'Promoting Compliance With International Environmental Standards', 2 Y.bk.I.E.L. (1991) pp. 43 et seq.

232 A. Kiss 'Compliance with International and European Environmental Obligations', Hague Y.bk.I.L. (1996) p. 52.

233 See 'M. Bothe, 'International Obligations, Means to Secure Performance', Encyclopaedia of Public International Law, 1(1992), p. 103; K. Sachariew, 'Promoting Compliance With International Legal Standards', 2 Y.bk.I.E.L. (1991) p. 41. 
concerned (Article 9(3)).234 The names of the parties that have not fully complied with these reporting and other obligations are to be mentioned in the reports of the Implementation Committee and of the U.N.E.P. Secretariat. 235

Without timely and detailed reports, it will always be difficult for implementing agencies to spot particular state parties that should be provided with financial/technical assistance in implementing the ozone treaties. Hence, as D. Victor suggests, it is no exaggeration to say that the N.C.P.'s effectiveness depends on the supply of data reports about national performance and the ability to compare that information with international standards. 236

To date, however, on-the-spot investigations based on states' consent are not initiated by the Implementation Committee.

Since its First Meeting held in 1991, the Implementation Committee has dealt with a continuing problem of non-reporting or insufficient and late data reports from both parties and non-parties to the Protocol. 237 It is said that 'the quality of data reporting by parties 'can at best be called moderate'. 238 As for 1995, only fifty parties reported required data out of 157 parties (as at 9 September 1996). 239 It is well-recognised, however, that its major contributing factors will be (i) low capacity to comply with such an obligation: (ii) an intention to maintain the confidentiality of reports regarding trade matters: and/or (iii) other reasons (e.g. change of government or administrative delays 240 ).

Non-Compliance with data reporting has been frequently observed in Parties operating under Article 5 developing countries, rather than in

\footnotetext{
234 See information by Boliva, Canada, Czech Republic, Germany, Islamic Republic of Iran, Kuwait, Norway, Romania, Slovenia in UNEP/OzL.Pro.8/3 para. 29.

235 See e.g. 'The Report of the Secretariat on Information Provided by the Parties in Accordance with Articles 7 and 9' (UNEP/OzL.Pro.8/3, 12 September 1996).

236 UNEP/OzL.Pro.7/INF.1, para. 36. It is also important to note that environmental Secretariat often lack the resources to accomplish its supervisory duties toward treaty compliance. The Ozone Secretariat has periodically received additional funds from the U.N.E.P. to compensate for incomplete contributions from parties. See United States General Accounting Office, International Environment: International Agreements Are Not Well Monitored, (January 1992) p. 20 \& pp. 28 et seq.

237 As we have seen, under Article IV of Montreal the Protocol trade restrictions will be imposed on 'non-treaty compliers'. See Chapter IV above.

238 See 20/18 International Environment Reporter, (3 September 1997) p. 820; U.N.E.P., 'Production and Consumption of Ozone-Depleting Substances 1986-1995: The Data Reporting System under the Montreal Protocol' (September 1997).

239 See UNEP/OzL.Pro.8/3, para. 26. These include the United Kingdom, the United States, Czech Republic, Thailand and Venezuela.

240 See UNEP/OzL.Pro/ImpCom/10/4, para. 14.
} 
Non-Article 5 parties. 241 The Implementation Committee, in its Third Meeting, explained that the principal reasons would be 'the turnover of personnel in the Customs service, their lack of training and experience, and the lack of qualified specialists to train them'. 242 Indeed, 'Training on data-monitoring and reporting could go a long way toward resolving reporting problems'. 243 Consequently, the Ozone Secretariat stressed the importance of the Country Studies/Programmes being carried out by the implementing organs of the Multilateral Ozone Fund, namely, the United Nations Development Programme ('U.N.D.P.'), the U.N.E.P. and the World Bank. 244

In 1993 the Implementation Committee invited, to its Seventh Meeting, nine parties that had persistently failed to provide reporting data.245 In that Meeting, the representative of Costa Rica stated that incompleteness of data was caused mainly by delays in receiving funds from the U.N.D.P. - that is to say, a lack of prompt financial assistance. 246 Belarus explained that difficulties in obtaining the data required stemmed from 'political and economic problems' concerned with its recent independence. 247 The representative of Italy suggested that its failure was the result of purely bureaucratic matters and that forthcoming legislation would resolve the problems of non-reporting. 248

The Implementation Committee, considering the E.C.'s significant production/'consumption' impacts, once expressed 'particular concern' about non-reporting from some members of the European Community (i.e.

241 Reports of the Committee include a list of countries whose data reporting are missing or still insufficient. Perhaps, this would pressure those states into providing such data required.

242 UNEP/OzL.Pro/ImpCom/3/3, paras. 16 and 17. See also the Secretariat's Third Report of Data, in J. Werksman (eds.), Improving Compliance with International Environmental Law, (1996) p. 119.

243 UNEP/OzL.Pro/ImpCom/12/3, para. 46. See further, UNEP's Efforts to Assist Data Reporting by Article 5 Countries, in UNEP/OzL.Prp/ImpCom/12/3/Annex III.

244 UNEP/OzL.Pro/ImpCom/3/3, para. 17. See Chapter VI below.

245 They include Belarus, Burkina Faso, Costa Rica, Islamic Republic of Iran, Italy, Maldives, Syrian Arab Republic, Togo, Trinidad and Tobago, and Ukraine. See UNEP/OzL.Pro/ImpCom/7/2. See, also, W. Lang, 'Ozone Layer', 5 Y.bk.I.E.L. (1994) p. 161-62. The reports of the Committee usually include the names of countries that do not participate in the meetings of the Committee regardless of its invitations. Keutsch argues that this can be an 'inherent threat' to such parties to comply with its invitations not to lose face. See A. Keutsch, 'Non-Compliance Procedures under the Montreal Protocol' in J. Werksman (eds.), Improving Compliance with International Environmental Law, (1996) p. 119.

246 Ibid., para. 7.

247 Ibid., para. 14.

248 Ibid., paras. 9 and 10 . 
The Montreal Non-Compliance Procedure and the Internal Institutions

Belgium, Greece, Italy and Portugal) and at missing 1991 'consumption' data from the Commission of the European Community. 249 It is likely that some members of the European Union - or the European Union itself - tried to preserve the confidentiality of the business information concerned. 250

In another case, the Implementation Committee decided to create conditionality between the supply of technical data and the M.F.L. funding. 251 The Committee recommended that Mauritania be reclassified as a Party not operating under Article 5 until it reported required data:252 this implies that the Government could not receive funds from the Montreal Multilateral Fund. 253 In its Twelfth Meeting the Implementation Committee noted that reports from many parties on required information were more than two years overdue, and that 'it should be made clear to the Meeting of the parties that the trend of late reporting should end, particularly in respect of those countries in which institutional strengthening projects have been carried out under the Multilateral Fund'.254

In order to settle these difficult situations, the World Bank has proposed (i) licensing the import of O.D.Ss. to facilitate data collection and to control imports, and (ii) an international labelling system for products containing C.F.Cs. and other O.D.Ss. 255

As for other M.E.As. régimes, developing state parties to the 1972 London Dumping Convention do not satisfactorily meet the reporting requirement, because they still lack financial resources, efficient infrastructure, technology, and trained staff needed to comply with the convention's various requirements. According to systematic studies on compliance with M.E.As., similar challenging situations have also occurred

\footnotetext{
249 UNEP/OzL.Pro/ImpCom/5/3, para. 10. See also UNEP/OzL.Pro/ImpCom/3/3, para. 10.

250 D. G. Victor, The Early Operation and Effectiveness of the Montreal Protocol's Non-Compliance Procedure, (1996) p. 9.

251 On conditionality between the Multilateral Fund and compliance with the Protocol see Chapter VI(III.4) above.

252 UNEP/OzL.Pro/7/12, para 36.

253 See UNEP/OzL.Pro/ImpCom/12/3, note by the Secretariat at p. 3.

${ }^{254}$ See UNEP/OzL.Pro/ImpCom/12/3. para 44. See also Decision VIII/2 (UNEP/OzL.Pro/8/7).

255 See further, UNEP, The Use of Trade Measures in Selected Multilateral Environmental Agreements, (1995) pp. 88-89.
} 
The Montreal Non-Compliance Procedure and the Internal Institutions

in many multilateral environmental agreements, including the 1973 M.A.R.P.O.L., and the 1972 C.I.T.E.S. 256

2. The Control Measures of C.F.Cs./O.D.Ss.

Compliance with Article 2 (and corresponding Article 5) control measures has formed the absolute basis of the international regulatory régime for the protection of the ozone layer (see Part A of Chapter III(III) above).

According to the recent data received by the U.N.E.P. Ozone Secretariat, it seems that most of the Non-Article 5 parties appear to comply with the detailed control measures. 257 Most of these developed state parties have introduced national regulations that could substantially achieve the various objectives and purposes of the international ozone régime (see Part B of Chapter III above). Whilst it is possible for the Ozone Secretariat and the Implementation Committee to dispute the scientific validity of data provided by those state parties, to date, neither of them has, however, taken such an action. 258

As we have seen, due to the ten years grace period, developing countries operating under Article 5 would only have to phase out C.F.Cs. by 2010 and halons by 2015 in accordance with the London Adjustments (see Chapter III(III.E)). Consequently, their compliance with these control measures remains to be seen. Perhaps it would be better to say that both the Ozone Secretariat and other implementing agencies are, at present, trying to achieve extensive improvement in non-reporting and/or inadequate reports from these developing state parties.

It can be assumed that a developing state party, which is officially informed that it has just crossed the borderline of acceptability of what is permissible under Article 5, could face sudden problems with anticipated loss of funding from international institutions as well as treaty noncompliance. 259 In this connection, the Ozone Meeting adopted Decision

256 See United States General Accounting Office, International Environment: International Agreements Are Not Well Monitored, (January 1992); D. S. Favre, International trade in Endangered Species, (1989), p. 235 et seq.

257 See e.g. UNEP/OzL.Pro/ImpCom/10/4; UNEP/OzL.Pro.4/6, para. 11; UNEP/OzL.Pro/5/5; UNEP/OzL.Pro/5/5 Add. 1.

258 It must be noted that some statistical data are, as noted above, the 'best possible estimates' and it could be probable that parties may often wield considerable discretion in this matter. See Article 7(1-2); D. C. Victor, (1996), p. 9 et seq.

259 For example, Kuwait and Slovenia whose per capita levels of consumption were once considered as above the ceiling in Article 5 collected their statistical data for 1993, and they thus avoided such a problem. See UNEP/OzL.Pro/ImpCom/10/4, para. 
The Montreal Non-Compliance Procedure and the Internal Institutions

IV/15 regarding the situation whereby low-volume-O.D.S.-consuming states exceed the 'consumption' limit. The Decision provides that state parties consider the situation on a 'case-by-case-basis' when requested to do so by the developing countries. 260

In the Tenth Meeting of the Committee, the U.N.E.P. Ozone Secretariat informed the Committee that Lebanon, which was conferred with the status of a developing country operating under Article 5, had exceeded the per capita consumption ceiling, and the matter remain unresolved. 261 In addition to this case, Lithuania once tried to obtain a delay of five years of control measures as provided in the automatically binding London/Copenhagen Adjustments, though the Implementation Committee stated that data reports were 'inadequate' and that the Government could not be eligible to receive assistance from financial institutions unless it ratified the 1990 London Amendment; 262 this provided a good example of environmental bargaining.

Lastly, it must be noted that illegal trade in C.F.Cs. and O.D.Ss. (breach of Article 2 control measures) has newly emerged in the international community and it weakens or threatens the effectiveness of the regulatory ozone régime (see also Chapter III(IV.F) above).263 At the 1995 Seventh Meeting of the Parties to the Protocol, many representatives indicated 'regrettable evidence' of illegal trade in controlled substances, 264 and the Vienna Ozone Meeting - and its subsequent meetings - adopted Decisions regarding illegal imports and exports of those substances. 265

Article 5 countries (China and India in particular) and Russia continue to produce large amount of C.F.Cs. and these substances are illegally imported from these countries to Non-Article 5 Countries. Duncan

24. See also D. C. Victor, The Early Operation and Effectiveness of the Montreal Rratocol's Non-Complizarez Prorzdurn, (1996) p. 14.

260 See UNEP/OzL.Pro.4/15, pp. 17-18. See also Decision VI/5 in UNEP/OzL.Pro.6/7. 261 Article $5(1)$ of the Protocol sets a 'consumption' threshold at $0.3 \mathrm{~kg}$ per capita for the core five CFCs and three halons (see Chapter I above). Lebanon did not accept the population figures offered by the secretariat. See UNEP/OzL.Prp/ImpCom/10/4, para. 8; UNEP/OzL.Pro/ImpCom/12/3, paras. 51-53.

262 UNEP/OzL.Pro/ImpCom/12/3, paras 54 and 55.

263 See e.g. F. P. Landers, Jr., 'The Black Market Trade in Chlorofluorocarbons: The Montreal Protocol Makes Banned Refrigerants a Hot Commodity', 26 Georgia J.I.C.L. (1997) pp. 457-85; D. Brack, International Trade and the Montreal Protocol (1996), Chapter 6; R. Benedick, Ozone Diplomacy, (1998) pp. 273-76 esp. See also 'The Ozone Layer may be Saved: Fattening the Ozone Layer', 344 The Economist, p. 613 (13 September 1997).

264 See UNEP/OzL.Pro.7/12, para. 69. See also UNEP/OzL.Pro.9/12, para. 66.

265 Decision VII/33, Decision VIII/20 \& Decision IX/23. 
The Montreal Non-Compliance Procedure and the Internal Institutions

Brack of the Royal Institute of International Affairs (R.I.I.A.) in London says that the above-mentioned countries are the main source of C.F.Cs. and O.D.Ss. and European countries and Australia may be seen as major destinations. 266 The Ozone Operations Resource Group (O.O.R.G.) established by the World Bank also reports that there has been startling increases in illegal C.F.C.-12 imports into the United States, and they eventually result in numerous arrests and indictments. 267 Until now, the United States has been the only country to take any decisive action to stop such illegal trade in O.D.Ss., and many European countries have been relatively much slower to act. 268 Yet in July 1997 the European Commission undercovered an illegal scheme to import 1,000 metric tons of O.D.Ss. that were imported from China. 269

It was agreed in the 1997 Montreal Ozone Meeting that parties shall institute a licensing system to help national governments track international trade in O.D.Ss. and discourage unlicensed black-market trade (see also Chapter III(IV.F) above). ${ }^{270}$ Now Article $4 \mathrm{~B}(1)$ requires the parties to establish and implement a system for licensing the import/export of new/recycled/reclaimed O.D.Ss. in Annexes A, B, C and E (by January 2000 or within three months of the entry into force of this new Article).

\section{Trade with Non-Parties}

The international ozone régime decided that, as we have observed, nonparties/non-complying states were to be denied access to foreign markets for C.F.Cs./O.D.Ss. (see Chapter IV(II) above). The Montreal Protocol does not currently impose any obligation to report to the U.N.E.P. Ozone Secretariat on the implementation of Article 4, however. 271 The parties

\footnotetext{
266 See The Environment Digest, (1996/10) p. 10. See also R. Benedick, Ozone Diplomacy, (1998) p. 274; 'Holed Up: Chemical Production/Controlling C.F.Cs.', 337 The Economist (9 December 1995) p. 690. The Japan Ministry of International Trade \& Industry says there is no evidence as to illegal trade in O.D.Ss. in Japan (information provided by Ms. Fukuhara of the M.I.T.I., 2 February 1998).

267 See The World Bank, 'The O.O.R.G. Report', Facing the Global Environment Challenge, (March 1995) pp. 16-17.

268 Ibid., p. 10. See also statements by a N.G.O. in UNEP/OzL.Pro.8/12, paras 68-69. Yet since 1995 the EC has developed a quota and licensing system of O.D.Ss. See ibid., para. 90. See also R. Benedick, Ozone Diplomacy, (1998), noting that at the 1995 Meeting of the Parties to the Protocol, a U.S. representative said that the penalties in some countries were 'almost laughable'.

269 See 20/16 International Environment Reporter, (6 August 1997) pp. 750-51.

270 See Article 4B and Decision IX/8 in UNEP/OzL.Pro/9/12.

271 But see e.g. UNEP/OzL.Pro.4/6, Section III; UNEP/OzL.Pro.5/5 Add.1.
} 
The Montreal Non-Compliance Procedure and the Internal Institutions

are only encouraged to inform the Ozone Secretariat of the implementation of Article 4 (see e.g. Decision III/16 \& Decision IV/17(1)). 272

In accordance with Decision IV/C regarding trade measures adopted by the Fourth Meeting of the Parties, 273 the Implementation Committee considered data reports from twenty two non-parties. 274 The Implementation Committee observed that thirteen countries such as Belgium, Hong Kong and Vietnam satisfied the requirements of the Decision IV C and they thus should be exempt from the trade controls under Article IV. 275

In the Tenth Meeting of the Committee, one member stated that, rather than focusing on the formalities of data-reporting, the Committee should concern itself more with reports of dumping of obsolete technologies and, the conclusion of joint venture agreements to construct C.F.C.-production facilities in developing countries. 276 Nevertheless, this sensitive issue was not extensively discussed and we have only limited information on this matter. 277

As the 1995 T.E.A.P./C.E.I.T. Report has pointed out, it is widely known that since January 1993 the Russian Federation is already in noncompliance with trade controls under Article 4 of the Ozone Protocol - this question is taken up in Section VII(B) below.

\section{B. CASE STUDIES: NON-COMPLIANCE BY THE RUSSIAN FEDERATION AND THE REACTIONS OF THE N.C.P. REGIME INSTITUTIONS}

Since early 1990 s the issues concerning the C.E.I.Ts.' non-compliance have formally been discussed in the Implementation Committee and in the Ozone Meeting of the Parties to the Protocol. Yet, it was not until 1995 that the Montreal N.C.P. régime was invoked, for the first time, to handle the

272 See W. Lang, 'Trade Restrictions as a Mean of Enforcing Compliance with International Environmental Law' in R. Wolfrum (ed.) Enforcing Environmental Standards: Economic Mechanisms as Viable Means? (1996) p. 270, noting the lack of data-reporting requirements 'may be traced back to a certain sense of political realism and to emerging doubts as to the full compatibility of Art. 4 with GATT-law'.

273 See 'Application of Trade Measures under Article 4 to Non-Parties to the Protocol' in UNEP/OzL.Pro/4/15.

274 They included; Belgium, Comoros, Congo, Dominican Republic, Gabon, Guyana, Hong Kong, Jordan, Laos, Lithuania, Madagascar, Mali, Myanmar, Nicaragua, Poland, Sudan, Suriname, Turky, Uruguay, Vietnam, Yugoslavia.

275 See UNEP/OzL.Pro/ImpCom/6/3, paras 15-17.

276 UNEP/OzL.Pro/10/4, para. 20.

277 See ibid., paras. 21-22. 
The Montreal Non-Compliance Procedure and the Internal Institutions

'voluntary' submission of anticipated non-compliance by several countries of the C.E.I.Ts., which include the Russian Federation, Belarus, Bulgaria, Poland and the Ukraine. For the present, however, we shall concentrate on Russia's Non-Compliance case, rather than on the C.E.I.Ts.' treaty noncompliance as a whole.

1. The Russian Federation and the C.E.I.Ts.

There are now twenty-seven states with their economies in a transitional state, and they are divided into four groups: (i) successor states to the former Soviet Union (Armenia, Azerbaijan, Georgia, Kazakhstan, Kyrgyzstan, Moldova, the Russian Federation, Tajikistan, the Ukraine and Uzbekistan); (ii) Baltic states (Estonia, Latvia and Lithuania); (iii) Central/Eastern European states (Albania, Bulgaria, the Czech Republic, Hungary, Poland, Romania and Slovakia); and (iv) successor states to the former Yugoslavia (Bosnia-Herzegovina, Croatia, Macedonia, Slovenia and Yugoslavia -Serbia and Montenegro). 278

It is worth noting that the estimated 1994 'consumption' of O.D.Ss. in these states is approximately equal to a quarter of the world 'consumption' in that year, 279 and the C.E.I.Ts. are, in fact, contributing immensely to ozone depletion.

Importantly, the Russian Federation exceeds sixty per cent of the 'consumption' of controlled substances in the C.E.I.Ts., and it is the only producer of these substances in that region. 280 Furthermore, the Russian Federation is the major exporter of controlled substances to both twenty C.E.I.Ts., at least, and possibly some other countries outside the C.E.I.Ts. 281 Hence, it is no exaggeration to say that, in the light of its considerable political/economic influence in the international community, the noncompliance behaviour of the Russian Federation above all would undermine the stability of the international regulatory ozone régime.

While the former Soviet Union adopted the 1987 version of the Montreal Ozone Protocol on 10 November 1988, after the Russian Federation

278 When the 1987 version of the Montreal Protocol was signed, only eight of the twenty seven states were sovereign states. See The 1995 T.E.A.P./C.E.I.T. Report, p. 11.

279 The 1995 T.E.A.P./C.E.I.T. Report, p. 12.

280 The 1995 T.E.A.P./C.E.I.T. Report, p. 25.

281 Ibid.; UNEP/OzL.Pro.7/12, para. 43. 
formally became an independent sovereign state on 24 August 1991,282 it has since taken over the obligations under the ozone treaties from the dissolved former Soviet Union. 283

The Russian Government has employed legislative and other appropriate measures to comply with regulations of the Ozone Protocol. For example, the Russian Federation adopted the 1992 Environmental Act (Article 56 on 'Ozone Layer Protection'); developed the National Programme on the Phaseout of O.D.Ss. and the introduction of alternative technologies; decided in 1993 to establish the Commission on Ozone Layer Protection under the Ministry for the Protection of the Environment; and adopted in 1995 a special act on the measures required to fulfil the obligations under ozone treaties. 284 The Russian Federation declared that it was 'in principle complying with the basic provisions of the Montreal Protocol'.285

\section{Russia's Non-Compliance Case}

In the Eleventh Open-ended Ad Hoc Working Group held in May 1995, the Russian Federation submitted a joint statement, speaking also on behalf of Belarus, Bulgaria, Poland and the Ukraine, that it did not appear possible to completely phase out production/'consumption' by January 1996 due mainly to the difficult economic situations the C.I.E.Ts. are faced with. 286

282 Russia's O.D.S. production in 1994 was 10,000 O.D.P. tonnes, and its O.D.S. 'consumption' in 1994 was 33.675 tonnes, respectively; it follows that Russia's O.D.S. 'consumption' per capita was $0.22 \mathrm{~kg}$. See the 1995 T.E.A.P./C.E.I.T. Report, p. 139.

283 According to On the Ratification of the Agreement on the Creation of the Commonwealth of the Independent States; 'For the purposes of the creating conditions necessary for the ratification of Article 11 of the said Agreement, to establish that the norms of the former U.S.S.R. shall apply on the territory of the R.S.F.S.R. (i.e., the Russian Federation) until the adoption of respective legislative acts of the R.S.F.S.R. in that part which is not contrary to the Constitution of the R.S.F.S.R., legislation of the R.S.F.S.R., and the present Agreement'. See Decree of the R.S.F.S.R. Supreme Soviet (12 December 1991), 17 Rossiiskaia gazeta, (1991), colso. 4-5. See also, On the Declaration of the Treaty on the Formation of the U.S.S.R., [Decree of the R.S.F.S.R. Supreme Soviet], (12 December 1991), 17 Rossiiskaia gazeta, (1991), colso. 4-5. The Russian Federation has already ratified the 1992 London Amendment in December 1991, but not the 1992 Copenhagen Amendment yet. See also Memorandum on Mutual Understanding on Issues of Succession to Treaties of the Former U.S.S.R. having Mutual Interest (6 July 1992).

284 See further the 1995 T.E.A.P./C.E.I.T. Report, p. 29.

285 UNEP/OzL.Pro/ImpCom/11/1/Annex II.

286 See UNEP/OzL.Prp/10/4, para. 31;E.P.L., 26/2/3(1996), p. 68. A subsequent statement made by the C.E.I.T. at the twelfth meeting of Open-ended Working Group read '[T] he processed connected with political, geopolitical and social change, with the break from the previous economic system and the transition to a market economy, have 
The Montreal Non-Compliance Procedure and the Internal Institutions

It is interesting to note that whilst the Russian Federation's original intention was to seek a special five-year grace period directly from the Meeting of the Parties, 287 that request was then first sent to the Implementation Committee 288 - to be precise, the Government of the Russian Federation first informed both the Ozone Meeting of the Parties and the Implementation Committee of anticipated treaty non-compliance, and it did not initially intend to invoke the mechanics of the Montreal N.C.P. régime.

After 'considerable prodding' by the United States, ${ }^{289}$ the Ozone Secretariat and the Implementation Committee agreed to accept this formal statement as a submission under paragraph(4) of the Non-Compliance Procedure under the Montreal Ozone Protocol régime. The Russian Federation did not attempt to deny this plausible interpretation by the Committee; as a result, the standing Implementation Committee has thus been furnished with a first opportunity to address non-compliance matters about Article 2 control measures under the Montreal N.C.P. régime.

In its Tenth Meeting the Implementation Committee expressed the simple fact that there were no treaty provisions that would allow any party a schedule for O.D.Ss. different from those of the Ozone Protocol régime, and it further suggested anticipated non-compliance by the Russian Federation should be addressed by a possible decision of the supreme decision-maker i.e. the Ozone Meeting of the Parties, but not by adding an amendment to the Montreal Protocol.290 The Committee then stated that: 'It should also be noted that the Russian Federation was the only one of the five Parties that had not reported data' 291 and required further information, including data on production/'consumption' of controlled substances and its compliance plan, for the elaboration of a committee recommendation.

Ultimately, since the Implementation Committee could not achieve an agreement with the Russian Federation particularly regarding monitoring issues and trade controls as contained in draft decision

\footnotetext{
demanded and continue to demand great moral, material and financial outlays' (emphasis added). See UNEP/OzL.Pro/ImpCom/11/1/Annex II.

287 See UNEP/OzL.Pro/ImpCom/11/1/Annex; The 1995 T.E.A.P./C.E.I.T. Report, p. 29. Compare with the fixed production/'consumption' schedule for controlled substances under the 1992 Copenhagen Adjustments (Chapter IV above).

288 See D. G. Victor, The Early Operation and Effectiveness of the Montreal Protocol's Non-Compliance Procedure, (1996) p. 28.

289 R. Benedick, Ozone Diplomacy, (1998) p. 281.

290 See the 1995 T.E.A.P./C.E.I.T. Report, p. 30.

291 UNEP/OzL.Pro/ImpCom/10/4, para. 32.
} 
The Montreal Non-Compliance Procedure and the Internal Institutions

VII/16,292 those recommendations made by the standing Committee were then brought to the 1995 Ozone Meeting of the Parties without a complete agreement by Russia. 293

At the 1995 Vienna Ozone Meeting, the Russian Federation argued that 'it was not the Russian Federation but the former Soviet Union and that ratified the Montreal Protocol, Russia, as the successor Party, cannot be fully responsible for fulfilling its commitments', and that 'the collapse of the Soviet Union constituted an event "force majeure" or a "fundamental change in circumstances" that justifies flexibility in the application of the Protocol to Russia'.294 As a result, in its Thirteenth Meeting, the Implementation Committee thus requested the Secretariat to seek clarification from the Legal Counsel of the United Nations on the status of the countries of the former Soviet Union regarding succession to the ozone treaties. 295

After much discussion, the 1995 Vienna Ozone Meeting adopted on consensus, despite the objection of Russia, Decision VII/18 - broadly similar to Decision VII/16 - with regard to anticipated non-compliance by the Russian Federation. 296 Decision VII/18 required not only data reporting, namely, more detailed information as to its firm commitments to the Ozone

292 See UNEP/OzL.Pro/7/9/Rev.

293 UNEP/OzL.Pro/7/12, para. 44; J. Werksman, 'Compliance and Transition: Russia's Non-Compliance Tests the Ozone Régime', 39 ZaoRV (1996) pp. 746-65 and its footnotes.

294 Statement by the Minister of the Environment and Natural Resources of the Russian Federation (translated from Russian), cited in J. Werksman, 'Compliance and Transition: Russia's Non-Compliance Tests the Ozone Régime', 39 ZaoRV (1996) p. 760. Article 62 of the Vienna Convention on the Law of treaties is considered as customary international law. See Fisheries Jurisdiction Case, (United Kingdom v. Iceland: Jurisdiction), I.C.J. Rep., (1973), paras. 37-43; Gabcikovo-Nagymaros Project Case (Hungary/Slovakia), para. 104. It is well-known that, in 1871, Russia similarly maintained the principle of rebus sic stantibus with regard to the Black Sea clause in the 1856 Peace Treaty.

295 UNEP/OzL.Pro/ImpCom/13/3, para. 8(b). The Counsel's advice on this issue was '. .. as far as the former Republics are concerned, they are treated as newly independent States and legally distinct from the former Soviet Union. Under the practice of the Secretary-General as depositary of multilateral treaties, they could become Parties to the Convention and the Protocol only pursuant to an explicit expression of consent to do so by their respective Governments. Such consent can be expressed either by (i) depositing an instrument of accession or by (ii) explicitly succeeding to these instruments which were previously applied on their territory. The SecretaryGeneral's practice does not include the concept of an 'aytomatic succession'. It is for a newly independent State to decide whether or not it should become a Party to any treaty deposited with the Secretary-General' (information provided by G. M. Bankobeza of the U.N.E.P. Ozone Secretariat, 10 December 1997).

296 It should be noted that the Russian Federation called for a vote upon the Decision VII/18; see UNEP/OzL.Pro/7/12, para. 129. 
Protocol, but also the 'necessary action' to secure that re-exports will be made from the C.I.S. to any party to the Ozone Protocol régime. 297 In this sense, it can be said that the Ozone Meeting of the Parties consolidated, to some extent, the contents of the previous Decision VII/16 taken by the Implementation Committee. 298

The representative of the Russian Federation, who considered such actions as 'discriminatory measures and sanctions against a Party', strongly disputed the paragraph addressing future trade restrictions, in vain however, 299 and thus regretted that 'it had not been able to accept the draft decision in its entirely. 300

This decision-making process illustrates nicely that, within the selfcontained international ozone régime, an individual conflicting opinion defended by only one party - i.e. the Russian Federation - eventually has to coincide with stated régime objectives; 301 this case pointedly illustrates the collective side of the Montreal N.C.P. régime.

However, Decision VII/18, at the same time, allows the Russian Federation to export controlled substances to C.I.S. parties operating under Article 2 of the Protocol (including Belarus and the Ukraine), and recommends, as an incentive, international assistance to help it comply with the ozone treaty obligations. 302 In reality, such funds will be

297 Decision VII/18 in UNEP/OzL.Pro/7/12. See also Decision VII/33 regarding illegal imports/exports of ODS in UNEP/OzL.Pro/7/12.

298 We may say that, in the light of the fact that the recommendations by the Commission were incorporated as the formal 'Decision' of the Parties, the Commission has developed its quasi-judicial functions.

The representative of the Russian Federation stated that 'that [such a stringent measure] was not mentioned at all in the Implementation Committee's recommendations'. See UNEP/OzL.Pro/7/12, para. 128.

299 See 'Comments Made at the Time of Adoption of the Decisions', in UNEP/OzL.Pro/7/12, paras. 123-134. The Russian Federation insisted that the Meeting of the Parties should apply appropriate measures in accordance with the Indicative List of Measures (Annex V) in an ascending order of importance, (i.e. from assistance, cautions to sanctions). However, wording of the Montreal N.C.P. would not necessarily prevent the Meeting of the Parties from choosing such 'appropriate measures' simultaneously regardless the order of the List.

300 See UNEP/OzL.Pro/7/12, para. 134, (emphasis added).

301 The Secretariat noted; '[W] hen only one Party objected to a draft decision, that decision would be carried by consensus and the position of the dissenting Party would be clearly reflected in the report of the Meeting'; see UNEP/OzL.Pro/7/12, para. 130. However, as stated earlier, the procedures to adopt Decisions are rather complex and controversial; while Article 11(4) provides that the Meeting 'consider and undertake any additional action that may be required for the achievement of the purposes of this Protocol', for instance, Article 40 of the Rules of Procedures for the Meeting of the Parties requires a two-third majority of the parties present and voting on all matters of substantial. See UNEP/OzL.Pro.1/5/Annex 1.

302 Ibid. 
The Montreal Non-Compliance Procedure and the Internal Institutions

indispensable for Russian lame-duck industries to virtually halt O.D.S. production and then convert existing production capacity to less ozonedepleting H.C.F.C. or H.C.F. production, although the Russian Federation, which prefers to use national production processes, is not willing to rely on transnational corporations' proprietary processes/licenses. 303

It is important to note, however, that since the Russian Federation is, in the light of its high levels of 'consumption' of O.D.Ss., by no means a 'developing country' operating under Article 5 of the Protocol, the highvolume-O.D.S.-consuming country is thus not entitled to receive funds from the Montreal Multilateral Fund.304 Consequently, the only international institution which is ready to contribute the necessary funds for the possible non-compliance by Russia, will be the Global Environmental Facility ('G.E.F.') that has no official legal status within the international ozone régime. 305

It has been quite obvious that the Russian Federation wants to ensure continuity of supplies of O.D.S. to developing countries to meet their 'basic domestic needs' - as permitted under the Protocol - and this fact supplies one of the rational reasons that it would not choose to withdraw from the legal régime for the protection of the ozone layer. Meanwhile the Group of 77 and China, which are fearful of the consequences of Russian illegal trade of O.D.Ss. in their markets, tried in vain to add to Decision VII/18 clear wording that would ban export/re-export of controlled substances to Article 5 parties. 306 Therefore, the final text is not completely clear on this crucial point. At the Open-Ended Working Group held in September 1996, Kenya submitted an amendment proposal that reads 'To allow. . . the Russian Federation to export substances controlled under the Montreal Protocol only to Parties operating under Article 2 of the Protocol. . . and not to any other Party, including those operating under Article 5 of the Protocol. This proposal was killed by Russian opposition

303 See the 1995 T.E.A.P./C.E.I.T. Report, p. 40.

304 See Article 5 of the Ozone Protocol; Chapter IV above.

305 It is interesting to note that, similarly, under the 1992 Climate Change Convention the Russian Federation is not eligible for financial assistance from the Convention's Financial Mechanism (Article 4(3)). See further J. Werksman, 'Compliance and Transition: Russia's Non-Compliance Tests the Ozone Régime', (unpublished: 1996), p. 14. For a discussion on the response of the G.E.F. Council, see, ibid., pp. 21-22; Part II of this Chapter below.

306 See UNEP/OzL.Pro.8/CPR.1. 
The Montreal Non-Compliance Procedure and the Internal Institutions

and by the hesitant Western countries including the United States and the European Community. 307

The Thirteenth Meeting of the Implementation Committee held in 1995 considered additional information offered by the Russian Federation in accordance with Decision VII/18.308 As a result, the Committee emphasised unmet needs for further information and then the Committee reiterated that the Russian Federation should monitor and report on the implementation of the trade restrictions. 309 It was reported that the G.E.F. Council had approved O.D.S. phase-out projects worth $\$ 43.6$ million for the Russian Federation, 310 and it had also prepared a Country Programme strategy funded by the Danish Ministry of the Environment. 311 The Committee further recommended that the G.E.F. Council and other funding institutions should consider additional steps to expedite financial assistance for future projects.

Although the information provided indicated discouraging signs of non-compliance for 1996, the Implementation Committee noted that the Russian Federation had taken 'important steps' to comply with Decision VII/18 and towards achieving full compliance with the control measures of the Protocol régime. 312 The Fourteenth Meeting of the Implementation Committee concluded that the Russian Federation satisfactorily answered all the questions taken up by the Committee and that the information offered should be adequate for the purposes of the Fourteenth Meeting of the Committee. 313

307 See R. Benedick, Ozone Diplomacy, (1998) p. 282 and Decision VIII/26(1). See also statement by Canada in the Open-Ended Working Group in UNEP/OzL.Pro/WG.1/15/3, para. 4, suggesting that Decision VIII/26 could be implemented solely through a decision by the Parties to modify the N.C.P.

308 See UNEP/OzL.Pro/ImpCom/13/3, paras. 14-18. The Report of the Meeting says that, despite an invitation by the Committee, representatives of the Russian Federation was not present for most of the meeting.

309 Ibid.

310 Ibid. See also UNEP/OzL.Pro.8.2, para. 16.

311 UNEP/OzL.Pro/IMpCom/12/3, para. 19. The Russian Federation and the World Bank has now developed a detailed closure plan for O.D.S. production facilities in the country, and to set up a multilateral financing scheme for supporting the closure effort. See further, World Bank, 'The World Bank and Russia: Working Together to Shut Down CFC Production', Facing the Global Environment Challenge, (Sep. 1995-Jan.. 1996), pp. 16-17.

312 See UNEP/OzL.Pro/ImpCom/13/3, para. 17.

313 See UNEP/OzL.Pro.8/2, para. 16. Victor says, however, that many observers are privately sceptical about the accuracy of the data provided by the Russian Federation. See D. C. Victor, The Early Peration and the Effectiveness of the Montreal Protocol's Non-Compliance Procedure, (1996) p. 31. 
At the Seventeenth Meeting of the Implementation Committee, the representative of the Russian Federation reiterated his country's commitment to meeting its international ozone treaty obligations, and he also said that a new federal phase-out programme would be implemented in co-operation with the international community and multilateral financing agencies. In this meeting the Committee made decisions that the Russian Federation had continued to produce O.D.Ss. during 1996 contrary to the provisions of the Montreal Ozone Protocol and Decision VII/18, and that Russia was still in non-compliance with the Protocol for 1996.314 Moreover, the Implementation Committee resolutely decided that the Russian Federation had exported both new and reclaimed substances to and also imported O.D.Ss. from - many developed and developing countries under the Montreal Ozone Protocol régime. 315 It was thus pointed out that 'there was a danger of a loss of credibility for the whole Montreal Protocol process if it was seen that Parties not operating under Article 5, which should have completed phase-out, were still importing and exporting controlled substances'.316 After the Eighteenth Meeting of the Implementation Committee, 317 Russia's persistent non-compliance case was further discussed in the 1997 Montreal Ozone Meeting of the Parties and the Ozone Meeting adopted Decision IX/31 based on the recommendations made by the Implementation Committee. 318

\section{CONCLUSIONS}

Since the adoption of the 1987 version of the Ozone Layer Protocol, the international legal régime for the protection of the ozone layer has been 'adjusting' itself to become more commensurate with the ecological impact of adverse effects caused by severe ozone depletion. Now, the optional dispute settlement procedures of the 1985 Vienna Ozone Layer Convention is effectively 'supplemented' with a flexible dispute avoidance/settlement mechanism - i.e. the Montreal Non-Compliance Procedure.

\footnotetext{
314 UNEP/OzL.Pro/ImpCom/17/3, para 25(b) and (c).

315 UNEP/OzL.Pro/ImpCom/17/3, para. 25(d).

316 UNEP.OzL.Pro/17/3, para. 23 (emphasis added).

317 See UNEP/OzL.Pro/ImpCom/18/3.

318 Decision IX/31 in UNEP/OzL.Pro.9/12. Decision IX/31 noted, for instance, that international financial assistance - the G.E.F. in particular - should continue favourably with a view to furnishing funds for projects to implement the programme for the phaseout of the production/consumption of O.D.Ss. in the Russian Federation.
} 
The Montreal Non-Compliance Procedure and the Internal Institutions

As we have seen, it is entirely fair to say that the Montreal N.C.P. régime is essential to the operation of a regulatory rule-oriented ozone legal system in the comparatively weak realm of legal obligations of global environmental protection, and in reality, it has turned out to be a great step forward in strengthening the collective compliance or 'horizontal enforcement' of international law principles of the environment, including the precautionary environmental 'principle'/approach and other generally accepted Stockholm/U.N.C.E.D. Principles. Therefore, we do not have to regret the absence of any reliable procedure of identifying, at an early stage, possible non-compliance with treaty obligations and of avoiding/ settling multilateral ozone disputes. At the same time, however, the deterrent influence of the traditional dispute 'settlement' procedures under the 1985 Vienna Ozone Convention should not be ignored: 'The possibility of resort to compulsory procedures may have a powerful impact on the dynamic and effectiveness of a treaty régime even if those procedures are in practice never used'.319

Yet the standing Committee's régime-monitoring instruments within the N.C.P. are largely limited to (i) extensive discussions on compliance matters; (ii) making recommendations to the Meeting of the Parties: and (iii) making non-compliance transparent. In addition, the Committee can still deliberately duck certain issues such as the legal status of monetary contributions to the financial mechanism, the Montreal Multilateral Fund and the meaning of 'non-compliance' with the Protocol. Furthermore, the Implementation Committee - as an international conciliator - does not have formal decision-making power, whilst it is to report regularly to the Meeting of the Parties. Until now the Committee is, as Mr. Széll observes, 'very careful not to exceed the scope of its mandate or the expectations of the Parties'. 320 Expanding the functions of the N.C.P. Committee beyond the notion of an ozone dispute conciliator would be hardly admissible, if at all.

Whilst in many cases the standing Committee's recommendations are widely accepted by the régime member states, unsettled questions as to non-compliance (and/or breach of treaty) must be ultimately referred to the supreme ozone institution, the Meeting of the Parties that is entrusted with all the powers that are indispensable for the fulfilment of its objectives and purposes in protecting the ozone layer. It may be

319 See A. E. Boyle, 'Settlement of Disputes Relating to the Law of the Sea and the Environment', 26 Thesaurus Acroasium (1996) p. 259.

320 See UNEP/OzL.Pro.7/INF.1, para. 29. 
The Montreal Non-Compliance Procedure and the Internal Institutions

reasonable to suppose that the Committee's influence as a conciliator in the ozone régime depends in part on the extent to which the Meeting of the Parties follows the Committee's recommendations.

The weakness of the Montreal N.C.P., since the decisions as to what kind of recommendations should be made and which measures must be taken are left largely to the broad discretion of intergovernmental institutions - i.e. the Committee and/or the Meeting of the Parties, is that it remains questionable whether political bodies consisting of governmental representatives can always act impartially and sincerely as trustees of the ozone layer. 321 Unlike international judicial institutions or human rights committees or commissions, the N.C.P. régime operators are not 'independent' and they do not necessarily have 'professional prestige'. In addition, we should not overlook the 'confidential aspects' of the Montreal N.C.P. decision-making process that is often crucial in understanding the hidden meaning of decisions of the internal régime institutions. 322

It was in 1995 that the Montreal N.C.P. régime started its active operation to handle the first formal ('voluntary') submission of treaty noncompliance. As I have contended, the original intention of the N.C.P. of the ozone régime is not to apply a sanction-related remedy that is not very effective and often self-defeating. However, by looking at the abovementioned fact that the Meeting of the Parties adopted Decision VII/18 'on consensus' against the will of the Russian Federation (an action that might be regarded by some commentators as certain forms of limited collective sanctions), we may say that 'friendly confrontation' may be beneficial to the effective operations of the existing Montreal N.C.P. régime. An ongoing useful lesson from Russia's non-compliance case is, simply, that, on occasion, the internal régime institutions have to exert 'appropriate' multilateral pressure on member states that do not comply persistently with their treaty obligations, by applying not only bunches of 'carrots', but also the appropriate 'stick' that is carefully chosen to strike the right balance. If, in this first test on the Montreal N.C.P. régime, the 1995

321 See A. E. Boyle, 'Saving the World? Implementation and Enforcement of International Environmental Law Through International Institutions', 3 J.E.L. (1991), pp. 229-45; idem, 'The Principle of Co-operation: Environment', in The United Nations and Principles of International Law: Essays in Memory of Michael Akehurst, (1994) pp. 129 et seq.

322 However, we need frequently to remind ourselves of the fact that, in many case, internal international institutions within treaty régimes are more suitable for interpretation of régime rules and settlement of disputes than other international tribunals external to them - often international legal régimes have, to a greater or lesser extent, their own 'jurisprudence'. 
The Montreal Non-Compliance Procedure and the Internal Institutions

Meeting of the Parties had merely followed the Committee's rather 'soft' recommendations, considerable doubts would have sprung up among the ozone régime members as to the effectiveness of this new dispute avoidance/settlement procedure against non-compliance.

Hence the Montreal N.C.P. régime is now regarded as one of the most sophisticated dispute avoidance/settlement procedures for ensuring compliance with environmental obligations and fixed regulatory standards: as Rummel-Bulska of the U.N.E.P. Ozone Secretariat, observed: 'The main element that had led to the régime being considered as a model for other environmental treaties was mainly its preventive character and the readiness to assist rather than to sanction a Party considered not in compliance'. 323

Lastly, as stated earlier, it should be noted that - to be more effective - the Montreal N.C.P. régime was to be reviewed based on Decision IX/35 of the 1997 Montreal Ozone Meeting of the Parties. 324 In addition, as Canada suggested in the Fifteenth Meeting of the Open-Ended Working Group, the Montreal N.C.P. should more clearly outline or define (i) identification of potential non-compliance, (ii) determination of non-compliance, (iii) consequences of non-compliance and (iv) monitoring and determination of a return to compliance. 325

The experience of the Montreal N.C.P. model would be helpful in designing other different non-compliance procedures under various international treaties of environmental protection. Yet it must be pointed out that, whilst the Montreal N.C.P. régime has turned out to be the very prototype, each M.E.A. should adopt, depending on the nature/contents of its established legal obligations and types of potential environmental

323 UNEP/OzL.Pro.7/INF.1, para. 30.

324 The newly established Ad Hoc Working Group of Legal and Technical Experts on the N.C.P. is to consider (i) any proposals by parties for strengthening the N.C.P. including how repeated instances of major significance of non-compliance could trigger the adoption of measures under the Indicative List of Measures with a view to ensuring prompt compliance with the Protocol; and (ii) any proposals for improving the effectiveness of the functioning of the Implementation Committee - including with respect to data-reporting and the conduct of its work. See Decision IX/35(5) in UNEP/OzL.Pro.9/12. The Working Group composed of fourteen members from both developed ('Article 5') and developing ('non-Article 5') countries, namely, Australia, Canada, European Community, Russian Federation, Slovakia, Switzerland, United Kingdom, Argentina, Botswana, China, Georgia, Morocco, Sri Lanka and St. Lucia.

See the following recent reports by the Ad Hoc Working Group: UNEP/OzL.Pro/WG/1/1/Add.1 (14 April 1998); UNEP/OzL.Pro/WG.4/1/1/Add.2 (18 May 1998); UNEP/OzL.Pro/WG/1/1/Add.1 (15 April 1998).

325 UNEP/OzL.Pro/WG.1/15/3, para. 8 ('Principles'). 
The Montreal Non-Compliance Procedure and the Internal Institutions disputes, a more suitable form of the N.C.P. régime 326 - but on the basis of the 'philosophy' of the Ozone Protocol N.C.P. model. 327

It is obvious that the N.C.P. régime alone will not strengthen compliance with ozone treaty obligations, unless it is accompanied by the financial assistance and the transfer of technology required to improve state parties' capacity to comply with them (see Chapter I(III.B) above). In Chapter VI, we shall be examining whether the Montreal Protocol's compliance system has provided ozone régime members with sufficient 'inducements' to comply with their international environment-related obligations.

326 For instance, the Montreal N.C.P. model would not be suitable for the Basel Convention non-compliance régime. For a discussion see P. Széll, 'Compliance Regimes for Multilateral Environmental Agreements: A Progress Report', 27/4 E.P.L. (1997) p. 305.

327 See Section V above. Yet, it is important to note that, as Professor A. E. Boyle says: 'The acceptance of more advanced models of institutional management and control remains limited, however, and does not justify the conclusion. . . that the 'precautionary principle' has replaced national freedom to act in the absence of proof of harm'. See 'The Principle of Co-operation: Environment', in The United Nations and the Principles of International Law: Essays in Memory of Michael Akehurst, (1994), p. 133. 


\section{CHAPTER VI}

THE FINANCIAL MECHANISM OF THE MONTREAL PROTOCOL AND THE INTERNATIONAL TRANSFER OF OZONE-FRIENDLY TECHNOLOGY: CAPACITY BUILDING IN THE OZONE REGIME

\section{THE CONCEPT OF 'CAPACITY BUILDING' \\ IN INTERNATIONAL LAW OF THE ENVIRONMENT}

\section{A. The Question of Defining 'Capacity Building' in International Environmental Law}

It is often said that rendering financial foreign aid or technical assistance to developing countries ${ }^{1}$ - such as bilateral overseas development aid ('O.D.A.') ${ }^{2}$ - has traditionally been considered as not strictly a 'legal' but rather a 'moral' obligation of donor industrialised countries to developing states' capacity building. Philosophically speaking, this 'justly acquired money' is meant to repair past grievous wrongs of colonisation against these aid-receiving poor countries in the Third World. ${ }^{3}$ In this way, the 'ethical aspect' of capacity building, under the branch of the international law of development in particular, ${ }^{4}$ may be generally understood as a repeated - but often largely fruitless - demand of poor industrialising countries for a possible improvement of the existing 'North-South' economic relations for the benefit of 'Southern' countries. Viewed from this historical perspective, it is therefore possible to argue that the concept of capacity building originated in the developing countries' 'N.I.E.O.' (New

\footnotetext{
1 Developing countries include economically less-developed countries of Asia, Africa and Latin America. On the technical definition of 'developing countries' under the Montreal Protocol, see Chapter III(2.B) above and Appendix IV. As at 15 May 1998, 105 of the 165 parties to the Montreal Protocol régime were classified as Article 5 developing countries.

2 See e.g. S. Johnston, 'Financial Aid, Biodiversity and International Law' in M. Bowman and C. Redgwell (eds.), International Law and the Conservation of Biological Diversity, (1996) pp. 271 et seq.

3 See T. Chengyuan, 'Legal Aspects of the Global Partnership between North and South', in N. Al-Nauimi and R. Meese (eds.), International Legal Issues Arising Under the United Nations Decade of International Law, (1995), p. 210; G. Handl, 'Environmental Protection and Development in Third World Countries: Common Destiny-Common Responsibility', 20 N.Y.U.J.I.L.P. (1988) pp. 606-08.

4 On international law of development, see e.g. H. Thierry, J. Combacau and S. Sur, Droit International Public, (1984), Chapter 14; T. Takashima, International Law of Development, (1995, Japanese).
} 
International Economic Order) movement, which won its first official political endorsement at the Sixth Special Session of the United Nations General Assembly held in $1974 .^{5}$

In the much narrower context of international environmental law and of its sectoral régimes - such as the ozone régime - the words 'capacity building' will acquire more specific or technical and different meanings. In other words, capacity building is not exactly equal to traditional foreign financial aid that would be originally designed to satisfy the basic human needs ('B.H.Ns.') of poor people who are barely surviving on the margin of everyday life and/or promote an industrialising country's economic development (e.g. O.D.A. funds). ${ }^{6}$ One of the major objectives of capacity building is to build the long-term capacity of aid-receiving countries to fully comply with strict and technical legal obligations of specialised international environmental régimes.

The notions of capacity building within a developing country and/or its private industry broadly encompass at least four categories, ${ }^{7}$ i.e. (i) bilateral, regional or international environmental financial assistance in general, (ii) (associated) international technology transfer $^{8}$ for intended environment protection purposes, (iii) institutional strengthening for implementation of environmental agreements (e.g. increases in administrative and legal capacities, improvements in data collection and analysis 9 ), and (iv) the development of a recipient country's awareness of environmental issues in question, including extension of their political commitment to the legal obligations of environmental régimes. ${ }^{10}$

\footnotetext{
5 See A. E. Boyle, 'Comment on the Paper by Diana Ponce-Nava' in W. Lang (ed.), Sustainable Development and International Law, (1995) p. 137.

6 Yet, since 1990s, not only governments of industrised countries but also the World Bank and other regional banks have made efforts to distinguish environmental aid from normal development assistance. See e.g. W. E. Franz, 'Appendix: The Scope of Global Environmental Financing - Cases in Context', in R. Keohane and M. Levy, Institutions for Environmental Aid, (1996) pp. 367-80.

7 See also J. Ohiorhenuan and S. Wunker, Capacity Building Requirements for Global Environmental Protection (G.E.F. Working Paper No. 12) pp. 3-5 esp.; L. Gündling, 'Compliance Assistance in International Environmental Law: Capacity Building through Financial and Technology Transfer', 39 ZaoRV (1996) pp. 800-02; D. Kaniaru and L. Kurukulasuriya, 'Capacity Building in Environmental Law' in F. Schlin (ed.), UNEP's New Way Forward: Environmental Law \& Sustainable Development, (1995) pp. 172-79.

8 On the definition of 'technology transfer' see Section IV(A) below.

9 Non-compliance with data reporting has been frequently observed in Article 5 developing countries. See further Chapter V(VII.A.1) above.

10 It is sometimes pointed out that effectiveness of environmental law in developing states is impaired by corruption of government officials. See e.g. M. G. Faure,
} 
The above-mentioned concept of capacity-building is deeply associated with universal and effective participation from a growing number of developing states whose contributions as polluters to global environmental problems (e.g. ozone depletion and global warming) are relatively minor. For the majority of poor developing countries, the protection of the global environment - such as the stratospheric ozone layer - may often be seen as merely an expensive problem or an inescapable 'by-product' of rich Northern states. Considered against this background, the concept of capacity-building can be properly regarded as an effective, but in a sense 'political', bargaining tool for modern diplomatic environmental negotiations that would eventually lead to the adoption of new international treaties on the protection of the environment. In other words, for most industrialising states - who may regard M.E.As. only as impediments to their economic growth, international financial resources for capacity building within environmental legal régimes have become the so-called 'carrots', required in advance of the establishment of environmental legal régimes (see Chapter I(III.B) above). ${ }^{11}$

\section{B. Capacity Building in M.E.As.}

Treaty provisions concerning the ideas of capacity building - financial aid and technology transfer in particular - are already included in some international environmental agreements precedent to the ozone layer régime.

With regard to environment protection funds, the 1972 U.N.E.S.C.O. Convention for the Protection of the World Cultural and National Heritage introduced the 'World Heritage Fund' ('W.H.F.') as a trust fund consisting of compulsory and voluntary contributions by contracting state parties. ${ }^{12}$ Likewise, the Fourth Meeting of the Conference of the Parties of the 1971 Ramsar Convention established, in 1990, the 'Wetland Conservation Fund' in

Enforcement Issues for Environmental Legislation in Developing Countries (U.N.U./I.N.T.E.C.H. Working Paper No. 19, March 1995) pp. 18-19.

11 The legal 'principle' of 'common-but-differentiated responsibility' (see Part A of Chapter III(E.3) above) could be also understood in this similar context of capacity building.

12 Article 15. Each party pays one per cent of its contribution to the Rugular Budget of the U.N.E.S.C.O. to the World Heritage Fund. On the Fund, see e.g. P. H. Sand, 'The Potential Impact of the GEF of the World Bank, UNDP and UNEP', a paper distributed at a symposium in Heidelberg (5-7 July 1995), Section I(1). 
order to assist developing country parties (Resolution $\mathrm{C}(4.3)) .13$ In addition to fund mechanisms within environmental treaties, in accordance with General Assembly Resolution 2997, the Environmental Convention Trust Funds were established in 1978 under the auspices of the U.N.E.P. for the greater implementation of legal obligations in particular environmental treaty régimes for sustainable development, though its relatively small total budget for each treaty handicaps its current operations. ${ }^{14}$

In respect of technology transfer, the 1982 U.N.C.L.O.S. deals with 'marine technology transfer' in two parts, i.e. the provisions on the international sea-bed régime and Part XIV (Articles 266 to 274). Under Articles 144 and 274, the 'International Sea Bed Authority' 15 is required to train nationals of developing countries, to make technical documentation on sea-bed mining available to developing states, and to assist these countries in the acquisition of sea-bed marine technology. ${ }^{16}$ Under Article 266(1), state parties are called on to co-operate in promoting the development and transfer of marine science and technology on fair and reasonable terms and conditions. ${ }^{17}$ The 1992 Climate Change Convention contains the 'classic environment technology transfer clause'18 (Article 4(5)) and, just as the Montreal Protocol, it has created conditionality between compliance by industrialising countries and the effective transfer of technology and financial resources (Article 4(7)). Other modern M.E.As. also contain provisions on technology transfer: they include the 1992 Biodiversity Convention (Article 16), ${ }^{19}$ the 1989 Basel Convention (Article

13 See P. Sands, Principles of International Environmental Law, (1995) p. 735 . In accordance with Resolution VI.6 the Fund was renamed in 1996 as the 'Ramsar Small Grants Fund ('S.G.F.'). See also the Operational Guidelines for the Triennium 19971999 under [http://iucn.org/themes/ramsar/key_sgf_guide.htm].

14 See P. H. Sand, op. cit. n. 12, Section II(2); idem, 'Trust for the Earth: New Financial Mechanisms for Sustainable Development' in W. Lang (ed.), Sustainable Development and International Law, (1995) pp. 172-74; U.N.E.P., Environmental Law in the UNEP, (1990).

15 On this treaty organ see 11 E.P.I.L. (1989) pp. 162-63.

16 R. Churchill and A. Lowe, The Law of the Sea, (1988) p. 302. But the Agreement on the Implementation of Part XI of the U.N.C.L.O.S. revised the technology transfer régime in the context of deep-sea bed mining.

17 See also Articles 202-203 ('Scientific and Technical Assistance to Developing States').

18 G. Verhoosel, 'International Transfer of Environmentally Sound Technology: The New Dimension of an Old Stumbling Block', 27/6 E.P.L. (1997) p. 475.

19 See I.U.C.N., A Guide to the Convention on Biological Diversity, (1994), noting that 'article 16 is probably the most controversial article' in the Convention. 
10) and the 1994 Sulphur Protocol to the 1979 Geneva L.R.T.A.P. (Article 3). 20

The organisation of this chapter is as follows: after evaluating the 1987 version of the Montreal Protocol in the particular context of financial and technical assistance, Section II analyses the negotiation process of the Montreal Multilateral Fund, including the issues of international technology transfer of O.D.Ss. Section III then investigates general aspects of the Financial Mechanism of the Protocol, including the Multilateral Fund, and it also considers the role of international institutions within the framework of the new Financial Mechanism. Section IV studies the current operation and effectiveness of the Multilateral Fund of the Protocol, focusing on the phase-out of O.D.Ss. and international transfer of ozone-friendly technology. The Section also briefly examines a case study of project implementation in the People's Republic of China.

\section{THE NEGOTIATION PROCESS OF THE MONTREAL MULTILATERAL FUND AND THE TECHNOLOGY TRANSFER -RELATED ISSUES}

\section{A. 'Capacity Building' Under the 1985 Vienna Ozone Convention and the 1987 version of the Montreal Ozone Protocol}

The 1985 framework Ozone Convention adopted in Vienna neither centres much international attention on the need for special considerations to be given to developing countries nor includes a clause concerning additional multilateral financial assistance from industrially advanced Northern states. Article 4 of the Vienna Ozone Convention only provided that (i) the state parties are to 'facilitate and encourage the exchange of scientific, technical, socio-economic, commercial and legal information relevant to this Convention'21 and that (ii) they shall also 'co-operate, consistent with their national laws, regulations and practices and take into account in particular the needs of the developing countries, in promoting, directly or

20 See also the 1979 L.R.T.A.P. (Article 8); the 1988 N.Ox. Protocol (Article 3); the 1991 V.O.C. Protocol (Article 4).

21 Article 4(1). For instance, socio-economic and commercial information include: (i) Production/production capacity; (ii) Use/use patterns; (iii) Imports/exports; (iv) The costs, risks and benefits of human activities which may indirectly modify the ozone layer and of the impacts of regulatory actions taken or being considered to control these activities. See Annex II(5). 
through competent international bodies, the development and transfer of technology and knowledge'.22

These treaty provisions indicate that, in most cases, global cooperation in transferring technology under the Vienna Ozone Convention is thus frequently subject to national laws regarding, for example, patents, trade secrets, and protection of confidential business or commercial information involved. During the negotiation of the Vienna Convention régime many experts had considered that Article 4 contained an escape clause that could or would undermine the Ozone Convention. In actual practice, it then deterred industrialising developing states from participating in the international ozone régime. ${ }^{23}$ Before the adoption of the 1987 Montreal Ozone Protocol, only a few developing countries 24 decided to become contracting parties to the framework Ozone Convention that may have been seen as merely an environmental régime of rich Northern states.

Since the ozone negotiations of the 1987 version of the Montreal Protocol were focused on technical and thorny issues on O.D.Ss. emission reductions, ${ }^{25}$ matters pertaining to an expected financial and technological assistance mechanism - including a multilateral fund, multilateral, regional and bilateral cooperation - were appropriately left to the Meeting of the Parties. Article 13(2) states that 'The Parties, at their first meeting, shall adopt by consensus financial rules for the operation of this Protocol'.26 The 1989 First Meeting of the Parties was thus to begin deliberations on the means of fulfilling these treaty obligations, including the preparation of workplans. 27 Yet, as was described in Chapter III(III.E.2) above, it was agreed that a special provision in Article 5 of the Protocol should allow developing countries to delay their treaty compliance with O.D.Ss. control measures for ten years.

According to Article 5(3) of the 1987 Ozone Protocol, state parties are only required 'to facilitate bilaterally or multilaterally the provision of

22 Several developing states preferred 'consistent with', instead of 'subject to'. See, UNEP/WG.94/8, p. 3.

23 See e.g. UNEP/WG.94/8, p. 4.

24 These countries include Guatemala (11 September 1987, [accession]) and Mexico (14 September 1987).

25 See Chapter III above for full account of the Montreal N.C.P. régime.

26 Yet, the Working Group on the Special Situation of Developing Countries noted that: '[W]hen the Financial Rules are drawn up it would be most important not to place undue financial burden on the developing countries whose contribution to depletion of the ozone layer is minimal'. See UNEP/WG.167/2, p. 32.

27 Article 10(3), Article 11(3)-(4). 
subsidies, aid, credits, guarantees or insurance programmes to Parties that are developing countries for the use of alternative technology and for substitute products'. Yet, it is important that Article 10(2) provides that any party or signatory to the Protocol can file a request to the U.N.E.P. Ozone Secretariat for technical assistance for the purposes of implementing or participating in the Ozone Protocol.

B. The Negotiation of the Montreal Multilateral Fund and the Technology Transfer

The First Meeting of the Open-Ended Working Group of the Parties to the Montreal Protocol was held in August 1989 in order to develop modalities for finance related mechanisms. ${ }^{28}$ The Meeting was attended by representatives from twenty-two contracting parties and twelve noncontracting parties (e.g. China, India and Republic of Korea). The Executive Director of the U.N.E.P. officially introduced the Meeting by giving an opening statement that the hesitation of developing states was due mainly to the lack of financial resources to comply with ozone treaty obligations without serious disruption of their development efforts. He also suggested that 'what they needed was concessional funding and outright grants additional to existing aid programmes'.29 The Executive Director further indicated that the financial mechanisms of the Montreal Ozone Protocol régime would constitute an important precedent for those of a global climate change treaty. 30

Industrialising states delegates - led by Mexico, Venezuela, China and India - strongly advocated the establishment of a trust fund within the U.N.E.P. or any other suitable institution with 'legally enforceable obligations of contributions' by developed state parties to the Ozone Protocol. 31 They also supported the view that the totality of funds should show an 'increase' - i.e. the concept of additionality - and that there must be burden sharing amongst these industrialised donor states. 32 However, industrialised donor states - including the United States, the United

\footnotetext{
28 UNEP/OzL.Pro.WG.I(1)/3 (the First Session of the First Meeting, held at U.N.E.P. headquarters in Nairobi from 21 to 25 August 1989).

29 UNEP/OzL.Pro.WG.I(1)/3, para. 2 (emphasis in original).

30 Ibid.

31 See UNEP/OzL.Pro.WG.I(1)/3, paras. 9 and 34 esp.: R. E. Benedick, Ozone Diplomacy, (1998) p. 153.

32 See UNEP/OzL.Pro.WG.I(1)/3, para. 26 (not officially agreed on the precise wording due to time constraints, however).
} 
Kingdom and Japan - advocated the use of existing bilateral aid programmes and/or multilateral financial assistance from the World Bank. They considered that the concept of an 'International Environmental Facility', as a clearing house mechanism to identify and match bilateral/multilateral funding with individual projects, would be one of the acceptable alternatives to the creation of such a new financial institution within the self-contained ozone régime, but may be external to existing international monetary organisations dominated by a handful of rich Northern states, including the United States. 33

The Working Group also introduced the definition of transfer of technology in the context of financial aid, which means 'facilitating access to environmentally safe alternative substances for Parties that are developing countries and assist them to make expeditious use of such alternatives' by meeting the incremental costs associated with transition from O.D.Ss. to alternatives and substitutes. ${ }^{34}$ It was also agreed that incremental costs covered by the financial mechanism would include (i) production, (ii) use as an intermediate good, and (iii) action at the consumer level. 35

Yet, industrialising states insisted that free access to technical information and non-profit technology transfer of substitutes for O.D.Ss. should not be subject to trade concerns relating to matters of intellectual property rights, licences and patents. 36 We may notice here that the definition of international technology transfer above does not necessarily refer to an anticipated difficult situation where certain Multinational Companies (M.N.Cs.) could often refuse to sell patents for O.D.Ss. emission control technology 37 - in the absence of promising economic benefits for these companies, the introduction of new technology would be difficult except by national regulations supported by socio-economic assistance from a government. In this context, the Director-General of the World Intellectual Property noted in a subsequent meeting that national governments have 'little space for manoeuvre with private industries beyond persuasion and incentives'.38

\footnotetext{
33 See UNEP/OzL.Pro.WG.I(1)/3, para. 9: R. E. Benedick, Ozone Diplomacy, (1998) p. 153.

34 Article 5(2), the 1987 Montreal Protocol. See also UNEP/OzL.Pro.WG.II(2)/7.

35 For further details, see, UNEP/OzL.Pro.WG.I(1)/3, para. 12.

36 See UNEP/OzL.Pro.WG.I(1)/3: R. E. Benedick, Ozone Diplomacy, (1998) p. 153.

37 T. Gehring, Dynamic International Régimes, (1994) p. 289.

38 See UNEP/OzL.Pro.WG.II(2)/7, para. 7.
} 
The meeting of the Bureau of the Montreal Protocol held in September 1989 made a recommendation that the Second Working Group should consider the creation of a binding financial mechanism based on compulsory contributions from advanced industrial countries and a situation in which private parties were not likely to release legal patents on O.D.Ss. technologies. 39

In the Open-Ended Working Group held in November 1989 an industrialising state group, which was led by Mexico, put forward a new Article 10bis, 'Transfer of Technology and Financial Assistance'; it provides that international technology transfer from industrialised to industrialising countries should be arranged on a 'preferential and noncommercial basis' and that an 'International Trust Fund' - proposed by an environmental N.G.O., the World Resources Institute -40 shall be established within U.N.E.P. to meet fully the incremental costs'. 41 The concept of the Trust Fund was comparatively more modest than that of the 'Earth Fund' this idea was put forward by the Executive Director of the U.N.E.P. - that would institute a global levy on the use of the environment, that is to say, the stratospheric ozone layer. 42

These states also introduced an amendment to Article 5 of the Protocol which reads that the obligation of Article 5 parties or industrialising countries to comply with O.D.Ss. control measures will be subject to the transfer of technologies and financial assistance as provided for in Article 10bis above. 43

The Second Meeting of the Open-Ended Working Group was held in March 1990.44 The Executive Director of the U.N.E.P. introduced the following six principles of a general agreement reached through previous formal/informal discussions: 45

39 UNEP/OzL.Pro.Bur.1/2, para. 8.

40 For further details, see UNEP/OzL.Pro.Mech.1/2, paras. 23-24. The other scheme put forward by the N.G.O. is a pilot investment programme for Sustainable Resource Use, 'ECOVEST'. See ibid., para. 25.

41 UNEP/OzL.Pro.WG.II(1)/5, p. 16.

42 See a Note by Dr. M. Tolba, 'Transfer of Technology and the Financing of Global Environmental Problems: The Role of Users' Fees' (UNEP/OzL.Fin.1/2), para. 31 esp.

43 UNEP/OzL.Pro.WG.II(1)/5, Article 5(2), p. 14.

44 See UNEP/OzL.Pro.WG.II(2)/7, (Geneva, 26 February - 5 March 1990 [second session]).

45 See a report of an informal consultations held in January 1990, UNEP/OzL.Pro.WG.II(2)/2: T. Gehring, Dynamic International Régimes, (1994) pp. 29091. 
(i) a new financial mechanism must be established and its funding must be additional to existing development assistance,

(ii) contributions should be on an assessed rather than voluntary basis,

(iii) existing bilateral/multilateral sources of funding should be maintained,

(iv) The U.N.E.P. - as an Ozone Secretariat - should be assigned a major role in catalysing/coordinating the work of other organisations in a joint venture,

(v) Decisions on policies and criteria for the use of the resources should be taken by the contracting parties, and this will require expanding the role of the U.N.E.P. Ozone Secretariat, and:

(vi) Whilst each country enjoys a prerogative to decide how to raise funds, the establishment of a 'user's fee' for ozone-depleting activities has several advantages. ${ }^{46}$

However, delegations of industrialised donor state parties pointed out the difficult and lengthy process that might be involved, and therefore they still defended their preference for existing financial/technical assistance through major international economic institutions - the World Bank in particular - over such a new multilateral financial treaty institution. Some of them even favoured only the creation of a 'clearinghouse' to furnish 'objective' information and to facilitate formal requests for possible assistance. ${ }^{47}$ Indeed, the Mechanism was likely to form a historical precedent for the United States government, as potentially the largest donor, to channel good money into a future $\mathrm{CO}_{2}$ financial mechanism. ${ }^{48}$ Recognising that they have not much say in the present market-oriented political-economic systems, developing states considered it undoubtedly favourable, strengthening the U.N.E.P.'s moderating influence on that very trying situation in the operation of the expected new environmental funding mechanism - this critical issue remained unsettled.

The Second Meeting of the Parties was held in London in June 1990, and, prior to that Meeting, the Forth Meeting of the Working Group managed to clear up several immediate problems such as the voting procedures of the Executive Committee. 49 Developing states such as India and China considered that their ratification of the Protocol would depend

46 See UNEP/OzL.Pro.WG.II(2)/7, para. 6: R. E. Benedick, Ozone Diplomacy, (1998) p. 155.

47 See R. E. Benedick, Ozone Diplomacy, (1991) pp. 155-56.

48 See R. Bowser, 'History of the Montreal Protocol's Ozone Fund', 20 I.E.R. (November, $1991)$ p. 637; R. E. Benedick, Ozone Diplomacy, (1998) p. 159.

49 See T. Gehring, Dynamic International Régimes, (1994) pp. 296-98. 
not only on the expected establishment of the ozone-related financial mechanism but also on sufficient guarantees for access to new technologies of O.D.Ss.. 50

At the London Ozone Meeting, India argued that, for instance, it is morally desirable that all C.F.Cs. production should be stopped, but only after developing countries receive alternative technologies. 51 The delegation of Malaysia even stated that denying access to modern technology amounts to a so-called 'environmental colonialism'.52

As Blake and Walters pointed out, it is said that underdeveloped Southern countries, which cannot help depending on international technology transfer via major M.N.Cs., generally consider that they have paid enough to the developed First World countries through the exploitation of their natural resources. They thus think that technology is part of 'human heritage' - but not proprietary scientific knowledge (i.e. the private property of the patentee) - and they should have a right of access to such technology to improve their low standards of living. 53 On the other hand, industrialised countries generally regard patent protection as an incentive for the development of new technology; it is true that the lack of a national legislative and regulatory régime with a limited enforcement mechanism has often destroyed certainty of making a business investment in the Third World. In practice, it has also discouraged various bilateral or multilateral overseas investments.

Yet, it is important to notice that at this Meeting the Parties adopted the interim Montreal N.C.P. régime - if developing countries have difficulties in gaining ozone-friendly technologies necessary to fully comply with the obligations of international ozone treaty including control measures of O.D.Ss., the internal treaty institutions such as the Implementation Committee and the Meeting of the Parties are to decide future remedial measures for these matters, such as appropriate financial and/or technical assistance. 54

After resolving major problems with the expected environmental fund, the parties to the Montreal Protocol decided to start operation of the

50 M. W. Browne, '93 Nations Move to Ban Chemicals that Harm Ozone' in N.Y. TIMES (30 June 1990).

51 See K. T. Litfin, Ozone Discourses, (1994) p. 144.

52 R. Benedick, Ozone Diplomacy (1998) p. 189.

53 D. H. Blake and R. S. Walters, The Politics of Global Economic Relations (1983) p. 156.

54 See Chapter $\mathrm{V}$ above for a full account of the Montreal N.C.P. régime. 
Financial Mechanism on 1 January 1991 for an interim period of three years, therefore, prior to the Amendment entering into force and the establishment of the actual institutional mechanism. Accordingly, the Interim Multilateral Fund for the Implementation of the Montreal Protocol was established by the 1990 London Meeting based on a simple Decision II/ 8 of the Ozone Meeting of the Parties. It was thought that, as a rule, the Interim Fund was to be transformed into the Montreal Protocol Multilateral Fund on a permanent basis as established under the Amendment.

In the 1992 Copenhagen Ozone Meeting members of the European Community - France, Italy, the Netherlands and the United Kingdom, in particular - disputed, however, the validity of such a transformation of the Fund and they were unwilling to reaffirm their financial commitment to the Multilateral Fund beyond 1993; however, not only Article 5 developing countries and small industrialised donor countries, but also the United States - which in the 1990 London Meeting greatly preferred the G.E.F. run by the World Bank - advocated the dominant and practical idea of newly establishing the Montreal Multilateral Fund. 55

As a result, the Forth Meeting conclusively established the Financial Mechanism, including the Multilateral Fund, and therefore the Interim Fund operated, in fact, until December 1992. In addition, the 1992 Copenhagen Meeting also decided that any resources remaining in the interim mechanism shall be transferred to the new Multilateral Fund.

\section{THE STRUCTURE OF THE FINANCIAL MECHANISM OF THEMONTREALOZONEPROTOCOL}

\section{A. General Legal Aspects}

As a beginning, we shall examine the following three fundamental aspects of the Montreal Protocol's Multilateral Fund ('M.L.F.').

First, the Multilateral Fund shall meet agreed incremental costs for Article 5 countries' treaty compliance, on a grant or concessional basis and in accordance with criteria decided upon by the state parties. ${ }^{56}$ In this respect, the 1990 London Meeting adopted a detailed 'Indicative List of Categories of Incremental Cost' - which is utterly fundamental to project

55 See UNEP/OzL.Pro.4/15: T. Gehring and S. Oberthür, 'The Copenhagen Meeting', 23/1 E.P.L., (1993) p. 10. See also R. Benedick, Ozone Diplomacy, (1998) pp. 209-12.

56 Article 10(3-a). 
eligibility for the M.L.F., although it cannot be considered as definitive or exclusive since it allows for costs not on the list to be met by the Fund (i) if they are identified/qualified, and (ii) if they are found by the Executive Committee 57 to be consistent with any criteria decided by the Parties. 58 Requests for financing incremental costs of an implementation project shall be considered in accordance with several general principles, including the concept of 'cost effectiveness'.59 Defining the term 'incremental costs' is a difficult task and in the meetings of the Executive Committee, some developing countries have tried to expand the list's coverage. 60

Second, the M.L.F. is to finance clearing-house functions concerning (i) a assistance for industrialising countries by way of country-specific studies and technical cooperation to identify their need for cooperation, (ii) technical cooperation to meet these identified needs, (iii) the distribution of information and relevant materials as provided for in Article 9, and the conduct of workshops, training sessions and other related activities, and; (iv) the promotion and monitoring of other multilateral, bilateral and regional cooperation. ${ }^{61}$

Third, the M.L.F. finances the independent Fund Secretariat ${ }^{62}$ and other related support costs. 63 It is important that the Fund would operate under the authority of the Meeting of the Parties and in accordance with this supreme institution's overall policies. 64 Furthermore, the Financial Mechanism under Article 10 of the Montreal Protocol is 'without prejudice to any future arrangements that may be developed with respect to other environmental issues'.65

57 See Section $\mathrm{B}(1)$ below.

58 Possible incremental costs include (i) cost of conversion of existing production facilities and equipments, (ii) costs arising from premature retirement or enforced idleness, (iii) cost of establishing new facilities for substitutes of capacity equivalent to capacy lost when plants are converted or scrapped (see UNEP/OzL.Pro/2/3, Appendix 1 of Decision II/8; UNEP/OzL.Pro/4/15, Decision IV/18, Annex VIII). See also U.N.E.P., The Study on the Financial Mechanism of the Montreal Protocol (March 1995) para. 214.

59 See further UNEP/OzL.Pro/2/3, Appendix 1 (Decision II/8) para. 1; UNEP/OzL.Pro/4/15, Decision IV/18, Section I(6).

60 See R. Benedick, Ozone Diplomacy, (1998) p. 257-58.

61 Article 10(3-b).

62 See Section $B(2)$ below.

63 Article 10(3-c).

64 Article 10(4).

65 Article 10(10). 
As we shall see later, major internal treaty institutions - i.e. the Meeting of the Parties, the Executive Committee, and the Fund Secretariat and pre-existing international institutions - i.e. the World Bank, the U.N.E.P., the U.N.D.P., and the U.N.I.D.O. - play important roles in the operation of the M.L.F. (see section B(3) below).

With regard to fund financing, the M.L.F. would be financed by contributions from all state parties not operating under Article 5(1) of the Ozone Protocol, including Russia and other C.E.I.Ts. 66 that do not have any financial obligations in the Climate Change Convention régime, and funds would be additional to other financial transfers to industrialising countries such as existing bilateral or multilateral O.D.A. flows. Contributions to the M.L.F. - which is in convertible currency or in kind and/or in national currency - would be made based on the United Nations scale of assessments, 67 and on the scale of contributions decided by the annual Meeting of the Parties. Yet there is no fixed date for making contributions to the Fund. 68

Until 1996 the total income of the Fund amounted to some U.S.\$550 million; 1, 400 projects had been approved and U.S.\$ 40 million remained available for distribution to projects submitted to the Twentieth Meeting of the Executive Committee. 69 Yet, it is also important to note that only 25 per cent of funds, allocated to the Implementing Agencies, had been disbursed to Article 5 developing countries. ${ }^{70}$ The major donors from 1991 to 1995 were the United States ( $\$ 136$ million), Japan (\$77 million), Germany ( $\$ 57$ million), France (\$38 million), the United Kingdom (\$31 million) and Italy (\$27 million). 71 More recently, the 1996 Eighth Meeting of Parties decided

\footnotetext{
66 See Chapter V(VII.A.1) above.

67 Article 10(5). The U.N. scale of assessment is an index system based on country economic factors. See further Decision VII/37(4): U.N.E.P., Handbook for the International Treaties for the Protection of the Ozone Layer, 4th edn. (1996) pp. 23639.

68 UNEP/OzL.Pro/ExCom/10/40, para. 102. As argued in Chapter V(III) above, it is not clear - as in the cases of the financial mechanisms of the Climate Change Convention and the Biodiversity Convention - whether non-payment of contributions can be regarded as ozone treaty non-compliance. Taking this into account, in my view, it is thus not possible to argue that - as in the case of O.D.A. funding - the duty of financial (and technical) assistance has constituted parts of customary international law of the environment. But see F. Biermann, Saving the Atmosphere: International Law, Developing Countries and Air Pollution (1995) pp. 114-19.

69 UNEP/OzL.Pro.7/Bur.1/3, para. 22.

70 UNEP/OzL.Pro.7/Bur.1/3, para. 23.

71 R. Benedick, Ozone Diplomacy, (1998) p. 253.
} 
to allocate U.S. \$540 million dollars for the period of 1997-1999 with a view to assist Article 5 developing countries. ${ }^{72}$

Bilateral and regional cooperation with a low-volume-O.D.S.consuming state will be regarded as a contribution to the Multilateral Fund up to a certain percentage, ${ }^{73}$ provided that such cooperation (i) strictly relates to compliance with the provisions of the Ozone Protocol, (ii) provides additional resources, and (iii) meets agreed incremental costs. ${ }^{74}$ The amount representing the annual bilateral cooperation would be credited for the year designated by the non-Article 5 party as part of its contribution. 75 In its Seventh Meeting of 1995, the Executive Committee adopted guidelines for cost assessment of bilateral and regional activities. ${ }^{76}$ Furthermore, it is important that contributions may be received by those not party to the Montreal Protocol, and by other governmental, intergovernmental, non-governmental and other sources. ${ }^{77}$

It is decided that the parties to the Protocol will decide upon the programme budget of the Fund for each fiscal period and upon the percentage of contributions of individual contracting parties. In addition, resources under the Fund are to be disbursed with the concurrence of the beneficiary party. ${ }^{78}$

Finally, it is worth mentioning that, in order to clarify the nature and legal status of the Fund as a treaty body under international law, the 1993 Sixth Meeting of the Parties adopted Decision VI/16. 79 Decision VI/16 provides, for instance, that the Fund enjoys 'legal capacity as is necessary for the exercise of its functions and the protection of its interests, . . . to acquire and dispose of movable property and to institute legal proceedings in defence of its interests'. The M.L.F. and the Fund Secretariat enjoy

\footnotetext{
72 Decision VIII/4 in UNEP/OzL.Pro.8/12; 27/2 E.P.L. (1997) pp. 86-87. See also R. Benedick, Ozone Diplomacy, (1998) pp. 302-03.

73 Terms of Reference for the Multilateral Fund clarifies that such contributions would be counted up to a total of twenty per cent of the total contribution by that party as decided by the annual Ozone Meeting of the Parties.

74 Article 10(6).

75 UNEP/OzL.Pro/ExCom/5/16: Annex IV, para. 12.

76 See UNEP/OzL.Pro/ExCom/7/30, para. 82 and Annex IV.

77 Annex IX(8).

78 Article 10(7-8).

79 See UNEP/OzL.Pro.6/7, para. 103. Yet, Japan made reservation on this Decision.
} 
privileges and immunities in the host country, Canada (Decision $\mathrm{VI} / 16$ (b)). 80

B. The Role of the International Institutions in the Financial Mechanism

(1) The Executive Committee

As with the Implementation Committee of the N.C.P. régime, the Executive Committee is a newly established permanent internal treaty organ of the international ozone régime. 81 The Executive Committee is assigned to 'develop and monitor the implementation of specific operational policies, guidelines and administrative arrangements for the purpose of achieving the objectives of the Multilateral Fund'.82 The Executive Committee has carried out the following five functions: 83

(i) Review and approval of country programmes, project proposals and the work programmes of the implementing agencies:

(ii) Monitoring and evaluating the performance of the Implementing Agencies through a review of their work programmes and progress reports:

(iii) Development of policies, guidelines and administrative practices to facilitate and clarify the process:

(iv) Managing the fund process:

(v) Reporting to the Parties about its activities on a regular basis and providing a formal progress report to the Annual Meeting.

It is worth mentioning that the Executive Committee established at its Ninth Meeting a 'Sub-Committee on Financial Matters' to review and assess the existing financial arrangements and procedures, and recommend modifications, where appropriate. 84 The Executive Committee also established a sessional 'Project Review Sub-Committee'. 85

$80 \mathrm{~W}$. Lang notes that several questions remain to be solved - e.g., whether the Meeting of the Parties had a clear mandate to adopt such a decision: Does it constitute itself a 'valid source of international law?.W. Lang, 'Ozone Layer', 5 Y.bk.I.E.L. (1994) p. 163.

81 See Section III(B) above.

82 Article 10(5). See also Annex IX(5).

83 See UNEP/OzL.Pro/ExCom/10/40: Annex I, para. 27.

84 See further UNEP/OzL.Pro/ExCom/9/20, para. 32: Annex II.

85 UNEP/OzL.Pro/ExCom/11/36, para. 156.8: UNEP/OzL.Pro/ExCom/15/45, para. 173. As for the Terms of Reference for the Sub-Committee, see, UNEP/OzL.Pro/ExCom/15/45, para. 173. With regard to participation by N.G.Os., it 
Unlike the Implementation Committee, 86 the Executive Committee has its own Rules of Procedure. 87 The Rules are to apply mutatis mutandis to the proceedings of any meeting of the Executive Committee.

According to Rule 11, the Executive Committee will consist of both seven parties from a group of industrialising countries operating under Article 5(1) and seven parties from a group of industrially advanced countries not operating under that article. Article 5 countries have organised themselves into three regions (i.e. Asia, Africa and Latin America and the Caribbean), and the donor countries into six groups (i.e. the European Union, the United States, Japan, Canada, Australia and New Zealand, the Nordic and E.F.T.A. countries and the Russian Federation). 88 Each group selects its own members of the Executive Committee and they must be formally endorsed by the Ozone Meeting of the Parties. ${ }^{89}$ Nongovernmental organisations are allowed to participate in any meeting of the Executive Committee as observers. 90

With regard to the voting procedure, decisions of the Committee are to be taken by consensus whenever possible. However, in a case where all efforts at consensus have been exhausted and no agreement reached, the decisions shall be then taken by a two-thirds majority of the parties representing both a majority of low-volume-O.D.S.-consuming parties and a majority of industrialised state parties not operating under Article 5(1).91 This voting procedure based on a North-South harmonious balance is

say that 'Non-governmental organisations may nominate one representative to observe the meeting of the Sub-Committee but may not participate'.

86 See Chapter V(B.2.a) above.

87 'Rules of Procedure for Meetings of the Executive Committee for the Interim Multilateral Fund for the Implementation of the Montreal Protocol' in UNEP/OzL.Pro.3/11/Annex VI. The provisions of the Ozone Protocol prevails over the Rules of Procedure, however (Rule 20).

88 UNEP/OzL.Pro/ExCom/10/40: Annex I, para. 25.

89 The 1995 Ozone Meeting of the Parties endorsed the selection of seven industrised state parties - i.e., Australia, Austria, Denmark, Japan, the Russian Federation, the United Kingdom (Vice-Chairman), and the United States, and seven Article 5 developing countries - Chile, Colombia, India, Egypt, Kenya (Chairman), the Philippines, and Senegal (Decision VII/27).

90 Rules 6 \& 7. See also Section V(D) below. See also R. Benedick, Ozone Diplomacy, (1998) p. 223 (and endnote no. 3), noting that N.G.Os. supported by the U.S., Canada and the Netherlands appealed to the Third Meeting of the Parties to overrule a more restrictive proposal by the Executive Committee.

91 The Rules of Procedure of the Executive Committee, Rule 17. On the utility of double majority see P. Széll, 'Decision-Making under Multilateral Environmental Agreements', 26/5 E.P.L. (1996) p. 213. Unlike this Multilateral Fund procedures, decisions by the G.E.F. Council are made by consensus, and if these is a disagreement among members, then such decisions are to be taken based on a 'contribution-weighted voting procedure', but representing sixty per cent of the votes of all states. 
particularly significant since the voting strength of developing states in major international economic institutions such as the World Bank and the I.M.F. is still less than one-third of the total, at its maximum. At the 1992 Copenhagen Meeting several government representatives mentioned that the M.L.F. assumes a democratic character as reflected in its decisionmaking processes and a change in the structure of the Fund would be merely counterproductive. ${ }^{92}$ To date, however, as with decision-making on control measures of O.D.Ss., all fund decisions have been taken by consensus, and in practice, this two-third majority voting system has not been required yet.

However, the Executive Committee has encountered serious difficulties in achieving consensus particularly when a member state of the Committee has a 'direct interest' in a given M.L.F. project. ${ }^{93}$ It is also suggested that some problems arising from the structure of the Executive Committee in itself - i.e. the turnover of Committee members and the interdependency of the Implementing Agencies in policy issue resolution have often made some policy issues even much more complicated. ${ }^{94}$

Finally, the Executive Committee is assisted by the U.N.E.P. Fund Secretariat.

\section{(2) The Multilateral Fund Secretariat}

The Fund Secretariat of the Montreal Protocol, operating under the Chief Officer, is located in Montreal, Canada. ${ }^{95}$ It consists of nine professional staff and nine support staff, which is broadly representative of the parties with two staff members from Asia, two from Africa, one from North America, one from Latin America, and two from Europe. 96

The tasks of the Fund Secretariat can be divided into seven categories: 97

92 See UNEP/OzL.Pro.4/15, para. 42.

93 U.N.E.P., The Study on the Financial Mechanism of the Montreal Protocol (March 1995) para. 228.

94 U.N.E.P., The Study on the Financial Mechanism of the Montreal Protocol (March 1995) paras. 28 and 283.

95 The officials of the Multilateral Fund Secretariat enjoy privileges and immunities necessary for the independent exercise of their functions of the Fund (Decision $\mathrm{VI} / 16(\mathrm{~b}))$. The Executive Committee thus accepted the offer of Canada to cover any additional costs relative to costs associated with U.N.E.P. Headquarters. See, UNEP/OzL.Pro/ExCom/8/29 (Annex III, para. 3.3)).

96 UNEP/OzL.Pro/ExCom/10/40: Annex I, para. 5.

97 See further, UNEP/OzL.Pro/10/40: Annex I, para. 29. 
(i) Preparation and documentation for the meetings of the Executive Committee:

(ii) Policy analysis and review:

(iii) Analysis and review of programmes and fund activities:

(iv) Monitoring the activities of the Implementing Agencies:

(v) Communications and public relations:

(vi) Administrative support, coordination and liaison for the Executive Committee: and,

(vii) Financial management/monitoring of the Fund.

For example, the Fund Secretariat and the Implementing Agencies shall co-operate with parties to provide information on funding available for relevant projects to secure the necessary contacts and to co-ordinate projects financed from other sources with activities financed under the Montreal Protocol. 98 The Fund Secretariat shall also make the necessary arrangements for the meetings of the Committee and it also performs all other functions the Executive Committee requires. 99

More specifically, the Secretariat assesses and offers recommendations to the Executive Committee with regard to country programmes and work programmes developed by the Implementing Agencies. 100 It is pointed out that 'Although almost all projects brought before the ExCom [Executive Committee] are ultimately approved, many are withdrawn, postponed, or modified at the suggestion of the secretariat before they are brought forward'.101 Thus the Multilateral Fund Secretariat also assumes, to some extent, control over institutional oversight or supervisory mechanisms.

Finally, the Chief Officer is to submit to the Executive Committee semi-annual reports covering budget and financial issues, and it shall also report on activities, including those requiring actions by the Executive Committee. 102

98 Annex IX(22).

99 The Rules of Procedure of the Executive Committee, Rule 15.

100 See Section IV(D.1-2) below.

101 E. DeSombre and J. Kauffman, 'The Montreal Protocol Fund: Partial Success Story', in R. Keohane and M. Levy (eds.), Institutions for Environmental Aid, (1996) pp. 12021.

102 These tasks include, for example, the revision of current year's budget for the Secretariat and three year plan and budget for the Fund. See further UNEP/OzL.Pro.ExCom/12Inf.6, p. 13. 
(3) The Implementing Agencies

The Terms of Reference for the M.L.F. provide that, under the supervision of the Executive Committee (i) Implementing Agencies would be requested by the Committee - in the context of country programmes 103 - to co-operate with and assist the parties within their respective area of expertise, and (ii) they would also be invited by the Committee to develop an inter-agency agreement and specific agreements with the Executive Committee acting on behalf of the parties. 104

The Executive Committee signed agreements with the U.N.E.P., 105 the U.N.D.P., 106 the U.N.I.D.O. 107 and the World Bank, 108 respectively. These Implementing Agencies, which are not ad hoc treaty organisations but well established international institutions, are to consult with the Executive Committee in fulfilling their responsibilities regarding the M.L.F. ${ }^{109}$ For a reference, a share of the Implementing Agencies in 1996 is described in Table IV below.

It is stated that '[I]mplementing Agencies shall apply only those considerations relevant to effective and economically efficient programmes and projects which are consistent with any criteria adopted by the Parties'. 110 In identifying and selecting projects, the World Bank, the U.N.D.P. and the U.N.I.D.O. have heavily relied on the frequent use of workshops and the contracts made by international experts. ${ }^{111}$ In addition, it is pointed out that these Implementing Agencies are strongly influenced not only by firms in industrialising countries but also by the governments of Article 5 states. Not surprisingly, these Agencies properly regard these enterprises and Article 5 parties as their primary 'clients' -

\footnotetext{
103 See Section IV(D.2) below.

104 Annex IX(2).

105 UNEP/OzL.Pro/ExCom/5/Inf.4.

106 UNEP/OzL.Pro/ExCom/5/Inf.3.

107 UNEP/OzL.Pro/ExCom/18/29, Annex IV.

108 UNEP/OzL.Pro/ExCom/5/Inf.2.

109 Annex IX(6). Added to this, the heads of these agencies would meet at least once a year to report on their activities and consult on cooperative arrangements. See ibid.

110 Annex IX(3).

111 U.N.E.P., The Study on the Financial Mechanism of the Montreal Protocol (March 1995) para. 349.
} 
however, as the U.N.E.P.'s Study Team COWIconsult of Denmark ${ }^{112}$ says, it is possible that this would come to contradict the root idea that Implementing Agencies are invited to participate in the Multilateral Fund by/on behalf of the Executive Committee as a higher decision-making institution. ${ }^{113}$

Finally, the Implementing agencies are entitled to receive support costs for their activities, having reached specific agreements with the Executive Committee. 114

TABLE no. IV: The Implementing Agencies' Share in 1996115

\begin{tabular}{|c|c|c|}
\hline Agency & $\begin{array}{c}\text { Percentage of Total } \\
(\%)\end{array}$ & $\begin{array}{l}\text { Level of Funds for Invest- } \\
\text { ment Projects in } 1996\end{array}$ \\
\hline U.N.D.P. & 30 & U.S. \$29 million \\
\hline U.N.I.D.O. & 25 & U.S. \$24 million \\
\hline World Bank & 45 & U.S. \$44 million \\
\hline
\end{tabular}

(a) The World Bank

The International Bank for Reconstruction and Development ('I.B.R.D.' or, more commonly, the World Bank) 116 is to co-operate with and assist the Executive Committee in administering and managing the programme to finance the agreed incremental costs of Article 5 countries. ${ }^{117}$ Regional development banks are also encouraged to participate in this process 118

112 In accordance with Decision IV/18(II.4) by the Forth Meeting of the Parties, the Team with support from Goss Gilroy Inc. of Canada was contracted by the U.N.E.P. to review and evaluate the effectiveness of the Financial Mechanism.

113 U.N.E.P., The Study on the Financial Mechanism of the Montreal Protocol (March 1995) para. 307 et seq. As for the competition among the Implementing Agencies, see ibid., paras. 324-31.

114 Annex IX(7).

115 UNEP/OzL.Pro/WG.1/13/3, para. 18.

116 On the I.B.R.D. see generally D. W. Bowett, The Law of International Institutions, 4th edn. (1982) pp. 109-10. On the role of the World Bank in environmental protection see J. Werksman, 'Greening Bretton Woods' in P. Sands (ed.), Greening International Law, (1993) pp. 65-84; K. Horta, 'The World Bank and the International Monetary Fund' in J. Werksman (ed.), Greening International Institutions, (1996) pp. 131-47; K. Paddington, 'The Role of the World Bank' in A. Hurrell and B. Kingsbury (eds.), International Politics of the Environment, (1992) pp. 212-27.

117 Annex IX 4(c) and 16. The President of the World Bank is the Administer of this programme that operates under the authority of the Executive Committee. See, ibid.

118 Annex IX 4(d) and 17. 
and they are required to report as appropriate based on the nature of their activities. 119

The World Bank shall (i) report on activities relating to country programmes and on project proposals or groups of project proposals, including those which require the Executive Committee's approval, and (ii) prepare a final report on operations financed by the Multilateral Fund. 120 The World Bank deals principally with Article 5 industrialising countries that are large consumers/producers of O.D.Ss., such as India and China. ${ }^{121}$

It is interesting that each Implementing Agency including the Bank has taken a different approach to M.L.F. project implementation. In this respect, the World Bank has advanced a rather slow process that emphasises the importance of national execution through designated financial intermediaries and agents. The World Bank says that 'There is no single more important aspect of project implementation than the establishment of local capacity to deal with the implementation of M.P. [Montreal Protocol] and ODS phaseout activities'.122 Thus, under Bank projects, developing countries in themselves are ultimately responsible for M.L.F. project implementation.

It is suggested that a number of delays have been caused by various disagreements between Article 5 countries and the World Bank on the flow of funds mechanism and on taxation issues. 123 Nevertheless, it is still possible to argue that the national execution of the M.L.F. projects possesses the advantage of potentially promoting greater ownership of activities by the national government and of building national capacity for project development and implementation. 124

119 UNEP/OzL.Pro/ExCom/3/18/Rev.1: Annex III.

120 UNEP/OzL.Pro/ExCom/3/18/Rev.1: Annex III. As for World Bank project preparation, see e.g. UNEP/OzL.Pro/ExCom/10/40, Annex I, paras. 72-81.

121 See Section V(C) below.

122 The World Bank, 'Implementation Performance Review of Bank-Implemented Montreal Protocol Investment Operations, (December 1994) para. 8.

123 U.N.E.P., The Study on the Financial Mechanism of the Montreal Protocol (March 1995) para. 377.

124 U.N.E.P., The Study on the Financial Mechanism of the Montreal Protocol (March 1995) para. 37; Global Environment Coordination, National Execution: Montreal Protocol Ozone Investment Portfolio. 
(b) The United Nations Development Programme (U.N.D.P.)

The U.N.D.P. 125 is to co-operate with and assist the Executive Committee in feasibility and pre-investment studies and in other technical assistance measures. 126 The U.N.D.P. is to:

(i) report on the status of activities related to country programmes including the activities of field offices;

(ii) prepare periodic progress reports on projects;

(iii) prepare an annual report on income and expenditures of previous years; and

(iv) prepare a final report after completion and/or termination of each project. ${ }^{127}$

With regard to its approaches to project implementation under the M.L.F., the U.N.D.P. and the U.N.I.D.O., unlike the World Bank, have centralised project identification, development and procurement operations - i.e. a so-called centralised execution. These two Implementing Agencies thus avoid national execution systems the Bank has adopted.128 In other words, unlike the World Bank, the U.N.D.P. and the U.N.I.D.O. have played more direct roles in the process of M.L.F. project implementation. Consequently, Article 5 governments are in principle not involved except to endorse the implementation projects.

As for project preparation and execution, since the U.N.D.P. is a highly decentralised U.N. international institution and therefore has a number of local field offices, unlike the World Bank, it does not necessarily need financial intermediaries or local institutions. 129 It is pointed out that in many cases industrialising Article 5 states have preferred the U.N.D.P. (or the U.N.I.D.O.) to the World Bank on investment projects. ${ }^{130}$

125 See generally H. G. Schemers and N. M. Blokker, International Institutional Law, 3rd edn. (1995) p. $1084 \& 1143-27$.

126 Annex IX(4-b).

127 UNEP/OzL.Pro/ExCom/3/18/Rev.1/Annex III. As for U.N.D.P. procedures for project development/implementation, see e.g., UNEP/OzL.Pro/ExCom/10/40, paras. 6065 and its figure 2.

128 U.N.E.P., The Study on the Financial Mechanism of the Montreal Protocol (March 1995) paras. 38 and 322.

129 UNEP/OzL.Pro/ExCom/10/40, Annex II, para. 32.

130 E. DeSombre and J. Kauffman, 'The Montreal Protocol Fund: Partial Success Story', in R. Keohane (eds.), Institutions for Environmental Aid, (1996) p. 112. 
The U.N.D.P. assists possible clients only on their specific request, and it focuses on developing local human resources and institutional capabilities. ${ }^{131}$

Lastly, it must be added that the U.N.D.P. has established a 'Montreal Protocol Unit' (M.P.U.) that is responsible for programme development and technical project monitoring. 132 The Implementation of actual M.L.F. projects is, however, handled by one of the U.N.D.P. executing agencies, namely, the United Nations Office of Projects Services (75\%), ${ }^{133}$ or is directly executed by national governments $(25 \%) .134$

\section{(c) The United Nations Environment Programme (U.N.E.P.)}

As we have already seen, the U.N.E.P. and its technical experts, the Nairobibased Ozone Secretariat, have greatly contributed to the establishment and maintenance of the international legal ozone régime (see Chapters II(II.B) \& III(II) above).

The U.N.E.P. - as per its agreement between the Executive Committee of the interim M.L.F. - has been tasked with the following work: ${ }^{135}$

(i) Political promotion of the objectives of the Montreal Ozone Protocol;

(ii) Research and data-gathering, in accordance with the provisions of the Protocol; and

(iii) Clearing-house function comprising the following activities:

(a) assist developing countries through country-specific studies and other technical cooperation, to identify their needs for cooperation;

(b) facilitate technical cooperation to meet these identified needs;

131 UNEP/OzL.Pro/ExCom/10/40, Annex I, p. 38.

132 UNEP/OzL.Pro/ExCom/10/40, para. 60.

133 The United Nations Office for Projects Services (U.N.O.P.S.) - which is designed as an implementation organisation for and provider of services to all the U.N. organs - is actively involved in U.N.D.P.-implemented projects. The U.N.O.P.S. often subcontracted under the national execution modality. See U.N.O.P.S., 'Project Information (Environment): Montreal Protocol - Fighting Ozone Depletion' under <http://www.unops.org/5proin/5pi20011.html.

134 Ibid.

135 See UNEP/OzL.Pro/ExCom/10/40: Annex I, para. 83. The Paris-based Industry and Environment Programme Activity Centre, in particular, takes on these clearinghouse and promotional activities. 
(c) collect and disseminate information and relevant materials, hold workshops and training sessions and other related activities for the benefit of developing country parties;

(d) facilitate and monitor other multilateral regional/bilateral cooperation available to developing countries.

In addition, the U.N.E.P., on the invitation of the Executive Committee, also acts as Treasure for the Fund. The U.N.E.P. states that no additional charge would be required for operating as Treasurer of the Fund and that all associated costs would be covered by its overhead charge assessed against the funds it receives in its role as one of the implementing agencies. 136

As to implementation 'philosophy', the U.N.E.P. follows a bottom-up approach in identifying needs and in devising its programmes, and it utilises the T.E.A.P. and its T.O.Cs. (Technical Options Committees), existing industry and government networks in both Article 5 and non-Article 5 countries. ${ }^{137}$

(d) The United Nations Industrial Development Organisation (U.N.I.D.O.)

The Executive Committee invites the U.N.I.D.O. 138 to co-operate and assist in project development and implementation comprising pre-investment studies and other technical assistance matters. ${ }^{139}$

U.N.I.D.O. as an Implementing Agency of the M.L.F. - which deploys technology experts to provide concrete technology assistance to Article 5 developing states - believes that the institution is 'best equipped' to work on smaller projects. ${ }^{140}$ The U.N.I.D.O.'s programme consists of nearly 260 projects in 58 countries with a total value of U.S.\$ 111 million. ${ }^{141}$

136 UNEP/OzL.Pro/ExCom/1/2, para. 13.

137 U.N.E.P., The Study on the Financial Mechanism of the Montreal Protocol, (March 1995) paras. 322 and 374.

138 On the U.N.I.D.O. see generally N. D. White, The Law of International Organisations, (1996) p. 152.

139 UNEP/OzL.Pro/ExCom/8/29, Annex IV. On U.N.I.D.O.'s project cycle, see e.g. UNEP/OzL.Pro/ExCom/10/40, paras. 66-70 and its figure 3 .

140 UNEP/OzL.Pro/ExCom/10/40, Annex I, p. 40.

141 UNEP/OzL.Pro.9/12, para. 34. 
The G.E.F., which is a World Bank financial mechanism, was originally established in 1990 in order to help developing countries meet 'agreed incremental costs' of activities on the protection of the global environment in four major areas, namely, (i) global warming, (ii) pollution of international waters, (iii) destruction of biodiversity, and (iv) the depletion of the stratospheric ozone layer. ${ }^{142}$ In 1994 the G.E.F. was restructured and replenished with over U.S.\$ 2 billion ('G.E.F. II'), and presently 156 countries participate in the financial mechanism. The G.E.F. is jointly implemented by the U.N.D.P., the U.N.E.P. and the World Bank as Implementing Agencies under the G.E.F. In addition, the 'functionally independent' G.E.F. Secretariat reports to and services the Council and Assembly of the G.E.F. As with the case of the Multilateral Fund, participating developing countries are not presently required to contribute to the G.E.F. funding.

The essential difference between the G.E.F. and the Financial Mechanism of the Montreal Protocol is that the G.E.F. utilises the Ozone Project Trust Fund ('O.T.F.') administered by the World Bank. ${ }^{143}$ The relationship between the Multilateral Fund of the Ozone Protocol and the O.T.F. is this concise administrative procedure; once projects are approved by the Executive Committee, the U.N.E.P. then transfers funds from the Multilateral Fund to the O.T.F. of the World Bank. ${ }^{144}$

14230 I.L.M. (1991) p. 1735; 33 I.L.M. (1994) p. 1273, reprinted in P. W. Birnie and A. E. Boyle, Basic Documents on International Law and the Environment (1995) p. 666. On the G.E.F. see among others J. Werksman, 'Consolidating Governance of the Global Commons: Insights from the Global Environmental Facility', 6 Y.bk.I.E.L. (1995) pp. 27-63; H. Sjoberg, 'The Global Environmental Facility' in J. Werksman (ed.), Greening International Institutions, (1996) pp. 148-62; L. Boisson de Chazournes, 'Le fonds por l'environnment mondial: recherche et conquéte de son identité' in 13 A.F.D.I. (1995) pp. 612-32. However, currently activities on land degradation and deforestation are also eligible for funding.

143 The World Bank, 'Establishment of the Global Environment Facility', (April 1991), Annex D and Supplement. Yet the G.E.F. bears several similarities with the Financial Mechanism of the Montreal Protocol - See U.N.E.P., The Study of the Financial Mechanism of the Montreal Protocol, (March 1995), Section 7.9.2.

144 On the relationship between the G.E.F. and the 1992 Climate Change Convention and the 1992 Biodiversity Convention, see e.g., L. Boisson de Chazournes, 'Le fonds pour l'environnement mondial: recherche et conquéte de son identité', 13 A.F.D.I. (1995) p. 15 et seq. 
Furthermore, it is important to note that financial assistance under the G.E.F. would be limited to those state parties to the Montreal Protocol that had ratified the 1990 London Amendment. ${ }^{145}$

Since the establishment of the Montreal Multilateral Fund, the subsidiary role of G.E.F. within the ozone régime is largely limited to middle-income countries and the C.E.I.Ts. - including the Russian Federation - that are ineligible for the Montreal Protocol Multilateral Fund. 146

To take a plain example, a G.E.F.-funded project, which is the first G.E.F. funding operation for O.D.Ss. phaseout in Russia, was structured as a framework project for a total of G.E.F. grant amount of U.S. $\$ 60$ million. It consists of (i) an investment component to finance twenty-one subprojects for O.D.Ss. phaseout in the aerosol and refrigeration sectors, (ii) a technical assistance component to strengthen project implementation and institutional capacity, and (iii) a sub-grant processing component. ${ }^{147}$ Recently the G.E.F. Council has approved O.D.Ss. phase-out projects worth \$43. 6. million for the Russian Federation. ${ }^{148}$

In comparison to the 'Montreal model' of the Financial Mechanism, the Study Team of the T.E.A.P. says that the G.E.F. has been more effective than the Financial Mechanism of the Protocol in linking G.E.F. resources not only to those of the regular programmes of the Implementing Agencies, but also to those of bilateral development agencies, N.G.Os., national governments and the private sector. ${ }^{149}$

\section{Strategies: Work Programmes, Country Programmes and Institutional Strengthening}

For effective and efficient implementation of M.L.F. projects designed to phase out C.F.Cs. and other O.D.Ss., régime members in the Montreal Protocol's Financial Mechanism - including Article 5 developing countries,

145 UNEP/OzL.Pro.7/12, para. 51.

146 For a definition of the C.E.I.Ts., see Chapter V(VII.B) above. For an analysis of O.D.Ss. projects in the C.E.I.T., see e.g. The World Bank, Bulgaria: ODSs Phaseout Project, (October 1995); idem, Czech Republic: Technical Support and Investment Project for the Phaseout of ODSs, (August 1994); idem, Poland: ODSs Phaseout Project, (February 1997).

147 See further The World Bank, Russian Federation: Ozone Depleting Substance Consumption Phase-out Project [Project Document], (May 1996).

148 UNEP/OzL.Pro.8/2, para. 16; Chapter IV(7.B) above.

149 See U.N.E.P., Study of the Financial Mechanism of the Montreal Protocol, (March 1995) paras. 659-60. 
developed state governments and four specialised international institutions - make use of the following three key concepts, i.e. (i) work programmes, (ii) country programmes, and (iii) institutional strengthening for project implementation.

\section{(1) Work Programmes}

The Executive Committee has invited the Implementing Agencies and other appropriate agencies, depending on their technical expertise, to develop work programmes in cooperation with potential recipient countries. 150

It is decided that the work programmes should specify, for example, types of activities and projects on which agreement has been reached between the Implementing Agency and the concerned party, and types of activities and projects which must be defined to allow the Executive Committee to review and monitor these Fund activities. ${ }^{151}$ In developing these work programmes, there should be effective, result-oriented coordination among the operational units of all the Implementing Agencies. ${ }^{152}$ Work programmes are to be approved by the Executive Committee on an annual basis and reviewed semi-annually - approval of work programmes should be based on project eligibility criteria. 153

Each Implementing Agency is responsible for implementation and supervision of projects within its work programmes. ${ }^{154}$ For instance, the U.N.E.P.'s work programmes currently cover (i) information clearinghouse, (ii) training, and (iii) workshops, networking and country programmes for low-volume-O.D.Ss. consuming countries. ${ }^{155}$ These activities are designed to contribute largely to capacity building in Article 5 industrialising countries.

\section{(2) Country Programmes}

The Executive Committee has invited each Article 5 industrialising country, wishing to receive support from the Multilateral Fund, to develop a country

\footnotetext{
150 UNEP/OzL.Pro/ExCom/3/18/Rev.1: Annex III, Section II.2.1.

151 See further UNEP/OzL.Pro/ExCom/3/18/Rev.1: Annex III, section II.2.2.

152 UNEP/OzL.Pro/ExCom/3/18/Rev.1, para. 66.

153 UNEP/OzL.Pro/ExCom/3/18/Rev.1: Annex III, Section II.2.3.

154 UNEP/OzL.Pro/ExCom/3/18/Rev.1: Annex III, Section II.2.5.

155 UNEP/OzL.Pro/ExCom/10/40, para. 83.
} 
programme and projects, in accordance with paragraph $10(\mathrm{~g})$ of the Terms of Reference of the Committee. 156

Country programmes can be prepared by the countries in themselves, or in cooperation with an Implementing Agency or through bilateral cooperation. 157 In principle, the country programme is a prerequisite for investment support from the Multilateral Fund, though the Executive Committee often allows exceptions. ${ }^{158}$ In addition, it provides a government and Implementing Agencies with a strategic plan for phasing out O.D.Ss. based on an assessment of the country's O.D.Ss. consumption and production patterns, identification of priority investment projects, and so forth. 159 The Study Team points out that the sense of government ownership of the country programme is an important contributing factor in the effectiveness of the country programme related assistance. 160

The Executive Committee decided that country programmes should be viewed as flexible instruments which set out the framework for that country's actions to meet the requirements of the Montreal Ozone Protocol.161 The Executive Committee requested governments to present annually to the Executive Committee information on progress being made in the implementation of country programmes, in accordance with the decision of the Executive Committee on implementation of country programmes. ${ }^{162}$

\section{(3) Institutional Strengthening for Project Implementation}

Support for institutional strengthening within a developing country, which formulates one of the basic concepts of capacity building, ${ }^{163}$ would often be an essential element in achieving the objectives of the Montreal Protocol régime and of the M.L.F. This is particularly true at the stage when an Article 5 country has just become a party to the Protocol; in this initial phase the stakeholders and the general public have to be aware of a

156 UNEP/OzL.Pro/ExCom/3/18/Rev.1: Annex III, Section II. 1.1.

157 UNEP/OzL.Pro/ExCom/10/40, para. 12.

158 U.N.E.P., Study on the Financial Mechanism of the Montreal Protocol, (March 1995) para. 484.

159 Ibid. See also R. Benedick, Ozone Diplomacy, (1998) p. 256.

160 Ibid., paras $488-91$ and 59 et seq..

161 UNEP/OzL.Pro/ExCom/5/16, para. 28a.

162 UNEP/OzL.Pro/ExCom/17/60, Decision 17/34 (para. 57).

163 See Section I above. 
number of fundamental ozone-related issues. ${ }^{164}$ In this regard, the socalled 'national ozone units' that are 'local counterparts' to the Protocol's institutions have been established in more than seventy developing countries. 165

It might be surprising, however, that issues on institutional capacity building were not originally included in the Indicative List of Incremental Cost Categories. It was in its 1992 Seventh Meeting that the Executive Committee decided to allocate limited funding for institutional strengthening related activities and assistance, in accordance with their own merits, i.e. on case-by-case basis. ${ }^{166}$ Yet, it is said that a number of non-Article 5 countries regard this kind of expenditure as an 'overhead element', which will increase the administrative cost of the operation of the Fund. 167

The main objective of institutional strengthening is to provide necessary resources to an eligible country to enable it to strengthen an institutional mechanism within the Article 5 country to facilitate expeditious implementation of projects for phase-out of C.F.Cs. and O.D.Ss. as well as to ensure effective liaison between the country on the one hand, and the Committee, the Fund Secretariat and Implementing Agencies on the other. 168

The concrete elements of institutional strengthening would include (i) office equipment, (ii) personnel cost and (iii) operational cost (e.g., costs of post/telecommunication, stationery, maintenance of equipment and creation of awareness). 169 Until December 1995 a total of only about U.S.\$10 million had been approved for sixty-one countries for institutional capacity building, including country programmes and workshops to enhance data reporting capabilities of developing countries. ${ }^{170}$ The U.N.E.P.'s Study Team has thus pointed out that shifting more emphasis on

164 UNEP/OzL.Pro/ExCom/5/16, para. 28d; UNEP/OzL.Pro/ExCom/19/52, para. 36

165 R. Benedick, Ozone Diplomacy, (1998) p. 255.

166 U.N.E.P., The Study on the Financial Mechanism of the Montreal Protocol (March 1995) para. 62.

167 U.N.E.P., The Study on the Financial Mechanism of the Montreal Protocol (March 1995) para. 74.

168 UNEP/OzL.Pro/ExCom/7/30, para. 74.2.

169 UNEP/OzL.Pro/ExCom/19/52, para. 6.

170 UNEP/OzL.Pro/ExCom/19/52, para. 9. For details of activities of the Implementing Agencies in assisting data reporting, see e.g., UNEP/OzL.Pro/ImCom/8/3, Section III; UNEP/OzL.Pro/ImCom/14/4, Section V; Chapter V(VII.A.1) above. 
institutional strengthening would lead not only to a faster project implementation but also to overall O.D.Ss. phase-out. ${ }^{171}$

(4) The Conditionality between the M.L.F. Funding and Compliance with the Protocol

It seems that the relationship between the M.L.F. funding and compliance with the Protocol's requirements is gradually strengthened. Just like Article 4 trade restrictions considered in Chapter IV, loss of the M.L.F. funding can be also regarded as a certain 'stick' within the ozone régime (see Chapter I(III.B) above). Yet, as far as is known, the Executive Committee has never formally brought non-compliance problems about Fund operations to the meetings of the Implementation Committee of the N.C.P. régime. ${ }^{172}$ In addition, Fund-related Decisions by the Executive Committee (and the Meeting of the Parties) have been monitored almost entirely by the Executive Committee and the Multilateral Fund Secretariat. As D. C. Victor noted, 'the link between the M.L.F. and the Non-Compliance Procedure remains surprisingly weak'. 173

As described in Chapter V(VII.A.1) above, in the case of Mauritania, the Implementation Committee of the N.C.P. decided to create conditionality between the M.L.F. funding and the supply of baseline data. ${ }^{174}$ In this regard the Meeting of the Parties adopted Decision VI/5, saying that an Article 5 developing country would lose its status 'if it does not report baseyear data as required by the Protocol within one year of the approval of its country programme and its institutional strengthening by the Executive Committee'. In addition, the G.E.F. has made funding of ozone-related projects in the C.E.I.T. parties conditional on compliance with the Montreal Protocol and its 1990 London Amendment. The World Bank requires recipient countries to be members of and in compliance with all relevant environmental agreements. ${ }^{175}$

171 U.N.E.P., The Study on the Financial Mechanism of the Montreal Protocol (March 1995) para. 58.

172 On the legal status of contributions to the Fund see Chapter V(III.A) above.

173 D. C. Victor, The Early Operation and Effectiveness of the Montreal Protocol's Non-Compliance Procedure, (1996), p. $17 \&$ p. 24. On the legal status of contributions to the Fund see Chapter V(III.A) above.

174 On the international base level see Chapter III(III.B.2) above.

175 D. C. Victor, Early Operation of the Montreal Protocol's Non-Compliance Procedure, (1996) p. 25. 
As noted in Chapter III above, by using the international financial aid, Article 5 countries given a grace period 176 could potentially build industrial plants capable of producing or using C.F.Cs. other destructive chemicals (e.g. India). It is pointed out that Indian firms are selling C.F.Cs. to the Middle East. ${ }^{177}$ In this context, the Executive Committee decided in 1995 that it would prohibit any grants for India's conversion of factories that had installed O.D.S. capacity after July 1995.178

\section{SPECIAL CONSIDERATIONS FOR THE INTERNATIONAL TRANSFER OF OZONE-FRIENDLY TECHNOLOGY}

We shall now confine our attention exclusively to the international technology transfer under the ozone layer régime.

\section{A. International Technology Transfer}

To begin with, the term technology transfer 179 is defined in U.N.C.T.A.D.'s 'Draft International Code of Conduct on the Transfer of Technology' as the transfer of systematic knowledge for 'the manufacture of a product, for the application of a process or for the rendering of a service and does not extend to the transactions involving merely the sale or mere lease of goods'. ${ }^{180}$ Although technology covered by patent has territorial protection, it is possible that environmentally-friendly technology can be transferred to third parties - or developing countries in the present case through the transfer of the property rights on the technology, or by the granting of a user's licence.

176 See Chapter III(III.E) above.

177 'Holed Up: Chemicals Production/Controlling CFCs', 337 The Economist, (9 December 1995) p. 690.

178 Biermann, Financing Environmental Policies, pp. 44-45 cited in R. Benedick, Ozone Diplomacy, (1998), p. 258. On M.L.F. projects in India see The World Bank, Ozone Projects Trust Fund Grant: Technical Support and Investment Project (ODS Phaseout 1), (July 1994); idem, Ozone Projects Trust Grant: Phaseout of Ozone Depleting Substances (ODS Phaseout II), (February 1995).

179 On technology transfer in international environmental law see also Section I(B) above.

180 See TD/CODE TOT/41. In addition, The United Nations General Assembly Resolution 36/192 adopted in 1981 states that: 'The General Assembly [recognise] that environmental deficiencies generated by the conditions of under-development pose grave problems and can best be remedied by accelerated development through the transfer of substantial quantities of financial and technical assistance'. 
More recently, according to Chapter 34 of Agenda 21, environmentally sound technology is defined as being 'less polluting, using all resources in a more sustainable manner, recycling more of their wastes and products, and handling residual wastes in a more acceptable manner than the technologies for which they were substitutes'.181 In regard to this point, it is also important that Agenda 21 emphasises that environmentally sound technologies are 'total systems which include know-how, procedures, goods and services, and equipment as well as organisational and managerial procedures'.182

Furthermore, Principle 9 of the Rio Declaration states that:

'States should cooperate to strengthen endogenous capacity-building for sustainable development by improving scientific understanding through exchanges of scientific and technological knowledge, and by enhancing the development, adaptation, diffusion and transfer of technologies, including new and innovative technologies'. ${ }^{183}$

\section{B. The International Technology Transfer of O.D.Ss. Reduction}

It may be said that the cost of ozone-friendly technology will be particularly expensive since it would require new or additional foreign investment, additional supervision, re-training of personnel, and so forth. ${ }^{184}$

Article 5 industrialising countries that need technology transfer of O.D.Ss. can be generally divided into three categories, that is, (i) importers of O.D.Ss.- related products and components (most of newly industrialising states belong to this category); (ii) users of O.D.Ss. in the manufacturing process (e.g. Egypt, Tunisia, Turkey and Taiwan); and (iii) 'self-sufficient' producers/users of O.D.Ss. (e.g. Argentina, Brazil, China, India, Indonesia, Korea, Mexico and Venezuela). ${ }^{185}$ It is clear that the last category of developing countries is not necessarily affected by Article 4 trade restrictions under the Protocol, and therefore, they persistently demanded

\footnotetext{
181 Para, 34.1. See also para. 34.2.

182 Para. 34.3.

183 See also Chapter 34 of Agenda 21, para. 34.18 esp.

184 See e.g. UNEP/WG.78/6.

$185 \mathrm{~K}$. Hope, 'International Trade and International Technology to Eliminate ODSs', I.E.A., (1996) p. 36.
} 
the establishment of new financial mechanisms and funding additional to existing bilateral or multilateral aid programmes. 186

The international transfer of technology, which is necessary to enable developing countries in their compliance with the Montreal Protocol, involves, inter alia: (i) identification of needs, (ii) acquisition of patents, (iii) acquisition of designs, (iii) adaptation of technology for local assimilation, (iv) identification and procurement of appropriate equipment and materials, (v) training of personnel, and (vi) technical assistance. 187 In the light of these lists, it must be emphasised that, as Chapter 34 of Agenda 21 states, 'Environmentally sound technologies are not just individual technologies, but total systems which include know-how, procedures, goods and services, and equipments as well as organisational and material procedures'.

New Article 10A of the Montreal Protocol as amended in 1990 now requires state parties to take every practicable step, consistent with the programmes supported by the financial mechanism to ensure the transfer of the best available, environmentally safe substitutes and related technologies under fair and most favourable conditions. Not only developed country parties but also the C.E.I.Ts. currently assume the obligation of providing technology transfer to Article 5 developing countries. ${ }^{188}$ Yet, it is obvious that, in the light of the Protocol text itself and its travaux préparatories, parties to the Protocol are not required to compel their industries to transfer relevant technology under any circumstances - for instance, industrialised state parties would not be obliged to export environmentally sound technology of O.D.Ss. to developing countries that do not provide 'adequate' intellectual property protection. ${ }^{189}$ This is in line with the T.R.I.Ps. Agreement that requires member states to respect the principle of the M.F.N. and of national treatment, and to provide other intellectual-property-related protections. 190

However, it is still true that some other information would be obtained through academic and government exchanges, scientific

186 See Section II(B) above.

187 UNEP/OzL.Pro/ExCom/18/63, para. 9.

188 In this respect, under the 1992 Climate Change Convention régimes the C.E.I.T. do not have such a legal obligation to transfer environmentally sound technology.

189 See U.N.E.P. The Use of Trade Measures in Selected Multilateral Environmental Agreements, (1995) p. 86.

190 On the T.R.I.Ps. see Chapter IV(III.B) above. 
publications and international (economic) institutions, including various technical organisations. ${ }^{191}$

\section{THE OPERATION OF THE FINANCIAL MECHANISM OF THE MONTREAL OZONE PROTOCOL REGIME}

\section{A. The Effectiveness of the Montreal Multilateral Fund}

The Montreal Protocol's Multilateral Fund began its operations in January 1991. Since then, 781 projects have been approved for 79 Article 5 countries; these include (i) investment projects (275) and (ii) project preparation activities (147) followed by technical assistance (120), (iii) country programmes (89), (iv) training (85), (v) institutional strengthening (49), and (vi) demonstration projects. 192 Major recipient countries include China (U.S.\$95 million: see section B below), Egypt and Argentina (U.S.\$27 million), Brazil, India, Mexico, Malaysia, Thailand and so on.

A quick but objective judgement of the effectiveness of the Financial Mechanism of the Montreal Protocol and its Multilateral Fund would depend on the global phase-out of O.D.Ss., i.e. the amounts of controlled O.D.Ss. phased out and the international transfer of environmentally sound technologies of O.D.S. emission reductions.

However, it should not be forgotten that the M.F.L. is only one of the important factors that will affect O.D.S. phase-out processes in Article 5 developing countries. Among others are, for example, existing international market forces, 193 issues of illegal foreign trade in O.D.Ss., ${ }^{194}$ the grace period given to Article 5 developing countries in the Third World, 195 the effectiveness of the Montreal N.C.P. régime, political, economic and social factors at national level, 196 and so forth.

191 See e.g. E/CN.17/1993/10, Section II; Section IV(2). below.

192 U.N.E.P., Study on the Financial Mechanism of the Montreal Protocol (March 1995) para. 20. As of February 1997 the Fund had approved 1,200 projects.

193 See R. Benedick, Ozone Diplomacy, (1998) pp. 266-67, noting that some members of industries in developing countries consider that the M.L.F. as a new bureaucratic mechanism may be of doubtful utility.

194 See Part A of Chapter III(IV.F) \& Chapter V(VII.A.2) above.

195 See Part A of Chapter III(III.E) above. For example, ten Article 5 countries namely, China, India, Mexico, Thailand, Yugoslavia, Brazil, Indonesia, Saudi Arabia, Malaysia and Argentina - account for an unconstrained consumption of approximately 150,000 O.D.P. tonnes, which is over seventy per cent of total estimated ODS 
(1) The Phase-out of Controlled O.D.Ss.

In early 1995 the U.N.E.P.'s Study Team suggested that since 1990 an estimated 3,000 O.D.P. 197 weighted tons of O.D.Ss. had been eliminated on a yearly basis through Fund-supported implementation projects - however, if approved projects have been carried out without delay, an estimated 2,500 O.D.P. tonnes could have been phased out. ${ }^{198}$ In practice, until the middle of 1995, only 5,349 tons of controlled O.D.Ss. had been phased out - which is, therefore, less than one-third of O.D.Ss. consumption in Article 5 developing countries. ${ }^{199}$

During 1995 in particular, the Executive Committee approved U.S.\$211 million worth of projects, 511 individual projects/activities, including 289 investment projects. 200 In 1994/1995 the Multilateral Fund had thus achieved a total O.D.Ss. elimination of approximately 15,000 tonnes, which is approximately equal to the annual consumption of Article 5 developing countries. 201 The Executive Committee reported that since the commencement of the M.L.F. a total of 12,611 O.D.P. tonnes had been phased out.202 It was further reported at the Bureau of the 1995 Vienna Meeting that projects implemented would result in the phase-out of 66,000 O.D.P.weighted tonnes of O.D.Ss. 203

The considerable delays in implementation of M.L.F. projects, already described above, are due mainly to the complexity of the administrative process of the Financial Mechanism and the Fund, i.e. (i) long delays from project approval to actual implementation start-up, which is caused by ineffective procedures within implementing agencies, and (ii) lack of effective implementation of projects designed for national execution. 204

consumption in Article 5 countries. See U.N.E.P., The Study on the Financial Mechanism of the Montreal Protocol (March 1995) para. 796.

196 Obviously, India lacks the will to realise the Montreal Protocol's stated purposes. See R. Benedick, Ozone Diplomacy, (1998) pp. 248-51.

197 On O.D.Ps. see Chapter III(III.B.3) above.

198 U.N.E.P., Study on the Financial Mechanism of the Montreal Protocol (March 1995) paras. 16 and 17.

199 UNEP/OzL.Pro/ExCom/17/9.

200 UNEP/OzL.Pro.7/12, para. 46.

201 UNEP/OzL.Pro/WG.1/13/3, para. 8.

202 UNEP/OzL.Pro.8/12, para. 79.

203 UNEP/OzL.Pro.7/Bur.1/3, para. 22.

204 U.N.E.P., Study on the Financial Mechanism of the Montreal Protocol (March 1995) para. 17. 
In accordance with Decision VII/22, the 1995 Vienna Meeting decided that the '21 Actions' set out in Annex V of its report should be taken to improve the functioning of the Financial Mechanism of the Montreal Protocol. On the second point in particular, as we have already seen, the Executive Committee have carefully invested money on the matter of institutional strengthening for Article 5 developing country parties.

As regards monitoring, reporting and supervision of projects completed, the M.L.F. does not presently have monitoring guidelines for reviewing implementation projects, including post-project technical and safety monitoring and evaluation. 205 However, based on Decisions of the Executive Committee, a consultant group, 'Universalia', has prepared several reports on a monitoring and evaluation system for the M.L.F.206

(2) The Transfer of Technology of O.D.Ss.

For example, the U.N.E.P.'s Study Team reported that it verified no evidence of serious impediments in the international technology transfer supported by the Fund or of systematic bias and inappropriate advice on technology choice, though some enterprises located in Article 5 countries suggested that licence fees for technology transfer are high and that production licences for alternative substances are in reality difficult to obtain. 207 Yet, the Study Team says that the major current impediment to the international technology transfer is the slow pace of M.L.F. project implementation. 208

It is interesting to note here that in the Meeting of the W.T.O. Trade and Environment Committee, 209 India argued that although developing countries adhered to the international consensus to phase out certain environmentally injurious substances under M.E.As., 'substitute technologies were not transferred by multilateral enterprises on "fair and most favourable terms", as required in Article 16 of the Biodiversity

205 See U.N.E.P., The Study of the Financial Mechanism of the Montreal Protocol (march 1995) paras. 427-32; E. DeSombre and J. Kauffman, 'The Montreal Protocol Multilateral Fund: Partial Success Story', in R. Keohane (eds.), Institutions for Environmental Aid (1996) p. 123.

206 See 'Monitoring and Evaluation System for the Multilateral Fund (revised draft), UNEP/OzL.Pro/ExCom/21/30.

207 U.N.E.P., The Study on the Financial Mechanism of the Montreal Protocol (March 1995) paras. 54, 106 and 551. See also UNEP/OzL.Pro/ExCom/18/63, para. 13. But see e.g. UNEP/OzL.Pro.7/12, para. 79.

208 U.N.E.P., The Study on the Financial Mechanism of the Montreal Protocol, (March 1995) para. 107.

209 On the W.T.O.'s C.T.E. see Chapter IV(I.B) above. 
Convention and Article 10A of the Montreal Protocol'.210 India further suggested that certain projects were not being cleared under the Financial Mechanism of the Montreal Protocol due to their very high costs. 211

The Industry Cooperative for Ozone Layer Protection ('I.C.O.L.P.'), 212 which is a quasi-N.G.O. comprised of ten M.N.Cs. and twenty-two affiliate members, 213 provides non-C.F.Cs. technologies and information on C.F.Cs. alternatives to both developing and developed countries. The members of the I.C.O.L.P. have worked in sixteen countries, including China, India, Korea, Russia and Vietnam, and they now provide firms in industrialising states with technical assistance and information needed to achieve the gradual transition to ozone-friendly technology.

In 1993 the I.C.O.L.P. joined an implementation project with the World Bank to oversee technology cooperation projects to phase out O.D.Ss. in seven Article 5 countries, including China, India and Mexico. The goals of the I.C.O.L.P./World Bank Global Solvents Phaseout Project were to increase awareness of ozone depletion and O.D.S. use, introduce companies to O.D.Ss.-free environmental technology, and assist companies in their phase-out efforts by helping them access funds through the M.L.F.214 In addition, the I.C.O.L.P. received in 1994 a $\$ 150,000$ grant from the U.S. Environment Protection Agency to begin a technology cooperation project in the Russian Federation. 215

\section{B. Case Study: The People's Republic of China}

We shall now look more carefully into the operation of implementation projects under the Multilateral Fund, focusing specifically on one Article 5

\footnotetext{
210 PRESS/TEOO9 (1 May 1996).

211 Ibid. But see R. Benedick, Ozone Diplomacy, (1998) pp. 247-48, noting that such a view is 'more negotiating rhetoric than reality'.

212 The I.C.O.L.P. was formerly known as the International Cooperative for Ozone Layer Protection, which was established in 1989 to achieve the cost effective phaseout of ozone-depleting solvents.

213 The corporate members include, for example, AT\&T, British Aerospace Defence, Ford Motor Company, and four Japanese companies such as Toshiba Corporation. The U.N.E.P. (U.N.E.P./IE-France) participates in the I.C.O.L.P. as a affiliate. See I.C.E.L., The International Cooperative for Ozone Layer Protection 1990-1995: New Spirit of Industry and Government Cooperation, Appendix I.
}

214 See ibid., p. 20.

215 Ibid., p. 20. 
developing country, the People's Republic of China. It is said that China's participation in the M.L.F. demonstrated 'reasonableness and flexibility. 216

China is the largest consumer and producer of O.D.Ss. among Article 5 developing countries. In 1991 China's consumption of O.D.Ss. was approximately 50,000 tons and its production was about 30,000 tons. China's consumption, in particular, has been increasing at an average rate of eleven per cent every year - it is surprising that, if not controlled under the ozone régime, by 2010 it would eventually amount to 250,000 tons. Yet, unlike India, China is 'one of the most co-operative and conscientious parties to the Protocol' and it has currently reduced its use of O.D.Ss. 217

The Chinese government ratified the 1987 version of Montreal Protocol in June 1991 and the state - as an Article 5 country - is now eligible for M.L.F. funding.

Under the Multilateral Fund, as at November 1995, 155 projects have been implemented exclusively for China, and it is estimated that 31,000 O.D.P. tons of O.D.Ss. would be eliminated $(1,700$ tons have already been phased out). 218 Out of these 155 projects, two main Implementing Agencies under the current Fund Mechanism, i.e. the World Bank and the U.N.D.P., deal with about sixty projects, respectively. 219 As a bilateral contributor, the United States in particular launched about ten projects for O.D.Ss. phase-out in China.

An O.D.Ss. Country Programme for China, which would last fifteen years, was prepared by the Chinese government, the U.N.D.P. and the World Bank, and it was then approved in March 1993 by the Executive Committee. 220 The Country Programme 'aims to cap and then reduce O.D.S. consumption while introducing O.D.S. replacement technologies through a strong regulatory framework', and it also includes 'policy, strategy, costs and an action plan to achieve O.D.S. phaseout'.221

216 R. Benedick, Ozone Diplomacy, (1998) p. 265. See also 'Presentation of Tokens of Appreciation by the Government of China' in UNEP/OzL.Pro.9/12, para. 16.

217 Ibid., p. 264. China publicly announced that the country would reduce the 1996 C.F.C. production/consumption by 50 per cent by the end of 2000 . See W. Xi, 'Country Reports: China', 7 Y.bk.I.E.L. (1996) p. 333.

218 See also W. Xi, 'Country Report: China', 6 Y.bk.I.E.L. (1995) P. 488.

219 See U.N.E.P., Multilateral Fund for the Implementation of the Montreal Protocol: Inventory of Approved Projects (As at November 1995), pp. 104-44. 94,557,338 U.S. dollars are allocated for these 155 projects.

220 The World Bank, Ozone Projects Trust Fund Grant (ODS Phaseout III) (June 1995) para. 3.

221 The World Bank, China: Ozone Projects Trust Fund Grant (ODS Phaseout III) (June 1995), paras. 3 and 5, and its Annex I. 
The World Bank approved the First Montreal Protocol O.D.Ss. Phaseout Project ('O.D.Ss. I') 222 in October 1993, the Second O.D.Ss. Phaseout Project ('O.D.Ss. II') 223 in May 1994, and the Third O.D.Ss. Phaseout Project ('O.D.Ss. III') in June 1995,224 respectively. In brief, the objectives of these O.D.Ss. Programmes, those of the O.D.Ss. III in particular, have been to (i) support China's total O.D.Ss. programme by establishing an efficient/flexible institutional mechanism to prepare and implement many sub-projects (i.e. institutional strengthening), (ii) implement cost-effective priority subprojects, and (iii) allow O.D.Ss. phaseout to proceed at/ahead of the schedule (2010) under the Montreal Ozone Protocol.225 The Bank says that on the completion of these O.D.Ss. I/II, 14,000 metric tons of O.D.Ss. will eventually be eliminated. 226

The Bank reports that it encountered several difficult problems arising from O.D.Ss. I project process, and consequently these caused serious delays in Fund project implementation. These problems include, for example, 'inadequate technical review during the project preparation, issues of institutional strengthening and a lack of coordination and support within the World Bank.227 In order to remedy the acute situation, necessary and immediate corresponding actions were then taken by the World Bank and/or the Chinese government. 228

One of the biggest Bank-implemented projects in China is the conversion of C.F.C.-12 air conditioning compressor production to H.C.F.C.22 at Beijing Machinery Factory (G.M.R.I.), which is a technology transfer related agreement negotiated with Arctic Circle in the United Kingdom. The Fund project is expected to be completed in December 1997. Concerning this project, the Executive Committee, which has been assigned the politically delicate task of approving Fund projects, suggested that while

222 See The World Bank, Ozone Projects Trust Fund Grant (ODS Phaseout I) (October 1993). The O.D.Ss. I aimed to develop the sectors of aerosols, foams and halons and its rant amount was about U.S. 7,000 million.

223 See The World Bank, Ozone Projects Trust Fund Grant (Ozone Projects Phaseout II) (May 1994). The O.D.Ss. II focused on a sector of foams and its grant amount was about U.S. 4.800 million.

224 The O.D.Ss. III is an umbrella agreement with U.S. 90 million dollars and it aims to develop all sectors of O.D.Ss. phaseout strategies. See The World Bank, Ozone Projects Trust Fund Grant (Ozone Projects Phaseout III) (June 1995).

$225_{\text {Ibid., para. } 8 .}$

226 Ibid., para. 6 .

227 See The World Bank, Implementation Performance Review of Bank-Implemented Montreal Protocol Investment Operations (December 1994) paras. 2-7.

228 See ibid., its Annex B (Attachment D), 'Implementation Performance Review: Issues and Actions Worksheet', pp. 1 et seq. 
the use of H.C.F.Cs. - which has a long-term greenhouse effect ${ }^{229}$ - should be avoided as much as possible, in the light of the advice provided by the World Bank expert and so forth, it was 'appropriate' to proceed with the technology in question (i.e. H.C.F.Cs.). 230

In some other cases, United Nations Implementing Agencies (e.g. the U.N.D.P.) provide technical assistance through institutional strengthening of China's Project Management Office, and demonstration phaseout projects in solvent cleaning, foams and other activities. 231 Moreover, the Environmental Agency of the United States has assisted in developing a national halon recycling programme and ozone-friendly household refrigerators for the Chinese market. 232

\section{(4) The Montreal Protocol's Multilateral Fund and N.G.Os. 233}

N.G.Os. are allowed to participate in Executive Committee meetings of the M.L.F. (see Section III(B.1) above). N.G.Os. are generally critical about M.L.F. projects, particularly ones implemented by the I.B.R.D., the World Bank. They argue, for example, that the Bank is too slow to implement its projects; the decision-making of the Executive Committee is largely controlled by the World Bank;234 the Bank frequently uses chemicals that still destroy C.F.Cs. or are significant green house gases; 235 the Bank heavily relies on the recommendations of the O.O.R.G. whose members have links with multilateral O.D.S.-related companies. 236 At least one M.L.F. Fund

229 The E.P.A. of the United States notes, for instance, that the Agency believes that 'the use of HCFCs should be limited to only those applications where other environmentally acceptable alternatives do not exist'. See E.P.A., Federal Register: Protection of Stratospheric Ozone - Final Rule vol. 58, No. 236 (December 10, 1993), p. 65026. See also Chapter III above.

230 See U.N.E.P., Multilateral Fund for the Implementation of the Montreal Protocol: Inventory of Approved Projects (As at November 1995), p. 130.

231 Ibid., para. 6.

232 Ibid., para. 6.

233 See in detail O. Yoshida and A. Sakota, 'The Role of N.G.Os. in the International Legal Régime for the Protection of the Ozone Layer' in the Japanese Society of HumanEnvironment Related Problems (ed.), NGOs and Global Environmental Problems, (October 1998, Japan Environment Agency), Japanese.

234 Greenpeace, 'World Bank Gives More Excuses for Inaction on Ozone', (Press Release, 10 October 1994).

235 Ibid. But see also The World Bank, 'World Bank Assistance to 25 countries for Phasing out Harmful Ozone Depleting Substances Beginning to Produce Results', 7/4 Environment Bulletin, (Winter 1995/96).

236 E. DeSombre and J. Kauffman, 'The Montreal Protocol Multilateral Fund: Partial Success Story' in R. Koehane and M. Levy (eds.), Institutions for Environmental Aid, (1996) p. 117. 
project (Bank-implemented project of H.C.F.C.-22 in Mexico) was cancelled because of N.G.Os.' efforts. 237

In the Fifteenth Meeting of the Executive Committee, the observers for environmental N.G.Os., Greenpeace and Friends of Earth, and the representative of Denmark expressed concern at the Executive Committee, approving many projects that would employ H.C.F.Cs. or 'fifty per cent C.F.C. reduced technology'. 238 The observer for Greenpeace argued, for instance, that the Committee 'should ask for a full analysis of the scientific aspects and political considerations surrounding the use of C.F.Cs.'.239

\section{CONCLUSIONS}

Now it should be briefly concluded, from what has been said above, that the establishment of the Montreal Protocol's Multilateral Fund, as an expression of international solidarity of the ozone layer régime, was indispensable for (i) universal and effective participation of hesitant sovereign states - particularly developing countries in the Third World, and for (ii) future build-up of Article 5 industrialising states' capabilities to fully comply with technical and stringent ozone environmental treaty obligations and rules, including control measures of C.F.Cs./O.D.Ss. and reporting requirements under Article 7 of the Montreal Protocol. It can be easily assumed that, without the Multilateral Fund, the precautionary environmental 'principle'/approach for the protection of the ozone would never be universally observed in the international community. Owing to the participation by a number of Third World countries - including India and China, the Vienna Ozone Convention and its 'dynamic' Montreal Protocol could have transformed from a mere 'North-oriented régime' to a real international legal régime in the field of global environmental protection.

With regard to the two points just mentioned above, it is especially important that the M.L.F. has been managed not only by the pre-existing

237 See R. Benedick, Ozone Diplomacy, (1998) pp. 260-61, reporting that the Friends of Earth was invited to an O.O.R.G. meeting, and an O.O.R.G. adviser and a U.S.E.P.A. representative corroborated an objection by the Friends of Earth to the Fund project.

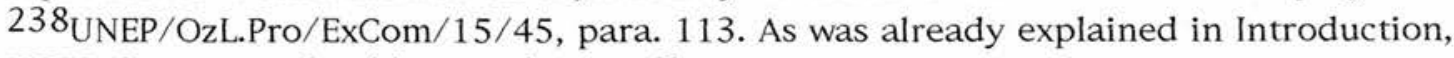
HCFCs have considerable greenhouse effect.

239 Ibid. 
international financial organisation, the World Bank - which is essentially dominated by developed countries, namely, the O.E.C.D. countries - and three United Nations specialised agencies (i.e. U.N.D.P., U.N.I.D.O., U.N.E.P.), but also by new internal treaty institutions within the ozone régime, namely, the Executive Committee, equally representing both developed and developing state parties, and the independent Multilateral Fund Secretariat that is carefully selected based on the principle of equitable geographic distribution. In addition, it must not be forgotten that the 'democratic' supreme body of the environmental régime, the Meeting of the Parties will regularly exercise 'parental' control over the operation of the Financial Mechanism of the Montreal Protocol, although the Meeting, unlike the Executive Committee, does not necessarily formulate specific M.L.F. policies. This structure of the Montreal Protocol's Multilateral Fund thus encourages the legitimate expectation that the direct or complete control of the Northern régime members over the South is not necessarily probable in the current operation of the Fund Mechanism.

Furthermore, it is also important to note that there now exists a linkage between the 'effective implementation of the financial cooperation and transfer of technology' and gradual development of capacity building in Third World countries. 240 As was described, not only major I.G.Os. but also various N.G.Os. that are interested in ozone-related activities - such as M.N.Cs. and I.C.O.L.P. - directly participate in the process of capacity building for Article 5 developing countries.

In spite of considerable delays in implementation of M.L.F. projects, the Fund has contributed, to an appreciable extent, to the phase-out of controlled O.D.Ss. and the international transfer of ozone-friendly technology, and the institutional régime actors of the Mechanism - the Executive Committee, the Implementing Agencies and the Multilateral Fund Secretariat- continue their organised steady efforts in improving the operations and effectiveness of the Financial Mechanism of the Montreal Protocol.

Finally, only two points are particularly recommended here.

In the first place, the Executive Committee should put more emphasis on an institutional strengthening aspect of capacity building for Article 5

\footnotetext{
240 Article 5(4) as amended in 1990. In this respect, Article 4(7) of the 1992 Climate Change Convention similarly states that 'The extent o which developing country Parties will effectively implement their commitments under the Convention will depend on the effective implementation by developed country Parties of their commitments under the Convention related to financial resources and transfer of technology ....'.
} 
The Financial Mechanism and Technology Transfer

developing countries - it is certain that this will help resolve the thorny issues of treaty non-compliance with Article 7 data reporting requirements, which is frequently observed in a number of developing state parties to the Protocol. 241

In the second place, since fragmentary official reports on projects alone do not necessarily constitute effective and efficient international supervision of Fund-supported projects, the Executive Committee should therefore develop - as soon as possible - not only a systematic approach to policy development, but also a monitoring and evaluation system for the Multilateral Fund in achieving Ozone Protocol's established environmental objectives.

241 See Chapter V(VII.A.1) above. 
PART V

CONCLUSIONS 


\title{
CHAPTER VII
}

\author{
THE INTERNATIONAL LEGAL RÉGIME \\ FOR THE PROTECTION OF THE OZONE LAYER
}

Part I (i.e. Chapter I) analysed international legal régimes for the environment, focusing upon their relationship with lawmaking/developing, international environmental co-operation, soft enforcement of treaty by international treaty bodies and, finally, nongovernmental organisations. In the first Part, the international regulatory régime for ozone was conceptually characterised as the 'selfcontained' environmental régime for international obligations erga omnes in the sphere of general public international law.

Part II (composed of Chapters II \& III) is devoted to the detailed legal analysis of the international treaties for the protection of the stratospheric ozone layer. Chapter III examined the 1985 Vienna Ozone Layer Convention in the context of modern international law of the environment. Chapter III dealt with the gradual internationalisation of O.D.S. regulatory measures under the Montreal Protocol and national implementation and enforcement of the ozone layer treaties.

Part III (i.e. Chapter IV) discussed extensively the relationship between Article 4 T.R.E.Ms. of the Montreal Protocol and the G.A.T.T./W.T.O. trade law régime. It was established that - viewed in its entirety - Article 4 trade restrictions seem to be compatible with the stringent trade rules of the G.A.T.T./W.T.O. economic law.

Part IV (composed of Chapters V \& VI) examined the compliance system of the ozone layer régime. In Chapter V, the dispute avoidance/settlement system of the Ozone Layer Protocol, i.e. the NonCompliance Procedure ('N.C.P.') and the functions of the internal treaty organs were closely examined. Chapter VI then investigated the Financial Mechanism of the Montreal Protocol, including the Multilateral Fund.

There is no intention here in this final Part $V$ (i.e. Chapter VII) to provide a detailed summary of the arguments contained in these preceding chapters. This Chapter is primarily intended as a (provisional) evaluation 


\section{CONCLUSION}

of the dynamic international legal régime for the protection of the ozone layer in the field of public international law. ${ }^{1}$

The basic role of international legal régimes has been to organise 'partly unorganised society' 2 that still lacks a centralised supreme authority, and their directly corresponding role is to legally regulate previously unregulated areas of international relations. International legal régimes are strictly not meant to be supranational lawmaking/developing institutions or supranational enforcement mechanisms, even though they might be contributory to the future establishment of such organisations. ${ }^{3}$

Until the early 1980s, global protection of upper atmospheric ozone in the stratosphere had been an 'unregulated area' of international environmental relations. Nation states were free to deplete the ozone shield. Apart from relevant customary principles/rules of international environment protection law considered in Chapter II above (e.g. Stockholm Principle 21/Rio Principle 2), states owed virtually no legal obligations to protect ozone under international law.

However, the creation of the international legal régime for ozone (i.e. the 1985 Vienna Ozone Layer Convention and the 1987 Montreal Ozone Layer Protocol as amended/adjusted) dramatically changed this challenging situation.

Faced with conflicting scientific evidence, ozone negotiators finally decided to take the framework convention-implementing protocol approach: the Convention laid down the legal basis for future international environmental co-operation particularly in scientific research and information exchange; the subsequent implementing Protocol then introduced detailed O.D.S. regulations or standards within its international legal instruments, which has been adjusted by the Meeting of the Parties four times so far. At present the stratospheric ozone enjoys the international legal status of the C.C.M. (common concern of mankind) having erga omnes character. The rapid entry into force of the ozone

\footnotetext{
${ }^{1}$ In order to deepen or facilitate the understanding of this final analysis on the ozone layer régime, ideally, Part I of this doctoral thesis should be read first.

2 On this concept see G. Schwarzenberger, A Manual of International Law, 5th edn. (1967) pp. 8-15 esp.

3 Cf. H. J. Morgenthau, Politics among Nations: The Struggle for Power and Peace, (1962) Chapter 23, arguing that U.N. organs (e.g. the U.N.E.S.C.O.) would not help establish the world government and that 'a world community must antedate a world state'. See also V. Rittberger, Regime Theory and International Relations, (1992) pp. 395-98.
} 
layer treaties indicated that multilateral treaty régimes could provide an efficient legal means of global law-making. 4 The ozone régime has been widely regarded as a global precautionary régime for the protection of the environment, although at present relevant scientific uncertainty has been greatly reduced. The Protocol's concept of international environmental cooperation has been well translated into partnership at the national level: parties - both Non-Article 5 and Article 5 countries - have dedicated considerable efforts to meet the legal requirements of the Montreal Protocol; many of those parties are in ahead of the Protocol's reduction schedules, and only a few countries - such as the C.E.I.Ts. including the Russian Federation - are currently not fully complying with Article 2 control provisions of the regulatory Protocol. The problem of illegal trade in C.F.Cs. of which Russia and two Article 5 countries, i.e. China and India are the main supply sources is now being tackled in earnest by the parties; rising C.F.C. prices - which rocketed in the summer of 1996 with high demand and low availability - suggests that black market trade has gradually declined. 5 In order to mitigate emerging illegal trade in C.F.Cs./O.D.Ss., the Meeting of the Parties decided to further strengthen the existing Montreal N.C.P. régime and to newly institute an import/export licensing system for trade in O.D.Ss.

The strict trade restrictions on O.D.Ss. provided for in Article 4 of the Protocol will continue to be valuable for the maintenance of the ozone layer régime. During the negotiation leading up to the 1987 Montreal Protocol, the United States strongly argued that 'Without restrictions on imports of ozone-depleting chemicals from non-parties, there would be a strong incentive for the development of "pollution havens"'.6 This proposition defended by the U.S. government was well established: when trade controls over non-parties entered into force and became fully effective (i.e. the period from 1990 to 1993), the number of Article 5 developing countries roughly doubled. ${ }^{7}$ The Montreal Protocol's T.R.E.Ms. therefore helped accommodate universal participation by state parties including L.V.Cs. and have prevented C.F.C.-producing countries and potential producers staying outside the ozone layer régime to gain market shares left behind.

\footnotetext{
4 P. Birnie and A. Boyle, International Law and the Environment (1992), p. 12.

5 See R. Benedick, Ozone Diplomacy, (1998) p. 276.

6 See discussion paper submitted by the United States, 'GATT Considerations and the Ozone Protocol', 4 Spetember, 1987) p. 1.

7 R. Benedick, Ozone Diplomacy, (1998) p. 243.
} 
Obviously, the question - 'to what extent may W.T.O. dispute settlement panels take into account multilateral environmental agreements and general international environmental law in the interpretation of G.A.T.T./W.T.O. rules on trade-related environmental measures?' 8 - is a very interesting one. The Montreal Protocol's Article 4 trade controls are an integral part of the international ozone layer régime that is based on general public international law of the environment. In this respect, 'the customary rules of interpretation of public international law' as codified in the 1969 Vienna Convention on the Law of Treaties is to be welcomed.

The Montreal Protocol's compliance system should be also highly acclaimed. The Montreal N.C.P. - as an internally instituted dispute settlement system consistent with the 'consensus building of communication within an international régime' 9 - can be regarded as an unprecedented procedural régime that is designed to 'operate' erga omnes, i.e. the global protection of the ozone layer. 10 The Montreal N.C.P. is therefore meant to overcome the recognised deficiencies of general public international law of the environment. The standing Implementation Committee within the N.C.P. (note: this is not an ad hoc organ) has taken up many non-compliance issues in good time on the O.D.S. control measures, reporting requirements and trade restrictions, and it effectively controlled and/or resolved them (i.e. the dispute 'avoidance' function); tactfully classified Non-Article 5 and Article 5 countries based on available O.D.S. data submitted; created a tentative conditionality between treaty compliance by developing countries (i.e. data reporting) and the M.L.F. funding. The Implementation Committee of the N.C.P., the Meeting of the Parties to the Protocol and the Implementing Agency of the World Bank dealing with the G.E.F. funding - currently make collaborative and

8 E. U. Petersmann, The GATT/WTO Dispute Settlement System, (1997) p. 120. As Professor Petersmann indicated in his articles, this will include e.g. Stockholm Principle 21/Rio Principle 2.

9 See T. Gehring, 'International Environmental Regimes', 1 Y.bk.I.E.L. (1990) p. 37; Chapter V above.

10 See also T. Usuki, 'The Development of Dispute Settlement Procedures in Global Environmental Conventions', in International Law for Dispute Settlement: Essays in Celebration of Judge Oda's Seventieth Birthday, (1997) pp. 182-83 (Japanese). Cf. Y. Takamura, 'International Control over Compliance with International Environmental Treaties', 119 Hitotsubashi Law Review (1998: Japanese), p. 72 \& its endnotes 35-36, discussing the Montreal N.C.P. in the context of a 'special régime' introduced by the I.L.C.

Of course, as Dr. M. Ragazzi says, an risk of proliferation of candidates of obligations erga omnes should be avoided carefully, since the use and abuse of this concept is essentially a question of political nature. See The Concept of International Obligations Erga Omnes, (1997) p. 217. 
organised efforts at solving the C.E.I.Ts.' non-compliance cases, including those of Russia and the Czech Republic. Yet the Montreal N.C.P. is not meant to readily 'supplant' or 'replace' traditional legal settlement procedures. Günther Handl acutely points out that 'Where basic constituent principles and "hard" legal parameters are concerned, disputes should be amended both technically and politically to formal third-party decision making "in accordance with international law" narrowly defined'. ${ }^{11}$

Although often criticised as a 'slow implementation mechanism', the Financial Mechanism of the Montreal Protocol - particularly the Multilateral Fund within the ozone régime and M.L.F. projects - has contributed to a greater or lesser extent to enhancing Article 5 developing countries' capacity building to comply with the ozone treaties. As R. E. Benedick suggested, it is important to notice that the Multilateral Fund is designed to fill a gap: 12 the M.L.F. funding is indispensable not only for key Article 5 countries such as China and India but also for the remaining many L.V.C. parties and their industries whose access to initial investment capital and ozone-friendly technologies would be severely restricted. The international transfer of technologies cannot be fully made in the absence of an 'equitable' global financial institution such as the Protocol's M.L.F.

As with the Implementation Committee of the N.C.P., the Executive Committee of the M.L.F. now gives a sign of potential conditionality between the implementation of the ozone treaties and the M.L.F. funding: for instance, the Executive Committee decided in 1995 that it would prohibit any grants for India's conversion of factories that had installed O.D.S. capacity after July 1995.13

The Montreal Protocol's decision-making procedures may deserve special notice by international law/relations scholars. Under Article 2(9) adjustments of O.D.S. control measures are to bind all the parties; although this two-thirds majority voting procedure - 'as a great novelty in international environmental law'14 - has never been used so far, its

11 G. Handl, 'Controlling Implementation of and Compliance with International Environmental Commitments: The Rocky Road from Rio', 5 Colorado J.E.P. (1994) p. 330.

12 R. Benedick, Ozone Diplomacy, (1998) p. 267.

13 By using the M.L.F funding, India has potentially built new industrial plants capable of producing or using C.F.Cs. other destructive chemicals. See Chapter VI(III.D.4) above.

14 J. G. Lammers, 'Second Report of the International Committee on Legal Aspects of Long-Distance Air Pollution', the I.L.A. Warsaw Conference, (1988) p. 12, cited P. Széll, Decision Making under Multilateral Environmental Agreements', 26/5 E.P.L. (1996) p. 213. 
political impact on 'the parameters of the expectations'15 shared by ozone régime-members cannot be ignored. It is uncertain, however, whether other environmental régimes should follow the precedent that was adopted in the particular circumstances where the total elimination of C.F.Cs. was widely anticipated among all prospective parties to the Protocol. ${ }^{16}$ Perhaps such a revolutionary approach would be unacceptable in a majority of M.E.As. Yet it is important to note at the same time that this new voting system is designed to reflect the opinions of developing country parties by requiring double majorities of both Non-Article 5 and Article 5 countries. This new approach based on North-South balance is also adopted in the Executive Committee's decision-making structure.

Attention should be also directed at the role of non-governmental organisations in the ozone régime's establishment and maintenance. ${ }^{17}$ Environmental N.G.Os. actively participate in the meetings of the periodic Meeting of the Parties, the Executive Committee of the M.L.F. and the OpenEnded Working Group of the Parties to the Protocol. The functions of environmental N.G.Os. in the context of compliance monitoring at the international and national levels are particularly worth mentioning: information regarding potential non-compliance derived from environmental N.G.Os. might - without any governmental support - reach the Montreal N.C.P. régime through the U.N.E.P. Ozone Secretariat; N.G.Os. could organise community pressure to enforce non-binding ozone recommendations and decisions by the Implementation Committee of the N.C.P. and of the Meeting of the Parties; in the meetings of the Executive Committee, N.G.Os. frequently criticise M.L.F. projects that might be regarded as not necessarily visionary, from environmental perspectives. As Alexandre-Charles Kiss puts, it will be true that 'the most powerful. . . . tool for ensuring compliance with international environmental obligations is public awareness and the will to impose upon governments

$15 \mathrm{~J}$. Werksman, 'The Conference of Parties to Environmental Treaties' in idem, Greening International Institutions, (1996) p. 61.

16 P. Széll, 'Decision Making under Multilateral Environmental Agreements', 26/5 E.P.L. (1996) p. 213. See also Chapter III(III.C) above.

17 See in detail O. Yoshida and A. Sakota, 'The Role of N.G.Os. in the International Legal Régime for the Protection of the Ozone Layer' in the Japanese Society of HumanEnvironment Related Problems (ed.), NGOs and Global Environmental Problems, (October 1998, the Japan Environment Agency). 
the protection of the environment values which are essential for the survival of humanity'.18

Certainly, there still exist many substantive issues concerning the regulatory régime's maintenance: control measures on several O.D.Ss. (e.g. H.C.F.Cs. and methyl bromide) must be further strengthened by the Meeting of the Parties; probably two thirds of Article 5 developing countries will have difficulties in achieving the 1999 freeze of C.F.C. consumption; undeniably, the Montreal N.C.P. and the M.L.F. as new international mechanisms have to be improved; only 67 countries have so far ratified the 1992 Copenhagen Amendment to the Montreal Protocol. Strictly speaking, the implementation and enforcement of the international ozone layer treaties has been only partially successful.

Yet the international ozone treaties as a highly technical treaty régime tell us how Stockholm/Rio Principles - including the customary international law of the environment - can be well maintained in the international environmental community of over 190 nation states. The Vienna Ozone Layer Convention claimed to implement Principle 21 of the 1972 Stockholm Declaration and, for the first time, referred to the term 'precautionary measures' in international environment protection law. Now the Montreal Protocol as amended/adjusted contains stringent binding controls of C.F.Cs./O.D.Ss, which will help avoid or mitigate adverse effects caused by consequences of global ozone depletion. In addition, the ozone layer régime would be regarded as the first M.E.A. that specifically addressed the 'principle' or approach of common-but-differentiated responsibility: the régime contains the ten years' grace period; created the Financial Mechanism of the Montreal Protocol including the M.L.F.; includes the provisions for 'basic domestic needs' in Article 5. The ozone layer régime also shows equity considerations for developing countries: as noted, under the present ozone régime, decisions on O.D.S. adjustments are to be taken by a two thirds majority vote of the parties representing a majority of both Non-Article 5 developed and Article 5 developing countries; the Executive Committee of the M.L.F. consists of both seven parties from a group of Article 5 industrialising countries operating and seven parties from a group of Non-Article 5 industrially advanced countries. The ozone régime will be arguably the first international cooperation régime for the environment that successfully acquired the

18 A. Kiss, 'Compliance with International and European Environmental Obligations', Hague Y.bk.I.L. (1996) p. 54. 


\section{CONCLUSION}

delicate global balance of economic/political interests of both Northern and Southern nations. It will be this kind of international legal régimes having 'equitable' institutional mechanisms that can contribute to the achievement or maintenance of the globally recognised customary principle of sustainable development, ${ }^{19}$ consisting of two constituent elements, namely, 'development' and 'environmental protection'.

The ozone layer régime may be seen as a 'comparatively autonomous legal system' or 'self-contained' régime in international law: as Thomas Gehring indicated, the sectoral régime controlled by its supreme political organ often seems separate from long-established traditional rules/principles of public international law. 20 Nevertheless, the legal régime for ozone has been based on the partly changing system of these principles/rules of international law we have considered: the interaction between the international ozone layer régime and general public international law should be correctly understood.

The impact of the ozone layer régime upon the general development of international law should not be underestimated.

19 See separate opinion of Vice-President Weeramantry attached to the I.C.J.'s Gabcikovo-Nagymaros Case, (Hungary/Slovakia) stating that 'The principle of sustainable development is thus a part of modern international law by reason not only of its inescapable logical necessity, but also by reason of its wide and general acceptance by the global community.

20 See Chapter I above. 
APPENDIX 


\section{APPENDIX I \\ THE 1985 VIENNA CONVENTION FOR THE PROTECTION OF THE OZONE LAYER}

\section{Preamble}

The Parties to this Convention,

Aware of the potentially harmful impact on human health and the environment through modification of the ozone layer,

Recalling the pertinent provisions of the Declaration of the United Nations Conference on the Human Environment, and in particular principle 21, which provides that "States have, in accordance with the Charter of the United Nations and principles of international law, the sovereign right to exploit their own resources pursuant to their own environment policies, and the responsibility to ensure that activities within their jurisdiction or control do not cause damage to the environment of other States or of areas beyond the limits of national jurisdiction",

Taking into account the circumstances and particular requirements of developing countries,

Mindful of the work and studies proceeding within both international and national organizations and, in particular, of the World Plan of Action on the Ozone Layer of the United Nations Environment Programme,

Mindful also of the precautionary measures for the protection of the ozone layer which have already been taken at the national and international levels,

Aware that measures to protect the ozone layer from modifications due to human activities require international co-operation and action, and should be based on relevant scientific and technical considerations,

Aware also of the need for further research and systematic observations to further develop scientific knowledge of the ozone layer and possible adverse effects resulting from its modification,

Determined to protect human health and the environment against adverse effects resulting from modifications of the ozone layer,

HAVE AGREED AS FOLLOWS:

\section{Article 1: Definitions}

For the purposes of this Convention:

1. "The ozone layer" means the layer of atmospheric ozone above the planetary boundary layer.

2. "Adverse effects" means changes in the physical environment or biota, including changes in climate, which have significant deleterious effects on human health or on the composition, resilience and productivity of natural and managed ecosystems, or on materials useful to mankind. 


\section{Appendix I}

3. "Alternative technologies or equipment" means technologies or equipment the use of which makes it possible to reduce or effectively eliminate emissions of substances which have or are likely to have adverse effects on the ozone layer.

4. "Alternative substances" means substances which reduce, eliminate or avoid adverse effects on the ozone layer.

5. "Parties" means, unless the text otherwise indicates, Parties to this Convention.

6. "Regional economic integration organizations" means an organization constituted by sovereign States of a given region which has competence in respect of matters governed by this Convention or its protocols and has been duly authorized, in accordance with its internal procedures, to sign, ratify, accept, approve or accede to the instruments concerned.

7. "Protocols" means protocols to this Convention.

\section{Article 2: General obligations}

1. The Parties shall take appropriate measures in accordance with the provisions of this Convention and of those protocols in force to which they are party to protect human health and the environment against adverse effects resulting or likely to result from human activities which modify or are likely to modify the ozone layer.

2. To this end the Parties shall, in accordance with the means at their disposal and their capabilities:

(a) Co-operate by means of systematic observations, research and information exchange in order to better understand and assess the effects on human health and the environment from modification of the ozone layer;

(b) Adopt appropriate legislative or administrative measures and co-operate in harmonizing appropriate policies to control, limit, reduce or prevent human activities under their jurisdiction or control should it be found that these activities have or are likely to have adverse effects resulting from modification or likely modification of the ozone layer;

(c) Co-operate in the formulation of agreed measures, procedures and standards for the implementation of this Convention, with a view to the adoption of protocols and annexes;

(d) Co-operate with competent international bodies to implement effectively this Convention and protocols to which they are party.

3. The provisions of this Convention shall in no way affect the right of Parties to adopt, in accordance with international law, domestic measures already taken by a Party, provided that these measures are not incompatible with their obligations under this Convention.

4. The application of this article shall be based on relevant scientific and technical considerations.

\section{Article 3: Research and systematic observations}

1. The Parties undertake, as appropriate, to initiate and co-operate in, directly or through competent international bodies, the conduct of research and scientific assessments on: 


\section{Appendix I}

(a) The physical ad chemical processes that may affect the ozone layer;

(b) The human health and other biological effects deriving from any modifications of the ozone layer, particularly those resulting from changes in ultra-violet solar radiation having biological effects (UV-B);

(c) Climatic effects deriving from any modifications of the ozone layer;

(d) Effects deriving from any modifications of the ozone layer and any consequent change in UV-B radiation on natural and synthetic materials useful to mankind;

(e) Substances, practices, processes and activities that may affect the ozone layer, and their cumulative effects;

(f) Alternative substances and technologies;

(g) Related socio-economic matters;

and as further elaborated in annexes I and II.

2. The Parties undertake to promote or establish, $s$ appropriate, directly or through competent international bodies and taking fully into account national legislation and relevant ongoing activities at both the national and international levels, joint or complementary programmes for systematic observation of the state of the ozone layer and other relevant parameters, as elaborated in annex I.

3. The Parties undertake to co-operate, directly or through competent international bodies, in ensuring the collection, validation and transmission of research and observational data through appropriate world data centers in a regular and timely fashion.

Article 4: Co-operation in the legal, scientific and technical fields

1. The Parties shall facilitate and encourage the exchange of scientific, technical, socio-economic, commercial and legal information relevant to this Convention as further elaborated in annex II. Such information shall be supplied to bodies agreed upon by the Parties. Any such body receiving information regarded as confidential by the supplying Party shall ensure that such information is not disclosed and shall aggregate it to protect confidentiality before it is made available to all Parties.

2. The Parties shall co-operate, consistent with their national laws, regulations and practices and taking into account in particular the needs of the developing countries, in promoting, directly or through competent international bodies, the development and transfer of technology and knowledge. Such co-operation shall be carried out particularly through:

(a) Facilitation of the acquisition of alternative technologies by other Parties;

(b) Provision of information on alternative technologies and equipment, and supply of special manuals or guides to them;

(c) The supply of necessary equipment and facilities for research and systematic observations;

(d) Appropriate training of scientific and technical personnel. 


\section{Appendix I}

\section{Article 5: Transmission of Information}

The Parties shall transmit, through the secretariat, to the Conference of the Parties established under article 6 information on the measures adopted by them in implementation of this Convention and of protocols to which they are party in such form and at such intervals as the meetings of the parties to the relevant instruments may determine.

\section{Article 6: Conference of the Parties}

1. A Conference of the Parties is hereby established. The first meeting of the Conference of the Parties shall be convened by the secretariat designated on an interim basis under article 7 not later than one year after entry into force of this Convention. Thereafter, ordinary meetings of the Conference of the Parties shall be held at regular intervals to be determined by the Conference at its first meeting.

2. Extraordinary meetings of the Conference of the Parties shall be held at such other times as may be deemed necessary by the Conference, or at the written request of any Party, provided that, within six months of the request being communicated to them by the secretariat, it is supported by at least one third of the Parties.

3. The Conference of the Parties shall by consensus agree upon and adopt rules of procedures and financial rules for itself and for any subsidiary bodies it may establish, as well as financial provisions governing the functioning of the secretariat.

4. The Conference of the Parties shall keep under continuous review the implementation of this Convention. and in addition, shall:

(a) Establish the form and the intervals for transmitting the information to be submitted in accordance with article 5 and consider such information as well as reports submitted by any subsidiary body;

(b) Review the scientific information on the ozone layer, on its possible modification and on possible effects of any such modifications;

(c) Promote, in accordance with article 2, the harmonization of appropriate policies, strategies and measures for minimizing the release of substances causing or likely to cause modification of the ozone layer, and make recommendations on any other measures relating to this Convention.

(d) Adopt, in accordance with articles 3 and 4, programmes for research, systematic observations, scientific and technological co-operation, the exchange of information and the transfer of technology and knowledge.

(e) Consider and adopt, as required, in accordance with articles 9 and 19, amendments to this Convention and its annexes;

(f) Consider amendments to any protocol, as well as to any annexes thereto, and, if so decided, recommend their adoption to the parties to the protocol concerned;

(g) Consider and adopt, as required, in accordance with article 10, additional annexes to this Convention;

(h) Consider and adopt, as required, protocols in accordance with article 8;

(i) Establish such subsidiary bodies as are deemed necessary for the implementation of this Convention; 


\section{Appendix I}

(j) Seek, where appropriate, the services of competent international bodies and scientific committees, in particular the World Meteorological Organization and the World Health Organization as well as the Co-ordinating Committee on the Ozone Layer, in scientific research, systematic observations and other activities pertinent to the objectives of this Convention, and make use as appropriate of information from these bodies and committees;

(k) Consider and undertake any additional action that may be required for the achievement of the purposes of this Convention.

5. The United Nations, its specialized agencies and the International Atomic Agency, as well as any State not party to this Convention, may be represented at meetings of the Conference of the Parties by observers. Any body or agency, whether national or international, governmental or non-governmental, qualified in fields relating to the protection of the ozone layer which has informed the secretariat of its wish to be represented at a meeting of the Conference of the Parties as an observers may be admitted unless at least one-third of the Parties present object. The admission and participation of observers shall be subject to the rules of procedure adopted by the Conference of the Parties.

\section{Article 7: Secretariat}

1. The functions of the secretariat shall be:

(a) To arrange for and service meetings provided for in articles $6,7,8$ and 10;

(b) To prepare and transmit reports based upon information received in accordance with articles 4 and 5, as well as upon information derived from meetings of subsidiary bodies established under article 6;

(c) To perform the functions assigned to it by any protocol;

(d) To prepare reports on its activities carried out in implementation of its functions under this Convention and present them to the Conference of the Parties;

(e) To ensure the necessary co-ordination with other relevant international bodies, and in particular to enter into such administrative and contractual arrangements as may be required for the effective discharge of its functions;

(f) To perform such other functions a may be determined by the Conference of the Parties.

2. The secretariat functions will be carried out on an interim basis by the United nations Environment Programme until the completion of the first ordinary meeting of the Conference of the Parties held pursuant to article 6. At its first ordinary meeting, the Conference of the Parties shall designate the secretariat from amongst those existing competent international organizations which have signified their willingness to carry out the secretariat functions under this Convention.

\section{Article 8: Adoption of protocols}

1. The Conference of the Parties may at a meeting adopt protocols pursuant to Article 2.

2. The text of any proposed protocol shall be communicated to the parties by the secretariat at six months before such a meeting. 


\section{Appendix I}

\section{Article 9: Amendments of the Convention or protocols}

1. Any party may propose amendments to this Convention or to any protocol. Such amendments shall take due account, inter alia, of relevant scientific and technical considerations.

2. Amendments to this Convention shall be adopted at a meeting of the Conference of the Parties. Amendments to any protocol shall be adopted at a meeting of the Parties to the protocol in question. The text of any proposed amendment to this Convention or to any protocol, except as may otherwise be provided in such protocol, shall be communicated to the Parties by the secretariat at least six months before the meeting at which it is proposed for adoption. The secretariat shall also communicate proposed amendments to the signatories to this Convention for information.

3.. The Parties shall make every effort to reach agreement on any proposed amendment to this Convention by consensus. If all efforts at consensus have been exhausted, and no agreement reached, the amendment shall as a last resort be adopted by a threefourths majority vote of the Parties present and voting at the meeting, and shall be submitted by the Depositary to all Parties for ratification, approval or acceptance.

4. The procedure mentioned in paragraph 3 above shall apply to amendments to any protocol, except that a two-thirds majority of the parties to that protocol present and voting at the meeting shall suffice for their adoption.

5. Ratification, approval or acceptance of amendments shall be notified to the Depositary in writing. Amendments adopted in accordance with paragraph 3 or 4 above shall enter into force between parties having accepted them on the ninetieth day after the receipt by the Depositary of notification of their ratification, approval or acceptance by at least three-fourths of the Parties to this Convention or by at least tothirds of the parties to the protocol concerned, except as may otherwise be provided in such protocol. Thereafter the amendments shall enter into force for any other Party on the ninetieth day after that Party deposits its instrument of ratification, approval or acceptance of the amendments.

6. For the purposes of this article, "Parties present and voting" means Parties present and casting an affirmative or negative vote.

\section{Article 10: Adoption and amendment of annexes}

1. The annexes to this Convention or to any protocol shall form an integral part of this Convention or of such protocol, as the case may be, and, unless expressly provided otherwise, a reference to this Convention or its protocols constitutes at the same time a reference to any annexes thereto. Such annexes shall be restricted to scientific, technical and administrative matters.

2. Excepts as may be otherwise provided in any protocol with respect to its annexes, the following procedure shall apply to the proposal, adoption and entry into force of additional annexes to this Convention or of annexes to protocol:

(a) Annexes to this Convention shall be proposed and adopted according to the procedure laid down in article 9, paragraph 2 and 3, while annexes to any protocol shall be proposed and adopted according to the procedure laid down in article 9, paragraphs 2 and 4;

(b) Any party that is unable to approve an additional annex to this Convention or annex to any protocol to which it is party shall so notify the Depositary, in writing, within six months from the date of the communication of the adoption by the Depositary. The Depositary shall without delay notify all Parties of any such 


\section{Appendix I}

notification received. A Party may at any time substitute an acceptance for a previous declaration of objection and the annexes shall thereupon enter into force for that Party;

(c) On the expiry of six months from the date of the circulation of the communication by the Depositary, the annex shall become effective for all Parties to this Convention or to any protocol concerned which have not submitted a notification in accordance with the provision of subparagraph (b) above.

3. The proposal, adoption and entry into force of amendments to annexes to this Convention or to any protocol shall be subject to the same procedure as for the proposal, adoption and entry into force of annexes to the Convention or annexes to a protocol. Annexes and amendments thereto shall take due account, inter alia, of relevant scientific and technical considerations.

4. If an additional annex or an amendment to an annex involves an amendment to this Convention or to any protocol, the additional annex or a amendment shall not enter into force until such time as the amendment to this Convention or to the protocol concerned enters into force.

\section{Article 11: Settlement of disputes}

1. In the event of a dispute between Parties concerning the interpretation or application of this Convention, the parties concerned shall seek solution by negotiation.

2. If the parties concerned cannot reach agreement by negotiation, they may jointly seek the good officers of, or request mediation by, a third party.

3. When ratifying, accepting, approving or acceding to this Convention, or at any time thereafter, a State or regional economic integration organization may declare in writing to the Depositary that for a dispute not resolved in accordance with paragraph 1 or 2 above, it accepts one or both of the following means of dispute settlement as compulsory:

(a) Arbitration in accordance with procedures to be adopted by the Conference of the Parties at its first ordinary meeting;

(b) Submission of the dispute to the International Court of Justice.

4. If the parties have not, in accordance with paragraph 3 above, accepted the same or any procedure, the dispute shall be submitted to conciliation in accordance with paragraph 5 below unless the parties otherwise agree.

5. A conciliation commission shall be created upon the request of one of the parties to the dispute. The commission shall be composed of an equal number of members appointed by each party concerned and a chairman chosen jointly by the members appointed by each party. The commission shall render a final and recommendatory award, which the parties shall consider in good faith.

6. The provisions of this Article shall apply with respect to any protocol except as provided in the protocol concerned.

\section{Article 12: Signature}

The Convention shall be open for signature by States and by regional economic integration organizations at the Federal Ministry for Foreign Affairs of the Republic 


\section{Appendix I}

of Austria in Vienna from 22 March 1985 to 21 September 1985, and at the United Nations Headquarters in New York from 22 September 1985 to 21 March 1986.

\section{Article 13: Ratification, acceptance or approval}

1. This Convention and any protocol shall be subject to ratification, acceptance or approval by States and by regional economic integration organizations. Instruments of ratification, acceptance or approval shall be deposited with the Depositary.

2. Any organization referred to in paragraph 1 above which becomes a Party to this Convention or any protocol without any of its member States being a Party shall be bound by all the obligations under the Convention or the protocol, as the case may be. In the case of such organizations, one or more of whose member States is a Party to the Convention or relevant protocol, the organizations and its member States shall decide on their respective responsibilities for the performance of their obligation under the Convention or protocol, as the case may be. In such cases, the organization and the member States shall not be entitled to exercise rights under the Convention or relevant protocol concurrently.

3. In their instruments of ratification, acceptance or approval, the organizations referred to in paragraph 1 above shall declare the extent of their competence with respect to the matters governed by the Convention or the relevant protocol. Those organizations shall also inform the Depositary of any substantial modification in the extent of their competence.

\section{Article 14: Accession}

1. This Convention and any protocol shall be open for accession by States and by regional economic integration organizations from the date on which the Convention or the protocol concerned is closed for signature. The instruments of accession shall be deposited with the Depositary.

2. In their instruments of accession, the organizations referred to in paragraph 1 above shall declare the extent of their competence with respect to the matters governed by the Convention or the relevant protocol. Those organizations shall also inform the Depositary of any substantial modification in the extent of their competence.

3. The provisions of article 13 , paragraph 2 , shall apply to regional economic integration organizations which accede to this Convention or any protocol.

\section{Article 15: Right to vote}

1. Each Party to this Convention or to any protocol shall have one vote.

2. Except as provided for in paragraph 1 above, regional economic integration organizations, in matters within their competence, shall exercise their right to vote with a number of votes equal to the number of their member States which are Parties to the Convention or the relevant protocol. Such organizations shall not exercise their right to vote if their member States exercise theirs, and vice versa.

\section{Article 16: Relationship between the Convention and its protocols}

1. A State or a regional economic integration organization may not become a party to a protocol unless it is, or become at the same time, a Party to the Convention.

2. Decisions concerning any protocol shall be taken only by the parties to the protocol concerned. 


\section{Appendix I}

\section{Article 17: Entry into force}

1. This Convention shall enter into force on the ninetieth day after the date of deposit of the twentieth instrument of ratification, acceptance, approval or accession.

2. Any protocol, except as otherwise provided in such protocol, shall enter into force on the ninetieth day after the date of deposit of the eleventh instrument of ratification, acceptance or approval of such protocol or accession hereto.

3. For each Party which ratifies, accept or approves this Convention or accedes thereto after the deposit of the twentieth instrument of ratification, acceptance, approval or accession, it shall enter into force on the ninetieth day after the date of deposit by such Party of its instrument of ratification, acceptance, approval or accession.

4. Any protocol, except as otherwise provided in such protocol, shall enter into force for a party that ratifies, accepts or approves that protocol or accedes thereto after its entry into force pursuant to paragraph 2 above, on the ninetieth day after the date on which that party deposits its instrument of ratification, acceptance, approval or accession, or on the date which the Convention enters into force for that Party, whichever shall be the later.

5. For the purposes of paragraphs 1 and 2 above, any instrument deposited by a regional economic integration organization shall not be counted as additional to those deposited by member States of such organization.

\section{Article 18: Reservations}

No reservation may be made to this Convention.

\section{Article 19: Withdrawal}

1. At any time after four years from the date on which this Convention has entered into force for a Party, that Party may withdraw from the Convention by giving written notification to the Depositary.

2. Except as may be provided in any protocol, at any time after four years from the date on which such protocol has entered into force for a party, that party may withdraw from the protocol by giving written notification to the Depositary.

3. Any such withdrawal shall take effect upon expiry of one year after the date of its receipt by the Depositary, or on such later date as may be specified in the notification of the withdrawal.

4. Any Party which withdraws from this Convention shall be considered as also having with drawn from any protocol to which it is party.

\section{Article 20: Depositary}

1. The Secretary-General of the United Nations shall assume the functions of depositary of this Convention and any protocols.

2. The Depositary shall inform the Parties, in particular, of:

(a) The signature of this Convention and of any protocol, and the deposit of instruments of ratification, acceptance, approval or accession in accordance with articles 13 and 14. 


\section{Appendix I}

(b) The date on which the Convention and any protocol will come into force in accordance with article 17;

(c) Notification of withdrawal made in accordance with article 19;

(d) Amendments adopted with respect to the Convention and any protocol, their acceptance by the parties and their date of entry into force in accordance with article 9.

(e) All communications relating to the adoption and approval of annexes and to the amendment of annexes in accordance with article 10;

(f) Notification by regional economic integration organizations of the extent of their competence with respect to matters governed by this Convention and any protocols, and of any modifications thereof.

(g) Declarations made in accordance with article 11, paragraph 3.

\section{Article 21: Authentic texts}

The original of this Convention, of which the Arabic, Chinese, English, French, Russian and Spanish texts are equally authentic, shall be deposited with the Secretary-General of the United Nations.

IN WITNESS WHEREOF the undersigned, being duly authorized to that effect, have signed this Convention.

DONE AT VIENNA ON THE 22ND DAY OF MARCH 1985 


\section{APPENDIX II \\ THE 1987 MONTREAL PROTOCOL ON SUBSTANCES THAT DEPLETE THE OZONE LAYER}

as adjusted/amended by the Second Meeting of the Parties (London, 27-29 June 1990) and by the Fourth Meeting of the Parties (Copenhagen, 23-25 November 1992) and adjusted by the Seventh Meeting of the Parties (Vienna, 5-7 December 1995) and further adjusted/amended by the Ninth Meeting of the Parties

(Montreal, 15-17 September 1997)

The Parties to this Protocol,

Being Parties to the Vienna Convention for the Protection of the Ozone Layer,

Mindful of their obligation under that Convention to take appropriate measures to protect human health and the environment against adverse effects resulting or likely to result from human activities which modify or are likely to modify the ozone layer,

Recognising that world-wide emissions of certain substances can significantly deplete and otherwise modify the ozone layer in a manner that is likely to result in adverse effects on human health and the environment,

Conscious of the potential climatic effects of emissions of these substances,

Aware that measures taken to protect the ozone layer from depletion should be based on relevant scientific knowledge, taking into account technical and economic considerations,

Determined to protect the ozone layer by taking precautionary measures to control equitably total global emissions of substances that deplete it, with the ultimate objective of their elimination on the basis of developments in scientific knowledge, taking into account technical and economic considerations and bearing in mind the developmental needs of developing countries,

Acknowledging that special provision is required to meet the needs of developing countries, including the provision of additional financial resources and access to relevant technologies, bearing in mind that the magnitude of funds necessary is predictable, and the funds can be expected to make a substantial difference in the world's ability to address the scientifically established problem of ozone depletion and its harmful effects,

Noting the precautionary measures for controlling emissions of certain chlorofluorocarbons that have already been taken at national and regional levels,

Considering the importance of promoting international co-operation in the research, development and transfer of alternative technologies relating to the control and reduction of emissions of substances that deplete the ozone layer, bearing in mind in particular the needs of developing countries,

\section{HAVE AGREED AS FOLLOWS:}

\section{Article 1: Definitions}

For the purpose of this Protocol: 


\section{Appendix II}

1. "Convention" means the Vienna Convention for the Protection of the Ozone Layer, adopted on 22 March 1985.

2. "Parties" means, unless the text otherwise indicates, Parties to this Protocol.

3. "Secretariat" means the Secretariat of the Convention.

4. "Controlled substance" means a substance in Annex A, Annex B, Annex C or Annex $\mathrm{D}$ to this Protocol, whether existing alone or in a mixture. It includes the isomers of any such substance, except as specified in the relevant Annex, but excludes any controlled substance or mixture which is in a manufactured product other than a container used for the transportation or storage of that substance.

5. "Production" means the amount of controlled substances produced, minus the amount destroyed by technologies to be approved by the Parties and minus the amount entirely used as feedstock in the manufacture of other chemicals. The amount recycled and reused is not to be considered as "production".

6. "Consumption" means production plus imports minus exports of controlled substances.

7. "Calculated levels" of production, imports, exports and consumption means levels determined in accordance with Article 3.

8. "Industrial realization" means the transfer of all or a portion of the calculated level of production of one Party to another, for the purpose of achieving economic efficiencies or responding to anticipated shortfalls in supply as a result of plant closures.

\section{Article 2: Control Measures}

\section{Incorporated in Article $2 \mathrm{~A}$.}

\section{Replaced by Article $2 B$.}

\section{Replaced by Article 2A.}

\section{Replaced by Article $2 A$.}

5. Any Party may, for one or more control periods, transfer to another Party any portion of its calculated level of production set out in Articles 2A to 2E, and Article $2 \mathrm{H}$, provided that the total combined calculated levels of production of the Parties concerned for any group of controlled substances do not exceed the production limits set out in those Articles for that group. Such transfer of production shall be notified to the Secretariat by each of the Parties concerned, stating the terms of such transfer and the period for which it is to apply.

5 bis. Any Party not operating under paragraph 1 of Article 5 may, for one or more control periods, transfer to another such Party any portion of its calculated level of consumption set out in Article 2F, provided that the calculated level of consumption of controlled substances in Group I of Annex A of the Party transferring the portion of its calculated level of consumption did not exceed 0.25 kilograms per capita in 1989 and that the total combined calculated levels of consumption of the Parties concerned do not exceed the consumption limits set out in Article 2F. Such transfer of consumption shall be notified to the Secretariat by each of the Parties concerned, stating the terms of such transfer and the period for which it is to apply. 


\section{Appendix II}

6. Any Party not operating under Article 5, that has facilities for the production of Annex A or Annex B controlled substances under construction, or constructed for, prior to 16 September 1987 , and provided for in national legislation prior to 1 January 1987, may add the production from such activities to its 1986 production of such substances for the purposes of determining its calculated level of production for 1986, provided that such facilities are completed by 31 December 1990 and that such production does not raise that Party's annual calculated level of consumption of the controlled substances above 0.5 kilograms per capita.

7. Any transfer of production pursuant to paragraph 5 or any additional of production pursuant to paragraph 6 shall be notified to the Secretariat, no later than the time of the transfer or addition.

8. (a) Any Party which are Member States of a regional economic integration organization as defined in Article 1(6) of the Convention may agree that they shall jointly fulfil their obligations respecting consumption under this Article and Articles $2 \mathrm{~A}$ to $2 \mathrm{H}$ provided that their total combined calculated level of consumption does not exceed the levels required by this Article and Articles $2 \mathrm{~A}$ to $2 \mathrm{H}$.

(b) The Parties to any such agreement shall inform the Secretariat of the terms of the agreement before the date of the reduction in consumption with which the agreement is concerned.

(c) Such agreement will become operative only if all Member States of the regional economic integration organization and the organization concerned are Parties to the Protocol and have notified the Secretariat of their manner of implementation.

9. (a) Based on the assessments made pursuant to Article 6, the Parties may decide whether:

(i) Adjustments to the ozone depleting potentials specified in Annex A, Annex B, Annex $\mathrm{C}$ and/or Annex $\mathrm{E}$ should be made and if so, what the adjustments should be; and

(ii) Further adjustments and reductions of production or consumption of the controlled substances should be undertaken and, if so, what the scope, amount and timing of any such adjustments and reductions should be;

(b) Proposals for such adjustments shall be communicated to the Parties by the Secretariat at least six months before the meeting of the Parties at which they are proposed for adoption;

(c) In taking such decisions, the Parties shall make every effort to reach agreement by consensus. If all efforts at consensus have been exhausted, and no agreement reached, such decisions shall, as a last resort, be adopted by a two-thirds majority vote of the Parties present and voting representing a majority of the Parties operating under Paragraph 1 of Article 5 present and voting and a majority of the Parties not so operating present and voting;

(d) The decisions, which shall be binding on all Parties, shall forthwith be communicated to the Parties by the Depositary. Unless otherwise provided in the decisions, they shall enter into force on the expiry of six months from the date of the circulation of the communication by the Depositary.

10. Based on the assessments made pursuant to Article 6 of this Protocol and in accordance with the procedure set out in Article 9 of the Convention, the Parties may decide: 


\section{Appendix II}

(a) whether any substances, and if so which, should be added to or removed from any annex to this Protocol, and

(b) the mechanism, scope and timing of the control measures that should apply to those substances;

11. Notwithstanding the provisions contained in this Article and Articles $2 \mathrm{~A}$ to $2 \mathrm{H}$ Parties may take more stringent measures than those required by this Article and Articles $2 \mathrm{~A}$ to $2 \mathrm{H}$.

\section{Article 2A: CFCs}

1. Each Party shall ensure that for the twelve-month period commencing on the first day of the seventh month following the date of entry into force of this Protocol, and in each twelve-month period thereafter, its calculated level of consumption of the controlled substances in Group I of Annex A does not exceed its calculated level of consumption in 1986. By the end of the same period, each Party producing one or more of these substances shall ensure that its calculated level of production of the substances does not exceed its calculated level of production in 1986, except that such level may have increased by no more than ten per cent based on the 1986 level. Such increase shall be permitted only so as to satisfy the basic domestic needs of the Parties operating under Article 5 and for the purposes of industrial rationalization between Parties.

2. Each Party shall ensure that for the period from July 1991 to 31 December 1992 its calculated levels of consumption and production of the controlled substances in Group I of Annex A do not exceed 150 per cent of its calculated levels of production and consumption of those substances in 1986; with effect from 1 January 1993, the twelvemonth control period for these controlled substances shall run from 1 January to 31 December each year.

3. Each Party shall ensure that for the twelve-month period commencing on 1 January 1994, and in each twelve-month period thereafter, its calculated level of consumption of the controlled substances in Group I of Annex A does not exceed, annually, twentyfive per cent of its calculated level of consumption in 1986. Each Party producing one or more of these substances shall, for the same periods, ensure that its calculated level of production of the substances does not exceed, annually, twenty-five per cent of its calculated level of production in 1986. However, in order to satisfy the basic domestic needs of the Parties operating under paragraph 1 of Article 5, its calculated level of production may exceed that limit by up to ten per cent of its calculated level of production in 1986.

4. Each Party shall ensure that for the twelve-month period commencing on 1 January 1996, and in each twelve-month period thereafter, its calculated level of consumption of the controlled substances in Group I of Annex A does not exceed zero. Each Party producing one or more of these substances shall, for the same periods, ensure that its calculated level of production of the substances does not exceed zero. However, in order to satisfy the basic domestic needs of the Parties operating under paragraph 1 of Article 5, its calculated level of production may exceed that limit by up to fifteen per cent of its calculated level of production in 1986. This paragraph will apply save to the extent that the Parties decide to permit the level of production or consumption that is necessary to satisfy uses agreed by them to be essential.

\section{Article 2B: Halons}

1. Each Party shall ensure that for the twelve-month period commencing in 1 January 1992, and in each twelve-month period thereafter, its calculated level of consumption of the controlled substances in Group II of Annex A does not exceed, annually, its 
calculated level of consumption in 1986. Each Party producing one or more of these substances shall, for the same periods, ensure that its calculated level of production of the substances does not exceed, annually, its calculated level of production in 1986. However, in order to satisfy the basic domestic needs of the Parties operating under paragraph 1 of Article 5, its calculated level of production may exceed that limit by up to ten per cent of its calculated level of production in 1986.

2. Each Party shall ensure that for the twelve-month period commencing on 1 January 1994 , and in each twelve-month period thereafter, its calculated level of consumption of the controlled substances in Group II of Annex A does not exceed zero. Each Party producing one or more of these substances shall, for the same periods, ensure that its calculated level of production of the substances does not exceed zero. However, in order to satisfy the basic domestic needs of the Parties operating under paragraph 1 of Article 5, its calculated level of production may exceed that limit by up to fifteen per cent of its calculated level of production in 1986. This paragraph will apply save to the extent that the Parties decide to permit the level of production or consumption that is necessary to satisfy uses agreed by them to be essential.

\section{Article 2C: Other fully halogenated CFCs}

1. Each Party shall ensure that for the twelve-month period commencing on 1 January 1993, its calculated level of consumption of the controlled substances in Group I of Annex B does not exceed, annually, eighty per cent of its calculated level of consumption in 1989. Each Party producing one or more of these substances shall, for the same period, ensure that its calculated level of production of the substances does not exceed, annually, eighty per cent of its calculated level of production in 1989. However, in order to satisfy the basic domestic needs of the Parties operating under paragraph 1 of Article 5, its calculated level of production may exceed that limit by up to ten per cent of its calculated level of production in 1989.

2. Each Party shall ensure that for the twelve-month period commencing on 1 January 1994, and in each twelve-month period thereafter, its calculated level of consumption of the controlled substances in Group I of Annex B does not exceed, annually, twentyfive per cent of its calculated level of consumption in 1989. Each Party producing one or more of these substances shall, for the same periods, ensure that its calculated level of production of the substances does not exceed, annually, twenty-five per cent of its calculated level of production in 1989. However, in order to satisfy the basic domestic needs of the Parties operating under paragraph 1 of Article 5, its calculated level of production may exceed that limit by up to ten per cent of its calculated level of production in 1989.

3. Each Party shall ensure that for the twelve-month period commencing on 1 January 1996, and in each twelve-month period thereafter, its calculated level of consumption of the controlled substances in Group I of Annex B does not exceed zero. Each Party producing one or more of these substances shall, for the same periods, ensure that its calculated level of production of the substances does not exceed zero. However, in order to satisfy the basic domestic needs of the Parties operating under paragraph 1 of Article 5, its calculated level of production may exceed that limit by up to fifteen per cent of its calculated level of production in 1989. This paragraph will apply save to the extent that the Parties decide to permit the level of production or consumption that is necessary to satisfy uses agreed by them to be essential.

\section{Article 2D: Carbon tetrachloride}

1. Each Party shall ensure that for the twelve-month period commencing on 1 January 1995, its calculated level of consumption of the controlled substance in Group II of Annex B does not exceed, annually, fifteen per cent of its calculated level of consumption in 1989. Each Party producing the substances shall, for the same period, 


\section{Appendix II}

ensure that its calculated level of production of the substance does not exceed, annually, fifteen per cent of its calculated level of production in 1989. However, in order to satisfy the basic domestic needs of the Parties operating under paragraph 1 of Article 5, its calculated level of production may exceed that limit by up to ten per cent of its calculated level of production in 1989.

2. Each Party shall ensure that for the twelve-month period commencing on 1 January 1996, and in each twelve-month period thereafter, its calculated level of consumption of the controlled substance in Group II of Annex B does not exceed zero. Each Party producing the substance shall, for the same periods, ensure that its calculated level of production of the substance does not exceed zero. However, in order to satisfy the basic domestic needs of the Parties operating under paragraph 1 of Article 5, its calculated level of production may exceed that limit by up to fifteen per cent of its calculated level of production in 1989. This paragraph will apply save to the extent that the Parties decide to permit the level of production or consumption that is necessary to satisfy uses agreed by them to be essential.

\section{Article 2E: 1,1,1-Trichloroethane (Methyl chloroform)}

1. Each Party shall ensure that for the twelve-month period commencing on 1 January 1993, its calculated level of consumption of the controlled substance in Group III of Annex B does not exceed, annually, its calculated level of consumption in 1989. Each Party producing the substance shall, for the same period, ensure that its calculated level of production of the substance does not exceed, annually, its calculated level of production in 1989. However, in order to satisfy the basic domestic needs of the Parties operating under paragraph 1 of Article 5, its calculated level of production may exceed that limit by up to ten per cent of its calculated level of production in 1989.

2. Each Party shall ensure that for the twelve-month period commencing on 1 January 1994, and in each twelve-month period thereafter, its calculated level of consumption of the controlled substance in Group III of Annex B does not exceed, annually, fifty per cent of its calculated level of consumption in 1989. Each Party producing the substance shall, for the same periods, ensure that its calculated level of production of the substance does not exceed, annually, fifty per cent of its calculated level of production in 1989. However, in order to satisfy the basic domestic needs of the Parties operating under paragraph 1 of Article 5, its calculated level of production may exceed that limit by up to ten per cent of its calculated level of production in 1989.

3.. Each Party shall ensure that for the twelve-month period commencing on 1 January 1996, and in each twelve-month period thereafter, its calculated level of consumption of the controlled substance in Group III of Annex B does not exceed zero. Each Party producing the substance shall, for the same periods, ensure that its calculated level of production of the substance does not exceed zero. However, in order to satisfy the basic domestic needs of the Parties operating under paragraph 1 of Article 5, its calculated level of production may exceed that limit by up to fifteen per cent of its calculated level of production in 1989. This paragraph will apply save to the extent that the Parties decide to permit the level of production or consumption that is necessary to satisfy uses agreed by them to be essential.

\section{Article 2F: Hydrochlorofluorocarbons}

1. Each Party shall ensure that for the twelve-month period commencing on 1 January 1996, and in each twelve-month period thereafter, its calculated level of consumption of the controlled substance in Group I of Annex C does not exceed, annually, the sum of: 


\section{Appendix II}

(a) Two point eight per cent of its calculated level of consumption in 1989 of the controlled substances in Group I of Annex A; and

(b) Its calculated level of consumption in 1989 of the controlled substances in Group I of Annex C.

2. Each Party shall ensure that for the twelve-month period commencing on January 2004 , and in each twelve-month period thereafter, its calculated level of consumption of the substances in Group I of Annex C does not exceed, annually, sixty-five per cent of the sum referred to in paragraph 1 of this Article.

3. Each Party shall ensure that for the twelve-month period commencing on 1 January 2010 , and in each twelve-month period thereafter, its calculated level of consumption of the substances in Group I of Annex C does not exceed, annually, thirty-five per cent of the sum referred to in paragraph 1 of this Article.

4.. Each Party shall ensure that for the twelve-month period commencing on 1 January 2015 , and in each twelve-month period thereafter, its calculated level of consumption of the controlled substances in Group I of Annex C does not exceed, annually, ten per cent of the sum referred to in paragraph 1 of this Article.

5. Each Party shall ensure that for the twelve-month period commencing on 1 January 2020, and in each twelve-month period thereafter, its calculated level of consumption of the controlled substances in Group I of Annex C does not exceed, annually, zero point five per cent of the sum referred to in paragraph 1 of this Article. Such consumption shall, however, be restricted to the servicing of refrigeration and air conditioning equipment existing at that date.

6. Each Party shall ensure that for the twelve-month period commencing on 1 January 2030 , and in each twelve-month period thereafter, its calculated level of consumption of the controlled substances in Group I of Annex C does not exceed zero.

7. As of 1 January 1996, each Party shall endeavour to ensure that:

(a) The use of controlled substances in Group I of Annex C is limited to those applications where other more environmentally suitable alternative substances or technologies are not available;

(b) The use of controlled substances in Group I of Annex C is not outside the areas of application currently met by controlled substances in Annexes A, B and C, except in rare cases for the protection of human life or human health; and

(c) Controlled substances in Group I of Annex C are selected for use in a manner that minimizes ozone depletion, in addition to meeting other environmental, safety and economic considerations.

\section{Article 2G: Hydrobromofluorocarbons}

Each Party shall ensure that for the twelve-month period commencing on 1 January 1996 , and in each twelve-month period thereafter, its calculated level of consumption of the controlled substances in Group II of Annex C does not exceed zero. Each Party producing the substances shall, for the same periods, ensure that its calculated level of production of the substances does not exceed zero. This paragraph will apply save to the extent that the Parties decide to permit the level of production or consumption that is necessary to satisfy uses agreed by them to be essential. 


\section{Appendix II}

\section{H: Methyl bromide}

1. Each Party shall ensure that for the twelve-month period commencing on 1 January 1995, its calculated level of consumption of the controlled substance Annex E does not exceed, annually, its calculated level of consumption in 1991. Each Party producing the substance shall, for the same period, ensure that its calculated level of production of the substance does not exceed, annually, its calculated level of production in 1991. However, in order to satisfy the basic domestic needs of the Parties operating under paragraph 1 of Article 5, its calculated level of production may exceed that limit by up to ten per cent of its calculated level of production in 1991.

2. Each Party shall ensure that for the twelve-month period commencing on 1 January 1999, and in the twelve-month period thereafter, its calculated level of consumption of the controlled substance in Annex E does not exceed, annually, seventy-five per cent of its calculated level of consumption in 1991. Each Party producing the substance shall, for the same periods, ensure that its calculated level of production of the substance does not exceed, annually, seventy-five per cent of its calculated level of production in 1991. However, in order to satisfy the basic domestic needs of the Parties operating under paragraph 1 of Article 5, its calculated level of production may exceed that limit by up to ten per cent of its calculated level of production in 1991.

3. Each Party shall ensure that for the twelve-month period commencing on 1 January 2001, and the twelve-month period thereafter, its calculated level of consumption of the controlled substance Annex E does not exceed, annually, fifty per cent of its calculated level of consumption in 1991. Each Party producing the substance shall, for the same period, ensure that its calculated level of production of the substance does not exceed, annually, fifty per cent of its calculated level of production in 1991. However, in order to satisfy the basic domestic needs of the Parties operating under paragraph 1 of Article 5, its calculated level of production may exceed that limit by up to ten per cent of its calculated level of production in 1991.

4. Each Party shall ensure that for the twelve-month period commencing on 1 January 2003, and in the twelve-month period thereafter, its calculated level of consumption of the controlled substance in Annex E does not exceed, annually, thirty per cent of its calculated level of consumption in 1991. Each Party producing the substance shall, for the same periods, ensure that its calculated level of production of the substance does not exceed, annually, thirty per cent of its calculated level of production in 1991. However, in order to satisfy the basic domestic needs of the Parties operating under paragraph 1 of Article 5, its calculated level of production may exceed that limit by up to fifteen per cent of its calculated level of production in 1991. This paragraph will apply save to the extent that the Parties decide to permit the level of production or consumption that is necessary to satisfy uses agreed by them to be critical agricultural uses.

5. Each Party shall ensure that for the twelve-month period commencing on 1 January 2005 , and in the twelve-month period thereafter, its calculated level of consumption of the controlled substance in Annex E does not exceed zero. Each Party producing the substance shall, for the same periods, ensure that its calculated level of production of the substance does not exceed zero. However, in order to satisfy the basic domestic needs of the Parties operating under paragraph 1 of Article 5, its calculated level of production may exceed that limit by up to fifteen per cent of its calculated level of production in 1991. This paragraph will apply save to the extent that the Parties decide to permit the level of production or consumption that is necessary to satisfy uses agreed by them to be critical agricultural uses.

6. The calculated levels of consumption and production under this Article shall not include the amount used by the Party for quarantine and pre-shipment application. 


\section{Appendix II}

\section{Article 3: Calculation of control levels}

For the purposes of Articles 2, 2A to $2 \mathrm{H}$ and 5, each Party shall, for each group of substances in Annex A, Annex B and Annex C or Annex E determine its calculated levels of:

(a) Production by:

(i) multiplying its annual production of each controlled substance by the ozone depleting potential specified in respect of it in Annex A, Annex B, Annex C or Annex E;

(ii) adding together, for each such Group, the resulting figures;

(b) Imports and exports, respectively, by following, mutatis mutandis, the procedure set out in subparagraph (a); and

(c) Consumption by adding together its calculated levels of production and imports and subtracting its calculated level of exports as determined in accordance with subparagraphs (a) and (b). However, beginning on 1 January 1993, any export of controlled substances to non-Parties shall not be subtracted in calculating the consumption level of the exporting Party.

\section{Article 4: Control of trade with non-Parties}

1. As of 1 January 1990, each party shall ban the import of the controlled substances in Annex A from any State not party to this Protocol.

1 bis. Within one year of the date for the entry into force of this paragraph, each Party shall ban the import of any controlled substances in Group II of Annex B from any State not party to this Protocol.

1 ter. Within one year of the date for the entry into force of this paragraph, each Party shall ban the import of any controlled substances in Group II of Annex C from any State not party to this Protocol.

1 qua. Within one year of the date for the entry into force of this paragraph, each Party shall ban the import of any controlled substances in Annex E from any State not party to this Protocol.

2. As of 1 January 1993, each party shall ban the export of any controlled substances in Annex A to any State not party to this Protocol.

2 bis. Commencing one year of the date for the entry into force of this paragraph, each Party shall ban the export of any controlled substances in Annex B to any State not party to this Protocol.

2 ter. Commencing one year of the date for the entry into force of this paragraph, each Party shall ban the export of any controlled substances in Group II of Annex C to any State not party to this Protocol.

2 qua. Commencing one year of the date for the entry into force of this paragraph, each Party shall ban the export of any controlled substances in Annex E to any State not party to this Protocol.

3. By 1 January 1992, the Parties shall, following the procedures in Article 10 of the Convention, elaborate in an annex a list of products containing controlled substances 


\section{Appendix II}

in Annex A. Parties that have not objected to the annex in accordance with those procedures shall ban, within one year of the annex having become effective, the import of those products from any State not party to this Protocol.

3 bis. Within three years of the date of the entry into force of this paragraph, the Parties shall, following the procedures in Article 10 of the Convention, elaborate in an annex a list of products containing controlled substances in Annex B. Parties that have not objected to the annex in accordance with those procedures shall ban, within one year of the annex having become effective, the import of those products from any State not party to this Protocol.

3 ter. Within three years of the date of the entry into force of this paragraph, the Parties shall, following the procedures in Article 10 of the Convention, elaborate in an annex a list of products containing controlled substances in Group II of Annex C. Parties that have not objected to the annex in accordance with those procedures shall ban, within one year of the annex having become effective, the import of those products from any State not party to this Protocol.

4. By 1 January 1994, the Parties shall determine the feasibility of banning or restricting, from States not party to this Protocol, the import of products produced with, but not containing, controlled substances in Annex A. If determined feasible, the Parties shall, following the procedures in Article 10 of the Convention, elaborate in an annex a list of products containing controlled substances in Annex A. Parties that have not objected to the annex in accordance with those procedures shall ban, within one year of the annex having become effective, the import of those products from any State not party to this Protocol.

4 bis. Within five years of the date of the entry into force of this paragraph, the Parties shall determine the feasibility of banning or restricting, from States not party to this Protocol, the import of products produced with, but not containing, controlled substances in Annex B. If determined feasible, the Parties shall, following the procedures in Article 10 of the Convention, elaborate in an annex a list of products containing controlled substances in Annex A. Parties that have not objected to the annex in accordance with those procedures shall ban, within one year of the annex having become effective, the import of those products from any State not party to this Protocol.

4 ter. Within five years of the date of the entry into force of this paragraph, the Parties shall determine the feasibility of banning or restricting, from States not party to this Protocol, the import of products produced with, but not containing, controlled substances in Group II of Annex C. If determined feasible, the Parties shall, following the procedures in Article 10 of the Convention, elaborate in an annex a list of products containing controlled substances in Annex A. Parties that have not objected to the annex in accordance with those procedures shall ban, within one year of the annex having become effective, the import of those products from any State not party to this Protocol.

5. Each Party undertakes to the fullest practicable extent to discourage the export to any State not party to this Protocol of technology for producing and for utilizing controlled substances in Annexes A and B and Group II of Annex C and Annex E.

6. Each Party shall refrain from providing new subsidies, aid, credits, guarantees or insurance programmes for the export to States not party to this Protocol of products, equipment, plants or technology that would facilitate the production of controlled substances in Annexes A and B and Group II of Annex C and Annex E.

7. Paragraphs 5 and 6 shall not apply to products, equipment, plants or technology that improve the containment, recovery, recycling or destruction of controlled 


\section{Appendix II}

substances, promote the development of alternative substances, or otherwise contribute to the reduction of emissions of controlled substances in Annexes A and B and Group II of Annex C and Annex E.

8. Notwithstanding the provisions of this Article, imports and exports referred to in paragraph 1 to 4 ter of this Article may be permitted from, or to, any State not party to this Protocol, if that State is determined, by a meeting of the Parties, to be in full compliance with Article 2, Articles $2 \mathrm{~A}$ to $2 \mathrm{E}$, Article $2 \mathrm{G}$ and $2 \mathrm{H}$ and this Article, and have submitted data to that effect as specified in Article 7.

9. For the purposes of this Article, the term "State not party to this Protocol" shall include, with respect to a particular controlled substance, a State or regional economic integration organization that has not agreed to be bound by the control measures in effect for that substance.

10. By 1 January 1996, the Parties shall consider whether to amend this Protocol in order to extend the measures in this Article to trade in controlled substances in Group I of Annex C and in Annex E with States not party to the Protocol.

\section{Article 4A: Control of Trade with Parties}

1. Where, after the phase-out date applicable to it for a controlled substances, a Party is unable, despite having all practicable steps to comply with its obligation under the Protocol, to cease production of that substance for domestic consumption, other than for used, recycled and reclaimed quantities of that substance, other than for the purpose of destruction.

2. Paragraph 1 of this Article shall apply without prejudice to the operation of Article 11 of the Convention and the non-compliance procedure developed under Article 8 of the Protocol.

\section{B: Licensing}

1. Each Party shall, by January 2000 or within three months of the date of entry into force of this Article for it, whichever is the later, establish and implement a system for licensing the import and export of new, recycled and reclaimed controlled substances in Annexes A, B, C and E.

2. Notwithstanding paragraph 1 of this Article, any Party operating under paragraph 1 of Article 5 which decides it is not in a position to establish and implement a system for licensing the import and export of controlled substances in Annexes $\mathrm{C}$ and E, may delay taking those actions until 1 January 2005 and 1 January 2002, respectively.

3. Each Party shall, within three months of the date of introducing its licensing system, report to the Secretariat on the establishment and operation of that system.

4. The Secretariat shall periodically prepare and circulate to all Parties a list of the Parties that have reported to it on their licensing systems and shall forward this information to the Implementation Committee for consideration and appropriate recommendations to the Parties.

\section{Article 5: Special situation of developing countries}

1. Any Party that is a developing country and whose annual calculated level of consumption of the controlled substances in Annex A is less than 0.3 kilograms per capita on the date of the entry into force of the Protocol for it, or any time thereafter until 1 January 1999, shall, in order to meet its basic domestic needs, be entitled to 


\section{Appendix II}

delay for ten years its compliance with the control measures set out in Article 2A to $2 \mathrm{E}$, provided that any further amendments to the adjustments or Amendment adopted at the Second Meeting of the Parties in London, 29 June 1990, shall apply to the Parties operating under this paragraph after the review provided for in paragraph 8 of this Article has taken place and shall be based on the conclusions of that review.

1 bis. The Parties shall, taking into account the review referred to in paragraph 8 of this Article, the assessments made pursuant to Article 6 and any other relevant information, decide by 1 January 1996, through the procedure set forth in paragraph 9 of Article 2:

(a) With respect to paragraphs 1 to 6 of Article 2F, what base year, initial levels, control schedules and phase-out date for consumption of the controlled substances in Group I of Annex C will apply to Parties operating under paragraph 1 of this Article;

(b) With respect to Article 2G, what phase-out date for production and consumption of the controlled substances in Group II of Annex C will apply to Parties operating under paragraph 1 of this Article;

(c) With respect to Article $2 \mathrm{H}$, what base year, initial levels and control schedules for consumption and production of the controlled substances in Annex E will apply to Parties operating under paragraph 1 of this Article.

2. However, any Party operating under paragraph 1 of this Article shall exceed neither an annual calculated level of consumption of the controlled substances in Annex A of 0.3 kilograms per capita nor an annual calculated level of consumption of controlled substances of Annex B of 0.2 kilograms per capita.

3. When implementing the control measures set out in Articles $2 \mathrm{~A}$ to $2 \mathrm{E}$, any Party operating under paragraph 1 of this Article shall be entitled to use:

(a) For controlled substances under Annex A, either the average of its annual calculated level of consumption for the period 1995 to 1997 inclusive or a calculated level of consumption of 0.3 kilograms per capita, whichever is the lower, as the basis for determining its compliance with the control measures relating to consumption.

(b) For controlled substances under Article B, the average of its annual calculated level of consumption for the period 1998 to 2000 inclusive or a calculated level of consumption of 0.2 kilograms per capita, whichever is the lower, as the basis for determining its compliance with the control measures relating to consumption.

(c) For controlled substances under Annex A, either the average of its annual calculated level of production for the period 1995 to 1997 inclusive or a calculated level of production of 0.3 kilograms per capita, whichever is the lower, as the basis for determining its compliance with the control measures relating to production

(d) For controlled substances under Annex B, either the average of its annual calculated level of production for the period 1998 to 2000 inclusive or a calculated level of production of 0.2 kilograms per capita, whichever is the lower, as the basis for determining its compliance with the control measures relating to production

4. If a Party operating under paragraph 1 of this Article, at any time before the control measures obligations in Articles $2 \mathrm{~A}$ to $2 \mathrm{H}$ become applicable to is, finds itself unable to obtain an adequate supply of controlled substances, it may notify this to the Secretariat. The Secretariat shall forthwith transmit a copy of such notification to the Parties, which shall consider the matter at their next Meeting, and decide upon appropriate action to be taken. 


\section{Appendix II}

5. Developing the capacity to fulfil the obligations of the Parties operating under paragraph 1 of this Article to comply with the control measures set out in Articles 2A to $2 \mathrm{E}$, and any control measures in Articles $2 \mathrm{~F}$ to $2 \mathrm{H}$ that are decided pursuant to paragraph 1 bis of this Article, and their implementation by those same Parties will depend upon the effective implementation of the financial co-operation as provided by Article 10 and the transfer of technology as provided by Article 10A.

6. Any Party operating under paragraph 1 of this Article may, any time, notify the Secretariat in writing that, having all practical steps it is unable to implement any or all of the obligations laid down in Articles 2A to 2E, or any or all obligations in Articles $2 \mathrm{~F}$ to $2 \mathrm{H}$ that are decided pursuant to paragraph 1 bis of this Article, due to the inadequate implementation of Article 10 and 10A. The Secretariat shall forthwith transmit a copy of the notification to the Parties, which shall consider the matter at their next Meeting, giving due recognition to paragraph 5 of this Article and shall decide appropriate action to be taken.

7. During the period between notification and the Meeting of the Parties at which the appropriate action referred to in paragraph 6 above is to be decided, or for a further period if the Meeting of the Parties so decides, the non-compliance procedures referred to in Article 8 shall not be invoked against notifying Party.

8. A Meeting of the Parties shall review, not later than 1995, the situation of the Parties operating under paragraph 1 of this Article, including the effective implementation of financial co-operation and transfer of technology to them, and adopt such revisions that may be deemed necessary regarding the schedule of control measures applicable to those Parties.

8 bis. Based on the conclusions of the review referred to in paragraph 8 above:

(a) With respect to the controlled substances in Annex A, a Party operating under paragraph 1 of this Article shall, in order to meet its domestic needs, be entitled to delay for ten years its compliance with the control measures adopted by the Second Meeting of the Parties in London, 29 June 1990, and reference by the Protocol to Articles $2 \mathrm{~A}$ to $2 \mathrm{~B}$ shall be read accordingly;

(b) With respect to the controlled substances in Annex B, a Party operating under paragraph 1 of this Article shall, in order to meet its domestic needs, be entitled to delay for ten years its compliance with the control measures adopted by the Second Meeting of the Parties in London, 29 June 1990, and reference by the Protocol to Articles $2 \mathrm{C}$ to $2 \mathrm{E}$ shall be read accordingly.

8 ter. Pursuant to paragraph 1 bis above:

(a) Each Party operating under paragraph 1 of this Article shall ensure that for the twelve-month period commencing on 1 January 2016, and in each twelve-month period thereafter, its calculated level of consumption of the controlled substances in Group I of Annex C does not exceed, annually, its calculated level of consumption in 2015;

(b) Each Party operating under paragraph 1 of this Article shall ensure that for the twelve-month period commencing on 1 January 2040, and in each twelve-month period thereafter, its calculated level of consumption of the controlled substances in Group I of Annex C does not exceed zero;

(c) Each Party operating under paragraph 1 of this Article shall comply with Article $2 \mathrm{G}$

(d) With regard to the controlled substance contained in Annex E: 


\section{Appendix II}

(i) As of 1 January 2002 each Party operating under paragraph 1 of this Article shall comply with the control measures set out in paragraph 1 of Article $2 \mathrm{H}$ and, as the basis for its compliance with these control measures, it shall use the average of its annual calculated level of consumption and production, respectively, for the period of 995 to 1998 inclusive;

(ii) Each Party operating under paragraph 1 of this Article shall ensure that for the twelve-month period commencing on 1 January 2005, and in each twelve-month period thereafter, its calculated level of consumption of the controlled substances in Annex $E$ does not exceed, annually, eighty per cent of the average of its annual calculated level of consumption and production, respectively, for the period of 1995 to 1998 inclusive;

(b) Each Party operating under paragraph 1 of this Article shall ensure that for the twelve-month period commencing on 1 January 2015 and in each twelve-month period thereafter, its calculated level of consumption and production of the controlled substances in Annex E do not exceed zero. This paragraph will apply save to the extent that the Parties decide to permit the level of production or consumption that is necessary to satisfy uses agreed by them to be critical uses;

(iv) The calculated levels of consumption and production under this subparagraph shall not include the amounts used by the Party for quarantine and pre-shipment applications.

9. Decisions of the Parties referred to in paragraph 4, 6 and 7 of this Article shall be taken according to the same procedure applied to decision making under Article 10.

\section{Article 6: Assessment and review of control measures}

Beginning in 1990, and at least every four years thereafter, the Parties shall assess the control measures provided for in Article 2 and Articles $2 \mathrm{~A}$ to $2 \mathrm{H}$ on the basis of available scientific, environmental, technical and economic information. At least one year before each assessment, the Parties shall convene appropriate panels of experts qualified in the fields mentioned and determine the composition and terms of reference of any such panels. Within one year of being convened, the panels will report their conclusions, through the Secretariat, to the Parties.

\section{Article 7: Reporting of data}

1. Each Party shall provide to the Secretariat, within three months of beginning a Party, statistical data on its production, imports and exports of each of the controlled substances in Annex A for the year 1986, or the best possible estimates of such data are not available.

2. Each Party shall provide to the Secretariat statistical data on its production, imports and exports of each of the controlled substances.

- in Annexes B and C, for the year 1989;

- in Annex E, for the year 1991,

or the best possible estimates of such data where actual data are not available, not later than three months after the date when the provisions set out in the Protocol with regard to the schedules in Annexes B, C and E respectively enter into force for that Party.

3. Each Party shall provide to the Secretariat statistical data on its annual production (as defined in paragraph 5 of Article 1) of each of the controlled substances listed in Annexes A, B, C and E and, separately, for each substance, 


\section{Appendix II}

- Amounts used for feedstocks,

- Amounts destroyed by technologies approved by the Parties, and

- Imports from and exports to Parties and non-Parties respectively,

for the year during which provisions concerning the substances in Annexes A, B, C and $\mathrm{E}$ respectively entered into force for that Party and for each year thereafter. Data shall be forwarded not later than nine months after the end of the year to which the data relate.

3 bis. Each Party shall provide to the Secretariat separate statistical data of its annual imports and exports of each of the controlled substances listed in Group II of Annex A and Group I of Annex C that have been recycled.

4. For Parties operating under the provisions of paragraph 8(a) of Article 2, the requirements in paragraph $1,2,3$ and 3 bis of this Article in respect of statistical data on imports and exports shall be satisfied if the regional economic integration organization concerned provides data on imports and exports between the organization and States that are not members of that organization.

\section{Article 8: Non-compliance}

The Parties, at their first meeting, shall consider and approve procedures and institutional mechanisms for determining non-compliance with the provisions of this Protocol and for treatment of Parties found to be in non-compliance.

Article 9: Research, development, public awareness and exchange of information

1. The Parties shall co-operate, consistent with their national laws, regulations and practices and taking into account in particular the needs of developing countries, in promoting, directly or through competent international bodies, research, development and exchange of information on:

(a) best technologies for improving the containment, recovery, recycling, or destruction of controlled substances or otherwise reducing their emissions;

(b) possible alternatives to controlled substances, to products containing such substances, and to products manufactured with them; and

(c) costs and benefits of relevant control strategies.

2. The Parties, individually, jointly or through competent international bodies, shall co-operate in promoting public awareness of the environment effects of the emissions of controlled substances and other substances that deplete the ozone layer.

3. Within two years of the entry into force of this Protocol and every two years thereafter, each Party shall submit to the Secretariat a summary of the activities it has conducted pursuant to this Article.

\section{Article 10: Financial Mechanism}

1. The Parties shall establish a mechanism for the purposes of providing financial and technical co-operation, including the transfer of technologies, to Parties operating under paragraph 1 of Article 5 of this Protocol to enable their compliance with the control measures set out in Articles $2 \mathrm{~A}$ to $2 \mathrm{E}$, and any control measures in Articles $2 \mathrm{~F}$ to $2 \mathrm{H}$ that are decoded pursuant to paragraph 1 bis of Article 5 of the Protocol. The mechanism, contributions to which shall be additional to other financial transfers to Parties operating under that paragraph, shall meet all agreed incremental costs of 


\section{Appendix II}

such Parties in order to enable their compliance with the control measures of the Protocol. An indicative list of the categories of incremental costs shall be decided by the meeting of the Parties.

2. The mechanism established under paragraph 1 shall include a Multilateral Fund. It may also include other means of multilateral, regional and bilateral co-operation.

3. The Multilateral Fund shall:

(a) Meet, on a grant or concessional basis as appropriate, and according to criteria to be decided upon by the Parties, the agreed incremental costs;

(b) Finance clearing-house functions to:

(i) Assist Parties operating under paragraph 1 of Article 5, through country specific studies and other technical co-operation, to identify their needs for co-operation;

(ii) Facilitate technical co-operation to meet these identified needs;

(iii) Distribute, as provided for in Article 9, information and relevant materials, and hold workshops, training sessions, and other related activities, for the benefit of Parties that are developing countries; and

(iv) Facilitate and monitor other multilateral, regional and bilateral co-operation available to Parties that are developing countries;

(v) Finance the secretariat services of the Multilateral Fund and related support costs.

4. The Multilateral Fund shall operate under the authority of the Parties who shall decide on its overall policies.

5. The Parties shall establish an Executive Committee to develop and monitor the implementation of specific operational policies, guidelines and administrative arrangements, including the disbursement of resources, for the purpose of achieving the objectives of the Multilateral Fund. The Executive Committee shall discharge its tasks and responsibilities, specified in its terms of reference as agreed by the Parties, with the co-operation and assistance of the International Bank for Reconstruction and Development (World Bank), the United Nations Environment Programme, the United Nations Development Programme or other appropriate agencies depending on their respective area of expertise. The members of the Executive Committee, which shall be selected on the basis of a balanced representation of the Parties operating under paragraph 1 of Article 5 and of the Parties not so operating, shall be endorsed by the Parties.

6. The Multilateral Fund shall be financed by contributions from Parties not operating under paragraph 1 of Article 5 in convertible currency or, in certain circumstances, in kind and/or in national currency, on the basis of the United Nations scale of assessments. Contributions by other Parties shall be encouraged. Bilateral and in particular cases agreed by a decision of the Parties, regional co-operation may, up to percentage and consistent with any criteria to be specified by decision of the Parties, be considered as a contribution to the Multilateral Fund, provided that such co-operation, as a minimum:

(a) Strictly relates to compliance with the provisions of this Protocol;

(b) Provides additional resources; and

(c) Meets agreed incremental costs. 


\section{Appendix II}

7. The Parties shall decide upon the programme budget of the Multilateral Fund for each fiscal period and upon the percentage of contributions of the individual Parties thereto.

8. Resources under the Multilateral Fund shall be disbursed with the concurrence of the beneficiary Party.

9. decisions by the Parties under this Article shall be taken by consensus whenever possible. If all efforts at consensus have been exhausted and no agreement reached, decisions shall be adopted by a two-thirds majority vote of the Parties present and voting, representing a majority of the Parties operating under paragraph 1 of Article 5 present and voting and a majority of the Parties not so operating present and voting.

10. The financial mechanism set out in this Article is without prejudice to any future arrangements that may be developed with respect to other environmental issues.

\section{Article 10A: Transfer of technology}

Each Party shall take every practical step, consistent with the programmes supported by the financial mechanism, to ensure:

(a) that the best available, environmentally safe substitutes and related technologies are expeditiously transferred to Parties operating under paragraph 1 of Article 5; and

(b) that the transfers referred to in subparagraph(a) occur under fair and most favourable conditions.

\section{Article 11: Meetings of the Parties}

1. The Parties shall hold meetings at regular intervals. The Secretariat shall convene the first meeting of the Parties not later than one year after the date of the entry into force of this Protocol and in conjunction with a meeting of the Conference of the Parties to the Convention, if a meeting of the latter is scheduled within that period.

2. Subsequent ordinary meetings of the parties shall be held, unless the Parties otherwise decide, in conjunction with meetings of the Conference of the Parties to the Parties to the Convention. Extraordinary meetings of the Parties shall be held at such other times as may be deemed necessary by a meeting of the Parties, or at the written request of any Party, provided that within six months of such a request being communicated to them by the Secretariat, it is supported by at least one third of the Parties.

3. The Parties, at their first meeting, shall:

(a) adopt by consensus rules of procedure for their meetings;

(b) adopt by consensus the financial rules referred to in paragraph 2 of Article 13;

(c) establish the panels and determine the terms of reference referred to in Article 6;

(d) consider and approve the procedures and institutional mechanisms specified in Article 8; and

(e) begin preparation of workplans pursuant to paragraph 3 of Article 10. [Article 10 of the original 1987 Montreal Protocol]. 


\section{Appendix II}

4. The functions of the meetings of the Parties shall be to:

(a) review the implementation of this Protocol;

(b) decide on any adjustments or reductions referred to in paragraph 9 of Article 2;

(c) decide on any addition to, insertion in or removal from any annex of substances and on related control measures in accordance with paragraph 10 of Article 2;

(d) establish, where necessary, guidelines or procedures for reporting of information as provided for in Article 7 and paragraph 3 of Article 9;

(e) review requests for technical assistance submitted pursuant t paragraph 2 of Article 10;

(f) review reports prepared by the secretariat pursuant to subparagraph (c) of Article 12 ;

(g) assess, in accordance with Article 6, the control measures;

(h) consider and adopt, as required, proposals for amendments of this Protocol or any annex and for any new annex;

(i) consider and adopt the budget for implementing this Protocol; and

(j) consider and undertake any additional action that may be required for the achievement of the purposes of this Protocol.

5. The United Nations, its specialized agencies and the International Atomic Energy Agency, as well as any State not party to this Protocol, may be represented at meetings of the Parties as observers. Any body or agency, whether national or international, governmental or non-governmental, qualified in fields relating to the protection of the ozone layer which has informed the secretariat of its wish to be represented at a meeting of the Parties as an observer may be admitted unless at least one third of the Parties present object. The admission and participation of observers shall be subject to the rules of procedure adopted by the Parties.

\section{Article 12: Secretariat}

For the purposes of this Protocol, the Secretariat shall:

(a) arrange for and service meetings of the Parties as provided for in Article 11;

(b) receive and make available, upon request by a Party, data provided pursuant to Article 7;

(c) prepare and distribute regularly to the Parties reports based on information received pursuant to Articles 7 and 9;

(d) notify the Parties of any request for technical assistance received pursuant to Article 10 so as to facilitate the provision of such assistance;

(e) encourage non-Parties to attend the meetings of the Parties as observers and to act in accordance with the provisions of this Protocol;

(f) provide, as appropriate, the information and requests referred to in subparagraph

(c) and (d) to such non-party observers; and 


\section{Appendix II}

(g) perform such other functions for the achievement of the purposes of this Protocol as may be assigned to it by the Parties.

\section{Article 13: Financial provisions}

1. The funds required for the operation of this Protocol, including those for the functioning of the Secretariat related to this Protocol, shall be charged exclusively against contributions from the Parties.

2. The Parties, at their first meeting, shall adopt by consensus financial rules for the operation of this Protocol.

\section{Article 14: Relationship of this Protocol to the Convention}

Except as otherwise provided in this Protocol, the provisions of the Convention relating to its protocols shall apply to this Protocol.

\section{Article 15: Signature}

The Protocol shall be open for signature by States and by regional economic integration organizations in Montreal on 16 September 1987, in Ottawa from 17 September 1987 to 16 January 1988, and at United Nations Headquarters in New York from January 1988 to 15 September 1988.

\section{Article 16: Entry into force}

1. The Protocol shall enter into force on 1 January 1989, provided that at least eleven instruments of ratification, acceptance, approval of the Protocol or accession thereto have been deposited by States or regional economic integration organizations representing at least two-thirds of 1986 estimated global consumption of the controlled substances, and the provisions of paragraph 1 of Article 17 of the Convention have been fulfilled. In the event that these conditions have not been fulfilled by that date, the Protocol shall enter into force on the ninetieth day following the date on which the conditions have been fulfilled.

2. For the purposes of paragraph 1, any such instrument deposited by a regional economic integration organization shall not be counted as additional to those deposited by member States of such organization.

3. After the entry into force of this Protocol, any State or regional economic integration organization shall become a Party to it on the ninetieth day following the date of its instrument of ratification.

\section{Article 17: Parties not joining after entry into force}

Subject to Article 5, any State or regional economic integration organization which becomes a Party to this Protocol after the date of its entry into force, shall fulfil forthwith the sum of the obligations under Article 2, as well as Articles $2 \mathrm{~A}$ to $2 \mathrm{H}$ and Article 4, that apply at that date to the States and regional economic integration organizations that become Parties on the date the Protocol entered into force.

\section{Article 18: Reservations}

No reservation may be made to this Protocol. 
Article 19: Withdrawal

Any Party may withdraw from this Protocol by giving written notification to the Depositary at any time after four years of assuming the obligations specified in paragraph 1 of Article 2A. Any such withdrawal shall take effect upon expiry of one year after the date of its receipt by the Depositary, or on such later date as may be specified in the notification of the withdrawal.

\section{Article 20: Authentic texts}

The original of this Protocol, of which the Arabic, Chinese, English, French, Russian and Spanish texts are equally authentic, shall de deposited with the Secretary-General of the United Nations.

IN WITNESS WHEREOF THE UNDERSIGNED, BEING DULY AUTHORIZED TO THAT EFFECT, HAVE SIGNED THIS PROTOCOL

DONE AT MONTREAL THIS SIXTEENTH DAY OF SEPTEMBER, ONE THOUSAND NINE HUNDRED AND EIGHTY SEVEN

[ANNEXES ARE NOT REPRODUCED] 


\section{APPENDIX III}

\section{STATUS OF RATIFICATION/ACCESSION/ACCEPTANCE/APPROVAL OF THE AGREEMENTS ON THE PROTECTION OF THE STRATOSPHERIC OZONE LAYER (15 MAY 1998)}

\begin{tabular}{|c|c|c|c|c|c|c|}
\hline & $\begin{array}{l}\text { Signature } \\
\text { Vienna } \\
\text { Convention }\end{array}$ & $\begin{array}{l}\text { Signature } \\
\text { Montreal } \\
\text { Protocol }\end{array}$ & $\begin{array}{l}\text { Ratification } \\
\text { Vienna } \\
\text { Convention }\end{array}$ & $\begin{array}{l}\text { Ratification } \\
\text { Montreal } \\
\text { Protocol }\end{array}$ & $\begin{array}{l}\text { Ratification } \\
\text { London } \\
\text { Amendment }\end{array}$ & $\begin{array}{l}\text { Ratification } \\
\text { Copenhagen } \\
\text { Amendment }\end{array}$ \\
\hline Country & & & & & & \\
\hline Algeria & & & $\begin{array}{l}20.10 .1992 \\
\text { (Ac) }\end{array}$ & $\begin{array}{l}20.10 .1992 \\
\text { (Ac) }\end{array}$ & $\begin{array}{l}20.10 .1992 \\
\text { (Ac) }\end{array}$ & \\
\hline $\begin{array}{l}\text { Antigua \& } \\
\text { Barbuda }\end{array}$ & & & $\begin{array}{l}3.12 .1992 \\
(\mathrm{Ac})\end{array}$ & $\begin{array}{l}3.12 .1992 \\
(\mathrm{Ac})\end{array}$ & $\begin{array}{l}23.2 .1993 \\
\text { (Ac) }\end{array}$ & $\begin{array}{l}19.7 .1993 \\
(\mathrm{Ac})\end{array}$ \\
\hline Argentina & 22.3 .1985 & 29.6.1988 & $18.1 .1990(R)$ & $18.9 .1990(R)$ & $4.12 .1992(\mathrm{R})$ & $\begin{array}{l}20.4 .1995 \\
(\mathrm{Ac})\end{array}$ \\
\hline Australia & & 8.6 .1988 & $\begin{array}{l}16.9 .1987 \\
(\mathrm{Ac})\end{array}$ & $19.5 .1989(\mathrm{R})$ & $\begin{array}{l}11.8 .1992 \\
\text { (Ap) }\end{array}$ & $\begin{array}{l}30 . .6 .1994 \\
\text { (Ac) }\end{array}$ \\
\hline Austria & 16.9.1985 & 29.8.1988 & $19.8 .1987(R)$ & $3.5 .1989(\mathrm{R})$ & $\begin{array}{l}11.12 .1992 \\
\text { (R) }\end{array}$ & $\begin{array}{l}19.9 .1996 \\
\text { (Ap) }\end{array}$ \\
\hline Azerbaijan & & & $\begin{array}{l}12.6 .1996 \\
(\mathrm{Ac})\end{array}$ & $\begin{array}{l}12.6 .1992 \\
\text { (Ac) }\end{array}$ & $\begin{array}{l}12.6 .1992 \\
\text { (Ac) }\end{array}$ & $\begin{array}{l}12.6 .1992 \\
\text { (Ac) }\end{array}$ \\
\hline Bahamas & & & $1.4 .1993(\mathrm{Ac})$ & $4.5 .1993(\mathrm{Ac})$ & $4.5 .1993(\mathrm{Ac})$ & $4.5 .1993(\mathrm{Ac})$ \\
\hline Bahrain & & & $\begin{array}{l}27.4 .1990 \\
(\mathrm{Ac})\end{array}$ & $\begin{array}{l}27.4 .1990 \\
(\mathrm{Ac})\end{array}$ & $\begin{array}{l}23.12 .1992 \\
\text { (Ac) }\end{array}$ & \\
\hline Bangladesh & & & $2.8 .1990(\mathrm{Ac})$ & $2.8 .1990(\mathrm{AC})$ & $18.3 .1994(\mathrm{R})$ & \\
\hline Barbados & & & $\begin{array}{l}16.10 .1992 \\
\text { (Ac) }\end{array}$ & $\begin{array}{l}16.10 .1992 \\
\text { (Ac) }\end{array}$ & $\begin{array}{l}20.7 .1994 \\
\text { (At) }\end{array}$ & $\begin{array}{l}20.7 .1994 \\
\text { (At) }\end{array}$ \\
\hline Belarus & 22.3 .1985 & 22.1 .1988 & $\begin{array}{l}20.6 .1986 \\
\text { (At) }\end{array}$ & $\begin{array}{l}31.10 .1988 \\
\text { (At) }\end{array}$ & $10.6 .1996(\mathrm{R})$ & \\
\hline Belgium & 22.3.1985 & 16.9 .1987 & $\begin{array}{l}17.10 .1988 \\
\text { (R) }\end{array}$ & $\begin{array}{l}30.12 .1988 \\
(\mathrm{R})\end{array}$ & $5.10 .1993(\mathrm{R})$ & $7.8 .1997(\mathrm{R})$ \\
\hline Belize & & & $6.6 .1997(\mathrm{Ac})$ & $9.1 .1998(\mathrm{Ac})$ & $9.1 .1998(\mathrm{Ac})$ & $9.1 .1998(\mathrm{Ac})$ \\
\hline Benin & & & $1.7 .1993(\mathrm{AC})$ & $1.7 .1993(\mathrm{Ac})$ & & \\
\hline Bolivia & & & $\begin{array}{l}3.10 .1994 \\
(\mathrm{Ac})\end{array}$ & $\begin{array}{l}3.10 .1994 \\
(\mathrm{AC})\end{array}$ & $\begin{array}{l}3.10 .1994 \\
\text { (Ac) }\end{array}$ & $\begin{array}{l}3.10 .1994 \\
\text { (Ac) }\end{array}$ \\
\hline $\begin{array}{l}\text { Bosnia \& } \\
\text { Herzegovina }\end{array}$ & & & $6.3 .1992(\mathrm{Sc})$ & $6.3 .1992(\mathrm{Sc})$ & & \\
\hline Botswana & & & $\begin{array}{l}4.12 .1991 \\
(\mathrm{Ac})\end{array}$ & $\begin{array}{l}4.12 .1991 \\
(\mathrm{Ac})\end{array}$ & $\begin{array}{l}13.5 .1997 \\
(\mathrm{Ac})\end{array}$ & $\begin{array}{l}13.5 .1997 \\
(\mathrm{Ac})\end{array}$ \\
\hline Brazil & & & $\begin{array}{l}19.3 .1990 \\
\text { (Ac) }\end{array}$ & $\begin{array}{l}19.3 .1990 \\
\text { (Ac) }\end{array}$ & $\begin{array}{l}1.10 .1992 \\
\text { (At) }\end{array}$ & $25.6 .1997(R)$ \\
\hline $\begin{array}{l}\text { Brunei } \\
\text { Darussalam }\end{array}$ & & & $\begin{array}{l}26.7 .1990 \\
(\mathrm{Ac})\end{array}$ & $\begin{array}{l}27.5 .1993 \\
\text { (Ac) }\end{array}$ & & \\
\hline Bulgaria & & & $\begin{array}{l}20.11 .1990 \\
(\mathrm{Ac})\end{array}$ & $\begin{array}{l}20.11 .1990 \\
\text { (AC) }\end{array}$ & & \\
\hline $\begin{array}{l}\text { Burkina } \\
\text { Faso }\end{array}$ & 12.12 .1985 & 14.9 .1988 & $30.3 .1989(\mathrm{R})$ & $\begin{array}{l}20 . .7 .1989 \\
\text { (R) }\end{array}$ & $10.6 .1994(\mathrm{R})$ & $\begin{array}{l}12.12 .1985 \\
\text { (R) }\end{array}$ \\
\hline Burndi & & & $6.1 .1997(\mathrm{Ac})$ & $6.1 .1997(\mathrm{Ac})$ & & \\
\hline Cameroon & & & $\begin{array}{l}30.8 .1989 \\
\text { (Ac) }\end{array}$ & $\begin{array}{l}30.8 .1989 \\
(\mathrm{Ac})\end{array}$ & $8.6 .1992(\mathrm{Ac})$ & $\begin{array}{l}25.6 .1996 \\
\text { (Ap) }\end{array}$ \\
\hline Canada & 22.3 .1985 & 16.9 .1987 & $4.6 .1986(\mathrm{R})$ & $30.6 .1988(\mathrm{R})$ & $5.7 .1990(\mathrm{Ac})$ & $16.3 .1994(\mathrm{R})$ \\
\hline $\begin{array}{l}\text { Central } \\
\text { African } \\
\text { Republic }\end{array}$ & & & $\begin{array}{l}29.3 .1993 \\
(\mathrm{Ac})\end{array}$ & $\begin{array}{l}29.3 .1993 \\
(\mathrm{Ac})\end{array}$ & & \\
\hline Chad & & & $\begin{array}{l}18.5 .1989 \\
\text { (Ac) }\end{array}$ & $7.6 .1994(\mathrm{R})$ & & \\
\hline Chile & 22.3 .1985 & 14.6 .1988 & $6.3 .1990(\mathrm{R})$ & $26.3 .1990(\mathrm{R})$ & $9.4 .1992(\mathrm{Ac})$ & $14.1 .1994(\mathrm{R})$ \\
\hline China & & & $\begin{array}{l}11.9 .1989 \\
\text { (Ac) }\end{array}$ & $\begin{array}{l}14.6 .1991 \\
(\mathrm{Ac})\end{array}$ & $\begin{array}{l}14.6 .1991 \\
(\mathrm{Ac})\end{array}$ & \\
\hline Colombia & & & $\begin{array}{l}16.7 .1990 \\
(\mathrm{Ac})\end{array}$ & $\begin{array}{l}6.12 .1993 \\
\text { (Ac) }\end{array}$ & $\begin{array}{l}6.12 .1993 \\
(\mathrm{AC})\end{array}$ & 5.8 .1997 (At) \\
\hline Comoros & & & $\begin{array}{l}31.10 .1994 \\
\text { (Ac) }\end{array}$ & $\begin{array}{l}31.10 .1994 \\
\text { (AC) }\end{array}$ & $\begin{array}{l}31.10 .1994 \\
\text { (Ac) }\end{array}$ & \\
\hline Congo & & 15.9 .1988 & $\begin{array}{l}16.11 .1994 \\
\text { (AC) }\end{array}$ & $\begin{array}{l}16.11 .1994 \\
\text { (AC) }\end{array}$ & $\begin{array}{l}16.11 .1994 \\
\text { (Ac) }\end{array}$ & \\
\hline
\end{tabular}




\section{Appendix III}

Congo,

Democratic

Republic of

Costa Rica

Cote d'lvoire

Croatia

Cuba

\section{Cyprus}

Czech

Republic

Denmark

Dominica

Dominican

Republic

Ecuador

Egypt

El Salvador

Equatorial

Guinea

Estonia

Ethiopia

European

Community

Federal States

of Micronesia

Fiji

Finland

22.3.1985

16.9.1987

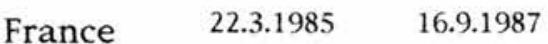

Gabon

Gambia

Georgia

Germany

Ghana

Greece

Grenada

Guatemala

Guinea

Guyana

Hondura

Hungary

Iceland

India

Indonesia

Iran, Islamic

Republic of

Ireland

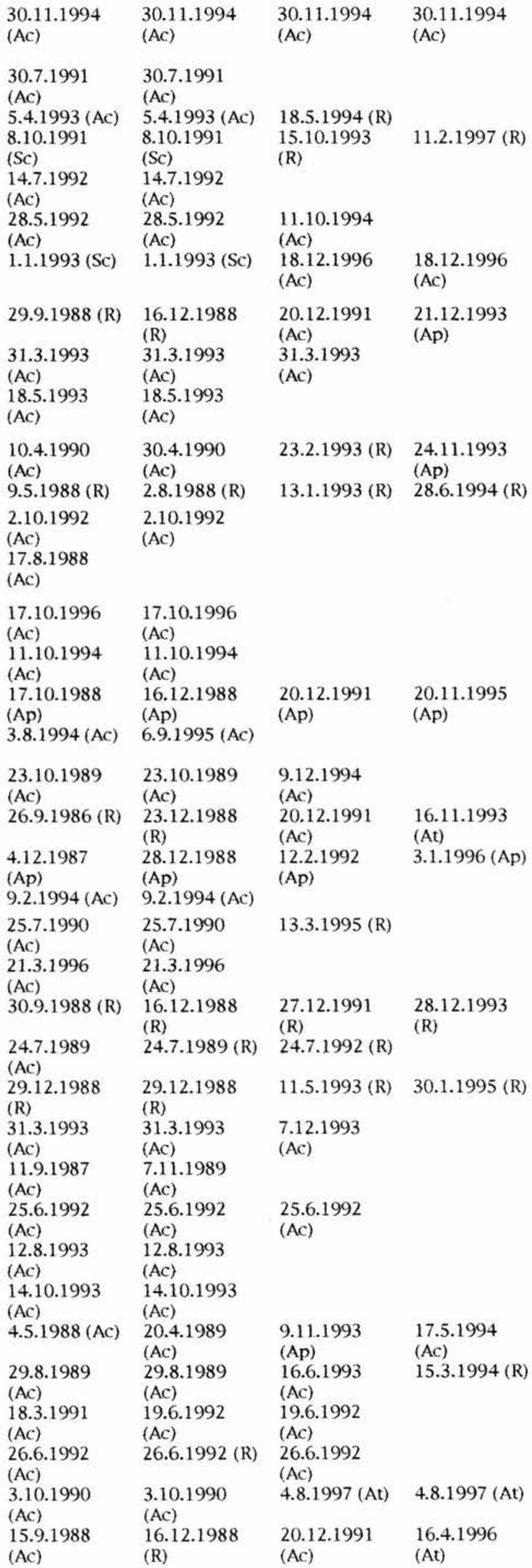


Appendix III

\begin{tabular}{|c|c|c|c|c|c|c|}
\hline Israel & & 14.1.1988 & $\begin{array}{l}30.6 .1992 \\
(\mathrm{Ac})\end{array}$ & 30.6.1992 (R) & 30.6.1992 (R) & $5.4 .1995(\mathrm{R})$ \\
\hline Italy & 22.3 .1985 & 16.9 .1987 & $19.9 .1988(\mathrm{R})$ & 16.12 .1988 & $\begin{array}{l}21.2 .1992 \\
\text { (Ap) }\end{array}$ & $4.1 .1995(\mathrm{R})$ \\
\hline Jamaica & & & $\begin{array}{l}31.3 .1993 \\
(\mathrm{Ac})\end{array}$ & $\begin{array}{l}31.3 .1993 \\
\text { (Ac) }\end{array}$ & $\begin{array}{l}31.3 .1993 \\
(\mathrm{Ac})\end{array}$ & $6.11 .1997(\mathrm{R})$ \\
\hline Japan & & 16.9 .1987 & $\begin{array}{l}30.9 .1988 \\
(\mathrm{Ac})\end{array}$ & $\begin{array}{l}30.9 .1988 \\
\text { (At) }\end{array}$ & $4.9 .1991(\mathrm{Ac})$ & $\begin{array}{l}20.12 .1994 \\
\text { (At) }\end{array}$ \\
\hline Jordan & & & $\begin{array}{l}31.5 .1989 \\
\text { (Ac) }\end{array}$ & $\begin{array}{l}31.5 .1989 \\
(\mathrm{Ac})\end{array}$ & $\begin{array}{l}12.11 .1993 \\
(R)\end{array}$ & $30.6 .1995(\mathrm{R})$ \\
\hline Kenya & & 16.9 .1987 & $\begin{array}{l}9.11 .1988 \\
(\mathrm{AC})\end{array}$ & $9.11 .1988(\mathrm{R})$ & $27.9 .1994(\mathrm{R})$ & $27.9 .1994(\mathrm{R})$ \\
\hline Kiribati & & & $7.1 .1993(\mathrm{Ac})$ & $7.1 .1993(\mathrm{Ac})$ & & \\
\hline $\begin{array}{l}\text { Korea, } \\
\text { Democratic }\end{array}$ & & & $\begin{array}{l}24.1 .1995 \\
(\mathrm{Ac})\end{array}$ & $\begin{array}{l}24.1 .1995 \\
(\mathrm{Ac})\end{array}$ & & \\
\hline $\begin{array}{l}\text { People's } \\
\text { Republic of }\end{array}$ & & & & & & \\
\hline $\begin{array}{l}\text { Korea, } \\
\text { Republic of }\end{array}$ & & & $\begin{array}{l}27.2 .1992 \\
(\mathrm{Ac})\end{array}$ & $\begin{array}{l}27.2 .1992 \\
(\mathrm{Ac})\end{array}$ & $\begin{array}{l}10.12 .1992 \\
(\mathrm{Ac})\end{array}$ & $\begin{array}{l}2.12 .1994 \\
\text { (At) }\end{array}$ \\
\hline Kuwait & & & $\begin{array}{l}23.11 .1992 \\
\text { (Ac) }\end{array}$ & $\begin{array}{l}23.11 .1992 \\
\text { (Ac) }\end{array}$ & $\begin{array}{l}22.7 .1994 \\
\text { (AC) }\end{array}$ & $\begin{array}{l}22.7 .1994 \\
(\mathrm{Ac})\end{array}$ \\
\hline Latvia & & & $\begin{array}{l}28.4 .1995 \\
(\mathrm{AC})\end{array}$ & $\begin{array}{l}28.4 .1995 \\
(\mathrm{Ac})\end{array}$ & & \\
\hline Lebanon & & & $\begin{array}{l}30.3 .1993 \\
\text { (Ac) }\end{array}$ & $\begin{array}{l}31.3 .1993 \\
\text { (Ac) }\end{array}$ & $\begin{array}{l}31.3 .1993 \\
(\mathrm{Ac})\end{array}$ & \\
\hline Lesotho & & & $\begin{array}{l}25.3 .1994 \\
(\mathrm{Ac})\end{array}$ & $\begin{array}{l}25.3 .1994 \\
(\mathrm{AC})\end{array}$ & & \\
\hline Liberia & & & 15.1 .1996 & 15.1 .1996 & 15.1 .1996 & 15.1 .1996 \\
\hline Libyan Arab & & & $\begin{array}{l}\text { (AC) } \\
11.7 .1990\end{array}$ & $\begin{array}{l}\text { (Ac) } \\
11.7 .1990\end{array}$ & & \\
\hline Jamahiriya & & & $(\mathrm{Ac})$ & $(\mathrm{Ac})$ & & \\
\hline Liechtenstein & & & $8.2 .1989(\mathrm{Ac})$ & 8.2 .1989 (Ac) & $24.3 .1994(\mathrm{R})$ & $\begin{array}{l}22.11 .1996 \\
\text { (Ac) }\end{array}$ \\
\hline Lithuania & & & $\begin{array}{l}18.1 .1995 \\
(\mathrm{Ac})\end{array}$ & $\begin{array}{l}18.1 .1995 \\
\text { (Ac) }\end{array}$ & $3.2 .1998(\mathrm{R})$ & 3.2 .1998 (R) \\
\hline Luxembourg & 17.4 .1985 & 20.1 .1988 & $\begin{array}{l}17.10 .1988 \\
\text { (R) }\end{array}$ & $\begin{array}{l}17.10 .1988 \\
\text { (R) }\end{array}$ & 20.5.1992 (R) & $9.5 .1994(\mathrm{R})$ \\
\hline Madagascar & & & $\begin{array}{l}7.11 .1996 \\
(\mathrm{Ac})\end{array}$ & $\begin{array}{l}7.11 .1996 \\
(\mathrm{AC})\end{array}$ & & \\
\hline Malawi & & & 9.1 .1991 (AC) & $9.1 .1991(\mathrm{Ac})$ & 8.2 .1994 (Ap) & $\begin{array}{l}28.2 .1994 \\
(\mathrm{Ac})\end{array}$ \\
\hline Malaysia & & & $\begin{array}{l}29.8 .1989 \\
(A C)\end{array}$ & $\begin{array}{l}29.8 .1989 \\
(\mathrm{AC})\end{array}$ & $\begin{array}{l}16.6 .1993 \\
(\mathrm{Ac})\end{array}$ & $5.8 .1993(\mathrm{Ac})$ \\
\hline Maldives & & 12.7 .1988 & $\begin{array}{l}26.4 .1988 \\
(\mathrm{Ac})\end{array}$ & 16.5.1989(R) & $31.7 .1991(\mathrm{R})$ & \\
\hline Mali & & & $\begin{array}{l}28.10 .1994 \\
(\mathrm{AC})\end{array}$ & $\begin{array}{l}28.10 .1994 \\
\text { (AC) }\end{array}$ & $\begin{array}{l}28.10 .1994 \\
(\mathrm{AC})\end{array}$ & \\
\hline Malta & & 15.9 .1988 & $\begin{array}{l}15.9 .1988 \\
\text { (Ac) }\end{array}$ & $\begin{array}{l}29.12 .1988 \\
\text { (R) }\end{array}$ & $4.2 .1994(\mathrm{Ap})$ & \\
\hline Marshall & & & 11.3 .1993 & 11.3.1993 & 11.3 .1993 & 24.5 .1993 \\
\hline Islands & & & & & & \\
\hline Mauritania & & & $\begin{array}{l}26.5 .1994 \\
\text { (Ac) }\end{array}$ & $\begin{array}{l}26.5 .1994 \\
(\mathrm{Ac})\end{array}$ & & \\
\hline Mauritius & & & $\begin{array}{l}18.8 .1992 \\
(\mathrm{Ac})\end{array}$ & $\begin{array}{l}18.8 .1992 \\
\text { (Ac) }\end{array}$ & $\begin{array}{l}20.10 .1992 \\
(\mathrm{Ac})\end{array}$ & $\begin{array}{l}30.11 .1993 \\
(\mathrm{R})\end{array}$ \\
\hline Mexico & 1.4 .1985 & 16.9 .1987 & $14.9 .1987(\mathrm{R})$ & $\begin{array}{l}31.3 .1988 \\
\text { (At) }\end{array}$ & $\begin{array}{l}11.10 .1991 \\
\text { (At) }\end{array}$ & $\begin{array}{l}16.9 .1994 \\
\text { (At) }\end{array}$ \\
\hline Moldova & & & $\begin{array}{l}24.10 .1996 \\
(\mathrm{Ac})\end{array}$ & $\begin{array}{l}24.10 .1996 \\
(\mathrm{Ac})\end{array}$ & & \\
\hline Monaco & & & $\begin{array}{l}12.3 .1993 \\
(\mathrm{Ac})\end{array}$ & $\begin{array}{l}12.3 .1993 \\
\text { (Ac) }\end{array}$ & $\begin{array}{l}12.3 .1993 \\
(\mathrm{Ac})\end{array}$ & \\
\hline Mongolia & & & $7.3 .1996(\mathrm{Ac})$ & $7.3 .1996(\mathrm{AC})$ & $7.3 .1996(\mathrm{Ac})$ & $7.3 .1996(\mathrm{Ac})$ \\
\hline Morocco & 7.2 .1986 & 7.1 .1988 & $\begin{array}{l}28.12 .1995 \\
(R)\end{array}$ & $\begin{array}{l}28.12 .1995 \\
(\mathrm{R})\end{array}$ & $\begin{array}{l}28.12 .1995 \\
(\mathrm{R})\end{array}$ & $\begin{array}{l}28.12 .1995 \\
(\mathrm{Ac})\end{array}$ \\
\hline Mozambique & & & $9.9 .1994(\mathrm{AC})$ & $9.9 .1994(\mathrm{Ac})$ & $9.9 .1994(\mathrm{AC})$ & $9.9 .1994(\mathrm{Ac})$ \\
\hline Myanmar & & & $\begin{array}{l}24.11 .1993 \\
(\mathrm{Ac})\end{array}$ & & & \\
\hline Namibia & & & $\begin{array}{l}20.9 .1993 \\
\text { (Ac) }\end{array}$ & $\begin{array}{l}20.9 .1993 \\
(\mathrm{Ac})\end{array}$ & $6.11 .1997(\mathrm{R})$ & \\
\hline Nepal & & & $6.7 .1994(\mathrm{Ac})$ & $6.7 .1994(\mathrm{Ac})$ & $6.7 .1994(\mathrm{Ac})$ & \\
\hline Netherlands & 22.3 .1985 & 16.9 .1985 & $\begin{array}{l}\text { 28.9.1988 } \\
(\mathrm{AC})\end{array}$ & $\begin{array}{l}16.12 .1988 \\
\text { (At) }\end{array}$ & $\begin{array}{l}20.12 .1991 \\
(\mathrm{Ac})\end{array}$ & $\begin{array}{l}25.4 .1994 \\
(\mathrm{AC})\end{array}$ \\
\hline $\begin{array}{l}\text { New } \\
\text { Zealand }\end{array}$ & 21.3 .1986 & 16.9 .1987 & $2.6 .1987(R)$ & $21.7 .1988(\mathrm{R})$ & $\begin{array}{l}1.10 .1990 \\
\text { (Ac) }\end{array}$ & $4.6 .1993(R)$ \\
\hline
\end{tabular}


Appendix III

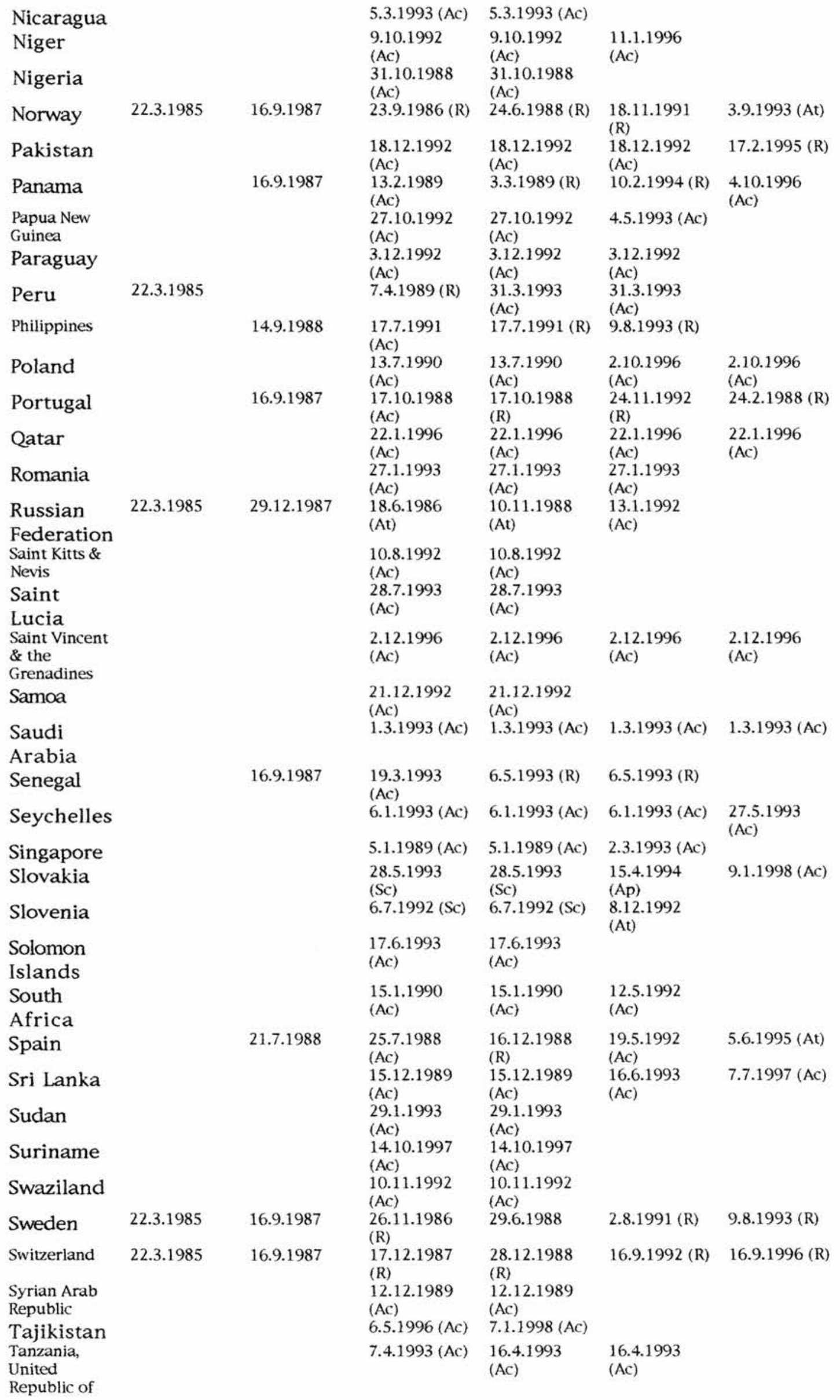




\section{Appendix III}

\begin{tabular}{|c|c|c|c|c|c|c|}
\hline \multirow{2}{*}{\multicolumn{2}{|c|}{$\begin{array}{l}\text { Thailand } \\
\text { The Former } \\
\text { Yugoslav } \\
\text { Republic of } \\
\text { Macedonia }\end{array}$}} & 15.9 .1988 & $7.7 .1989(\mathrm{Ac})$ & $7.7 .1989(\mathrm{R})$ & 25.6.1992 (R) & $1.12 .1995(\mathrm{R})$ \\
\hline & & & $\begin{array}{l}10.3 .1994 \\
(\mathrm{Sc})\end{array}$ & $\begin{array}{l}10.3 .1994 \\
\text { (Sc) }\end{array}$ & & \\
\hline Togo & & 16.9 .1987 & $\begin{array}{l}25.2 .1991 \\
(\mathrm{Ac})\end{array}$ & $25.2 .1991(R)$ & & \\
\hline $\begin{array}{l}\text { Trinidad } \\
\text { \& Tobago }\end{array}$ & & & $\begin{array}{l}28.8 .1989 \\
\text { (Ac) }\end{array}$ & $\begin{array}{l}28.8 .1989 \\
(\mathrm{Ac})\end{array}$ & & \\
\hline Tunisia & & & $\begin{array}{l}25.9 .1989 \\
(\mathrm{Ac})\end{array}$ & $\begin{array}{l}25.9 .1989 \\
\text { (Ac) }\end{array}$ & $\begin{array}{l}15.7 .1993 \\
(\mathrm{Ac})\end{array}$ & $2.2 .1995(\mathrm{Ac})$ \\
\hline Turkey & & & $\begin{array}{l}20.9 .1991 \\
(\mathrm{Ac})\end{array}$ & $\begin{array}{l}20.9 .1991 \\
(\mathrm{Ac})\end{array}$ & $13.4 .1995(\mathrm{R})$ & $\begin{array}{l}10.11 .1995 \\
(\mathrm{R})\end{array}$ \\
\hline Turkmenistan & & & $\begin{array}{l}18.11 .1993 \\
\text { (Ac) }\end{array}$ & $\begin{array}{l}18.11 .1993 \\
(\mathrm{Ac})\end{array}$ & $\begin{array}{l}15.3 .1994 \\
\text { (Ac) }\end{array}$ & \\
\hline Tuvalu & & & $\begin{array}{l}15.7 .1993 \\
(\mathrm{Ac})\end{array}$ & $\begin{array}{l}15.7 .1993 \\
(\mathrm{Ac})\end{array}$ & & \\
\hline Uganda & & 15.9 .1988 & $\begin{array}{l}24.6 .1988 \\
(\mathrm{Ac})\end{array}$ & $15.9 .1988(\mathrm{R})$ & 20.1 .1994 (R) & \\
\hline Ukraine & 22.3.1985 & 18.2 .1988 & $\begin{array}{l}18.6 .1986 \\
\text { (At) }\end{array}$ & $\begin{array}{l}20.9 .1988 \\
\text { (At) }\end{array}$ & $6.2 .1997(\mathrm{R})$ & \\
\hline $\begin{array}{l}\text { United Arab } \\
\text { Emirates }\end{array}$ & & & $\begin{array}{l}22.12 .1989 \\
\text { (Ac) }\end{array}$ & $\begin{array}{l}22.12 .1989 \\
(\mathrm{Ac})\end{array}$ & & \\
\hline $\begin{array}{l}\text { United } \\
\text { Kingdom }\end{array}$ & 20.5 .1985 & 16.9 .1987 & 15.5.1987 (R) & $\begin{array}{l}16.12 .1988 \\
\text { (R) }\end{array}$ & $\begin{array}{l}20.12 .1991 \\
\text { (R) }\end{array}$ & $4.1 .1995(\mathrm{R})$ \\
\hline $\begin{array}{l}\text { United States } \\
\text { of America }\end{array}$ & 22.3 .1985 & 16.9 .1987 & $27.8 .1986(R)$ & 21.4 .1988 (R) & $\begin{array}{l}18.12 .1991 \\
\text { (R) }\end{array}$ & $2.3 .1994(R)$ \\
\hline Uruguay & & & $\begin{array}{l}27.2 .1989 \\
(\mathrm{Ac})\end{array}$ & $8.1 .1991(\mathrm{Ac})$ & $\begin{array}{l}16.11 .1993 \\
(\mathrm{R})\end{array}$ & $3.7 .1997(\mathrm{Ac})$ \\
\hline Uzbekistan & & & $\begin{array}{l}18.5 .1993 \\
\text { (Ac) }\end{array}$ & $\begin{array}{l}18.5 .1993 \\
\text { (Ac) }\end{array}$ & & \\
\hline Vanuatu & & & $\begin{array}{l}21.11 .1994 \\
\text { (AC) }\end{array}$ & $\begin{array}{l}21.11 .1994 \\
(\mathrm{Ac})\end{array}$ & $\begin{array}{l}21.11 .1994 \\
\text { (At) }\end{array}$ & $\begin{array}{l}21.11 .1994 \\
\text { (At) }\end{array}$ \\
\hline Venezuela & & 16.9 .1987 & $1.9 .1988(\mathrm{Ac})$ & $6.2 .1989(\mathrm{R})$ & 29.7.1993 (R) & $\begin{array}{l}10.12 .1997 \\
\text { (R) }\end{array}$ \\
\hline Viet Nam & & & $\begin{array}{l}26.1 .1994 \\
(\mathrm{Ac})\end{array}$ & $\begin{array}{l}26.1 .1994 \\
\text { (Ac) }\end{array}$ & $\begin{array}{l}26.1 .1994 \\
(\mathrm{Ac})\end{array}$ & $\begin{array}{l}26.1 .1994 \\
(\mathrm{Ac})\end{array}$ \\
\hline Yemen & & & $\begin{array}{l}21.2 .1996 \\
\text { (Ac) }\end{array}$ & $\begin{array}{l}21.2 .1996 \\
(\mathrm{Ac})\end{array}$ & & \\
\hline Yugoslavia & & & $\begin{array}{l}16.4 .1990 \\
(\mathrm{Ac})\end{array}$ & $3.1 .1991(\mathrm{Ac})$ & & \\
\hline Zambia & & & $\begin{array}{l}24.1 .1990 \\
\text { (Ac) }\end{array}$ & $\begin{array}{l}24.1 .1990 \\
\text { (Ac) }\end{array}$ & $15.4 .1994(\mathrm{R})$ & \\
\hline Zimbabwe & & & $\begin{array}{l}3.11 .1992 \\
\text { (Ac) }\end{array}$ & $\begin{array}{l}3.11 .1992 \\
(\mathrm{AC})\end{array}$ & $3.6 .1994(\mathrm{R})$ & 3.6.1994 (R) \\
\hline Total & 28 & 46 & 166 & 165 & 120 & 78 \\
\hline
\end{tabular}

Source: Information provided by the Depositary, the U.N. Office of Legal Affairs, as of 15 May 1998.

$<$ NOTES $>$

$\mathrm{R}=$ Ratification; $\mathrm{Ac}=\mathrm{Accession} ; \mathrm{At}=\mathrm{Acceptance} ; \mathrm{Ap}=\mathrm{Approval} ; \mathrm{Sc}=$ Succession

*Entry into force is after ninety days of following date of ratification, accession, acceptance and approval of those states which concluded the treaty after it entered into force, i.e.:

Vienna Convention (22 September 1988)

Montreal Protocol (1 January 1989)

London Amendment (10 August 1992)

Copenhagen Amendment (14 June 1994) 


\title{
APPENDIX IV
}

\section{THE LIST OF PARTIES CATEGORISED AS OPERATING UNDER ARTICLE} 5 PARAGRAPH 1 OF THE MONTREAL PROTOCOL

\author{
1. Algeria \\ 2. Antigua \& Barbuda \\ 3. Argentina \\ 4. Bahamas \\ 5. Bahrain \\ 6. Bangladesh \\ 7. Barbados \\ 8. Benin \\ 9. Bolivia \\ 10. Bosnia \& Herzegovina \\ 11. Botswana \\ 12. Brazil \\ 13. Brunei Darussalam \\ 14. Burkina Faso \\ 15. Cameroon \\ 16. Central African Republic \\ 17. Chile \\ 18. China \\ 19 Colombia \\ 20. Congo \\ 21. Congo, Democratic Republic of \\ 22. Costa Rica \\ 23. Cote d'lvoire \\ 24. Croatia \\ 25. Cuba \\ 26. Cyprus \\ 27. Dominica \\ 28. Dominican Republic \\ 29. Ecuador \\ 30. Egypt \\ 31. El Salvador \\ 32. Ethiopia \\ 33. Fiji \\ 34. Gabon \\ 35. Gambia \\ 36. Georgia \\ 37. Ghana \\ 38. Guatemala \\ 39. Guinea \\ 40. Guyana \\ 41. Hondura \\ 42. India \\ 43. Indonesia \\ 44. Iran, Islamic Republic of \\ 45. Jamaica \\ 46. Jordan \\ 47. Kenya \\ 48. Kuwait \\ 49. Lebanon \\ 50. Lesotho \\ 51. Libyan Arab Jamahiriya
}


52. Malawi

53. Malaysia

54. Maldives

55. Malta

56. Mauritania

57. Mauritius

58. Mexico

59. Moldova

60. Morocco

61. Mozambique

62. Myanmar

63. Namibia

64. Nicaragua

65 . Niger

66. Nigeria

67. Pakistan

68. Panama

69. Papua New Guinea

70. Paraguay

71. Peru

72. Philippines

73. Qatar

74. Republic of Korea

75. Romania

76. Saint Kitts and Nevis

77. Saint Lucia

78. Saint Vincent and the Grenadines

79. Saudi Arabia

80. Senegal

81. Seychelles

82. Singapore

83. Slovenia

84. Solomon Islands

85. South Africa

86. Sri Lanka

87. Sudan

88. Swaziland

89. Syrian Arab Republic

90. Tanzania, United Republic of

91. Thailand

92. The Former Yugoslav Republic of Macedonia

93. Togo

94. Trinidad and Tobago

95. Tunisia

96. Turkey

97. Uganda

98. United Arab Emirates

99. Uruguay

100. Venezuela

101. Viet Nam

102. Yemen

103. Yugoslavia

104. Zambia

105. Zimbabwe 
Appendix IV

${ }^{*}$ List of Parties Temporarily Categorised as Operating under Article 5 Paragraph 1 of the Montreal Protocol

1. Belize

2. Burundi

3. Chad

4. Comoros

5. Federated States of Micronesia

6. Grenada

7. Kiribati

8. Korea, Democratic People's Republic of

9. Liberia

10. Madagascar

11. Mali

12. Marshall Island

13. Mongolia

14. Nepal

15. Samoa

16. Suriname

17. Tuvalu

18. Vanuatu

19. Yemen 


\section{APPENDIX V}

\section{N.G.Os. Participating in the Periodic Meeting of the Parties to the Montreal Ozone Layer Protocol as Observers}

The regular Meeting of the Parties to the Montreal Protocol (1989-97)

\begin{tabular}{|c|c|c|c|c|c|c|c|c|c|}
\hline $\begin{array}{c}\text { Observers } \\
\text { (Name of NGO) }\end{array}$ & 1 & 2 & 3 & 4 & 5 & 6 & 7 & 8 & 9 \\
\hline $\begin{array}{l}\text { Air Conditioning and } \\
\text { Refrigeration } \\
\text { Institute }\end{array}$ & & $\bar{X}$ & $\bar{X}$ & $\bar{X}$ & & $\mathrm{X}$ & $\mathrm{X}$ & $\mathrm{X}$ & $\bar{X}$ \\
\hline $\begin{array}{l}\text { Alliance for } \\
\text { Responsible } \\
\text { Atmospheric Policy }\end{array}$ & & $\bar{X}$ & $\mathrm{X}$ & $\bar{X}$ & $\bar{X}$ & $\bar{X}$ & $\mathrm{X}$ & $\mathrm{X}$ & $\mathrm{X}$ \\
\hline $\begin{array}{l}\text { Centre for Science } \\
\text { and Environment }\end{array}$ & & & & & & $\mathrm{X}$ & $\mathrm{X}$ & & \\
\hline $\begin{array}{l}\text { European Chemical } \\
\text { Industry Federation }\end{array}$ & & & & & & & $\mathrm{X}$ & $\mathrm{X}$ & $\bar{X}$ \\
\hline Friends of Earth & $\mathrm{X}$ & $\mathrm{X}$ & $\mathrm{X}$ & $\mathrm{X}$ & $X$ & $\mathrm{X}$ & $\mathrm{X}$ & $\mathrm{X}$ & $\mathrm{X}$ \\
\hline $\begin{array}{l}\text { Greenpeace } \\
\text { International }\end{array}$ & $\mathrm{X}$ & $\bar{X}$ & $\mathrm{X}$ & $\mathrm{X}$ & $\mathrm{X}$ & $\mathrm{X}$ & $\mathrm{X}$ & $\mathrm{X}$ & $\mathrm{X}$ \\
\hline $\begin{array}{l}\text { International } \\
\text { Chamber of } \\
\text { Commerce }\end{array}$ & $\mathrm{X}$ & $\mathrm{X}$ & $\mathrm{X}$ & $\mathrm{X}$ & & & & & \\
\hline $\begin{array}{l}\text { Japan's Save the } \\
\text { Ozone Layer }\end{array}$ & & & & & & & & $\mathrm{X}$ & $\bar{X}$ \\
\hline $\begin{array}{l}\text { Japan Industrial } \\
\text { Conference for } \\
\text { Ozone Laver }\end{array}$ & & & $\mathrm{X}$ & $X$ & $X$ & $\mathrm{X}$ & $\mathrm{X}$ & $\mathrm{X}$ & $\mathrm{X}$ \\
\hline $\begin{array}{l}\text { Korean Speciality } \\
\text { Chemical Industry } \\
\text { Association }\end{array}$ & & & & & & $\mathrm{X}$ & & & $\mathrm{X}$ \\
\hline $\begin{array}{l}\text { Natural } \\
\text { Resources } \\
\text { Defence Council }\end{array}$ & $\mathrm{X}$ & $\mathrm{X}$ & & $\mathrm{X}$ & & & & & \\
\hline $\begin{array}{l}\text { World Watch } \\
\text { International }\end{array}$ & & $\mathrm{X}$ & & $\mathrm{X}$ & & & & & \\
\hline $\begin{array}{l}\text { World Wildlife } \\
\text { Fund }\end{array}$ & $\mathrm{X}$ & $\mathrm{X}$ & & & & & & & \\
\hline
\end{tabular}

*Sources of Information:

1st. UNEP/OzL.Pro. $1 / 5$, para. 4

2nd. UNEP/OzL.Pro.2/3, para. 12.

3rd. UNEP/OzL.Pro.3/11, para. 19.

4th. UNEP/OzL.Pro.4/15, para. 17.

5th. UNEP/OzL.Pro.5/12, para. 9.

6th. UNEP/OzL.Pro.6/7, para. 14.

7th. UNEP/OzL.Pro.7/12, para. 12.

8th. UNEP/OzL.Pro.8/12, para, 15.

9th. UNEP/OzL.Pro.9/12, para. 19.

This table is not meant to be inclusive and there are many other participating NGOs. 


\section{BIBLIOGRAPHY}


Aldraaca, N., 'The North American Agreement on Environmental Cooperation', 2/3 R.E.C.I.E.L. (1994) pp. 98-104.

Al-Nauimi, N. and Meese, R., International Legal Issues Arising under the United Nations Decade of International Law, (Netherlands: Kluwer Law International, 1995).

Aman, A. C., 'The Earth As Eggshell Victim: A Global Perspective on Domestic Regulation', 102 Yale Law Journal (1993) pp.2107-2122.

Amerasinghe, C. F., Local Remedies in International Law, (Cambridge, Grotius Publications Ltd. 1990).

Bales, J. S., 'Transnational Responsibility and Recourse for Ozone Depletion', 19 Boston C.I.C.L.J. (1996).

Baker, B., 'Protection, Not Protectionism: Multilateral Environmental Agreement and the GATT', 26Vanderbilt Journal of Transnational Law, (1993) pp. 437-68.

- 'Eliciting Non-Party Compliance With Multilateral Environmental Treaties: U.S. Legislation and the Jurisdictional Bases for Compliance Incentives in the Montreal Protocol', G.Y.bk.I.L. pp. 333-65.

Beacham, G., 'International Trade and the Environment: Implications of the General Agreement on Tariffs and Trade for the Future of Environmental Protection Efforts', 3 Colorado Journal of International Environmental Law \& Policy, (1992) pp. 655-682.

Beck, J. J. (eds.), International Rules: Approaches from International Law and International Relations, (New York/Oxford: Oxford U.P. 1996).

Bernhardt, R., 'International Organisation, Internal Law and Rules', Encyclopaedia of Public International Law: - International Organisations in General: International Organisations and Cooperation, vol. 5 (1982) pp. 142-45.

Barnhoorn, L. A. N. M., 'Diplomatic Law and Unilateral Remedies', 25 N.Y.bk.I.L. (1994) pp.39-81.

Barratt-Brown, E., 'Building a Monitoring and Compliance Regime Under the Montreal Protocol', 16 Yale J.I.L. (1991) pp.519-82.

Bateman, I., Pearce, D. and Turner, R. K., Environmental Economics: An Elementary Introduction, (London: Harvester Wheatsheaf, 1994).

Baxter, R., 'Multilateral Treaties As Evidence of Customary International Law', XLI B.Y.bk.I.L. (1965-66) p. 275.

Bello, J. H., 'The WTO Dispute Settlement Understanding: Less is More', 90 A.J.I.L. (1996) pp.416-18.

Benedick, R. E.,Ozone Diplomacy. New Directions in Safeguarding the Planet. (Cambridge, Mass: Harvard University Press, 1998).

Bergesen, H. O. and Parmann, G., Green Globe Yearbook of International Co-operation on Environment and Development, (Oxford: Oxford U.P. 1994).

Bernauer, T., 'The Effect of International Environmental Institutions: How We Might Learn More', 49 International Organisations, (1995) pp. 351-377.

Biermann, Saving the Atmosphere: International Law, Developing Countries and Air Pollution, (Germany: Peter Lang, 1995).

Biggs, G., 'The Montevideo Law Programme', 87 A.J.I.L. (1993) pp. 328-34.

Bilder, R. B., 'The Settlement of Dispute in the Field of the International Law of the Environment', 144 Hague Recueil (1975) pp.139-239.

Bilderbeek, S., Biodiversity and International Law, (London: I.O.S. Press, 1992).

Birnie, P., 'The Role of International Law in Solving Certain Environmental Conflicts', in Carroll, J. E., International Environmental Diplomacy, (Cambridge: Cambridge U.P. 1988) pp. 95-121. 
- International Regulation of Whaling: From Conservation of Whaling to Conservation of Whales and Regulation of Whale-Watching, 2 vols.

(New York/London/Rome: Ocean Publications Inc., 1985).

-'Environmental Protection and Development', 20 Melbourne U.L.R. (1995) pp. 67-125.

- 'Legal Techniques of Settling Disputes" The "Soft Settlement" Approach', in Butler, W. E. (ed.), Perestroika and International Law,

(The Netherlands: Kluwer Academic Publishers, 1990).

- and Boyle, A. E., International Law of the Environment, (Oxford: Oxford University Press, 1992).

- and Boyle, A. E. Basic Documents on International Law and the Environment, (Oxford: Oxford University Press, 1995).

Biswas, A. K., (ed.) The Ozone Layer: Proceeding of the Meeting of Experts Designated by Governments, International and Nongovrnmental Organisations on the Ozone Layer Organised by the United Nations Environmental Programme in Washington D.C. 1-9 March 1977, (Oxford: Pergamon Press, 1979):

Bojkov, R. D., The Changing Ozone Layer, (U.N.E.P./W.M.O., 1995).

Boss, A. and Siblesz, H. (eds.), Realism in Law-Making: Essays on International Law in Honour of William Riphagen, (Dordrecht/Boston/Lancaster: Martinus Nijhoff Publishers, 1986).

Bothe, M. (ed.), Trends in Environmental Pollution and Law, (Gland, Switzerland: I.U.C.N. 1980).

- 'International Obligations, Means to Secure Performance', Encyclopaedia of Public International Law - International Organisations in General: International Organisations and Cooperation, vol.5 (1982) pp. 101-06.

- 'Compliance Control beyond Diplomacy: The Role of Non-Governmental Actors', 27/4 E.P.L. (1997) p. 293.

Bowser, R., 'History of the Montreal Protocol's Ozone Fund', 20 I.E.R. (1991) pp. 636-40.

Bowett, D. W., The Law of International Institutions, 4th edn. (London: Sweet \& Maxwell, 1982).

-'Reservations to Non-Restricted Multilateral Treaties', XLVIII BYIL, (1977), pp. 67-92.

- (eds.), The International Court of Justice: Process, Practice and Procedure, (London, The British Institute of International and Comparative Law, 1997).

- 'Contemporary Developments in Legal Techniques in the Settlement of Diputes', 180 Hague Recueil, pp. 169-236.

Bowman, M. and Redgwell, C., International Law and the Conservation of Biological Diversity, (Great Britain: Kluwer Law International, 1995).

Boyle, A. E., 'Saving the World? Implementation and International Environmental Law Through International Institution,' 3 J.E.L. (1991) pp. 229-45.

-'Marine Pollution under the Law of the Sea Convention', 79 A.J.I.L.(1985) pp. 347-72.

- 'State Responsibility and International Liability for Injurious Consequences of Acts Not Prohibited By International Law: Necessary Distinction?' 39 I.C.L.Q. (1990) pp. 1-26.

-'State Responsibility for Breach of Obligations to Protect the Global Environment' in W. E. Butler (ed.), Control Over Compliance with International Law,

(The Hague: Kluwer Academic Publishers, 1991) pp. 69-81.

-'The Principle of Co-operation: Environment', in Lowe, V. and Warbrick, C. (eds.), The United Nations and the Principles of International Law: Essays in Memory of Michael Akehurst, (London: Routledge, 1994).

- 'International Law and the Protection of the Global Atmosphere: Concepts, Categories and Principles' in D. Freestone and Churchill, R. 


\section{Bibliography}

(eds.), International Law and Global Climate Change,

(London: Graham \& Trotman/Martinus Nijhoff, 1991).

- (ed.) Environmental Regulation and Economic Growth, (Oxford: Claredon Press, 1994).

- 'The Rio Convention on Biological Diversity' in Bowman, M. and Redgwell, C. (eds.), International Law and the Conservation of Biological Diversity, pp. 33-49.

-'Land-based Sources of Marine Pollution: Current Legal Regime', 16 Marine Policy, (January 1992) pp. 20-35.

-'Protecting the Marine Environment: Some Problems and Developments in the Law of the Sea', 16 Marine Policy, (March 1992) pp. 79-85.

-'Chernobyl and the Development of International Environmental Law' in W. E. Butler (ed.), Perestroika and International Law, (The Netherlands: Kluwer Academic Publishers, 1990).

-'Nuclear Energy and International Law: An Environmental Perspective', B.Y.bk.I.L.(1989) pp. 257-307.

- 'Dispute Settlement and the Law of the Sea Convention: Problems of Fragmentation and Jurisdiction', 46 I.C.L.Q. (1997) pp. 37-54.

-'Settlement of Disputes Relating to the Law of the Sea and the Environment', 26 Thesaurus Acroasium (1996, forthcoming) p. 259.

-'Making the Polluter Pay? Alternatives to State Responsibility in the Allocation of Transboundary Environmental Costs' in Francioni, F. and Scovazzi, T., International Responsibility for Environmental Harm, (London: Graham \& Trotman, 1991).

- 'Remedying Harm to International Common Spaces and Resources: Compensation and Other Approaches' in Harm to the EnvironmentL The Right to Compensation and the Assessment of Dameges, (New York: Oxford Clarendon Press, 1997).

- 'UNCLOS, the Marine Environment and the Settlement of Disputes' in Competing Norms in the Law of Marine Environmental Protection, (forthcoming).

Brack, D., International Trade and the Montreal Protocol, (London: The Royal Institute of International Affairs, 1996).

Brownlie, I., Principles of Public International Law, 4th edn. (Oxford: Oxford University Press 1990). Trans. by Shimada, Y. and others, Kokusaikouhou, (Japan, Seibundo, 1989).

-'A Survey of International Customary Rules of Environmental Protection', 13 Natural Resources Journal, (1973) pp. 179-89.

Brunnee, J., Acid Rain and Ozone Layer Depletion: International Law and Regulation, (Dobbs Ferry/New York, Transnational Publishers, 1988).

- and Toope, S., 'Environmental Security and Freshwater Resources: A Case for International Ecosystem Law', 6 Y.bk.I.E.L. (1994) p. 41-76.

- '"Common Interest" - Echoes from an Empty Shell?', 49 ZAORV, (1989) pp. 791-808.

Buckley, R., 'International Trade, Investment and Environmental Regulation: An Environmental Management Perspective', 27 J.W.T. (1993) pp. 101-148.

Burley, A. M., 'International Law and International Relations Theory: A Dual Agenda', 87 A.J.I.L. (1993) pp. 205-39.

Butler, W. E. (ed.), International Law and the International System, (1987).

Buzan, B., 'Negotiating by Consensus: Developments in Technique at the United Nations Conference on the Law of the Sea', 75 A.J.I.L. (1981) pp. 324-48.

Caldwell, L., International Environmental Policy: Emergence and Dimensions, 2nd edn. (Durham, NC: Duke University Press, 1990).

Camble, J. K., 'Reservations to Multilateral Treaties: A Macroscopic View of State Practice', 74 A.J.I.L. (1980) pp. 372-94. 


\section{Bibliography}

Cameron, J. and Robinson, J., 'The Use of Trade Provisions in International Environmental Agreements and Their Compatibility with the GATT', 5 Y.bk.I.E.L. (1994) pp. 3-30.

Cameron, J., Demaret, P. and Geradin, D., Trade and the Environment: The Search for Balance, 3 vols. (London: Cameron May Ltd. 1994). (London: Earthscan Publications 1996).

-and Abouchar, J., 'The Precautionary Principle: A Fundamental Principle of Law and Policy for the Protection of the Global Environment', 14 B.C.Int'i.\& Comp.L.R., (1991) pp. 1-27.

-and O'Riordon, Interpreting the Precautionary Principle, (London: Earthcan Publications Ltd., 1994).

Campbell, B. and Twum-Barima, R., Protecting the Ozone Layer through Trade Measures: Reconciling the Trade Provisions of the Montreal Protocol and the Rules of the GATT, (U.N.E.P., 1994).

Campiglio, L. (eds.). The Environment after Rio: International Law and Economics. (London/Dordercht/Boston: Graham and Trotman, Martinus Nijhoff, 1994).

Carlson, S. N., 'The Montreal Protocol's Environmental Subsidies and GATT: A Needed Reconciliation', 29 Texas I.L.J. (1994) pp. 211-230.

Caron, D., 'Protection of Stratospheric Ozone Layer and the Structure of International Environmental Law-Making', 14 Hastings International and Comparative Law Review, (1991) p. 755.

Caron, D., 'Protection of Stratospheric Ozone Layer and the Structure of International Environmental Law-Making', 14 Hastings International and Comparative Law Review, (1991)p. 755.

- 'La protection de la couche d'ozone stratospherique et la structure de l'active normative internationale en matier d'environment', A.F.D.I. (1990) p. 704.

Carroll, J. E. (ed.), International Environmental Diplomacy: The Management and Resolution of Transfrontier Environmental Problems. (Cambridge: Cambridge University Press 1988).

Cassese, A., International Law in a Divided World, (Oxford: Clarendon Press, 1986).

Carlson, S. N., 'The Montreal Protocol's Environmental Subsidies and GATT: A Needed Reconciliation', 29 Texas ILJ, (1994) pp. 211-30.

Charney, J. I., 'Universal International Law', 87 A.J.I.L. (1993) pp. 529-51.

- 'Transnational Corporations and Developing Public International Law', Duke Law Journal, (1983) pp. 748-88.

Charnovitz, S., 'Improving Environmental and Trade Governance', International Environmental Affairs, pp. 59-91.

- 'Exploring the Environmental Exceptions in GATT Article XX', 25 J.W.T. (1991) pp. 37-55.

- 'Environmentalism Confronts GATT Rules: Recent Developments and New Opportunities', 27 JWT, (1993) pp. 37-53.

- GATT and the Environment: Examining the Issues', in International Environmental Affairs, pp. 204-33.

Chayes, A. and Chayes, A. H., The New Sovereignty: Compliance with International Regulatory Agreements, (Cambridge/London: Harvard U.P. 1995).

Chazournes, L., 'Mise en oeuvre du droit international dans le domaine de la protection de l'environment: enjeux et défis', Revue générale de droit international public, (1995) pp. 37-76.

- 'Le fonds pour l'environment mondial:recherche et conquéte de son identité', XLI A.F.D.I. (1995) pp.612-32.

Cheyne, I., 'Environmental Unilateralism and the WTO/GATT System', 24 Georgia J.I.C.L. (1995) pp. 433-65.

Chinkin, C. M., 'The Challenge of Soft Law: Development and Change in International Law', 38 I.C.L.Q. (1989) pp. 850-66. 


\section{Bibliography}

Chittick, D. R., 'The Transfer of chlorofluorocarbon technologies:

A Case-Study in Industry Cooperation', ATAS Bulletin, 7(1992), pp. 194-98.

Chodosh, H. E., 'Neither Treaty nor Custom: The Emergence of Declarative International Law', 26 Texas I.L.J.(1991) pp. 87-124.

Churchill, R. R. and Freestone D., International Law and Global Climate Change. (London: Martinus Nijhoff, 1991).

- and Kütting, G. and Warren, L. M., 'The 1994 UN ECE Sulphur Protocol', 7 J.E.L. (1995) pp. 169-197.

- and Lowe, A. V., The Law of the Sea, 2nd edn.

(Manchester: Manchester U.P. 1988).

Combacau, J., 'Sanctions', 9 Encyclopeadis of Public International Law International Relations \& Legal Cooperation in General: Diplomacy \& Consular Relations, (1982) pp. 337-40.

Conforti, B., 'The Legal Effect of Non-Compliance With Rules of Procedure in the U.N. General Assembly and Security Council', 63 A.J.I.L. (1969) pp. 479-89.

Cooper, C. A., 'The Management of International Environmental Disputes in the Context of Canada-United States Relations: A Survey and Evaluation of Techniques and Mechanisms', 14 C.Y.bk.I.L. (1986) pp. 247-312.

Coplin, W. D., The Functions of International Law: An Introduction to the Role of International Law in the Contemporary World, (Chicago: Rand McNally, 1966).

Corcelle, G. and Johnson, S. P., The Environmental Policy of European Communities, (London/Dordrecht/Boston: Graham \& Trotman, 1989).

Cosbey, A. and Shaw, N., 'GATT, the World Trade Organization, and Sustainable Development', 6 International Environmental Affairs, (1994) pp. 245-72.

Cot, J. P., International Conciliation, Trans. by Myers, R., (London: Europa Publications, 1972).

Dam, K. W., 'The GATT as an International Organisation', 3 J.W.T. (1969) pp. 374-89.

D'Amato, A, et al., "Agora: What Obligation Does Our Generation we Owe to the Next? An Approach to Global Environmental Responsibility', 84 A.J.I.L. (1990) pp. 190-198.

-'Trashing Customary International Law', in 81 A.J.I.L. (1987) pp. 101-105.

Demaret, P., 'The Metamorphoses of the GATT: From the Havana Charter to the World Trade Organization', 34 Columbia J.T.L. (1995) pp. 123-71.

Danilenko, G. M. 'The New Russian Constitution and International Law', 88 A.J.I.L. (1994) pp. 451-70.

Davidson, C. B., 'The Montreal Protocol: The First Step toward Protecting the Global Ozone Layer', 20 N.Y.J.I.L.P.(1988) pp. 793-823.

Dott, L. and Schiff, H., The Ozone War, (Garden City: Doubleday \& Company, 1978).

Dunoff, J. L., 'Institutional Misfits: The GATT, the ICJ \& Trade-Environment Disputes', 15 Michigan J.I.L. (1994) pp. 1043-1128.

Dupuy, P. M., Droit International Public. Padone, (1992).

- 'Soft Law and the International Law of the Environment' 12 Michigan J.I.L. (1990) pp. 420-435.

-'The International Law of State Responsibility: Revolution or Evolution?', 11 Michigan J.I.L.(1990) pp.105-127.

- 'Humanity and the Environment', 2 Colorado Journal of International Environmental Law and Policy, (1991) pp. 201-204.

Ebbesson, J., Compatability of International and National Environmental Law, (London/The Hague/Boston: Kluwer Law International, 1996).

El-Kholy, O. A. and Tolba, M. K. (eds.), The World Environment19721992: Two Decades of Challenge. (London: Chapman and Hall, 1992). 
Elson, D. M., Atmospheric Pollution: A Global Problem, 2nd edn., (Oxford: Blackwell, 1992).

Enders, A. and Porges, A., 'Successful Conventions and Conventional Success : Saving the Ozone Layer' in Anderson, K. and Blackhurst, K, (eds.), The Greening of World Trade Issues, (London: Harvester Wheatsheaf, 1992).

Engfeldt, L., 'The United Nations and the Human Environment: Some Experience', 27 International Organisations, (1973) pp.393-412.

Esty, D. C., Greening the GATT: The Trade, Environment and the Future, (Washington D. C.: Institute for International Economics, 1994).

Faure, M. G., Enforcement Issues for Environmental Legislation in Developing Countries, (UNU/INTECH Working Paper No. 19, March 1995).

Favre, D., International Trade in Endangered Species, (London: Martinus Nijhoff Publishers, 1989).

Feraru, A. T., 'Transnational Political Interests and the Global Environment' 28 International Organisations, (1974) pp. 31-55.

Finger, M. and Princen, T., Environmental NGOs in World Politics, (London: Routledge, 1994).

Fischer, W., The Verification of International Conventions on Protection of the Environment and Common Resources, (1992).

Fitzmaurice, M. A., 'International Environmental Law as a Special Field', 25 N.Y.bk.I.L. (1994) pp. 181-226.

- and Lowe, V. (eds.), Fifty Years of the International Court of Justice, (Cambridge, Cambridge U.P., 1996).

Flinterman, C., Kwiatkowska, B., and Lammers, J. G.,Transboundary Air Pollution: International Legal Aspects of the Co-operation of States, (Boston: Martinus Nijhoff, 1986).

Fox, H., International Economic Law and Developing Countries: Some Aspects, Trans. by Ochiai, K., (Waseda, Tokyo: Keibundo, 1992, in Japanese).

Francioni, F. and Scovazzi, T. (ed.), International Responsibility for Environmental Harm, (London: Graham and Trotman, 1991).

- 'International "Soft Law": A Contemporary Assessment' in Lowe, V. and Fitzmaurice M. (eds.), Fifty Years of the International Court of Justice: Essays in Honour of Sir Robert Jennings, (Cambridge, Cambridge U.P. 1996).

Frank, T., 'Some Instances of Fairness in Establishing Environmental Normative Systems', 240 Hague Recueil, (1993) pp. 1-498.

- Fairness in International Law and Institutions, (Oxford: Clarendon Press, 1995).

- 'Legitimacy in the International System', 82 A.J.I.L. (1988) pp. 705-59.

Freestone, D., The Road from Rio: International Environmental Law after the Earth Summit', 6 J.I.L. (1994) pp. 193-218.

- and Hey, E., The Precautionary Principle and International Law, (The Netherlands: Kluwer Law International, 1996).

- and Makuch, Z., 'The New International Environmental Law of Fisheries: The 1995 United Nations Straddling Stocks Agreement', 7 Y.bk.I.E.L. (1996) p. 9.

Friedmann, W., 'The Use of "General Principles" in the Development of International Law', 57 A.J.I.L. (1963) pp. 279-299.

Gaines, S. E., 'The Polluter-Pays Principle: From Economic Equity to Environmental Ethos', 26 Texas I.L.J. (1991) pp. 436-96.

Garvey, J. I., 'Trade Law and Quality of Life - Dispute Resolution Under the NAFTA Side Accords on Labour and the Environment', 89 A.J.I.L. (1995) pp. 439-53.

Gavouneli, M., Pollution from Offshore Installations, (London/Dordrecht/Boston: Martinus Nijoff, 1995).

Gehring, T., 'International Environmental Regimes: Dynamic Sectoral Legal Systems', 1 Y.bk.I.E.L. (1990) pp. 35-56. 


\section{Bibliography}

- Dynamic International Regimes: Institutions for International

Environmental Governance, (Germany: Peter Lang, 1992).

- and Oberthür, 'The Copenhagen Meeting', 23/1 E.P.L.(1993).

Geradin, D., 'Trade and Environmental Protection: Community

Harmonisation and National Environmental Standards',

13 Yearbook of European Law, (1993) pp. 151-199

Ghebali, V. Y., The International Labour Organisation: A Study on the Evolution of U.N. Specialised Agencies, (1988).

Gold, J., 'Strengthening the Soft International Law of Exchange Arrangements', 77 A.J.I.L. (1983) pp. 443-498.

Goldie, L. F. E., 'Special Régimes and Pre-Emptive Activities in International Law', 11 I.C.L.Q. (1962) pp. 670-700.

Gray, C., Judicial Remedies in International Law, (1987).

Grimwade, N., International Trade Policy: A Contemporary Analysis, (London: Routledge, 1996).

Gündling, L., 'Status in International Law of the Principle of

Precautionary Action', 5 Int'IJ.Estuarine \& Coastal L. (1990) pp. 23-30.

- 'Compliance Assistance in International Environmental Law: Capacity Building through Financial and Technology Transfer', 39 ZaoRV (1996) pp. 796-809.

Haggard, S and Simmons, B. A., 'Theories of International Regimes' 41 International Organisations, (1987) pp.491-517.

Handl, G., 'Environmental Protection and Development in Third World Countries: Common Destiny - Common Responsibility', 20 N.Y.U.J.I.L.P. (1988) pp. 603-27.

- 'Environmental Security and Global Change: The Challenge to International Law', 1 Y.bk.I.E.L. (1990) pp. 3-33.

- 'Controlling Implementation of and Compliance with International Environmental Commitments: The Rocky Road from Rio', 5 Colorado Journal of International Environmental Law and Policy (1994) pp. 305-31.

- 'Balancing of Interests and International Liability for the Pollution of International Watercourses: Customary Principles of Law Revisited', 13 C.Y.bk.I.L. (1975) pp. 156-194.

-'Territorial Sovereignty and the Problem of Transnational Pollution', 69 A.J.I.L. (1975) pp. 50-76.

-'International Liability of States for Marine Pollution', 11 C.Y.bk.I.L. (1983) pp. 85-117.

Harris, D. J., Cases and Materials on International Law, 4th edn. (London: Sweet \& Maxwell, 1991).

Hass, P., 'Banning Chlorofluorocarbons: Epistemic Community Efforts to Protect Stratospheric Ozone', 46 International Organisations, (1992) p. 215.

- and Haas, E. B., 'Learning to Learn: Improving International Goverance', 1 Global Governance, (1995) pp. 255-285.

- and Keohane, R. O. and Levy, M. A., Institutions for the Earth: Sources of Effective International Environmental Protection, (Cambridge/ Mass./London: M.I.T. Press, 1993).

Heigh, N., 'The European Community and International Environmental Policy', 3 International Environmental Affairs, (1991) p. 160.

Heimsoeth, H., 'The Protection of the Ozone Layer', 10 E.P.L. (1983) pp. 34-36.

Henkin, L., 'International Law and the Behaviour of Nations', 114 Hague Recueil (1965) pp. 167-281.

- How Nations Behave: Law and Foreign Policy, 2nd edn.

(New York: Columbia University Press, 1979).

- and Pugh, R., Schachter, O., and Smit, H., International Law: Cases and Materials, 2nd edn. (St, Paul, Minn.: West Publishing Co. 1987). 


\section{Bibliography}

Hey, E., 'The Precautionary Concept in Environmental Policy and

Law: Institutionalising Caution', 4 Georgia I.E.L.R. (1992) pp. 303-18.

Higgins, R., Problems and Process: International Law and How We Use It, (Oxford: Clarendon Press, 1994).

Hilderland, P. M., 'The European Community's Environmental Policy, 19571992: From Incidental Measures to an International Regimes ?'

1 Environmental Politics, (1992) pp. 13-43.

Hohmann, H., Precautionary Legal Duties and Principles of Modern International Environmental Law - The Precautionary Principle:

International Environmental Law between Exploitation \& Protection, (London/Dordecht/Boston: Martinus Nijhoff, 1994).

- Basic Documents of International Environmental Law, 3 vols. (London/Dordecht/Boston, Martinus Nijhoff, 1992).

Horlick, G. N. and DeBusk, A., 'Dispute Resolution under NAFTA: Building on the U.S.-Canada FTA, GATT and ICSID', 27 J.W.T. (1993) pp. 21-41.

Hurdec, R. E., 'The GATT Legal System: A Diplomat's Jurisprudence', 4 JWT, (1970) pp.-665.

- The GATT Legal System and World Trade Diplomacy, (1975).

Houtte, H. V., The Law of International Trade, (London: Sweet \& Maxwell, 1995).

Hunt, K. J., 'International Environmental Agreements in Conflict with GATT-Greening GATT after the Urguay Round Agreement', 30 The International Lawyer, (1996) pp. 163-191.

Hurlbut, D., 'Beyond the Montreal Protocol: Impact on Nonparty States and Lessons for Future Environment Protection Regimes', 4 Colorado Journal of International Environmental Law \& Policy, (1993) pp. 344-368.

Hurlock, M. H., 'The GATT, U.S. Law and the Environment: A Proposal to Amend the GATT in Light of the Tuna/Dolphin Decision',

92 Columbia L.R. (1992) pp. 2098-2161.

Hutter, B. M., Compliance: Regulation \& Environment, (Oxford: Oxford University Press, 1997).

Iluyomade, B. O., 'The Scope and Content of a Complaint of Abuse of Right in International Law', 16 A.J.I.L. (1975) pp. 47-92.

Ishibashi, K., 'The Effectiveness of 'Supervision' or 'Compliance Control' in the Implementation of Multilateral Environmental Treaties',

15/2 Kagawa Hogaku, (1995) pp. 53-128 (in Japanese).

I.U.C.N., A Guide to the Convention on Biological Diversity, (Cambridge: I.U.C.N. 1994).

Iwasawa, Y., WTO Dispute Settlement, (Japan: Sanseido, 1995, in Japanese).

- 'WTO Dispute Settlement: The Significance of the 1994 Dispute Settlement Undersyanding', 1071 Jurist, (1995) pp. 53-58.

Iwata, N., 'Environmental Problems and Trade Disputes in the WTO System', 6 Trade Journal, (1996, in Japanese).

Jachtenfuchs, M., 'The European Community and the Protection of Ozone Layer', 18 Journal of Common Market Studies, (1990) p. 261.

Jackson, J. H., Davey, W. J., and Sykes, A. O., Legal Problems of International Economic Relations: Cases, Materials and Text, 3rd edn. (St. Paul, Minn.: West Publishing Co. 1995).

- The World Trading System: Law \& Policy of International Economic Relations, 2nd edn. (1997).

- and and Croley, S. P., 'WTO Dispute Procedures, Standard of Review, and Difference to National Governments', 90 A.J.I.L. (1996) pp.193-213.

- Restructuring the GATT System, (London: Pinter Publishers, 1990).

Jackson, R. H., Quasi-States: Sovereignty, International Relations and the Third World, (Great Britain: Cambridge University Press, 1990).

Jacobs, F. G., and White, R. C. A., The European Convention on Human Rights, (Oxford: Clarendon Press, 1996).

Jennings, R., 'The Role of the International Court of Justice in the 
Development of International Protection Law', 3 R.E.C.T.E.L. pp. 241-44.

-'What is International Law and How Do We Tell It When We See

It?', 37 Annuaire suisse de droit international, (1981) pp.58-88.

Japan M.I.T.I. (ed.), The Ozone Protection Law, (Japan: Gyosei, 1991).

Jurgielewicz, L., 'Global Environmental Change and International Law', Ph.D. Thesis, London University, (1994).

Kanehara, A., 'Precautionary Remedies in the Convention on Global Environmental Protection', 93 The Journal of International Law and Diplomacy, (1994) pp. 160-203 (in Japanese).

- 'The "Legal Damage" to be Remedied by the Law of State Responsibility and the Concept of General Interest: A Critical Review', 94 The Japanese Journal of International Law \& Policy, (October 1995) pp. 1-50.

Kennedy, D., 'The Sources of International Law', 2 A.U.J.I.L.P. (1987) pp. 1-96.

Keohane, O., Levy, M. C., Institutions for Environmental Aid, (Cambridge/London: The M.I.T. Press, 1996).

Kimball, L., 'Toward Global Environmental Management: the Institutional Setting', 2 Y.bk.I.E.L. (1991) pp. 18-42.

Kindt, J and Menefee, S., 'The Vexing Problem of Ozone Depletion in International Law and Policy', 24 Texas I.L.J.(1989) pp. 261-293.

Kingsbury, B., 'The Tuna-Dolphin Controversy, The World Trade Organization, and the Liberal Project to Reconceptualize International Law', 6 Y.bk.I.E.L. (1994) pp. 1-41.

- 'Environment and Trade: The GATT/WTO Regime in the International Legal System', pp. 189-231, in Boyle, A. E. (ed.), Environmental Regulation and Economic Growth, (Oxford: Clarendon Press, 1994).

- and Hurrell, A. (eds.),The International Politics of the Environment: Actors, Interests, and Institutions (Oxford: Clarendon Press, 1992).

- and Robert, A., United Nations, Divided World: The UN's Roles in International Relations, 2nd edn. (Oxford: Claredon Press, 1993).

Kirgis, F. L. Jr., International Organizations in Their Legal Setting, 2nd edn. (St. Paul, Minn.: West Publishing Co. 1993).

- 'Standing to Challenge Human Endeavours that could Change the Climate', 84 A.J.I.L. (1990) pp. 525-30.

Kiss, A., Droit international de l'environment, (Paris: Pedone, 1989).

- and D. Shelton, International Environmental Law, (London/New York: Transnational Publishers, 1991).

-(ed.), A Law for the Environment, (London: I.U.C.N. 1994).

-'Nouvelles tendances en droit international de l'environnment', 16 G.Y.bk.I.L. pp. 241-63.

-'Protection de l'environment', 34 Annuaire Français de Droit International, (1988) pp. 701-708.

- 'Mechanisms of Supervision of International Environmental Rules', in Essays on the Development of the International Legal Order, (The Netherlands: Sijthoff \& Noordhoff, 1980) pp. 99-112.

- 'Compliance with International and European Environmental Obligations', Hague Y.bk.I.L. (1996) pp. 45-54.

- 'La notion de patrimoine commun de l'humanité', 175 Hague Recueil, pp. 98-256.

Komuro, N., 'The WTO Dispute Settlement Mechanism: Coverage and Procedures of the WTO Understanding', 23 J.W.T. (1993) pp. 5-95.

Koskenniemi, M.,'Breach of Treaty or Non-Compliance? Reflections on the Enforcement of the Montreal Protocol', 3 Y.bk.I.E.L. (1992) pp. 123-62.

-'Peaceful Settlement of Environmental Disputes', 60 Nordic J.I.L. (1991) pp. 73-92.

Krämer, L., 'Community Environmental Law: Towards a Systematic Approach', 11 Yearbook of European Law 1991, (1992) pp. 151-84. 


\section{Bibliography}

- Focus on European Environmental Law

(London: Sweet and Maxwell 1992).

- E. C. Treaty and Environmental Law, 2nd edn.

(London: Sweet and Maxwell 1995).

Krasner, S. (ed.), International Regimes,

(London: Cornell U.P. 1983).

- Defending the National Interest: Raw Materials and U.S. Foreign Policy, (Princeton: Princeton University Press, 1978).

Kummer, K., International Management of Hazardous Wastes:

The Basel Convention and Related Legal Rules,

(Oxford: Oxford U.P. 1995).

- 'Providing Incentives to Comply with Multilateral Environmental Agreements: An Alternative to Sanctions',

European Environmental Law Review, (October 1994) pp. 256-63.

Kuwabara, S., The Legal Regime of the Protection of the Mediterranean against Pollution from Land-Based Sources, (London, Martinus Nijhoff Publishers, 1984).

Kuyper, P. J., 'The Law of GATT as a Special Field of International Law', 25 N.Y.bk.I.L. (1994) pp. 227-57.

Lachs, M., 'The Development and General Trends of International Law in', Our Time', 151 Hague Recueil (1980) pp.161-252.

Lammers, J., 'Efforts to Develop a Protocol on Chlorofluorocarbons to the Vienna Convention for the Protection of the Ozone Layer', 1 Hague Yearbook of International Law, (1988) pp. 255-269.

-and Kalshoven, F., Kuyper P. J., Essays on the Development of the International Legal Order in Memory of Haro F. Van Panhuys, (Maryland: Sijthoff \& Noordhoff, 1980).

- (eds.), Transboundary Air Pollution, (Dordrecht/Boston/Lancaster, Martinus Nijhoff Publishers, 1986).

Landy, E. A., The Effectiveness of International Supervision: Thirty Years of ILO Experience, (London: Stevens \& Sons, 1966).

Lang, J., 'The Ozone Layer Convention: a New Solution to the Question of Community Participation in 'Mixed' International Agreements',

23 Common Market Law Review, (1986) pp. 157-176.

Lang, W., 'Diplomacy and International Environmental Law-Making: Some Observations', 3 Y.bk.I.E.L. (1992) p. 108-122.

- (eds.), Environmental Protection and International Law, (London/Dordrecht/Boston: Martinus Nijhoff, 1992).

- 'Les mesures commercials au service de la protection de l'environment' R.G.D.I.P. (1995).

- (ed.), Sustainable Development and International Law, (London: Martinus Nijhoff, 1995).

- 'Compliance-Control in Respect of the Montreal Protocol', The Proc. A.S.I.L. 89th Annual Meeting (1995) p. 206.

- 'Is the Protection of the Environment a Challenge to the International Trading System?', 7 Georgetown I.E.L.R. (1995) pp. 463-83.

- 'Ozone Layer', 4 Y.bk.I.E.L.(1993) p. 139.

- 'Negotiations on the Environment' in Kremenyuk, V. A., International Negotiation, (Oxford: Jossey-Publishers, 1991) pp. 343-356.

- 'The United Nations and International Environmental Law', IX International Geneva Yearbook 1995, (Switzerland, 1995) pp. 47-59.

- 'International Environmental Agreements and the GATT: The Case of Montreal Protocol', 3-4 Internationaler Handel und Umwelt, (1993) pp. 364-372.

Lauterpacht, The Function of International Law in the International Community, (Oxford: Clarendon Press, 1933).

Lawrence, P. M., 'International Legal Regulation for Protection of the Ozone Layer: Some Problems of Implementation', 2 J.E.L. (1990) pp. 17-52. 
Lee, J. R., 'Process and Product: Making the Link between Trade and the Environment', International Environmental Affairs, pp. 321-347.

Lister, C., European Union Environmental Law: A Guide for Industry, (Chichester: John Wiley \& Sons, 1996).

Litfin, K., Ozone Discourses: Science and Politics in Global Environmental Cooperation, (New York: Columbia U.P. 1994).

Lowe, V. and Warbrick, C., The United Nations and the Principles of International Law: Essays in Memory of Michael Akehurst, (London: Routledge, 1994).

Lukashuk, I. I., 'The Principle Pacta Sunt Servanda and the Nature of Obligation under International Law', 83 A.J.I.L. (1989) pp.513-18.

Lyster, S., 'The Convention on the Conservation of Migratory Spiecies of Wild Animals', 29 N.R.J. (1989) pp. 979-1000.

- International Wildlife Law: An Analysis of International Treaties Concerned with the Conservation of Wildlife, (Great Britain: Cambridge University Press, 1985).

Makuch, Z., 'The World Trade Organisation and the General Agreement on Tariffs and Trade' in Werksman, J. (ed.), Greening International Institutions, (London: Earthcan Publications, 1996).

Marceau, G., 'Transition from GATT to WTO: A Most Pragnatic Operation', 29 J.W.T. (1995) pp. 149-63.

Mathews, J. T. (ed.). Preserving the Global Environment: The Challenge of Shared Leadership. (New York: W. W. Norton and Co. 1991).

Matsushita, M., International Economic Law, (Japan, Yuhikaku, 1996, in Japanese).

McRae, A. D., 'The Legal Effects of Interpretative Declarations', 49 B.Y.bk.I.L. (1978).

Meese, R. and Al-Nauimi, N., International Legal Issues Arising under the United Nations Decade of International Law, (1995).

Merrills, J. G., International Dispute Settlement, (Cambridge: Grotius Publications Ltd. 1991).

Mertens, S. K., 'Towards Accountability in the Restructured Global Environmental Facility', 3 R.E.C.I.E.L. (1994) pp. 105-117.

M'Gonigle, R. M., '"Developing Sustainability" and the Emerging Norms of International Environmental Law: the Case of Land-Based Marine Pollution Control', 13 C.Y.bk.I.L. (1990) pp.169-225.

- and Zacher, M. W., Pollution, Politics and International Law, (Berkley/Los Angeles/London: Unversity of California Press, 1979).

Miller, D., 'Effectiveness of Regional Seas Agreements', 24/2/3 E.P.L.(1994) p. 56.

Milner, H., 'International Theories of Cooperation Among Nations: Strength and Weaknesses', 44 World Politics, (1992) pp. 466-96.

Minami, S., 'The Development of International Environmental Law and E.I.A.', Hitotsubashi Law Review (1996) pp. 190-208 (in Japanese).

Morgenstern, F., 'Wilfred Jenks in the I.L.O.', 46 B.Y.bk.I.L. (1972-73) pp. xvi-xxx.

Morgenthau, H. J., Politics among Nations: The Struggle for Power and Peace, (New York: Knopf, 1962).

Morrisette, P. M., 'The Evolution of Policy Responses to Stratospheric Ozone Layer', 29 N.R.J. (1989) pp. 793-820.

Müllerson, R., International Law, Rights and Politics: Developments in Eastern Europe and the CIS, (London: Routledge, 1994).

Murase, S., Perspectives From International Economic Law on transnational Environmental Issues, 253 Hague Recueil(1995) p. 287.

- and Okuwaki, N., Furukawa, T., and Tnanaka, T., Indicators of Contemporary International Law, (Tokyo: Yuhikaku, 1994, in Japanese).

- 'The Principle of Good Faith in the Implementation of International Obligations: The Function of Complaint Procedures in the Framework of 
International Régimes', 38 Sophia University Law Review, (1995) pp. 189-221 (in Japanese).

- 'The Changing Views on the Sources of International Law', 25 Rikkyo Review of Law and Politics, (1985) pp. 81-111.

Murray, T. and Walter, I., 'Quantitative Restrictions, Developing Countries, and GATT', 11 J.W.T. (1977) pp. 391-421.

Nadelmann, E. A., 'Global Prohibition Regimes: The Evolution of Norms in International Society', 44 International Organisations, (1990) pp. 479-526.

Nanda, V. P., 'Global Warming and International Environmental Law - A Preliminary Inquiry', 30 Harvard I.L.J. (1989) p. 375.

Nilsson, S. and Pitt, D., Protecting the Atmosphere: The Climate Change Convention and Its Context, (London: Earthcan Publications Ltd. 1994).

Nolkaemper, A., The Legal Regime for Transboundary Water Pollution: Between Discretion and Constraint, (London: Martinus Nijhoff, 1993).

Nomura, Y. and Sakumoto, N., Environmental Law of Developing Countries, (1996, in Japanese).

Ntambirweki, J., 'The Developing Countries in the Evolution of an International Environmental Law', 14 Hasting I.C.L.R. (1991) pp. 905-28.

O'Connell, M. E., 'Enforcing the New International Law of the Environment', 35 G.Y.bk.I.L. (1992) pp. 292-32.

O'Connell, D. P., International Law, 2 vols. (London: Stevens \& Sons, 1970).

O'Connor, J. F., Good Faith in International Law, (Great Britain, Dartmouth Publishing Company, 1991).

Ohiorhenuan, J. and Wunker, S., Capacity Building Requirements for Global Environmental Protection, (G.E.F. Working Paper no. 12).

Ogawa, K., The Law of Treaties, (Japan, Toshindo, 1989, in Japanese).

Okowa, P. N., 'Procedural Obligations in International Environmental Agreements', 67 B.Y.bk.I.L.(1996) pp. 275-336.

- 'The Europan Community and International Environmental Agreements', 15 Yearbook of European Law, (1995) pp. 169-192.

Oda, S. (eds.), Modern International Law, (Japan, Yuhikaku, 1986).

Onuf, N. G., 'International Legal Order As a Idea', 73 A.J.I.L. (1979) pp. 244-66.

Onuma, Y. (ed.), Inter-Civilisational Law: Cases and Materials, (Japan, Toshindo, 1996, in Japanese)

Oppenheim, L. (Lauterpacht, H. [ed.] ), International Law: Disputes, War and Neutrality, (London: Longman, 1952).

Ott, H., 'The New Montreal Protocol: A Small Step for the Protection of the Ozone Layer, a Big Step for International Law and Relations', 2 Law and Politics in Africa and Asia, (1991) pp. 188-208.

Palmer, G., 'New Ways to Make International Environmental Law', 86 A.J.I.L. (1992) pp. 259-283.

Papasavva, S. and Moomaw, W. R., 'Adverse Implications of the Montreal Protocol Grace Period for Developing Countries', 9 International Environmental Affairs, (1997) pp. 219-231.

- (eds.), International Environmental Law and World Order, (St. Paul, Minn.: West Publishing Co. 1994).

Patlis, J. M., 'The Multilateral Fund of the Montreal Protocol: A Prototype for Financial Mechanisms in Protecting Global Environment', 25 Cornell I.L.J. (1992) pp. 181-230.

Patterson, E., 'GATT and the Environment: Rules Changes to Minimize Adverse Trade and Environmental Effects', 26 J.W.T. (1992) pp. 99-109.

Pescatore, P., 'The GATT Dispute Settlement Mechnism: Its Present Situation and Its Prospects', 27 JWT, (1993) pp. 5-20.

Petersmann, E., 'International Competition Rules for the GATT-MTO World 
Trade and Legal System', 27 JWT, (1993) pp. 35-86.

-'International Trade Law and International Environmental Law':

Prevention and Settement of International Environmental

Disputes in GATT', 27 J.W.T. (1993) pp. 43-81.

- and Detlev, C. D., (eds.), Foreign Trade in the Present and a New Economic

Order, (Boulder, Co.: Westview, Fribourg U.P. 1988).

- 'Violation-Complaints and Non-Violation Complaints in

Public International Trade Law', 34 G.Y.bk.I.L. (1991) pp.175-229.

- 'The Dispute Settlement System of the WTO and the Evolution of the GATT

Dispute Settlement System Since 1948', 31 C.M.L.R.(1994) pp. 1157-1244.

- The GATT/WTO Dispute Settlement System: International Law,

International Organisations and Dispute Settlement,

(London/The Hague/Boston: Kluwer Law International, 1997).

- International and European Trade Law and Environmental Law after

Uruguay Round,

(London/The Hague/Boston: Kluwer Law International, 1996).

- (ed.), International Trade Law and the GATT/WTO Dispute Settlement System, (London/The Hague/Boston, Kluwer Law International, 1997).

Petsonk, C. A., 'Recent Developments in International Organisations: The Role of the United Nations Environmental Programme (UNEP) in the Development of International Environmental Law',

5 A.U.J.I.L.P. (1990) pp. 351-391.

Pisillo-Mazzeschi, R., 'The Due Diligence Rule and the Nature of the International Responsibility of States', 35 G.Y.bk.I.L. (1992) pp. 9-51.

Ragazzi, M., The Concept of International Obligations Erga Omnes, (New York: Oxford U.P. 1997).

Rama-Montaldo, M., 'International Legal Personality and Implied Powers of International Organisations', 14 B.Y.bk.I.L. (1970) pp.111-55.

Rege, V., 'GATT Law and Environment-Related Issues Affecting the Trade of Developing Countries', 28 J.W.T. (1994) pp. 95-169.

Read, J. F., 'The Trail Smelter Dispute', 1 C.Y.bk.I.L. (1963) pp. 213-29.

Reistein, R. A., 'Trade and the Environment: The Case for and against Unilateral Actions' in Lang, W. (ed.), Sustainable development and International Law, (London: Martinus Nijhoff/Graham \& Trotman, 1995).

Rest, A., 'Ecological Damage in Public International Law', 22/1 E.L.P. (1992) p. 31.

-'Need for an International Court for the Environment? Underdeveloped Legal Protection for the Individual in Transboundary Litigation', 24/4 E.L.P. (1994) pp. 173-87.

Rittberger, V., (ed.), Régime Theory and International Relations, (Oxford: Clarendon Press, 1992).

Robins, N., 'European Community Funding for the Environment in Developing Countries', 3 R.E.C.I.E.L. (1994) pp. 127-32.

Robinson, N. A., 'Universal and National Trends in International Environmental Law', 23/3/4 E.P.L. (1993) p. 148.

Roht-Arriaza, N., 'Private Voluntary Standard-Setting, the International Organisation for Standardization, and International Environmental LawMaking', 6 Y.bk.I.E.L. (1995) pp. 107-63.

Posencranz, A., 'The ECE Convention of 1979 on Long-Range Transboundary Air Pollution, 75 A.J.I.L. (1981) pp. 975-982.

Rowlands, I. H., The Politics of Global Atmospheric Change, (Manchester/New York: Manchester University Press, 1995).

Rubin, H., International Technology Transfer, (London/The Hague/Boston Kluwer Law International, 1996).

Sachariew, K., 'Promoting Compliance With International Environmental Legal Standards: Reflections on Monitoring and Reporting Mechanisms', 2 Y.bk.I.E.L. (1991) pp. 31-52.

-'The Definition of Thresholds of Tolerance For Transboundary 


\section{Bibliography}

Environmental Injury Under International Law: Development and Present Status', 37 N.I.L.R. (1990) pp. 193-206.

Sands, P. 'European Community Environmental Law: The Evolution of a Regional Regime of International Environmental Protection', 100 Yale Law Journal, (1991) pp.2511-2523.

-(eds.).Documents in International Environmental Law: Principles of International Environmental Law IIA, (Manchester: Manchester University Press, 1994).

- (ed.), Greening International Law, (London: Earthcan Publishing Limited, 1993).

- 'Methods to Expedite Environment Protection: International Ecostandards', 66 A.J.I.L. (1972) pp. 37-59.

- Principles of International Environmental Law: Frameworks, Standards and Implementation, (Manchester, New York:

Manchester University Press 1995).

-'International Law in the Field of Sustainable Development', 66 B.Y.bk.I.L. (1995) pp. 303-81.

- 'The Environment, Community and International Law', 30 Harvard I.L.J. (1989).

Sand, P. H., 'UNCED and the Development of International Environmental Law', 3 Y.bk.I.E.L. (1992) p. 3.

- 'International Economic Instruments for Sustainable Development: Sticks, Carrots and Games', 26 Indian Y.bk.I.L. (1996) pp.1-16.

- Marine Environmental Law in the United Nations Environmental Programme: An Emergent Eco-Regime.

(New York: Tycooly Publishing 1988).

-'The Vienna Convention is Adopted', 27/5 Environment, (1985) pp. 19-23.

-'New Approaches to Transnational Environmental Disputes', 3 International Environmental Affairs,(1991) pp. 193-206.

-Lessons Learned in Global Environmental Governance, (Washington, D. C.: World Resources Institute, 1990).

Trans. by Takamura, Y and Shinobu, T., Kokusaikankyo kanri no kyokun, (Japan, Kokusaishoin, 1994).

-'International Cooperation: The Environmental Experience' in Mathews, J. T., (ed.), Preserving the Global Environment: the Challenge of Shared Leadership, (U.S.A.: W.W.Norton \& Company, 1991).

- 'Whither CITES? The Evolution of a Treaty Regime in the Borderland of Trade and Environment', 8 EJIL (1997) pp. 29-58.

- (ed.), The Effectiveness of International Environmental Agreements: A Survey of Existing Legal Instruments, (Cambridge: Grotius, 1992).

Sato, T., Evolving Constitutions of International Organisations, (London/The Hague/Boston, Kluwer Law International, 1996).

Schachter, O., 'Recent Trends in International Law Making', in 12 A.Y.I.L. (1988-89) pp. 1-15.

- 'United Nations Law', 88 A.J.I.L. (1994) pp. 1-23.

- 'Recent Trends in International Law Making', 12 Australian Y.bk.I.L. (1989) pp. 1-15.

- and Joyner, C. C. (eds.), United Nations Legal Order, 3 vols. (Cambridge: Cambridge U.P./A.S.I.L., 1995).

Schermers, H. G. and Blokker, N. M., International Institutional Law: Unity and Diversity, 3rd edn. (London, Martinus Nijhoff Publishers, 1995).

Schlagenhof, M., 'Trade Measures Based on Environmental Process and Production Methods', 30 J.W.T. (1995) pp. 123-55.

Schlickman, J. A. (ed.), International Environmental Law and Regulation, (1991).

Schneider, J., World Public Order of the Environment: Towards an International Ecological Law and Organisation. (Toronto: University of Toronto Press, 1979). 


\section{Bibliography}

Schoenbaum, T. J., 'Free International Trade and Protection of the Environment: Irreconcilable Conflicts', in "Agora: Trade and Environment," 86 A.J.I.L. (1992) p. 700.

- 'International Trade and Protection of the Environment: The Continuing Search for Reconciliation', 91 A.J.I.L. (1997) pp. 268-313.

Schrijver, N., Sovereignty over Natural Resources: Balancing Rights and Duties, (Cambridge: Cambridge University Press, 1997).

- (eds.), Joint Implementation to Curb Climate Change: Legal and Economic Aspects, (Dordrecht/Boston/London: Kluwer Academic, 1994).

Schultz, J., 'The GATT/WTO Committee on Trade and the Environment Toward Environmental Reform', 89 A.J.I.L. (1995) pp. 423-39.

-'Environmental Reform of the GATT/WTO International Trading System', 18 World Competition, (1994) pp. 77-113.

Schwarzenberger, G., A Manual of International Law, 5th edn. (London: Stevens \& Sons Ltd., 1967).

- The Dynamics of International Law, (Great Britain: Professional Books, 1976).

- 'The Most-Favoured-Nation Standard in British Practice', 22 B.Y.bk.I.L. (1945) pp. 96-121.

- The Frontiers of International Law, (1962).

Seidl-Hohenveldern, I., International Economic Law,

(The Netherlands: Martinus Nijhoff, 1989).

- 'International Economic "Soft Law"', 163 Hague Recueil,pp. 165-246.

Shaw, M. N., International Law, 4th (Great Britain: Cambridge U.P. 1997).

Shh, W. C., 'Multilateralism and the Case of Taiwan in the Trade Environment Nexus: The Potential Conflict between CITES and GATT/WTO', 30 J.W.T. (1996) pp. 109-139.

Shklar, J. N., Legalism, (1964), Trans. by Tanaka, S., (Japan: Iwanami-Shoten, 1981, in Japanese).

Simma, B., 'Self-Contained Regimes', 16 N.Y.bk.I.L. (1985), pp. 111-36.

Sjoberg, H., 'The Global Environmental Facility' in Werksman, J. (ed.), Greening International Institutions, (London, Earthscan Publications Ltd., 1996) pp. 148-62.

Sjostedt, G. (ed.), International Environmental Negotiation, (London: SAGE Publications, 1993).

Skilton, T. E., 'GATT and the Environment in Conflict: The Tuna-Dolphin Dispute and the Quest for an International Conservation Strategy', 26 Cornell Int'l L.J. (1993) p. 455.

Sohn, L. B., 'Settlement of Disputes', Hague Recueil, pp. 259-80.

Soon, A. (ed.), Implementation of the Law of the Sea Convention through International Institutions, (Honolulu: The Law of the Sea Institute, 1990).

Sørensen, M., (ed.), Manual of Public International Law, (London: St Martin;s Press, 1968).

Spector, B. I., Sjostedt, G. and Zartman, I. W., Negotiating International Regimes: Lessons Learned from the United Nations Conference on Environment and Development (UNCED), (London: Martinus Nijhoff, 1994).

Spero, J. E., The Politics of International Economic Relations, 4th edn. (London: Routledge, 1990).

Spinedi, M., 'Les conséquences juridiques d'un fait internationalement illicite causant un dommage a l'environnement' in Francioni, F. and Scovazzi, T., International; Responsibility for Environmental Harm, (London: Graham \& Trotman, 1991).

Springer, A. L., The International Law of Pollution: Protecting the Global Environment in a World of Sovereign States, (London: Quoroum Books, 1983). 
Sprinz, D. and Vaahtoranta, T., 'The Interest-Based Explanation of International Environmental Policy', 48 International Organisations, (1994) pp. 77-105.

Skubiszewski, K. 'Enactment of Law by International Organisation' XLI B.Y.bk.I.L. $(1965-66)$ p. 198.

Stein, R. E., 'The Settlement of Environmental Disputes: Towards a System of Flexible Dispute Settlement', 12 Sry.J.Int'1 L. Com. (1985) pp. 283-98.

Steiner, H. J. and Alston, P., International Human Rights in Context: Law, Politics, Morals, (Oxford: Clarendon Press, 1996).

Susskind, L., Environmental Diplomacy: Negotiating More Effective International Agreements. (New York: Oxford University Press, 1992).

Széll. P., 'Compliance Regimes for Multilateral Environmental Agreements: A Progress Report', 27/4 E.P.L. (1997) pp. 304-07.

- 'Decision-Making under Multilateral Environmental Agreements', 26/5 E.P.L. (1996) pp. 210-14.

Swanson, T. M., 'The Evolving Trade Mechanisms in CITES', 1 R.E.C.I.E.L. (1992) pp. 57-63.

Talbot, L. B., 'Recent Development in the Montreal Protocol on Substances that Deplete the Ozone Layer: The June 1990 Meeting and Beyond', 26 The International Lawyer(1992).

Takamura, Y., 'The Concept of Sustainable Development and Environmental Interests' in Otani, Y. (ed.), The Concept of Common Interests and International Law, (Japan, Kokusaishoin, 1993).

Takano, Y., International Institutional Law, (Japan: Yuhikaku, 1961, in Japanese).

Takashima, T., International Law of Development, (Japan, Keiotsushin, 1995).

Tarasofsky, 'Ensuring Compatability between MEAs and GATT/WTO', 7 Y.bk.I.E.L. (1996) pp. 52-74.

Thierry, H., Combacau, J., Sur S., and Vallée, C., Droit international public, (Paris: Editions Montchrestien, 1986).

Tiar, T., The Role of UNEP in the Development of International Environmental Law, (Ph. D. thesis, University of Southampton, 1986).

Tinker, C., 'Environmental Planet Management By the United Nations', 22 N.Y.U.J.I.L.P. (1990) p. 793.

Tolba, M. K. (eds.), The World Environment 1972-1992: Two Decades of Challenge, (London/New York/Tokyo, Chapman \& Hall, 1992).

Townsend, M., 'The International Transfer of Technology', 23/2 E.P.L. (1993) pp. 66-69.

Trip, J., 'The UNEP Montreal Protocol: Industrial and Developing Countries Sharing the Responsibility for Protecting the Stratospheric Ozone Layer', 20 N.Y.U.J.I.L.P. (1988) pp. 733-52.

Tunkin, G., 'International Law in the International System', 147 Hague Recueil, pp. 1-218.

- Theory of International Law, Trans. by Butler, W.E., (Cambridge: Harvard University Press, 1974).

Twum-Barima, R. and Campbell, L. B., Protecting the Ozone Layer Through Trade Measures: Reconciling the Trade Provisions of the Montreal Protocol and the Rules of the GATT, (Geneva: UNEP, 1994).

U.N.E.P., Handbook for the International Treaties for the Protection of the Ozone Layer, 4th edn. (Kenya: UNEP, 1996).

- The Use of Trade Measures in Selected Multilateral Environmental Agreements, (U.N.E.P. 1995).

- Regulations to Control Ozone-Depleting Substances: A Guidebook, (U.N.E.P./Stockholm Environment Institute, 1996).

- Study on the Financial Mechanism of the Montreal Protocol, (COWIconsult/Goss Gilroy Inc. March 1995).

- Environmental Effects of Ozone Depletion: 1994 Assessment, 
(U.N.E.P. November 1994).

- UNEP's New Way Forward: Environmental Law and Sustainable Development, (1995).

- and W.M.O., Scientific Assessment of Ozone Depletion 1994, (W.M.O. Global Ozone Research \& Monitoring Project: Report no. 37).

United Nations, Handbook on the Peaceful Settlement of Disputes between States, (New York: United Nations, 1992).

United States General Accounting Office, International Environment: International Agreements Are Not Well Monitored, (January 1992).

Usuki, T., 'The Development of Dispute Settlement Procedures in Global Environmental Conventions' in Sugihara, T. (ed.), International Law for Dispute Settlement: Essays in Celebration of Judge Shigeru Oda's Seventieth Birthday, (Japan: Sanseido, 1997) pp. 167-92 (in Japanese).

Utton, A. E., 'International Environmental Law and Consultation Mechanisms', 12 Columbia J.T.L. (1973) pp. 56-72.

Vallette, J., Allied Signal, Quimobasicos and the Frio Banditos: A Case Study of the Black Market in CFCs - An Ozone Action Report, (Washington, D. C.: Ozone Action, Inc. 1996).

Valticos, N., 'Les commissions d'enquéte de I'Organisation internationale du travail', 91 Revue générale de droit international public,(1987) pp. 847-79.

van Bergeijk, P. A. G., 'International Trade and the Environmental Challenge', 25 J.W.T. (1996) pp. 105-115.

van Lierof, R. F., (ed.), 'Compliance with International Environmental Treaties', Proc.A.S.I.L. (1997) pp. 234-58.

van Mensbrugghe, Y., 'Legal Status of North Sea Conference Declarations', 5 I.J.E.C.L. (1990) pp. 15-22.

Verhoosel, G., 'International Transfer of Environmentally Sound Technology: The New Dimension of an Old Stumbling Block', 27/6 E.P.L.(1997).

von Bogdandy, 'The Non-Violation Procedure of Article XXIII:2, GATT: Its Operation and Rationale', 26 J.W.T. (1992) pp. 95-111.

Victor, D. G., The Early Operation and Effectiveness of the Montreal Protocol's Non-Compliance Procedure, (Austria, IIASA, 1996).

- The ILO System of Supervision and Compliance Contro: A Review and Lessons for Multilateral Environmental Agreements, (Austria, IIASA, 1996).

- Design Options for Article 13 of the Framework Convention on Climate Change: Lessons from the GATT Dispute Panel System, (Austria, IIASA, 1996).

- ' The Montreal Protocol's Non-Compliance Procedure: Lessons for Making Other International Environmental Régimes More Effective' in Lang, W. (ed.), The Ozone Treaties and Their Influence on the Building of Environmental Régimes, Austrian Foreign Policy Documentation, Austrian Ministry of Foreign Affairs.

Virally, M., 'Good Faith in Public International Law', 77 A.J.I.L. (1983) pp. 130-34.

Wapner, P., 'Politics Beyond the State: Environmental Activism and World Civic Politics', 44 World Politics, (1995) pp. 311-40.

Ward, H., 'Trade and Environment in the Round-And After', 6 J.E.L. (1994) pp. 263-95.

Weatherill, S. and Beaumont, P., EC Law: The Essential Guide to the Legal Workings of the European Community, (London: Penguin Books, 1993).

Weiss, E. D., In Fairness to Future Generations: International Law, Common Patrimony, and Intergenerational Equity, (Tokyo: United Nations University, 1989). Trans. by Iwama, T., (Japan: Nihonhyoronsha, 1992). 


\section{Bibliography}

- 'Strengthening National Compliance with International Environmental Agreements', $27 / 4$ E.P.L.(1997).

- and Jacobson, H. K., 'Strengthening Compliance with International Environmental Accords: Preliminary Observations from a Collaborative Project', 1 Global Governance, (1995).

Wesierski, G., 'A Framework for Understanding Soft Law', 30 McGill L.J. (1984) pp. 37-88.

Wettestad, J., 'Acid Lessons? LRTAP Implementation and Effectiveness', 7 G.E.C. (1997) pp. 235-49.

Weksman, J., 'Trade Sanctions Under the Montreal Protocol', 1 R.E.C.I.E.L. (1992) p. 69.

- (ed.), Greening International Institutions, (London: Earthscan Publications Ltd. 1996).

- 'Compliance and Transition: Russia's Non-Compliance Test the Ozone Régime', ZaoRV(1996) pp. 750-773.

(ed.), Improving Compliance with International Environmental Law, (London, Earthscan Publications Ltd. 1996).

- and Jordan, A., 'Additional Funds, Incremental Costs and the Global Environment', 3 R.E.C.I.E.L. (1994) pp. 81-87.

- 'Consolidating Governance of the Global Commons: Insights from the Global Environmental Facility', 6 Y.bk.I.E.L. (1995) pp. 27-63.

- and P. Sands, 'Procedural Aspects of International Law in the Field of Sustainable Development' in Ginther, K. (ed.), Sustainable Development and Good Goverance, (The Netherlands: Kluwer Academic Publishers, 1995) pp. 178-204.

Wilkinson, D., 'Using the European Union's Structural and Cohesion Funds for the Protection of the Environment', 3 R.E.C.I.E.L. (1994) pp. 119-26.

White, N. D., The Law of International Organisations, (Manchester: Manchester U.P. 1996).

Williams, S., 'The Protection of the Ozone Layer in Contemporary International Law', 10 International Relations, (1990) pp. 167-178.

Wolfrum, R., 'Purposes and Principles of International Environmental Law', 33 G.Y.bk.I.L. (1990) pp. 308-30.

- (ed.), Enforcing Environmental Standards: Economic Mechanisms as Viable Means?, (Berlin/New York/London/Tokio: Springer, 1996).

Wood, A., 'The Multilateral Fund for the Implementation of the Montreal Protocol', 5 International Environmental Affairs, (1993) pp. 335-54.

World Bank, Facing the Global Environment Challenge, (September 1995 - January 1996).

W.C.E.D., Environmental Protection and Sustainable Development: Legal Principles and Recommendations. Adopted by the Experts Group on Environmental Law of World Commission and Development. (London: Graham and Trotman, 1987).

Yasutaka, A. and Awagi, T., Environmental Law, (Japan, Yuhikaku, 1995).

Yokota, Y. (ed.), Theory and Practice of International Organisations, (Japan, Kokusaishoin, 1992, in Japanese).

Yamamoto, Y., 'International Regimes: Search for Governance without Government', 95 Japanese Journal of International Law and Diplomacy (April 1996) pp. 1-54.

Yoshida, O., "'Soft Enforcement" of Treaty: The Montreal Non-Compliance Procedure and the Functions of the Internal International Institutions', 10 Colorado Journal of International Environmental Law \& Policy, vol. 1 (1999, forthcoming).

- and Sakota, A., 'The Role of N.G.Os. in the International Legal Régime for the Protection of the Stratospheric Ozone Layer' in The Japanese Society for Human-Environment Related Problems (ed.), N.G.Os. and Global Environmental Problems, (October 1998, Japan E.P.A.). 


\section{Bibliography}

Young, O., 'The Politics of International Regime Formation: Managing Natural Resources and the Environment',

43 International Organoisations (1989) pp.349-375.

-and Osherenko, G., Polar Politics: Creating International Environmental Regimes, (London: Cornell U.P. 1993).

- (ed.), Global Goverance: Drawing Insights from the Environmental Experience, (Cambridge/London: The M.I.T. Press, 1997).

Zamora, S., 'Is There Customary International Economic Law?', 32 G.Y.bk.I.L. (1989) pp. 9-42.

Zarco, J. R., 'Legal and Financial Techniques for Technology Transfer to Developing Countries', 7 ATAS Bulletin,(1992) pp. 181-87.

Zoller, E., La bonne foi en droit international public, (Paris: Editions A. Pedone, 1977). 